\title{
International Energy Outlook
}

\section{7}

\author{
April 1997 \\ Energy Information Administration \\ Office of Integrated Analysis and Forecasting \\ U.S. Department of Energy \\ Washington, DC 20585
}

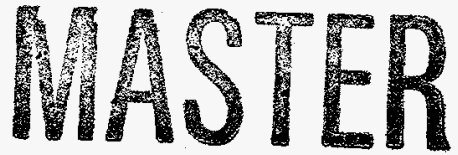

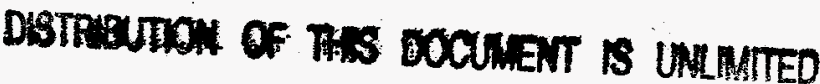

$$
\text { ih }
$$

This report was prepared by the Energy Information Administration, the independent statistical and analytical agency within the Department of Energy. The information contained herein should not be construed as advocating or reflecting any policy position of the Department of Energy or of any other organization. 


\section{Contacts}

The International Energy Outlook is prepared by the Energy Information Administration (EIA). General questions concerning the contents of the report should be referred to Mary J. Hutzler (202/586-2222), Director, Office of Integrated Analysis and Forecasting; Arthur T. Andersen (202/586-1441), Director, Energy Demand and Integration Division; or Gerald E. Peabody (202/ 586-1458), Chief, International, Economic, and Integrated Forecasting Branch. Specific questions about the report should be referred to Linda E. Doman (202/5861041) or the following analysts:

\begin{tabular}{|c|c|c|c|}
\hline \multirow[t]{2}{*}{ World Energy Consumption } & Gerald E. Peabody & (gpeabody@eia.doe.gov, & 202/586-1458) \\
\hline & Leslye Brown & (lbrown@eia.doe.gov, & $202 / 586-4268)$ \\
\hline \multirow[t]{3}{*}{ World Oil Markets } & G. Daniel Butler & (gbutler@eia.doe.gov, & $202 / 586-9503)$ \\
\hline & Gerald E. Peabody & (gpeabody@eia.doe.gov, & $202 / 586-1458)$ \\
\hline & L. Knight & $(\mathrm{k}$ & $202 / 586-$ \\
\hline \multirow[t]{2}{*}{ Natural Gas } & E. Doman & $\mathrm{v}$ & $202 / 586-1041)$ \\
\hline & Martin & & $202 / 586-9592)$ \\
\hline Coal & el Mellish & & $202 / 586-2136)$ \\
\hline Nuclear .... & Lat & & $202 / 586-1494)$ \\
\hline Nuclear Power in India & th C. Wade & qq.doe.gov, & $202 / 426-1248)$ \\
\hline Renewable Energy $\ldots .$. & E. Doman & & $202 / 586-1041)$ \\
\hline \multirow[t]{2}{*}{ Electricity } & Lindstrom & & $202 / 586-0934)$ \\
\hline & & & $202 / 586-1041)$ \\
\hline Economic Growth & Kay A. Smith & (ksmith@eia.doe.gov, & $202 / 586-1455)$ \\
\hline
\end{tabular}

\section{Electronic Access and Related Reports}

The IE097 will be available on (D-ROM and the EIA Home Page on the Internet (http/(woww.eia.doe.gov) by May 1997. The IEO97 displays on the EIA Home Page will include text, forecast tables, and graphics. To download the tables or the entire publication. go to the ElA FTP Site: ffp-liffp, eia doe gov.

For ordering information and questions on other energy statisties available from EIA, please contact EIA's National Energy Information Center. Addresses, telephone numbers, and hours are as follows:

\section{National Energy Information Center EI-231 \\ Energy Information Administration Forrestal Building, Room $1 \mathrm{~F} 048$ Washington, DC 20585}

Telephone: $202 / 586-8800$

TIY For people who are deaf or hard of hearing: $202 / 586-1181$

9 a.m. to 5 p.m, eastern time, M-F
Email: infoctr@eia.doe.got

World Wide Web Site http:/hwarv.ela.doe.gov Gopher Site: gopher//gopher eia doe gov FTP Site: ItpIIffp.eia.doe.gov 
Preface

Highlights

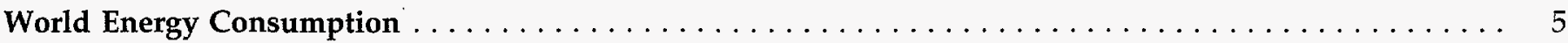

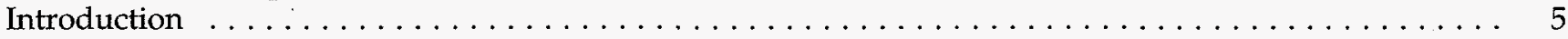

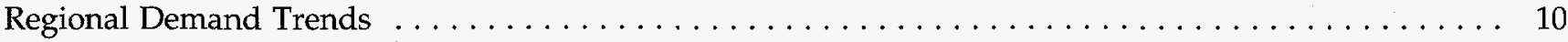

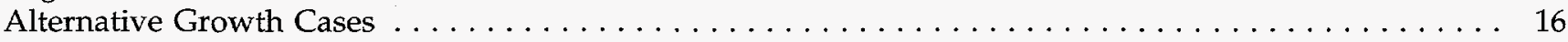

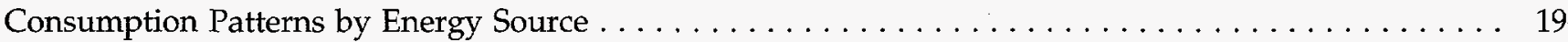

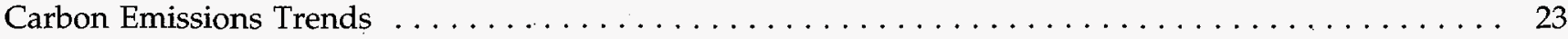

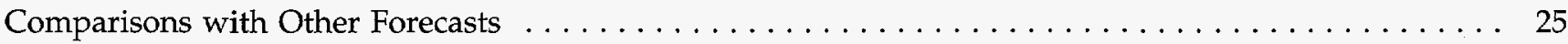

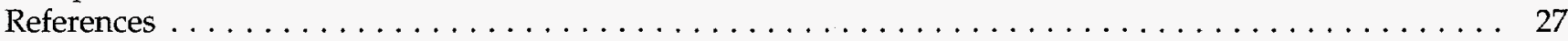

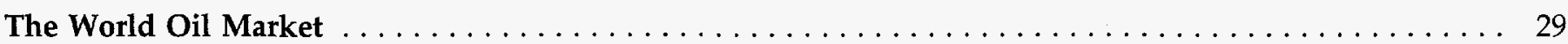

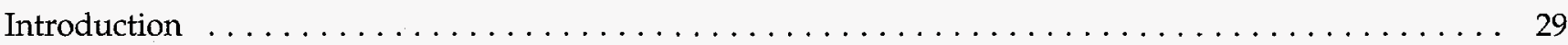

Growth in Oil Demand . . . . . . . . . . . . . . . . . . . . . . . . . 30

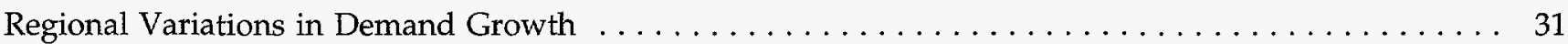

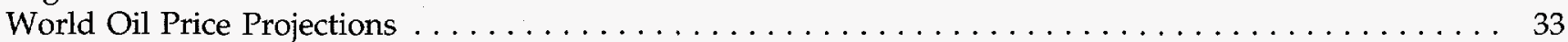

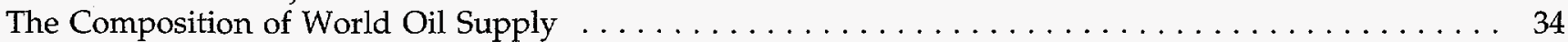

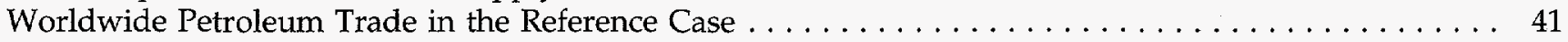

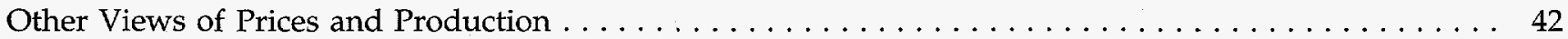

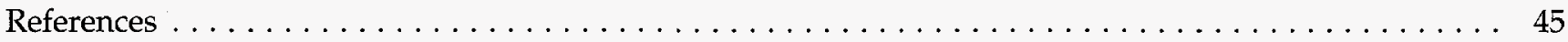

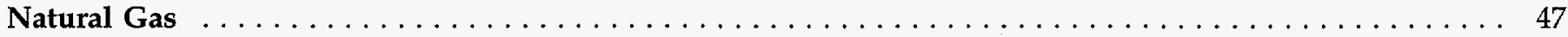

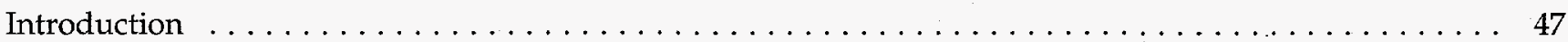

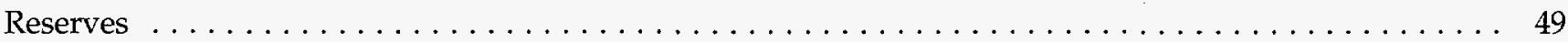

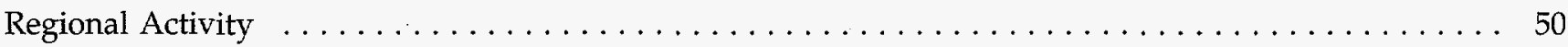

Regional Activity in Liquefied Natural Gas . . . . . . . . . . . . . . . . . . . . . 57

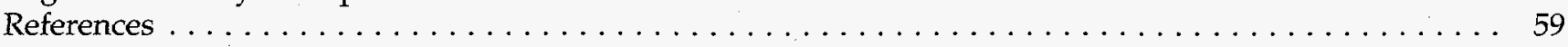

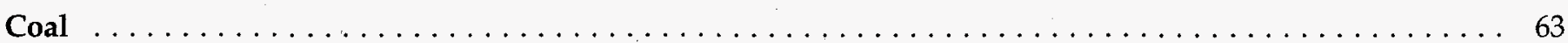

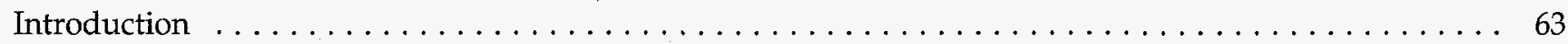

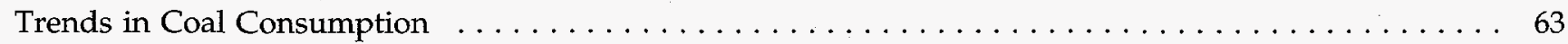

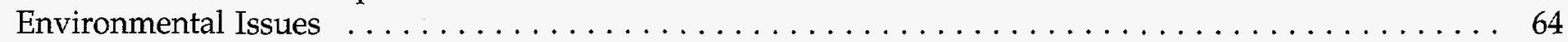

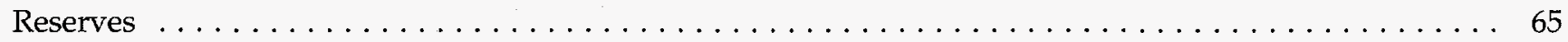

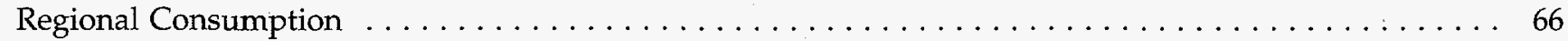

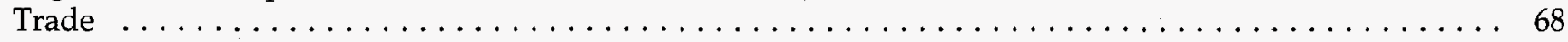

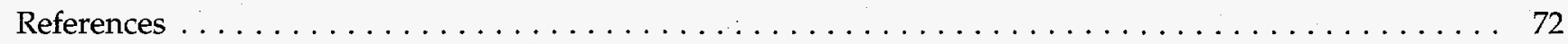

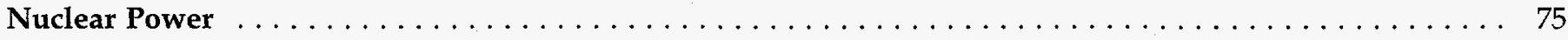

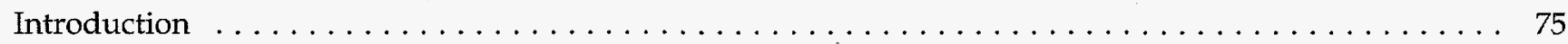

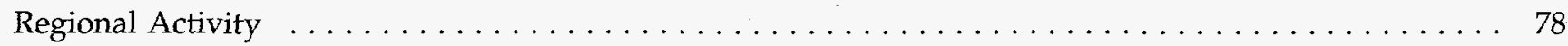

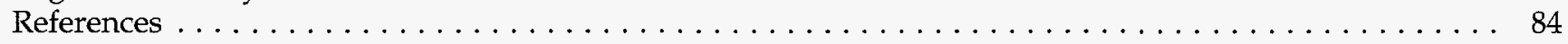

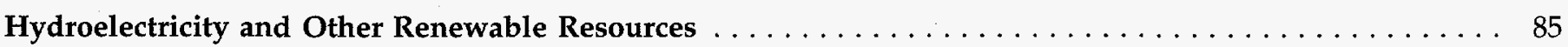

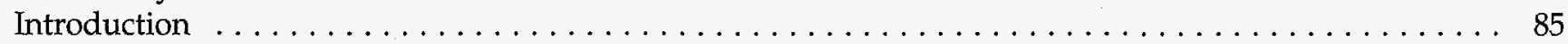

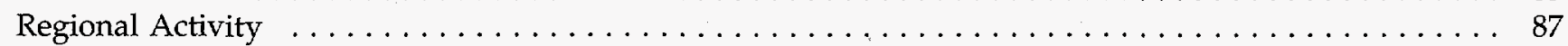

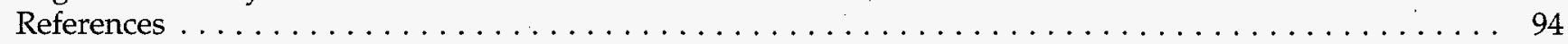

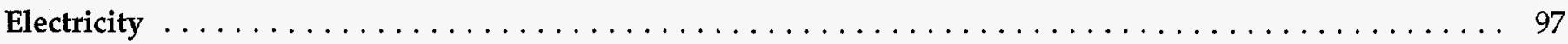

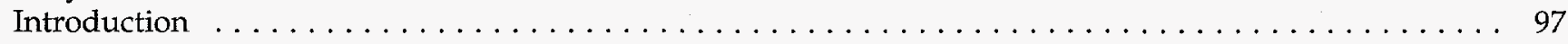

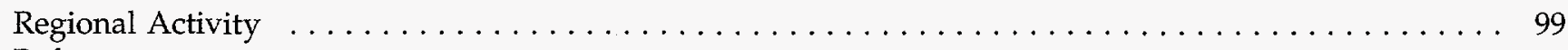

References . . . . . . . . . . . . . . . . . . . . . . . . . 110 


\section{Contents (Continued)}

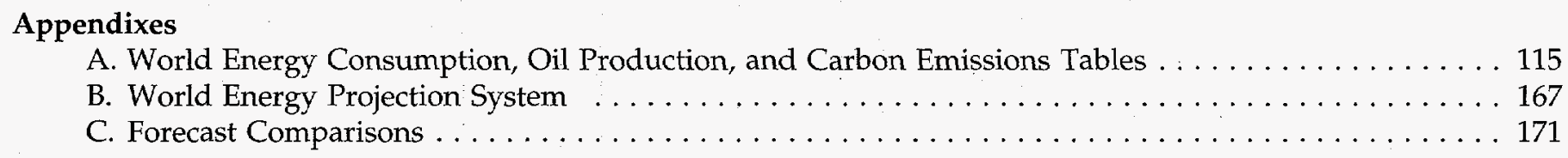

Index

\section{Tables}

1. World Energy Consumption by Region, $1970-2015 \ldots \ldots \ldots \ldots \ldots \ldots \ldots \ldots \ldots \ldots \ldots \ldots \ldots$

2. World Energy Consumption by Fuel, $1970-2015 \ldots \ldots \ldots \ldots \ldots \ldots \ldots \ldots \ldots \ldots \ldots \ldots \ldots \ldots \ldots$

3. World Energy Consumption by Region and Country, $1970-2015 \ldots \ldots \ldots \ldots \ldots \ldots \ldots \ldots \ldots \ldots \ldots$

4. Developing Asia Energy Consumption by Fuel, $1970-2015 \ldots \ldots \ldots \ldots \ldots \ldots \ldots \ldots \ldots \ldots$

5. Eastern Europe/Former Soviet Union Energy Consumption by Fuel, 1970-2015 . . . . . . . . . . . 14

6. Annual Growth Rates in Gross Domestic Product by Region and for Selected Countries, 1970-2015 . . . 16

7. Annual World Energy Consumption by Region in Three Economic Growth Cases,

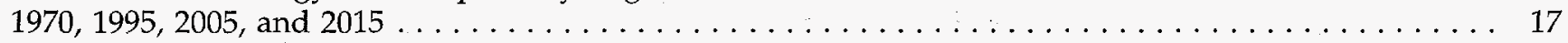

8. Average Energy Elasticity (Change in Consumption Versus Change in Gross Domestic Product), 1970-2015: World, Industrialized, EE /FSU, Developing, and Developing Asia . . . . . . . . . . . . 19

9. Variation in Nonindustrialized Energy Consumption in 2015, Given Alternative Assumptions About Energy Intensity . . . . . . . . . . . . . . . . . . . . . . . . 20

10. World Energy Consumption by Region and Fuel, $1970-2015 \ldots \ldots \ldots \ldots \ldots \ldots \ldots \ldots \ldots \ldots \ldots .22$

11. Comparison of Energy Consumption Growth Rate Projections, 1990-2010, by Region . . . . . . . . . 26

12. Comparison of Economic Growth Rate Assumptions, 1990-2010, by Region . . . . . . . . . . . . . 26

13. Estimated Undiscovered and Ultimately Recoverable Conventional Oil Resources

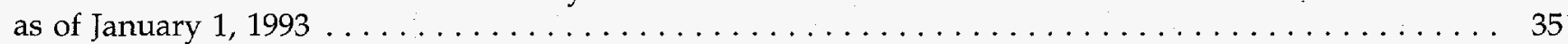

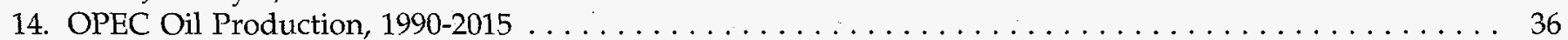

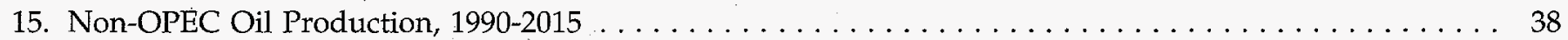

16. Worldwide Petroleum Trade in the Reference Case, 1995 and $2015 \ldots \ldots \ldots \ldots \ldots \ldots \ldots \ldots \ldots . \ldots 4$

17. Comparison of World Oil Price Projections, $1995-2015 \ldots \ldots \ldots \ldots \ldots \ldots \ldots \ldots \ldots \ldots \ldots \ldots$

18. Comparison of World Oil Production Forecasts $\ldots \ldots \ldots \ldots \ldots \ldots \ldots \ldots \ldots \ldots \ldots \ldots \ldots \ldots \ldots$

19. World Natural Gas Reserves by Country as of January $1,1997 \ldots \ldots \ldots \ldots \ldots \ldots \ldots \ldots \ldots . \ldots .49$

20. World Coal Flows by Importing and Exporting Regions, Reference Case, 1995, 2000, and 2015 . . . . 69

21. Historical and Projected Operable Nuclear Capacities, $1995-2015 \ldots \ldots \ldots \ldots \ldots \ldots \ldots \ldots \ldots$

22. Installed Wind Capacity in Selected Countries, 1994 and $1995 \ldots \ldots \ldots \ldots \ldots \ldots \ldots \ldots \ldots$

23. Photovoltaic Technology Installed in India as of July $1996 \ldots \ldots \ldots \ldots \ldots \ldots \ldots \ldots \ldots \ldots$

24. World Energy Consumption for Electricity Generation by Region and Fuel, 1993-2015 . . . . . . . . . 99

A1. World Total Energy Consumption by Region, Reference Case, $1990-2015$. . . . . . . . . . . . . . 115

A2. World Total Energy Consumption by Region and Fuel, Reference Case, 1990-2015 . . . . . . . . . . 116

A3. World Total Oil Consumption by Region, Reference Case, 1990-2015 . . . . . . . . . . . . . . . . . 118

A4. World Total Natural Gas Consumption by Region, Reference Case, 1990-2015 . . . . . . . . . . . . 119

A5. World Total Coal Consumption by Region, Reference Case, $1990-2015$. . . . . . . . . . . . . . 120

A6. World Net Nuclear Energy Consumption by Region, Reference Case, 1990-2015 . . . . . . . . . . . . . 121

A7. World Consumption of Hydroelectricity and Other Renewable Energy by Region, Reference Case, $1990-2015$. . . . . . . . . . . . . . . . . . . . . . . . . . . . . . . . . . . . 122

A8. World Total Net Electricity Consumption by Region, Reference Case, 1990-2015 . . . . . . . . . . 123

A9. World Total Carbon Emissions by Region, Reference Case, 1990-2015 . . . . . . . . . . . . . . . . . 124

A10. World Carbon Emissions from Oil Use by Region, Reference Case, 1990-2015 . . . . . . . . . . . 125

A11. World Carbon Emissions from Natural Gas Use by Region, Reference Case, 1990-2015 . . . . . . . . . . 126

A12. World Carbon Emissions from Coal Use by Region, Reference Case, 1990-2015 . . . . . . . . . . . 127

A13. World Total Energy Consumption in Oil-Equivalent Units by Region, Reference Case, 1990-2015 . . . . 128

A14. World Total Energy Consumption by Region, High Economic Growth Case, 1990-2015 . . . . . . . . 129

A15. World Total Energy Consumption by Region and Fuel, High Economic Growth Case, 1990-2015 . . . . 130

A16. World Total Oil Consumption by Region, High Economic Growth Case, 1990-2015 . . . . . . . . . . 132 
A17. World Total Natural Gas Consumption by Region, High Economic Growth Case, 1990-2015 . . . . . . 133

A18. World Total Coal Consumption by Region, High Economic Growth Case, 1990-2015 . . . . . . . . . 134

A19. World Net Nuclear Energy Consumption by Region, High Economic Growth Case, 1990-2015 . . . . . 135

A20. World Consumption of Hydroelectricity and Other Renewable Energy by Region,

High Economic Growth Case, $1990-2015$. . . . . . . . . . . . . . . . . . . . . . . . . . 136

A21. World Total Net Electricity Consumption by Region, High Economic Growth Case, 1990-2015 . . . . . 137

A22. World Total Carbon Emissions by Region, High Economic Growth Case, 1990-2015 . . . . . . . . . . 138

A23. World Carbon Emissions from Oil Use by Region, High Economic Growth Case, 1990-2015 . . . . . . . 139

A24. World Carbon Emissions from Natural Gas Use by Region, High Economic Growth Case,

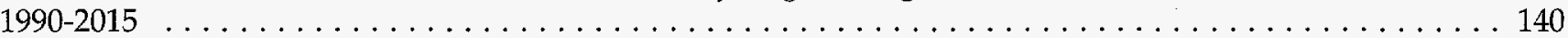

A25. World Carbon Emissions from Coal Use by Region, High Economic Growth Case, 1990-2015 . . . . . . 141

A26. World Total Energy Consumption in Oil-Equivalent Units by Region, High Economic Growth Case,

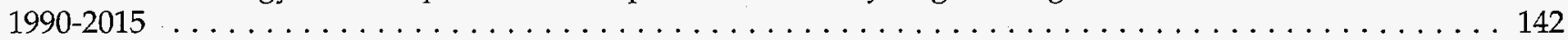

A27. World Total Energy Consumption by Region, Low Economic Growth Case, 1990-2015 . . . . . . . . . 143

A28. World Total Energy Consumption by Region and Fuel, Low Economic Growth Case, 1990-2015 . . . . 144

A29. World Total Oil Consumption by Region, Low Economic Growth Case, 1990-2015 . . . . . . . . . . . 146

A30. World Total Natural Gas Consumption by Region, Low Economic Growth Case, 1990-2015 . . . . . . 147

A31. World Total Coal Consumption by Region, Low Economic Growth Case, 1990-2015 . . . . . . . . . . 148

A32. World Net Nuclear Energy Consumption by Region, Low Economic Growth Case, 1990-2015 . . . . . . 149

A33. World Consumption of Hydroelectricity and Other Renewable Energy by Region,

Low Economic Growth Case, $1990-2015$. . . . . . . . . . . . . . . . . . . . . . . . . 150

A34. World Total Net Electricity Consumption by Region, Low Economic Growth Case, 1990-2015 . . . . . 151

A35. World Total Carbon Emissions by Region, Low Economic Growth Case, 1990-2015 . . . . . . . . . 152

A36. World Carbon Emissions from Oil Use by Region, Low Economic Growth Case, 1990-2015 . . . . . . 153

A37. World Carbon Emissions from Natural Gas Use by Region, Low Economic Growth Case, 1990-2015 . . . . . . . . . . . . . . . . . . . . . . . . . . . . . . . . . . . . . . . 154

A38. World Carbon Emissions from Coal Use by Region, Low Economic Growth Case, 1990-2015 . . . . . . 155

A39. World Total Energy Consumption in Oil-Equivalent Units by Region, Low Economic Growth Case, $1990-2015$. . . . . . . . . . . . . . . . . . . . . . . . . . . . . . . . . 156

A40. World Oil Production Capacity by Region and Country, Reference Case, 1990-2015 . . . . . . . . . . 157

A41. World Oil Production Capacity by Region and Country, High Oil Price Case, 1990-2015 . . . . . . . 158

A42. World Oil Production Capacity by Region and Country, Low Oil Price Case, 1990-2015 . . . . . . . . 159

A43. World Oil Production Capacity by Region and Country, High Non-OPEC Supply Case, 1990-2015 . . . 160

A44. World Oil Production by Region and Country, Reference Case, 1990-2015 . . . . . . . . . . . . . . 161

A45. World Oil Production by Region and Country, High Oil Price Case, 1990-2015 . . . . . . . . . . . 162

A46. World Oil Production by Region and Country, Low Oil Price Case, 1990-2015 . . . . . . . . . . . . . 163

A47. World Oil Production by Region and Country, High Non-OPEC Supply Case, 1990-2015 . . . . . . . . 164

C1. Comparison of World Energy Consumption Growth Rates, 1990-2010, by Fuel . . . . . . . . . . . 171

C2. Comparison of Energy Consumption Growth Rates, 1990-2010, by Region . . . . . . . . . . . . 172

C3. Comparison of Energy Consumption Growth Rates, 1993-2010, by Region . . . . . . . . . . . 173

C4. Comparison of Oil Consumption Growth Rates, 1993-2010, by Region . . . . . . . . . . . . . . . 174

C5. Comparison of Natural Gas Consumption Growth Rates, 1993-2010, by Region . . . . . . . . . . 175

C6. Comparison of Coal Consumption Growth Rates, 1993-2010, by Region . . . . . . . . . . . . . . 176

C7. Comparison of Nuclear Power Consumption Growth Rates, 1993-2010, by Region . . . . . . . . . . 177

C8. Comparison of Other Energy Consumption Growth Rates, 1993-2010, by Region . . . . . . . . . . 178

\section{Figures}

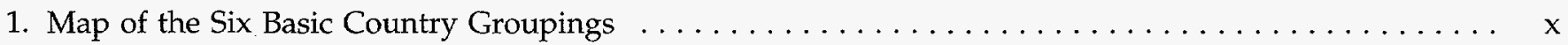

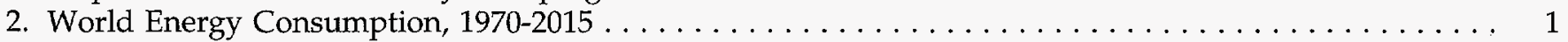

3. World Energy Consumption by Region, $1970-2015 \ldots \ldots \ldots \ldots \ldots \ldots \ldots \ldots \ldots \ldots \ldots \ldots \ldots$

4. Nonindustrialized Energy Consumption by Region, $1970-2015 \ldots \ldots \ldots \ldots \ldots \ldots \ldots \ldots \ldots \ldots \ldots$

5. Comparison of 1996 and 1997 World Oil Price Projections $\ldots \ldots \ldots \ldots \ldots \ldots \ldots \ldots \ldots \ldots \ldots \ldots$ 


\section{Figures (Continued)}

6. World Energy Consumption Shares by Fuel Type, 1970, 1995, and $2015 \ldots \ldots \ldots \ldots \ldots \ldots \ldots$

7. World Energy Consumption by Fuel Type, 1970, 1995, and $2015 \ldots \ldots \ldots \ldots \ldots \ldots \ldots \ldots \ldots$

8. World Carbon Emissions by Region, $1990-2015 \ldots \ldots \ldots \ldots \ldots \ldots \ldots \ldots \ldots \ldots \ldots \ldots \ldots \ldots$

9. World Energy Consumption by Fuel Type, $1970-2015 \ldots \ldots \ldots \ldots \ldots \ldots \ldots \ldots \ldots \ldots \ldots \ldots$

10. World Energy Consumption per Capita by Region, $1970-2015 \ldots \ldots \ldots \ldots \ldots \ldots \ldots \ldots \ldots \ldots \ldots$

11. World Energy, GDP, and Population Trends, $1970-2015 \ldots \ldots \ldots \ldots \ldots \ldots \ldots \ldots \ldots \ldots \ldots$

12. Energy, GDP, and Population Trends in Developing Countries, $1970-2015 \ldots \ldots \ldots \ldots \ldots \ldots$

13. Energy, GDP, and Population Trends in the Industrialized Countries, 1970-2015 . . . . . . . . . . 9

14. Nonindustrialized Energy Consumption by Region, $1970-2015 \ldots \ldots \ldots \ldots \ldots \ldots \ldots \ldots \ldots \ldots$

15. Developing Asia Energy Consumption by Fuel, 1995 and $2015 \ldots \ldots \ldots \ldots \ldots \ldots \ldots \ldots \ldots \ldots \ldots$

16. Developing Asia Electricity Consumption by Country Group, 1995 and 2015 . . . . . . . . . . . . 12

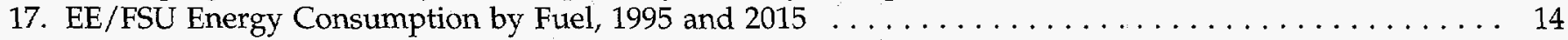

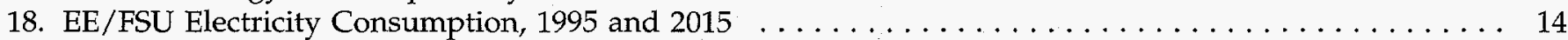

19. World Energy Consumption in Three Cases, $1970-2015 \ldots \ldots \ldots \ldots \ldots \ldots \ldots \ldots \ldots \ldots \ldots \ldots \ldots$

20. Energy Intensities by Region, $1970-2015 \ldots \ldots \ldots \ldots \ldots \ldots \ldots \ldots \ldots \ldots \ldots \ldots \ldots \ldots \ldots \ldots$

21. Nonindustrialized Electricity Consumption by Region, $1970-2015 \ldots \ldots \ldots \ldots \ldots \ldots \ldots \ldots \ldots$. . . . . . 20

22. World Energy Use for Electricity Generation by Fuel Type, $1995-2015 \ldots \ldots \ldots \ldots \ldots \ldots$. . . . . . . . 20

23. Industrialized Energy Use for Electricity Generation by Fuel Type, 1995-2015 . . . . . . . . . . . . . . . 21

24. Nonindustrialized Energy Use for Electricity Generation by Fuel Type, 1995-2015 . . . . . . . . . . . . 21

25. Industrialized Energy Consumption by Fuel Type, $1970-2015 \ldots \ldots \ldots \ldots \ldots \ldots \ldots \ldots \ldots \ldots \ldots . \ldots 22$

26. Nonindustrialized Energy Consumption by Fuel Type, $1970-2015 \ldots \ldots \ldots \ldots \ldots \ldots \ldots \ldots \ldots \ldots . \ldots 22$

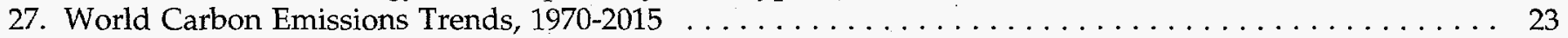

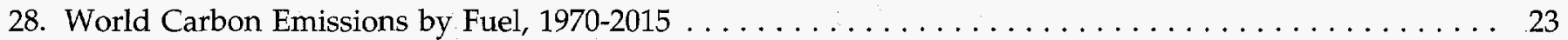

29. World Carbon Emissions by Region and Fuel, 1990, 2000, and $2015 \ldots \ldots \ldots \ldots \ldots \ldots \ldots \ldots \ldots$

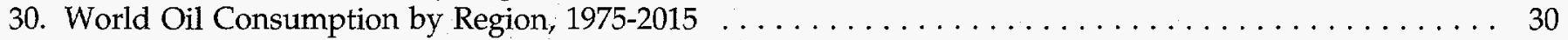

31. World Oil Consumption in Three Economic Growth Cases, $1970-2015 \ldots \ldots \ldots \ldots \ldots \ldots \ldots$

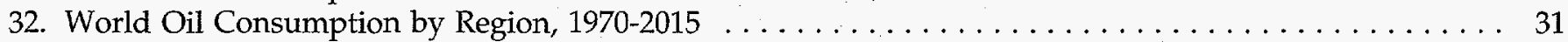

33. Nonindustrialized Oil Demand by Region, 1970, 1995, and $2015 \ldots \ldots \ldots \ldots \ldots \ldots \ldots \ldots \ldots \ldots$

34. World Oil Prices in Three Oil Price Cases, $1970-2015 \ldots \ldots \ldots \ldots \ldots \ldots \ldots \ldots \ldots \ldots \ldots \ldots \ldots . \ldots \ldots$

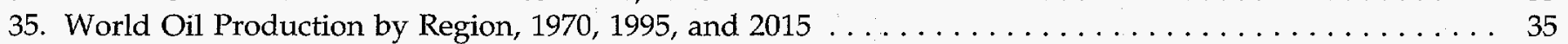

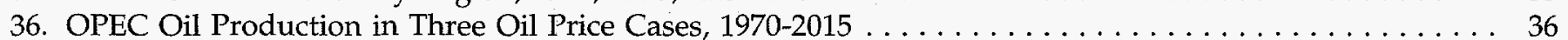

37. Non-OPEC Oil Production in Two Cases, $1990-2015 \ldots \ldots \ldots \ldots \ldots \ldots \ldots \ldots \ldots \ldots \ldots \ldots \ldots \ldots . . .4 . \ldots \ldots$

38. Non-OPEC Oil Production by Region in Two Cases, $2015 \ldots \ldots \ldots \ldots \ldots \ldots \ldots \ldots \ldots \ldots \ldots \ldots \ldots .40$

39. Imports of Persian Gulf Petroleum by Importing Region, 1995 and $2015 \ldots \ldots \ldots \ldots \ldots \ldots \ldots$. . . . . . 42

40. World Consumption of Natural Gas, $1970-2015 \ldots \ldots \ldots \ldots \ldots \ldots \ldots \ldots \ldots \ldots \ldots \ldots \ldots$

41. Natural Gas Consumption by Region, 1995, 2005, and $2015 \ldots \ldots \ldots \ldots \ldots \ldots \ldots \ldots \ldots \ldots \ldots 47$

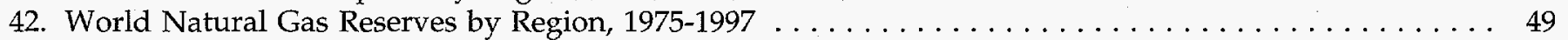

43. World Natural Gas Reserves by Region, as of January 1, $1997 \ldots \ldots \ldots \ldots \ldots \ldots \ldots \ldots \ldots \ldots .49$

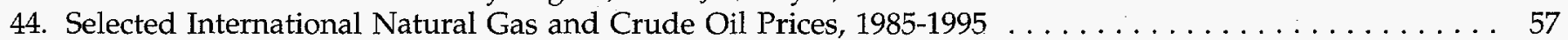

45. Coal Share of Total Energy Consumption by Region, $1970-2015$. . . . . . . . . . . . . . . 64

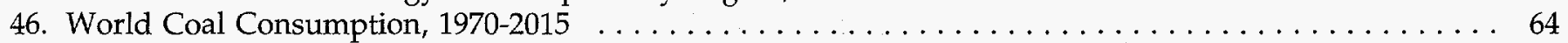

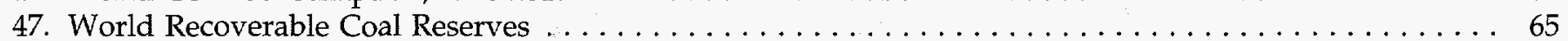

48. World Coal Consumption by Region, 1980,1995 , and $2015 \ldots \ldots \ldots \ldots \ldots \ldots \ldots \ldots \ldots \ldots \ldots$

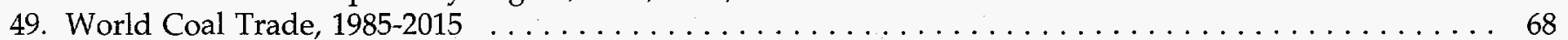

50. Production and Imports of Hard Coal by Region, $1985-1995 \ldots \ldots \ldots \ldots \ldots \ldots \ldots \ldots \ldots \ldots \ldots$

51. World Nuclear Capacity by Region, 1970, 1995, and $2015 \ldots \ldots \ldots \ldots \ldots \ldots \ldots \ldots \ldots \ldots$

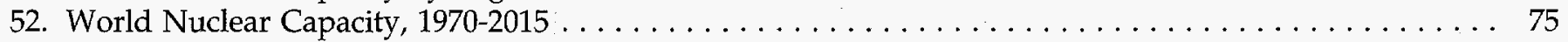

53. World Consumption of Electricity From Nuclear Power Relative to All Other Fuels, 1970-2015 . . . . 76

54. World Consumption of Hydroelectricity and Other Renewables Relative to All Other Fuels, 1970-2015 . 85

55. Average Cost of Wind-Powered Electricity Generation in the United States, 1975-2010 . . . . . . . . 85

56. World Consumption of Hydroelectricity and Other Renewables, $1970-2015$. . . . . . . . . . . 86

57. World Consumption of Hydroelectricity and Other Renewables by Region, 1995, 2005, and 2015 . . . . 87

58. Grid-Connected Wind Power Plants in the United States as of December 31, $1995 \ldots \ldots \ldots \ldots \ldots$ 


\section{DISCLAIMER}

This report was prepared as an account of work sponsored by an agency of the United States Government. Neither the United States Government nor any agency thereof, nor any of their employees, make any warranty, express or implied, or assumes any legal liability or responsibility for the accuracy, completeness, or usefulness of any information, apparatus, product, or process disclosed, or represents that its use would not infringe privately owned rights. Reference herein to any specific commercial product, process, or service by trade name, trademark, manufacturer, or otherwise does not necessarily constitute or imply its endorsement, recommendation, or favoring by the United States Government or any agency thereof. The views and opinions of authors expressed herein do not necessarily state or reflect those of the United States Government or any agency thereof. 


\section{DISCLAMMER}

Portions of this document may be illegible in electronic image products. Images are produced from the best available original document. 
Figures (Continued)

59. Hydroelectric Capacity on the Lower Caroni River, Venezuela, $1990-2010$. . . . . . . . . . . . . . . . 93

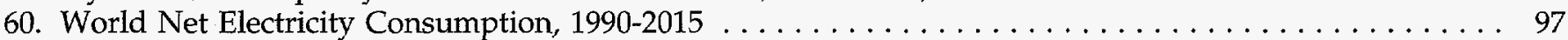

61. Fuels Consumed for Electricity Generation Worldwide, 1995 and $2015 \ldots \ldots \ldots \ldots \ldots \ldots \ldots$. . . . . 100

62. North America Net Electricity Consumption, $1990-2015$. . . . . . . . . . . . . . . . . . . . . 100

63. Energy Use for Electricity Generation in Canada by Fuel, 1995 and $2015 \ldots \ldots \ldots \ldots \ldots \ldots$. . . . . . 100

64. Energy Use for Electricity Generation in Mexico by Fuel, 1995 and 2015 . . . . . . . . . . . . . . . . 101

65. Energy Use for Electricity Generation in the United States by Fuel, 1995 and 2015 . . . . . . . . . . . . 101

66. Energy Use for Electricity Generation in Western Europe by Fuel, 1995 and 2015 . . . . . . . . . . 102

67. Residential Electricity Rates for European Countries as of January 1, $1995 \ldots \ldots \ldots \ldots \ldots \ldots \ldots$

68. Industrialized Pacific Net Electricity Consumption, $1990-2015$. . . . . . . . . . . . . . . . . . . . . 103

69. Energy Use for Electricity Generation in Japan by Fuel, $1995-2015$. . . . . . . . . . . . . . . . . . . 104

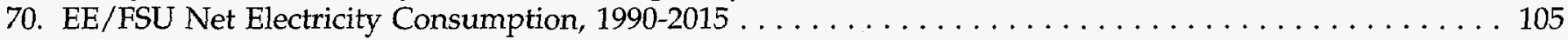

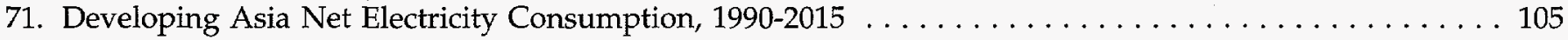

72. Energy Use for Electricity Generation in Developing Asia by Fuel, 1995 and 2015 . . . . . . . . . . . 106

73. Energy Use for Electricity Generation in Central and South America by Fuel, 1995-2015 . . . . . . . . . 108 



\title{
Preface
}

\author{
This Outlook presents EIA's assessment of international energy markets through \\ 2015, as well as historical data from 1970 to 1995. Specific projections of energy use, \\ carbon emissions, and oil production are presented. Prospects for oil, natural gas, coal, \\ nuclear power, hydroelectric and other renewable resources, and electricity are discussed.
}

The International Energy Outlook 1997 (IEO97) presents an assessment by the Energy Information Administration (EIA) of the outlook for international energy markets through 2015. The report is an extension of the EIA's Annual Energy Outlook 1997 (AEO97), which was prepared using the National Energy Modeling System (NEMS). U.S. projections appearing in the IEO97 are consistent with those published in the AEO97. IEO97 is provided as a statistical service to energy managers and analysts, both in government and in the private sector. The projections are used by international agencies, Federal and State governments, trade associations, and other planners and decisionmakers. They are published pursuant to the Department of Energy Organization Act of 1977 (Public Law 95-91), Section 205(c). The IEO97 projections are based on U.S. and foreign government policies in effect on October 1, 1996.

Projections in IEO97 are displayed according to six basic country groupings (Figure 1). The industrialized region (see text box in Chapter 1 , page 6 , for additional explanation of country groupings) includes projections for four individual countries-the United States, Canada, Mexico, and Japan-along with the subgroups Western Europe and Australasia (defined as Australia, New Zealand, and the U.S. Territories). The developing countries are represented by four separate regional subgroups: developing Asia, Africa, Middle East, and Central and South America. China and India are represented in developing Asia. Eastern Europe and the former Soviet Union (EE/FSU) are considered as a separate country grouping.

The report begins with a review of world trends in energy demand. The historical time frame begins with data from 1970 and extends to 1995, providing readers with a 25-year historical view of energy demand. The forecasts cover the 20-year period from 1995 to 2015. New to this year's report is an expanded look at energy use in developing Asia and the EE/FSU-the regions of greatest uncertainty. High economic growth and low economic growth cases were developed to depict a set of alternative growth paths. These scenarios consider alternative growth paths of regional gross domestic product (GDP). The resulting projections and the uncertainty associated with making international energy projections in general are discussed in the first chapter of the report. The status of environmental issues, including global carbon emissions, is reviewed. Comparisons of the IEO97 projections with other available international energy forecasts are included in the first chapter.

The next part of the report is organized by energy source. Regional consumption projections for oil, natural gas, coal, nuclear power, and renewable energy (hydroelectricity, geothermal, wind, solar, and other renewables) are presented in the five fuel chapters, along with a review of the current status of each fuel on a worldwide basis. The last part of the report contains a discussion of energy consumed by electricity producers.

Summary tables of the IEO97 world energy consumption, oil production, and carbon emissions projections are provided in Appendix A. The reference case projections of total foreign energy consumption and of natural gas, coal, and renewable energy were prepared using EIA's World Energy Projection System (WEPS) model, as were projections of carbon emissions and net electricity consumption. Reference case projections of foreign oil production and consumption were prepared using the International Energy Module of the National Energy Modeling System (NEMS). Nuclear consumption projections were derived from the International Nuclear Model, PC Version (PC-INM). Alternatively, nuclear capacity projections were developed using two methods: the reference case projections were based on analysts' knowledge of the nuclear programs in different countries; the optimistic case was generated by the World Integrated Nuclear Evaluation System (WINES)-a demand-driven model. In addition, the NEMS Coal Export Submodule (CES) was used to derive flows in international coal trade. 


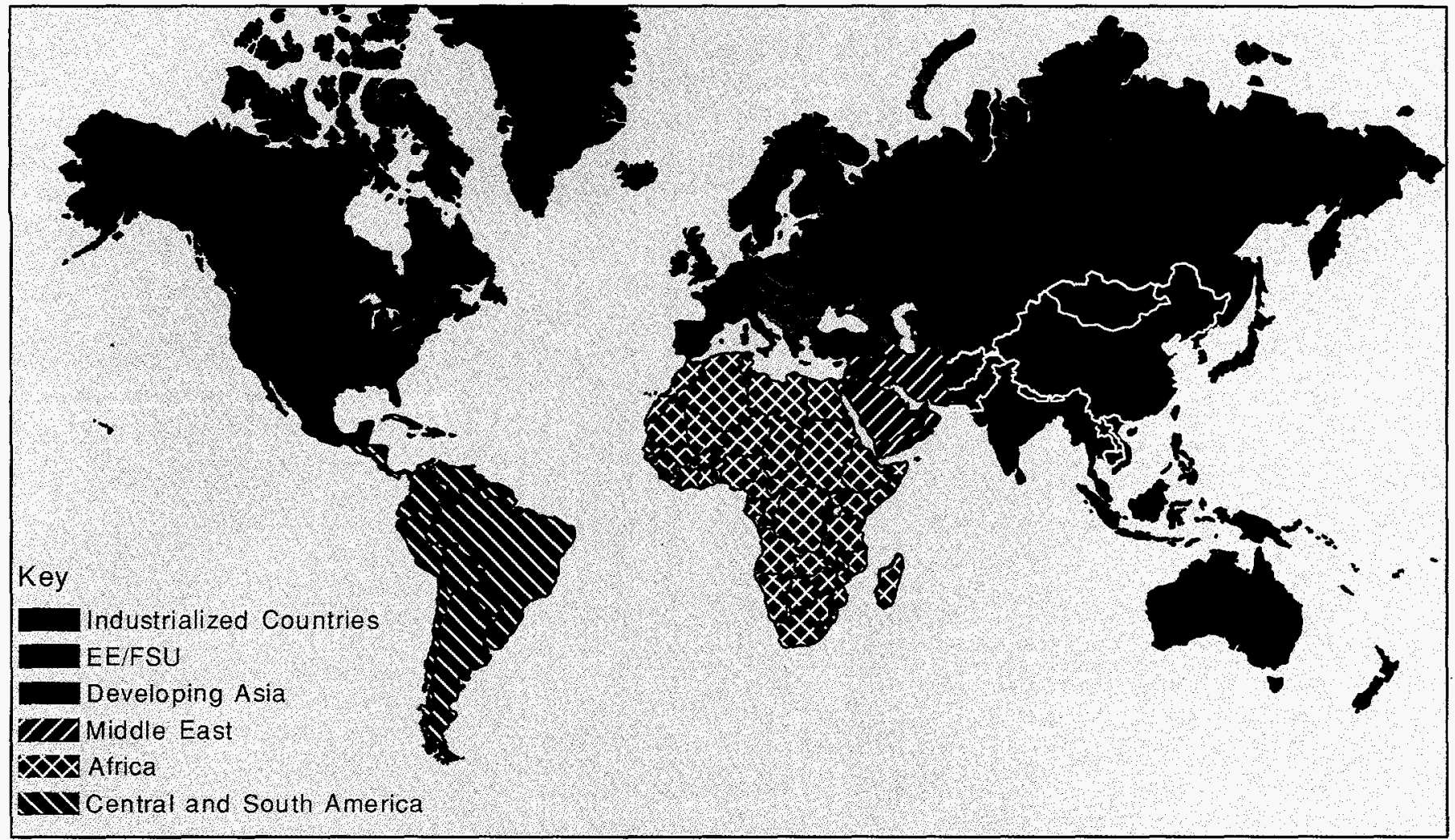

Source: Energy Information Administration, Office of Integrated Analysis and Forecasting.

The six basic country groupings used in this report (Figure 1) are defined as follows:

- Industrialized Countries (18 percent of the 1996 world population): Australia, Austria, Belgium, Canada, Denmark, Finland, France, Germany, Greece, Iceland, Ireland, Italy, Japan, Luxembourg, Mexico, the Netherlands, New Zealand, Norway, Portugal, Spain, Sweden, Switzerland, Turkey, the United Kingdom, and the United States.

- Eastern Europe and the former Soviet Union (EE/FSU) (7 percent of the 1996 world population):

- Eastern Europe: Albania, Bulgaria, Czech Republic, Hungary, Poland, Romania, Slovakia, and former Yugoslavia.

- Former Soviet Union (FSU): The Baltic States of Estonia, Latvia, and Lithuania, as well as Armenia, Azerbaijan, Belarus, Georgia, Kazakhstan, Kyrgyzstan, Moldova, Russia, Tajikistan, Turkmenistan, Ukraine, and Uzbekistan.

- Developing Asia (53 percent of the 1996 world population): Afghanistan, Bangladesh, Bhutan, Brunei, Cambodia (Kampuchea), China, Fiji, French Polynesia, Hong Kong, India, Indonesia, Kiribatia,
Laos, Malaysia, Macau, Maldives, Mongolia, Myanmar (Burma), Nauru, Nepal, New Caledonia, Niue, North Korea, Pakistan, Papua New Guinea, Philippines, Singapore, Solomon Islands, South Korea, Sri Lanka, Taiwan, Thailand, Tonga, Vanuatu, Vietnam, and Western Samoa.

- Middle East (2 percent of the 1996 world population): Bahrain, Cyprus, Iran, Iraq, Israel, Jordan, Kuwait, Lebanon, Oman, Qatar, Saudi Arabia, Syria, the United Arab Emirates, and Yemen.

- Africa (12 percent of the 1996 world population): Algeria, Angola, Benin, Botswana, Burkina Faso, Burundi, Cameroon, Cape Verde, Central African Republic, Chad, Comoros, Congo, Djibouti, Egypt, Equatorial Guinea, Ethiopia, Gabon, Gambia, Ghana, Guinea, Guinea-Bissau, Ivory Coast, Kenya, Lesotho, Liberia, Libya, Madagascar, Malawi, Mali, Mauritania, Mauritius, Morocco, Mozambique, Namibia, Niger, Nigeria, Reunion, Rwanda, Sao Tome and Principe, Senegal, Seychelles, Sierra Leone, Somalia, South Africa, St. Helena, Sudan, Swaziland, Tanzania, Togo, Tunisia, Uganda, Western Sahara, Zaire, Zambia, and Zimbabwe. 
- Central and South America (7 percent of the 1996 world population): Antarctic Fisheries, Antigua and Barbuda, Argentina, Aruba, Bahama Islands, Barbados, Belize, Bolivia, Brazil, British Virgin Islands, Cayman Islands, Chile, Colombia, Costa Rica, Cuba, Dominica, Dominican Republic, Ecuador, El Salvador, Falkland Islands, French Guiana, Grenada, Guadeloupe, Guatemala, Guyana, Haiti, Honduras, Jamaica, Martinique, Montserrat, Netherlands Antilles, Nicaragua, Panama Republic, Paraguay, Peru, St. Kitts-Nevis, St. Lucia, St. Vincent/ Grenadines, Suriname, Trinidad and Tobago, Uruguay, and Venezuela.

In addition, the following commonly used country groupings are referenced in this report:

- G-7 Countries: United States, Japan, Canada, United Kingdom, France, Germany, and Italy.

- Organization of Petroleum Exporting Countries (OPEC): Algeria, Gabon, Indonesia, Iran, Iraq, Kuwait, Libya, Nigeria, Qatar, Saudi Arabia, the United Arab Emirates, and Venezuela.
- Pacific Rim Developing Countries: Hong Kong, Indonesia, Malaysia, Philippines, Singapore, South Korea, Taiwan, and Thailand.

- Persian Gulf: Bahrain, Iran, Iraq, Kuwait, Qatar, Saudi Arabia, and the United Arab Emirates.

- OECD: Australia, Austria, Belgium, Canada, Czech Republic, Denmark, Finland, France, Germany, Greece, Hungary, Iceland, Ireland, Italy, Japan, Luxembourg, Mexico, the Netherlands, New Zealand, Norway, Poland, Portugal, South Korea, Spain, Sweden, Switzerland, Turkey, the United Kingdom, and the United States.

- Annex I Countries: Australia, Austria, Belarus, Belgium, Bulgaria, Canada, Czech Republic, Denmark, European Economic Community, Estonia, Finland, France, Germany, Greece, Hungary, Iceland, Ireland, Italy, Japan, Latvia, Lithuania, Luxembourg, the Netherlands, Norway, Poland, Portugal, Romania, Russian Federation, Slovakia, Spain, Sweden, Switzerland, Turkey, Ukraine, the United Kingdom, and the United States.

The projections in IEO97 are not statements of what will happen, but what might happen given the specific assumptions and methodologies used. These projections provide an objective, policy neutral reference case that can be used to analyze international energy markets. As a policy-neutral data and analysis organization, EIA does not propose, advocate, or speculate on future legislative and regulatory changes. The projections are based on current U.S. and foreign government policies. Assuming current policies, even knowing that dhanges will occur, will naturally result in projections that differ from the final data.

Models are abstractions of energy production and consumption activities, regulatory activities, and producer and consumer behavior: The forecasts are highly dependent on the data, analy tical methodologies, model structures, and specific assumptions used in their development. Trends depicted in the analysis are indicative of tendencies in the real world rather than representations of specific real world outcomes. Even where trends are stable and well understood, the projections are subject to uncertainty. Many events that shape energy markets are random and cannot be anticipated, and assumptions concerning future technology characteristics, demographies, and resource availabilify cannot be known with any degree of certainty 


\section{Highlights}

Continued growth in energy use around the world is projected for the next 20 years. Rapid increases are projected for the developing nations, especially China, India, and other growing economies in Asia.

The outlook for energy use worldwide presented in the International Energy Outlook 1997 (IEO97) continues to show strong prospects for rising levels of demand over the next 20 years, led by growing demand in Asia. In the countries of developing Asia-especially China and India-consumption is expected to more than double by 2015. In fact, at the end of the forecast period, energy use in developing Asia exceeds U.S. consumption by 48 quadrillion British thermal units (Btu) in the reference case, an amount that is just over 50 percent of the current total U.S. energy consumption.

Total world energy consumption is projected to reach almost 562 quadrillion Btu in 2015, an increase of about 200 quadrillion Btu (54 percent) over the 1995 total (Figure 2). Most of the world's energy growth will occur in the developing countries (Figure 3). In 1995, energy consumed by the industrial countries exceeded that in the developing countries by almost 88 quadrillion Btu (78 percent); by 2015 the gap narrows to 35 quadrillion Btu (15 percent).

Developing economies in Asia are expected to dominate nonindustrialized energy consumption, accounting for

Figure 2. World Energy Consumption, 1970-2015

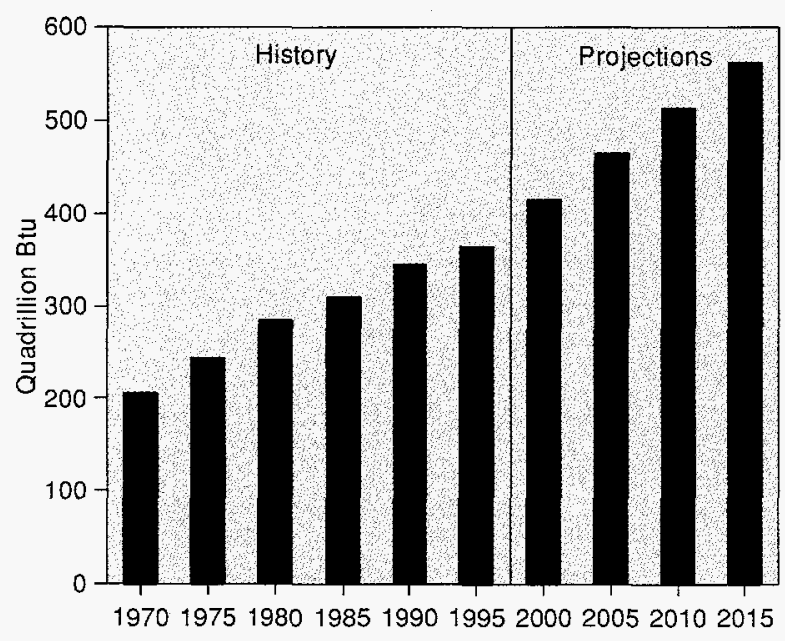

Sources: History: 1970-1975: Energy Information Administration (EIA), Office of Energy Markets and End Use, International Statistics Database. 1980-1995: ElA, International Energy Annual 1995, DOE/ EIA-0219(95) (Washington, DC, December 1996). Projections: EIA, World Energy Projection System (1997).
53 percent of the total by 2015 (Figure 4). Growth in the industrial sector is the driving force behind Asia's strong economic performance. For most countries in the region, the industrial sector remains the largest energyconsuming end-use sector. It should be noted, however, that much uncertainty attends the energy projectionsparticularly in China, where marked changes in transportation demand (beyond those projected here) may evolve. If developments in China follow those already seen in Thailand and South Korea, the demand for oil may be substantially higher than in the reference case forecast.

Energy consumption in the transitional economies of Eastern Europe and the former Soviet Union (EE/FSU) is another major source of uncertainty. This report projects EE/FSU energy growth at 1.8 percent annually over the next two decades, much slower than the 4.2 percent projected for developing Asia. The Russian Federation and other countries of the former Soviet Union (FSU) have had a difficult time recovering from the collapse of their centrally planned economies. Nevertheless, Russia and most of the rest of the FSU

Figure 3. World Energy Consumption by Region, 1970-2015

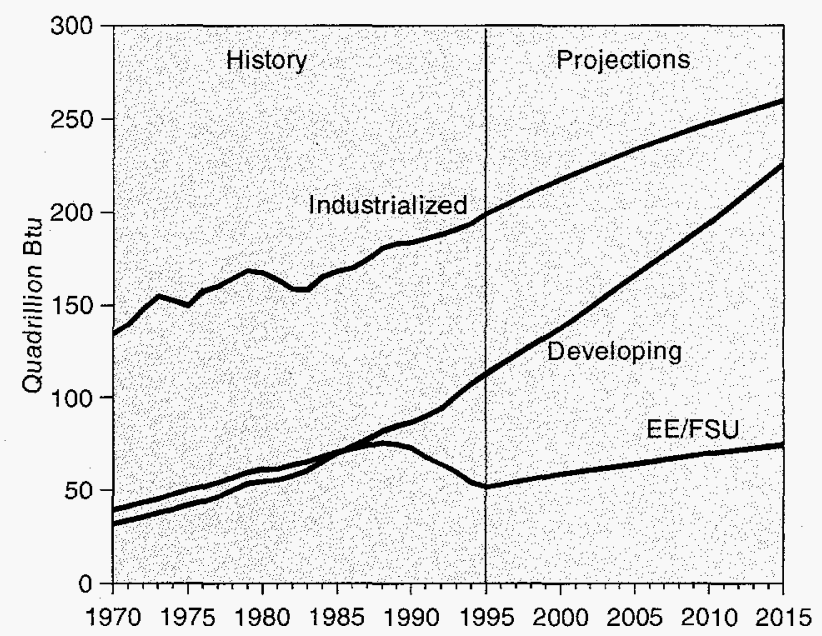

Sources: History: 1970-1979: Energy Information Administration (EIA), Office of Energy Markets and End Use, International Statistics Database. 1980-1995: EIA, International Energy Annual 1995, DOE/ EIA-0219(95) (Washington, DC, December 1996). Projections: EIA, World Energy Projection System (1997). 
Figure 4. Nonindustrialized Energy Consumption by Region, 1970-2015

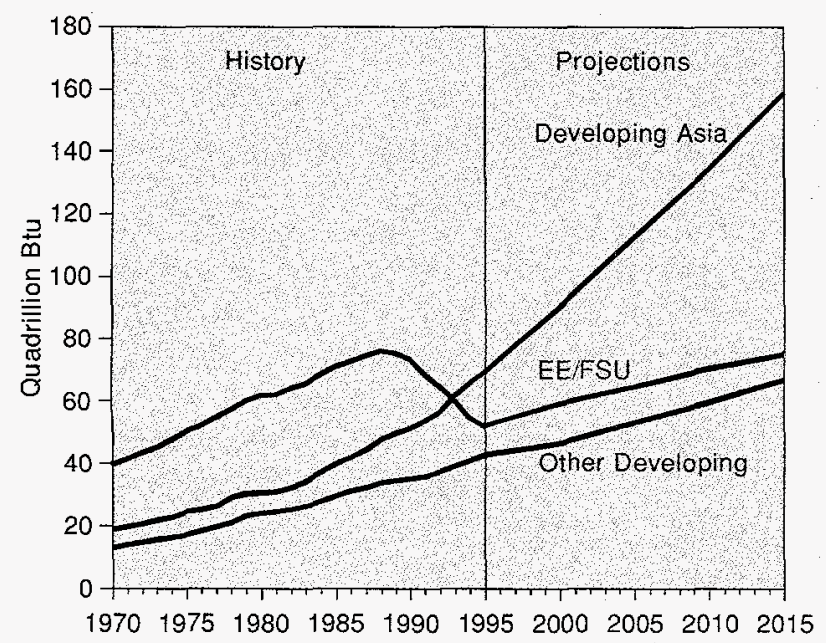

Sources: History: 1970-1979: Energy Information Administration (EIA), Office of Energy Markets and End Use, International Statistics Database. 1980-1995: ElA, International Energy Annual 1995, DOE/ EIA-0219(95) (Washington, DC, December 1996). Projections: EIA, World Energy Projection System (1997).

were expected to return to positive growth in 1997, so that it is now possible to concentrate on the rate of economic recovery, rather than estimating when the economic decline might end.

The disruption to the economies of Eastern Europe was less severe than in the FSU. Thus, Eastern Europe's energy consumption should surpass 1990 levels by 2005, whereas demand levels in the FSU are projected to remain below their 1990 levels through 2015. On the other hand, if economic reforms take hold more smoothly than anticipated, higher growth rates could follow more rapidly.

The long-term projections for world oil prices in the IEO97 reference case reflect a small downward revision relative to those presented last year (Figure 5). Growing understanding of the world's oil and natural gas resource base, along with improved methods of oil recovery, promise the potential of large future supply increments at relatively stable development and production costs. In the IEO97 reference case, oil prices rise to about $\$ 21$ per barrel (in constant 1995 dollars) in 2015. At the end of 1996, world oil prices were actually higher than those projected for 2015 in the reference case. It is generally believed, however, that transitory factors-including cold weather in early 1996 and political controversy that delayed the resumption of Iraqi oil exports-are driving current prices. These higher prices will not continue in the long term, although short-term issues can often introduce high levels of volatility in energy markets.
Figure 5. Comparison of 1996 and 1997 World Oil Price Projections

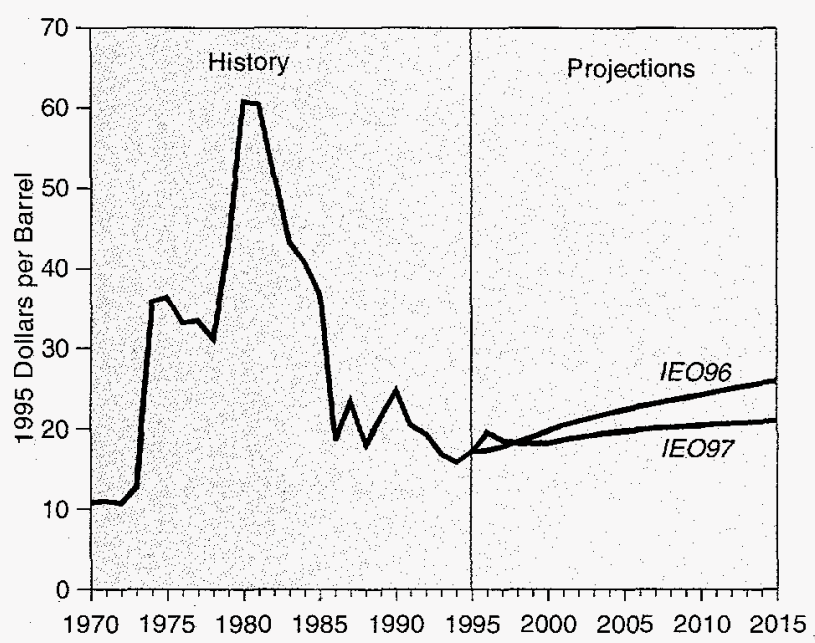

Sources: History: 1970-1979: Energy Information Administration (EIA), Office of Energy Markets and End Use, International Statistics Database. 1980-1995: EIA, International Energy Annual 1995, DOE/ EIA-0219(95) (Washington, DC, December 1996). IEO96: EIA, International Energy Outlook 1996, DOE/EIA-0484(96) (Washington, DC, May 1996). IEO97: World Energy Projection System (1997).

The potential to expand oil production in many areas of the world continues to grow at a rapid rate. Oil production is expected to reach nearly 105 million barrels per day in 2015, 50 percent higher than the 1995 level of 70 million barrels per day.

Evolving technologies are markedly improving the chances for oil recovery in existing production locales, including the North Sea, the Middle East, Argentina, and China. New technologies may make it economically feasible to tap resources in the environmentally harsh producing areas of the North Sea, the offshore United States, Mexico, Brazil, and Africa. Further, more governments are turning to policies that encourage private investment for resource development. The removal of foreign investment bans, modification of profit-sharing terms, and creation of government-private joint ventures are factors that might well encourage exploration and private investment in many parts of the world. Indeed, stable governments and investment climates will be the key determinants of an adequate future oil supply, given the current optimistic assessment of underlying resource availability.

Oil's share of world energy consumption actually drops slightly in the IEO97 forecast, from 39 percent in 1995 to 38 percent in 2015 (Figure 6). Slow growth is projected for oil demand in the industrial countries-increasing by an average of 1.1 percent annually over the forecast horizon-reflecting continued implementation of efficient energy-using technologies and the use of natural gas in place of oil for many applications. 
Growth in oil use in the industrialized countries will occur mainly in the transportation sector, where it has limited competition. Oil use in the developing countries-projected to grow by 3.5 percent annuallyincreases in all end-use sectors. Higher standards of living are expected to encourage increased demand for personal transportation and larger and better equipped homes in the world's developing countries, many of which do not have natural gas distribution infrastructures that would allow competition with oil.

Natural gas is expected to have the highest growth rate among the primary fuels, at 3.1 percent per year, gaining share relative to oil and coal (Figure 6). In fact, by 2015 , natural gas consumption should surpass coal consumption on a worldwide basis (Figure 7). Total world consumption of natural gas reaches nearly 145 trillion cubic feet in 2015, 85 percent higher than the 1995 level of 78 trillion cubic feet.

The highest regional growth rates in natural gas use are projected for the developing countries. In developing Asia, for example, the demand for natural gas is expected to increase by almost 8 percent annually. Much of the growth will fuel electricity generation in the region, but infrastructure projects are also underway for natural gas to displace polluting home heating and cooking fuels in major cities such as Bombay, Shanghai, and Beijing. Gas markets in Central and South America are also expected to experience substantial development over the forecast period, growing by about 5.3 percent annually through 2015. Most of the increased consump-

Figure 6. World Energy Consumption Shares by Fuel Type, 1970, 1995, and 2015

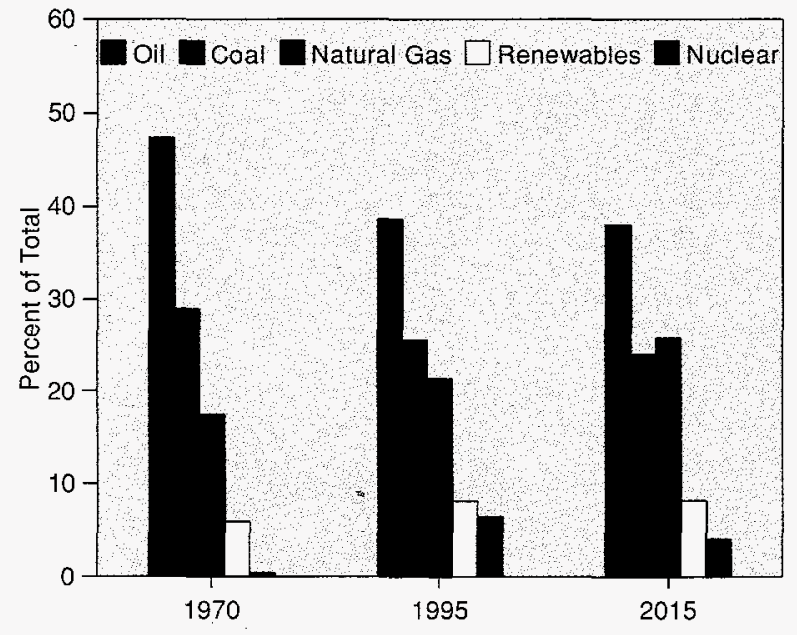

Sources: 1970: Energy Information Administration (E|A), Office of Energy Markets and End Use, International Statistics Database. 1995: EIA, International Energy Annual 1995, DOE/EIA-0219(95) (Washington, DC, December 1996). 2015: World Energy Projection System (1997). tion will supply the region's growing need for electric power and industrial energy. The fuel will allow substantial diversification for energy use in power generation in a region that has in the past relied heavily on hydroelectric power.

Coal's role in energy use worldwide will mainly be as a source of electricity generation and in a few key industrial sectors, such as steel, cement, and chemicals. Coal consumption is expected to increase by about 2.3 billion short tons over the next two decades (an increase of about 45 percent). Although coal use is expected to grow very slowly in the industrialized nations and decline in the EE/FSU over the forecast period, the coal share of total energy consumption decreases only slightly, from 26 percent in 1995 to 24 percent in 2015, mostly because of large increases projected in developing Asia. China and India combined are projected to account for 82 percent of the world's total increase in coal consumption (on a Btu basis) over the next two decades. Except in China, coal for electricity generation will account for virtually all of the projected growth in consumption.

Worldwide nuclear capacity is projected to decline from 344 gigawatts in 1995 to 332 gigawatts in 2015 in the IEO97 reference case. Although countries with existing nuclear power programs have derived an average of more than 20 percent of their total electricity generation from nuclear fuels in recent years, fewer than half are expected to expand capacity over the projection period. Market competition from natural gas, public concern

\section{Figure 7. World Energy Consumption by Fuel Type, 1970, 1995, and 2015}

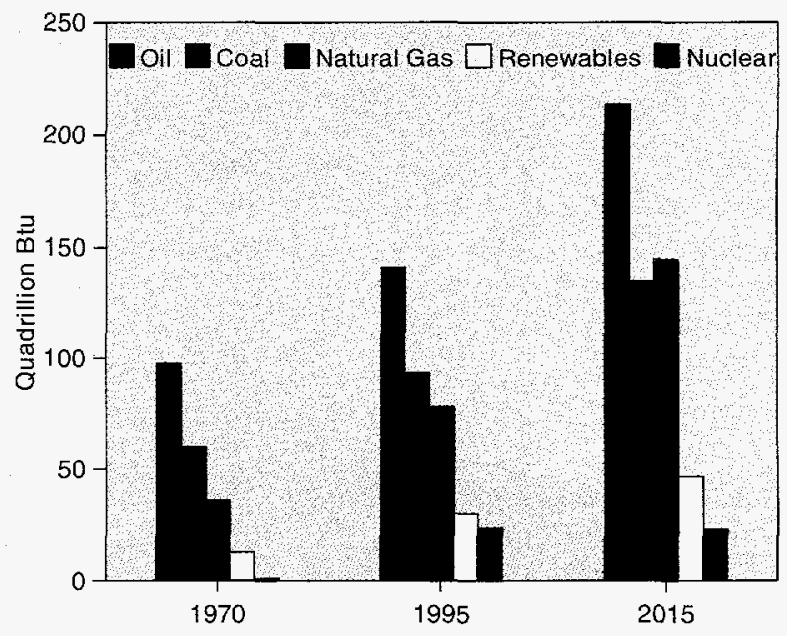

Sources: 1970: Energy Information Administration (EIA), Office of Energy Markets and End Use, International Statistics Database. 1995: ElA, International Energy Annual 1995, DOE/EIA-0219(95) (Washington, DC, December 1996). 2015: World Energy Projection System (1997). 
about the safety of nuclear reactor operations, and problems associated with the disposal of nuclear waste are constraining the expansion of nuclear power programs in many nations. Moreover, the widespread trend toward privatization and deregulation of the electric utility sector has also undermined the viability of the nuclear option, because of the high costs associated with building and operating nuclear power plants. Nevertheless, the operating performance of existing reactors continues to improve, and increased reliance on nuclear power is projected in the developing countries of Asia, including China, India, South Korea, and Taiwan.

In Western Europe-for environmental reasons-and in rural areas of developing countries where populations live far from institutional electricity grids, there is sustained interest in increasing the use of renewable energy sources. Although the IEO97 projections do not include estimates for renewables that are not part of electricity grids, consumption of hydroelectricity and other renewable resources is projected to grow by 56 percent over the forecast period, to about 46 quadrillion Btu in 2015. Wind is currently experiencing some of the strongest growth among renewables, notably in Germany and India, where government policies favor investment in wind programs. Large-scale hydroelectric projects in developing Asia, such as China's 18.2-gigawatt Three Gorges Dam project, support expectations that the use of renewables for electricity generation will more than double in that region over the next 20 years.

Net electricity consumption increases to almost 20 trillion kilowatthours in the IEO97 reference case in 2015, a 75-percent increase from the 1995 level of 11.4 trillion kilowatthours. In the industrialized countries, where electrification has been fully achieved, increased demand is fueled principally by economic growth and growing electrical applications for computers, communications, and other electronics for home and business uses. In the developing world, the use of electricity for conventional lighting and appliance operation is still in the early stages of development, and electricity use in those areas tends to match or exceed rates of growth in income. Rapid expansion of the electric power sector requires high rates of investment and development. To facilitate investment, energy policies are changing. Direct government ownership and control are being weakened in favor of restructuring to promote private investment and to increase competition, bringing market forces to bear for the benefit of consumers. In the developing world, privatization increasingly is seen as a way to attract foreign capital for investment in the energy infrastructure while preserving public capital for other important projects.

If world energy consumption reaches the levels projected in the IEO97 reference case, carbon emissions will rise by 3.5 billion metric tons between 1995 and 2015. According to this projection, world carbon emissions would exceed 1990 levels by 61 percent at the end of the forecast period. By 2000, carbon emissions in the industrialized world will be surpassed by emissions in the rest of the world (Figure 8). The increase in emissions in the nonindustrialized countries will represent about two-thirds of the projected increase worldwide. There are 166 countries that have signed the United Nations Framework Convention on Climate Change, which encourages efforts to stabilize greenhouse gases at their 1990 levels. If the industrialized countries were able to achieve such stabilization, world carbon emissions would still increase by 2.7 billion metric tons between 1995 and 2015. Policies to require worldwide stabilization would, obviously, dramatically change the projections contained in this IEO.

\section{Figure 8. World Carbon Emissions by Region, 1990-2015}

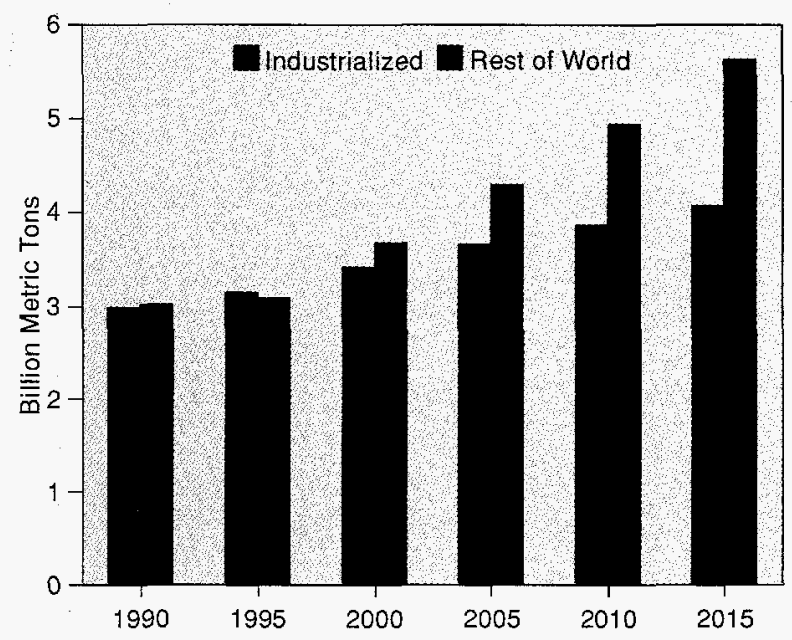

Sources: History: Derived from Energy Information Administration (E|A), International Energy Annual 1995, DOE/EIA-0219(95) (Washington, DC, December 1996). Projections: World Energy Projection System (1997). 


\title{
World Energy Consumption
}

\author{
The rising demand for electricity and other end-use energy \\ will be met primarily by fossil fuels. Oil, natural gas, and coal \\ are projected to supply almost 90 percent of the world's energy in 2015.
}

\section{Introduction}

\section{Energy Use}

The outlook for energy use throughout the world continues to show strong prospects for rising levels of consumption over the next two decades, led by growing demand for end-use energy in Asia. World energy demand in 2015 is projected to reach nearly 562 quadrillion British thermal units (Btu). The expected increment in total energy demand between 1995 and 2015almost 200 quadrillion Btu-would match the total world energy consumption recorded in 1970 , just before the energy crisis of 1973.

Two-thirds of all energy growth will occur in developing economies and economies in transition, with much of that growth concentrated in Asia. Energy growth in the developing countries of Asia is projected to average 4.2 percent per year, compared with 1.3 percent for industrialized economies. The U.S. growth rate is expected to average only about 1 percent per year. As recently as 1990, U.S. energy consumption exceeded total consumption in the nations of developing Asia by 33 quadrillion Btu. By 2015, energy use in developing Asia is expected to exceed U.S. consumption by 48 quadrillion Btu (Table 1).
All sources of energy except nuclear power are projected to grow (Table 2 and Figure 9). By 2015, oil use is expected to exceed 100 million barrels per day, a consumption rate 50 percent greater than in 1995. Oil trading patterns are expected to shift markedly as oil consumption in Asia Pacific areas far outpaces indigenous production gains, leading to a large increase in imports from Middle East suppliers. Worldwide, coal use is projected to exceed 7.3 billion short tons by 2015, compared with 5.1 billion tons in 1995. Growth in coal use will be regionally concentrated, occurring for the most part in India and China.

Natural gas is expected to have the highest growth rate among fossil fuels, at 3.1 percent a year, gaining share relative to oil and coal. By 2015 natural gas consumption on a Btu basis will exceed the total oil consumption recorded for 1995, at a level equivalent to two-thirds of the oil consumption projected for 2015. Natural gas consumption in 1995 was only about 55 percent of oil consumption.

Only about 8 percent of projected growth in energy demand over the next two decades will be served by non-fossil fuel sources. In fact, the non-fossil fuel share of world energy consumption declines from 15 percent to 12 percent over the projection period. Thus, world

Table 1. World Energy Consumption by Region, 1970-2015 (Quadrillion Btu)

\begin{tabular}{|c|c|c|c|c|c|c|}
\hline \multirow[b]{2}{*}{ Region } & \multirow[b]{2}{*}{1970} & \multirow[b]{2}{*}{1995} & \multirow[b]{2}{*}{2010} & \multirow[b]{2}{*}{2015} & \multicolumn{2}{|c|}{ Annual Percent Change } \\
\hline & & & & & 1970-1995 & 1995-2015 \\
\hline Industrialized & 135.1 & 200.2 & 248.7 & 260.8 & 1.6 & 1.3 \\
\hline United States & 67.6 & 90.6 & 107.9 & 110.9 & 1.2 & 1.0 \\
\hline Developing & 32.0 & 112.6 & 194.4 & 226.2 & 5.2 & 3.5 \\
\hline Asia . & 18.9 & 69.6 & 134.7 & 159.1 & 5.4 & 4.2 \\
\hline$\ldots \ldots \ldots \ldots$ & 39.7 & 52.1 & 70.5 & 75.0 & 1.1 & 1.8 \\
\hline Total World & 206.7 & 364.9 & 513.6 & 561.9 & 2.3 & 2.2 \\
\hline
\end{tabular}

Note: Totals may not equal sum of components due to independent rounding.

Sources: History: Energy Information Administration (EIA), Office of Energy Markets and End Use, International Statistics Database; and International Energy Annual 1995, DOE/EIA-0219(95) (Washington, DC, December 1996). Projections: EIA, World Energy Projection System (1997). 


\section{New Regional Definitions Used in the International Energy Outlook 1997}

The regional designations in the internationnl Energy Outlook 1997 (IEO97) differ somewhat from those used in the IE096. The membership of the Organization for Economic Cooperation and Development (OECD) grew to 29 nations in 1996 , with the formal induction of South Korea on December 12. Before Mexice joined the OECD in 1994 , the organization had not accepted any new members for more than 20 years. After the collapse of the Soviet Union and the ensuing transition of the newly independent nations in Eastern Europe and the former Soviet Union (EE/TSI) to market economies, several of those countries sought OECD membership. The Czech Republic became a member in 1995 and Hungary and Poland in 1996. When South Korea joined the organization it became the first new Asian nember since New Zealand in 1973.

The latest additions to the OUCD expand the economic character of the group beyond that of the "OECD region" designated in previous editions of the 1EO. In the past the OECD formed a collection of nations that could be reasonably said to have developed economies. In comparison, the newer members are not as economically advanced. In one measure of development, gross domestic product (GDP) per person, there is substantial difference between the group of OECD nations in last year's report and the new OECD members. The average per capita GDP for the 25 OECD member nations in 1995 (before the induction of Poland, Hungary, the Czech Republic, and South Korea) was $\$ 19,000$ (1990 U.S. dollars), compared with $\$ 1,700$ for Poland and $\$ 8100$ for South Korea, the most economically developed new member (see figure).

A further distinction between the older OECD members and the new ones, which is of particular importance to this report, is the availability of historical economic and energy consumption data. Not all of the data required to perform the $1 F O$ projections are available for the new OECD nember countries. For example, there are no historical data that distinguish energy consumption for the Czech Republic (which was formed when Czechoslovakia split into the Czech Republic and Slovakta in 1994) from that for Slovakia. As a result, economic growth rates are not currently avallable for the Czech Republic alone.
In view of these difficulties, the IEO97 retains the same regional groupings that were used in the $1 E 096$; however, to avoid using inappropriate labels for the different groups, the former OECD group is referred to in this report as the "Industrialized Countries," reflecting the generally more advanced industrial infrastructure in most of those nations. They include the countries of North America (United States, Canada, and Mexico), the countries of Western Europe, and the countries of the industrialized Pacific (Japan, Australia, New Zealand, and U.S. Territories).

The countries in the former non-OECD grouping have also been given new labels. Asia (excluding the industrialized Pacific nations), the Middle East; Central and South America, and Africa are now collectively termed "Developing Countries." The nations of Eastern Europe (including those that are now OECD members) and the former Soviet Union make up a third group, designated as the "EE/ISU." They are also referred to as countries with "economies in transition, reflecting their shift from centrally planned to market-oriented economies. The "Developing " and "EE/ISE" regions, in combination, are labeled as "Nonindustrialized Countries."

\section{GDP per Capita for Selected Regions and Countries}

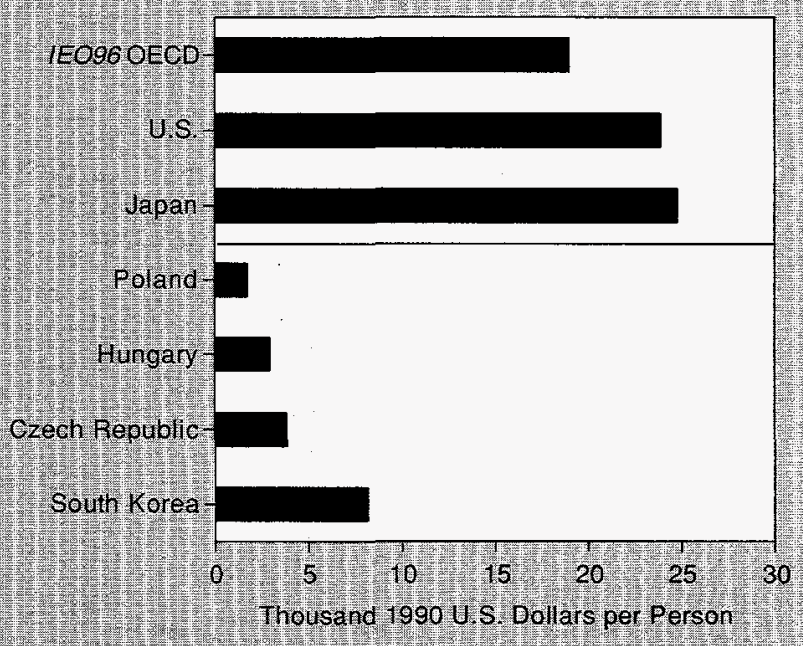

Source: WEFA Group, World Economic Oullook 20 Year Extension (Eddystone. PA March 1996). 
Table 2. World Energy Consumption by Fuel, 1970-2015 (Quadrillion Btu)

\begin{tabular}{|c|c|c|c|c|c|c|}
\hline \multirow[b]{2}{*}{ Energy Source } & \multirow[b]{2}{*}{1970} & \multirow[b]{2}{*}{1995} & \multirow[b]{2}{*}{2010} & \multirow[b]{2}{*}{2015} & \multicolumn{2}{|c|}{ Annual Percent Change } \\
\hline & & & & & $1970-1995$ & 1995-2015 \\
\hline Oil & 97.8 & 141.1 & 194.8 & 213.4 & 1.5 & 2.1 \\
\hline Natural Gas & 36.1 & 77.7 & 129.0 & 144.7 & 3.1 & 3.2 \\
\hline Coal ...... & 59.7 & 93.1 & 122.7 & 134.7 & 1.8 & 1.9 \\
\hline Nuclear & 0.9 & 23.3 & 25.0 & 22.8 & 13.9 & -0.1 \\
\hline Renewables & 12.2 & 29.7 & 42.1 & 46.3 & 3.6 & 2.3 \\
\hline$\ldots \ldots \ldots$ & 206.7 & 364.9 & 513.6 & 561.9 & 2.3 & 2.2 \\
\hline
\end{tabular}

Note: Totals may not equal sum of components due to independent rounding.

Sources: History: Energy Information Administration (EIA), Office of Energy Markets and End Use, International Statistics Database; and International Energy Annual 1995, DOE/EIA-0219(95) (Washington, DC, December 1996). Projections: EIA, World Energy Projection System (1997).

Figure 9. World Energy Consumption by Fuel Type, 1970-2015

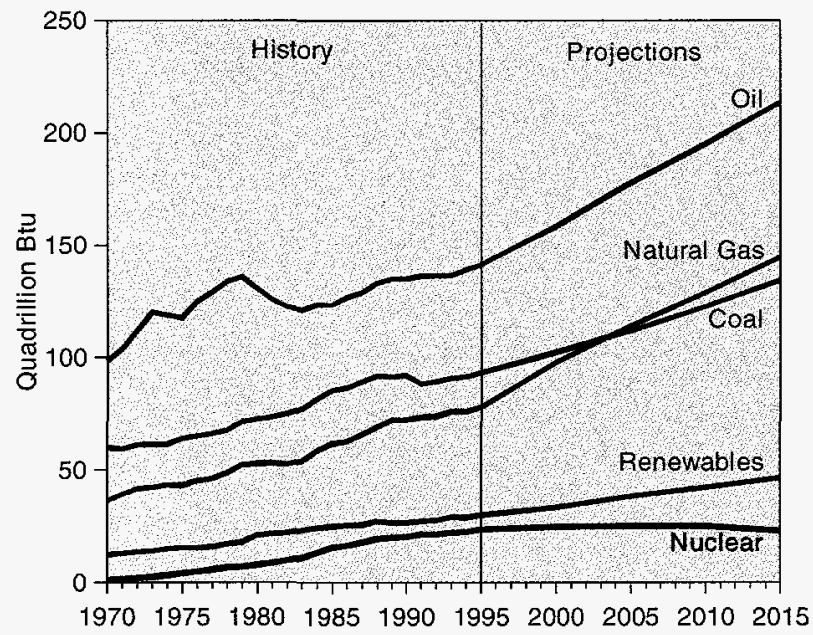

Sources: History: 1970-1979: Energy Information Administration (EIA), Office of Energy Markets and End Use, International Statistics Database. 1980-1995: EIA, International Energy Annual 1995, DOE/ EIA-0219(95) (Washington, DC, December 1996). Projections: EIA, World Energy Projection System (1997).

carbon emissions are likely to increase by 3.7 billion metric tons, or 61 percent, over the 1990 level by 2015. The Climate Change Convention of 1992 commits all signatories to search for and develop policies to moderate or stabilize carbon emissions. However, even if all the developed countries were able to achieve stabilization of their emissions relative to 1990 levels, overall world carbon emissions would still rise by 2.5 billion metric tons over the next two decades.

Per capita energy use in the world's industrialized economies, which far exceeds the levels in newly emerging economies, is expected to change only moder- ately in the next two decades. In some emerging economies (for example, India and China), per capita energy use may double. Even with such growth, however, average per capita energy use in the developing countries will still be less than one-fifth the average for the industrialized countries in 2015 (Figure 10).

This issue of the IEO reflects an upward revision in energy use projections relative to IEO96. For 2015, the IEO97 anticipates about 4 percent ( 20 quadrillion Btu) more energy demand than did IEO96. For the most part, the change is attributable to the prospects for

\section{Figure 10. World Energy Consumption per Capita by Region, 1970-2015}

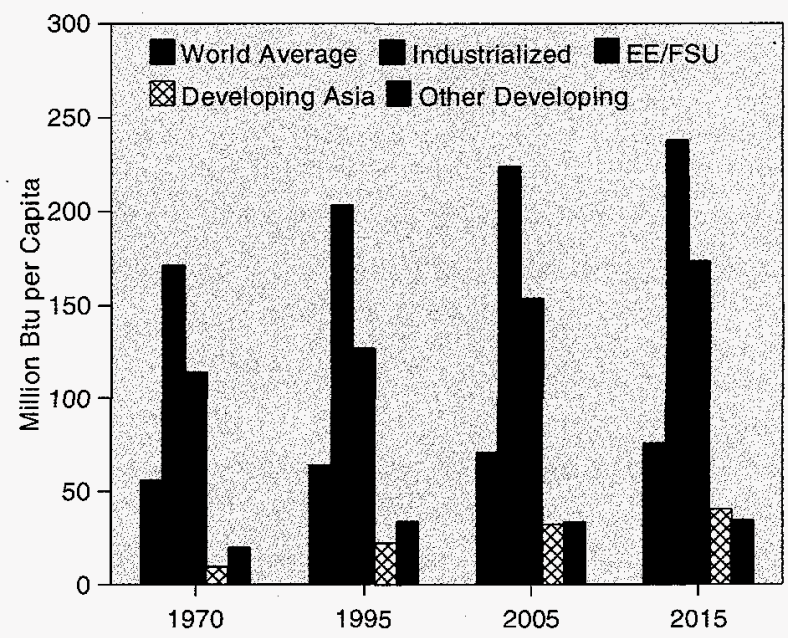

Sources: History: 1970: Energy Information Administration (EIA), Office of Energy Markets and End Use, International Statistics Database. 1995: EIA, International Energy Annual 1995, DOE/EIA0219(95) (Washington, DC, December 1996). Projections: EIA, World Energy Projection System (1997). Population: United Nations, World Population Prospects: The 1994 Revision Annex Tables (New York, NY, 1994), Tables A.1 and A.2. 
energy demand in the developing countries of Asia and of Central and South America. Expected consumption levels for both natural gas and oil are higher in this forecast. Although the future rate of penetration of new energy-intensive consumption patterns is difficult to determine, both regions appear to be capable of sustaining substantial improvements in economic wealth, which will increase personal demand for energy.

Despite the upward revision to energy demand from last year's report, energy prices are expected to increase only moderately over the projection horizon. The future of energy supply and cost does not appear to be at risk because of impending resource depletion. Technological capability continues to enhance production possibilities even in harsh producing environments. Increasingly favorable economic performance enhances investment prospects needed to produce and deliver energy services. However, as the Persian Gulf War illustrated, unforeseen political and economic events can result in price volatility.

\section{Economic Growth}

Economic growth is the main factor driving growth in energy demand. Between 1970 and 1995 world gross domestic product (GDP) rose from $\$ 12$ trillion (1990 U.S. dollars) to $\$ 25$ trillion. By 2015 world GDP is expected to increase by another $\$ 20$ trillion, rising to $\$ 45$ trillion. On average, demand for energy does not rise as rapidly as increases in income (Figure 11).

Between 1970 and 1995 energy consumption grew by 2.3 percent per year, while income rose at an annual rate of 2.8 percent. The IEO97 projections assume that world economic growth will average about 3.1 percent per year, while annual growth in energy use will average about 2.2 percent between 1995 and 2015.

For much of recent history and through much of the projection period, economic growth in developing countries is associated with an expansion of energyintensive industries whose outputs-concrete, steel, and chemicals, for example-are necessary to build the capital stock and related infrastructure associated with economic development. Energy demand in the developing countries typically grows at a rate much closer to the rate of economic growth than is the case for industrialized nations (Figure 12).

The relatively higher rate of energy growth in developing countries is also a result of changing lifestyles made possible by rising levels of personal income. Many areas of the world are now gaining access to electricity for the first time. Those that have electricity are expanding the variety of appliances they use. At the same time, personal automobile ownership is becoming an important component of consumer demand in newly
Figure 11. World Energy, GDP, and Population Trends, 1970-2015

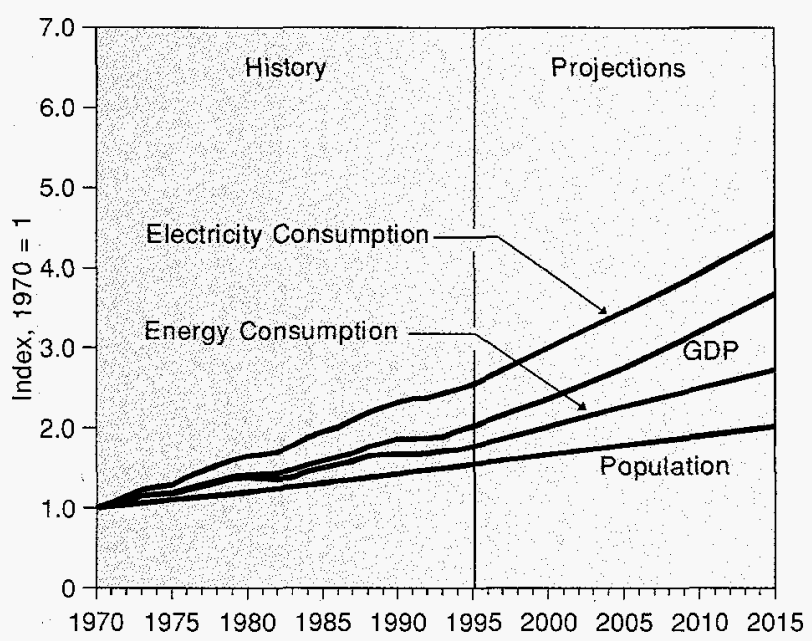

Sources: History: 1970-1979: Energy Information Administration (EIA), Office of Energy Markets and End Use, International Statistics Database. 1980-1995: EIA, International Energy Annual 1995, DOE/ EIA-0219(95) (Washington, DC, December 1996). Projections: EIA, World Energy Projection System (1997). Gross Domestic Product (GDP): WEFA Group, World Economic Service Historical Data (Bala Cynwyd, PA, July 1993); and World Economic Outlook, Vol. 1 (Eddystone, PA, November 1996). Population: United Nations, World Population Prospects: The 1994 Revision Annex Tables (New York, NY, 1994), Tables A.1 and A.2.

\section{Figure 12. Energy, GDP, and Population Trends in Developing Countries, 1970-2015}

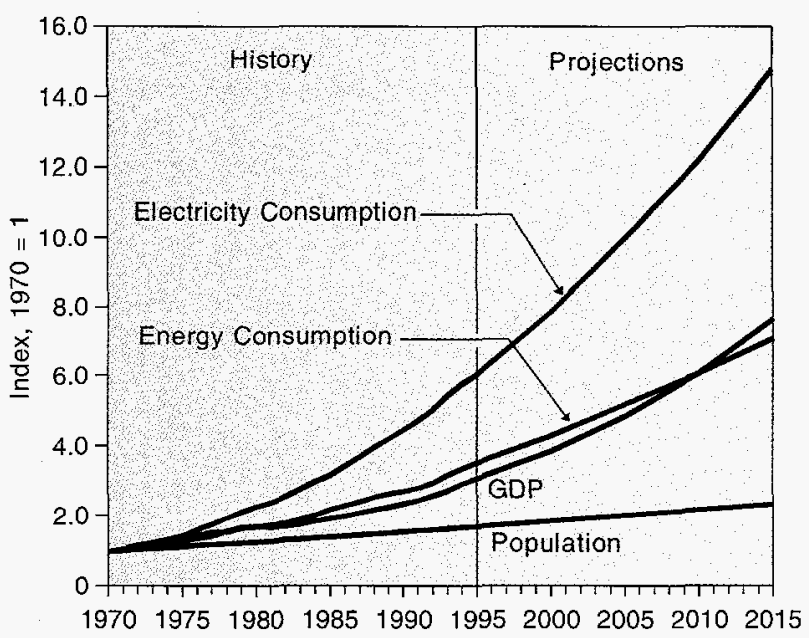

Sources: History: 1970-1979: Energy Information Administration (EIA), Office of Energy Markets and End Use, International Statistics Database. 1980-1995: EIA, International Energy Annual 1995, DOE/ EIA-0219(95) (Washington, DC, December 1996). Projections: EIA, World Energy Projection System (1997). Gross Domestic Product (GDP): WEFA Group, World Economic Service Historical Data (Bala Cynwyd, PA, July 1993); and World Economic Outlook, Vol. 1 (Eddystone, PA, November 1996). Population: United Nations, World Population Prospects: The 1994 Revision Annex Tables (New York, NY, 1994), Tables A.1 and A.2. 
industrializing areas. Double-digit growth rates in automobile ownership are evident in many countries, including South Korea, Thailand, the Philippines, India, and China. Automobile sales in Thailand alone increased by 17.6 percent in 1995 [1] and, by one estimate, are expected to grow by 15 percent annually through 2000 [2].

Electricity demand is especially sensitive to growth in income. Economic development leads to increased reliance on electricity for machine drive in industrial processes and increased use for heating, lighting, cooking, and other appliances in residential and commercial activities. The trend evident over the past 20 years-higher growth for electricity use than for energy use in general-is expected to continue throughout the projection period (Figure 12).

In industrialized economies, most of the new demand for products that use energy intensively is for new capital equipment to replace old capital stock. Thus, only a relatively small amount of the new equipment represents actually a net increase in capital stock. Moreover, the old stock is often less efficient than the replacement equipment. Demand growth in advanced economies also tends to favor the provision of less energy-intensive consumer goods and services. Consequently, although substantial economic expansion is projected over the next two decades in the industrialized countries, growth in energy demand is expected to be moderate (Figure 13).

\section{Forecast Uncertainties}

Much can change to alter these projections. Favorable expectations for economic growth rest on the continuance of government policies-in both a national and international context-which favor economic incentives that promote investment, market development, and trade. The projected continuing expansion in Asia Pacific countries, the improving prospects for Central and South America, and the continued lackluster performance of the former Soviet Union are directly reflective of expectations regarding government tolerance of private enterprise.

Government intervention in energy markets may shift markedly, especially if energy policy comes to be dominated by concerns about global warming and the greenhouse gas implications of continued reliance on fossil fuels. Changing policies toward local air pollution could also shift the outlook. China is the world's largest consumer of coal. As a consequence, China's particulate and sulfur oxide pollution is among the most extreme in the world. To date, Chinese policy favors the use of its coal resources to spur development over environ-
Figure 13. Energy, GDP, and Population Trends in the Industrialized Countries, 1970-2015

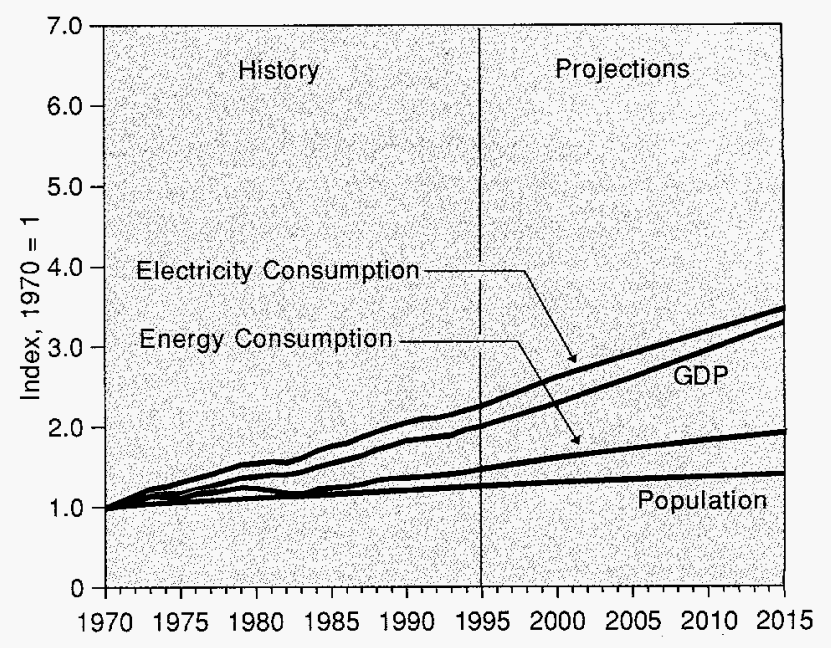

Sources: History: 1970-1979: Energy Information Administration (EIA), Office of Energy Markets and End Use, International Statistics Database. 1980-1995: EIA, International Energy Annual 1995, DOE/ EIA-0219(95) (Washington, DC, December 1996). Projections: EIA, World Energy Projection System (1997). Gross Domestic Product (GDP): WEFA Group, World Economic Service Historical Data (Bala Cynwyd, PA, July 1993); and World Economic Outiook, Vol. 1 (Eddystone, PA, November 1996). Population: United Nations, World Population Prospects: The 1994 Revision Annex Tables (New York, NY, 1994), Tables A.1 and A.2.

mental protection. Pollution control technologies used in the industrialized countries to reduce the environmental impact of coal use are not widely used in China. Were that policy to change, large adjustments to China's energy system would be necessary.

The pollution situation in China could be exacerbated in the future. China to date has primarily used cleaner burning coal that is available in the northern regions of the country, which is shipped by rail to the southeast regions where the bulk of the economic development is taking place. However, the rail system carrying the coal is running at full capacity, and coal is being stockpiled at the mines. Abundant reserves of coal are available much closer to the southeastern economic growth areas, but it is brown coal with a lower Btu content per ton of coal and a much higher level of pollutants. China therefore faces the expensive choices between substantially expanding the capacity to transport the cleaner fuel from the north, building electricity generation capacity in the north and a transmission system to bring the electricity to the south, or using the more polluting coal that is geographically more accessible.

The implications of these and related issues of uncertainty are reviewed in the following sections of this chapter. 


\section{Regional Demand Trends}

\section{Overview}

The developing countries in Asia have had the highest rate of economic growth in the world in recent years. With rapid growth expected to continue, the region as a whole is projected to have the highest level of energy consumption in 2015, surpassing North America. The economies of the EE/FSU region, on the other hand, have recently undergone severe disruptions that have led to declining economic activity and energy consumption. The majority of countries in Central and South America have not shown substantial economic growth in the past, but current institutional and economic changes may be laying the foundation for sustained economic expansion in the future.

The shifts in economic success have led to equally dramatic changes in the geographic distribution of energy consumption (Table 3). In 1970, the EE/FSU dominated energy consumption among nonindustrialized countries, consuming about 55 percent of the group's energy. However, the severe economic collapse in this region led to a 45-percent drop in income and a 29-percent decline in energy consumption between 1989 and 1995. By 1995, the EE/FSU share of energy consumption among nonindustrialized countries had slipped to 32 percent. The stabilization of world carbon emissions levels in the early 1990s (at 6.0 billion metric tons annually between 1990 and 1993) was wholly the result of reduced energy consumption in the EE/FSU region.

Eastern European countries have begun to rebound from the region's economic setback. Since 1993, they have experienced positive levels of economic growth, ranging from 0.1 percent (in 1993) to 5.4 percent (in 1995) per year [3, p. 5.5]. Russia and other republics of the FSU (apart from the Baltics), on the other hand, have had a more difficult time recovering, and while they appear to have stopped the decline in their economic output, they are not yet showing clear signs of recovery.

By 2015, the developing economies of Asia are expected to dominate nonindustrialized energy consumption, accounting for 53 percent of the total, while the EE/FSU share falls to 25 percent. The ability of the developing nations of Asia to sustain their current high rates of economic growth, along with the rate at which the EE/FSU can recover from its decline and resume sustained growth, will be major determinants of the course of energy consumption in the developing world over the next two decades.

Energy consumption forecasts for the other developing regions-Central and South America, the Middle East, and Africa-appear comparatively flat relative to those

Table 3. World Energy Consumption by Region and Country, 1970-2015

(Quadrillion Btu)

\begin{tabular}{|c|c|c|c|c|c|c|}
\hline \multirow[b]{2}{*}{ Region/Country } & \multirow[b]{2}{*}{1970} & \multirow[b]{2}{*}{1995} & \multirow[b]{2}{*}{2010} & \multirow[b]{2}{*}{2015} & \multicolumn{2}{|c|}{ Annual Percent Change } \\
\hline & & & & & 1970-1995 & 1995-2015 \\
\hline$\ldots \ldots \ldots \ldots \ldots \ldots$ & 135.1 & 200.2 & 248.7 & 260.8 & 1.6 & 1.3 \\
\hline North America & 76.0 & 108.3 & 134.7 & 140.2 & 1.4 & 1.3 \\
\hline Western Europe & 44.7 & 64.6 & 79.3 & 83.8 & 1.5 & 1.3 \\
\hline Pacific ...... & 14.3 & 27.3 & 34.7 & 36.8 & 2.6 & 1.5 \\
\hline Nonindustrialized & 71.7 & 164.7 & 264.9 & 301.1 & 3.4 & 3.1 \\
\hline EE/FSU $\ldots \ldots$ & 39.7 & 52.1 & 70.5 & 75.0 & 1.1 & 1.8 \\
\hline Former Soviet Union . . . . . . . . . . . . . . & 29.0 & 40.0 & 53.8 & 56.8 & 1.3 & 1.8 \\
\hline Eastern Europe $\ldots \ldots \ldots \ldots \ldots \ldots \ldots$ & 10.7 & 12.1 & 16.7 & 18.1 & 0.5 & 2.0 \\
\hline$\ldots \ldots \ldots \ldots \ldots \ldots$ & 18.9 & 69.6 & 134.7 & 159.1 & 5.4 & 4.2 \\
\hline$\ldots \ldots \ldots \ldots \ldots \ldots$ & 11.6 & 35.7 & 69.1 & 82.9 & 4.6 & 4.3 \\
\hline India $\ldots \ldots \ldots \ldots \ldots$ & 2.6 & 10.5 & 21.6 & 26.0 & 5.7 & 4.6 \\
\hline Central and South America $\ldots \ldots \ldots \ldots \ldots$ & 6.6 & 16.8 & 26.0 & 30.2 & 3.8 & 3.0 \\
\hline Middle East $\ldots \ldots \ldots \ldots \ldots \ldots \ldots \ldots$ & 2.9 & 14.1 & 17.5 & 19.1 & 6.5 & 1.5 \\
\hline Africa $\ldots \ldots \ldots \ldots \ldots \ldots \ldots \ldots$ & 3.6 & 12.1 & 16.1 & 17.8 & 5.0 & 1.9 \\
\hline
\end{tabular}

Note: Totals may not equal sum of components due to independent rounding.

Sources: History: Energy Information Administration (EIA), Office of Energy Markets and End Use, International Statistics Database; and International Energy Annual 1995, DOE/EIA-0219(95) (Washington, DC, December 1996). Projections: ElA, World Energy Projection System (1997). 
for Asia and EE/FSU (Figure 14). Nevertheless, the consumption levels in these regions are, in fact, projected to grow substantially over the 1995-2015 period. From 1970 to 1995, annual energy consumption in Central and South America rose at the slowest rate among these three regions, slightly more than doubling, from 6.6 to 16.8 quadrillion Btu. For the forecast period, however, this region is expected to have the highest growth among the three regions, at 3.0 percent a year. Consumption in the Middle East, which rose from 2.9 quadrillion Btu in 1970 to 14.1 quadrillion Btu in 1995, is expected to grow by 1.5 percent per year to 19.1 quadrillion in 2015. Africa's energy consumption rose from 3.6 to 12.1 quadrillion Btu from 1970 to 1995 and is expected to add an additional 6 quadrillion Btu by 2015.

\section{Developing Asia}

By 2015, the developing countries of Asia are expected to consume 159 quadrillion Btu of energy a year, about 60 percent of total consumption by the industrialized countries (Table 4). Consumption of energy by fuel varies substantially by country in Asia, depending on the resources available in each country (Figure 15). Both China and India are heavily dependent on coal, although oil and natural gas consumption is growing at a faster rate than coal in both countries as they experience fast-paced development in the transportation sector and expand their use of natural gas for electricity generation, heating, and cooking. Both countries have large reserves of coal and have drawn heavily upon them in the course of their economic development. Because of its size, China has the largest consumption of oil of any developing country in the region, even though oil is a relatively small portion of its total energy portfolio.
Figure 14. Nonindustrialized Energy Consumption by Region, 1970-2015

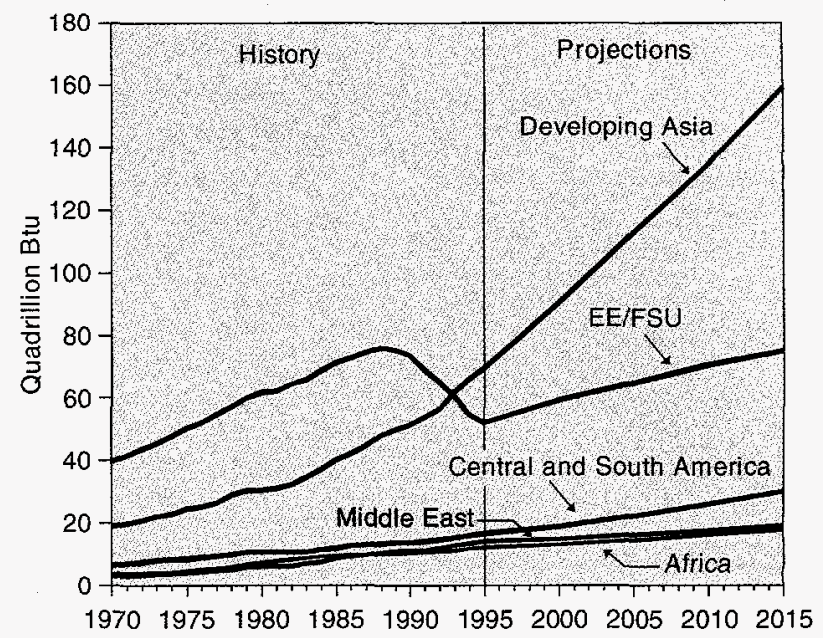

Sources: History: 1970-1979: Energy Information Administration (EIA), Office of Energy Markets and End Use, International Statistics Database. 1980-1995: ElA, International Energy Annual 1995, DOE/ EIA-0219(95) (Washington, DC, December 1996). Projections: EIA, World Energy Projection System (1997).

Coal is expected to remain the dominant fuel in the region-bolstered by the strong growth in China and India-although it has the lowest growth rate of the three major fossil fuels. Natural gas consumption is expected to grow at the fastest rate of any fuel, 7.9 percent per year, leading to more than a fourfold increase in consumption in 2015 from its 1995 level. Oil demand grows at 4.1 percent per year.

The newly industrialized countries in Asia (principally South Korea and Taiwan in terms of total energy consumption) rely most heavily upon oil, with coal next. However, natural gas consumption in these countries is

Table 4. Developing Asia Energy Consumption by Fuel, 1970-2015 (Quadrillion Btu)

\begin{tabular}{|c|c|c|c|c|c|c|}
\hline \multirow[b]{2}{*}{ Energy Source } & \multirow[b]{2}{*}{1970} & \multirow[b]{2}{*}{1995} & \multirow[b]{2}{*}{2010} & \multirow[b]{2}{*}{2015} & \multicolumn{2}{|c|}{ Annual Percent Change } \\
\hline & & & & & 1970-1995 & 1995-2015 \\
\hline Oil & 4.9 & 23.2 & 43.8 & 52.2 & 6.4 & 4.1 \\
\hline Natural Gas & 0.3 & 4.8 & 18.0 & 21.7 & 11.6 & 7.9 \\
\hline Coal ...... & 12.8 & 36.6 & 62.1 & 72.8 & 4.3 & 3.5 \\
\hline Nuclear & 0.0 & 1.2 & 2.6 & 3.2 & 16.5 & 5.1 \\
\hline Renewables & 0.8 & 3.8 & 8.2 & 9.2 & 6.4 & 4.5 \\
\hline Total $\ldots \ldots \ldots$ & 18.9 & 69.6 & 134.7 & 159.1 & 5.4 & 4.2 \\
\hline
\end{tabular}

Note: Totals may not equal sum of components due to independent rounding.

Sources: History: Energy Information Administration (EIA), Office of Energy Markets and End Use, International Statistics Database; and International Energy Annual 1995, DOE/EIA-0219(95) (Washington, DC, December 1996). Projections: EIA, World Energy Projection System (1997). 
Figure 15. Developing Asia Energy Consumption by Fuel, 1995 and 2015

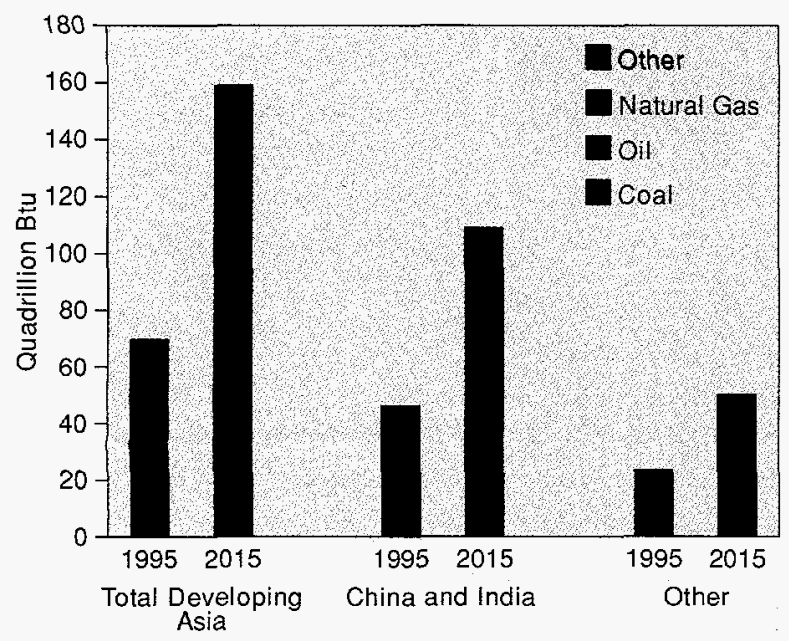

Sources: 1995: Energy Information Administration, International Energy Annual 1995, DOE/EIA-0219(95) (Washington, DC, December 1996). 2015: ElA, World Energy Projection System (1997).

growing at an explosive rate. The remaining developing countries in Asia also rely more heavily on oil, and they also are expected to have high rates of growth for natural gas consumption.

Growth in the industrial sector is the driving force behind the region's strong economic performance. In most countries in developing Asia, the industrial sector is the largest user of energy (the exception being Thailand, where the transportation sector dominates). Energy-intensive industries such as iron and steel, chemicals, cement, and pulp and paper account for 50 to 80 percent of final industrial sector energy demand.

Increasingly, industrial energy demand in the region is relying on electricity, the fastest growing source of enduse energy (Figure 16). Electrification for commercial and residential activities is also spreading, as rising living standards in cities increase the penetration of modern electric appliances and electricity service spreads into more rural areas.

\section{China}

China currently has an energy intensity ${ }^{1}$ that is among the highest in the world. The nation's energy consumption is concentrated in a few major industries that are by nature highly energy intensive and, in China, use energy inefficiently. The inefficiency results from using less efficient technology, having smaller plants (which
Figure 16. Developing Asia Electricity Consumption by Country Group, 1995 and 2015

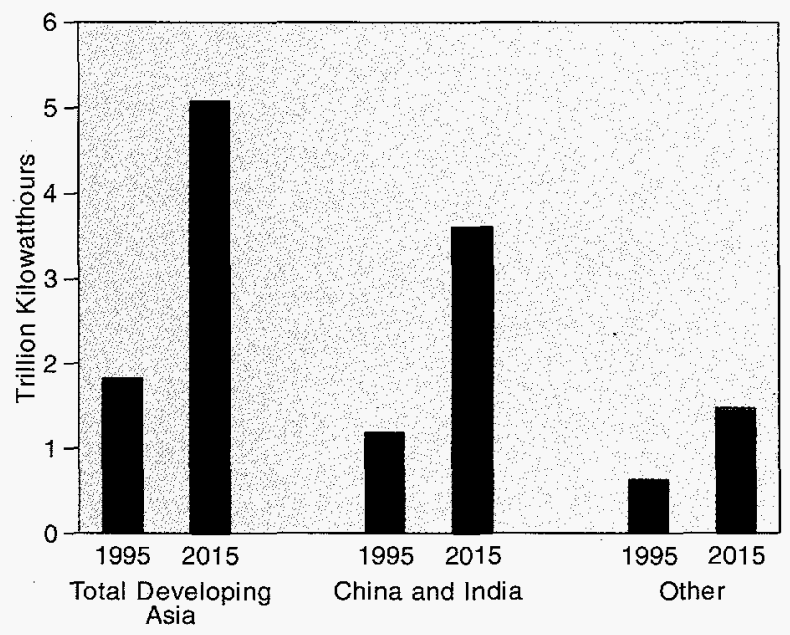

Sources: 1995: Energy Information Administration, International Energy Annual 1995, DOE/EIA-0219(95) (Washington, DC, December 1996). 2015: EIA, World Energy Projection System (1997).

reduces the opportunities for attaining economies of scale), and failure to maintain energy-efficient operations within plants [4, p. 196]. The industries-including chemicals, primary metals, cement, and pulp and paper-are those that are necessary for the development of infrastructure that underpins economic growth.

The chemical industry uses the largest amount of industrial energy in China. China is also one of the largest iron and steel producers in the world, and that industry claims the second largest share of the nation's energy consumption. Energy intensity in the Chinese steel industry was 35 percent higher than in the United States in 1995 [5]. China produces one-fifth of the world's cement, making it the largest producer in the world. Growth in these industries is expected to remain strong as China continues to develop basic infrastructure.

Most of the improvement in China's energy intensity has come in the industrial sector. One study estimated that 80 percent of the improvement from 1980 to 1985 was in industrial consumption, of which 91 percent was due to improvement in the efficiency of energy use [6]. The other 9 percent was due to shifts in industrial output to less energy-intensive products. China has ongoing, explicit plans for efficiency improvements in these core industries. The plans have been successful in the past and are expected to continue to be so in the future. A gradual shift to less energy-intensive activities

${ }^{1}$ Energy intensity is the ratio of energy consumption to gross domestic product. 
is expected to continue. Consequently, China's energy intensity is expected to improve by about 50 percent over the course of the projections.

The transportation system in China is relatively underdeveloped, accounting for a modest share (about 9 percent) of the nation's total energy consumption [4, pp. 182-183]. Rail plays a major role in the transportation sector, accounting for 29 percent of transportation sector consumption. However, the rail system in China is fully utilized and is expected to be under increasing pressure to ship freight. Moreover, as is often the case for developing economies, increased personal wealth has resulted in the desire for more individual and comfortable means of transportation. The number of small cars in China grew from less than 250,000 in 1980 to almost 1.3 million in 1990 to nearly 2 million in 1993.

Passenger road traffic grew by 13 percent per year between 1990 and 1994, which was twice the rate of growth for rail traffic; and road passenger traffic grew from 32 to 45 percent of all passenger traffic. Nevertheless, the overall 5-percent growth rate in transportation energy consumption was below the 10-percent growth rate in GDP [5]. A substantial expansion of the road network in China is expected, but growth in road transportation will be hindered by the current low level of development of roads and related infrastructure. The rail system has been dominated by coal-fired steam locomotives, which are being replaced by diesel-fired locomotives, further increasing the demand for petroleum fuels in the transportation sector.

A major source of uncertainty regarding future energy requirements in China is the way in which transportation demand, associated especially with light-duty vehicles, may evolve. If recent experience in Thailand and South Korea [7] is repeated in China, the growth projected here could be drastically underestimated.

\section{Eastern Europe and the Former Soviet Union}

\section{Economic Growth}

The Russian Federation and other countries of the former Soviet Union have had a difficult time recovering from their economic transition. Their economies remain in the doldrums, with negative or only slightly positive economic growth [8]. Russia, whose economy dominates the FSU, accounting for slightly more than 60 percent of its total income, is expected to have shown a modest decline in GDP in 1996 to be followed by a small rise in 1997. Ukraine, the second largest economy in the group with just over 15 percent of GDP, will lag slightly behind Russia, with the potential for a 7-percent decline in 1996, but its economy should have a slight rise in 1997. Most of the rest of the FSU is expected to have positive GDP growth in 1996, with possibly one or two exceptions among countries that have small levels of GDP [9, pp. 2.4-2.5].

The Baltic states (Estonia, Latvia, and Lithuania) have led the economic turnaround in the FSU, with positive economic growth in 1995. These countries account for only about 3 percent of the region's total GDP, however, and so have little impact on the statistics for the FSU overall. Thus, the central economic question for the FSU turns from "when will the decline be arrested" to "how fast will the economies grow."

The countries of Eastern Europe experienced a much less severe disruption to their economies than did those in the former Soviet Union in their transition from centrally planned to market economies, but the economic picture in the region has been mixed in recent years. Poland-the dominant economy in the region, accounting for about 40 percent of its total income-was the first to recover, experiencing positive growth in 1992 $[10, p$. xii]. The region as a whole had positive economic growth in 1993 as Romania (the region's fourth largest economy), Slovenia, and Albania joined Poland in the positive growth category. The Czech Republic, which has the second highest level of income in the region, showed a slight decline in 1993 but joined the rest of the countries in 1994 when all had positive economic growth.

Because it started its recovery earlier and now seems to be moving more quickly toward resolution of some of its political and institutional problems, the Eastern Europe region is assumed to have a higher rate of economic growth over the forecast period than is the FSU. The EE/FSU region as a whole is expected to surpass its 1990 level of economic activity by 2010, when energy consumption is projected to total about 71 quadrillion Btu-a level only slightly below that for 1990 (Table 5). The pace of future growth for the region is still highly uncertain, however, as the transition from centrally planned to market economies and from totalitarian Communist to democratic political systems poses many difficulties.

\section{Energy Use}

Oil and natural gas dominate energy consumption in the FSU, whereas coal is the principal energy source in Eastern Europe (Figure 17). For the EE/FSU region as a whole, natural gas dominates, followed by coal and then oil. By 2015, coal consumption in the region is expected to decline slightly, while natural gas and oil use increase by almost 70 percent.

Electricity consumption in the EE/FSU region fell by about 20 percent between 1990 and 1995. Over the 
Table 5. Eastern Europe/Former Soviet Union Energy Consumption by Fuel, 1970-2015 (Quadrillion Btu)

\begin{tabular}{|c|c|c|c|c|c|c|c|}
\hline \multirow[b]{2}{*}{ Energy Source } & \multirow[b]{2}{*}{1970} & \multirow[b]{2}{*}{1990} & \multirow[b]{2}{*}{1995} & \multirow[b]{2}{*}{2010} & \multirow[b]{2}{*}{2015} & \multicolumn{2}{|c|}{ Annual Percent Change } \\
\hline & & & & & & 1970-1995 & $1995-2015$ \\
\hline Oil & 13.5 & 21.0 & 12.1 & 17.8 & 20.2 & -0.4 & 2.6 \\
\hline Natural Gas & 7.4 & 26.0 & 21.0 & 33.2 & 35.8 & 4.3 & 2.7 \\
\hline Coal ..... & 17.2 & 20.8 & 13.4 & 13.1 & 12.5 & -1.0 & -0.3 \\
\hline Nuclear & 0.0 & 2.9 & 2.5 & 2.9 & 2.3 & 18.2 & -0.6 \\
\hline Renewables & 1.5 & 2.8 & 3.1 & 3.6 & 4.1 & 2.8 & 1.4 \\
\hline Total $\ldots \ldots \ldots \ldots$ & 39.7 & 73.6 & 52.1 & 70.5 & 75.0 & 1.1 & 1.8 \\
\hline
\end{tabular}

Note: Totals may not equal sum of components due to independent rounding.

Sources: History: Energy Information Administration (EIA), Office of Energy Markets and End Use, International Statistics Database; and International Energy Annual 1995, DOE/EIA-0219(95) (Washington, DC, December 1996). Projections: EIA, World Energy Projection System (1997).

Figure 17. EE/FSU Energy Consumption by Fuel, 1995 and 2015

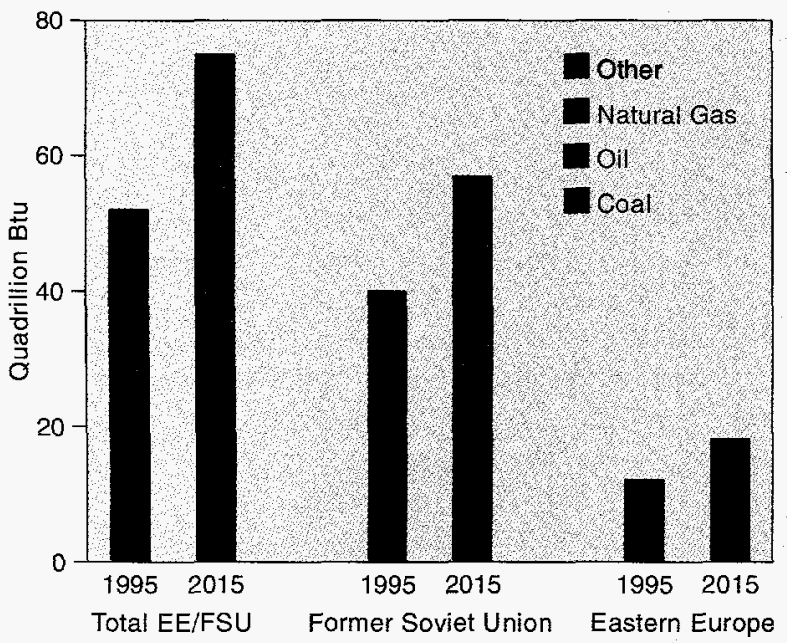

Sources: 1995: Energy Information Administration, International Energy Annual 1995, DOE/EIA-0219(95) (Washington, DC, December 1996). 2015: EIA, World Energy Projection System (1997).

forecast period, however, electricity use rises by 29 percent in the FSU and by 54 percent in the countries of Eastern Europe (Figure 18). Natural gas is expected to remain the major fuel source for electricity generation in the FSU, because of the favorable economics of gas-fired generation and because the gas infrastructure is already well established [11, p. 153]. The International Energy Agency has estimated that demand for electricity will rise more quickly in the residential sector in the FSU than in the industrial sector, which now consumes more than 70 percent of total generation [12, p. 375].

In Eastern Europe, electricity consumption is projected to reach 589 billion kilowatthours in 2015. Here, too,
Figure 18. EE/FSU Electricity Consumption, 1995 and 2015

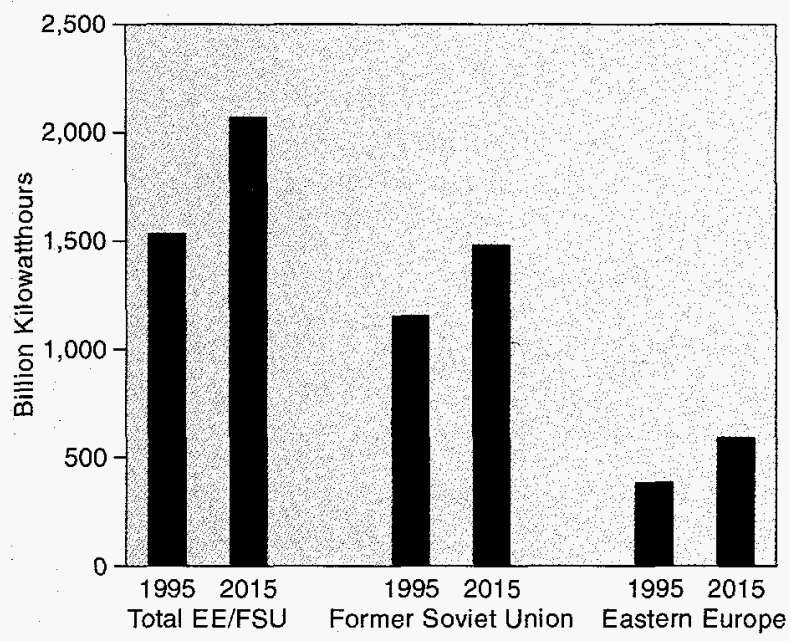

Sources: 1995: Energy Information Administration, International Energy Annual 1995, DOE/EIA-0219(95) (Washington, DC, December 1996). 2015: EIA, World Energy Projection System (1997).

industry consumes most of the electricity that is generated (62 percent in 1994), and the strongest demand growth is expected for the residential sector [12, p. 375]. At present, coal is the leading fuel source for electricity generation in Eastern Europe, but the share claimed by natural gas is projected to double in the forecast, from 8 percent in 1995 to 18 percent in 2015 , as the countries in the region strive to diversify their fuel supplies with new pipeline connections to Western Europe.

Before the start of its economic collapse, the EE/FSU had one of the highest energy intensities in the world. Over the 1970 to 1989 period, its energy intensity rose while the world average fell slightly, and the average 
intensity for developing Asia fell even faster. Inefficiency in the EE/FSU region was the result of policies in which domestic energy prices were kept below world market prices. The artificially low energy prices encouraged development of an industrial base that uses energy very inefficiently. With the decline in its economic fortunes, the EE/FSU energy intensity index rose substantially over the past several years even as energy consumption declined every year since 1989 [7, p. 169], because GDP declined even faster.

Economic activity and energy consumption in the EE/FSU are projected to resume positive growth beyond 1995, but the EE/FSU nations will likely continue to be the world's most inefficient users of energy for some time. Energy distribution systems are not geared to metering and pricing to encourage economizing of energy use. Residences frequently do not have energy meters or control equipment, and energy use in the residential sector is inelastic with respect to both price and income. An analysis of the appliances currently in use and the opportunities for increasing their efficiency suggests that improvement in the sector will be a slow process.

Capital shortage makes it difficult to reform energy economies within the industrial sector. Although progress toward price reform has been made, much more is necessary to moderate the subsidization of energy use throughout the economy. One of the reasons for the high energy intensity of the EE/FSU is that industry, as is the case for developing Asian countries, accounts for a substantial portion of total economic activity, and the region has a relatively small service sector. In 1990 in the FSU, industry accounted for a bit less than 50 percent of total energy consumption, although IEA estimates suggest that level had fallen to about 27 percent by 1993 [11, p. 138].

In the past, there was little incentive to build energy efficiency into industrial processes, a factor that boosted industrial energy demand even further. The future course of energy intensity will depend on the level of investment in new capital equipment in energyintensive industries with energy use characteristics more in line with practices in the industrialized countries, as well as the relative rate of growth of less energy-intensive industrial activities.

Along with the return to positive economic growth, the EE/FSU is expected to experience a rise in energy consumption (Table 5). In 2015, total projected consumption reaches 75 quadrillion Btu, 23 more than in 1995. However, as energy consumption fell more slowly than income during the decline, it is also expected to rise more slowly as the economies begin to grow. This region is expected to have a smaller energy-to-GDP elasticity (a more rapidly declining energy intensity) than any other region of the world over the forecast period. As the region's economies rebuild, they are expected to reduce the inefficiency in energy use through the use of more efficient technology and the rationalization of the energy system by moving toward a system of prices that properly reflect the market costs of the fuel, in contrast to the artificially low, subsidized prices that characterized the region before 1990.

Energy intensity in the EE/FSU region in 2015 is expected to be well below the peak reached in 1993 and even a bit below its 1970 level. Energy intensity drops more rapidly than the world average and even faster than the intensity for developing Asia over the forecast period. The growth in energy use per capita falls behind that of developing Asia, where energy consumption rises more rapidly, but grows at twice the rate of the world average. This region is projected to have the lowest population growth rate among the nonindustrialized regions, at 0.2 percent per year, an important factor contributing to the rise in energy consumption per capita.

\section{Fuel Mix}

The FSU is among the richest regions of the world in terms of energy resources, including having the largest known reserves of natural gas. Natural gas has been the dominant fuel in the EE/FSU, and its use is projected to increase the most over the forecast period. From 21 quadrillion Btu in 1995, natural gas consumption is expected to increase by more than 70 percent to 35.8 quadrillion Btu in 2015.

In the past, the region has relied almost as heavily on coal and oil as it has on natural gas. In 1990, both oil use and coal use were around 21 quadrillion Btu (Table 5). By 1995, however, the consumption of oil had fallen much more than coal, dropping almost 9 quadrillion Btu, compared with a decline of about 7.4 quadrillion Btu in coal use. In contrast, oil consumption is projected to rebound with the economic turnaround, reaching 20.2 quadrillion in 2015, whereas coal consumption is expected to continue declining to 12.5 quadrillion Btu in 2015 as it is displaced by cleaner natural gas and as more energy-efficient equipment is installed.

With the substantial shift from coal to natural gas, carbon emissions in the EE/FSU are projected to remain well below their 1990 level through 2015, even though total energy consumption in the forecast for 2015 is slightly higher than it was in 1990. Although coal historically has been the largest source of carbon emissions in the region, by 2000 carbon emissions from 
natural gas are expected to surpass those from coal, and by 2010 carbon emissions from oil edge past those from coal.

\section{Alternative Growth Cases}

Long-term projections of energy consumption are subject to substantial uncertainties. Two key issues for energy consumption projections relate to (1) consequences of alternative paths of economic growth and (2) consequences of alternative paths of energy use relative to income growth. The IEO97 forecasts include a baseline set of assumptions for these variables to provide a reference case. To depict a range of uncertainty, two additional cases have been developed, with higher and lower economic growth rates relative to those in the reference case. The consequences of alternative assumptions about changes in energy. intensity are examined below for the nonindustrialized nations.

In the reference case, total economic activity worldwide is expected to grow at an average rate of 3.1 percent a year from 1995 to 2015 (Table 6). The industrialized nations are assumed to average 2.5-percent annual growth, compared with an average of 4.7 percent a year for the developing nations and 3.6 percent for EE/FSU. Growth rates within the developing areas are expected to vary widely: China's growth is projected at 7.3 percent per year, while Central and South America are expected to grow at less than half that rate.

There have been substantial differences in economic growth rates both within and between regions over time. For developing nations, in particular, unexpected outcomes have played a major role in national or regional development in the past and are likely to do so in the future. The more mature industrialized economies grow more slowly and show less variation than those of the developing nations and the EE/FSU, but their economic growth is also subject to uncertainty.

For the high and low economic growth cases, different assumptions were made about the range of possible economic growth rates for developing and industrialized nations, reflecting the greater uncertainty inherent in attempts to forecast economic growth in developing economies. The same pattern of change in energy

Table 6. Annual Growth Rates in Gross Domestic Product by Region and for Selected Countries, 1970-2015 (Percent per Year)

\begin{tabular}{|c|c|c|c|c|c|}
\hline \multirow[b]{2}{*}{ Region/Country } & \multicolumn{2}{|c|}{ History } & \multicolumn{3}{|c|}{ Projections } \\
\hline & $1970-1980$ & 1980-1990 & $1990-2000$ & $2000-2015$ & 1995-2015 \\
\hline$\ldots \ldots \ldots \ldots \ldots \ldots \ldots$ & 3.2 & 2.8 & 2.3 & 2.4 & 2.5 \\
\hline$\ldots \ldots \ldots \ldots \ldots \ldots$ & 3.0 & 2.6 & 2.7 & 2.3 & 2.4 \\
\hline Western Europe & 3.0 & 2.6 & 2.0 & 2.5 & 2.5 \\
\hline Pacific $\ldots \ldots \ldots \ldots \ldots \ldots \ldots$ & 4.3 & 4.0 & 2.4 & 2.7 & 2.8 \\
\hline Nonindustrialized & 4.4 & 2.8 & 2.4 & 4.5 & 4.5 \\
\hline EE/FSU $\ldots \ldots \ldots \ldots \ldots \ldots \ldots$ & 3.2 & 2.1 & -3.6 & 3.6 & 3.6 \\
\hline Former Soviet Union $\ldots \ldots \ldots \ldots \ldots \ldots$ & 3.2 & 2.1 & -4.0 & 3.5 & 3.6 \\
\hline Eastern Europe $\ldots \ldots \ldots \ldots \ldots \ldots$ & 3.5 & 1.8 & -0.5 & 4.2 & 4.0 \\
\hline Developing ..... & 5.4 & 3.3 & 5.1 & 4.7 & 4.7 \\
\hline Asia ... . & 6.3 & 6.9 & 7.2 & 5.8 & 6.0 \\
\hline$\ldots \ldots \ldots \ldots \ldots \ldots \ldots \ldots$ & 5.8 & 8.9 & 10.2 & 7.1 & 7.3 \\
\hline Other $\ldots \ldots \ldots \ldots \ldots \ldots \ldots$ & 6.4 & 6.3 & 6.1 & 5.2 & 5.3 \\
\hline Middle East $\ldots \ldots \ldots \ldots \ldots \ldots \ldots$ & 4.8 & 1.5 & 2.6 & 2.8 & 2.7 \\
\hline Africa $\ldots \ldots \ldots \ldots \ldots \ldots \ldots$ & 4.2 & 1.4 & 3.4 & 3.5 & 3.4 \\
\hline Central and South America . . . . . . . & 5.8 & 1.1 & 3.9 & 3.6 & 3.5 \\
\hline Total World & 3.5 & 2.8 & 2.3 & 3.0 & 3.1 \\
\hline
\end{tabular}

Note: India is included in other developing Asia.

Sources: History: Derived from WEFA Group, World Economic Service Historical Data (July 1993). Projections: WEFA Group, World Economic Outlook, Vol. 1 (Bala Cynwyd, PA, November 1995); U.S. data from Energy Information Administration (EIA), Annual Energy Outlook 1997, DOE/EIA-0383(97) (Washington, DC, December 1996); and EIA, World Energy Projection System (1997). 
intensity relative to change in GDP (discussed below) was assumed for the high and low growth cases as for the reference case. For industrialized countries, increments of +0.5 and -0.5 percentage points, respectively, were added to the reference case growth rates to generate the high and low growth cases. For nonindustrialized countries and/or regions, apart from China and EE/FSU, increments of +1.5 and -1.5 percentage points were used to generate the high and low growth cases.

China and the EE/FSU countries are special cases with regard to prospects for future economic growth. China has experienced quite high economic growth in the past few years, and the EE/FSU region has suffered a severe economic downturn. For both regions, the opportunity for a substantial change in growth exists: China has the potential for a larger decline in growth rate given its currently high rate, and there are prospects for a substantial increase in the rate of growth for EE/FSU nations should their current political and institutional problems be moderated sufficiently for the recovery of a considerable industrial base. Reflecting these uncertainties, -3 percentage points were added to China's growth rate for the low economic growth case and +1.5 for the high case; and +3.0 percentage points were added to the EE/FSU growth rate for the high economic growth case and -1.5 for the low case.

In the reference case, total world energy consumption is projected to reach 562 quadrillion Btu in 2015, with industrialized countries consuming 261 quadrillion Btu and the rest of the world 301 quadrillion Btu (Table 7 and Figure 19). Under the assumptions of the high economic growth case, total world energy consumption would be 650 quadrillion Btu in 2015, 89 quadrillion Btu higher than the reference case projection. In the low economic growth case, worldwide consumption would be 482 quadrillion Btu, down 80 quadrillion Btu from

\section{Figure 19. World Energy Consumption in Three Cases, 1970-2015}

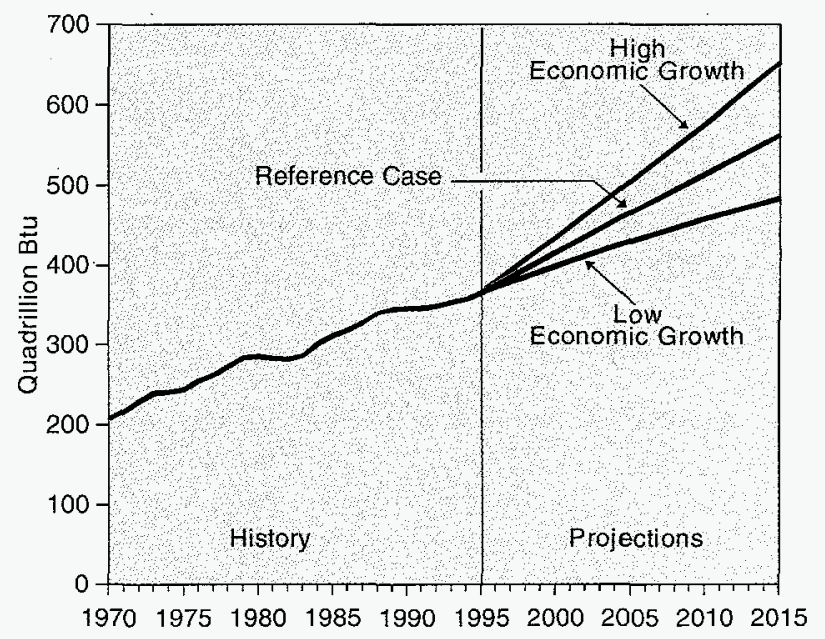

Sources: History: 1970-1979: Energy Information Administration (EIA), Office of Energy Markets and End Use, International Statistics Database. 1980-1995: EIA, International Energy Annual 1995, DOE/ EIA-0219(95) (Washington, DC, December 1996). Projections: EIA, World Energy Projection System (1997).

Table 7. Annual World Energy Consumption by Region in Three Economic Growth Cases, 1970, 1995, 2005, and 2015

(Quadrillion Btu)

\begin{tabular}{|c|c|c|c|c|c|c|c|c|}
\hline \multirow[b]{3}{*}{ Region } & \multicolumn{2}{|c|}{ History } & \multicolumn{6}{|c|}{ Projections } \\
\hline & \multirow[b]{2}{*}{1970} & \multirow[b]{2}{*}{1995} & \multicolumn{3}{|c|}{2005} & \multicolumn{3}{|c|}{2015} \\
\hline & & & Low & Reference & High & Low & Reference & High \\
\hline Industrialized & 135.1 & 200.2 & 227.2 & 235.0 & 242.5 & 245.4 & 260.8 & 276.9 \\
\hline EE/FSU & 39.7 & 52.1 & 60.0 & 64.8 & 74.2 & 65.1 & 75.0 & 97.4 \\
\hline Developing & 32.0 & 112.6 & 141.9 & 166.0 & 185.4 & 171.4 & 226.2 & 276.1 \\
\hline China . & 11.6 & 35.7 & 47.3 & 57.1 & 62.2 & 58.4 & 82.9 & 97.7 \\
\hline Other Asia & 7.2 & 33.9 & 48.2 & 55.8 & 63.5 & 60.2 & 76.3 & 94.8 \\
\hline Total World . . . & 206.7 & 364.9 & 429.1 & 465.7 & 502.1 & 481.9 & 561.9 & 650.4 \\
\hline
\end{tabular}

Note: India is included in developing other Asia.

Sources: 1970: Energy Information Administration (EIA), Office of Energy Markets and End Use, International Statistics Database. 1995: EIA, International Energy Annual 1995, DOE/EIA-0219(95) (Washington, DC, December 1996). Projections: EIA, Annual Energy Outlook 1997, DOE/EIA-0383(97) (Washington, DC, December 1996); and ElA, World Energy Projection System (1997). 
the reference case. Thus, for the range of growth rates used in the high and low cases, the associated spread in total international consumption is 169 quadrillion Btu, or 30 percent of the total consumption projected for 2015 in the reference case. Developing nations contribute 105 quadrillion Btu to the spread, reflecting the higher potential variability in economic growth rates associated with their economic development.

Changes in energy intensity (the ratio of total energy consumption to GDP) also have a substantial influence on the projections presented in this report. As economies grow, the energy intensity of the additional economic activity will influence the course of energy consumption. In industrialized countries, the expansion of economic activity has tended to be in areas that are less energy intensive. Further, more energy-efficient technology has been adopted in many areas. As a result, energy consumption in the industrialized countries has grown more slowly than GDP since the mid-1970s (Figure 13). The divergence, which developed after the Arab oil embargo of 1973-1974, has persisted even as oil and other energy prices have fallen to pre-embargo levels in real terms. Thus, by 2015, world GDP is expected to be almost 4 times its 1970 level but energy use only 3 times its 1970 level.

In contrast, energy demand has risen at a more rapid rate than GDP in some regions (Figure 12). This pattern is expected to persist during the early years of the projection period. While the future path of energy intensity for the developing nations and economies in transition is subject to much uncertainty and is therefore more difficult to project than that for industrialized nations, the IEO97 projections assume that, between 2000 and 2015, energy intensity will decline in developing regions. Figure 20 depicts the historical and projected energy intensities used in this report.

The dynamics of growth in energy consumption are demonstrated by considering an approximate measure of the elasticity of change in energy consumption relative to change in GDP. To smooth the year-to-year differences, an average elasticity is calculated for a 5year period. The elasticity is the percentage change in energy consumption divided by the percentage change in GDP. When the elasticity is greater than 1, each percentage point increase in GDP results in more than 1 percentage point increase in consumption. Consequently, when the average elasticity is greater than 1, energy intensity is increasing; and when it is less than 1, energy intensity is decreasing.

For the industrialized nations as a whole, the energy-toGDP elasticity has been less than 1 (Table 8 ). The economic troubles of the EE/FSU countries distorted their
Figure 20. Energy Intensities by Region, 1970-2015

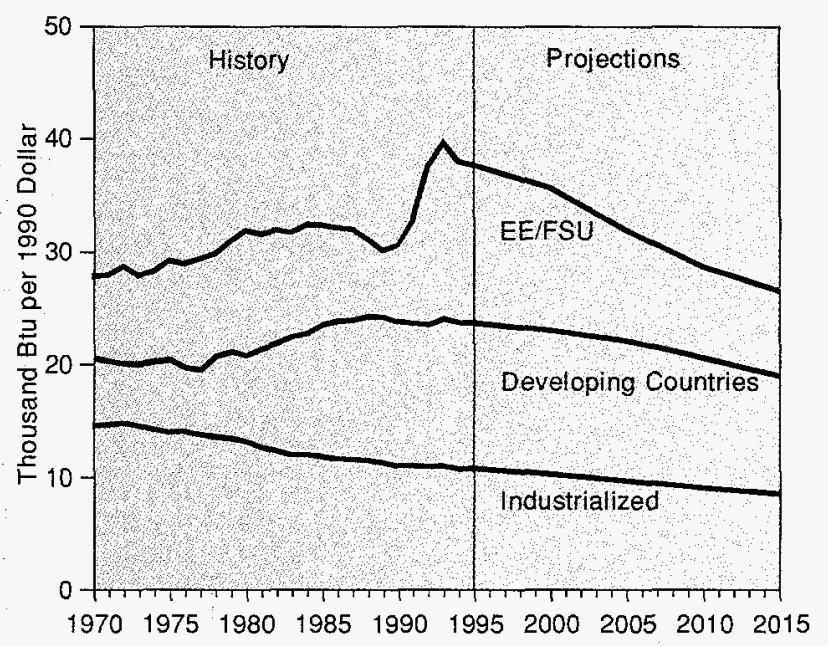

Sources: History: 1970-1979: Energy Information Administration (EIA), Office of Energy Markets and End Use, International Statistics Database. 1980-1995: ElA, International Energy Annual 1995, DOE/ EIA-0219(95) (Washington, DC, December 1996). Projections: ElA, World Energy Projection System (1997).

energy intensity picture for the 1990 to 1995 period, when GDP and energy consumption were both declining, but GDP fell more rapidly, leading to a rise in energy intensity and a positive energy-to-GDP elasticity. For developing nations, the average elasticity hovered around 1 for the 1970 to 1980 period, corresponding to relatively flat energy intensity values (Table 8); from 1980 to 1985 the average elasticity was about 2, and it has since declined through 1995.

The decline in energy-to-GDP elasticity for developing nations is projected to continue through 2015 in the IEO97 forecasts, but at a slower rate than that for industrialized nations. The projected reduction in energy intensity is based on the assumption that energy-efficient technologies used in industrialized nations will increasingly be adopted in the developing nations. The widespread use of efficient technology could come about through pressures for economic efficiency as the developing and transitional economies become more market driven and more integrated into a world market. Environmental considerations could be another factor contributing to the adoption of more efficient technologies around the world, but they will have to compete with more extensive use of energy technologies in industry, buildings, and transportation. The balance of that competition is uncertain, as is the pace at which energy-saving technologies will be introduced.

The reference case projections assume a substantial rate of decline in energy intensity. Several recent reports on 
Table 8. Average Energy Elasticity (Change in Consumption Versus Change in Gross Domestic Product), 1970-2015: World, Industrialized, EE/FSU, Developing, and Developing Asia

\begin{tabular}{|c|c|c|c|c|c|c|c|c|c|}
\hline \multirow[b]{2}{*}{ Region/Country } & \multicolumn{5}{|c|}{ History } & \multicolumn{4}{|c|}{ Projections } \\
\hline & 1975 & 1980 & 1985 & 1990 & 1995 & 2000 & 2005 & 2010 & 2015 \\
\hline Total World & 0.95 & 0.92 & 0.67 & 0.65 & 0.85 & 0.83 & 0.73 & 0.64 & 0.63 \\
\hline Industrialized & 0.74 & 0.65 & 0.04 & 0.54 & 0.94 & 0.66 & 0.54 & 0.46 & 0.43 \\
\hline $\mathrm{EE} / \mathrm{FSU}$ & 1.27 & 1.70 & 1.13 & 0.39 & 0.64 & 0.70 & 0.44 & 0.43 & 0.45 \\
\hline Developing & 0.97 & 1.07 & 2.03 & 1.03 & 1.00 & 0.87 & 0.81 & 0.69 & 0.65 \\
\hline Asia & 1.03 & 0.61 & 0.85 & 0.71 & 0.79 & 0.84 & 0.74 & 0.63 & 0.60 \\
\hline China & 0.88 & 0.53 & 0.50 & 0.52 & 0.46 & 0.64 & 0.59 & 0.56 & 0.55 \\
\hline Other $\ldots \ldots \ldots \ldots \ldots \ldots \ldots$ & 1.21 & 0.83 & 1.10 & 0.91 & 1.07 & 0.98 & 0.85 & 0.64 & 0.61 \\
\hline
\end{tabular}

Notes: $E E / F S U=$ Eastern Europe/Former Soviet Union. The elasticity was calculated for each 5-year period by dividing the percentage change in energy consumption by the percentage change in GDP. India is included in other developing Asia.

Sources: History: Derived using gross domestic product data from WEFA Group, World Economic Service Historical Data (July 1993) and World Economic Outlook, Vol. 1 (1996), and energy consumption data from Energy Information Administration (ElA), International Energy Annual 1995, DOE/EIA-0219(95) (Washington, DC, December 1996). Projections: ElA, World Energy Projection System (1997).

China illustrate different views on this subject. In one report, China: Issues and Options in Greenhouse Gas Emissions Control [13], which provides a forecast to the year 2020, the baseline forecast has an energy-to-GDP elasticity of 0.56 , comparable to that assumed for IEO97. In contrast, the discussion paper, Energy Demand in Five Major Asian Developing Countries [14], assumes an elasticity of 0.78 through 2005 . Using this larger energy-toGDP elasticity with the GDP growth assumptions in IEO97 to 2015 (well beyond the intended range of the discussion paper) would give a total energy consumption for China in 2015 that is about 27 quadrillion Btu larger than the reference case forecast of 83 quadrillion Btu.

Still another report, Pacific Energy Outlook by the EastWest Center [15], has a more optimistic view of the decline in China's future energy intensity, with an implicit energy-to-GDP elasticity of about 0.47 for the 1995 to 2010 period. This elasticity applied to the IEO97 GDP growth rates would place total energy consumption for China at about 71 quadrillion Btu in 2015. Thus, the range of estimates for China's energy consumption, using this range of estimates for energy-to-GDP elasticities, is about 39 quadrillion Btu, or 47 percent of the IEO97 reference case forecast for China's total consumption.

Because assumptions about energy intensity have such a strong influence on energy consumption projections, it is useful to consider the effects of alternative assumptions for the developing nations group and the
EE/FSU. Under the possibly pessimistic view that development in the nonindustrialized nations will not result in changes in energy intensity (an energy-to-GDP elasticity of 1.0), total energy consumption in 2015 by nonindustrialized nations would be 435 quadrillion Btu, an increase of 134 quadrillion Btu over the reference case projection (Table 9). On the optimistic side, if it is assumed that the average energy intensity for nonindustrialized nations will decline on average at the same rate as that for industrialized nations, their total energy consumption in 2015 would be 55 quadrillion Btu less than in the reference case (Table 9).

\section{Consumption Patterns by Energy Source}

\section{Electricity Use}

Electricity is the most rapidly growing component of energy demand throughout the world (Figures 2, 3, and 4). In the industrialized countries, electricity showed strong growth between 1970 and 1995, at 3.3 percent per year, in contrast to 1.6-percent annual growth in total energy use. Between 1995 and 2015 the growth rate for electricity demand in the industrialized economies is projected to slow to 2.2 percent per year, exceeding 10 trillion kilowatthours by 2015 . Electricity consumption in the rest of the world grew by 4.7 percent per year between 1970 and 1995 and is expected to grow by 3.7 percent per year between 1995 and 2015, reaching 9 trillion kilowatthours (see Table A8 in Appendix A). 
Table 9. Variation in Nonindustrialized Energy Consumption in 2015, Given Alternative Assumptions About Energy Intensity

(Quadrillion Btu)

\begin{tabular}{|c|c|c|}
\hline Alternative Assumptions & $\begin{array}{l}\text { Nonindustrialized Energy } \\
\text { Consumption, } 2015\end{array}$ & $\begin{array}{l}\text { Change from } \\
\text { Reference Case }\end{array}$ \\
\hline $\begin{array}{l}\text { Developing and EE/FSU energy intensities } \\
\text { remain constant at } 1995 \text { levels } \ldots \ldots \ldots \text {. }\end{array}$ & 435 & +134 \\
\hline IEO97 reference case & 301 & - \\
\hline $\begin{array}{l}\text { Developing and EE/FSU energy intensities } \\
\text { decline at industrialized rate } \ldots \ldots \ldots \ldots \ldots \ldots \ldots\end{array}$ & 246 & -55 \\
\hline
\end{tabular}

Source: Energy Information Administration, World Energy Projection System (1997).

Electricity growth has been particularly strong in developing Asia, where the 1995 level of electricity consumption was about 6.9 times its 1970 level (Figure 21). In that region, electricity consumption is expected to nearly triple again by 2015 , as aggressive industrialization and urbanization plans also entail aggressive development of electricity supplies.

\section{Fuels for Electricity Generation}

Throughout the forecast, coal is expected to remain the dominant fuel used for electricity generation worldwide (Figure 22). Slow growth in coal-fired generating capacity in industrialized countries (Figure 23) is expected to be offset by rapid expansion in the rest of the world (Figure 24), primarily in Asia. The large increase in electricity consumption in developing Asia-particular-

Figure 21. Nonindustrialized Electricity Consumption by Region, 1970-2015

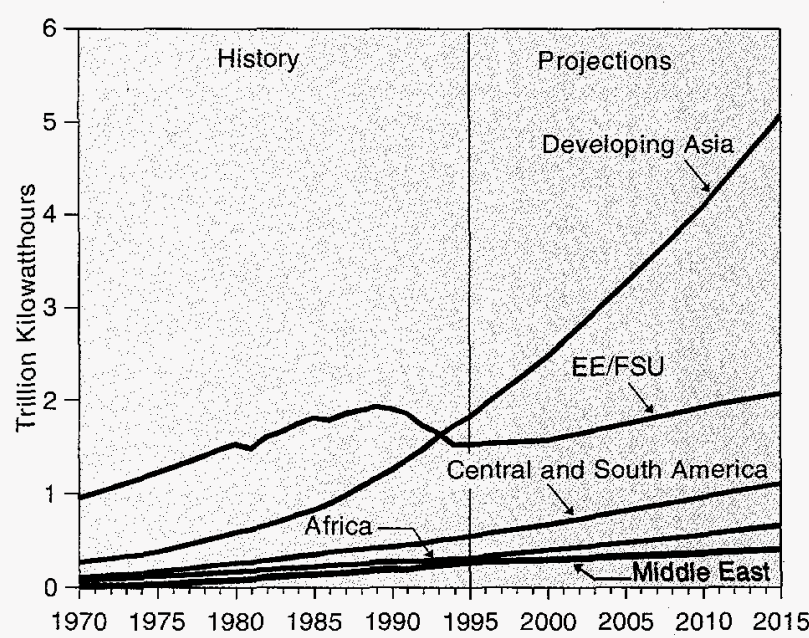

Sources: History: 1970-1979: Energy Information Administration (E|A), Office of Energy Markets and End Use, International Statistics Database. 1980-1995: EIA, International Energy Annual 1995, DOE/ EIA-0219(95) (Washington, DC, December 1996). Projections: EIA, World Energy Projection System (1997). ly, China and India-accounts for a major portion of the overall rise in coal-fired generation. Both countries are rich in coal reserves and have well-developed infrastructures for coal mining and distribution, and because their oil and natural gas infrastructures are relatively less developed, coal is their most economical fuel.

Renewables (primarily hydropower) are currently the world's second largest source for electric power generation, followed closely by nuclear power and natural gas (Figure 22). Both renewables and natural gas continue to grow as energy sources for electricity generation throughout the forecast. China contributes substantially to the growth in renewables through an expansion of hydropower, and a number of countries in developing Asia and other parts of the world are turning to gas as their first choice for expansion of generation capacity.

Figure 22. World Energy Use for Electricity Generation by Fuel Type, 1995-2015

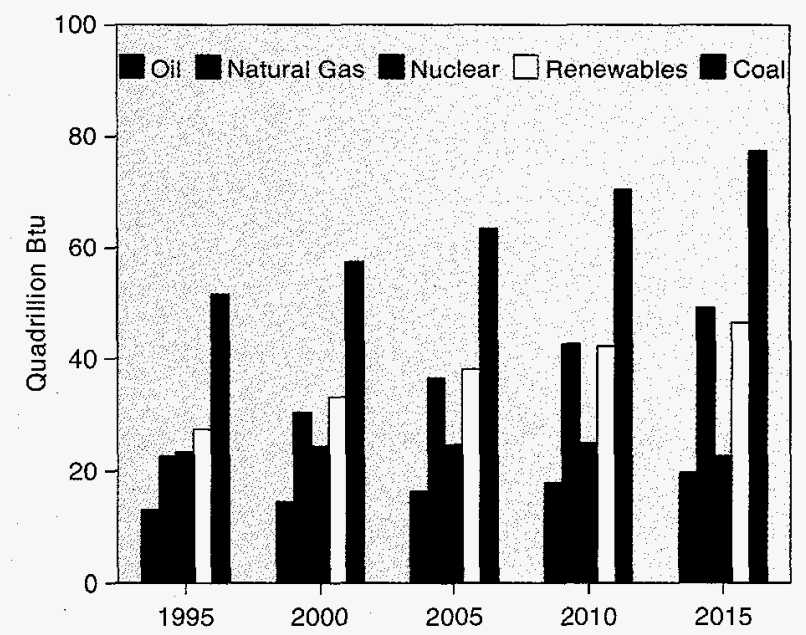

Sources: History (1995): Energy Information Administration, International Energy Annual 1995, DOE/ EIA-0219(95) (Washington, DC, December 1996). Projections: EIA, World Energy Projection System (1997). 
Oil use for electricity generation changes little in the forecast.

Only nuclear power, among all energy sources, is expected to decline both relatively and absolutely over the projection horizon. Some areas will increase reliance on nuclear power: new plants will be commissioned in China, Japan, and South Korea. However, plants in the United States and in other countries with mature nuclear programs are expected to be retired more rapidly than new plants are activated in other areas. Substantial capacity reduction is expected in the FSU and after 2010 in the United States, where plants that reach the end of their designated operating lives are, in general, expected to be retired.

\section{Natural Gas}

Among all fossil fuels, natural gas use is expected to increase at the most rapid rate over the next two decades. By 2015 the energy value of natural gas consumption worldwide is expected to exceed that of coal (Table 2). In 1970, coal consumption exceeded natural gas use (in energy value) by 65 percent. As the level of gas use has risen, the geographical dispersion of consumption has also broadened greatly. In 1970 the major portion of natural gas consumption was in the United States. Since 1970, growth in natural gas consumption has occurred in all regions. By 1990 the U.S. share of world gas consumption had dropped to almost 27 percent, and Europe and the FSU had become major users. Over the next two decades, the use of natural gas in

Figure 23. Industrialized Energy Use for Electricity Generation by Fuel Type, 1995-2015

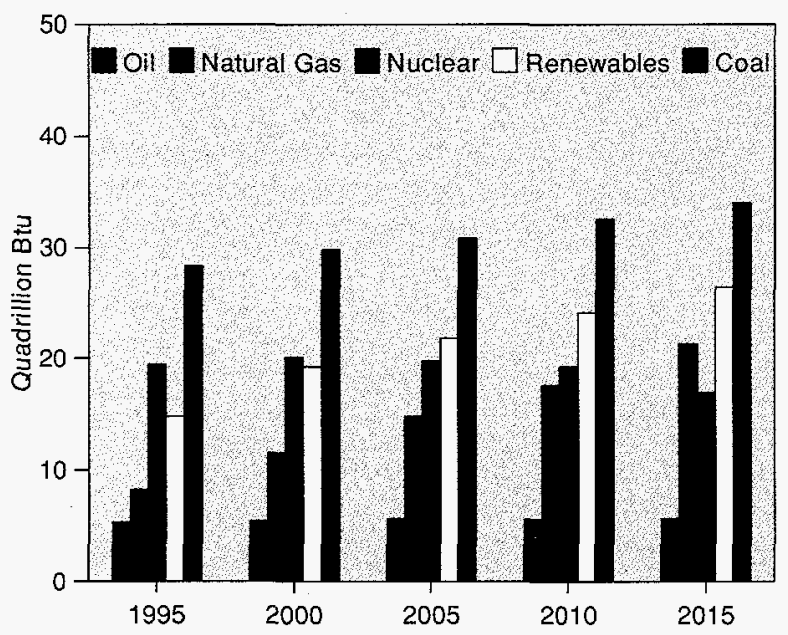

Sources: History (1995): Energy Information Administration, International Energy Annual 1995, DOE/ ElA-0219(95) (Washington, DC, December 1996). Projections: ElA, World Energy Projection System (1997) established markets is expected to rise, while in Asia and Central and South America major increments will be added to demand (Table 10).

Factors boosting natural gas use include widespread availability of recoverable reserves, rapid expansion of systems for gas gathering and distribution, and the favorable emissions characteristics of natural gas combustion. Use of natural gas helps to moderate local air pollution problems, especially when gas is substituted for coal in electric power generation.

\section{Oil}

Oil has been the dominant energy source historically and is projected to remain so during the projection period (Figure 9 and Table 10). By 2015, oil consumption throughout the world is projected to total about 105 million barrels per day. On the other hand, growth in oil consumption is expected to trail growth in total energy use over the next two decades. Oil demand in industrialized countries is projected to increase by only about 1.1 percent per year (Figure 25 and Table 10), with much of the projected growth occurring in the transportation sector, where petroleum fuels continue to have limited competition from other energy sources. In the rest of the world, oil demand is expected to increase by 3.3 percent per year on average, with growth occurring in all economic sectors (Figure 26 and Table 10). By 2015, the developing economies and EE/FSU combined are projected to consume as much oil as the industrialized economies, and world oil requirements

\section{Figure 24. Nonindustrialized Energy Use for Electricity Generation by Fuel Type, 1995-2015}

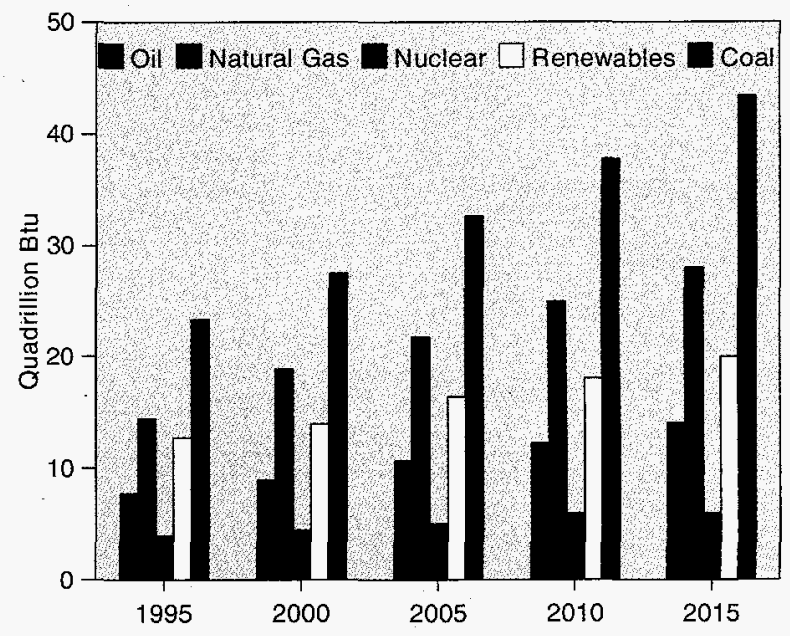

Sources: History (1995): Energy Information Administration, International Energy Annual 1995, DOE/ ElA-0219(95) (Washington, DC, December 1996). Projections: EIA, World Energy Projection System (1997). 
Table 10. World Energy Consumption by Region and Fuel, 1970-2015 (Quadrillion Btu)

\begin{tabular}{|c|c|c|c|c|c|c|}
\hline \multirow[b]{2}{*}{ Region and Energy Source } & \multirow[b]{2}{*}{1970} & \multirow[b]{2}{*}{1995} & \multirow[b]{2}{*}{2010} & \multirow[b]{2}{*}{2015} & \multicolumn{2}{|c|}{ Annual Percent Change } \\
\hline & & & & & $1970-1995$ & $1995-2015$ \\
\hline Industrialized & 135.1 & 200.2 & 248.7 & 260.8 & 1.6 & 1.3 \\
\hline Oil & 70.6 & 84.8 & 101.2 & 105.0 & 0.7 & 1.1 \\
\hline Natural Gas & 27.1 & 42.1 & 63.3 & 70.2 & 1.8 & 2.6 \\
\hline Coal ...... & 27.7 & 36.9 & 40.9 & 42.3 & 1.2 & 0.7 \\
\hline Nuclear & 0.8 & 19.4 & 19.2 & 16.9 & 13.4 & -0.7 \\
\hline Renewables & 8.8 & 17.0 & 24.1 & 26.4 & 2.7 & 2.2 \\
\hline Developing and EE/FSU & 71.7 & 164.7 & 264.9 & 301.1 & 3.4 & 3.1 \\
\hline Oil & 27.2 & 56.4 & 93.6 & 108.4 & 3.0 & 3.3 \\
\hline Natural Gas & 9.1 & 35.5 & 65.6 & 74.5 & 5.6 & 3.8 \\
\hline Coal ...... & 32.0 & 56.2 & 81.8 & 92.4 & 2.3 & 2.5 \\
\hline Nuclear & 0.1 & 3.9 & 5.9 & 5.9 & 17.8 & 1.9 \\
\hline Renewables & 3.3 & 12.7 & 18.0 & 19.9 & 5.5 & 2.3 \\
\hline
\end{tabular}

Note: Totals may not equal sum of components due to independent rounding.

Sources: History: Energy Information Administration (EIA), Office of Energy Markets and End Use, International Statistics Database; and International Energy Annual 1995, DOE/EIA-0219(95) (Washington, DC, December 1996). Projections: EIA, World Energy Projection System (1997).

are expected to exceed 1995 levels by more than 35 million barrels per day. This increment is greater than the current level of oil production from all of OPEC.

The oil demand projections for 2015 are higher by 5.7 million barrels per day in IEO97 than they were in IEO96. The additional consumption reflects primarily a higher assessment of the quantity of petroleum prod-

Figure 25. Industrialized Energy Consumption by Fuel Type, 1970-2015

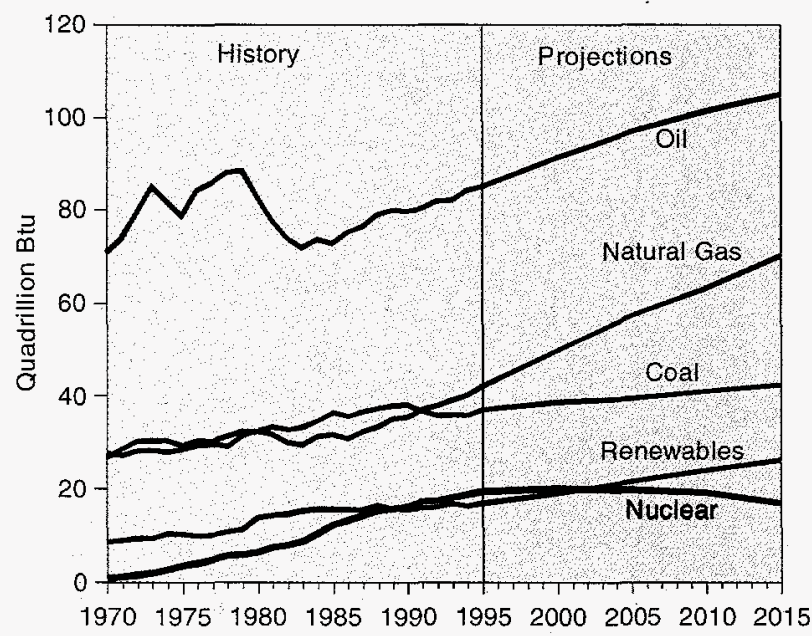

Sources: History: 1970-1979: Energy Information Administration (EIA), Office of Energy Markets and End Use, International Statistics Database. 1980-1995: EIA, International Energy Annual 1995, DOE/ EIA-0219(95) (Washington, DC, December 1996). Projections: EIA, World Energy Projection System (1997). ucts expected to be used for transportation in developing countries.

The worldwide growth in oil demand is expected to lead to a rise in oil prices over the projection period, but the price rise projected in IEO97 is smaller than in last year's forecast. Oil prices in the reference case reach $\$ 21$ a barrel (1995 dollars) in 2015, \$5 lower than the

\section{Figure 26. Nonindustrialized Energy Consumption by Fuel Type, 1970-2015}

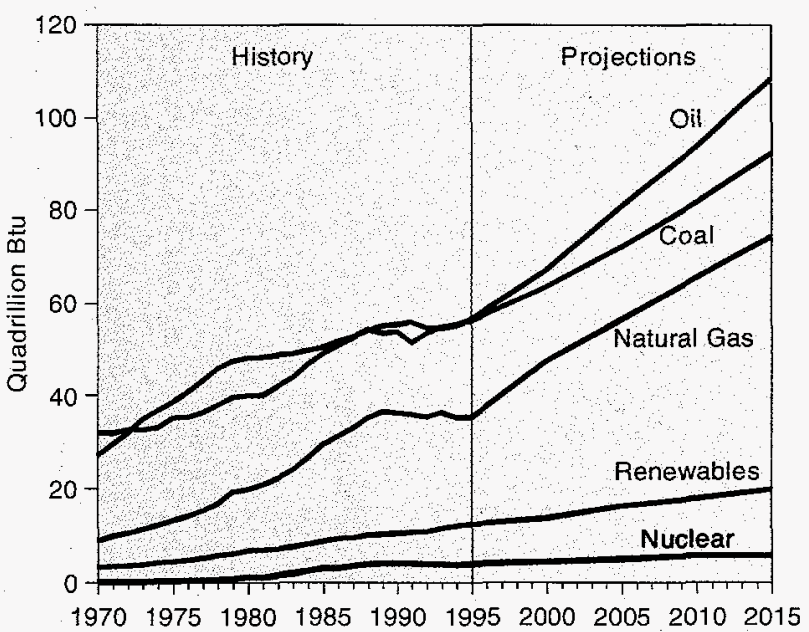

Sources: History: 1970-1979: Energy Information Administration (EIA), Office of Energy Markets and End Use, International Statistics Database. 1980-1995: EIA, International Energy Annual 1995, DOE/ EIA-0219(95) (Washington, DC, December 1996). Projections: EIA, World Energy Projection System (1997). 
2015 price of $\$ 26$ a barrel that was projected last year. The high and low world oil price cases included in the IEO97 forecast cover a range between $\$ 14$ and $\$ 28$ per barrel in 2015, as detailed in the following chapter.

A principal factor underlying the lower growth rate for oil prices in IEO97 is the expectation that oil production in non-OPEC nations will continue to expand in the near future. There has been a marked improvement in technology applied to oil exploration, development, and production in recent years. The increasingly widespread use of three-dimensional seismic imaging, horizontal drilling, and subsea well completion technologies has helped to revive production from mature oil provinces and to reduce development and production costs from new provinces. As a consequence, the size and geographic diversity of economical sources of oil supply have grown. While the vast reserves of the Middle East still hold the most promise for assuring large-scale availability of reasonably priced oil, the reserve and production potentials of other areas of the world have expanded substantially. Thus, future growth in oil demand may be served by a wider array of supply areas than was hitherto thought possible.

\section{Carbon Emissions Trends}

World carbon emissions are expected to increase by 3.5 billion metric tons over current levels by 2015-growing at a rate just over 2 percent per year-if world energy consumption reaches the levels projected in the IEO97 reference case (Table A9 and Figure 27). According to this projection, world carbon emissions in 2015 would exceed 1990 levels by 61 percent. Oil and coal contribute about 1.5 and 1.1 billion metric tons, respectively, to the projected increase, and natural gas provides the remainder (Tables A10, A11, and A12 and Figure 28).

Carbon emissions from energy use in industrialized countries are expected to increase by 923 million metric tons to about 4.1 billion metric tons in 2015 (Figure 29), or by about 1.3 percent a year. Emissions from the combustion of petroleum products account for more than 40 percent of the increase, and those from natural gas approach the level of carbon emissions from coal. Coal, which is "dirtier" with respect to carbon dioxide (as well as sulfur dioxide and nitrogen oxide), will remain a major source of emissions, primarily because of its role as an economical fuel for baseload electric power generation in the absence of increased regulation of carbon emissions.

By 2000 , carbon emissions in the rest of the world are expected to surpass those in the industrialized countries, even though developing countries will use less
Figure 27. World Carbon Emissions Trends, 1970-2015

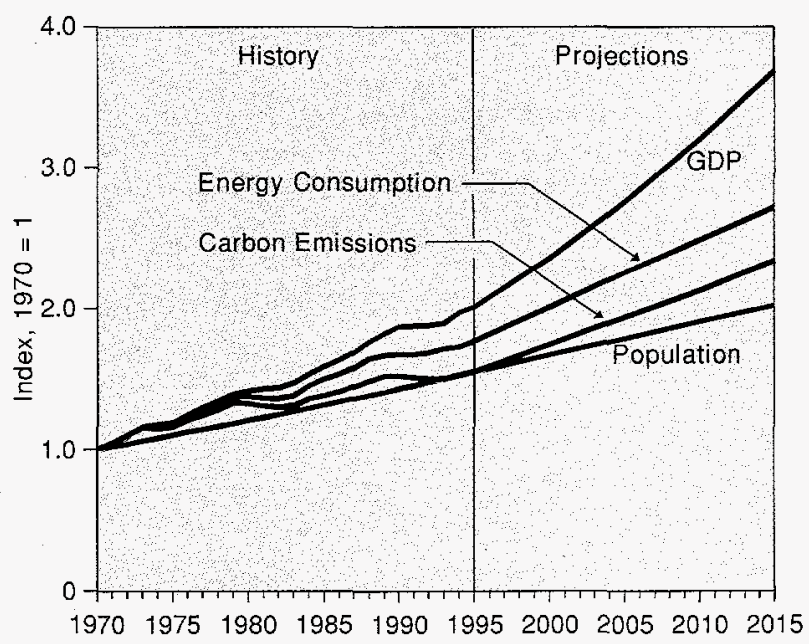

Sources: History: 1970-1979: Energy Information Administration (EIA), Office of Energy Markets and End Use, International Statistics Database. 1980-1995: ElA, International Energy Annual 1995, DOE/ EIA-0219(95) (Washington, DC, December 1996). Projections: Gross Domestic Product (GDP): WEFA Group, World Economic Outlook, Vol. 1 (Eddystone, PA, November 1996). Energy Consumption: EIA, World Energy Projection System (1997).

Figure 28. World Carbon Emissions by Fuel, 1970-2015

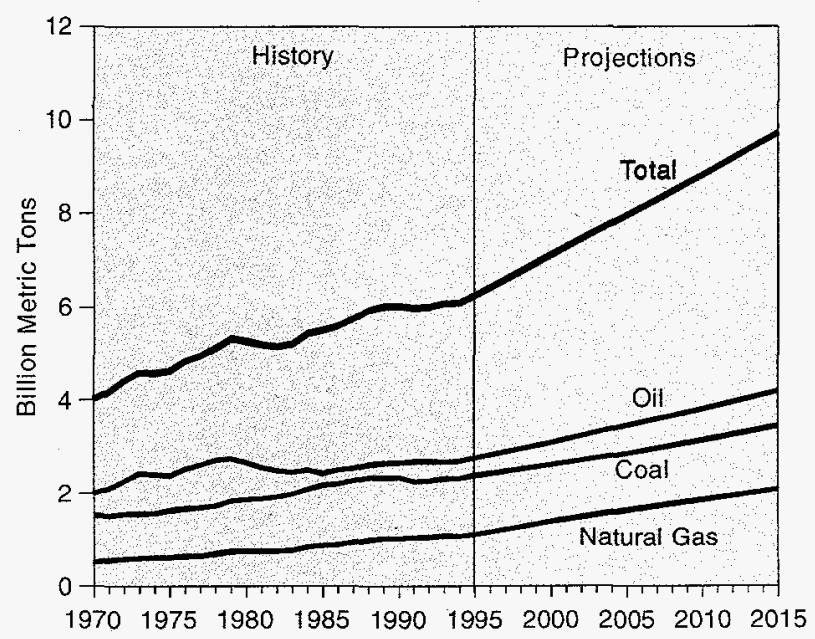

Sources: History: 1970-1979: Energy Information Administration (EIA), Office of Energy Markets and End Use, International Statistics Database. 1980-1995: EIA, International Energy Annual 1995, DOE $t$ ElA-0219(95) (Washington, DC, December 1996). Projections: EIA, World Energy Projection System (1997).

energy at that time. Total emissions in the nonindustrialized regions are expected to increase by 2.5 billion metric tons to a total of 5.6 billion metric tons in 2015 (Figure 29), representing about 73 percent of the projected increase worldwide. The sizable rise in emissions 


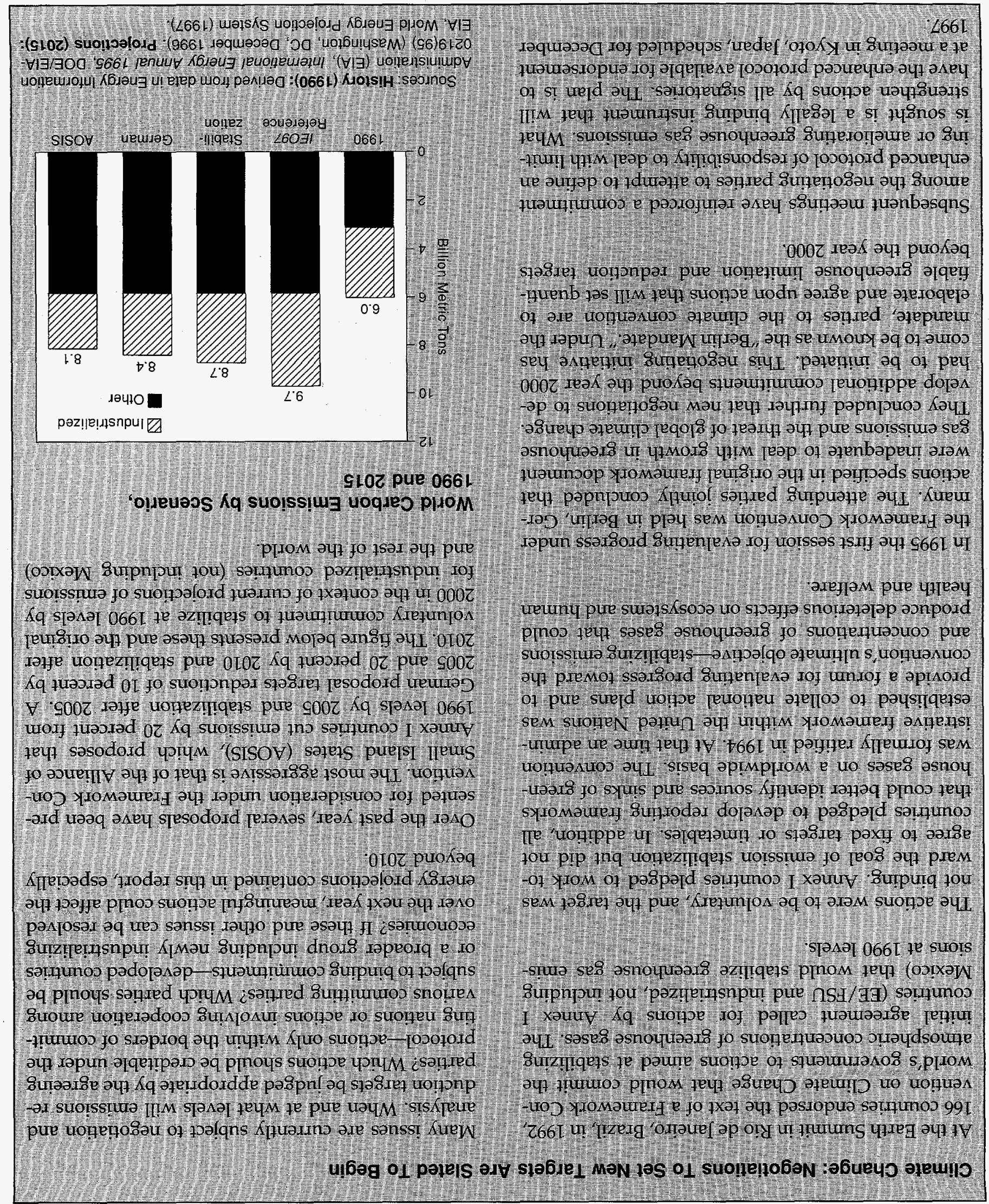


Figure 29. World Carbon Emissions by Region and Fuel, 1990, 2000, and 2015

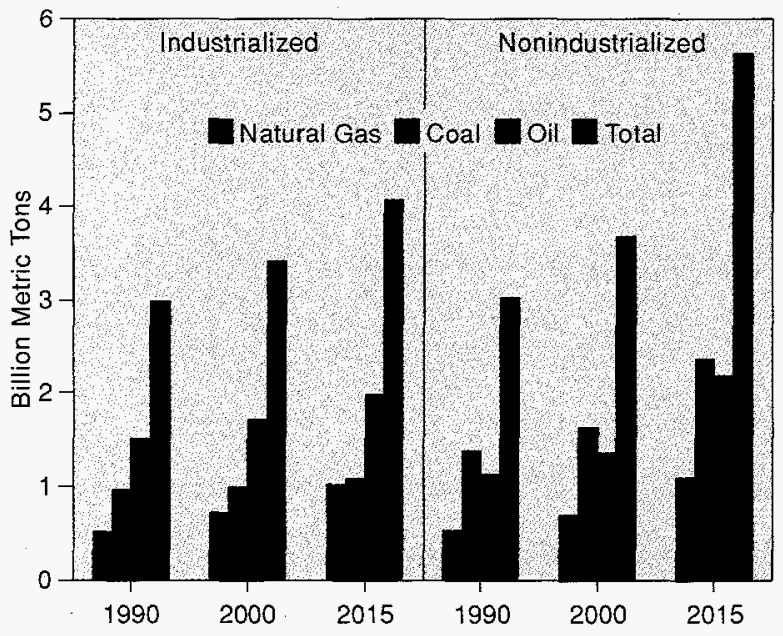

Sources: History (1990): Derived from Energy Information Administration (EIA), International Energy Annual 1995, DOE/EIA0219(95) (Washington, DC, December 1996). Projections: EIA, World Energy Projection System (1997).

from developing countries is partially a result of their heavy dependence on coal, the most carbon-intensive of the fossil fuels. Coal is used extensively in the developing Asia region, which has the highest expected rate of economic growth. Carbon emissions in developing Asia are projected to increase from 1.5 billion metric tons in 1995 to 3.2 billion metric tons in 2015.

While coal use grows at the slowest rate among the three fossil fuels worldwide, the relatively high level of carbon emissions per Btu of energy from coal leads to higher growth in emissions from coal than from oil or natural gas. A high rate of natural gas penetration is the principal factor curtailing the growth of emissions relative to the growth rate for energy in the projection period. Alternative energy sources are not expected to grow sufficiently to mitigate carbon emissions. Although the share of renewables in the overall energy supply is projected to increase slightly, that trend is offset by a reduction in the use of nuclear power.

More than 100 countries are signatories to the United Nations Framework Convention on Climate Change. The ultimate concern of the Convention is to encourage worldwide efforts to achieve stabilization of greenhouse gas concentrations at levels that would forestall the threat of global warming. Industrialized countries within the OECD have pledged to pursue efforts that could stabilize greenhouse gas emissions at their 1990 levels. Negotiations are currently underway to clarify commitments regarding projected stabilization targets (see box on opposite page).
Energy combustion accounts for 85 percent of all greenhouse gas emissions. Thus, what happens to international energy use is of fundamental importance to the concerns identified in the Convention agreement. Although developed countries are projected to increase their energy use relatively slowly, at this point, taken as a whole, they are not on a path to stabilizing greenhouse gas emissions from energy use. If such stabilization were achieved by the industrialized nations, annual carbon emissions in 2015 would be about 1 billion metric tons less than projected in this report; nonetheless, worldwide emissions would still rise by 45 percent from their 1990 levels-to about 8.7 billion metric tons in 2015-because of the rapid rate of growth in energy use in other parts of the world.

\section{Comparisons with Other Forecasts}

Another way to depict uncertainty in the IEO97 projections (in addition to the alternative cases described above) is to compare them with other forecasts. Three organizations provide forecasts comparable to those in IEO97. The International Energy Agency provides two energy demand scenarios in its World Energy Outlook 1996-the Capacity Constraints Case (IEA CC) and the Energy Savings Case (IEA ES). Petroleum Economics, Ltd. (PEL) and Petroleum Industry Research Associates (PIRA) also publish energy forecasts. Two of the forecasts (IEA CC and PIRA) expect higher levels of growth in energy demand over the next two decades than those presented here, and the PEL forecast projects roughly the same level of growth (Table 11).

All the forecasts for total world energy consumption fall within the range spanned by the IEO97 low economic growth and high economic growth cases (Table 11). Generally speaking, regional forecasts for energy demand are fairly similar in that they show modest growth over the forecast horizon for the industrialized countries, strong demand growth in the developing world, and small growth or declines in the EE/FSU region. PEL is the most pessimistic about economic recovery in the EE/FSU, projecting an annual average decline in energy demand of 1.2 percent over its forecast horizon. IEO97 projects slightly faster growth in energy demand between 1990 and 2010 than was projected in last year's IEO, with higher growth expected in the industrialized and developing countries but lower expectations for the recovery of energy demand in the EE/FSU.

One major reason for differences between the forecasts lies in their assumptions about regional economic growth rates (Table 12). The four forecasts show similar expectations with respect to economic growth in the 
Table 11. Comparison of Energy Consumption Growth Rate Projections, 1990-2010, by Region (Average Annual Percent Growth)

\begin{tabular}{|c|c|c|c|c|c|c|c|c|}
\hline \multirow[b]{2}{*}{ Region } & \multicolumn{3}{|c|}{ IEO97 } & \multirow[b]{2}{*}{ IEO96 } & \multirow[b]{2}{*}{ IEA CC ${ }^{a}$} & \multirow[b]{2}{*}{ IEA ES ${ }^{a}$} & \multirow[b]{2}{*}{ PEL } & \multirow[b]{2}{*}{ PIRA $^{b}$} \\
\hline & $\begin{array}{l}\text { Low } \\
\text { Growth }\end{array}$ & Reference & $\begin{array}{l}\text { High } \\
\text { Growth }\end{array}$ & & & & & \\
\hline Industrialized Countries & 1.3 & 1.5 & 1.7 & 1.3 & 1.4 & 0.8 & 1.2 & 1.5 \\
\hline EE/FSU & -0.7 & -0.2 & 0.8 & -0.1 & 0.8 & 0.0 & -1.2 & -0.9 \\
\hline Developing Countries & 3.0 & 4.1 & 4.9 & 3.7 & 4.3 & 4.0 & 4.4 & 5.3 \\
\hline Total World . . . . . . . . . & 1.4 & 2.0 & 2.6 & 1.8 & 2.2 & 1.8 & 1.9 & 2.4 \\
\hline
\end{tabular}

a IEA growth rates are for the period 1993-2010.

bPIRA growth rates are for the period 1990-2005.

Sources: IEO97: Energy Information Administration (EIA), World Energy Projection System (1997). IEO96: EIA, International Energy Outlook 1996, DOE/EIA-0484(96) (Washington, DC, May 1996), Table A1, p. 91. IEA CC: International Energy Agency, World Energy Outlook 1996 (Paris, France, 1996), Capacity Constraints Case, pp. 237-249. IEA ES: International Energy Agency, World Energy Outlook 1996 (Paris, France, 1996), Energy Savings Case, pp. 257-269. PEL: Petroleum Economics, Ltd., Oil and Energy Outlook to 2010 (London, United Kingdom, December 1996). PIRA: Petroleum Industry Research Associates, Inc., Annual Retainer Client Seminar-World Energy (New York, NY, October 1996), Table II-4.

Table 12. Comparison of Economic Growth Rate Assumptions, 1990-2010, by Region (Average Annual Percent Growth)

\begin{tabular}{|c|c|c|c|c|c|c|c|}
\hline \multirow[b]{2}{*}{ Region } & \multicolumn{3}{|c|}{ IEO97 } & \multirow[b]{2}{*}{ IEO96 } & \multirow[b]{2}{*}{ IEA $^{a}$} & \multirow[b]{2}{*}{ PEL } & \multirow[b]{2}{*}{ PIRA $^{b}$} \\
\hline & Low Growth & Reference & High Growth & & & & \\
\hline Industrialized & 1.9 & 2.4 & 2.7 & 2.4 & 2.5 & 2.2 & 2.1 \\
\hline North America $\ldots \ldots \ldots$ & 2.0 & 2.4 & 2.8 & 2.2 & 2.6 & 2.3 & 2.1 \\
\hline Western Europe $\ldots \ldots \ldots$ & 1.8 & 2.2 & 2.6 & 2.3 & 2.5 & 2.0 & 2.1 \\
\hline Pacific $\ldots \ldots \ldots \ldots \ldots$ & 2.2 & 2.6 & 3.0 & 2.7 & 2.5 & 2.2 & 2.2 \\
\hline EE/FSU $\ldots \ldots \ldots \ldots \ldots$ & -1.0 & 0.1 & 2.4 & -0.2 & 2.9 & - & 0.0 \\
\hline Former Soviet Union . . . . . . . & -1.3 & -0.1 & 2.1 & -0.5 & 2.3 & -0.1 & - \\
\hline Eastern Europe $\ldots \ldots \ldots$ & 0.6 & 1.8 & 4.0 & 1.5 & 4.1 & 1.8 & - \\
\hline Developing Countries $\ldots \ldots$ & 3.3 & 4.9 & 5.9 & 4.8 & 5.4 & - & 5.9 \\
\hline Developing Asia ..... & 4.8 & 6.6 & 7.6 & 6.2 & 6.6 & - & 6.9 \\
\hline China . . . . . . . & 5.8 & 8.7 & 9.5 & 8.4 & 7.8 & 8.4 & 8.5 \\
\hline Other Asia & 4.4 & 5.6 & 6.8 & 5.4 & 6.0 & 6.3 & 5.2 \\
\hline Middle East & 1.5 & 2.7 & 3.9 & 3.3 & 3.6 & 3.5 & 3.4 \\
\hline Africa $\ldots \ldots \ldots \ldots \ldots$ & 2.0 & 3.4 & 4.4 & 2.8 & 4.1 & 3.2 & 2.9 \\
\hline Central and South America .. & 2.1 & 3.6 & 4.5 & 3.8 & 3.7 & 3.3 & 3.5 \\
\hline Total World $\ldots \ldots \ldots \ldots \ldots$ & 1.9 & 2.7 & 3.3 & 2.6 & 3.2 & 2.8 & 3.6 \\
\hline
\end{tabular}

${ }^{a}$ IEA uses the same GDP growth assumptions in the Capacity Constraints and Energy Savings cases. Growth rates are for the period 1993-2010.

bPIRA growth rates are for the period 1990-2005.

Notes: IEO97, IEO96: India is included in Developing Other Asia. Mexico is included in North America. PEL: North America includes only the United States. Industrialized Pacific includes only Japan. Mexico is included in Central and South America. PIRA: North America includes only the United States and Canada. Mexico is included in Central and South America. Industrialized Pacific includes only Japan. Asia is defined as South Asia and Southeast Asia and Pacific.

Sources: IEO97: Energy Information Administration (EIA), World Energy Projection System (1997). IEO96: EIA, International Energy Outlook 1996, DOE/EIA-0484(96) (Washington, DC, May 1996). IEA: International Energy Agency, World Energy Outlook 1996 (Paris, France, 1996), Table A2, p. 234. PEL: Petroleum Economics, Ltd., Oil and Energy Outlook to 2010 (London, United Kingdom, December 1996). PIRA: Petroleum Industry Research Associates, Inc., Annual Retainer Client Seminar-World and U.S. Oil (New York, NY, October 1996), Table II-1. 
industrialized world. Economic growth rates assumed for the industrial countries differ by only four-tenths of a percentage point. There are sizable differences, however, in the assumptions made about the rate of economic recovery in the EE/FSU, underscoring the uncertainty that surrounds the region's economic future. Both of the IEA forecast cases expect an average annual growth rate of 2.9 percent over the forecast horizon, much more optimistic than the PIRA forecast, whichhaving the lowest estimate for the region-shows no economic growth in the region whatsoever.

It should be noted, however, that the IEA estimate is for the period 1993 to 2010 rather than 1990 to 2010, and the PIRA estimate is for the period 1990 to 2005. The time differences are significant, because there was a substantial loss of GDP between 1990 and 1993 for the EE/FSU region (about 31 percent), and there is substantial potential for recovery in the region after 2005. Further, IEO97 projects average growth of 2.4 percent a year between 1993 and 2010 for the EE/FSU but an average decline of -1.1 percent a year between 1990 and 2005. Indeed, all three forecasts in which GDP growth rates were projected for the EE/FSU over the 2000 to 2010 time period (IEO97, IEA, and PEL) show expected annual economic growth of about 4 percent. Even though the forecasts generally expect some economic recovery in the EE/FSU economies, GDP levels are not expected to recover to their 1990 levels before 2010 .

All the forecasts agree that the countries of developing Asia will experience the most rapid growth over the 20year period. Further, all agree that China, with GDP growth assumptions ranging from 7.8 to 8.7 percent a year, will have the strongest economic growth worldwide. The IEO97 estimate is the highest of the four forecasts.

In large part, differences in projected world energy requirements flow directly from different assumptions about economic growth. As seen for the comparison of economic growth rates (Table 12), the IEO97 projection of 2.0-percent annual growth in total world energy use (Table 11) is in the middle of the forecasts, which range from 1.8 percent (IEA ES) and 1.9 percent (PEL) to 2.2 percent (IEA CC) and 2.4 percent (PIRA). Small differences in growth rates can lead to sizable differences in estimates of future consumption when projected over 20 years. For example, the difference of 0.4 percentage point between the PIRA and IEO97 reference case growth rates for world energy consumption translates into about 40 quadrillion Btu more energy use in 2010 in the PIRA forecast.

\section{References}

1. J. Cox, "Thailand Thrives in Investment Fast Lane," The Detroit News (March 3, 1996).

2. W. Raynal, "Expansion-Minded Automakers Are Looking to the East," The Detroit News (January 25, 1996).

3. WEFA Group, World Economic Outlook, Vol. 1 (Eddystone, PA, November 1996).

4. International Energy Agency, World Energy Outlook 1994 (Paris, France, 1994).

5. E.I. McCreary, A.Y. Gu, V.W. Loose, and J.M. Roop, China's Energy: A Forecast to 2015 (Los Alamos, NM: Los Alamos and Pacific Northwest National Laboratories, September 1996).

6. F. Liu, W.B. Davis, and M.D. Levine, An Overview of Energy Supply and Demand in China, LBL-32275 (Berkeley, CA: Lawrence Berkeley National Laboratory, May 1992).

7. Energy Information Administration, International Energy Annual 1995, DOE/EIA-0219(95) (Washington, DC, December 1996).

8. PlanEcon, Review and Outlook for the Former Soviet Republics (Washington, DC, August 1996).

9. WEFA Group, Eurasia Economic Outlook (Eddystone, PA, November 1996).

10. PlanEcon, Review and Outlook for Eastern Europe (Washington, DC, December 1996).

11. International Energy Agency, World Energy Outlook 1996 (Paris, France, 1996).

12. International Energy Agency, Energy Statistics and Balances of Non-OECD Countries, 1993-1994 (Paris, France, 1996).

13. T.M. Johnson, J. Li, Z. Jiang, and R.P. Taylor, eds., China: Issues and Options in Greenhouse Gas Emissions Control, World Bank Discussion Paper No. 330 (Washington, DC, June 1996).

14. M. Ishiguro and T. Akiyama, Energy Demand in Five Major Asian Developing Countries: Structure and Prospects, World Bank Discussion Paper (Washington, DC, April 1995).

15. F. Fesharaki, A. Clark, and D. Intarapravich, Energy Outlook to 2010: Asia-Pacific Demand, Supply, and Climate Change, No. 19 (Honolulu, HI: East-West Center, April 1995). 



\title{
The World Oil Market
}

\author{
Despite substantial growth in world oil demand, oil prices are projected to \\ rise only moderately over the next two decades. New assessments of oil resources and \\ improved technologies for their exploitation point to increased supplies at relatively low costs.
}

\section{Introduction}

Perhaps the most surprising development in world oil markets in 1996 was the strength of oil prices. Early in 1996 most analysts were expecting that the resumption of Iraqi oil exports would lead to price weakness throughout the year. However, the resumption was delayed until December 1996, forestalling an increase of between 500,000 and 600,00 barrels per day (depending on the world oil price) in aggregate OPEC supply. In addition, exceptionally cold weather in Europe and the United States in early 1996 boosted petroleum demand beyond expectations, causing a decline in world petroleum stocks. As a consequence, oil prices at the end of 1996 were nearly 40 percent higher than a year earlier (see box on page 34). At about $\$ 24.00$ a barrel, year-end 1996 oil prices were higher than the projected 2015 price in the IEO97 reference case. This development is particularly notable given that the IEO97 long-term price projections reflect a small downward revision relative to those in the IEO96 forecast.

The current price developments are believed to be transitory, in view of the long-term forces facilitating expansion of crude oil supply. Growing understanding of the world's oil (and natural gas) resource base, along with improved oil recovery methods, promises the potential of large future supply increments at relatively stable development and production costs. Future oil prices could follow a higher trajectory, but not because of resource constraints-rather because of political developments that might discourage or delay investment and development in areas with rich resource potential. Moreover, unexpected political and economic events can be expected to result in future short-lived fluctuations, as occurred, for example, during the Persian Gulf War.

Some key supply developments for 1996 include:

- European oil production continued to expand. Led by increased production in Norway, overall production in North Sea areas rose by more than 7 percent in 1996 [1, p. 5]. In 1996 Norway achieved a rank of number 2 oil exporter in the world [2]. New resource assessments suggest that production will be maintained, and may increase, through at least 2005.
In Italy, a major new onshore discovery in the southern Apennines was confirmed, with estimated recoverable reserves in excess of 1 billion barrels [3].

- Prospects for increased production in North Africa brightened. A range of new discoveries were announced in Libya, Egypt, and Algeria. Algeria has eased terms for outside investment to develop indigenous energy resources; consequently, participation by international oil companies in Algeria has increased, and oil output is poised to rise by 50 percent or more over the next 4 years [4].

- Substantial new offshore production potential was identified in equatorial Africa. While onshore production gains were noted in Nigeria and Angola, the most promising developments reported involve deep offshore prospects from Nigeria south to Angola $[5,6]$.

- In South America notable gains in production are in prospect for Argentina, Venezuela, Colombia, and Brazil. Major improvements in Venezuela's output have already been achieved through agreements with foreign investors to revive production from existing oil fields, using new seismic and drilling technologies [7, p. 6].

- In North America major progress in the deep offshore Gulf of Mexico and offshore Eastern Canada continues. Optimism for deep Gulf production was underscored by record-setting bidding activity for Federal leases awarded in 1996. In Canada, construction commitments target the beginning of production from Hibernia in 1997, reaching a peak level of at least 135,000 barrels per day in 2000; two other projects could triple output by 2005 [8].

- Prospects for Caspian Sea development improved. The resource potential for the Caspian Sea area is estimated to be sufficient to support exports of about 2 million barrels a day, although exports could reach 4 million barrels a day in the high nonOPEC supply case. Current shipments are less than 300,000 barrels a day, as transport outlets await development. In 1996 significant steps were taken toward advancing the development of new pipeline outlets, which could be operational within 5 years. 


\section{Growth in Oil Demand}

Oil demand in the industrialized countries is projected to grow by 1.1 percent per year, rising from 42.2 million barrels per day in 1995 to 52.3 million barrels per day in 2015 (Figure 30). Although oil is still the most important energy source in the majority of industrialized countries, its share of total energy consumption is expected to drop by 2 percentage points (from 42 to 40 percent) over the 1995 to 2015 period. This decline reflects the continuation of trends in Europe, Japan, North America, and other countries in which newer technologies use oil more efficiently and natural gas and other energy sources replace oil for many uses. The major portion of oil's growth within industrialized economies is in fuels used for transportation, where it has no substantial competition.

Growth in oil use in developing countries, on the other hand, occurs across all economic sectors. The growth is expected to average 3.5 percent per year, leading to a rise in oil consumption from 21.4 million barrels per day in 1995 to 42.7 million barrels per day in 2015 . Developing nations, which accounted for 31 percent of world oil consumption in 1995, will account for 41 percent in 2015.

The projected growth in oil demand in the developing countries is attributed to robust economic growth, which gives rise to rapidly increasing demand for transportation fuels as well as an expansion in demand for oil in a wide range of industrial, residential, and

\section{Figure 30. World Oil Consumption by Region, 1975-2015}

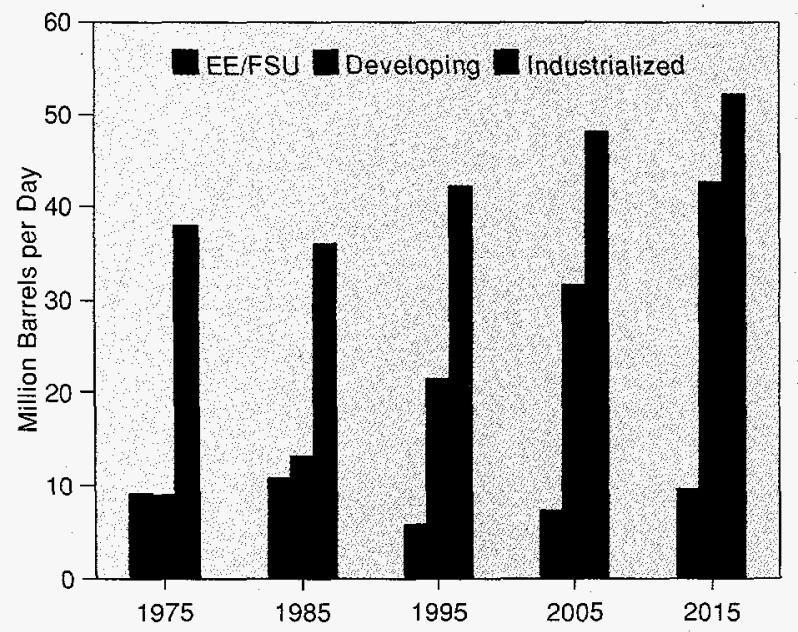

Sources: History: 1975: Energy Information Administration (EIA), Office of Energy Markets and End Use, International Statistics Database. 1985, 1995: EIA, International Energy Annual 1995, DOE ElA-0219(95) (Washington, DC, December 1996). Projections: EIA, World Energy Projection System (1997). commercial uses. Many developing countries do not have distribution infrastructures for natural gas to compete with oil; consequently, more incremental energy demand is met by oil. In developing countries, growth in energy demand tends to track increases in income more closely than in developed countries. Improved wealth encourages increased use of personal transportation, larger and better equipped homes, and substantial development of infrastructure to support increased commerce.

In the IEO97 high and low economic growth cases, oil consumption worldwide could reach 120.5 million barrels per day or be as low as 90.4 million barrels per day (Figure 31). It is possible that the growth in oil demand will exceed the reference case projection. Oil demand is highly income-elastic, especially in countries like China and India, which have underdeveloped personal transportation systems but 38 percent of the world's population.

Although high growth rates in oil use are projected for China and India in the reference case, the rates are much lower than those experienced in the recent past by the rapidly growing economies of Indonesia, Malaysia, South Korea, Taiwan, and Thailand. In South Korea, for example, oil consumption grew at an average rate of 13.1 percent per year from 1985 to 1995, and in 1995 the country's annual oil consumption was 15.9 barrels per capita. In China and India, oil consumption currently is less than 1 barrel per capita annually, even though their usage levels have increased by 76 percent

\section{Figure 31. World Oil Consumption in Three Economic Growth Cases, 1970-2015}

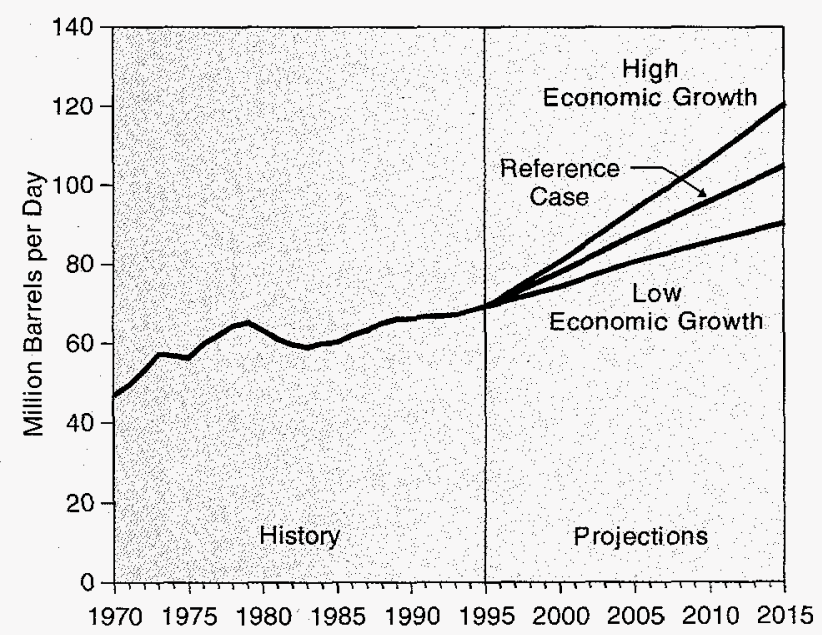

Sources: History: 1970-1979: Energy Information Administration (EIA), Office of Energy Markets and End Use, International Statistics Database. 1980-1995: ElA, International Energy Annual 1995, DOE/ EIA-0219(95) (Washington, DC, December 1996). Projections: EIA, World Energy Projection System (1997). 
and 77 percent, respectively, since 1985. If future growth in oil demand in China and India were to match the historical rate for South Korea, their combined consumption in 2015 would be 45.5 million barrels per day higher than projected in the reference case-an amount that exceeds the entire oil demand for industrialized countries in 1995.

\section{Regional Variations in Demand Growth}

For developing countries in Asia, the reference case projections show oil consumption growing by 4.1 percent per year from 1995 to 2015 (Figure 32). In the other regions of the developing world (Middle East, Africa, and Central and South America) the growth rate for oil is a more modest 2.8 percent per year. In the EE/FSU, oil consumption is expected to resume growth in the next year, but the projected consumption in 2015 is still below 1990 levels. Opportunities for substantial improvements in the efficiency with which oil is used, increased reliance on natural gas, and a prognosis of relatively sluggish recovery in economic growth contribute to the expectations of modest growth in future oil consumption in the EE/FSU region.

\section{Industrialized Countries}

The industrialized countries in 1995 accounted for almost two-thirds of total world oil demand, whereas over the next two decades they are expected to account

\section{Figure 32. World Oil Consumption by Region, 1970-2015}

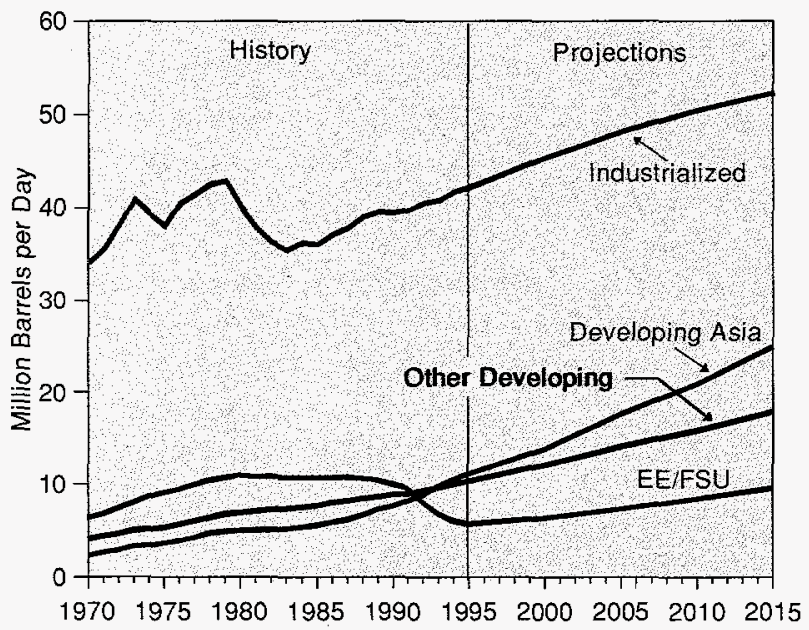

Sources: History: 1970-1979: Energy Information Administration (EIA), Office of Energy Markets and End Use, International Statistics Database. 1980-1995: EIA, International Energy Annual 1995, DOE/ EIA-0219(95) (Washington, DC, December 1996). Projections: EIA, World Energy Projection System (1997). for only one-third of incremental demand growth. The reference case projection anticipates about 52 million barrels per day of oil demand in 2015, up by 10 million barrels per day from 1995. North America-the United States, Canada, and Mexico-is expected to account for 6 million barrels per day of incremental demand. The projected growth in U.S. oil demand is the slowest within North America (1 percent per year). U.S. consumption in 2015 is expected to be more than 4 million barrels per day higher than the 1995 level of 18 million barrels per day. Mexico has the highest projected increase in North America, primarily because economic growth is expected to proceed at twice the rate for the United States and Canada.

Oil demand in industrialized Asia is projected to rise from 7.0 million barrels per day in 1995 to 9.4 million in 2015. Japan, with a higher projected growth rate for oil consumption than most other industrialized countries, accounts for most of the change. Lacking indigenous resources, Japan is expected to diversify its energy use development in order to spread dependence over a range of fuels and suppliers.

The slowest growth in oil use is projected for Western Europe, where overall oil demand is expected to rise by a total of only 1.5 million barrels per day over the next two decades. Oil use for power generation and home heating is declining and being replaced by natural gas throughout the region. Oil is also losing market share to natural gas and electricity in many industrial energy uses. In addition, energy-intensive industries are beginning to be replaced by service industries, which are more likely to use natural gas and electricity than oil.

\section{Developing Countries}

In developing countries, the increase in oil demand between 1995 and 2015 in the reference case is more than 21 million barrels per day, reflecting a doubling of oil demand over the forecast period. The major impetus to growth is expected from Asia. Oil consumption in the developing countries of Asia is projected to grow by 4.1 percent per year, rising from 11.1 million barrels per day in 1995 to about 24.9 million barrels per day in 2015 (Figure 33).

Developing Asia countries will become a dominant force on the demand side of the world oil market over the projection period. The region's oil demand in the year 2000 is expected to average 13.9 million barrels per day, close to Western Europe's 14.3 million barrels per day, and its expected level of 20.9 million barrels per day in 2010 is close to the projected consumption in the United States (21.6 million barrels per day). By 2015, developing Asia's share of world oil consumption is 
Figure 33. Nonindustrialized Oil Demand by Region, 1970, 1995, and 2015

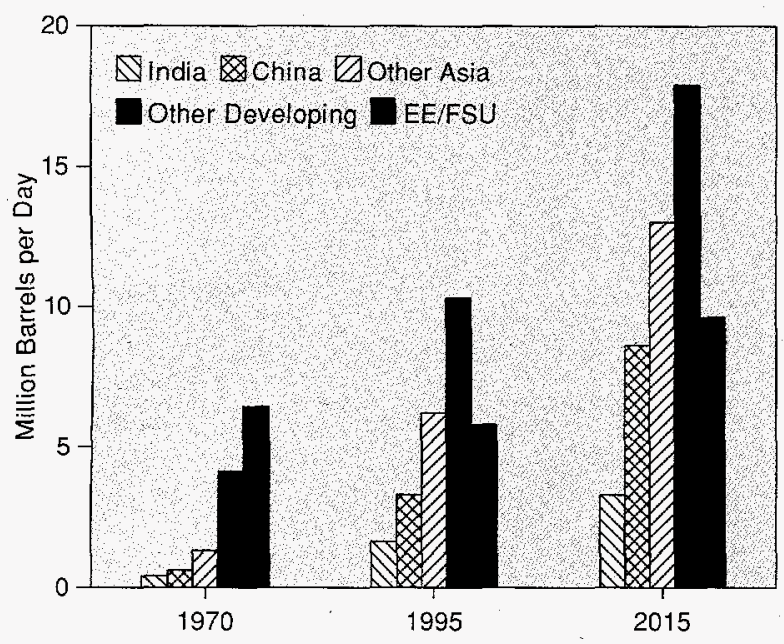

Sources: 1970: Energy Information Administration (EIA), Office of Energy Markets and End Use, International Statistics Database. 1995: EIA, International Energy Annual 1995, DOE/EIA-0219(95) (Washington, DC, December 1996). 2015: EIA, World Energy Projection System (1997).

expected to be more than twice what it was in 1995. High rates of economic growth and rising standards of living drive these expectations.

In China, oil consumption is expected to grow at an average rate of 4.9 percent per year from 1995 to 2015, with oil consumption nearly tripling (Figure 33). As compared with 19 percent in 1995, oil is expected to account for 22 percent of China's total energy consumption in 2015. The potential for oil demand growth in China is large, given its huge population and the potential for sustained long-term economic growthChina's economy over the projection period is assumed to grow at an average rate of 7.3 percent a year. In 2015. China's oil consumption is expected to approach 39 percent of U.S. consumption and 56 percent of Western Europe's.

The transportation sector in China is underdeveloped relative to other economic sectors and has a substantial rail component [9]. The rail system depends heavily on coal-fired engines but is switching to diesel or electric engines, which will lead to some increase in the demand for oil. More importantly, road transportation in China is limited, both for freight hauling and for personal travel, and is likely to develop rapidly in the future. The increase in demand for motor fuels will lead to an increase in the use of lighter petroleum products in China. The industrial sector will continue to be dominated by coal, but moderate growth in oil use is expected. Increases in oil demand are also expected in the residential and commercial sectors for heating and cooking.

In India, growth in oil demand is projected to average 3.8 percent per year between 1995 and 2015. Although oil consumption is rising-currently supplying 31 percent of India's total energy consumption-its share is expected to decline over the forecast period to 27 percent of total energy consumption in 2015. India currently imports refined petroleum products, as well as crude oil to feed domestic refineries. Its import requirement for petroleum products is expected to grow until new refining capacity comes on stream, at which time the import emphasis will switch from products to crude oils.

The remaining developing Asian countries (of which Indonesia, Malaysia, South Korea, Taiwan, and Thailand are the major energy consumers) are much more dependent on oil, which claimed a 57-percent share of their total energy consumption in 1995. A significant factor contributing to higher reliance on oil use in these countries is rapid growth in road transportation, especially for personal vehicles [9, p. 155].

Substantial growth in oil demand is also anticipated outside of Asia, in other developing regions. In Central and South America oil consumption is expected to nearly double between 1995 to 2015 . Following substantial reforms in government policies led by developments in Argentina and Chile, substantial economic growth is projected-35 percent greater than for developed economies. Such growth (3.5 percent annually) can promote substantial improvements in living standards and, in concert, strong increases in demand for energy and oil-using products. In this region, large increases in transportation fuel use can be expected, and demand for nontransportation uses will also grow. Oil use for baseload electricity generation will decrease, but its use will increase in remote areas and for peak load generation. Large investments are being made in gas and electricity transmission in Central and South America, and a significant portion of incremental power generation is expected to rely on natural gas. However, diesel-fired combustion turbines will continue to be used to satisfy a significant portion of the region's demand for electric power [7, p. 5].

\section{Eastern Europe and the Former Soviet Union}

The reference case projection for the EE/FSU region anticipates a rise in oil demand of nearly 4 million barrels per day between 1995 and 2015. Nonetheless, in 2015, oil use is expected still to be less than in 1990, before economic depression befell the region. Signs of economic recovery are now clearly evident in Eastern 
Europe, where several countries have posted positive gains in GDP since 1993 [10, pp. 2.4-2.5]. Performance within the FSU has been less favorable, but positive gains in GDP are now expected to become evident in 1997 and beyond. As economic recovery proceeds, oil demand will also recover. However, recovery within the region will occur in the context of shifting patterns of energy use. Outside of the transportation sector, serious efforts to increase reliance on natural gas are underway, in part because of economics and in part because of environmental concerns.

Oil demand in Eastern Europe is expected to increase by about 2 percent per year between 1995 and 2015 . Most of the growth in oil demand will be for transportation and home heating, although home heating will increasingly be fueled by natural gas [9, pp. 219220]. The demand for oil in the transportation sector is expected to grow well above the rate of growth in GDP. In contrast, oil demand for industry and power generation in Eastern Europe is expected to decline as the use of natural gas increases.

Oil demand projections for the FSU are highly uncertain because there remain substantial political and economic uncertainties about the region. If the EE/FSU nations were able to achieve political and economic stability, structural changes could take place in their economies that would substantially determine the future course of oil demand. In the IEO97 high economic growth case, which assumes a much more favorable economic future for the FSU, oil demand could reach 10 million barrels per day in 2015, compared with the more modest reference case estimate of 7.7 million barrels per day.

\section{World Oil Price Projections}

Despite expectations of substantial growth in world oil demand, oil prices are projected to rise only moderately over the next two decades. In the reference case, prices rise by about 1.0 percent per year, reaching $\$ 21$ in constant 1995 dollars by 2015 (Figure 34). In nominal dollars, the reference case reaches $\$ 39$ per barrel in 2015. In the high and low price cases, the 2015 prices are about $\$ 7$ higher and lower, respectively, than in the reference case (in 1995 dollars).

Over the past 20 years, oil prices have been highly volatile. In the future one can expect volatile behavior to recur principally because of unforeseen political and economic circumstances. It is well recognized that tensions in the Middle East, for example, could easily give rise to serious disruptions in normal oil production and trading patterns. On the other hand, significant excursions from the reference price trajectory are not
Figure 34. World Oil Prices in Three Oil Price Cases, 1970-2015

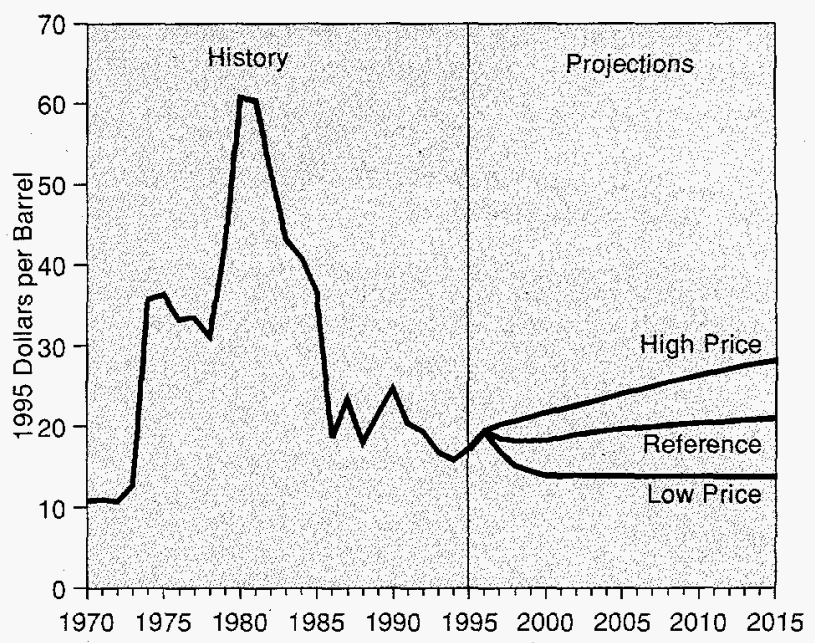

Sources: History: 1970-1979: Energy Information Administration (EIA), Office of Energy Markets and End Use, International Statistics Database. 1980-1995: EIA, International Energy Annual 1995, DOE/ EIA-0219(95) (Washington, DC, December 1996). Projections: EIA, World Energy Projection System (1997).

likely to be long sustained. High real prices deter consumption and encourage the emergence of significant competition from marginal but large sources of oil and non-oil energy supplies. Persistently low prices have the opposite effects.

The IEO97 reference case price forecast for 2015 is $\$ 5.00$ lower than the corresponding IEO96 projection. As noted earlier in this chapter, current oil prices (December 1996) are higher than the reference case projection for 2015. However, transition factors are driving current prices-principally, cold weather in early 1996 and political controversy throughout the year that has delayed the resumption of Iraqi exports (see box on following page). They are not a harbinger of return to a high and persistently rising oil price trajectory.

From a long-term standpoint, the key news of 1996 is that oil production possibilities continue to grow at a rapid rate. Technologies continue to evolve which markedly improve recovery possibilities in existing production locales from the North Sea to the Middle East, Argentina, and China. Additionally, technology advances permit economical access to resource-rich, but environmentally harsh, producing areas such as the North Sea and deep offshore waters in the United States, Mexico, Brazil, and Africa.

Equally important, government policies to encourage private investment for resource development continue to evolve in many nations. Some of those changes reflect marginal adjustments with only limited potential 
impact, but others have far wider implications. For example, removing the ban on Alaskan exports modestly raises wellhead prices in the oil-producing areas of Alaska, encouraging more exploration while at the same time increasing potential returns for enhanced oil recovery projects in California. More significant is the removal of bans on foreign investment in Venezuela and Algeria, which opens up exploration in areas with rich production potential. In other areas, modification of terms for profit sharing in Norway, Yemen, and Indonesia will help to sustain investment that otherwise would cease or decline; and the creation of government-private joint ventures offers prospects for increased oil development in Oman, Brazil, the former Soviet Union, and elsewhere.

The stability of government institutions and the investment climate created by government energy policies will be much more significant determinants of the adequacy of future oil supply development than will underlying resource availability. Even though oil prices in real terms have, for more than a decade, remained at levels only one-third as high as in the late 1970s, world proven reserves have risen by more than 30 percent $[11$, pp. 4-5].

The most recent assessment of conventional oil resources prepared by the U.S. Geological Survey (USGS) for the World Petroleum Congress provides clear insights into the expansive potential for future oil supply. Table 13 shows estimates of cumulative production, identified reserves, and a range of undiscovered conventional crude oil. By summing these estimates, a range of ultimately recoverable oil is derived. Considerable uncertainty is evident in these numbers.
Estimates of undiscovered resources range from 292 billion to 1 trillion barrels. This range implies remaining conventional crude oil resources of between 1.4 and 2.1 trillion barrels. A feature of the lower portion of this range would be a significant increase in OPEC's market share. The upper portion of the range implies that OPEC could remain at less than a one-half share of worldwide production for at least the first two decades of the next century, even in the face of sustained demand growth.

An important assumption in the USGS assessment is the holding constant of current technology and economics; however, dramatic progress has been made in both exploration and recovery technologies in just the first half of this decade. If similar technology advances were projected into the longer term oil assessment, the ultimately recoverable resource base could potentially double the current mean estimates by the USGS, and the potential could be even greater if the real price of world oil increased.

\section{The Composition of World Oil Supply}

An alternative hypothesis regarding the prospect of future increases in real oil prices would have OPEC operate to promote significant price escalation through conservative capacity expansion decisions. In the IEO97 reference case, world petroleum demand rises at an annual average rate of 2.1 over the forecast period. Over the past two decades, the growth in non-OPEC oil supply has played a significant role in the erosion of OPEC's market share. The long-term outlook for nonOPEC supply remains optimistic even in the face of

\section{The 1996 Oil Price Runup}

Between June and December 1996, oil prices rose by more than 20 percent, raising concerns that we may be moving into a regime of persistently higher prices. The projection in this outlook is for prices to recede from current levels and remain relatively stable in real terms over the next several years.

Cold weather in the United States and Europe, combined with unexpectedly strong growth in oil demand in Asia and Latin America, caused oil demand to rise by more than 2.4 percent in 1996 , compared with average growth of 1.2 percent between 1991 and 1995 [12, $\mathrm{p}, 39]$. At the same time, it was expected that Iraqi oil exports would begin to flow at mid-year, which did not happen until December. As a consequence, world oil stocks were drawn down throughout 1996, and by the end of the year were as much as 15 percent below the levels at the end of 1995 .

In 1997 , stock building is expected to occur as ineremental sources of supply come to market. In addition to Iraqi shipments in the range of 500,000 to 600,000 barrels a day (depending on the price of oil), increased supplies from Nigeria, Venezuela, and Qatar are scheduled for early 1997 [13,pp. 1-2]. Non-OPEC supply is also expected to rise as production in the North Sea and Latin America increases.

Thus, while an additional increment in world oil demand in the range of 1.8 million barrels per day is expected in 1997, production capacity expansion is expected to more than keep pace. In the longer term, continued grow th in oil demand is expected to be met more than proportionately by expansion of output from the Middle East, with important increments in supply from non-OPEC production in the North Sea, the former Soviet Union, and Latin America. 
Table 13. Estimated Undiscovered and Ultimately Recoverable Conventional Oil Resources as of January 1, 1993

(Billion Barrels)

\begin{tabular}{|c|c|c|c|c|c|c|}
\hline \multirow[b]{2}{*}{ Region } & \multicolumn{2}{|c|}{ Undiscovered Oil } & \multirow[b]{2}{*}{$\begin{array}{l}\text { Cumulative } \\
\text { Production }\end{array}$} & \multirow[b]{2}{*}{$\begin{array}{l}\text { Identified } \\
\text { Reserves }\end{array}$} & \multicolumn{2}{|c|}{ Ultimate Resources } \\
\hline & $\begin{array}{c}\text { Low } \\
\text { Estimate }\end{array}$ & $\begin{array}{l}\text { High } \\
\text { Estimate }\end{array}$ & & & $\begin{array}{c}\text { Low } \\
\text { Estimate }\end{array}$ & $\begin{array}{c}\text { High } \\
\text { Estimate }\end{array}$ \\
\hline OPEC & 95.3 & 319.8 & 282.9 & 706.4 & $1,084.6$ & $1,309.1$ \\
\hline $\begin{array}{l}\text { Persian Gulf . } \\
\text { Other ...... }\end{array}$ & $\begin{array}{l}74.2 \\
21.1\end{array}$ & $\begin{array}{r}232.0 \\
87.8\end{array}$ & $\begin{array}{l}177.0 \\
105.9\end{array}$ & $\begin{array}{l}583.0 \\
123.4\end{array}$ & $\begin{array}{l}834.2 \\
250.4\end{array}$ & $\begin{array}{l}992.0 \\
317.1\end{array}$ \\
\hline Non-OPEC $\ldots \ldots \ldots \ldots \ldots$ & 196.9 & 685.4 & 415.7 & 396.8 & $1,009.4$ & $1,497.9$ \\
\hline $\begin{array}{l}\text { OECD } \ldots \ldots \ldots \\
\text { Eurasia } \ldots \ldots \\
\text { Rest of World } \ldots \ldots\end{array}$ & $\begin{array}{l}68.4 \\
77.5 \\
51.0\end{array}$ & $\begin{array}{l}223.9 \\
330.6 \\
130.9\end{array}$ & $\begin{array}{r}225.4 \\
142.3 \\
48.0\end{array}$ & $\begin{array}{r}156.4 \\
163.7 \\
76.7\end{array}$ & $\begin{array}{l}450.2 \\
383.5 \\
175.7\end{array}$ & $\begin{array}{l}605.7 \\
636.6 \\
255.6\end{array}$ \\
\hline Total World $\ldots \ldots \ldots \ldots \ldots$ & 292.2 & $1,005.2$ & 698.6 & $1,103.2$ & $2,094.0$ & $2,807.0$ \\
\hline
\end{tabular}

Notes: Identified reserves are the nominal sum of proved, probable, and possible reserves, or some major part thereof. Ultimate resources $=$ cumulative production + identified reserves + undiscovered oil. Eurasia = China, former Soviet Union, and Eastern Europe.

Source: C. Masters, E. Attanasi, and D. Root (U.S. Geological Survey), "World Petroleum Assessment and Analysis," Proceedings of the Fourteenth World Petroleum Congress (John Wiley and Sons, New York, 1994).

lower world oil prices. New exploration and production technologies, aggressive cost-reduction programs by industry, and attractive fiscal terms to producers by governments all contribute to the outlook for continued growth in non-OPEC oil production.

On the other hand, the reference case projection depicts increases in demand over the next two decades being met more than proportionately by increases in production by members of OPEC rather than by non-OPEC suppliers. OPEC production capacity in 2015 is projected to be nearly 27 million barrels per day higher than it was in 1995 (Figure 35). Some analysts question whether OPEC producers would pursue such a strategy, however, suggesting that they might prefer instead to see oil prices escalate as demand increases. The reference case view presented here discounts the latter scenario, for the reasons discussed below.

\section{Expansion of OPEC Production Capacity}

There is general agreement that OPEC members with large reserves and relatively low costs to expand production capacity can accommodate sizable increases in petroleum demand. In the IEO97 reference case, the production call on OPEC producers grows at a robust annual rate of 3.5 percent (Table 14 and Figure 36). With the expected growth in demand, especially in the developing countries of the Pacific Rim, OPEC capacity utilization is expected to increase sharply after 2000, reaching 95 percent by 2010 and remaining there for the duration of the forecast period.
Figure 35. World Oil Production by Region, 1970, 1995, and 2015

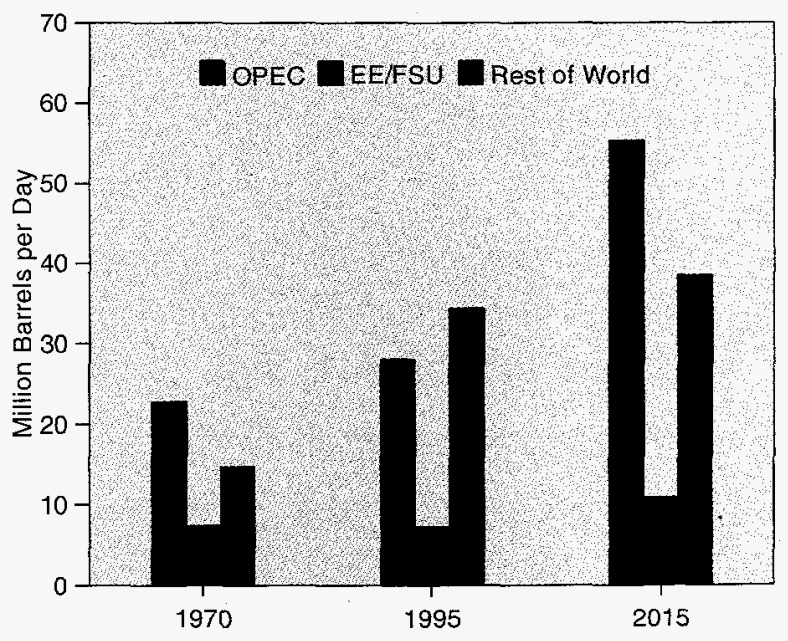

Sources: 1970: Energy Information Administration (EIA), Office of Energy Markets and End Use, International Statistics Database. 1995: EIA, International Energy Annual 1995, DOE/E|A-0219(95) (Washington, DC, December 1996). 2015: ElA, World Energy Projection System (1997).

Given the OPEC production capacity expansion requirements implied by the IEO97 estimates, much attention has been focused on the oil development, production, and operating costs of individual OPEC producers. With the reserve-to-production ratio of Persian Gulf producers exceeding 80 years, significant capacity expansion is obviously feasible. But what can 
Table 14. OPEC Oil Production, 1990-2015

(Million Barrels per Day)

\begin{tabular}{|c|c|c|c|}
\hline Year & $\begin{array}{c}\text { Reference } \\
\text { Case }\end{array}$ & $\begin{array}{c}\text { High } \\
\text { Oil Price }\end{array}$ & $\begin{array}{l}\text { Low } \\
\text { Oil Price }\end{array}$ \\
\hline \multicolumn{4}{|l|}{ History } \\
\hline 1990 & 24.5 & - & - \\
\hline $1995 \ldots$ & 28.0 & - & - \\
\hline \multicolumn{4}{|l|}{ Projections } \\
\hline $2000 \ldots$ & 32.6 & 30.5 & 35.2 \\
\hline 2005 & 40.4 & 36.4 & 46.6 \\
\hline 2010 & 47.5 & 41.6 & 56.2 \\
\hline$\ldots \ldots$ & 55.3 & 47.0 & 66.1 \\
\hline
\end{tabular}

Note: Includes the production of crude oil, natural gas plant liquids, refinery gain, and other liquid fuels.

Sources: History: Energy Information Administration (EIA), International Petroleum Statistics Report, DOE/EIA0520(96/12) (Washington, DC, December 1996), Table 1.4. Projections: EIA, World Energy Projection System (1997).

Figure 36. OPEC Oil Production in Three Oil Price Cases, 1970-2015

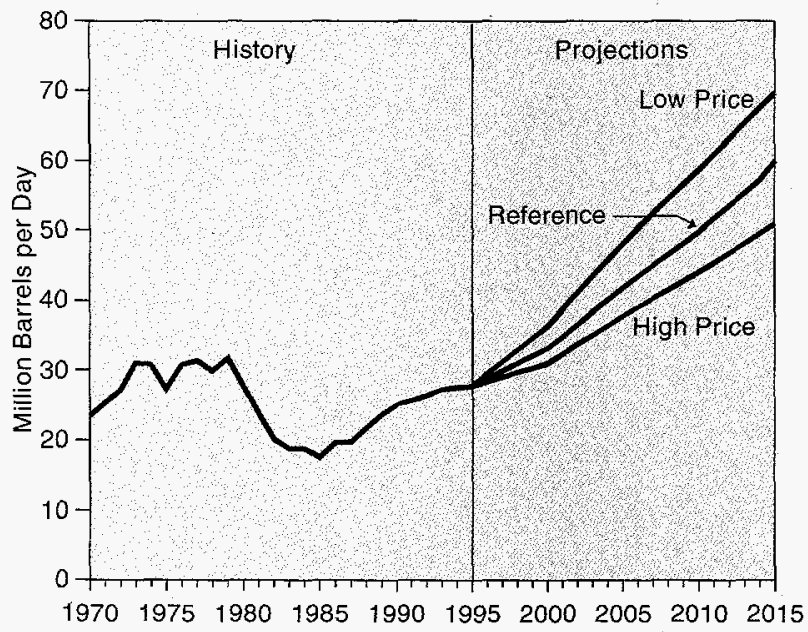

Sources: History: 1970-1979: Energy Information Administration (EIA), Office of Energy Markets and End Use, International Statistics Database. 1980-1995: EIA, International Energy Annual 1995, DOE/ EIA-0219(95) (Washington, DC, December 1996). Projections: EIA, World Energy Projection System (1997).

be said about the economics of capacity expansion given the alternative world oil price projections included in IEO97?

The cost to produce a barrel of oil in Persian Gulf OPEC nations ranges between $\$ 0.99$ and $\$ 1.49$ per barrel, depending on field size. The capital investment required to increase production capacity by 1 barrel per day in Persian Gulf OPEC nations ranges between $\$ 2,515$ and $\$ 4,866$ [14], also depending on field size.
Assuming a world oil price of $\$ 14$ per barrel and midsize fields only, total development and operating costs over the entire forecast period expressed as a percentage of gross revenues range only between 15 and 20 percent. Thus, for the Persian Gulf producers, the total cost of capacity expansion is a relatively small percentage of projected gross revenue even in the low oil price case.

For OPEC producers outside the Persian Gulf, the cost to expand production capacity by 1 barrel per day is considerably greater, ranging from $\$ 7,610$ (Indonesia) to $\$ 10,240$ (Venezuela); however, even this group of producers can expect margins in excess of 40 percent on investments to expand production capacity over the long term in the low price case [15]. Venezuela has the greatest potential for capacity expansion and has already announced plans to increase its production capacity by 3.5 to 4 million barrels per day by the year 2005. Tables A40-A43 in Appendix A show the ranges of production potential for both OPEC and non-OPEC producers.

The reference case projection implies aggressive efforts by OPEC to apply or attract investment capital to implement a wide range of production capacity expansion projects. If those projects were not undertaken, world oil prices could escalate. The reference case assumes that an aggressive expansion strategy will be pursued. Several considerations underlie this assumption. The first relates to the potential profitability of expansion. As noted above, even relatively high-cost producers within OPEC stand to gain substantially from expanding the overall volume of production at reference case prices.

A second factor relates to the threat of competition, which, thanks to the experience of the past decade, is now better understood than it was in the 1970s following the first oil crisis. One source of competition is nonOPEC oil supply. Non-OPEC oil supply potential is now recognized to be quite robust. Extensive exploration, improved technology, and government policies that encourage investment sustain expectations that non-OPEC supply expansion could displace or replace OPEC if OPEC efforts are not competitive. Moreover, all oil producers recognize that significant portions of the market for oil are threatened by competition from other fuels, including oil from nonconventional sources and other energy substitutes.

In the developed countries, during the period of high oil prices, oil lost market share in all end-use segments except transportation. Since 1986, despite the fact that oil prices have moderated, oil is still shut out of most nontransportation energy markets in the United States 
and Western Europe. Even at current prices, oil's share in energy markets is being challenged throughout the world by natural gas. If oil prices begin to move to persistently higher levels, nontransportation compo- nents of oil demand could shrink markedly. Even increased use of nonconventional hydrocarbon resources, as described in the box below, is a growing competitive threat.

\section{Nonconventional Oil Resources}

Nonconventional resources are lyd rocarbons with the potential for producing liquid fuels. They are nonconventional because they are not economical at today's prices and technology. Assuming current technology, around 550 billion bartels of noneonventional oil can be produced at a cost of $\$ 30$ per barrel or less. Assuming significant technological advances, approximately 2 trillion barrels of nonconventional oil would be economical to produce at a cost of $\$ 30$ per barrel within 25 years. The figure below presents one study's assessment of the size and estimated cost of nonconventional resources [16]

At costs of $\$ 30$ per barrel and above, it has been proven that it is teehnically possible to produce liquid fuels from coal One such project creates a stable emulsion of natural bitumen and water, which is being used as a boiler fuel in some power stations in North America, Europe, and Asia, It is handled as easily as heavy fuel oil and employs the same storage facilities, but it is considerably more envirommentally acceptable, making it more attractive to some classes of cistomers.

In Venezuela, heavy oil is expected to become increas ingly competitive with conventional fuels, but production volumes will probably remain small I Teavy oil is extracted by pumping steam into the reservoir. Capital costs are high because of the cost of the steamrelated infrastructure, the difficulties in transportation, and the cost of upgrading the heavy oil.

Production of synthetic crude oil from Canadian tar sands actually began as early as 1978. The tar sand is mined and transported to a processing plant where the bitumen is separated, cleaned, and upgraded for use as a refinery feedstock. Teehnology has reduced the operating cost of the operation from $\$ 28$ per barrel to $\$ 11$ per barrel. Because the investments were already made almost two decades ago, oil production from tar sands is profitable and accounts for about 260,000 barrels per day of Canadian production [17].

Huge shale oil reserves, such as those in the United States, can also be exploited, but only at a cost of about $\$ 40$ per barrel. If is not considered likely that they will become economical within the next 25 years.
For natural gas, the challenge is either to use it as an energy source or feedstock at its discovery site or to convert it to fuels that can be exported easily and cheaply Demonstration synfuel units have been inplemented, which use wet natural gas as a feedstock and ulfimately produce a slate of clean transportation fuels: an ecological gasoline with no sulfur, no aromatics, and no olefins; a jet fuel with very low smoke and freezing points: a diesel fuel with no sulfur; and select heavier cuts such as lubricants and waxes. Preliminary economic assessments provide for a profitable production complex with a capacity of 75,000 barrels per day at an investment cost of $\$ 2.4$ billion and operating costs of $\$ 5$ per barrel using natural gas whose cost does not exceed $\$ 0.50$ per million Btu [18].

Cost reductions for monconventional resources are not anticipated to have any significant impact on total non-OPEC oil supply over the next two decades, They might, however, help to define a lower celling price for conventional oil - a consideration that is critical to organizations making price projections for world oil supplies.

\section{Size and Estimated Cost of Nonconventional Oil Resources}

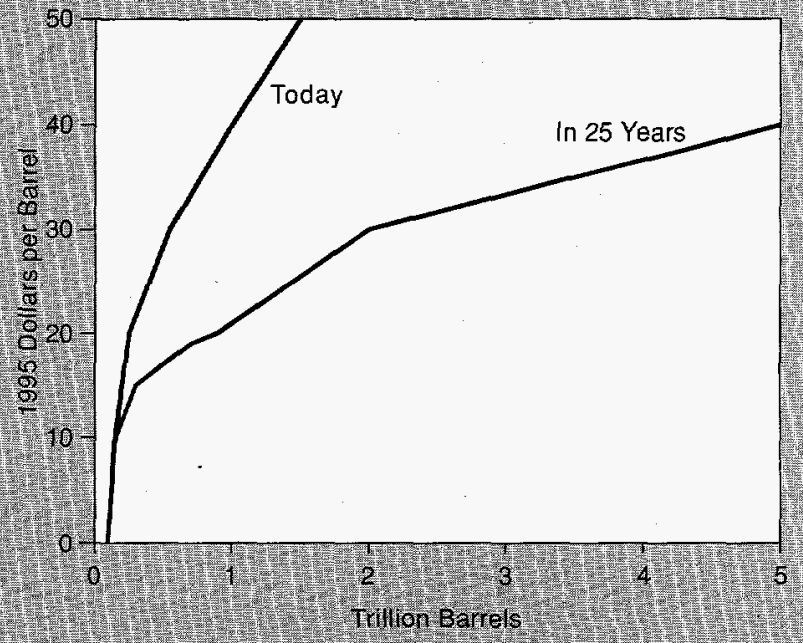

Source. M. Lynch, OI Prices to 2000. The Economics of the Or Market, The Economist intelligence Unil (1989). 
Finally, actual and potential rivalry within OPEC cannot be ignored. Substantial diversity of interest within the OPEC membership conditions the organization's strategic objectives. The differences are related to preferred rates of resource development, the role of private enterprise in promoting development, and perceived risks associated with the potential consequences of alternative price paths.

Thus, although OPEC's market share is expected to increase in response to projected growth in oil demand, the increased market share will be enjoyed in the context of a strong competitive environment. One can expect continuing significant competition from a geographically diverse range of non-OPEC suppliers that have shown surprising resilience even in the recent low price environment. Rivalry from those suppliers and other threats are expected to encourage OPEC to pursue aggressive growth strategies as the best path for capitalizing on the opportunities that will be fostered by growth in world oil markets.

\section{Non-OPEC Supply}

As noted earlier, the growth in non-OPEC oil supplies played a significant role in the erosion of OPEC's market share over the past two decades. During that period, non-OPEC oil supply became increasingly diverse. North America dominated non-OPEC supply in the early 1970s, the North Sea and Mexico evolved as major producers into the 1980s, and much of the new production in the 1990s has come from the developing countries.

In the IEO97 reference case, non-OPEC supply from proven reserves is expected to increase steadily, by a total of 7.5 million barrels per day by 2015 (Table 15). The projections do not include recently identified additional reserve potential (especially in Africa) or new prospects for tapping known resources (especially in the former Soviet Union).

Several important differences emerge when the IEO97 production profiles are compared with those in the IEO96:

- U.S. production does not decline as severely in the IEO97 projections, and the production recovery by the end of the forecast period actually exceeds current production levels as a result of technological progress that has expanded the economically recoverable resource base.

- North Sea production rises more and does not decline as rapidly, due to enhanced subsea technology that makes small field development cheaper and permits access to harsh producing environments west of the Shetland Islands.
- Oil production in the former Soviet Union rebounds more quickly in the IEO97 forecast as a result of less severe physical problems and improved institutional factors, including progress toward more stable tax and private ownership rules. Political uncertainty remains a key barrier in this resourcerich region.

- The production outlook for the developing countries of Central and South America is more optimistic in IEO97, based on a combination of increased drilling, technology dissemination, and improved fiscal environments.

In the IEO97 forecast, North Sea production reaches a new high in 1997, approaching 7 million barrels per day, Production from Norway, Western Europe's largest producer, is expected to peak at about 3.5 million barrels per day in 1997 and then gradually decline to about 2.8 million barrels per day by the end of the forecast period with the maturing of some of its larger and older fields. The United Kingdom sector is expected to produce about 2.9 million barrels per day for the next decade, followed by a decline to about 2 million barrels per day by the end of the forecast period.

Two non-OPEC Persian Gulf producers are expected to increase output gradually to the end of this decade. Enhanced recovery techniques are expected to increase current output in Oman by 250,000 barrels per day, with no production decline anticipated until after 2005. Current oil production in Yemen could increase by 400,000 barrels per day early in the next century, and those levels could be maintained throughout the forecast period. Syria is expected to show a modest production increase out to the end of this decade and a gradual decline thereafter.

Table 15. Non-OPEC Oil Production, 1990-2015 (Million Barrels per Day)

\begin{tabular}{|c|c|c|c|}
\hline Year & $\begin{array}{l}\text { Reference } \\
\text { Case }\end{array}$ & $\begin{array}{c}\text { High } \\
\text { Oil Price }\end{array}$ & $\begin{array}{c}\text { Low } \\
\text { Oil Price }\end{array}$ \\
\hline \multicolumn{4}{|l|}{ History } \\
\hline $1990^{\circ}$ & 41.9 & - & - \\
\hline 1995. & 41.8 & - & - \\
\hline \multicolumn{4}{|l|}{ Projections } \\
\hline $2000 \ldots$ & 45.2 & 46.0 & 44.4 \\
\hline 2005 & 46.8 & 48.3 & 44.8 \\
\hline 2010 & 48.1 & 50.1 & 45.5 \\
\hline 2015 & 49.3 & 52.2 & 46.5 \\
\hline
\end{tabular}

Note: Includes the production of crude oil, natural gas plant liquids, refinery gain, and other liquid fuels.

Sources: History: Energy Information Administration (EIA), International Petroleum Statistics Report, DOE/EIA0520(96/12) (Washington, DC, December 1996), Table 1.4. Projections: EIA, World Energy Projection System (1997). 
Oil producers in the Far East are beginning to reap the benefits of enhanced exploration and extraction technologies. A significant increase in output potential is projected well into the next century. Assuming no impediments to foreign investment, India could be producing 1 million barrels per day late in the forecast period. Deepwater fields offshore from the Philippines is expected to produce in excess of 250,000 barrels per day by the year 2000 . There is much optimism regarding the long-term production potential for Vietnam, where output is projected to exceed 600,000 barrels per day by the end of the forecast period. Australian production is expected to peak before the turn of the century, but enhanced extraction technologies will temper the production declines somewhat after 2000. Malaysia's output will gradually decline to about 500,000 barrels per day by 2005 and 400,000 barrels per day by 2015 . Exploration and test-well activity have indicated some production potential for Bangladesh and Mongolia, but significant output would not be realized until the turn of the century.

Central and South America's producers have the greatest potential for increasing output over the next decade. Colombia is expected to more than double its output by 2000. Brazil will join Colombia by the turn of the century on the relatively short list of worldwide producers whose output exceeds 1 million barrels per day: Brazil is viewed as having vast untapped production potential and, given a favorable climate for attracting foreign investment, could exceed 2 million barrels per day by 2015. Argentina is expected to raise its current production levels by at least 200,000 barrels per day by the end of this decade, and former OPEC member Ecuador is expected to increase its production capacity to allow additional output of 250,000 barrels per day.

Non-OPEC producers in Africa are expected to show only modest increases in production out to the end of the decade. West African producers Angola, Congo, and Zaire are on track to combine for about 300,000 barrels per day in additional output and are expected to maintain those levels for the remainder of the forecast period. However, recent offshore exploration suggests that output gains may ultimately exceed those totals by a substantial margin. Significant discoveries were reported in 1996 from Nigeria south to Angola.

North African producers Algeria, Libya, Tunisia, and Egypt produce from mainly mature fields, which are likely to be in decline beyond the year 2000. New discoveries were recently reported in Algeria and Egypt, however, and all four countries have modified government policies to induce foreign investment in enhanced recovery operations from existing assets. New producers Chad and the Sudan, which are expected to begin production in 1997, are projected to combine for 500,000 barrels per day by the turn of the century. Other African producers with output potential beyond 2000 include the Ivory Coast, Equatorial Guinea, Somalia, and South Africa.

For North America, with falling U.S. output, a steady decline in total production is expected into the early years of the next century. Canada's output is expected to increase by 200,000 barrels per day by the end of the decade, mainly from Newfoundland's Hibernia oil project, which could produce 135,000 barrels per day at its peak sometime near the turn of the century. Offshore discoveries in the Gulf of Mexico, incremental Alaskan production from Cook Inlet, and technological advances in extraction methods eventually reverse the downward trend in U.S. production, which actually exceeds current levels in the last 3 years of the forecast. Mexico's continuing encouragement of foreign investment in its oil sector will lead to more efficient use of its vast resource base. Production volumes are expected to reach 3.5 million barrels per day in 2005 and could exceed 4 million barrels per day by 2015 .

Oil production in the former Soviet Union is expected to exceed 9.1 million barrels per day by 2005 and to reach 10.6 million barrels per day by 2015 . Thus, by the end of the forecast period, the FSU would be a net exporter of almost 3 million barrels of petroleum per day. While China's output is expected to increase steadily, to about 3.5 million barrels per day in 2015, its domestic demand for oil grows even more rapidly. China is already a net petroleum importer and will consume 2.5 times more oil than it produces by the end of the forecast.

The estimates for non-OPEC production potential presented in this outlook are based on such parameters as numbers of exploration wells, finding rates, reserve-toproduction ratios, advances in both exploration and extraction technologies, and the world oil price. It. should be noted that non-OPEC production potential could be significantly greater if no constraints were placed on the exploration and development of undiscovered resources. For the purpose of the IEO97 reference case, low oil price, and high oil price assessments, no more than 15 percent of the mean estimate of undiscovered oil was allowed to be developed over the forecast period. Tables A44-A47 in Appendix A show the ranges of production potential for both OPEC and non-OPEC producers.

\section{High Non-OPEC Supply Case}

The non-OPEC production potential in the reference case is based on a country-by-country assessment that includes assumptions of numbers of exploration wells, 
finding rates, reserve-to-production ratios, the price of oil, and other physical and economic factors. The range of estimates for non-OPEC production potential presented in Tables A44-A47 are the result of varying the world oil price assumption, while holding other assumptions constant. With prices being the only variable across the low price, reference, and high price cases, the range in non-OPEC supply by the end of the forecast period is modest (less than 4 million barrels per day). However, a fourth view of non-OPEC production is provided by assuming that a portion of the undiscovered oil (based on U.S. Geological Survey estimates [19]) in non-OPEC nations will be developed and produced over the forecast period.

Figure 37 compares OPEC and non-OPEC production estimates over the forecast period for the reference case and for a high non-OPEC supply case. The high nonOPEC supply case was developed from the following assumptions:

- World oil prices are the same as in the reference case.

- U.S. production is the same as in the reference case.

- The estimates of undiscovered oil in the former Soviet Union, Latin America, and West Africa are higher than in the reference case, reflecting increased optimism about the production potential of offshore fields.

\section{Figure 37. Non-OPEC Oil Production in Two Cases, 1990-2015}

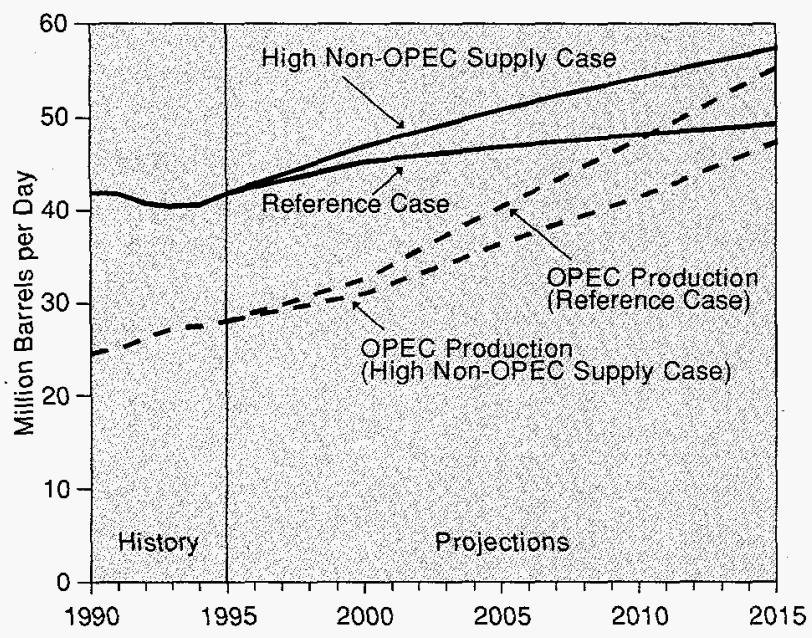

Sources: History: Energy Information Administration (ElA), International Energy Annual 1995, DOE/EIA-0219(95) (Washington, DC, December 1996). Projections: EIA, World Energy Projection System (1997).
- One-third of the world's undiscovered oil is considered economical to develop over the forecast period.

- Technology improvements over the forecast period are assumed to be transferrable worldwide.

- It is assumed that no institutional barriers will constrain production.

- A reserve-to-production ratio of 15 years (slightly less than the current non-OPEC ratio) is used as a lower bound for production estimates.

These assumptions result in 1.6-percent annual growth in non-OPEC production over the forecast periodabout double the growth rate in the reference case (Figure 37). Non-OPEC production reaches a peak of 57.3 million barrels per day in the high case in 2015, compared with a high of 49.3 million barrels per day in the reference case. Figure 38 compares peak production levels for six non-OPEC regions in the reference and high non-OPEC supply cases.

In the reference case, OPEC production peaks at 55.3 million barrels per day, and the OPEC share of worldwide production does not begin to exceed that of nonOPEC suppliers until 2011. In the high non-OPEC supply case, OPEC production peaks at 47.3 million barrels per day and never assumes the majority market share during the remainder of the forecast period.

Figure 38. Non-OPEC Oil Production by Region in Two Cases, 2015

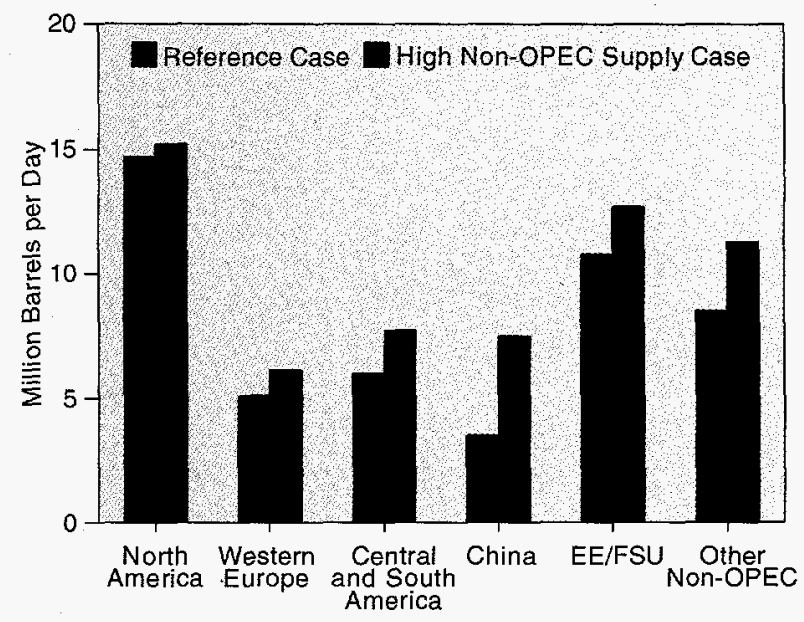

Source: Energy Information Administration, World Energy Projection System (1997). 


\section{Worldwide Petroleum Trade in the Reference Case}

In 1995, industrialized countries imported 15.8 million barrels of oil per day from OPEC producers. Of that total, 9.3 million barrels per day came from the Persian Gulf region. Oil movements to industrialized countries represented more than two-thirds of the total petroleum exported by OPEC member nations and more than 60 percent of all Persian Gulf exports (Table 16). By the end of the forecast period, OPEC exports to industrial- ized countries are estimated to be 8 million barrels per day higher than their 1995 level, and more than threequarters of the increase is expected to come from the Persian Gulf region.

Despite such a substantial increase, the projected share of total OPEC petroleum exports in 2015 that goes to the industrialized nations is lower than their 1995 share, at slightly over 50 percent. Their share of all Persian Gulf exports falls even more dramatically, to around 42 percent. This significant shift in the balance of OPEC export shares between the industrialized and

Table 16. Worldwide Petroleum Trade in the Reference Case, 1995 and 2015 (Million Barrels per Day)

\begin{tabular}{|c|c|c|c|c|c|c|c|c|}
\hline \multirow[b]{3}{*}{ Exporting Region } & \multicolumn{8}{|c|}{ Importing Region } \\
\hline & \multicolumn{4}{|c|}{ Industrialized } & \multicolumn{4}{|c|}{ Nonindustrialized $_{\mathrm{i}}$} \\
\hline & $\begin{array}{c}\text { North } \\
\text { America }\end{array}$ & $\begin{array}{c}\text { Western } \\
\text { Europe }\end{array}$ & Asia & Total & $\begin{array}{l}\text { Pacific } \\
\text { Rim }\end{array}$ & China & $\begin{array}{l}\text { Rest of } \\
\text { World }\end{array}$ & Total \\
\hline & \multicolumn{8}{|c|}{1995} \\
\hline \multicolumn{9}{|l|}{ OPEC } \\
\hline Persian Gulf & 1.8 & 3.4 & 4.2 & 9.3 & 4.1 & 0.4 & 1.5 & 6.0 \\
\hline North Africa & 0.3 & 1.9 & 0.0 & 2.2 & 0.0 & 0.0 & 0.1 & 0.1 \\
\hline West Africa & 1.0 & 0.6 & 0.1 & 1.7 & 0.3 & 0.0 & 0.1 & 0.4 \\
\hline South America & 1.6 & 0.3 & 0.0 & 1.9 & 0.1 & 0.0 & 0.6 & 0.6 \\
\hline Asia $\ldots \ldots \ldots \ldots \ldots$ & 0.1 & 0.0 & 0.5 & 0.7 & 0.1 & 0.0 & 0.0 & 0.1 \\
\hline Total OPEC $\ldots \ldots \ldots \ldots \ldots$ & 4.8 & 6.2 & 4.8 & 15.8 & 4.5 & 0.4 & 2.2 & 7.2 \\
\hline \multicolumn{9}{|l|}{ NON-OPEC } \\
\hline North Sea ..... & 0.7 & 2.6 & 0.1 & 3.4 & 0.0 & 0.0 & 0.4 & 0.4 \\
\hline Caribbean Basin . . . . . . . . . & 2.8 & 0.3 & 0.1 & 3.2 & 0.1 & 0.0 & 0.9 & 1.1 \\
\hline Former Soviet Union . . . . . . . . & 0.0 & 1.6 & 0.0 & 1.7 & 0.3 & 0.0 & 0.7 & 1.0 \\
\hline Total Non-OPEC $\ldots \ldots \ldots \ldots$ & 3.5 & 4.6 & 0.1 & 8.3 & 0.5 & 0.0 & 2.0 & 2.5 \\
\hline \multirow[t]{2}{*}{ World Total Petroleum Exports .. } & 8.3 & 10.8 & 5.0 & 24.1 & 5.0 & 0.5 & 4.2 & 9.7 \\
\hline & \multicolumn{8}{|c|}{2015} \\
\hline \multicolumn{9}{|l|}{ OPEC } \\
\hline 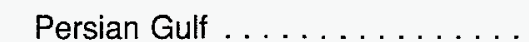 & 3.9 & 5.3 & 6.5 & 15.6 & 11.4 & 5.0 & 5.0 & 21.4 \\
\hline North Africa $\ldots \ldots \ldots \ldots \ldots$ & 0.3 & 2.7 & 0.1 & 3.1 & 0.2 & 0.1 & 0.1 & 0.3 \\
\hline West Africa & 1.0 & 0.9 & 0.2 & 2.0 & 0.3 & 0.0 & 0.2 & 0.5 \\
\hline South America & 2.4 & 0.5 & 0.1 & 3.0 & 0.1 & 0.0 & 1.1 & 1.2 \\
\hline Asia $\ldots \ldots \ldots$. & 0.0 & 0.0 & 0.1 & 0.1 & 0.0 & 0.0 & 0.0 & 0.0 \\
\hline Total OPEC $\ldots \ldots \ldots \ldots \ldots$ & 7.6 & 9.3 & 6.9 & 23.8 & 12.0 & 5.1 & 6.4 & 23.5 \\
\hline \multicolumn{9}{|l|}{ Non-OPEC } \\
\hline North Sea $\ldots \ldots \ldots$ & 0.4 & 1.8 & 0.0 & 2.1 & 0.0 & 0.0 & 0.2 & 0.2 \\
\hline Caribbean Basin $\ldots \ldots \ldots \ldots$ & 3.7 & 0.5 & 0.1 & 4.3 & 0.2 & 0.0 & 1.5 & 1.8 \\
\hline Former Soviet Union $\ldots \ldots \ldots \ldots$ & 0.0 & 2.1 & 0.1 & 2.2 & 0.6 & 0.0 & 1.2 & 1.7 \\
\hline Total Non-OPEC $\ldots . . . .$. & 4.1 & 4.4 & 0.2 & 8.7 & 0.8 & 0.0 & 2.9 & 3.7 \\
\hline World Total Petroleum Exports .. & 11.7 & 13.7 & 7.1 & 32.5 & 12.7 & 5.1 & 9.3 & 27.2 \\
\hline
\end{tabular}

Notes: Totals may not equal sum of components due to independent rounding.

Sources: 1995: Energy Information Administration (EIA), Energy Markets and Contingency Information Division. 2015: EIA, Office of Integrated Analysis and Forecasting, WORLD Reference Model (1997). 
nonindustrialized nations is a direct result of the robust economic growth anticipated for the developing nations of the world, especially those of Asia. OPEC petroleum exports to developing countries are expected to increase by more than 16 million barrels per day over the forecast period, with about three-fourths of the increase going to the developing countries of Asia. China, alone, will most likely import more than 5 million barrels per day from OPEC by the year 2015, almost all of which is expected to come from Persian Gulf producers.

North America's petroleum imports from the Persian Gulf region are expected to more than double over the forecast period (Figure 39). Significant increases are also anticipated in the volume of petroleum imports to North America from Latin American producers, including Venezuela, Brazil, Colombia, and Mexico. Caribbean Basin refiners are expected to account for most of the increase in North American refined product imports.

With a modest decline in North Sea production accompanied by declining availability of petroleum exports from the former Soviet Union, Western Europe is expected to import increasing amounts from Persian Gulf producers and from both the North and West African OPEC countries. Industrialized Asian nations are expected to increase their already heavy dependency on Persian Gulf oil as Indonesia's export potential declines. The developing countries of the Pacific Rim are expected to more than double their petroleum imports between 1995 and 2015, with a heavy dependency on Persian Gulf oil anticipated.

Figure 39. Imports of Persian Gulf Petroleum by Importing Region, 1995 and 2015

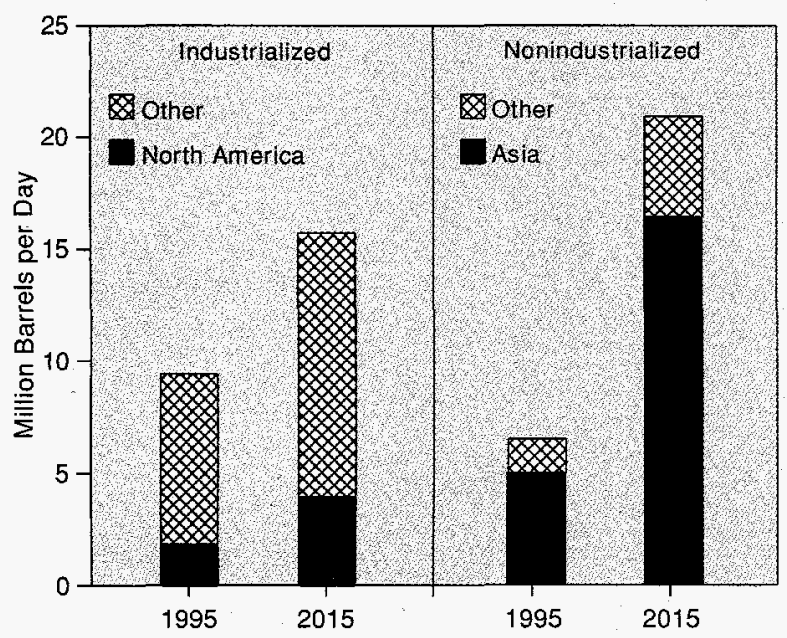

Sources: 1995: Energy Information Administration (EIA), Energy Markets and Contingency Information Division. 2015: EIA, Office of Integrated Analysis and Forecasting, WORLD Reference Model (1997).
Worldwide crude oil distillation refining capacity was 74.6 million barrels per day at the beginning of 1996 . To meet the projected growth in international oil demand in the reference case, worldwide refining capacity will have to increase by more than 30 million barrels per day by 2015. Substantial growth in distillation capacity is expected in the Middle East, Central and South America, and especially in the Asia Pacific region. Refiners in North America and Europe, while making only modest additions to their distillation capacity, will continue to improve product quality and enhance the usefulness of the heavier portion of the barrel through investment in downstream capacity. Likewise, future investments by developing countries must also include more advanced configurations in order to meet the anticipated increase in demand for lighter products.

\section{Other Views of Prices and Production}

World oil price forecasts are prepared by many oil market analysts. Table 17 compares the IEO97 projections with similar forecasts from DRI/McGraw-Hill (DRI), the International Energy Agency (IEA), Petroleum Economics, Ltd. (PEL), Petroleum Industry Research Associates, Inc. (PIRA), the Gas Research Institute (GRI), Natural Resources Canada (NRCan), and NatWest Securities, Ltd. (NatWest). Among the forecasts, the IEO97 price expectations tend to be higher than most of the comparable forecasts. However, this comparative set represents a very broad range of prices: the 2005 price estimates range from $\$ 15.25$ per barrel (PEL) to $\$ 26.22$ (IEA CC), with IEO97 at $\$ 19.72$ in the reference case. For 2010 , the range is $\$ 12.91$ (PEL) to $\$ 26.22$ (IEA CC), with IEO97 at \$20.41. For 2015, IEO97 is almost $\$ 21$, DRI is almost $\$ 23$, WEFA is $\$ 19.87$, NatWest is $\$ 18.58$, and GRI, which has assumed constant prices in real terms, is at $\$ 16.65$.

The price forecasts are strongly influenced by different views about the anticipated composition of world oil production. Two issues are particularly important in considering the composition of world production: (1) the expected strength of production expansion within OPEC areas, and (2) the timing of production recovery in the EE/FSU region. Generally, the forecasts agree that production recovery in the FSU will be slow. The EE/FSU share of oil production among all forecasts ranges from 10 percent to, in the most optimistic case, 13 percent (Table 18). Only NatWest projects that the EE/FSU will reach and maintain a 13-percent market share, which is not attained until 2010 even in the NatWest forecast.

Expectations for the split between OPEC producers and the rest of the world (excluding the EE/FSU) vary more 
Table 17. Comparison of World Oil Price Projections, 1995-2015 (1995 Dollars per Barrel)

\begin{tabular}{|c|c|c|c|c|c|}
\hline Forecast & 1995 & 2000 & 2005 & 2010 & 2015 \\
\hline \multicolumn{6}{|l|}{ IEO97 } \\
\hline Reference Case & 17.26 & 18.20 & 19.72 & 20.41 & 20.98 \\
\hline High Price Case & 17.26 & 21.69 & 24.13 & 26.44 & 28.23 \\
\hline Low Price case . & 17.26 & 14.08 & 14.08 & 14.03 & 13.99 \\
\hline \multicolumn{6}{|l|}{ DRI } \\
\hline$\ldots \ldots \ldots \ldots \ldots$ & 17.24 & 16.28 & 19.02 & 21.33 & 22.94 \\
\hline Low Case $\ldots \ldots \ldots \ldots \ldots \ldots \ldots \ldots$ & 16.80 & 16.07 & 16.07 & 16.07 & 16.07 \\
\hline \multicolumn{6}{|l|}{ IEA } \\
\hline Capacity Constraints (CC) Case $\ldots \ldots \ldots$ & 17.10 & 17.83 & 26.22 & 26.22 & - \\
\hline Energy Savings (ES) Case $\ldots \ldots \ldots \ldots$ & 17.10 & 17.83 & 17.83 & 17.83 & - \\
\hline $\mathrm{PEL}^{\mathrm{a}}$ & 17.00 & 17.68 & 15.25 & 12.91 & - \\
\hline$\therefore \ldots \ldots \ldots \ldots$ & 18.40 & 15:97 & 15.66 & - & - \\
\hline WEFA & 17.23 & 18.35 & 19.42 & 19.70 & 19.87 \\
\hline GRI . . & 17.23 & 16.65 & 16.65 & 16.65 & 16.65 \\
\hline NRCan . & 18.40 & 20.00 & 20.00 & 20.00 & 20.00 \\
\hline$\ldots \ldots \ldots \ldots \ldots$ & 17.14 & 19.45 & 19.45 & 19.11 & 18.58 \\
\hline
\end{tabular}

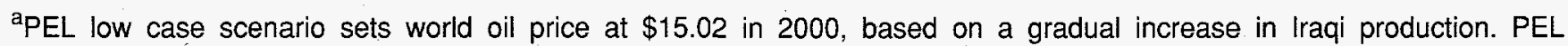
foresees no reason to expect upward price pressure after 2000 , based on a substantial oil reserve base.

Notes: IEO97 projections are for average landed imports to the United States. DRI, GRI, and WEFA projections are for composite refiner acquisition prices. PEL projections are for Brent crude oil. PIRA and NRCan projections are for West Texas Intermediate crude oil at Cushing.

Sources: IEO97: Energy Information Administration, Annual Energy Outlook 1997, DOE/EIA-0383(97) (Washington, DC, December 1996). DRI: DRI/McGraw-Hill, World Energy Service: U.S. Outlook, Spring-Summer 1996 (Lexington, MA, April 1996). IEA: International Energy Agency, World Energy Outlook 1996 (Paris, France, 1996), pp. 231-232. PEL: Petroleum Economics, Ltd., World Oil and Energy Outlook to 2010 (London, United Kingdom, December 1996). PIRA: Petroleum Industry Research Associates, Inc., Retainer Client Seminar-Part One (New York NY, October 1996), Table II-3. WEFA: WEFA Group, U.S. Long-Term Economic Outlook, Vol. 1 (Fourth Quarter 1996), pp. 5.94-5.95. GRI: Gas Research Institute, 1997 Data Book of the GRI Baseline Projections of U.S. Energy Supply and Demand to 2015, Vol. II, GRI-96/0431-2 (Washington, DC, January 1997), p. PRC-2. NRCan: Natural Resources Canada, The Greenhouse Gas Emissions Outlook, 1996-2020, prepared for Joint Federal, Provincial, Territorial Energy and Environmental Ministers Meeting (Toronto, Ontario, December 12, 1996), p. 3. NatWest: NatWest Securities, Ltd., Strategic Assessment: Global Oils (London, United Kingdom, June 1996).

widely. The IEO97 reference case has the highest estimate for the OPEC share, growing from 40 percent in 1995 to 46 percent in 2005. Forecasts that are more bullish for non-OPEC producers include NatWest and PIRA, which have the OPEC share at 40 and 33 percent, respectively, in 2005. For 2010 and beyond, the PEL, NatWest, DRI, and IEO97 high non-OPEC supply case forecasts show the OPEC share remaining below 50 percent, whereas IEO97 and the two IEA forecasts show an OPEC share at or above 50 percent. In general, the more optimistic analysts are about the development of non-OPEC supplies, the lower are their price expectations. 
Table 18. Comparison of World Oil Production Forecasts

(Percent of World Total)

\begin{tabular}{|c|c|c|c|}
\hline Forecast & OPEC & $\mathrm{EE} / \mathrm{FSU}^{\mathrm{a}}$ & Other \\
\hline \multicolumn{4}{|l|}{ History } \\
\hline$\ldots \ldots \ldots \ldots \ldots$ & 40 & 11 & 50 \\
\hline \multicolumn{4}{|l|}{ Projections } \\
\hline \multicolumn{4}{|l|}{1995} \\
\hline$\ldots \ldots \ldots \ldots \ldots \ldots$ & 40 & 10 & 49 \\
\hline DRI $\ldots \ldots \ldots \ldots \ldots \ldots \ldots \ldots \ldots$ & 41 & 11 & 48 \\
\hline IEA Capacity Constraints Case $\ldots \ldots \ldots \ldots \ldots$ & 41 & 11 & 48 \\
\hline IEA Energy Savings Case ${ }^{c} \ldots \ldots \ldots \ldots \ldots$ & 41 & 11 & 48 \\
\hline PEL $\ldots \ldots \ldots \ldots \ldots \ldots \ldots \ldots \ldots \ldots \ldots \ldots \ldots$ & 40 & 11 & 49 \\
\hline PIRA $\ldots \ldots \ldots \ldots \ldots \ldots \ldots \ldots$ & 35 & 11 & 54 \\
\hline NatWest $\ldots \ldots \ldots \ldots \ldots \ldots \ldots \ldots \ldots$ & 38 & 11 & 51 \\
\hline \multicolumn{4}{|l|}{2000} \\
\hline IEO97 Reference Case . . . . . . . . . . . . & 42 & 10 & 48 \\
\hline IEO97 High Non-OPEC Supply Case $\ldots \ldots \ldots \ldots$ & 40 & 11 & 49 \\
\hline IEA Capacity Constraints Case $\ldots \ldots \ldots \ldots \ldots$ & 42 & 11 & 48 \\
\hline IEA Energy Savings Case . . . . . . . & 40 & 11 & 49 \\
\hline PEL $\ldots \ldots \ldots \ldots \ldots \ldots \ldots \ldots \ldots$ & 41 & 10 & 49 \\
\hline PIRA $\ldots \ldots \ldots \ldots \ldots \ldots \ldots \ldots \ldots \ldots \ldots \ldots \ldots \ldots \ldots \ldots \ldots \ldots \ldots$ & 32 & 10 & 58 \\
\hline NatWest $\ldots \ldots \ldots \ldots \ldots \ldots \ldots \ldots \ldots$ & 39 & 11 & 50 \\
\hline \multicolumn{4}{|l|}{2005} \\
\hline IEO97 Reference Case $\ldots \ldots \ldots \ldots \ldots \ldots$ & 46 & 11 & 43 \\
\hline IEO97 High Non-OPEC Supply Case $\ldots \ldots \ldots \ldots$ & 42 & 12 & 47 \\
\hline PEL $\ldots \ldots \ldots \ldots \ldots \ldots \ldots \ldots \ldots$ & 44 & 11 & 45 \\
\hline PIRA $\ldots \ldots \ldots \ldots \ldots \ldots \ldots \ldots \ldots \ldots \ldots \ldots \ldots \ldots \ldots$ & 33 & 11 & 56 \\
\hline NatWest $\ldots \ldots \ldots \ldots \ldots \ldots \ldots \ldots \ldots$ & 40 & 12 & 48 \\
\hline \multicolumn{4}{|l|}{2010} \\
\hline IEO97 Reference Case . . . . . . . . . & 50 & 10 & 40 \\
\hline IEO97 High Non-OPEC Supply Case & 43 & 11 & 42 \\
\hline IEA Capacity Constraints Case $\ldots \ldots \ldots \ldots \ldots$ & 51 & 11 & 38 \\
\hline IEA Energy Savings Case $\ldots \ldots \ldots \ldots \ldots \ldots \ldots$ & 54 & 11 & 35 \\
\hline $\mathrm{PEL}, \ldots \ldots \ldots \ldots \ldots \ldots \ldots \ldots \ldots \ldots \ldots \ldots \ldots \ldots$ & 48 & 12 & 40 \\
\hline NatWest $\ldots \ldots \ldots \ldots \ldots \ldots \ldots \ldots \ldots \ldots$ & 42 & 13 & 45 \\
\hline \multicolumn{4}{|l|}{2015} \\
\hline IEO97 Reference Case $\ldots \ldots \ldots \ldots \ldots \ldots$ & 53 & 10 & 37 \\
\hline IEOg7 High Non-OPEC Supply Case . . . . . . . . . . . & 45 & 12 & 43 \\
\hline DRI $\ldots \ldots \ldots \ldots \ldots \ldots \ldots \ldots \ldots \ldots \ldots \ldots \ldots \ldots$ & 48 & 11 & 41 \\
\hline NatWest $\ldots \ldots \ldots \ldots \ldots \ldots \ldots \ldots \ldots$ & 43 & 13 & 44 \\
\hline
\end{tabular}

aPIRA projections include only the former Soviet Union.

Note: Percentages may not add to 100 due to independent rounding.

Sources: IEO97: Energy Information Administration, World Energy Projection System (1997) and "DESTINY" International Energy Forecast Software (Dallas, TX: Petroconsultants, 1997). DRI: DRI/McGraw-Hill, World Energy Service: World Outlook 1996 (Lexington, MA, February 1996), p. 27. IEA: International Energy Agency, World Energy Outlook 1996 (Paris, France, 1996), p. 31. PEL: Petroleum Economics, Ltd., World Oil and Energy Outlook to 2010 (London, United Kingdom, December 1996). PIRA: Petroleum Industry Research Associates, Inc., Retainer Client Seminar-Part One (New York NY, October 1996), Tables III-1 and III-2. NatWest: NatWest Securities, Ltd., Strategic Assessment: Global Oils (London, United Kingdom, June 1996), world oil supply files updated as of January 2, 1997. 


\section{References}

1. Energy Information Administration, International Petroleum Statistics Report, DOE/EIA-0520(97/01) (Washington, DC, January 1997).

2. Energy Information Administration, "Country Analysis Brief: North Sea," web site www.eia. doe.gov (April 1996).

3. "What's New Around the World," Petroleum Intelligence Weekly, Vol. 34, No. 40 (October 2, 1995), pp. 6-8.

4. DRI/McGraw-Hill, World Energy Service: Africal Middle East Outlook (Lexington, MA, April 1996).

5. Energy Information Administration, "Country Analysis Brief: Angola," web site www.eia.doe.gov (December 1996).

6. Energy Information Administration, "Country Analysis Brief: Nigeria," web site www.eia.doe.gov (December 1996).

7. DRI/McGraw-Hill, World Energy Service: Latin American Outlook (Lexington, MA, July 1996).

8. "Hibernia Project Promises Big Returns," Maclean Hunter Business Magazine Online, bizlink web site (August 12, 1996).

9. International Energy Agency, World Energy Outlook 1994 (Paris, France, 1994).

10. WEFA Group, Eurasia Economic Outlook (Eddystone, PA, November 1996).
11. British Petroleum Company, BP Statistical Review of World Energy 1996 (London, UK, June 1996).

12. Energy Information Administration, Short-Term Energy Outlook, First Quarter 1997, DOE/EIA-0202 (97/1Q) (Washington, DC, January 1997).

13. "OPEC on Verge of Another Jump in Crude Capacity," Petroleum Intelligence Weekly, Vol. 35, No. 51 (December 16, 1996).

14. Energy Information Administration, Oil Production Capacity Expansion Costs for the Persian Gulf, DOE/ EIA-TR/0606 (Washington, DC, February 1996).

15. DRI/McGraw Hill, Oil Market Outlook (Lexington, MA, July 1995), Table 1, p. 10.

16. Statoil Energy Studies Program, Oil Price Scenarios Towards 2020 (Oslo, Norway, June 1996).

17. National Oil Sands Task Force, Canada's Oil Sands Industry: Yesterday, Today, and Tomorrow (Alberta, Canada, Spring 1995).

18. F. Cima and M. Scarpetti, World Gas Markets: Liquid Fuels from Gas, presentation to the SAIS-AGIP Energy Conference (Wáshington, DC, May 4, 1995).

19. C. Masters, E. Attanaśi, and D. Root (U.S. Geological Survey), "World Petroleum Assessment and Analysis," Proceedings of the Fourteenth World Petroleum Congress (New York, NY: John Wiley and Sons, 1994). 



\section{Natural Gas}

\section{Growing demand for natural gas is expected in all regions of the world, as resource availability, cost, and environmental considerations all favor its use. Gathering and distribution infrastructures are being expanded throughout the world.}

\section{Introduction}

The role of natural gas in the world's energy supply is growing rapidly. Over the next two decades, gas use is projected to rise at more than three times the rate for oil use, with an expected incremental gain in annual gas use of about 66 trillion cubic feet (Figure 40). The growth in natural gas consumption is equivalent to more than 33 million barrels of oil per day. In comparison, oil use in 2015 is projected to be 35 million barrels per day higher than it was in 1995. Resource availability, cost, and environmental considerations all favor growing reliance on gas in industrial applications and electricity generation, and natural gas is replacing other fuels in residential and commercial sector uses as well.

Lack of infrastructure is the major barrier to increased gas consumption. Throughout the world, major efforts to reduce gathering, transmission, and distribution constraints are proceeding. In 1996, more than 12,000 miles of new natural gas pipeline were completed [1, pp. 29-31], and an additional 15,000 miles were under construction to be completed in 1997 and beyond.

Figure 40. World Consumption of Natural Gas, 1970-2015

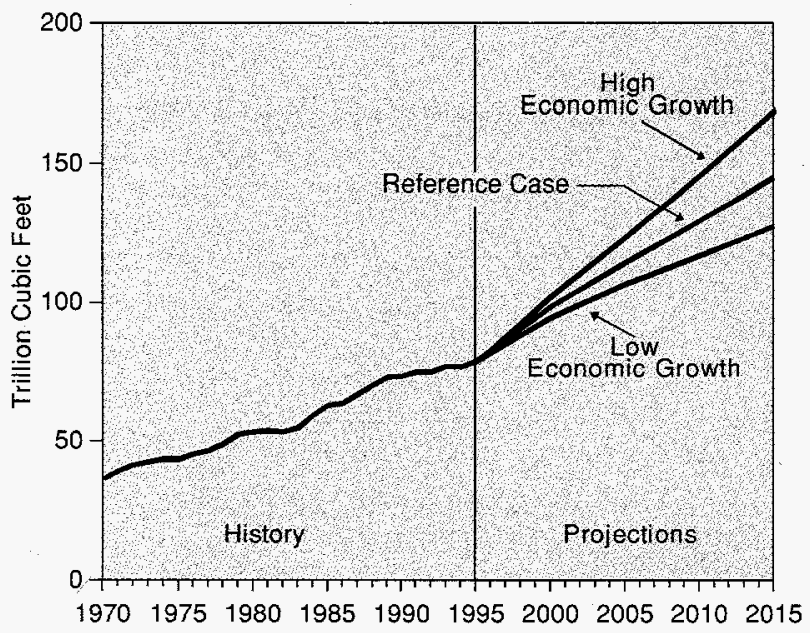

Sources: History: 1970-1979: Energy Information Administration (EIA), Office of Energy Markets and End Use, International Statistics Database. 1980-1995: EIA, International Energy Annual 1995, DOE/ EIA-0219(95) (Washington, DC, December 1996). Projections: EIA, World Energy Projection System (1997).
Regionally, more than 50 percent of ongoing pipeline construction activity is in South America and Asiaareas that currently account for less than 15 percent of the world's gas consumption.

Proposals and plans for further infrastructure expansion are numerous. Enron in 1995 undertook to catalog project proposals involving the construction of 300 or more miles of pipeline per project [2, p. 22]. Nearly 400 such projects were identified, involving 77,000 miles of additional construction. Thus, the dynamic to expand infrastructure to utilize abundant natural gas resources is strong and will result in many more miles of pipeline development beyond the 15,000 miles of construction currently underway.

The highest growth rates in natural gas demand are projected for the developing countries of the world, where overall demand in the reference case rises by 5.0 percent annually between 1995 and 2015 (Figure 41). Developing Asia is expected to experience annual gas consumption increases of almost 8 percent. Much of this growth will fuel electricity generation in the region,

Figure 41. Natural Gas Consumption by Region, 1995, 2005, and 2015

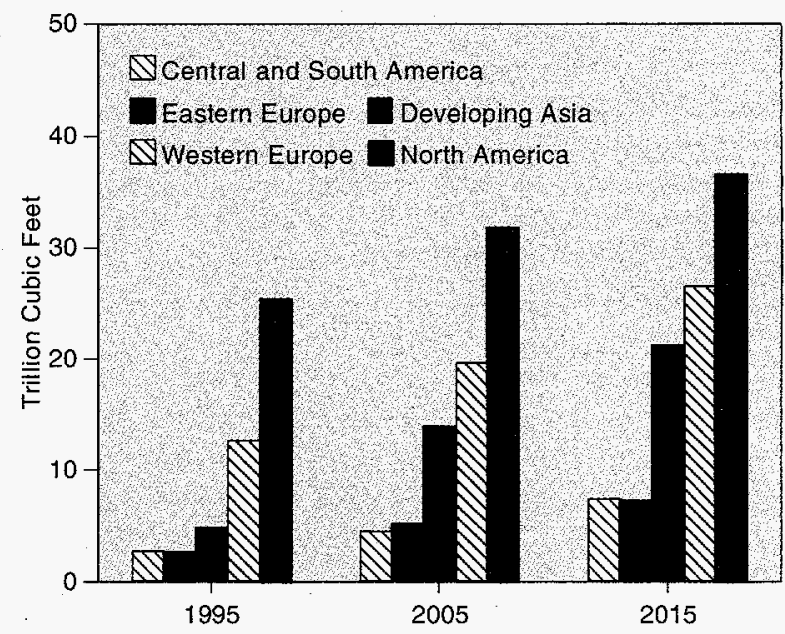

Sources: 1995: Energy Information Administration (EIA), International Energy Annual 1995, DOE/EIA-0219(95) (Washington, DC, December 1996). Projections: EIA, World Energy Projection System (1997). 
but infrastructure projects are also underway for natural gas to displace polluting home heating and cooking fuels in such major cities as Bombay, Shanghai, and Beijing.

Gas markets in Central and South America are also expected to undergo substantial development during the forecast period. Consumption increases of about 5.3 percent annually are projected. Much of the additional consumption will be used to supply the region's growing needs for electric power and industrial energy. Natural gas use will permit substantial diversification in energy use for power generation. Heretofore the region has relied heavily on hydroelectric power. While hydroelectricity is still expected to provide more than 50 percent of the energy required for power generation in the region, a major share of the incremental supply will come from gas, causing its share of input for generation to double from 10 percent in 1995 to more than 24 percent in 2015.

Industrialized countries, where natural gas markets are most mature, will also increase their reliance on natural gas. Over the next two decades, demand in the industrialized countries is expected to grow by 2.6 percent annually, more than twice the rate of increase in oil use. In the United States, gas demand is expected to rise by 1.7 percent annually, mainly because of growth in gas-fired electricity generation.

Among the industrialized regions, Western Europe is projected to have the highest growth rate in gas use, at 3.8 percent. Privatization and restructuring of the electric utility sector in many countries of Western Europe have resulted in plans to increase the use of natural gas for generating electricity. Further, many nations of Western Europe view natural gas as one way to decrease greenhouse gas emissions. As a result, European governments are encouraging the development of gas infrastructure in an attempt to move away from reliance on the more carbon-intensive coal and oil.

In Eastern Europe and the former Soviet Union (EE/FSU), gas consumption is expected to rise by 2.7 percent annually. Much of the projected growth in this region is attributed to the countries of Eastern Europe, where economic recovery occurs more rapidly over the forecast, than in the FSU. Eastern Europe's gas demand grows by 5.2 percent per year in the forecast, whereas continued slow economic growth in the FSU leads to a more modest annual rate of 2.3 percent. Nevertheless, gas demand in the EE/FSU rises by 70 percent over the forecast period. An infrastructure that is fast becoming integrated with the gas system of Western Europe supports the growth in East European gas use.
Some key developments supporting the world's natural gas markets in 1996 include:

- Multiple advances were made to strengthen supply and delivery capabilities in European markets. Several major projects aimed at bringing new supplies to the lucrative European market will help diversify suppliers to the continent. The Maghreb-Europe gas pipeline was completed and commercial sales began at the end of 1996, increasing Algeria's European delivery capacity from 700 billion cubic feet per year (through Algeria's first pipeline, the Transmed, which supplies Italy) to more than 1,050 billion cubic feet per year. Deliveries from Norway's Troll reservoir also began. Still another potential supply source moved closer to reality as construction began on the Interconnector gas pipeline to run from Bacton, Norfolk, in the United Kingdom (UK) to Zeebrugge, Belgium. The pipeline will allow the UK to tap into the European continental market with the potential to supply up to 700 billion cubic feet per year. In addition, improved interconnections with Southern and Eastern Europe were commissioned.

- Production from China's largest offshore natural gas project, Yacheng 13-1, began in 1996 [3]. The Yacheng field has an estimated 3 trillion cubic feet of reserves, the bulk of which is to be transported to Hong Kong through a 480-mile subsea pipeline and used for electricity generation by Castle Peak power company.

- Planning for the development of a trans-Asian gas pipeline system proceeded in 1996 [4]. After meeting in July 1996, Asian energy ministers agreed to seek private-sector help to construct a $\$ 15$ billion gas pipeline linking Indonesia with Malaysia, Myanmar, Thailand, Singapore, and the Philippines. Vietnam has also shown interest in the pipeline system, which could become operational as early as 2002.

- Several major projects to expand liquefied natural gas (LNG) trade went to contract. New greenfield LNG processing facilities ${ }^{2}$ are now or soon will be under construction in Oman, Qatar, Nigeria, and Trinidad [5, p. 54]. Japan, South Korea, Taiwan, and Thailand are the largest customers committing to purchase output from the new facilities. While LNG is more expensive than piped natural gas because of the high costs of processing and shipping the product, it is also an attractive export commodity for OPEC countries because it is not limited by OPEC oil production quotas.

${ }^{2} \mathrm{~A}$ "greenfield" project is an industrial development in a rural area with no established infrastructure. 


\section{Reserves}

As of January 1, 1997, proven world natural gas reserves $^{3}$ (Table 19) were estimated at 4,945 trillion cubic feet [6], 11.6 trillion cubic feet more than the estimate for 1996. Whereas natural gas reserves have declined slightly in the industrialized countries over the past decade, they have increased fairly dramatically in the EE/FSU and developing countries (Figure 42). Between 1995 and 1996, gas reserves in the Middle East grew by 20 trillion cubic feet, whereas reserves in Africa, Western Europe, and Asia declined by about 19 trillion cubic feet combined.

About 73 percent of the world's reserves are located in the FSU and countries of the Middle East (Figure 43).

Table 19. World Natural Gas Reserves by Country as of January 1, 1997

\begin{tabular}{|c|c|c|}
\hline Country & $\begin{array}{l}\text { Reserves } \\
\text { (Trillion } \\
\text { Cubic Feet) }\end{array}$ & $\begin{array}{l}\text { Percent of } \\
\text { World } \\
\text { Total }\end{array}$ \\
\hline World Total . . . . . . . . . & $4,945.4$ & 100.0 \\
\hline Top 20 Countries $\ldots \ldots \ldots$ & $4,592.0$ & 92.9 \\
\hline Former Soviet Union . . . . . . & $1,977.0$ & 40.0 \\
\hline $\operatorname{Iran} \ldots \ldots \ldots \ldots \ldots$ & 741.6 & 15.0 \\
\hline$\ldots \ldots \ldots \ldots \ldots$ & 250.0 & 5.1 \\
\hline United Arab Emirates $\ldots \ldots$ & 204.9 & 4.1 \\
\hline Saudi Arabia $\ldots \ldots \ldots \ldots$ & 188.6 & 3.8 \\
\hline United States . . . . . . . & 165.1 & 3.3 \\
\hline Venezuela $\ldots . \ldots \ldots \ldots$ & 141.6 & 2.9 \\
\hline Algeria ... & 130.3 & 2.6 \\
\hline Iraq .. & 118.0 & 2.4 \\
\hline Nigeria . & 104.7 & 2.1 \\
\hline Malaysia & 80.2 & 1.6 \\
\hline Indonesia & 72.3 & 1.5 \\
\hline Canada . & 68.1 & 1.4 \\
\hline Mexico . & 67.7 & 1.4 \\
\hline Netherlands .. & 64.1 & 1.3 \\
\hline Kuwait ...... & 52.4 & 1.1 \\
\hline Norway & 47.7 & 1.0 \\
\hline Libya ... . . . . . . & 46.3 & 0.9 \\
\hline China $\ldots \ldots \ldots \ldots$ & 41.4 & 0.8 \\
\hline Oman $\ldots .$. & 30.0 & 0.6 \\
\hline Rest of World $\ldots \ldots \ldots \ldots$ & 353.3 & 7.1 \\
\hline
\end{tabular}

Note: The sum of the shares for the top 20 countries may not equal their total share due to independent rounding.

Source: "Worldwide Look at Reserves and Production," Oil and Gas Journal, Vol. 94, No. 53 (December 30, 1996), pp. $40-41$.

\footnotetext{
${ }^{3}$ Proven reserves are the estimated quantities that analysis of geological and engineering data demonstrate with reasonable certainty to be recoverable in future years from known reservoirs under existing economic and operating conditions. However, significant reserves in the probable category are included in "reserves" estimates for various countries, including those of the former Soviet Union.
}

Reserves in the industrialized countries of the world have remained fairly stable over the past 20 years, although they have fallen continuously since 1993 (Figure 42). On the other hand, reserves in the EE/FSU and developing countries have more than doubled.

\section{Figure 42. World Natural Gas Reserves by Region, 1975-1997}

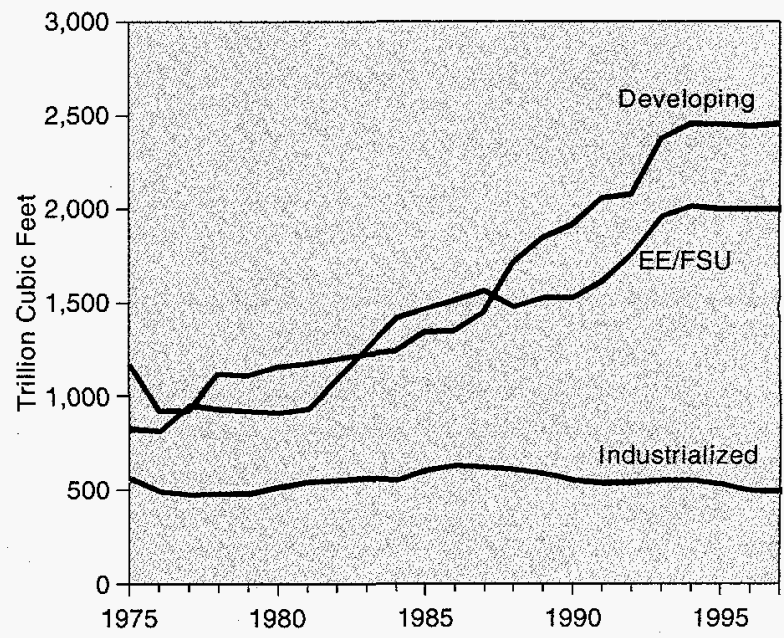

Sources: 1975-1996: International Petroleum Encyclopedia: Worldwide Oil and Gas at a Glance (Tulsa, OK: PennWell Publishing Co.), various issues. 1997: "Worldwide Look at Reserves and Production," Oil and Gas Journal, Vol. 94, No. 53 (December 30, 1996), pp. 40-41.

Figure 43. World Natural Gas Reserves by Region, as of January 1, 1997

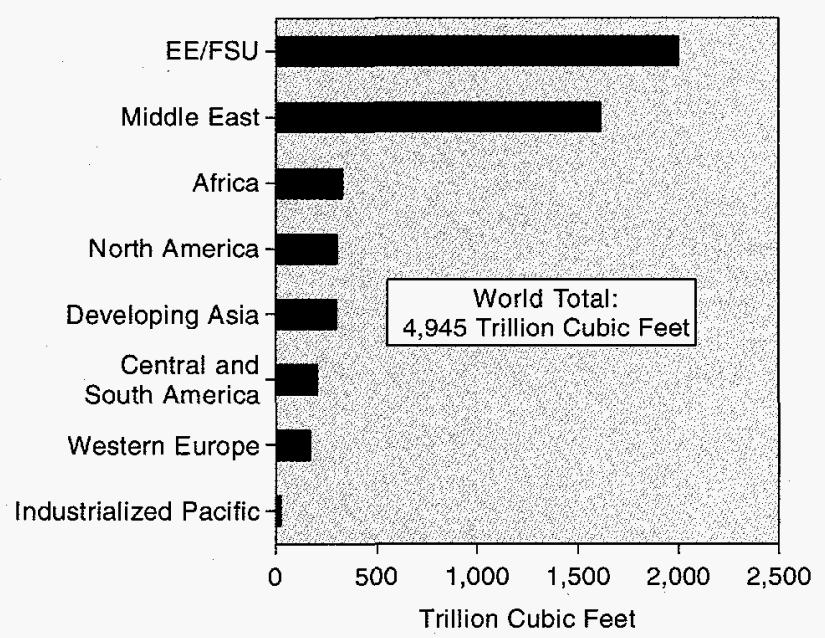

Source: "Worldwide Look at Reserves and Production," Oil and Gas Journal, Vol. 94, No. 53 (December 30, 1996), pp. 40-41. 
Natural gas reserves are less concentrated than oil reserves worldwide. Further, despite high rates of increase in gas consumption, especially over the past decade, regional reserves-to-production ratios tend to be high. Central and South America has a reserves-toproduction ratio of 73.9 years, the EE/FSU 80.4 years, and the Middle East more than 100 years [7, p. 20]. Additionally, in many areas, deposits of gas are known to exist but are not counted as reserves because the infrastructure needed to gather and distribute the gas is not available.

\section{Regional Activity}

\section{North America}

The North American natural gas market continues to expand throughout the forecast period, with total natural gas consumption growing from 25.4 trillion cubic feet in 1995 to 36.6 trillion cubic feet in 2015 . While the vast majority of the gas is consumed within the United States, strong growth in both Canada and Mexico leads to a decline in the U.S. share of total North American consumption, from 85.1 percent in 1995 to 82.5 percent in 2015. Mexico's consumption is projected to more than double, growing from 1.0 trillion cubic feet in 1995 to 2.7 trillion cubic feet in 2015, while consumption levels in the United States and Canada are projected to grow by about 39 and 35 percent, respectively.

More than one-half of the projected increase in U.S. natural gas consumption (from 21.6 trillion cubic feet in 1995 to 30.2 trillion cubic feet in 2015) results from growth in gas-fired electricity generation; however, growth is expected in all sectors, with increases of 1.3 trillion cubic feet in the industrial sector and 1.2 trillion cubic feet in the residential and commercial sectors. Spurred by rising demand, domestic natural gas production is projected to increase steadily between 1995 and 2015, primarily from lower 48 onshore conventional sources. An in-depth discussion of these forecasts and the U.S. natural gas market is contained in ELA's Annual Energy Outlook 1997 [8].

Proven reserves in North America at the end of 1996 totaled 300.9 trillion cubic feet and accounted for 6.1 percent of the world total [6]. The United States accounts for 54.9 percent of the North American reserves, Canada 22.6 percent, and Mexico 22.5 percent. Although North American reserves account for only 6.1 percent of the world total, North American production in 1995 accounted for 33.7 percent of the total, making North America the world's largest natural gas producer $[7$, p. 20]. With the exception of 1.6 billion cubic feet of
LNG exported to Japan, all of North America's production was consumed within the region.

Trade between the three North American countries continues to expand. In 1995, 12.4 percent of total U.S. natural gas consumption was supplied by Canada, and that share is projected to grow to 13.5 percent in 2015 [8], representing an average annual growth rate of 1.9 percent per year in net Canadian imports over the forecast period. The increase comes from assumed growth in, and higher utilization of, pipeline capacity between the United States and Canada, coupled with abundant supplies of Canadian gas at competitive prices. Canada has the production capacity and resource potential to remain a significant supplier of gas to the United States, but any significant increase in trade will require an expansion of existing pipeline capacity between the two countries.

Canada is currently facing a substantial imbalance between supply and demand, as a result of both increased drilling activity in western Canada and the capacityconstrained export market. Although a number of projects are underway to increase pipeline capacity between the United States and Canada, according to Paul R. Mortensen, senior analyst at the Canadian Energy Research Institute (CERI), "The earliest point we could see improvement in the export market would be when the Northern Border pipeline project comes on stream sometime in mid-1997" [9]. The IEO97 forecast is optimistic with regard to increased trade, and pipeline capacity between the two countries is projected to increase by 20.9 percent by 2015 .

Since 1984, U.S. natural gas trade with Mexico has consisted primarily of exports. That trend is expected to continue throughout the forecast period, with U.S. net exports to Mexico growing by 3.9 percent per year, from 0.05 trillion cubic feet in 1995 to 0.12 trillion cubic feet in 2015 [8]. A number of proposed projects to expand pipeline capacity between the United States and Mexico reflect the growing interest by U.S. firms in expanding their trade with Mexico. Additionally, the Comision Reguladora de Energia (CRE) in October granted MidCon Gas Natural de Mexico, a subsidiary of Occidental Petroleum Corporation, permission to build a 100-mile pipeline from Cuidad Aleman (near the U.S. border) to Monterrey, the capital of Nuevo León. MidCon will invest nearly $\$ 50$ million to build the pipeline with a capacity of 270 million cubic feet per day. Construction is scheduled to begin within the first 6 months 1997 [10].

While Mexico's substantial reserves and a reserve-toproduction ratio of greater than 30 years provide a prime opportunity for expansion of the natural gas 
market, uncertainty about future economic growth and development, political and policy risks, and issues related to the monopoly control and budgetary constraints of Petroleos Mexicano (PEMEX) could affect the future direction of the market. There is, however, a strong environmental incentive to replace high-sulfur heavy fuel oil with cleaner burning natural gas for power generation and industrial applications.

Foreign participation in oil and gas exploration, production, and refining is currently proscribed by the Mexican constitution, which allows only PEMEX to engage in those activities. The best opportunity for foreign investment in the natural gas industry is in the distribution segment [11], which was partially privatized by the Mexican congress in 1995. The government has recently called a tender to award Mexico's second natural gas distribution concession to the private sector. Existing PEMEX distribution lines will act as a base for the new system, which will serve industrial and residential customers in the city of Chihuahua and surrounding urban areas. An estimate of 5 years and $\$ 52$ million to develop the distribution system has been given.

In addition to encouraging development in the distribution infrastructure, the government is also encouraging competition. Guidelines have been issued by the Energy Regulatory Commission for the definition of natural gas distribution zones, which will be used to divide population centers into two or more zones (primarily in large cities, such as Mexico City, where the government is especially interested in fostering competition) [12].

\section{Western Europe}

In Western Europe, substantial growth in natural gas consumption is expected, mainly to fuel growing use of gas in the electric power sector. Overall, gas consumption in Europe is projected to more than double over the next 20 years, while the use of gas to generate electricity more than triples. The natural gas share of total energy used to generate electricity in the region is expected to rise from 10 percent in 1995 to 25 percent in 2015.

Resource availability, government energy policy, and infrastructure development all favor increased use of natural gas in Europe. Elements of government policy include the repeal of the 1991 ban by the European Commission (EC) on the use of natural gas for new power generation, allowing a substantial shift in utility power development strategy. Although the EC's ban, in reality, had allowed some exemptions, its removal came at a time that made adding natural-gas-fired power very appealing.
Environmental policy also encourages gas use. Natural gas prices have been competitive at the same time that requirements for fitting coal-fired generators with pollution control equipment have increased the costs associated with continued coal use. The environmental advantage of natural gas over other fossil fuels with respect to carbon emissions has also helped its growth in Western Europe. Many countries have cited government encouragement of natural gas use as part of official plans for reducing greenhouse gas emissions.

Privatization of the electricity sector and the ensuing widespread development of independent power plants add another dimension of policy encouraging expanded gas use. Independent power suppliers in general are choosing combined-cycle technology, which has fuel efficiency, relatively low capital requirements, and short construction times.

Growth in natural gas demand is being accompanied by much activity in terms of gas infrastructure (that is, construction of plants and pipelines), which will enable customers to diversify suppliers and gas supply contracts. Several important developments came to fruition in Europe in 1996.

Sales agreements for the gas from Norway's Troll field became official in October 1996 [13]. The agreements will secure gas exports from Troll for the next 20 years. The field is Europe's largest offshore gas development and will send-at its peak-about 3.2 billion cubic feet of gas per day to the Kollsnes terminal on Norway's west coast and, from there, through several thousand miles of underwater pipeline to the south. The export contract, which is Norway's largest ever, worth about $\$ 108$ billion, will provide gas to Germany, the Netherlands, France, Austria, and Spain.

In 1996, Greece received its first delivery of Russian gas, a total of about 18 million cubic feet in September [14]. The imports traveled through a 43-mile pipeline that runs across Bulgaria through the city of Kulata on the Bulgarian-Greek border. Plans are to increase the Russian imports through Bulgaria to 35 billion cubic feet of natural gas in 1997. The gas is to be distributed to customers in Athens and later to Thessaloniki.

Gas infrastructure is currently being developed in Northern Ireland, a process that will take several years to complete [15]. Phoenix Natural Gas will spend an estimated \$247.6 million (U.S. dollars) to provide a gas system for residential and commercial consumers. North and West Belfast, along with some parts of central Belfast City, will be among the first areas to be given access to natural gas, beginning in Spring 1997. Work has been completed on a transmission line to distribute gas from Premier Power Station at Ballylumford, 
where the first of six 200-megawatt gas-fired generating units came on stream in October 1996 [15, 16]. The facility is supplied with gas through an 84-mile pipeline running from Dumfries and Galloway (southwest Scotland), which has been extended another 16 miles to Belfast.

Financing and leasing were secured for the UK's Interconnector pipeline-and construction began-in 1996 [17]. The UK's Abbey National granted a \$633 million finance lease, and the European Investment Bank lent $\$ 534$ million for construction of the 150 mile subsea natural gas pipeline, which will run from a compression unit in Bacton, Norfolk, in the UK to Zeebrugge, Belgium. The pipeline is expected to supply up to 700 billion cubic feet of gas per year from the United Kingdom to Belgium [18]. Construction on the Interconnector began in October 1996 at the Zeebrugge end of the line. The pipeline system should become operational by October 1998 [19]. The German gas trading firm, Wingas, signed the first contract to buy gas from the Interconnector-35 billion cubic feet of gas per year beginning in 1998 [20].

Another important milestone for the European natural gas market was the completion of the Maghreb-Europe pipeline [21]. The nearly 800-mile pipeline runs from Hassi R'Mel (the largest gas field in Algeria) to Seville, in southern Spain, but will eventually supply gas to Portugal and then to France and Germany. Commercial sales to Spain began in November 1996 [22]. The pipeline has an initial capacity of 283 billion cubic feet per year, which will be expanded to as much as 706 billion cubic feet by 2000 , after new compression stations are installed in Algeria and Morocco.

Portugal-one of the builders of Maghreb-Europe-is constructing a $\$ 35$ million link to the pipeline, which ends in Spain [21]. Portugal has advanced the development of its new natural gas infrastructure, which is expected to be completed by the end of 1997, at an estimated cost of $\$ 1.3$ billion. The $\$ 850$ million pipeline portion of the system is nearly complete, with operations scheduled to begin in 1997 [23]. Portugal's Transgas is constructing a 335-mile pipeline to connect the Spanish and Portuguese grids at Campo Maior, extending to Leiria. From Leiria, the main transmission system runs north to Braga and then to the port of Setubal (south of Lisbon). Maghreb-Europe will supply Portugal with about 88 billion cubic feet of Algerian gas annually.

Linkages between Western and Eastern Europe also expanded in 1996. An important pipeline was completed in October-the 74-mile Hungary-Austria pipeline, which runs to Gyor, Hungary, from Baumgarten,
Austria [24, 25]. The pipeline was built by the Hungarian oil and gas company, Mol, and Austria's state oil company, OMV. It will be able to ship about 159 billion cubic feet of gas per year from western suppliers to Eastern Europe, diversifying supplies in countries that have been almost exclusively dependent on Russian natural gas [26]. The Hungary-Austria line will also allow Hungary to move gas to the former Yugoslavia, and it could open Eastern Europe to possible imports from Norway, the Netherlands, and, eventually, the British Interconnector. Since the pipeline became operational in October 1996, the German company, Ruhrgas, has been supplying Mol with natural gas [25]. OMV will provide 106 billion cubic feet of gas per year through the pipeline until the end of 2016.

Construction of a pipeline project to run from Tabriz, Iran to (eventually) Ankara, Turkey, will begin in March 1997 [27]. Initially, two segments of the pipeline will be constructed: a 156-mile segment on the Turkish side will run from the border to the eastern province of Erzurum, and a 169-mile segment will run from Tabriz to the Turkish border. When those segments are complete, Turkey plans to extend the pipeline another 500 miles, from Erzurum to Ankara. The project should be completed by the end of 1997 or early 1998, carrying an initial 106 billion cubic feet of gas per year to Turkey under a $\$ 23$ billion, 23-year contract. According to the agreement, the amount of gas supplied will increase to 353 billion cubic feet after 2005, supplying Turkey with a total of nearly 7 trillion cubic feet over the lifetime of the project.

In an effort to diversify Italy's gas suppliers, the national energy company, ENI, announced in November that it had secured a $\$ 3$ billion gas supply deal with Libya [28]. Italy currently relies on gas imports from Algeria, Russia, and the Netherlands. The Libyan arrangement provides for the export of gas from Libya's onshore Wafa field and Block NC-41-an offshore field located on the Mediterranean coast-as well as a 320-mile pipeline extending from Libya to Capo Passero, Sicily. The deal itself is of political interest since its value exceeds the limit of $\$ 40$ million per year imposed under the U.S. Iran-Libya Sanctions Act (signed in August 1996). The Sanctions Act penalizes non-U.S. firms investing in the energy industries of Libya and Iran as a method to deter international terrorism in those two countries.

\section{Eastern Europe and the Former Soviet Union}

Eastern Europe and the FSU account for approximately 40 percent of the world's proven natural gas reserves, almost all attributed to the FSU. Russia alone has more proven gas reserves than any other country in the world, accounting for 33 percent of the world's total. 
According to Gazprom, the Russian state gas company, potential gas reserves may be five times greater than proven reserves. Gazprom estimates that Russia's ultimate reserves could be over 7,413 trillion cubic feet, or roughly 1.5 times the world's current proven gas reserves [29]. Russia also currently accounts for more than 26 percent of the world's total production. Gazprom estimates that, in addition to supplying most of the natural gas used in Russia and several other FSU countries, it supplied approximately 21 and 56 percent of the natural gas used in Western and Eastern Europe, respectively, in 1995 [30].

Although the extent of their reserves provides significant potential for long-term growth, ongoing economic and political transitions in the FSU nations have been accompanied by a decline in the gas industry since 1990. Eastern Europe and the FSU saw natural gas consumption fall by 17.4 percent between 1990 and 1995, with a corresponding drop in production. This was the only region of the world experiencing a decline.

The downward trends for the FSU in both GDP and natural gas use are expected to be reversed as political and economic conditions stabilize. Natural gas consumption is projected to grow from 23.2 trillion cubic feet in 1995 to 39.4 trillion cubic feet in 2015. Gas use in Eastern Europe is projected to grow even more rapidly, at an annual rate of 5.2 percent between 1995 and 2010, compared with 2.3 percent for the FSU. Gazprom also forecasts a turnaround and anticipates that gas consumption in Russia will increase from 1997 onward, regaining its peak 1991 level in 2003 and growing by more than 20 percent between 1995 and 2010 [29]. There are already exceptions to the current decline in FSU gas industries: in Azerbaijan, Kazakhstan, and Uzbekistan, production increased between 1994 and 1995 by 3.1, 31.1 , and 3.0 percent, respectively; and Kazakhstan and Uzbekistan also showed increases in consumption [7, pp. 23, 25].

In addition to the projected growth in natural gas use within the EE/FSU region, Russia sees Europe as a strong market and is positioning itself to dominate supply. Key competitors will be Britain and Norway. Gazprom has indicated that in 1995 it exported 4.1 trillion cubic feet of gas to Europe and that, as of January 1996, it had long-term contracts to supply 55.7 trillion cubic feet of gas to Europe through 2010 [30].

Significant pipeline expansion aimed at bringing Russian supplies to European markets is currently in the planning stages, and more is anticipated. Cambridge Energy Research Associates (CERA) believes that Gazprom's planned Yamal pipeline across Poland and Belarus could be economically developed to deliver up to an additional 0.7 trillion cubic feet per year of Russian gas to West European markets. Although the Yamal pipeline has huge potential for delivery to Europe by 2010, the economics may prove difficult because of hostile climatic conditions (such as permafrost) in remote areas that the pipeline must cross in order to tap the extensive resources in the far north of western Siberia's Yamal Peninsula. Initial deliveries to Germany and Poland will provide gas from fields where the infrastructure is already in place rather than from the remote Yamal fields.

Current agreements with Germany and Poland call for Gazprom to begin delivering gas through the Yamal line in 1997, peaking at approximately 2.1 trillion cubic feet in 2004. Poland expects to be receiving nearly 0.4 trillion cubic feet by 2010, a portion of which will be free of charge as payment for the transit of Russian gas over Polish territory [31]. An additional market for Russian gas could be the Far East, where demand is rising sharply. Active negotiations appear to be underway for a dedicated pipeline to Beijing.

Foreign investment is likely to play a role in the future development of the EE/FSU natural gas industry. Most of the region's industry is still controlled by national governments, but privatization is beginning to take hold. Foreign investment in Russia had long been put on hold, largely as a result of delays in the passage of a property rights law. Even after the Oil and Gas Law was enacted, apprehensions over the survival of Russian democracy and corresponding economic reform continued to discourage foreign investment.

Although the move to a market economy involved the privatization of much of Russia's industry, the gas sector remained intact under the gas monopoly Gazprom until recently [11, p. 21]. In 1991, Gazprom was converted into a state-owned joint stock company. In 1993, 15 percent of the shares were allocated to employees and retired employees. Privatization began in 1994, with more than one-third of the shares distributed to Russian citizens via auction. The government has allocated 10 percent of the shares to Gazprom itself but intends to hold on to 40 percent for at least 3 years [29, p. 40]. Nine percent of the stock has been set aside for foreign ownership; however, as any sale of shares requires approval, the future of foreign ownership of any portion of the shares remains to be seen. The first offering of Gazprom shares to international investors, consisting of about 1 percent of the total, was recently announced [32]. Other EE/FSU countries have shown a willingness to allow foreign investment, and foreign firms are exploring investment in all areas of the industry. 


\section{Central and South America}

Natural gas consumption in Central and South America is expected to grow by 5.3 percent annually over the next 20 years. In the reference case, the region's natural gas demand in 2015 is 2.8 times its 1995 level, growing from 2.6 to 7.4 trillion cubic feet per day. The fastest growing markets for natural gas in the region are expected to be in the countries with the least amount of present natural gas infrastructure-Chile, in particular, where DRI/McGraw-Hill projects an increase in gas penetration from under 7 percent of the energy market in 1995 to nearly 24 percent in 2015 [33, p. 81].

There are extensive plans to expand natural gas pipelines throughout South America, as well as to construct gas-fired electricity plants. The industrial sector remains the largest gas consumer in the region, but the strongest growth is expected in the electric power sector [33, p. 7]. Several factors influence the growing use of natural gas for electricity generation. They include the development of efficient gas-fired generating capacity (especially combined-cycle gas turbines), the adoption of tight monetary policies, and the integration of markets throughout the region. Controlling inflation rates has made it possible to develop long-term contracts between gas producers and power generators, which in turn have made it easier to attract the financing needed for pipeline projects. Market integration is helping to reduce tariffs and bring regional consistency to natural gas prices. The price reforms encourage power projects, because they allow developers to anticipate regional prices.

Construction is expected to begin in mid-1997 on the Atacama pipeline, which will transport natural gas across the Andes Mountains from Salta, Argentina, to the port of Mejillones, Chile, about 35 miles north of Antofagasta [34, 35]. The pipeline will have an initial capacity of 106 million cubic feet per day, eventually rising to 212 million cubic feet per day. As part of the Atacama project, a 400-megawatt natural-gas-fired combined-cycle generating plant will be constructed at the end of the pipeline in Chile. The $\$ 700$ million integrated power project and pipeline should be operational by 1999.

The Chilean company, Empresa Nacional de Electricidad SA (Endesa), signed a $\$ 350$ million contract with Argentina's YPF to supply 64 million cubic feet of natural gas per day for the next 15 years to the planned electric power plant, San Isidro, to be located in central Chile [36]. The gas will be shipped through a pipeline to be constructed from Mendoza, Argentina, to Santiago, Chile, expected to be completed by the end of 1997. The Canadian company, NOVA Corporation, plans to build a third pipeline between Argentina and
Chile [37]. The $\$ 350$ million Gas de Sur pipeline would run from the Neuquen gas fields in southern Argentina to Chile's industrial city, Concepcon. Construction on Gas de Sur would begin in 1997 and operation in 1998.

The Brazilian government has agreed to allow construction of two pipelines to supply gas from Argentina to the Brazilian state, Rio Grande do Sul [38]. The pipelines are expected to be completed by 1998 at an estimated cost of $\$ 600$ million. The first project will feed a 450-megawatt gas-fired plant at Uruguaiana.

In September 1996, almost 60 years after it was first proposed, Brazil and Bolivia signed definitive agreements to begin work on the $\$ 1.8$ billion Bolivia-to-Brazil natural gas pipeline [39]. The 1,900-mile pipeline will run from Santa Cruz, Bolivia, to Sao Paulo, Brazil, and then extend to Porto Alegre, Brazil. Initially, Bolivia hopes to export 285 million cubic feet a day. Another pipeline has been planned to run from Santa Cruz to Trinidad, to supply a gas-fired power plant there [40]. The 273-mile pipeline, which will cost an estimated $\$ 15.5$ million to build, will have a capacity of about 45 million cubic feet per day.

Plans continue for a natural gas pipeline between Buenos Aires, Argentina, and Montevideo, Uruguay [41]. The 143-mile pipeline will be constructed under a $\$ 120$ million build-own-operate contract, which is expected to last for 30 years. Another agreement between Argentina and Uruguay is to build a gas pipeline between the Argentine province of Entre Rios and the Uruguayan coastline [42]. Construction on the 270-mile portion of the pipeline in Entre Rios began in late 1996 [43]. Expansion of the pipeline will allow Argentina to sell gas to Uruguay and Brazil.

Bolivia and Paraguay are negotiating the construction of a 558-mile natural gas pipeline from Yacuiba, Bolivia (on the Bolivia-Paraguay border), to Asuncion, Paraguay [44]. The pipeline would cost an estimated $\$ 300$ million and would be able to move 89 million cubic feet per day.

The Colombian government has instituted a "gas massification" plan in an effort to bring natural gas to consumers in all of the country's major population and industrial areas [45]. The program includes construction of 2,600 miles of gas transmission lines. Between 1990 and 1995, Colombia's gas pipeline system grew from 438 miles to more than 1,000. A new residential and industrial distribution system along the pipeline system is planned, at an estimated cost of $\$ 1.1$ billion.

Power generation is an important area for future gas use in Colombia, as well. At present, about 3 gigawatts of the country's electricity generation capacity is gasfired [45], and the Colombian government would like 
to add another 5 gigawatts by 2000 . The $\$ 150$ million, 199-megawatt combined-cycle gas-fired electric power plant, Termovalle, has been financed in Cali, Colombia [46]. The first stage of the project should become operational in late 1997, reaching full capacity some time in 1998. The power will be sold to the Chilean utility, Empresa de Energia del Pacifico, with the balance supplying various industrial customers.

\section{Asia}

Throughout the forecast period, natural gas demand in Asia (both industrial and developing) is expected to continue the strong growth it has enjoyed over the past decade-an average of 6.4 percent annually between 1985 and 1995. In the industrialized Asian countries of Japan, Australia, and New Zealand, gas demand is expected to increase at a slower pace of about 2.6 percent annually between 1995 and 2015, but growth of nearly 8 percent is expected in other areas - especially the emerging economies of developing Asia (China, India, Thailand, South Korea, Taiwan, and Indonesia).

Natural gas consumption in Asia as a whole is expected to reach 26.4 trillion cubic feet in 2015, triple the current levels of demand in the region. This sizable increase will require extensive investment in the region's gas infrastructure. Some development will involve pipeline construction, much of which is still in early planning stages. In addition, substantial expansion of Asian liquefied natural gas (LNG) imports is anticipated (see below).

China has secured three loans from foreign banks totaling $\$ 319$ million for the development of the Pinghu natural gas facility, south of Shanghai- $\$ 130$ million from the Asian Development Bank, $\$ 120$ million from the Japan Import-Export Bank, and $\$ 69$ million from the European Investment Bank [47]. Completion of the project is scheduled for the end of 1998. The project should supply about 42 million cubic feet of gas per day to Shanghai. In 1996, China completed a 182-mile gas pipeline that runs from the Cainan oil field in China's northwestern Junggar Basin to Karamay, a major oil production base in the Xinjiang Uygur Autonomous Region [48]. Natural gas previously flared from Cainan (and worth an estimated $\$ 12$ million per year) will now be transported to Karamay. The pipeline can accommodate about 106 million cubic feet of gas daily.

By the end of 1996, all legal matters surrounding the Dabhol power project in India had been resolved, and construction on the power project had resumed [49]. The U.S. company, Enron, had to renegotiate its contract for construction of the $\$ 2.5$ billion, 2.4-gigawatt plant after a newly elected Maharashtra state government filed suit to halt construction of the plant in
August 1995 [50]. The first phase of the multi-fuel-fired Dabhol project will have an installed capacity of 826 megawatts and is expected to be operational by 1999 . A timetable for Phase 2, which is to be constructed together with a liquefied natural gas terminal, has not yet been finalized.

Myanmar (formerly Burma) continued construction aimed at getting gas supplies to neighboring Thailand. Sales from the Yetagun field in Myanmar's Gulf of Martaban are expected to begin in 1999 [51]. Peak production from Yetagun is expected to be about 200 million cubic feet per day, and supplies should last about 20 years. There are plans to construct a pipeline from Yetagun to Zadi and then another 43 miles to the Thai border and to Ratchaburi, where several power plants have been planned, as well as at least three other pipelines. The projects will make Ratchaburi Thailand's first gas hub. The pipeline from Zadi to Ratchaburi will run parallel to the route of another pipeline running from the Gulf of Martaban's other major gas field, Yadana. The Yetagun field is also scheduled to be tapped by a pipeline to Yangoon, Myanmar.

Myanmar's Yadana gas field (located in the Andaman Sea, off the southern coast of Myanmar) could supply as much as 650 million cubic feet per day, the bulk of which state-owned Myanmar Oil and Gas Enterprise (MOGE) plans to export to Thailand [52]. Construction on the planned 254-mile pipeline (215 miles offshore and 39 miles onshore), which would run from the gas field to the Thai border, is expected to be completed by mid-1998. An additional 161-mile pipeline, to be constructed by the Petroleum Authority of Thailand, will extend from the Thai border to Ratchaburi (near Bangkok). The project has been the subject of controversy since its inception in 1992. Human rights organizations have protested that people along the pipeline route have been forcibly relocated, and environmental organizations have expressed concern about damage to the forests along which the line runs.

Thailand's state-owned Petroleum Authority of Thailand (PTT) is attempting to diversify its gas supplies as quickly as possible [51]. In addition to the Myanmar sources, PTT is negotiating with Vietnam, Indonesia (the Natuna project), and the Malaysia-Thailand Joint Development Area (JDA) for additional sources of gas. PTT would like to begin receiving gas supplies from the JDA in 2000, from Natuna in 2003, and from Vietnam in 2004.

In 1996 the ambitious PTT plan for a $\$ 12$ billion investment program to develop the natural gas pipeline system in Thailand was approved by the country's National Energy Policy Committee [53]. The committee gave six pipeline projects high priority, and another six 
were designated as alternatives. All of the pipelines are expected to be completed between 1997 and 2005. The six highest priority pipelines are (1) a pipeline from the JDA to the Erawan gas field's existing infrastructure in the Gulf of Thailand; (2) a 332-mile pipeline running from Erawan to Ratchaburi (estimated completion, 2000); (3) a 93-mile offshore line from Unocal Thailand's Pailin gas field to Erawan (estimated completion, 1999); (4) a 93-mile offshore line running from Ratchaburi to Wang Noi, Ayutthaya; (5) a 34-mile subsea line from the Benjamas field to the Tantawan field; and (6) a 37mile pipeline from Ratchaburi-Wang Noi to the South Bangkok power plant at Samut Prakan. The project alternatives include extensions of the Erawan-Ratchaburi line to Prachuab Kiri Khan and to Laem Chabang Chon Buri; a 186-mile line from the Khanom natural gas separation plant in Nakhon Si Thammarat to power plants in Surat Thani and Krabi; a 107-mile line from Pailin to Songkhla; a line from Yala (at the Thai-Malay border) to Songkhla; and a line from Laem Chabang to Mab Kha, Rayong.

First Gas Holdings Corporation is attempting to secure financing for construction of a $\$ 650$ million 900-megawatt natural-gas-fired power plant in Batangas province, near Manila in the Philippines [54]. The power plant is to be a joint venture between First Gas (itself a joint venture of British Gas and First Philippine Holdings Corporation) and Germany's Siemens AG. First Gas is also considering a joint venture with the Philippine National Oil Company-Exploration Corporation (PNOC-EC) to lay a $\$ 70$ million, 105 mile gas pipeline from the Philippines first commercial gas find at Camago-Malampaya in southern Philippines to a power plant in Bataan (northwest of Manila) [55]. PNOC-EC has already applied to the Philippines energy department for the authorization to construct what would be the country's first natural gas pipeline.

Analysts and natural gas suppliers view South Korea as one of the most important growth markets for natural gas, as many new gas-fired electricity generating plants become operational and the country expands its natural gas transmission network to supply growing industrial and residential demand [56]. Currently, South Korea's natural gas supplies are exclusively in the form of LNG. The country is one of the major Asian importers of LNG and has existing agreements with Indonesia (its main supplier), Malaysia, Brunei, and Australia. In addition, the Korea Gas Corporation (Kogas) has secured new long-term LNG supplies from Qatar and Oman, which will begin within the next decade. The company has also begun discussions with Yemen as an additional source of LNG.

Kogas estimates that, if gas use increases according to current expectations, the country could experience a shortfall of as much as 4 million tons by 2000 . Declining gas reserves in Indonesia might bring the shortfall to more than 12 million tons by 2010. Thus, major new contracts for supplies from Brunei and Australia need to be negotiated within the decade, subject to resource availability. Kogas is also pursuing potential gas supplies via pipeline from Siberia.

\section{Africa}

Natural gas markets in North Africa are dominated by Algeria, although there have been substantial gas discoveries in Tunisia and off the coast of Egypt. Much of the resulting gas production is targeted for markets in Southern Europe, although there are an increasing number of projects aimed at fueling domestic gas-fired power plants. For instance, the small gas field, Panthere, in the Ivory Coast is being developed specifically to supply a 150-megawatt power plant [57].

A major concern for Nigeria is the gathering of natural gas, which is now typically flared. ${ }^{4}$ Royal Dutch Shell has launched the first of its series of gas gathering projects, planned to eliminate flaring by 2008 at its Escravos field near the midwestern town of Warri [58]. The Odidi project, expected to cost $\$ 250$ million, will collect about 80 million cubic feet of gas per day, which will be supplied to customers in the Lagos area. The project should become operational in 1999.

Chevron Corporation is also implementing a gas gathering project in Escravos. The first phase, estimated to cost about $\$ 569$ million, involves processing about 150 million cubic feet of associated gas per day. It is expected to become operational in May 1997. There are also plans to build a pipeline from Nigeria to the West African countries of Benin, Togo, and Ghana [59]. The project had been under negotiation for 8 months, but in July 1996 an agreement was reached to move forward with the scheme, which will allow Nigeria to export gas from the Escravos field that is currently being flared. The World Bank estimates that $\$ 260$ million would be required to complete the project.

Another North African country with considerable natural gas reserves is Libya, with more than 45 trillion cubic feet of reserves as of January 1996 [7, p. 20]. In October 1996, Libya and Tunisia agreed to construct a

\footnotetext{
${ }^{4}$ Flared natural gas is gas that is burned in the field or at gas processing plants as a means of disposal (when there is no market for it and the operator does not elect to, or cannot, use it).
} 
natural gas pipeline through which Libya would supply Tunisia with natural gas for domestic consumption [60].

Algeria expects to be able to export 5.8 billion cubic feet of natural gas per day by 2000 , both through pipeline sales to Europe and through expanded LNG exports [61]. Algeria exports about 740 billion cubic feet of LNG per year currently, one-third of it to Gaz de France. Construction on the Maghreb-Europe gas pipeline was completed in September at a cost of almost $\$ 1.9$ billion [62]. The pipeline has the capacity to transport 335 billion cubic feet per year, and Algeria has plans to nearly double that capacity to 653 billion cubic feet sometime after 2000. Spain's gas company, Gas Natural, has stated that it expects 40 percent of its distribution in Spain by 2000 to be supplied by the Maghreb-Europe pipeline [63]. Algeria is already considering another pipeline to Europe, which would link the western Algerian port of Mostaganem to the Spanish coast [64], allowing Algeria to compete more aggressively in the lucrative European gas market with suppliers in the Netherlands, Norway, and Russia.

\section{Middle East}

For most of 1996, Israel and Egypt negotiated over the construction of a so-called "peace pipeline," which would extend about 285 miles from Egypt's Port Said to Israel's Port of Haifa, near the Gaza Strip, with links to Jericho and Jordan and Turkey [65]. The Egypt Trans Gas Company originally proposed the pipeline to supply Israel with about 70 billion cubic feet of natural gas per year beginning in 2000 [65, 66]; however, negotiations between the two countries deteriorated after the May election of Israel's new Prime Minister, Benjamin Netanyahu [65]. In November, Egypt, Turkey, and the U.S. company Amoco scrapped plans for the pipeline altogether, and instead signed an agreement to export the Egyptian gas to Turkey directly in the form of LNG [67]. While gas industry executives involved in the discussions claimed that the failure to proceed with talks on the peace pipeline were related to difficulties in the development of a gas infrastructure in Israel, clearly, the lack of progress in the Middle East peace process was the deciding factor in moving forward with the alternative LNG project.

Iran made advances during 1996 in establishing its position as a major gas exporter. A $\$ 23$ billion agreement was reached with Turkey to provide gas supplies by the beginning of 1998 . Construction on the pipeline to Ankara should begin in the first quarter of 1997. Iran's government has also announced that it will give priority to establishing pipeline links with Pakistan, India, and Armenia, as well as Turkey [68]. Progress on establishing pipelines to India and Pakistan has been impeded both by the high costs associated with their construction and by political obstacles. Iran has proposed a plan to supply Pakistan with 1.6 billion cubic feet per day, although once an agreement has been reached, it will take Iran another 4 years to supply Pakistan with the gas.

In October 1996 construction on the Iran-Turkmenistan natural gas pipeline began [69]. The 130-mile pipeline, with an annual throughput capacity of 8 billion cubic meters, is expected to be completed by the end of 1997 [70]. It will allow Turkmenistan to export gas to international markets such as Pakistan by using Iran's natural gas pipeline network.

\section{Regional Activity in Liquefied Natural Gas}

Liquefied natural gas (LNG) markets appear to be entering a new round of expansion with a more diversified range of customers and suppliers. There is a growing number of LNG supply contracts worldwide, despite the fact that average LNG prices have, for the most part, remained higher than prices of competing fuels (Figure 44). The fast-paced expansion of natural gas demand in recent years has meant substantial growth even in the relatively high-cost LNG market. As evidence of the optimism for LNG development, centers of production are under construction in new producing areas-Nigeria and Trinidad-and capacity expansion is underway or about to begin in established areas, including Oman, Qatar, Malaysia, and Australia [5, p. 54].

\section{Figure 44. Selected International Natural Gas and Crude Oil Prices, 1985-1995}

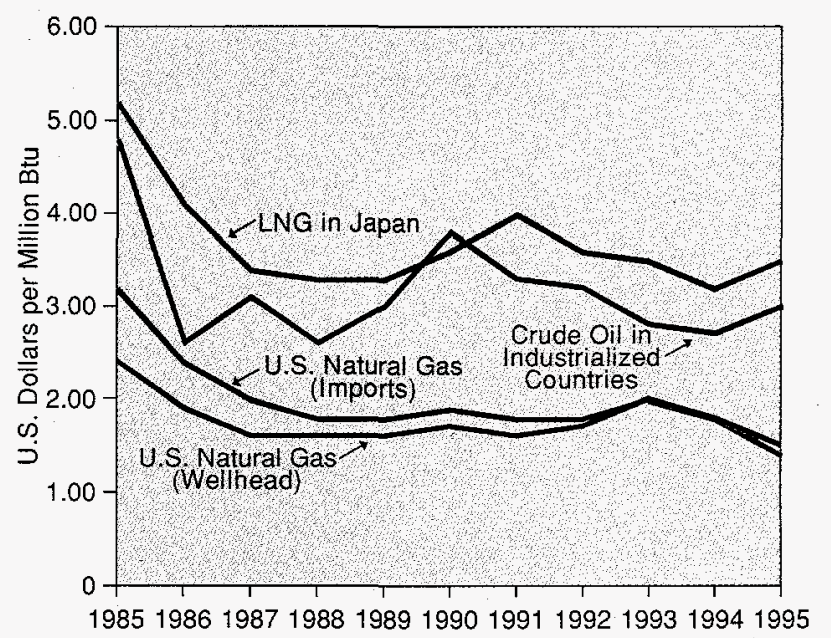

Source: British Petroleum Company, BP Statistical Review of World Energy 1996 (London, UK, June 1996), p. 29. 
There is a substantial amount of processing and expense associated with bringing LNG to the consumer. It must be converted to liquid form before shipping. It must be shipped in specially designed refrigerated ships and delivered to ports equipped with special receiving facilities. And finally, it must be regasified and distributed to customers through pipelines, just as natural gas is usually distributed. The considerable costs associated with processing and transporting LNG make it an expensive source of fuel even when the inputs of raw materials are inexpensive. On the other hand, evolving technology promises to reduce the scale requirements for both liquefication and transport, even as demand for LNG rises sharply with the expansion of economic activity, especially in South Korea and Thailand [71]. However, OPEC countries are showing increased interest in LNG, which is outside the organization's quota system.

In the past, Asia (especially Japan) has been the major market for LNG. In 1995, Japan, South Korea, and Taiwan combined imported 77 percent of the world's LNG exports [7, p. 28], and Japan continues to be the world's major importer. Qatar Liquefied Gas Company began exports of its first LNG to Japan in December 1996 [72]. The company shipped 65,000 tons of LNG to Japan's Chuba Electric Power, the first delivery of a 25year, 100-million-ton agreement. New potential markets for LNG in Asia are expected to be in China and Thailand, beginning after 2000. The Petroleum Economist projects that LNG demand in the Asia-Pacific may triple by 2015 [5].

Existing LNG contracts and new commitments indicate that global LNG trade might rise by as much as 60 percent (to 107 million tons) by 2000 [73]. In 1995, almost 68 million tons of LNG was traded. Abu Dhabi exported just over 1 million tons of short-term or "spot" sales, 30 percent of which was exported to Spain and the remainder to Belgium and France. Spain and Turkey each purchased 350,000 tons of Australian LNG in 1995.

Oman secured several important contracts for its LNG in 1996. State-owned Petroleum Authority of Thailand agreed to buy up to 2.2 million tons of Omani LNG annually, beginning in 2003 [74]. Oman is attempting to obtain \$2.25 billion in financing to complete its LNG project. So far, eight foreign banks are involved in arranging the loan. The final sales and purchase agreement between Oman LNG and the Petroleum Authority of Thailand should be signed by late 1997 [75]. Moreover, a 25-year agreement has been reached for sales from Oman LNG to Korea's state-owned Kogas for 4.1 million tons of LNG per year [76, p. 1]; with first deliveries scheduled to begin in 2000 . Three gas fields at Saih Rawl, Barik, and Saih Nihayda are being developed to help supply Oman LNG. Initial construction will include a processing plant (Saih Rawl), a gathering station (Barik), and a 221-mile pipeline extending to the Oman coast.

South Korea imported almost 7 million tons of LNG in 1995-5.1 million tons from Indonesia, 1 million tons from Malaysia, 700,000 tons from Brunei, and 70,000 tons from Australia [7, p. 28]. The South Korean government has announced plans to expand LNG supply for residential fuel to four southern cities (Kyongju, Pusan, Ulsan, and Kumi) [77], in the hope that natural gas will replace residential fuels such as liquefied petroleum gas. Official government estimates have South Korean LNG demand increasing by 16.2 million tons over the next 15 years.

The LNG industry will have two new producers as Nigeria and Trinidad begin LNG projects [5]. Shell Oil in Nigeria is currently constructing an LNG plant in Bonny, in the southeastern portion of the country [58]. Construction began in March 1996, and the $\$ 4$ billion plant is expected to produce 254 billion cubic feet of gas per year when completed in 1999 [58, 78]. The plant is to be used to process LNG for European markets in Spain, Italy, Turkey, and France [57].

LNG markets in Southern Europe might also gain a new supply source from the Atlantic LNG project under construction in Trinidad by the consortium of Amoco, British Gas, Repsol (Spain), U.S. Cabot, and the National Gas Company of Trinidad [79]. In June 1995, construction began on the $\$ 1$ billion single-train plant, beginning the first greenfield LNG venture in the Western Hemisphere in the past 25 years. Up to 450 million cubic feet of natural gas per day will be supplied to the LNG facility for an initial period of 20 years, with 60 percent of the resulting LNG exported to New England and the rest to Spain. The system is scheduled to become operational by the end of 1999 .

Another major development in European LNG market was the recent scheme to ship Egyptian LNG to Turkey, rather than pursuing a pipeline that would have supplied Turkey with the gas via Israel, through what has been called the "peace pipeline." The U.S. company Amoco will build a plant in Egypt to liquefy the gas for export, at an estimated cost of $\$ 2$ billion to $\$ 4$ billion, depending on the size of the plant and the speed at which it is constructed [80]. The LNG agreement will provide Turkey with more than 350 billion cubic feet of gas beginning in 2000. The switch to the LNG scheme demonstrates that LNG is still commercially viable in areas where political issues constrain pipeline development. 


\section{References}

1. A.D. Koen and W.R. True, "World's Developing Regions Provide Spark for Pipeline Construction," Oil \& Gas Journal, Vol. 94, No. 6 (February 5, 1996), pp. 27-30.

2. Enron Corporation, The 1995 Enron Outlook (Houston, TX, 1995).

3. "Arco, Chinese Leaders Celebrate Startup of China's Largest Offshore Natural Gas Project," Arco OnLine Press Release (January 10, 1996).

4. A.G. Bardsley, "Thais To Buy Gas from Natunas," StraitsTimes, dejanews web site (October 29, 1996).

5. A.R. Flower, "Asia-Pacific LNG Demand Set To Triple by 2015," Petroleum Economist, Vol. 63, No. 6 (June 1996), pp. 54-57.

6. "Worldwide Look at Reserves and Production," Oil \& Gas Journal, Vol. 94, No. 52 (December 30, 1996), pp. 39-40.

7. British Petroleum Company, BP Statistical Review of World Energy 1996 (London, UK, June 1996).

8. Energy Information Administration, Annual Energy Outlook 1997, DOE/EIA-0383(97) (Washington, DC, December 1996).

9. F. Barazi, "Electric Demand, Maintenance Provide Props for Gas Prices," Natural Gas Week, Vol. 12, No. 34 (August 19, 1996), p. 14.

10. Natural Gas Week; Vol. 12, No. 43 (October 21, 1996), p. 21.

11. Energy Information Administration, Privatization and the Globalization of Energy Markets, DOE/EIA-0609 (Washington, DC, October 1996), pp. 15, 16.

12. Latin American Energy Alert, Vol. 3, No. 23 (October 21, 1996).

13. Reuters America, Inc., "Norway Troll Gas Sales Agreements Come into Force," NewsPage web site (October 1, 1996).

14. L. Semerdjieva, "Bulgaria: Greece Receives Russian Gas Supplies Via Bulgaria" (Reuters Business Alert, September 18, 1996).

15. "Phoenix Rises in N. Ireland," Financial Times International Gas Report, Vol. 308 (September 27, 1996), p. 9.

16. M. Jones (Reuters America, Inc.), "N. Ireland Generator Switches to Gas on Schedule," NewsPage web site (October 7, 1996).
17. "Europe," Project \& Trade Finance. Vol. 159 (July 1996).

18. B. Lauwers (Reuters America, Inc.), "Interconnector Gas Pipeline Construction Starts," NewsPage web site (October 14, 1996).

19. "Interconnector Work Under Way," Financial Times International Gas Report, Vol. 310 (October 25, 1996), p. 8.

20. "German Wingas Seals First Interconnector Contract," World Gas Intelligence, Vol. 7, No. 4 (February 23, 1996), p. 5.

21. "Portugal's Privatization Campaign Sets Sights on Further Moves," Oil \& Gas Journal, Vol. 94, No. 15 (April 8, 1996).

22. Agence France Presse, "Algeria Inaugurates Gas Pipeline to Europe," NewsPage web site (November 11, 1996).

23. "Portugal Joins Ranks of Gas Users in Europe," World Gas Intelligence, Vol. 7, No. 16 (August 23, 1996), p. 7.

24. D. Albert (Reuters America, Inc.), "German Ruhrgas Starts Gas Supply to MOL," NewsPage web site (September 30, 1996).

25. E. Bartha (Reuters America, Inc.), "Horn, Vranitzky Open Hungary-Austria Gas Pipeline," NewsPage web site (October 29, 1996).

26. "Hungary Moves into Position of Maximum Regional Influence," World Gas Intelligence, Vol. 7, No. 10 (May 24, 1996), p. 5.

27. "Turk-Iran Gas Line Construction To Start in March," Reuters Business Alert (November 5, 1996).

28. Reuters America, Inc., "Italy's ENI Signs Libya Gas Deal-MEES" (November 4, 1996).

29. "Russia Set To Dominate Global Gas Supplies," Petroleum Economist, Vol. 63, No. 5 (May 1996), p. 37.

30. "Gazprom According to Gazprom," Financial Times International Gas Report, Vol. 309 (October 11, 1996), p. 7.

31. "Gazprom: Big Is Beautiful," Petroleum Economist, Vol. 63, No. 5 (May 1996), p. 46.

32. "Russian Gas Giant Launches Sell-off," Financial Times International Gas Report, Vol. 309 (October 11, 1996), pp. 6,8

33. DRI/McGraw-Hill, World Energy Service: Latin American Outlook 1996 (Lexington, MA, 1996). 
34. CMS Energy Corporation, "CMS Energy Adds NOVA Corp. as Partner in Atacama Pipeline Connecting Argentina and Chile," PR Newswire, NewsPage web site (September 3, 1996).

35. "CMS, Nova Advance Work on Northern Chilean Gas Pipeline," Latin American Energy Alert, Vol. 4, No. 1 (November 1, 1996), p. 7.

36. M. Orgill (Reuters America, Inc.), "YPF To Supply Chile's Endesa Plant," NewsPage web site (October 2, 1996).

37. M. Orgill (Reuters America, Inc.), "RPT-NOVA in Chile Natgas Pipeline Talks," NewsPage web site (October 3, 1996).

38. South American Business News, "Rio Grande do Sul State To Receive Natural Gas from Argentina," NewsPage web site (October 10, 1996).

39. "Bolivia-to-Brazil Pipeline To Begin Construction," World Gas Intelligence, Vol. 7, No. 17 (September 13, 1996), p. 1.

40. "Briefs: La Paz" Latin American Energy Alert, Vol. 4, No. 1 (November 1, 1996), p. 8.

41. "Latin America," Project \& Trade Finance, Vol. 159 (July 1996).

42. Xinhua (Comtex copyright), "Uruguay, Argentina Sign Agreements," NewsPage web site (September 21, 1996).

43. G. Haskel (Reuters America, Inc.), “Argentine Group Wins Order To Build Gas Pipeline," NewsPage web site (November 4, 1996).

44. "Briefs: La Paz," Latin American Energy Alert, Vol. 3, No. 20 (October 1, 1996), p. 8.

45. "Colombia Reluctant To Alter Upstream Terms and Prices," World Gas Intelligence, Vol. 7, No. 22 (November 29,1996$)$, p. 3.

46. Reuters America, Inc., "Chase Unit Funds Colombia Power Plant," NewsPage web site (October 10, 1996).

47. Reuters News Service, "China: Foreign Bank Loans Approved for China Gas Project" (September 15, 1996).

48. Xinhua (Comtex copyright), "New Gas Pipeline in China's Junggar Basin," NewsPage web site (October 2, 1996).

49. PR Newswire, "Court Rules in Favor of Dabhol Power Company, Dabhol Construction To Resume;" NewsPage web site (December 3, 1996).
50. Reuters America, Inc., "Enron India Project Nears Final Hurdle," NewsPage web site (October 3, 1996).

51. "Thailand Closes in on Yetagun Contract with Texaco," World Gas Intelligence, Vol. 7, No. 18 (September 27, 1996), p. 3.

52. "Myanmar: Unocal in Myanmar: Yadama Gas Project," Unocal World On-line Home Page (www. unocal.com).

53. "Gasline Blueprint Sails Ahead," Financial Times International Gas Report, Vol. 310 (October 25, 1996), p. 18.

54. "First Gas Eyes Six Banks To Fund Siemens Deal" (Reuters Business Alert, September 18, 1996).

55. Reuters America, Inc., "British Gas Unit in Philippines Pipeline Talks," NewsPage web site (September 27, 1996).

56. S. Swindells (Reuters America, Inc.), "South Korean Gas Import Needs Seen Rising Sharply," NewsPage web site (October 15, 1996).

57. L. Loxton, "South Africa: African Gas Faces Uphill Marketing Struggle" (Reuters Business Alert, September 20, 1996).

58. E. Ibagere, "Nigeria: Shell Nigeria Starts Gas Gathering Project" (Reuters News Service, September 12, 1996).

59. Reuters America, Inc., "Chevron Bids To Build West African Gas Pipeline," NewsPage web site (September 27, 1996).

60. Reuters America, Inc., "Gaddafi Says Gas Pipeline To Link Libya to Tunisia" (November 1, 1996).

61. "Algerian Pipeline Sales Move Ahead, While LNG Falters," World Gas Intelligence, Vol. 7, No. 13 (July 12, 1996), p. 10.

62. Reuters News Service, "Morocco: Maghreb-Europe Gas Pipeline Cost Cut 10 Pct-Metragaz" (September 25,1996$)$.

63. Reuters News Service, "Spain: Pipeline To Supply 40 Pct Gas Natural Gas" (September 18, 1996).

64. OPECNA Inter Press Service, "Algeria Discusses Third Gas Pipeline Link to Europe," NewsPage web site (November 14, 1996).

65. "Israel-Arab Flare-up Hits 'Peace' Gasline," Financial Times International Gas Report, Vol. 309 (October 11, 1996), pp. 5-6.

66. Reuters America, Inc., "Egypt Says Israel Gas Supply Plans Still Intact," NewsPage web site (October 21, 1996). 
67. M. Fahmy, "Egypt To Export Gas to Turkey, Bypassing Israel," Reuters Business Alert (November 13, 1996).

68. Reuter's America, Inc., "Iran's Oil Minister Outlines Foreign Gas Plans," NewsPage web site (November 14, 1996).

69. Reuters America, Inc., "Work on Iran-Turkmen Gas Pipeline Starts This Week," NewsPage web site (October 9, 1996).

70. "Iran/Turkmen Pipeline Construction Started," Financial Times East European Energy Report, Vol. 61 (October 1996), p. 30.

71. "When To Use Pipelines or LNG? The Line Continues To Blur," World Gas Intelligence, Vol. 7, No. 20 (October 25, 1996), p. 1.

72. Alexander's Gas \& Oil Connections, "Qatar Sent Off First Cargo LNG," web site www.gasandoil.com (December 23, 1996).

73. "What's New Around the World," World Gas Intelligence, Vol. 7, No. 17 (September 13, 1996), pp. 11-12.
74. S. Swindells, "Dubai: Oman Aims To Secure Gas Financing This Month" (Reuters Business Alert, September 16, 1996).

75. "Oman Seals Financing and an LNG Contract," World Gas Intelligence, Vol 7, No. 20 (October 25, 1996), p. 1.

76. "Oman Seals 'World Record' LNG Deal," Financial Times International Gas Report, Vol. 310 (October 25, 1996), pp. 1-2.

77. Reuters America, Inc. (Seoul Newsroom), “S. Korea To Expand Domestic LNG Supply-Ministry," NewsPage web site (September 25, 1996).

78. D. Knott, "OPEC States Seeking More Foreign Investment in Petroleum Sectors," Oil and Gas Journal, Vol. 94, No. 31 (July 29, 1996).

79. "Atlantic LNG Seems Destined To Grow by Leaps and Bounds," World Gas Intelligence, Vol. 7, No. 20 (October 25, 1996), p. 4.

80. Knight-Ridder/Tribune Business News: Chicago Tribune, "Egypt Taps Amoco for Big Natural Gas Plant," NewsPage web site (November 14, 1996). 



\section{Coal}

\section{Despite environmental issues and competitive pressure from other fuels, coal is expected to maintain a major share of the world's future energy use. Large increases in coal use are projected for the developing countries of Asia.}

\section{Introduction}

Coal's role in energy use worldwide has shifted substantially over the decades, from a fuel used extensively in all sectors of the economy to one that is now used primarily for electricity generation and in a few key industrial sectors, such as steel, cement, and chemicals. Although coal has lost market share to petroleum products and natural gas, it continues to be a key source of energy because of the dominant role it has maintained in its core markets and its success in penetrating markets in emerging economies. In 1995, coal accounted for 26 percent of the world's primary energy consumption and 37 percent of the energy consumed worldwide for electricity generation.

For coal to remain competitive with other sources of energy in the industrialized countries of the world, continuing technological improvements in all aspects of coal extraction have been necessary. Technological advances have led to strong productivity growth in many of the key coal-producing countries of the world. Between 1985 and 1994, annual improvements in mining productivity in major coal-exporting countries averaged 6.0 percent in Australia, 8.0 percent in the United States, 9.6 percent in South Africa, and 5.0 percent in Canada [1, Table 6.5]. By comparison, typical productivity improvements in manufacturing industries in the industrialized countries during the same period were in the range of 1 to 3 percent per year [2]..$^{5}$ These improvements have enabled coal to continue to compete as a fuel for power generation even as environmental control costs (especially in developed countries) have risen.

\section{Trends in Coal Consumption}

Historical trends in coal consumption have varied considerably by region. Consumption has continued to rise in the United States and Japan (on a Btu basis) over the past decade. In the same period, however, coal use in other industrialized countries has declined by about 17 percent, being displaced in considerable measure by growing use of natural gas and in France by nuclear power. Even sharper declines have occurred in the countries of Eastern Europe and former Soviet Union (EE/FSU), primarily as a result of reductions in economic activity.

Nonetheless, growth in overall coal use has been substantial and is expected to continue. Declines in coal usage in industrialized countries and in the FSU have been more than offset by strong growth elsewhere, particularly in China and other Asian countries. In 1980, China accounted for 17 percent of world coal use (on a Btu basis); in 1995, its share was 28 percent. As a group, the developing countries of Asia accounted for 39 percent of world coal consumption in 1995, whereas in 1980 their share was about 23 percent. The United States accounted for 21 percent of the world total in both 1980 and 1995.

Over the forecast period, coal is projected to account for approximately 24 percent of total energy consumption in the world. In the forecast, coal maintains its historical share because of the large increases in energy use projected for the developing countries of Asia, and the strong role that coal plays in their economies. Together, two of the key countries in the region, China and India, are projected to account for 32 percent of the world's total increase in energy consumption over the forecast period and 82 percent of the world's total projected increase in coal use. The share of total energy consumption met by coal in these countries declines from 69 percent in 1995 to 61 percent in 2015 (Figure 45), because consumption of other energy sources rises in the forecast at a more rapid rate than consumption of coal (4.6 percent and 10.6 percent per year for oil and gas, respectively).

\footnotetext{
${ }^{5}$ Includes productivity data for the following 12 countries: United States, Canada, Japan, Belgium, Denmark, France, Germany, Italy, Netherlands, Norway, Sweden, and the United Kingdom. In the United Kingdom, productivity in the manufacturing sector grew by 4.8 percent a year between 1985 and 1994. In the remaining countries, average productivity growth was lower, ranging from 1.3 percent per year in Canada to 3.2 percent per year in Sweden.
} 
Figure 45. Coal Share of Total Energy Consumption by Region, 1970-2015

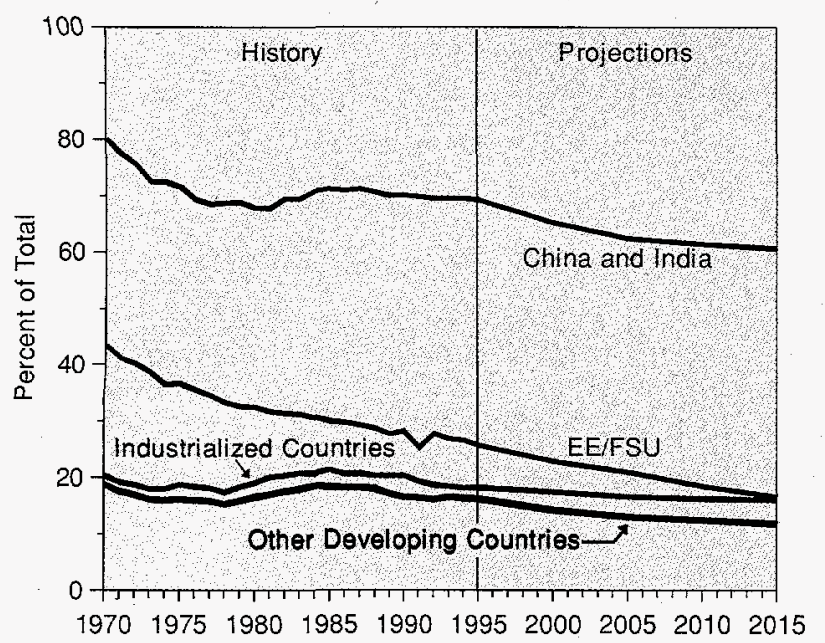

Sources: History: 1970-1979: Energy Information Administration (EIA), Office of Energy Markets and End Use, International Statistics Database. 1980-1995: ElA, International Energy Annual 1995, DOE/ EIA-0219(95) (Washington, DC, December 1996). Projections: EIA, World Energy Projection System (1997).

The most substantial decline in coal's share of total energy consumption is expected to occur in the $\mathrm{EE} / \mathrm{FSU}$, where its share decreases from 26 percent in 1995 to 17 percent in 2015 . In this region, natural gas is projected to capture an increasing share of the energy market over time. In the remaining regions-the industrialized countries and the other developing countriescoal's share of total energy consumption is projected to decline slightly over the forecast period. As in China and India, coal's declining share in these regions is attributable to a more rapid increase in the consumption of other sources of energy.

In physical units, coal usage increased from 4.1 billion tons $^{6}$ in 1980 to a peak of 5.3 billion tons in 1989 (Figure 46). Recently, growth in coal consumption in the developing countries of Asia has led to a recovery in worldwide coal consumption from a low of 5.0 billion tons in 1992 to 5.1 billion tons in 1995. In the forecast, world coal consumption rises by 45 percent between 1995 and 2015, reaching 7.4 billion tons in 2015. Based on alternative assumptions about economic growth rates, world coal consumption in 2015 could be as high as 8.7 billion tons or as low as 6.0 billion tons.

With the exception of China, coal for electricity generation will account for virtually all of the projected growth in coal consumption worldwide. In the nonelectricity sectors, other fuels-primarily, natural gas
Figure 46. World Coal Consumption, 1970-2015

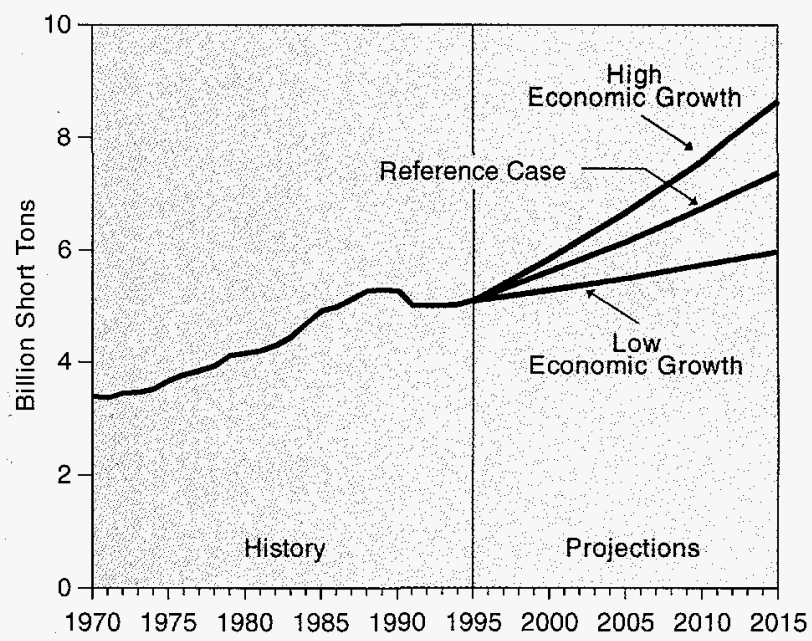

Sources: History: 1970-1979: Energy Information Administration (EIA), Office of Energy Markets and End Use, International Statistics Database. 1980-1995: ElA, International Energy Annual 1995, DOE/ EIA-0219(95) (Washington, DC, December 1996). Projections: EIA, World Energy Projection System (1997).

and electricity-are expected to gain market share. In China, however, coal should continue to be the primary fuel for industrial applications, in view of the nation's abundant coal reserves and limited access to alternative sources of energy. Consumption of coking coal is projected to decline slightly in most regions of the world as a result of technological advances in steelmaking, increasing output from electric arc furnaces, and continuing substitution of other materials for steel in enduse applications.

\section{Environmental Issues}

In future years, coal will face tough challenges, particularly in the environmental area. Increased concern. about the adverse environmental impacts associated with coal use has taken a toll on coal demand throughout industrialized areas. Coal combustion produces several air pollutants that adversely affect ground-level air quality. One of the most significant pollutants from coal is sulfur dioxide, which has been linked to acid rain. Many countries have implemented policies or regulations to limit sulfur dioxide emissions, which typically require electricity producers to switch to lower sulfur fuels or invest in technologies that reduce the amount of sulfur dioxide emitted. In addition, coal has the highest carbon content of all the fossil fuels. Carbon dioxide emissions per unit of energy obtained from coal

${ }^{6}$ Throughout this chapter, tons refers to short tons (2,000 pounds). 
are 80 percent higher than from natural gas and approximately 20 percent higher than from residual fuel oil-the petroleum product most widely used for electricity generation [3].

The first binding international legal agreement dealing directly with climate change-the United Nations Framework Convention on Climate Change ("the Rio Treaty") - became effective in March 1994. The Convention's primary objective is the "stabilization of greenhouse gas concentrations in the atmosphere at a level that would prevent dangerous anthropogenic interference with the climate system." It was initially presented at the Earth Summit in Rio de Janeiro in June 1992, where it was signed by representatives from 155 countries, including the United States and the countries of the European Union [4]. Carbon dioxide, because of the large volumes emitted worldwide, is the predominant greenhouse gas.

Followup meetings in March 1995 and July 1996 (Conference of Parties I and II) have led to a strengthening of the commitments to stabilize or reduce emissions of greenhouse gases. The first meeting produced the "Berlin Mandate," which initiates a process to set quantified greenhouse gas limitation and reduction objectives for the time period after 2000 [5]. The second meeting produced the "Geneva Declaration," which calls for legally binding objectives and significant reductions in greenhouse gas emissions in the post-2000 period and endorses the Second Assessment Report (SAR) by the Intergovernmental Panel on Climate Change (IPCC).

In its second report, the IPCC acknowledges the strong potential for a significant rise in average worldwide temperatures (approximately 2 degrees centigrade) by 2100 [6]. This outlook is based on the continuing buildup of greenhouse gases in the Earth's atmosphere that will occur without specific policies to mitigate emissions. A third meeting, to be held in Tokyo in December 1997, will focus on the implementation of a legally binding protocol or other legal instrument for controlling post-2000 emissions of greenhouse gases.

Decisions to maintain or reduce greenhouse gas emissions in the post- 2000 period could have a substantial adverse impact on coal. Indeed, it will be difficult to moderate carbon dioxide emissions at the same time that world energy demand is growing, particularly when coal or petroleum products are used in increasing amounts to meet the demand for energy.
In the future, environmental regulation will represent a major challenge for coal markets in many areas of the world. On the other hand, increases in coal use are possible in countries that have not yet committed to greenhouse gas emissions reduction programs. Although local air pollution problems in those areas may intensify and encourage greater use of alternative fuels, the available alternatives are more costly, and increased use will require multilateral policy decisions. In other areas, coal use will diminish or its growth will slow. Competitive pressure from other fuels-particularly, oil and natural gas-has intensified because of their current low prices, the availability of new technologies that favor the use of natural gas for electricity generation, and increased costs of environmental compliance for coal-fired energy sources. Nonetheless, coal use in the IEO97 reference case is projected to grow by 2.3 billion tons (45 percent) worldwide between 1995 and 2015.

\section{Reserves}

Total recoverable reserves of coal are estimated at 1,143 billion tons-enough to last another 220 years at current production levels (Figure 47). ${ }^{7}$ Although coal deposits are widely distributed, 57 percent of the world's recoverable reserves are located in three regions: the

\section{Figure 47. World Recoverable Coal Reserves}

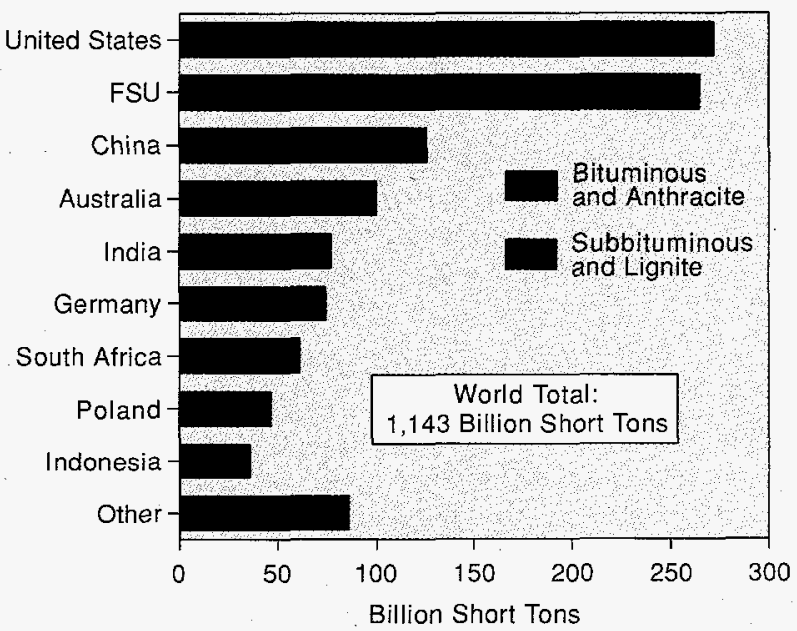

Note: Data shown for the United States represent recoverable reserves as of December 31, 1995. Data for all other countries are as of December 31, 1993.

Source: Energy Information Administration, International Energy Annual 1995, DOE/EIA-0219(95) (Washington, DC, December 1996).

\footnotetext{
${ }^{7}$ Recoverable reserves are those quantities of coal which geological and engineering information indicates with reasonable certainty can be extracted in the future under existing economic and operating conditions.
} 
United States (24 percent); FSU (23 percent); and China (11 percent). Another four countries-Australia, India, Germany, and South Africa-account for an additional 27 percent. In 1995, these seven regions accounted for 81 percent of total world coal production [7, Tables 5.2, 5.3 , and 5.4].

Quality and geological characteristics of coal deposits are other important parameters for coal reserves. Coal is a much more heterogeneous source of energy than is oil or natural gas, with quality varying significantly from one region to the next and even within an individual coal seam. For example, Australia, the United States, and Canada are endowed with substantial reserves of premium coals that can be used to manufacture coke. Together, these three countries supplied 85 percent of the metallurgical coal traded worldwide in 1995 (see Table 20, below).

At the other end of the spectrum are reserves of lowBtu lignite or brown coal. Coal of this type is not traded to any significant extent in world markets due to its relatively low heat content (which raises transportation costs on a Btu basis) and other problems related to transport and storage. In 1995, lignite accounted for 19 percent of total world coal production (on a tonnage basis) [7, Tables 5.2, 5.3, and 5.4]. The top three producers were Germany (213 million tons), the FSU (134 million tons), and the United States (86 million tons). As a group, these countries accounted for 44 percent of the world's total lignite production in 1995. On a Btu basis, lignite deposits show a considerable amount of variation. Estimates by the International Energy Agency indicate that the average heat content of lignite from major producers in OECD countries vary from a low of 4.7 million Btu per ton in Greece to a high of 13.5 million Btu per ton in Canada [1, pp. II.14II.17].

A potential new entrant as a producer of lignite is Pakistan, where interest has been sparked by the recent identification of 75 to 100 billion tons of lignite resources in the Tharparkar (Thar) Desert [8]. The discovery resulted from a joint program conducted by the Geological Survey of Pakistan and the U.S. Geological Survey. Initial production of Thar lignite could commence within the next several years to fuel coalfired units planned at a generating complex on Pakistan's coast $[9,10,11]$.

Several new low-cost producers, including Indonesia, Colombia, and Venezuela, have entered the coal supply picture in recent years and are rapidly penetrating world coal trade markets. Indonesia currently ranks ninth in the world in recoverable coal reserves, with an estimated 35 billion tons. As late as 1989, Indonesia's recoverable reserves were estimated at only 3 billion tons [12]. Indonesian coal production has increased rapidly, rising from less than 1 million tons in 1980 to 41 million tons in 1995 [7, Tables 5.2, 5.3, and 5.4]. Some of its coal reserves have unique characteristics that have made them sought after in international markets. Some have extremely low sulfur content $(0.08$ percent average by weight). Other high-quality Indonesian reserves are finding acceptance as soft coking coals and in the growing market for pulverized coal injection at blast furnaces [13].

Worldwide, the consumption of coal relative to other fuels is projected to drop slightly, from 26 percent of total energy consumption in 1995 to 24 percent in 2015. The fairly stable fuel share, however, masks strongly divergent trends.

\section{Regional Consumption}

\section{Asia}

As a result of fast-paced economic growth, coal consumption is expected to grow most rapidly in the developing countries of Asia. In the IEO97 forecast, this region's share of total world coal consumption increases from 39 percent in 1995 to 55 percent in 2015 (on a tonnage basis). Coal consumption in the region is projected to double, from 2,012 million tons in 1995 to 4,024 million tons in 2015 (Figure 48). In China alone, coal consumption is expected to increase by about 1,625 million tons. India, too, is poised for a substantial

\section{Figure 48. World Coal Consumption by Region, 1980, 1995, and 2015}

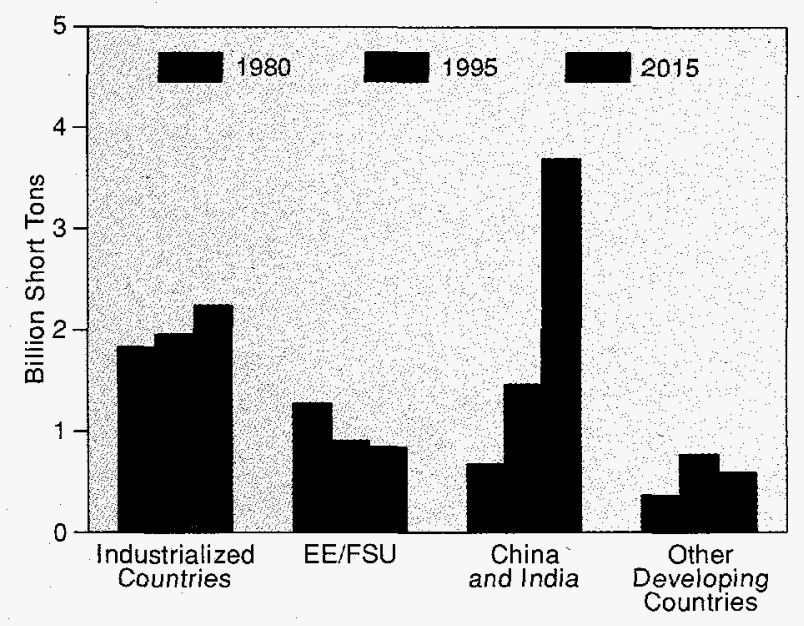

Sources: 1980, 1995: Energy Information Administration (EIA), International Energy Annual 1995, DOE/EIA-0219(95) (Washington, DC, December 1996). 2015: E|A, World Energy Projection System (1997). 
increase in coal usage, with consumption projected to rise by 279 million tons between 1995 and 2015 .

The large projected increases in coal consumption in China and India are based on an outlook for strong economic growth (7.3 percent per year in China and 6.1 percent per year in India) and the expectation that much of the increased demand for energy will be met by coal, particularly in the industrial and electricity sectors. The IEO97 forecast assumes no significant change in environmental policies in the two countries. It also assumes that necessary investments in the countries' mines, transportation, industrial facilities, and power plants will be made.

In China, 57 percent of the total increase in coal demand is projected to occur in the non-electricity sectors, primarily for steam and direct heat for industrial applications and for the manufacture of coal coke for input to the steelmaking process. Strong growth in steel demand is expected in China, as infrastructure and capital equipment markets expand.

In the electricity sector in China, coal use is projected to grow by 5.1 percent a year, from 7.5 quadrillion Btu in 1995 to 20.0 quadrillion Btu in 2015. In comparison, coal consumption by electric generators in the United States is projected to rise from 17.3 quadrillion Btu in 1995 to 21.0 quadrillion Btu in 2015. One of the key implications of the substantial rise in electricity coal demand in China is that large financial investments in new coalfired power plants and in the associated transmission and distribution systems will be needed. The projected growth in coal demand implies that China will need approximately 350 gigawatts of coal-fired capacity in $2015{ }^{8}$ In 1995, China had approximately 142 gigawatts of fossil-fuel-fired generating capacity [7, Table 6.4].

In India, projected growth in coal demand matches the pattern expected in most other areas of the world, with all of the increase occurring in the electricity sector. Between 1995 and 2015, coal use for electricity generation in India is projected to rise by 4.2 percent a year, from 3.8 quadrillion Btu in 1995 to 8.7 quadrillion Btu in 2015. This growth implies that India will need approximately 140 gigawatts of coal-fired capacity in $2015 .{ }^{9}$ In 1995, India's total fossil-fuel-fired generating capacity amounted to 69 gigawatts [7, Table 6.4].

In Japan, coal consumption is projected to increase at a much slower pace than in the other countries of Asia.
In the electricity sector, coal use is projected to rise at a rate of only 1.4 percent a year, from 1.6 quadrillion Btu in 1995 to 2.2 quadrillion Btu in 2015. Projected growth in the non-electricity sectors is even smaller, with only a slight increase expected over the forecast period. The limited growth in the non-electricity sectors is attributable in part to continuing efforts by Japanese steelmakers to increase pulverized coal injection rates at blast furnaces, which will reduce the overall amount of coal required per ton of hot metal produced.

\section{Western Europe}

Coal consumption in Western Europe has declined by 309 million tons since 1989, to a level of 678 million tons in 1995. Over the forecast period, the decline in coal consumption is expected to slow, and a slight recovery is expected after 2000. In Western Europe, environmental concerns play an important role in the competition among coal, natural gas, and nuclear power. Recently, other fuels, particularly natural gas, have been favored over coal. The countries of Western Europe are committed to the stabilization of greenhouse gas concentrations in the atmosphere as established by the Framework Convention on Climate Change.

Two key trends in Western Europe are at play over the forecast period. In the United Kingdom and Germanythe two top producers of hard coal ${ }^{10}$ in the regionindigenous coal production is expected to decline. As a result, coal consumption in these two countries is expected to decline slightly, because coal imports are not expected to fill the entire gap in energy supply left by the loss of indigenous coal. Rather, a combination of fuels-including natural gas, imported coal, and renewable energy-are expected to compensate for the reduction in domestic coal supply. Offsetting the decline in coal use in Germany and the United Kingdom are projected increases in the consumption of indigenous lignite for electricity generation in Turkey and Greece. Much of the increase is in Turkey, where coal (both lignite and hard coal) and natural gas are expected to fuel a large increase in electricity demand [1, pp. II.301II. $308 ; 14]$.

\section{Eastern Europe and the Former Soviet Union}

In the EE/FSU countries, the process of economic reform continues, as the transition to a market-oriented economy replaces centrally planned economic systems. The dislocations associated with these institutional

\footnotetext{
${ }^{8}$ Based on a 10-percent improvement in the average heat rate (or conversion efficiency) and a rise in the average capacity factor from approximately 55 percent in 1995 to 65 percent in 2015 .

${ }^{9}$ Based on a 10-percent improvement in the average heat rate (or conversion efficiency) and a rise in the average capacity factor from approximately 50 percent in 1995 to 60 percent in 2015 .

${ }^{10}$ Internationally, the term "hard coal" is used to describe anthracite and bituminous coal.
} 
changes have contributed substantially to the declines in both coal production and consumption. Coal consumption in the EE/FSU region has fallen by more than 540 million tons since 1988, reaching 904 million tons in 1995 [7, pp. 11-12]. In the future, total energy consumption in the EE/FSU is expected to rise, driven primarily by increasing production and consumption of natural gas. In the forecast, coal's share of total EE/FSU energy consumption declines from 26 percent in 1995 to 17 percent in 2015, while the portion of consumption met by natural gas increases from 40 percent in 1995 to 48 percent in 2015.

\section{North America}

In North America, coal consumption is concentrated in the United States, which, at 949 million tons, accounted for 93 percent of the regional total in 1995. By 2015, U.S. coal consumption is projected to rise to $1,156 \mathrm{mil}-$ lion tons. With its substantial supplies of coal reserves, the United States has come to rely heavily on coal for electricity generation and will continue to do so over the forecast. Coal provided 51 percent of total U.S. electricity generation in 1995 and is projected to provide 47 percent in 2015 [15]. Coal consumption in Canada and Mexico, taken together, is projected to rise from 70 million tons in 1995 to 107 million tons in 2015.

\section{Africa}

In Africa, coal production and consumption are concentrated almost entirely in South Africa. In 1995, South Africa produced 227 million tons of coal, 70 percent of which was routed to domestic markets and the remainder to exports [7, Tables 5.2, 5.3, and 5.4). South Africa ranks third in the world in exports, behind Australia and the United States, and is projected to maintain that position over the forecast. South Africa holds the distinction of being the world's largest producer of coalbased synthetic liquid fuels. In 1995, almost one-fifth of the coal consumed in South Africa (on a Btu basis) was used to produce coal-based synthetic fuels, which in turn accounted for approximately one-third of all liquid fuels consumed in South Africa during the year [16, 17].

For Africa as a whole, coal consumption is projected to increase by 11 million tons between 1995 and 2015, primarily to meet increased demand for electricity. There are substantial opportunities for trade in electricity and natural gas between South Africa and neighboring countries. Such trades may occur, given government reform in South Africa and the subsequent removal of trade sanctions. Another contributing factor to increasing electricity demand in Africa over the forecast is South Africa's commitment to rural electrification.

\section{Trade}

\section{Overview}

The amount of coal traded in international markets is small in comparison with total world consumption. In 1995 , world imports of coal amounted to 485 million tons (Table 20 and Figure 49), representing 9 percent of total consumption. By 2015, coal imports are projected to rise to 670 million tons, accounting for the same share of world coal consumption as in 1995. Although coal trade has accounted for a relatively constant share of consumption over time and should continue to do so in future years, the geographical composition of trade is shifting.

Figure 49. World Coal Trade, 1985-2015

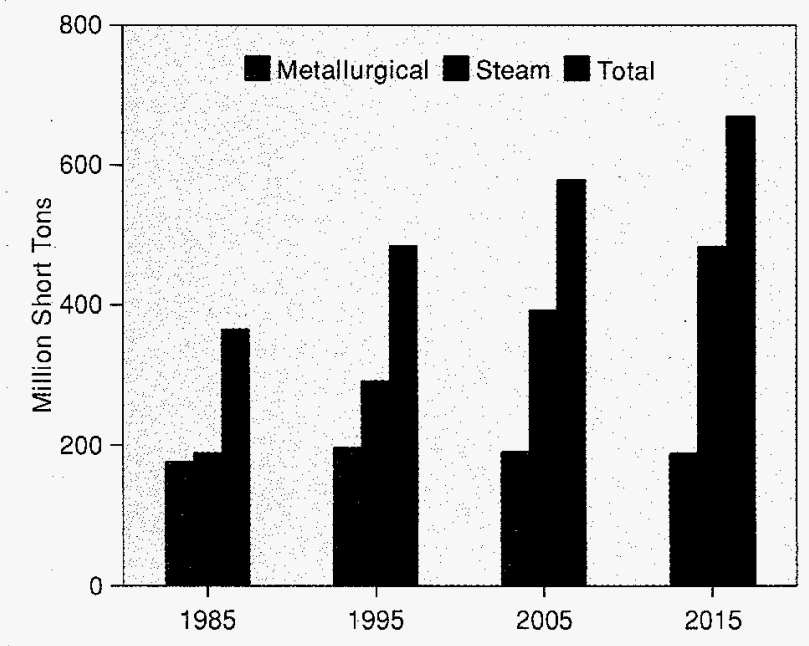

Sources: History: 1985: Energy Information Administration (ElA), Annual Prospects for World Coal Trade 1987, DOE/EIA-0363(87) (Washington, DC, May 1987). 1995: See Table 17. Projections: See Table 17.

In recent years, international coal trade has been characterized by relatively stable demand for coal imports in Western Europe and expanding demand in Asia (Figure 50). Rising production costs in the indigenous coal industries in Western Europe, combined with continuing pressure to reduce industry subsidies, have led to substantial declines in production there, creating the potential for large increases in coal imports; however, slow economic growth in recent years and increased electricity generation from natural gas, nuclear, and hydropower have curtailed the growth in coal imports. Conversely, growth in coal demand in Japan, South Korea, and Taiwan in recent years has contributed to a substantial rise in Asian coal imports. 
Table 20. World Coal Flows by Importing and Exporting Regions, Reference Case, 1995, 2000, and 2015 (Million Short Tons)

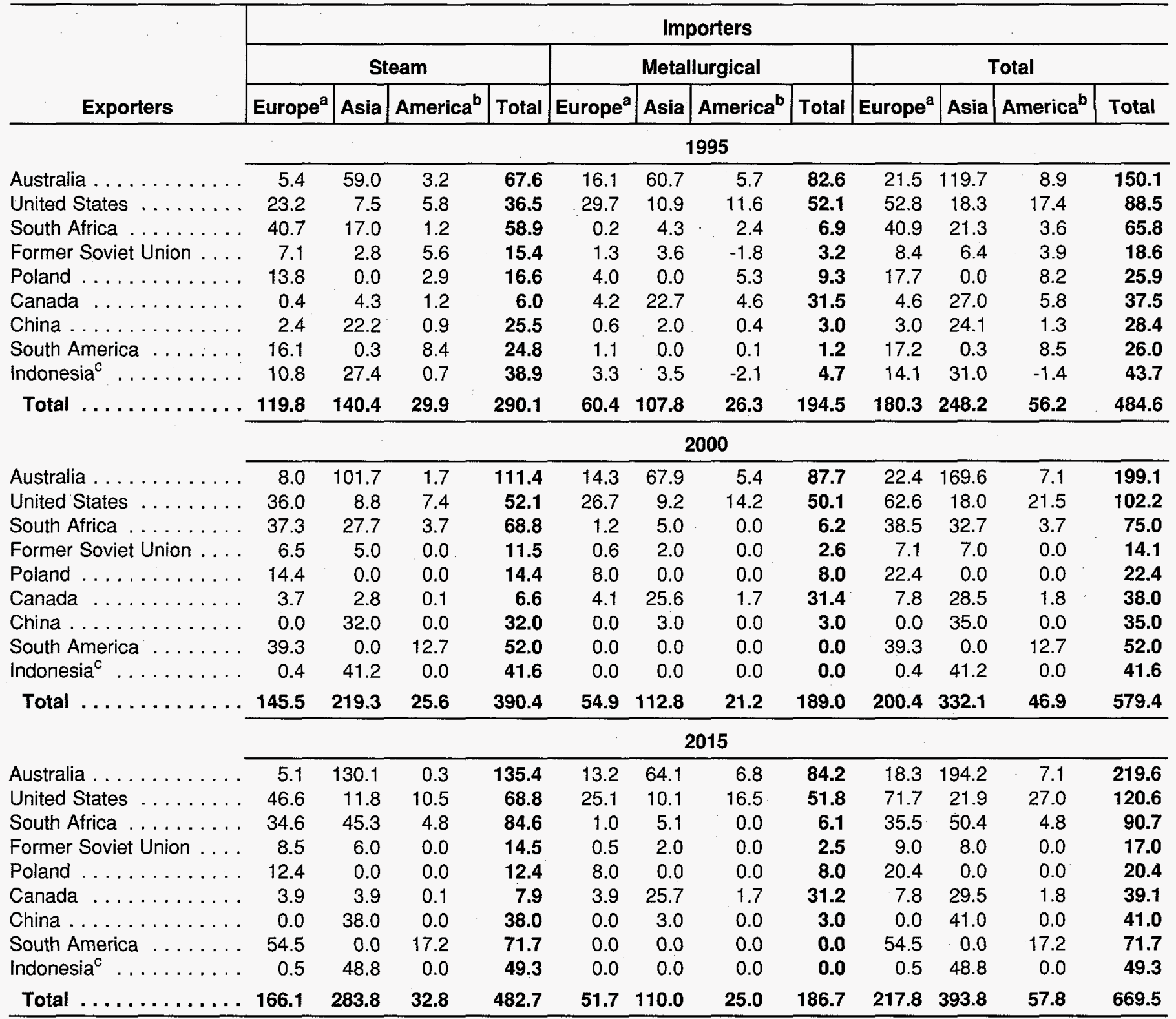

${ }^{a}$ Coal flows to Europe include shipments to the Middle East and Africa.

${ }^{b}$ For 1995, coal flows to America include a balancing item used by the International Energy Agency to reconcile discrepancies between reported exports and imports. The 1995 balancing items by coal type were 13.6 million tons (steam coal), 5.7 million tons (metallurgical coal), and 19.3 million tons (total). Negative quantities in the table are attributable to the balancing item.

CFor 1995, coal exports from Indonesia include shipments from other countries not modeled for the forecast period. The 1995 non-Indonesian exports by coal type were 6.5 million tons (steam coal), 2.3 million tons (metallurgical coal), and 8.8 million tons (total).

Notes: Data exclude. non-seaborne shipments of coal to Europe and Asia. Totals may not equal sum of components due to independent rounding. The sum of the columns may not equal the total, because the total includes a balancing item between importers' and exporters' data.

Sources: 1995: International Energy Agency, Coal Information 1995 (Paris France, July 1996); Energy Information Administration, Quarterly Coal Report, October-December 1995, DOE/EIA-0121(95/4Q) (Washington, DC, May 1996); and International Coal Report, Coal Year 1996 (London, United Kingdom: Financial Times Energy Press, May 1996). Projections: Energy Information Administration, Annual Energy Outlook 1997, DOE/EIA-0383(97) (Washington, DC, December 1996), National Energy Modeling System run AEO97B.D100296K. 
Figure 50. Production and Imports of Hard Coal by Region, 1985-1995

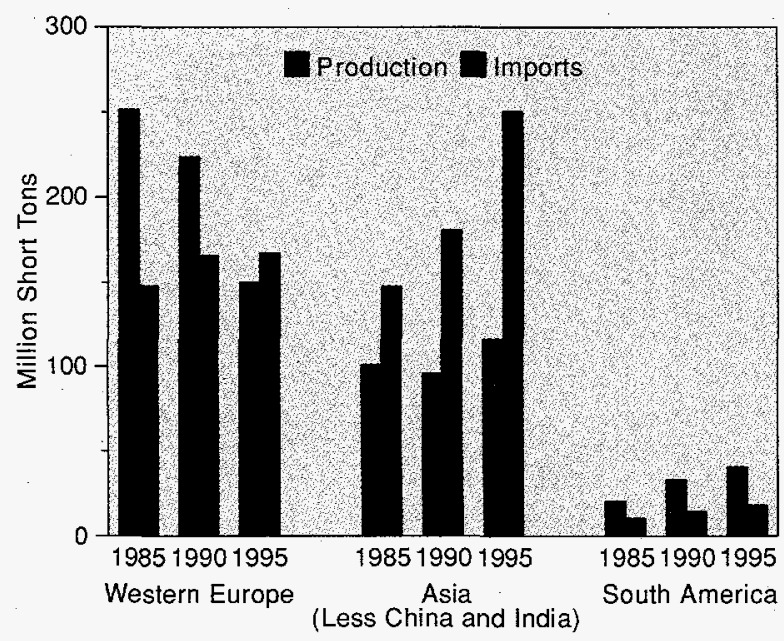

Sources: International Energy Agency, Coal Information 1994 (Paris, France, 1995) and Coal Information 1995 (Paris, France, July 1996).

\section{Asia}

Asian demand for imported coal is poised for additional increases over the forecast period, driven by strong growth in electricity demand in the region and the subsequent need for additional coal-fired generating capacity. Continuing the recent historical trend, Japan, South Korea, and Taiwan are projected to account for much of the regional growth in coal imports over the forecast period. Japan continues to be the world's leading importer of coal, accounting for 25 percent of total world imports in 2015 [18], as compared with its historical share of 28 percent in 1995 [1, Table 4.2].

China and India, which import relatively small quantities of coal at present, are expected to account for much of the remaining increase in Asian imports. Imports by China and India have the potential to be even higher than the projected amount. However, in the forecast, it is assumed that domestic coal will be given first priority in meeting the large projected increase (1.9 billion tons) in coal demand.

Australia should continue as the major exporter to Asia, meeting almost one-half of the region's total coal import demand in 2015, just as it did in 1995. Coal exports from China and Indonesia-Asia's internal coal suppliers-should keep pace with overall growth in Asian import demand. Together, they are projected to meet 23 percent of Asia's total import needs by 2015 .
During the 1980s, Australia became the leading coal exporter in the world, primarily by meeting increased demand for steam coal in Asia. Some growth in exports of metallurgical coal also occurred, however, as countries such as Japan began using some of Australia's semi-soft or weak coking coals in their coke oven blends. As a result, imports of hard coking coals from other countries, including the United States, were displaced. Australia's share of total world coal trade, which increased from 17 percent in 1980 to 31 percent in 1995, is projected to reach 33 percent in 2015 [19].

\section{Europe}

Coal imports to Europe also are projected to rise over the forecast period, although by only one-fourth the amount projected for Asia. Among the uncertainties surrounding the prospects for European imports are the extent and pace of the decline in indigenous coal production (primarily in Germany and the United Kingdom) and the extent to which natural gas and other sources of energy will substitute for coal in electricity generation (see box). In the IEO97 forecast, additional imports by Germany account for approximately twothirds of Europe's total increase in coal imports. Relatively smaller increases in imports are projected for Spain, France, Italy, the United Kingdom, Israel, and Turkey.

In future years, the United States and South America are projected to meet an increasing share of European coal import demand, primarily at the expense of Australia and South Africa. Coal exporters in Australia and South Africa are expected to direct most of their additional shipments of coal to the rapidly expanding Asian import markets.

\section{The Americas}

Compared with European and Asian coal markets, imports of coal by North and South America are relatively small, amounting to only 37 million tons ${ }^{11}$ in 1995 (Table 20). Brazil imported 35 percent of the 1995 total, followed by Canada ( 29 percent) and the United States (19 percent) [1, pp. I.76 and I.85]. Almost all (92 percent) of the imports to Brazil were metallurgical coal.

Over the forecast period, coal imports to the Americas increase by 21 million tons, with most of the additional tonnage going to South America and Mexico. Both Mexico and Chile are projected to increase their imports of steam coal for electricity generation, and Brazil is expected to import additional amounts of coal for use

\footnotetext{
${ }^{11}$ Excluding the balancing item used by the International Energy Agency to reconcile differences between reported exports and imports worldwide.
} 


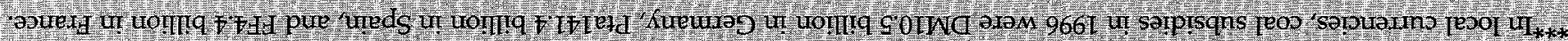

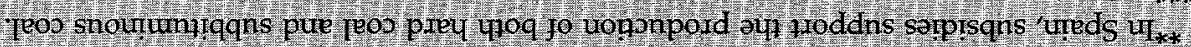

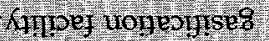

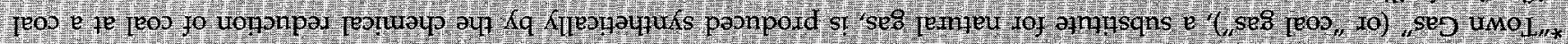

[9z]

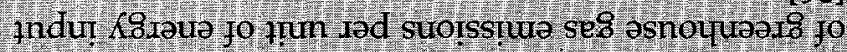

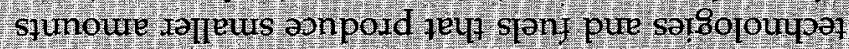

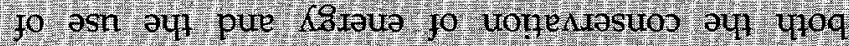

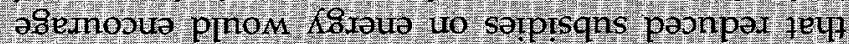

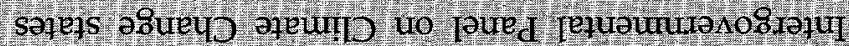

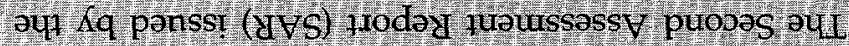

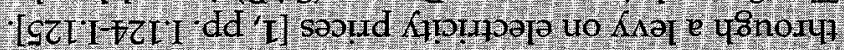
papung fljued ajan uneds pue fureutab ut salpisqhs

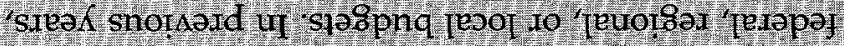

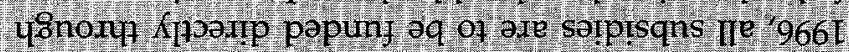

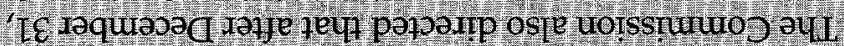

\section{Samsop aumu uouf jnsos}

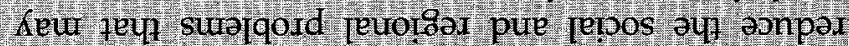
Io axpos of pasemosua are salmuno raquaW saum

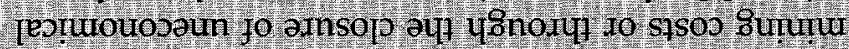

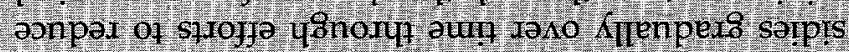

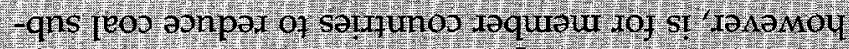

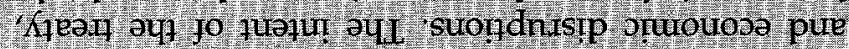

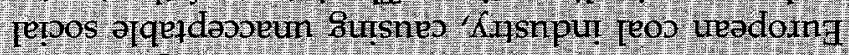

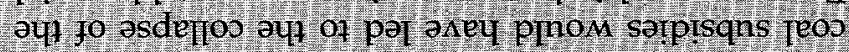
jiels go fuaunopueqe teu jaIaq aut uo paseq seM uogje stuL [sz] z00z yônoru sarnsnpul jeos-preq

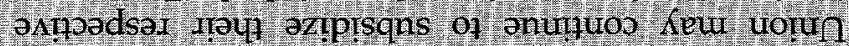
ueadoung aut un sampuno saquau 18661 ut uots -stunuos ueadoma aul fq paxordde fieaul e lopul

\section{sanjasar teor}

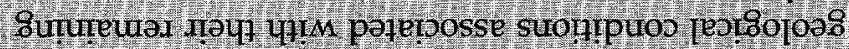

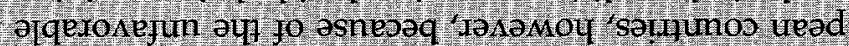

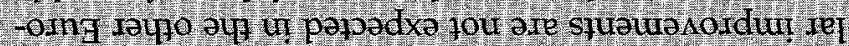

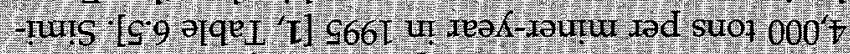

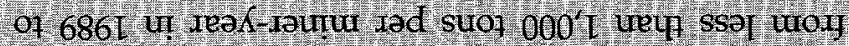

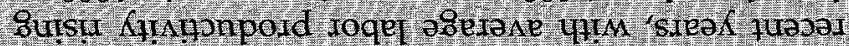

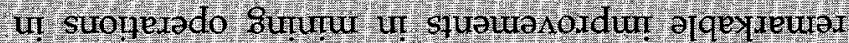
uaas sey fisnpu feoa yn a4I 0661 ul uesaq jeyt

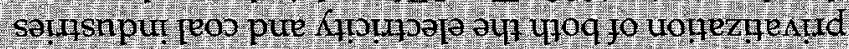
aut Bum 1sos-48it or satprsqns jeos wopoury patun ay u

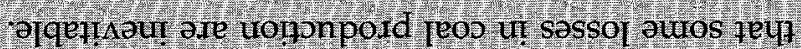

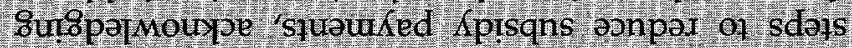

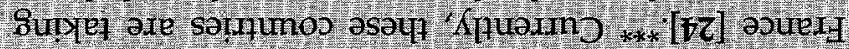

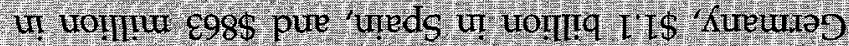
ui volita 698 to sarpisqns pasordde $966 \mathrm{~T}$ HIM

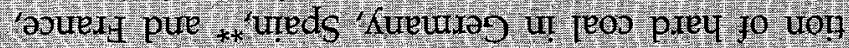
-anpord $1500-4814$ juddns of anumuoa sa!pisqns feoj

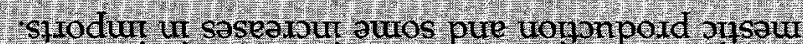
-op ui saunpap gununuos ul flusar oi pajoadxa axe

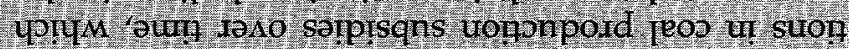

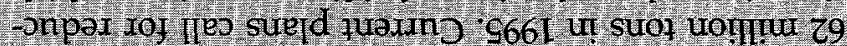
01 686 u suoq wolliu 88 wo. paupap paz!pisqns

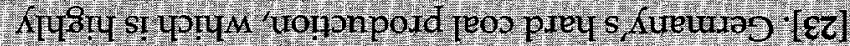

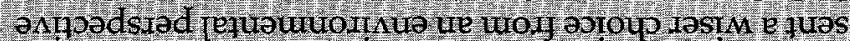
-ardar suotyets ramod pary-peoj-prey pue-sed-jernpeu

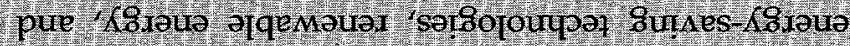

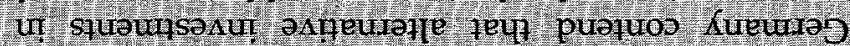

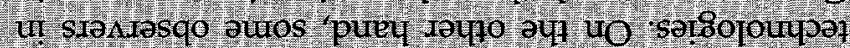
jouluoo nognilod pue uojsnquros olqpiese tsoq sunsn

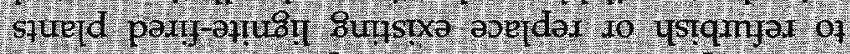

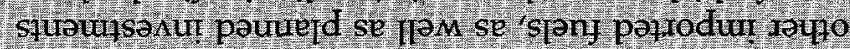

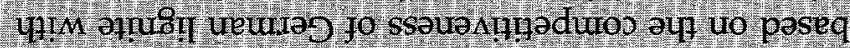

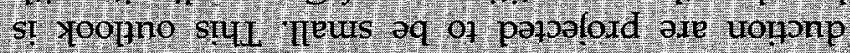

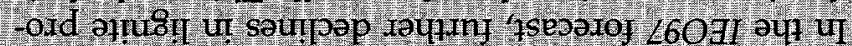

$766 \mathrm{~L}$ pur $686 \mathrm{~T}$ iajmag Aueuras

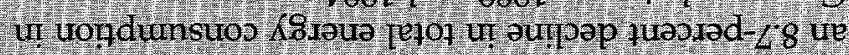

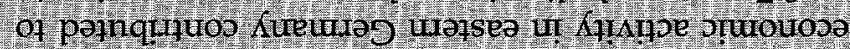

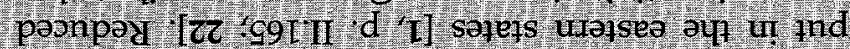

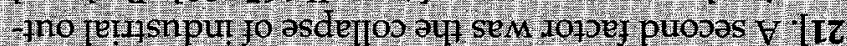

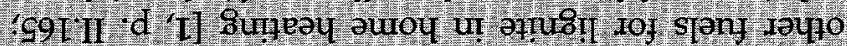
pure se8 fempeu fo Lommisqus se tfaM se $066 \mathrm{I}$ un uonesyrunas 8um

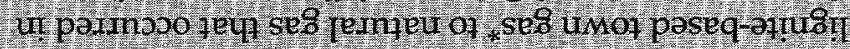

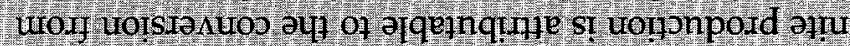

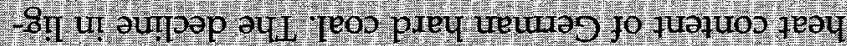

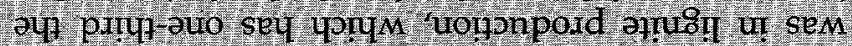

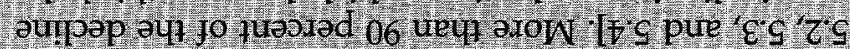

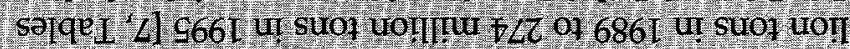

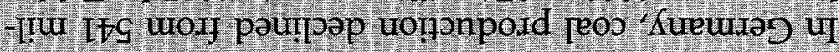

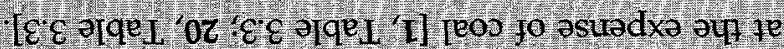
uonerauas paxy-se8 un aseasout pidex e of par yony

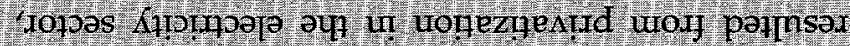

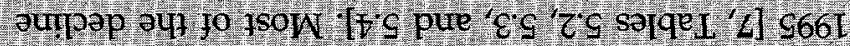

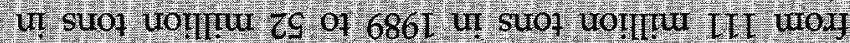
paunpap uograpord leos wopiury painn aut uा

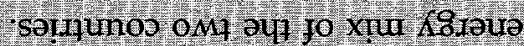

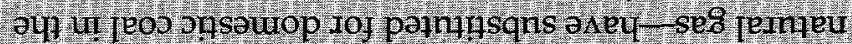

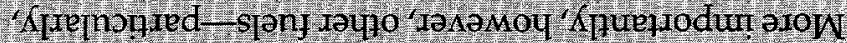

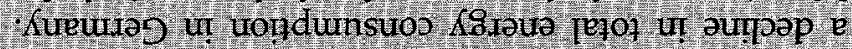

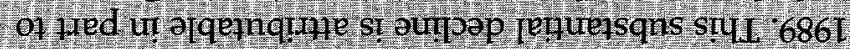

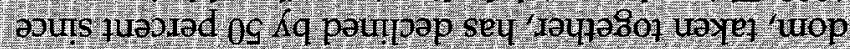

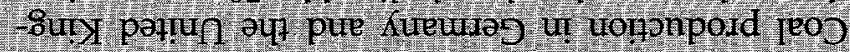


at integrated steel plants [27, 28, 29, 30]. Coal imports to the Brazilian steel industry are projected to rise as the result of strong growth in domestic steel demand and a continuing switch from charcoal to coal coke. The North American Free Trade Agreement (NAFTA) provides some economic incentive for coal trade between the United States, Canada, and Mexico, removing the previous taxes and duties levied on coal trade among the countries [31].

\section{Metallurgical Coal}

Historically, metallurgical coal has dominated world coal trade, but its share has steadily declined, from 55 percent in 1980 to 40 percent in 1995 (Figure 49) [32]. In the forecast, its share of world coal trade continues to shrink, falling to 28 percent by 2015 .

In absolute terms, metallurgical coal trade is projected to decline by only a small amount over the forecast. Factors that contribute to the decline are additional penetration of steel production from electric arc furnaces (which do not use coal coke as an input) and technological improvements at blast furnaces, including greater use of pulverized coal injection (PCI) equipment as well as higher average injection rates per ton of hot metal produced. One ton of pulverized coal (categorized as steam coal) used in steel production displaces approximately 1.4 tons of coking coal [33]. In 1995, an estimated 17 million tons of coal for PCI were traded worldwide, representing 8 percent of total coal imports for consumption at coke plants and blast furnaces [1]. Partly offsetting the downward pressure on metallurgical coal trade is an expected rise in imports to South Korea, Taiwan, India, and Brazil.

\section{References}

1. International Energy Agency, Coal Information 1995 (Paris, France, July 1996).

2. U.S. Department of Labor, Bureau of Labor Statistics, International Comparisons of Manufacturing Productivity and Unit Labor Cost Trends, 1995 (Washington, DC, July 1996), Table 1.

3. Energy Information Administration, Emissions of Greenhouse Gases in the United States 1995, DOE/EIA0573(95) (Washington, DC, October 1996), Table B1.

4. United Nations Environment Programme, "A Brief Introduction to the Climate Change Convention," web site www.unep.ch.

5. United Nations, Framework Convention on Climate Change, Report of the Conference of Parties on Its First Session, Held at Berlin from 28 March to 7 April 1995,
Part Two: Action Taken by the Conference of Parties at Its First Session, FCCC/CP/1995/7/Add.1, web site www.unfccc.de (June 6, 1995).

6. United Nations, Framework Convention on Climate Change, Report of the Conference of Parties on Its Second Session, Held at Geneva from 8 to 19 July 1996, Part Two: Action Taken by the Conference of Parties at Its Second Session, FCCC/CP/1996/15/Add.1, web site www.unfccc.de (October 29, 1996).

7. Energy Information Administration, International Energy Annual 1995, DOE/EIA-0219(95) (Washington, DC, December 1996).

8. Energy Information Administration, "Country Analysis Brief: Pakistan," web site www.eia.doe.gov (March 1996).

9. "Keti Bandar Power Station Complex," Economic Review, Vol. 27, No. 5 (May 1996), p. 40.

10. "CEPA Closes on Pakistan Imports," International Coal Report (August 7, 1995).

11. D. Dodd, "What Happened to Those Power Deals?" Institutional Investor (July 1995).

12. Energy Information Administration, International Energy Annual 1989, DOE/EIA-0219(89) (Washington, DC, February 1991), Table 36.

13. "Indonesian Coal: Strategies for Growth," Coal Trans International, Vol. 9, No. 3 (May/June 1994), pp. 1621.

14. Energy Information Administration, "Country Analysis Brief: Turkey," web site www.eia.doe.gov (April 1996).

15. Energy Information Administration, Annual Energy Outlook 1997, DOE/EIA-0383(97) (Washington, DC, December 1996), Table A8.

16. Energy Information Administration, "Country Analysis Brief: South Africa," web site www.eia.doe.gov (August 1996).

17. Energy Information Administration, "Energy Balance: 1995 South Africa," web site www.eia.doe.gov (September 4, 1996).

18. Energy Information Administration, National Energy Modeling System, run AEO97B.D100296K (1996).

19. Energy Information Administration, Annual Prospects for World Coal Trade 1991, DOE/EIA-0363(91) (Washington, DC, June 1991), Table 1.

20. International Energy Agency, Coal Information 1994 (Paris, France, 1995). 
21. "Eastern Germany Undergoes Swift Conversion to Natural Gas," Gas World International, Vol. 199, No. 4915 (June 1995), p. 36.

22. "Babcock Wins Landmark East German Power Contract," The Reuter European Business Report (October $17,1995)$.

23. "RWE Faces Fuels Dilemma," Power Europe (November 3, 1995).

24. Personal communication (FAX) from Mr. Christian Cleutinx, Head, Solid Fuels Unit, Directorate BIndustries and Markets: Fossil Fuels, DirectorateGeneral XVII-Energy, European Commission, Brussels, Belgium (March 6, 1997).

25. European Commission, "Community Rules for State Aid to the Coal Industry. Decision 3632/93/ECSC," web site europa.eu.int (December 9, 1996).

26. United Nations, Intergovernmental Panel on Climate Change, "IPCC Second Assessment Synthesis of Scientific-Technical Information Relevant to Interpreting Article 2 of the UN Framework Convention on Climate Change," web site www.unep.ch (1996).
27. Energy Information Administration, "Country Analysis Brief: Mexico," web site www.eia.doe.gov (February 1996).

28. "Chilean Steam Coal Imports To Double by 2000," Coal Week International, Vol. 17, No. 20 (May 7, 1996), p. 5.

29. "Chilean Imports Expand," International Coal Report (April 29, 1996), p. 5.

30. R. Buhler, "Recent Developments and Trends in Brazilian Steel Industry," paper presented at the Mississippi Valley Coal Trade and Transport Council's Fourteenth Annual World Coal Conference (New Orleans, LA, February 14-16, 1996).

31. "Mining Annual Review: Coal," The Mining Journal (July 1995).

32. Energy Information Administration, Annual Prospects for World Coal Trade 1987, DOE/EIA-0363(87) (Washington, DC, May 1987), Tables A2 and A3.

33. Energy Information Administration, Coal Data: $A$ Reference, DOE/EIA-0064(93) (Washington, DC, February 1995), pp. 33-35. 



\title{
Nuclear Power
}

\author{
Worldwide nuclear capacity for electricity generation is projected to decline slightly \\ over the next 20 years. Planned capacity increases in Japan and in nonindustrialized \\ nations are offset by expected reactor retirements in North America and Western Europe.
}

\section{Introduction}

Even as the performance of nuclear reactors improves worldwide, the prospects for increased reliance on nuclear power for electricity generation are dimming. In recent years, countries with nuclear power programs have derived an average of more than 20 percent of their total electricity generation from nuclear fuels; however, fewer than half of those countries are projected to experience net growth in nuclear capacity between 1995 and 2015.

In the IEO97 reference case, worldwide nuclear capacity is projected to decline from 344 gigawatts in 1995 to 332 gigawatts in 2015 (Figure 51), primarily because nearly one-third of the present U.S. nuclear capacity is scheduled for retirement by 2015. While not enough to offset planned retirements, significant increases in nuclear capacity are projected for developing Asian countries, including 31.5 gigawatts by 2015 in China, South Korea, India, and Taiwan. This area has the highest rate of growth in electricity demand in the world and is therefore in need of extensive baseload capacity additions.

\section{Figure 51. World Nuclear Capacity by Region,} 1970, 1995, and 2015

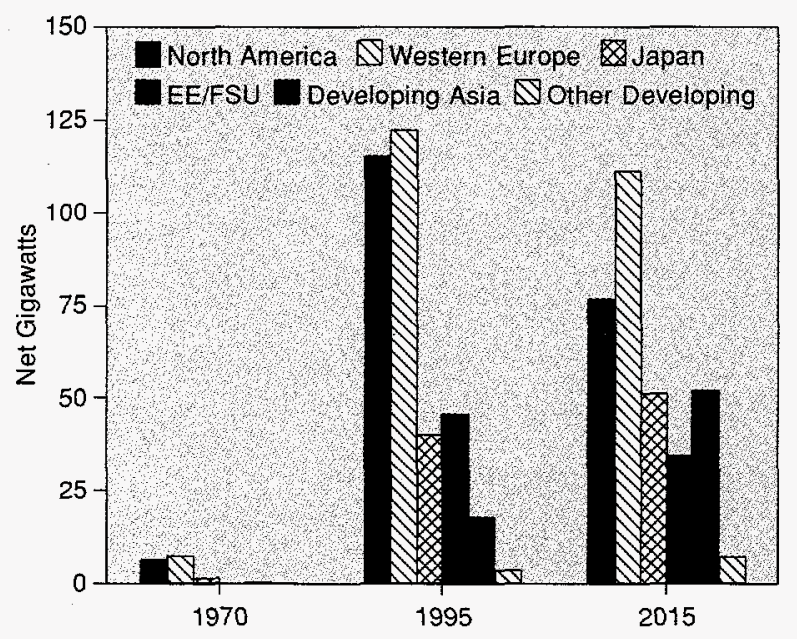

Sources: 1970: International Atomic Energy Agency, Nuclear Power Reactors in the World (Vienna, Austria, April 1993). 1995, 2015: Energy Information Administration, Nuclear Power Generation and Fuel Cycle Report 1996, DOE/EIA-0436(96) (Washington, DC, October 1996).
Two scenarios were developed for projections in this report (Figure 52). The reference case reflects a continuation of present trends in the nuclear power industry, resulting in minimal growth through 2010 and a decline by 2015 , as discussed above. For the United States, the reference case assumes that, in general, reactors will be retired when their licenses expire, as defined by the U.S. Nuclear Regulatory Commission. Additionally, reactors whose current operating costs exceed 4.0 cents per kilowatthour are assumed to be shut down 10 years before their license expiration dates. For foreign nuclear projections, the reference case reflects fairly conservative estimates of completion dates for units under construction, and of retirement dates.

The high growth case reflects a moderate revival in nuclear orders, with net capacity growth of 1.3 percent annually over the forecast period. In the United States, the high growth case assumes that all units will be retired 10 years later than in the reference case. The high growth case projections for foreign nuclear power programs are generally based on shorter construction times and allow for license extensions when determining

\section{Figure 52. World Nuclear Capacity, 1970-2015}

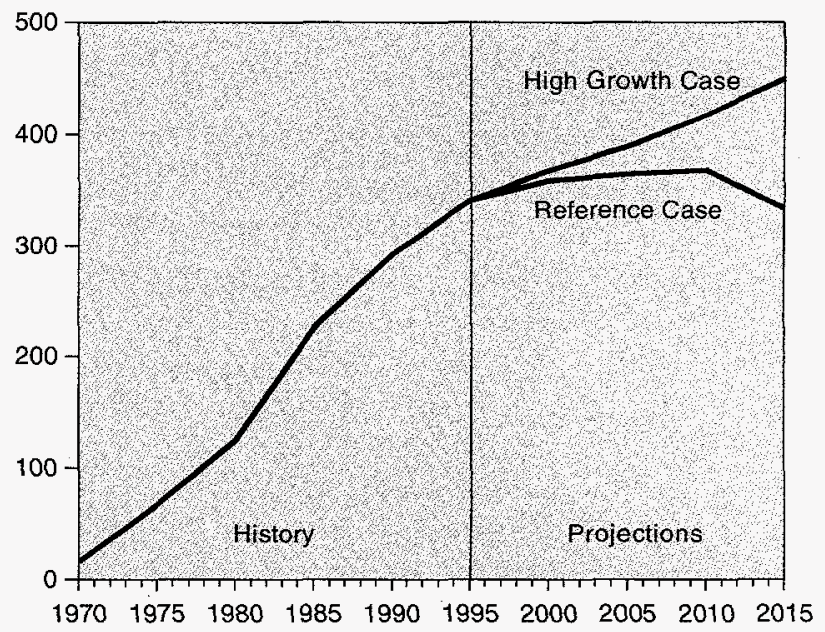

Sources: History: International Atomic Energy Agency, Nuclear Power Reactors in the World (Vienna, Austria, April 1993). Projections: Energy Information Administration, Nuclear Power Generation and Fuel Cycle Report 1996, DOE/EIA-0436(96) (Washington, DC, October 1996). 
retirement dates. They also include forecasts of new units not currently planned or under construction. In the high growth case, net increases in nuclear capacity are projected by 2015 for all but 12 of the 41 countries with nuclear programs (Table 21).

Consumption of electricity generated by nuclear power plants is projected to remain fairly flat, while overall electricity consumption grows (Figure 53). Several factors undermine the ability of nuclear power to compete in world markets. Public concern about the safety of nuclear reactor operations or the disposal of nuclear waste makes the siting of nuclear facilities difficult. In 1996 Japan joined the ranks of countries in which local voting initiatives recorded public opposition to the construction of nuclear facilities [1].

\section{Figure 53. World Consumption of Electricity From Nuclear Power Relative to All Other Fuels, 1970-2015}

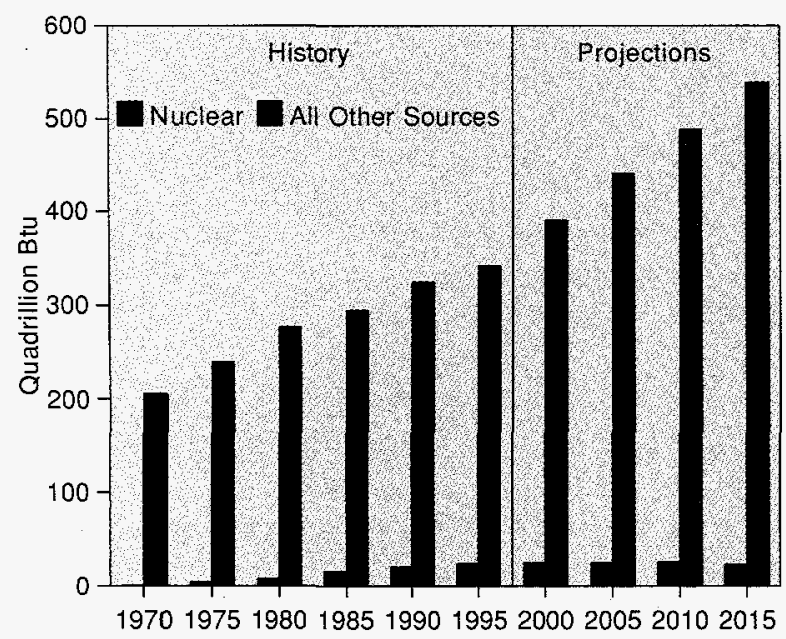

Sources: History: 1970-1975: Energy Information Administration (EIA), Office of Energy Markets and End Use, International Statistics Database. 1980-1995: EIA, International Energy Annual 1995, DOE/ EIA-0219(95) (Washington, DC, December 1996). Projections: EIA, World Energy Projection System (1997).

An equally important barrier to additions of nuclear power capacity in the industrialized countries is market competition, primarily from natural gas, which can be used to fuel highly efficient gas turbine power generators. Gas turbines tend to be relatively inexpensive from both a capital and operating standpoint, and they can be installed with short construction leadtimes. As a consequence, growth in natural gas infrastructure has been accompanied by substantial reliance on gas turbine technology to generate electricity.

The widespread trend toward utility deregulation and privatization has been a collateral force undermining the competitive potential of new nuclear power construction. Generation of electricity from new nuclear power plants is not competitive in open markets because of their high startup costs and variable operating costs.

The United Kingdom has been the most aggressive country in introducing market competition in the electricity sector, and so far its experience does not show nuclear power faring well. The British government has changed its views several times with regard to whether nuclear capacity should be privatized or continue to be government owned. The latest decision calls for the newest generation of nuclear units (almost threequarters of the operable nuclear capacity) to be privatized, but plans for new construction seem to have been abandoned with the removal of the Sizewell C unit from the construction pipeline. The older units were not privatized because they are not expected to generate enough revenue in their remaining lifetimes to meet accrued liabilities.

The entire European Union has recently passed a directive to open the electricity market to competition, starting in 1997 for a small portion of customers and increasing to almost one-third of the market by 2003. In the United States, restructuring is underway, and one trend seems to be that electricity producers are apprehensive about making any major commitments to baseload construction because of concerns that the capital outlays required may not be recovered. (See the electricity chapter of this report for further discussion of restructuring activities worldwide.)

On the positive side for nuclear power, the operating performance of existing reactors continues to improve. A review of 1995 performance, as measured by reactor load factors, indicates that 59 percent of all reactors achieved load factors above 75 percent [2]. Moreover, 48 reactors in various countries achieved load factors above 90 percent for the year. The highest national averages-all above 80 percent-were reported by Switzerland, Argentina, Finland, Hungary, South Korea, Netherlands, Slovenia, Spain, and Belgium. All of these countries, except Argentina, Slovenia and the Netherlands, operate four or more reactors.

In developing countries, especially in Asia, increased reliance on nuclear power is projected. China, India, South Korea, and Taiwan all have sizable construction projects planned and underway. In the reference case, nuclear generation capacity in developing countries is projected to increase threefold by 2015 (Table 21). In 1996, 25 nuclear reactors were under construction or on order in the countries of developing Asia [3]. 
Table 21. Historical and Projected Operable Nuclear Capacities, 1995-2015 (Net Gigawatts)

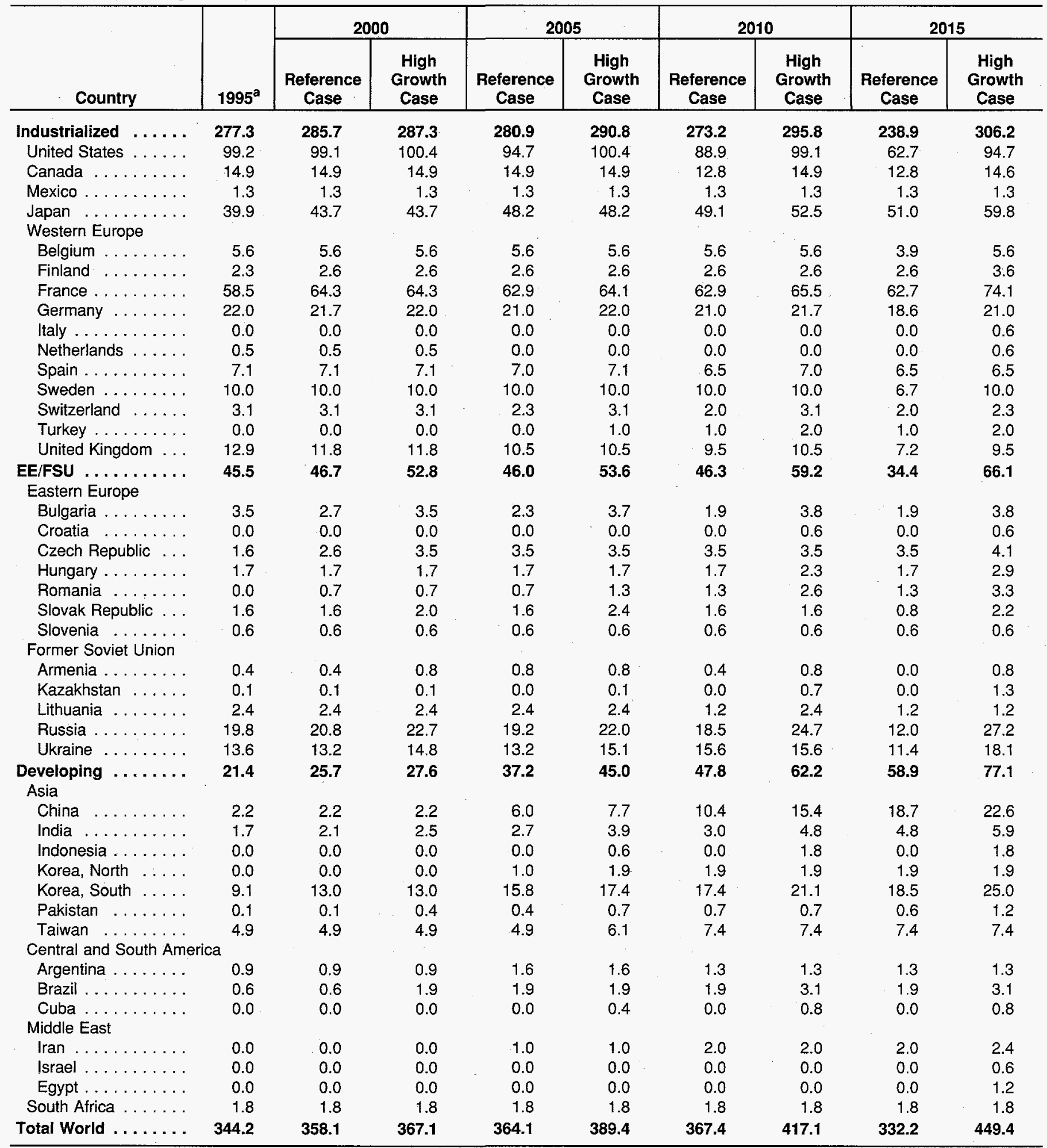

${ }^{\text {aS }}$ Status as of December 31, 1995.

Notes: EE/FSU = Eastern Europe/Former Soviet Union. Totals may not equal sum of components due to independent rounding.

Sources: United States: Energy Information Administration, Annual Energy Outlook 1997, DOE/EIA-0383(97) (Washington, DC, December 1996). Foreign: Energy Information Administration, Nuclear Power Generation and Fuel Cycle Report 1996, DOE/EIA-0436(96) (Washington, DC, October 1996). 


\section{Regional Activity}

\section{Developing Asia}

Countries in developing Asia currently operating nuclear power plants include China, South Korea, Taiwan, India, and Pakistan. With the exception of South Korea, the programs are small, but all expect growth in the future. At the end of 1995, these five countries had 18.0 gigawatts of nuclear capacity on line. By 2015, additional programs are expected to be operating in North Korea and possibly Indonesia, and nuclear capacity for the region is projected to be between 51.9 and 65.8 gigawatts. South Korea, currently the largest operator of nuclear power in the region, with 11 operable units totaling 9.1 gigawatts, projects at least a doubling of capacity to between 18.5 and 25.0 gigawatts by 2015. Even more striking is China's expected growth; by 2015 China is projected to have at least 18.7 gigawatts of nuclear capacity operating, more than eight times its current capacity.

During 1995 two new units became operable in the region: Yonggwang 4, a 950-megawatt pressurized-water reactor (PWR) in South Korea, and Kakrapar 2, a 202megawatt pressurized heavy-water reactor (PHWR) in India. At the end of 1995, 25 units were under construction or on order in developing Asian countries, including 10 in South Korea and 6 in China [3].

The latest power development plan for South Korea calls for 35 percent of new generating capacity over the next 10 years to come from nuclear power [4]. China also has aggressive plans to build additional nuclear power plants to meet rapid growth in electricity demand. Definite plans have been made for two additional 985-megawatt PWRs at Guangdong (the site of two currently operating units), and four additional units at the Qinshan site (one unit currently operating). The new units at the Guangdong site will be supplied by the French vendor Framatome. The units at Qinshan are 600-megawatt PWRs of a Chinese design, although foreign companies have been contracted to supply major components. Construction began on Qinshan 2 and 3 in 1996, and the units are expected to be complete in 2001 and 2002 [5]. In Taiwan, GE Nuclear Energy was selected to provide two nuclear reactors for the Lungmen power station. Construction on the two 1,350megawatt advanced boiling-water reactors (ABWRs) could begin in late 1996 or early 1997, with prospective dates for commercial service set at 2003 and 2004 [5].

\section{Other Developing Countries}

Other developing countries that currently operate nuclear power plants include Argentina, Brazil, and South Africa. Countries with the potential to have nuclear programs in place by 2015 include Cuba, Iran, Israel and Egypt. Argentina's two nuclear units provided 12 percent of the country's electricity in 1995. Brazil's one nuclear unit supplied just 1 percent of its total electricity generation. South Africa has two nuclear units currently operable, which provided 7 percent of the country's electricity generation in 1995. No new nuclear units are planned in South Africa. Nuclear capacity in the region is expected to grow from 3.3 gigawatts in 1995 to between 7.0 and 11.2 gigawatts in 2015.

Most of the other developing countries do not have the capital for large nuclear programs and, in fact, will likely require financial and technical assistance before undertaking nuclear power construction. Successful completion of Cuba's Juragua station will require international assistance. Russia has agreed to complete two units for Iran, at the Bushehr site, where construction was started in the 1970s.

\section{Industrialized Asia}

In the industrialized countries of Asia, only Japan has a well-established nuclear program, with 51 units totaling 39.9 gigawatts of operable capacity at the end of 1995. Japan's nuclear share of electricity in 1995 was 33 percent. Japan has ambitious plans for further nuclear expansion, mainly to help achieve energy independence. Japan's nuclear capacity is projected to increase by 11.1 gigawatts-to a total of 51.0 gigawatts-by 2015 in the reference case. The high growth case projects an increase in capacity to 59.8 gigawatts by 2015 . The aggressive expansion plan includes 14 units, totaling 15.4 gigawatts, in the construction pipeline at the end of 1995 [3].

Japan's first commercial nuclear power plant, Tokai Mura, will be shut down when current stocks of nuclear fuel are used up, according to a recent statement from the Japan Atomic Power Company. The plant operated reliably for 30 years, and the decision to shut down was mainly economic [6].

\section{Western Europe}

Western Europe relies heavily on nuclear power to satisfy its electricity demand. In 1995, Western Europe generated 43 percent of its electricity with nuclear power. In France and Belgium, 76 and 56 percent, respectively, of the national demand for electricity was supplied from nuclear power plants [3]. However, the overall trend in Western Europe is away from nuclear power builds.

In the reference case, only France, Finland and Turkey are projected to have net increases in nuclear capacity 


\section{Nuclear Power in India}

Last year's International Energy Outlook (IEO96) includ: ed a detailed look at the status and future prospects of the commercial nuclear power industry in China. IE097 considers nuclear power in India. Although India's nuclear program is not expected to be as $d y$ namic as China's, the country has all phases of the nuclear fuel cycle in place, in addition to having 12 nuclear plants either planned or under construction. Nuclear capacity in India is projected to grow by 5.3 percent annually between 1995 and 2015.
In 1956, India's first experimental nuclear reactor, Apsara at Trombay, began operation with the help of the United Kingdom and Canada. During the 1960s, India continued to build experimental reactors, including heavy water-moderated and plutonium-fueled reactor technologies. The nation's first commercial station, the Tarapur Atomic Power Station (TAPS), was built by U.S. General Electric Company as a turnkey project t The station's two 150-megawatt boiling-water reactors began operation in 1969 (see table below).

\section{Nuclear Power Units in India}

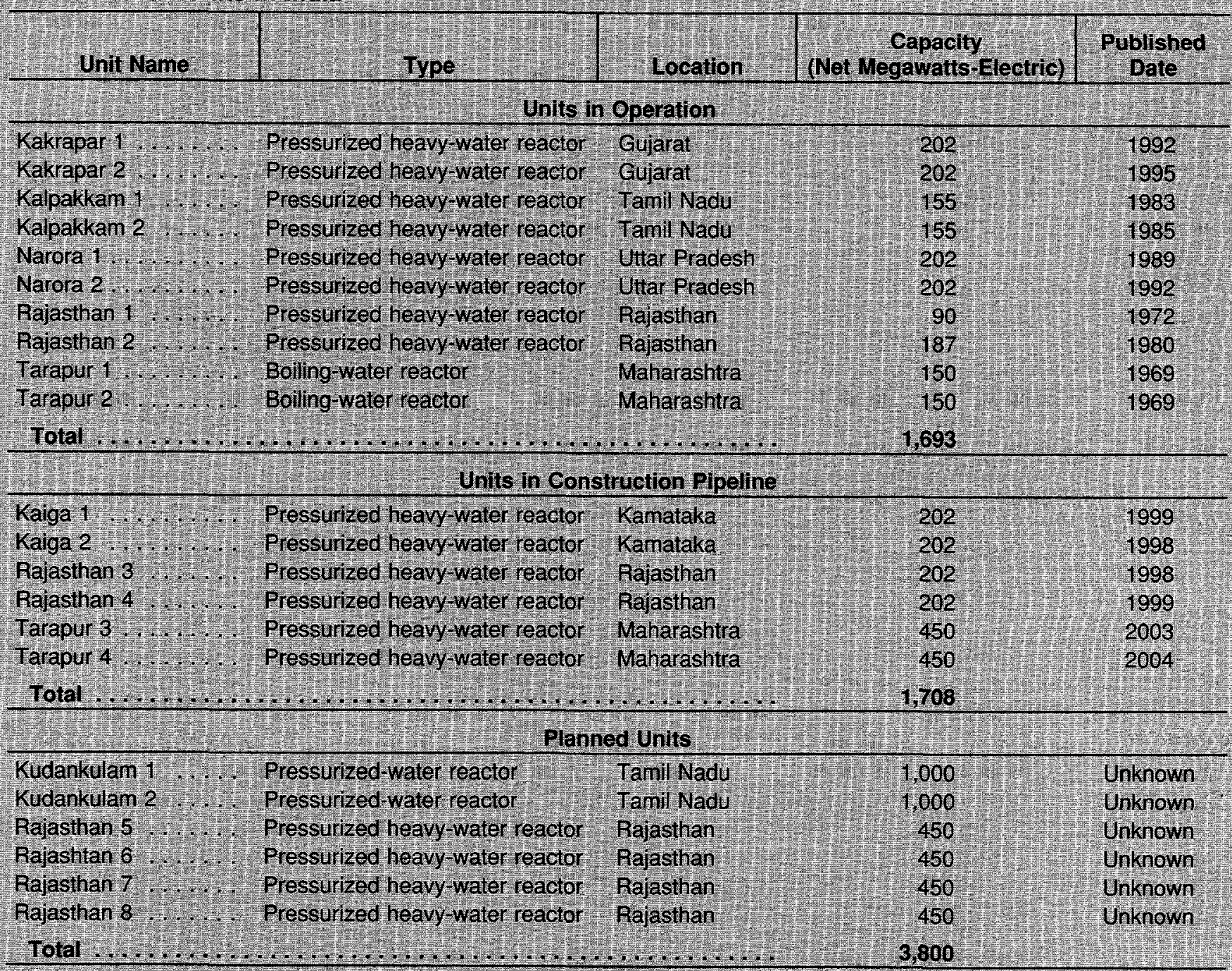

Source: Energy Information Administration, Nuclear Power Generation and Fuel Cycle Report 1996, DOEELIA-0436(96) (Washington, DC, October 1996), pp 105-108.

That is, General Electric performed all the necessay york of planning procurement, construction, completion, and testing of the turnkey project before thining it over to the owner for operation. 


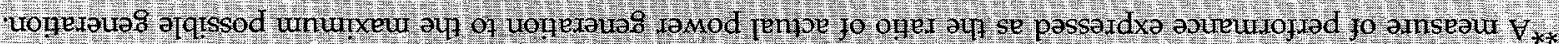

Apanjads -ar fooz pue co0z Aq jeurojerado aq 04 pajpadxa are $t$

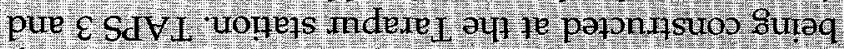

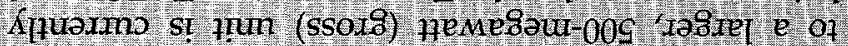
ubisap ropeal paztprepurezs aul jo uorsion dn-pajeos

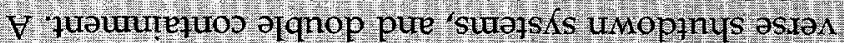
-1p 'sampaj juustas parordul saplodiobul tisisap

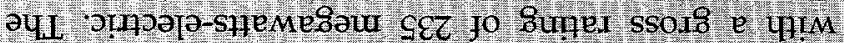

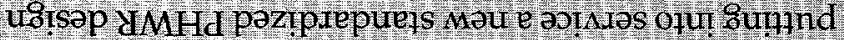

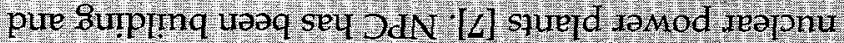

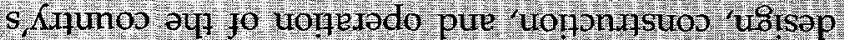
ә4 $10 \mathrm{f}$ AmIqIsuodsax aumsse on pauroy se W (bdN)

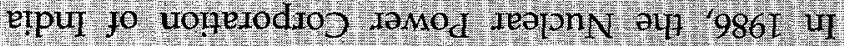

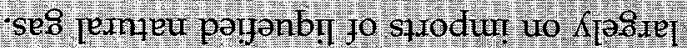

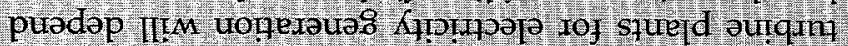

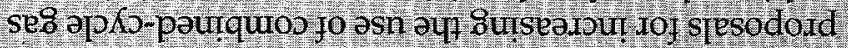

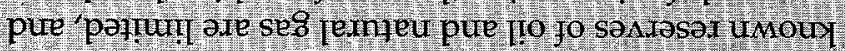

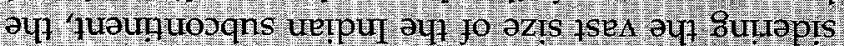

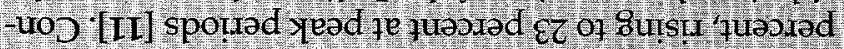

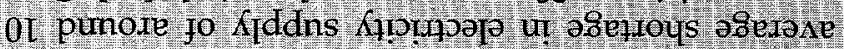

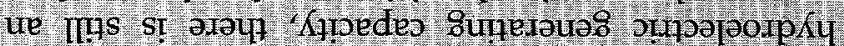
pure pauj-jeos jo suogmpe jejuejsqns ajidsap pure

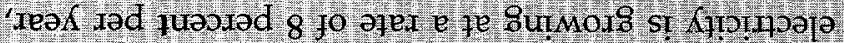

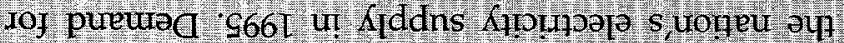

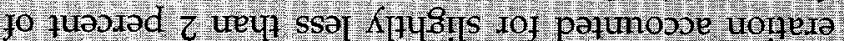

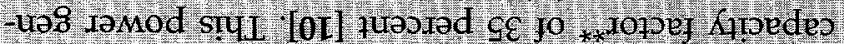

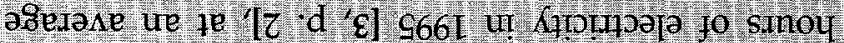

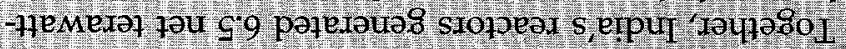

9861 pue 8861 ut ajaros sumanto 'seipey ti weypedjey le jinq aram sjum he hesou

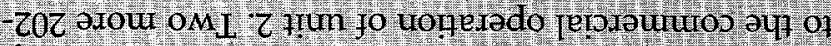

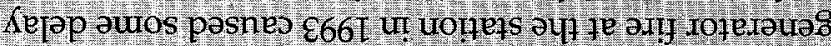
snomas $\nabla$ : Ajanjaadsat $266 \mathrm{~T}$ pue $686 \mathrm{I}$ il pur 24

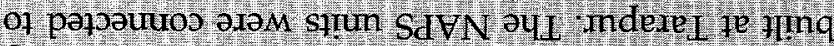

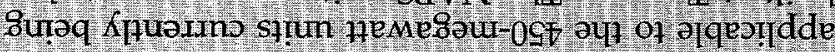
sajdpuind usisap pajeiodroou leu siojoear pazpre

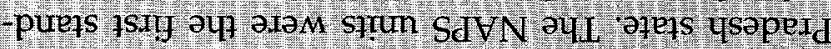

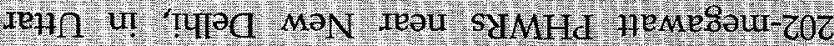

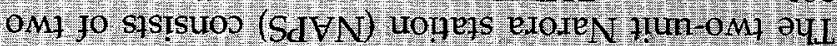

[6] S66I 4orew on pis' au o1 paypar

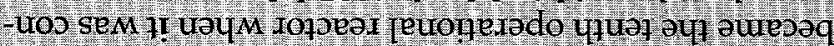

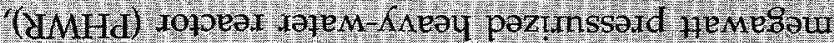

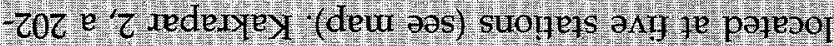

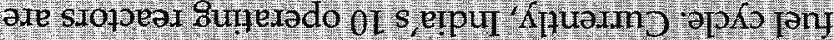
ajalduros ayt pure spured ramod reapnu fo urogonns

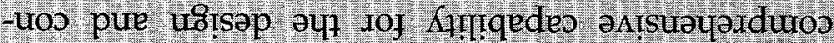

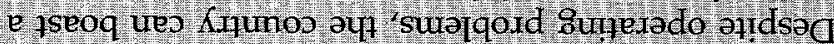

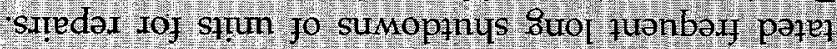

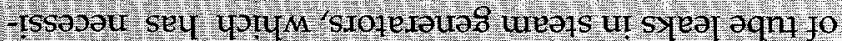
urargord aut waag sey suoneis ramod reapnu s, erpu

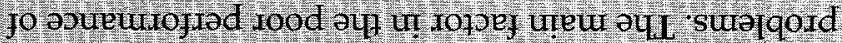

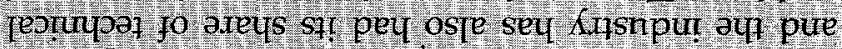
ruaurdoranap reapnu $s$, flunob aq sulfepo un 1 red e parejd oxey sanjod jeool pure sjumensuoo jejoureut

smeis wamn

Selvel

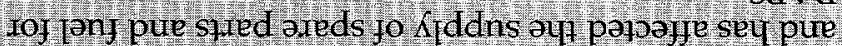

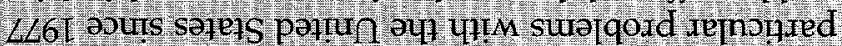
pasnea sey sprensajes adoas-11ny jáabe of jesnjar

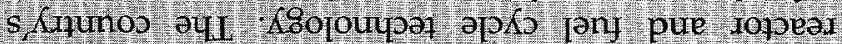

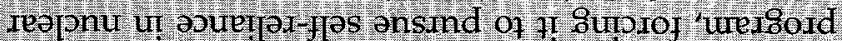
reapnu s Atgunos att pafejap sey - Rrojeunutsosip sem Afean aut ten uoydasrad aul uo paseq - Alearl

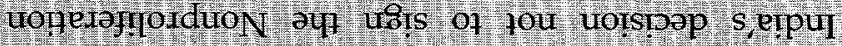

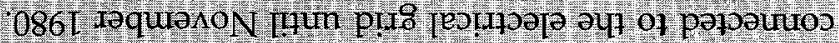

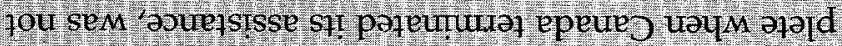

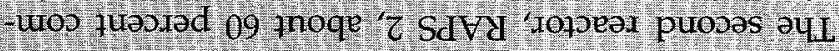

- әэцар reapau e papoldxa erpu

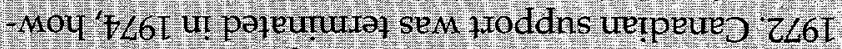

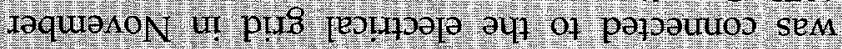

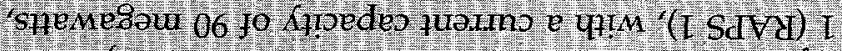

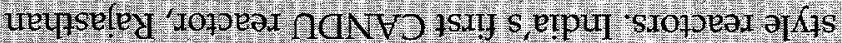

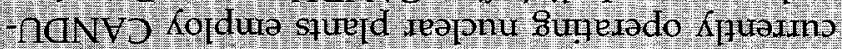

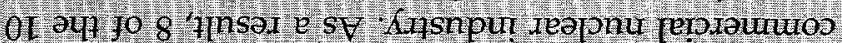

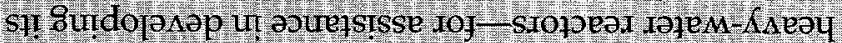

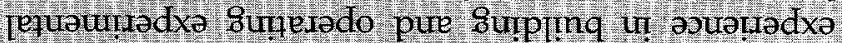

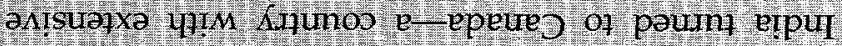

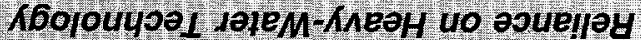

18. wimiout pue $\varepsilon \varepsilon z$-umirem

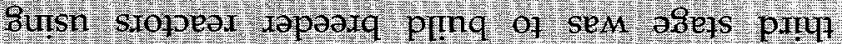
ay I Uuntropn

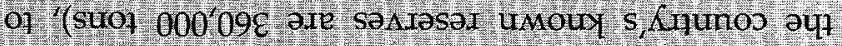

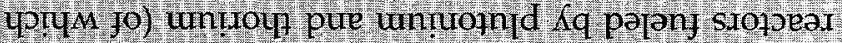

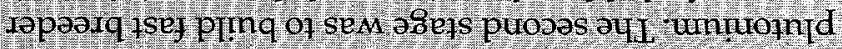

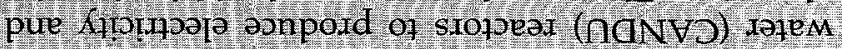

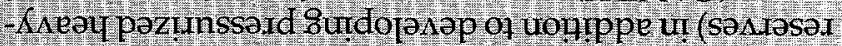

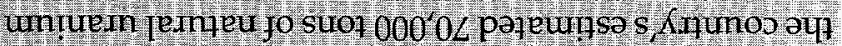

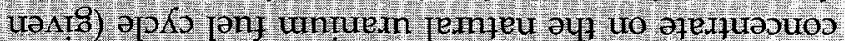

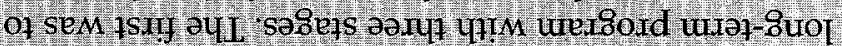

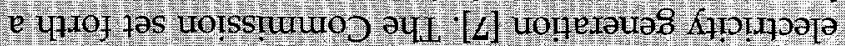
S. Alumos ay fo quasrad ol of dn apraord of $2000 z$

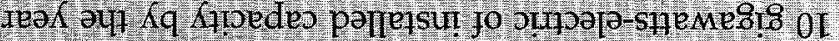

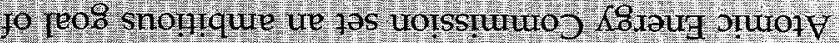

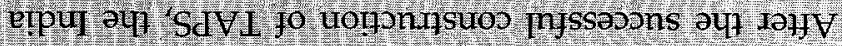




\section{Nuclear Power in India (Continued)}

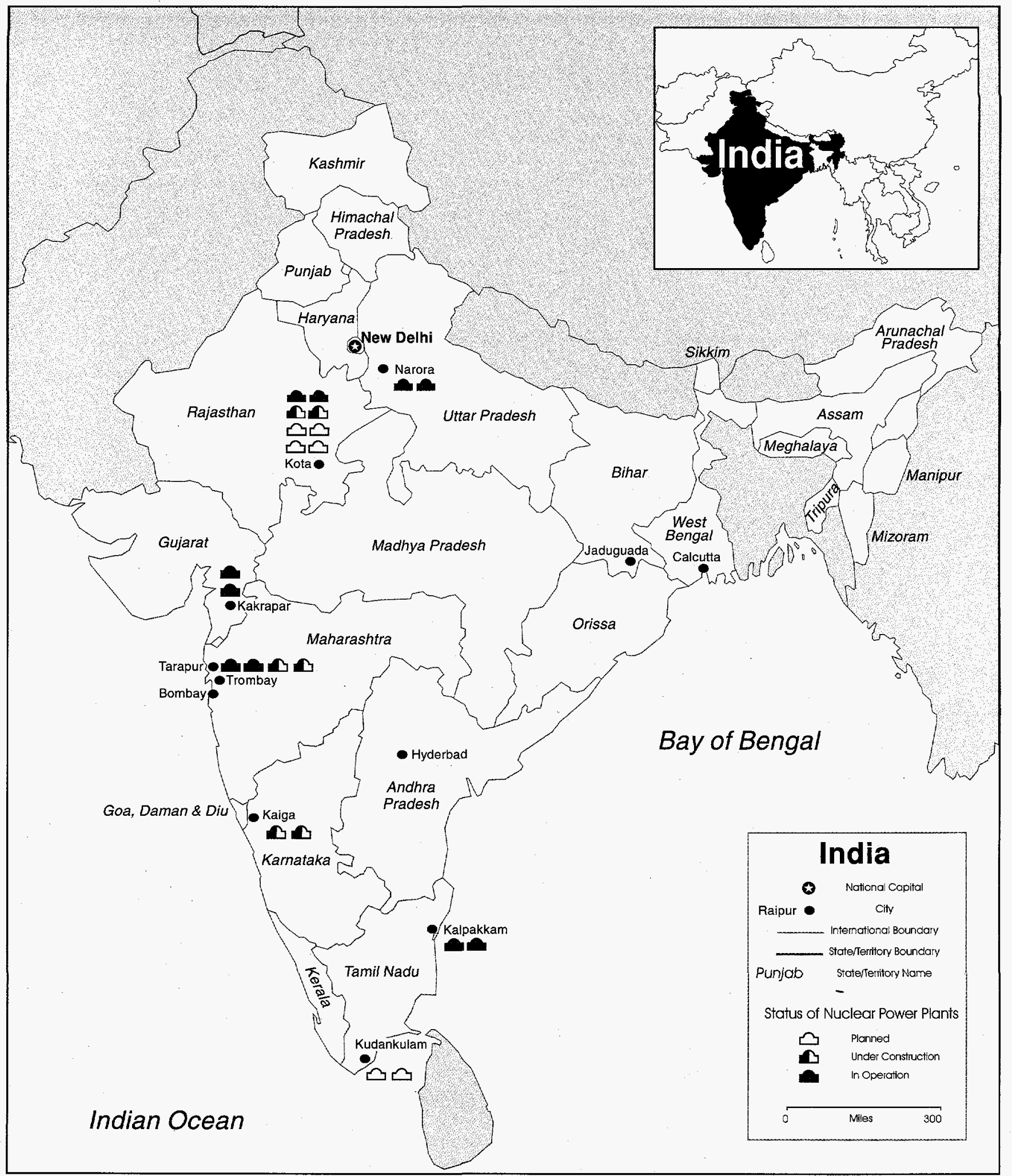

Source: NUEXCO, 1993 Annual NUEXCO Review (1994), p. 47. 


\section{Nuclear Power in India (Continued)}

Four 202-megawaft units are also under construction. Kaiga 1 and 2 in Kaiga, Karnataka, and Rajasthan 3 and 4 are projected to enter service between 1998 and 1999. Another four units are planned, Rajasthan 5 through 8, but they may not be realized until the middle of the next-decade.

In October 1995, India's NPC and a visiting Russian delegation signed a memorandum of understanding for the construction of two Russian VVER-1000 nuclear units at Kudankulam in southern India. An earlier plan for the plant was canceled affer the breakup of the Soviet Union. The two reactors will be supplied under a turnkey contract valued at an estimated $\$ 2,6$ billion. India will pay up to 15 percent of the cost in hard currency, and the remainder will be paid on credit with an annual interest rate of 4 percent [12]. There is some concern, however, about India's will ingness to accept full-scope safeguards at the proposed plant.

As a result of financial constraints, the country's goal of having 10 gigawatts of nuclear capacity in operation by 2000 now appears likely to fall short by half that figure, with 1.7 gigawatts currently operating and 1.7 gigawatts actively under construction. India's nuclear capacity is projected to be 4.8 gigawatts in 2015 but could reach 5.9 gigawatts according to the projections in the high growth case (see figure).

\section{Fuel Cycle}

India has all sectors of the nuclear fuel cycle in place, with the one exception of uranium enrichment for the two BWRs at Tarapur. Currently, China is supplying nuclear material for those plants. As an alternative, India's A tomic Energy Commission has developed the technology for mixed plutonium/uranium oxide (MOX) fuel fabrication and claims that it can now fuel the Tarapur reactor itself:

Adequate resources of uranium have been identified to meet the requirements of India's currently en- visaged nuclear power program. The uranium deposit at Jaduguda, Singhbhum district, Bihar, has been under exploitation since 1962. The uranium deposits at Bhatn and Narwapahar are also currently being exploited. Ore from the three deposits is treated in a mill located at Jaduguda in the Singhbhum region, and the yield is currently running at around 300 tons of uranium per year, which is more than sufficient to meet expected requirements through the early years of the next century. The Nuclear Fuel Complex at Hyderbad fabricates fuel for all types of reactors in India, including PHWRs and BWRs.

India has developed sufficient heavy water production capacity to meet the needs of its nuclear program and to allow for export. The eight plants currently in operation have a capacity of 655 tons a year, which is adequate to meet domestic requirements and has also allowed recent export sales of 100 tons to South Korea and 350 tons to Romania.

\section{India's Nuclear Power Capacity, 1995-2015}

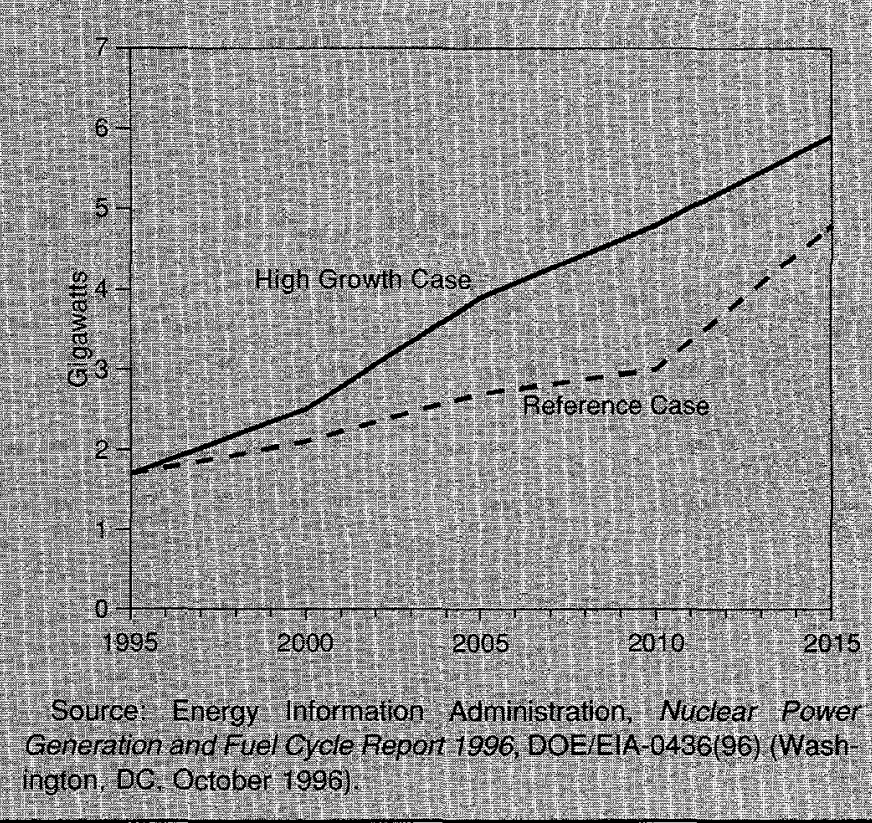

between 1995 and 2015. Finland's increase is the result of upgrades at a current site, which will increase effective capacity; no new units are expected to be built. Turkey, which currently has the fastest growing energy market in Europe, is exploring numerous power options to meet its rising energy demand [13]. As a result, at least one nuclear unit is expected to be in service by 2010 in Turkey. Seven other West European countries are projected to have decreases in total nuclear capacity due to plant retirements.
In early 1995, Sizewell B, a 1,188-megawatt PWR, was brought on line in the United Kingdom, after just under 7 years of construction time. Also in 1995, Germany retired the Wuergassen unit, a 640-megawatt boilingwater reactor (BWR). After operating for 24 years the unit was shut down to avoid costly repairs necessary for its continued use. In France, Chooz B1, a 1,450megawatt PWR, supplied electricity to the grid for the first time on September 30, 1996 [14]. A second unit, Chooz B2, was undergoing final testing in early 1997 to 
prepare for connection to the grid. These two reactors are slated as the first wholly French designed PWRs, created by the French company Alsthom. The output from the two new reactors will be shared between France ( 75 percent) and Belgium (25 percent).

Competition in the electricity market in Western Europe may be one cause of declining nuclear capacity in the future. On June 20, 1996, after many years of debate, European Union energy ministers agreed on a directive designed to open up the electricity market to international competition [14]. France, in particular, had been opposed to allowing third-party access to its power grid, which would threaten the monopoly held by Electricite de France (EdF), the country's national utility and operator of its 56 nuclear units. EdF claims that the current fleet of nuclear reactors is largely amortized, and that the marginal cost of production is quite low, thus ensuring current competitiveness in both domestic and foreign markets [15]. It is unclear, however, whether future investments in nuclear power plants will be economically justifiable. For countries such as Germany, Spain, and Switzerland, which have long had political opposition to nuclear power, the additional requirement for nuclear generation to be economically competitive could be the limiting factor for any new nuclear construction.

\section{North America}

Nuclear programs in North America exist in the United States, Canada, and Mexico. U.S. nuclear capacity is by far the largest in the region, although reliance on nuclear power is similar in the United States and Canada. In 1995, the nuclear share of electricity was 20 percent in the United States and 17 percent in Canada. Mexico's two units supplied 6 percent of that country's electricity during 1995. No growth is expected in this region.

In the United States, one new unit, Watts Bar 1, came on line in 1996. There are no other projects actively under construction or planned. By 2015, U.S. nuclear capacity is projected to decrease by 37 percent from the 1995 level in the reference case, due to retirements and the lack of new orders.

In Canada, with no new orders projected in the reference case, capacity decreases by 2.1 gigawatts by 2015 as a result of retirements. In the high growth case, nuclear capacity is projected to decrease only slightly, assuming life extensions for plants currently scheduled for retirement. During 1995, the Bruce 2 nuclear reactor was prematurely retired. Ontario Hydro $(\mathrm{OH})$, the operating utility, shut down several other baseload power plants as well, in an attempt to bring power demand and supply into balance. $\mathrm{OH}$ is planning to divide into separate generating, transmission, and distribution companies, with privatization of the generating sector occurring several years later. The first priority in preparing for restructuring is to improve nuclear plant performance [16].

Nuclear plant performance in the United States is steadily improving relative to past performance. A study of U.S. capacity factors for the 3-year period 1993-1995 showed improved performance for all categories of plants, grouped either by size or by age [17]. Almost three-quarters of U.S. plants had average capacity factors above 70 percent for 1993-1995, including a remarkable 23 units above 85 percent. Only 11 plants performed below 50 percent, including two units at the Browns Ferry site that have been temporarily out of service for most or all of the past 3 years. The median capacity factor was 79 percent, up from 73 percent in 1990-1992. Improvements in nuclear reactor performance in the United States should improve the competitive potential for nuclear power, but further reductions in operating and maintenance costs must also be achieved.

\section{Eastern Europe and the Former Soviet Union}

In the EE/FSU region, the nuclear share of total electricity generation was 19 percent in 1995; 75 percent of the region's electricity from nuclear plants was generated in the FSU [3]. Reliance on nuclear power varies in the region, from 86 percent in Lithuania to 12 percent in Russia. Several countries in the region have ambitious plans for additional nuclear capacity, but there are many challenges that will likely limit new nuclear builds.

In light of the uncertain potential for future projects, the region's projected nuclear capacity in 2015 ranges from a net loss of 11.1 gigawatts in the reference case to a gain of 20.6 gigawatts in the high growth case. The forecasts, particularly the high growth case, assume that either financing will be available to the Eastern European countries through international lending institutions, or the respective economies will recover sufficiently to make nuclear construction a viable option.

In the Ukraine, one new unit, Zaporazhe 6, a 950-megawatt PWR, was brought on line in October 1995. In Armenia, a unit that had been shut down since 1989 was reopened in 1995. Armenia 2, a 376-megawatt PWR, went through significant backfitting before it was restarted, and it was done without Western aid. The United States withheld support, believing that the reactor would be unsafe to operate at any expense. Armenia, however, facing another harsh winter and the possibility of only 2 hours of electricity per day, determined that reopening the nuclear plant was the 
best option. Once operable in November, the plant provided 40 percent of Armenia's electricity [18].

In Romania, a Canadian-built reactor at Cernavoda was opened in April 1996 [19]. The plant, which was expected to begin operating commercially by the end of the year, is the first Western-designed nuclear power plant in Eastern Europe.

The ability of EE/FSU countries to complete their aggressive plans to build new nuclear capacity (over 20 new units are under consideration) will depend on obtaining financial support and improving safety at existing units. In many cases, the power generated by nuclear plants cannot be supplied by any currently available alternative. In Lithuania, two RBMK reactors (Soviet-designed light-water-cooled, graphite-moderated reactors) provide 86 percent of the country's electricity as well as a portion for export.

In the Ukraine, the Chernobyl units are still operating to alleviate electricity shortages in the area, although the lack of fuel limited the output for several months during 1996. The government has tentatively agreed to close the plants by the year 2000, given that replacement power would come from upgraded VVERs (Soviet-designed light-water reactors). The European Union and the European Bank for Reconstruction and Development are currently reviewing a plan to finance the completion of the Rovno 4 and Khmelnitsky 2 nuclear plants, which the Ukraine has proposed as the most economical replacement power for the Chernobyl station [14]. In Slovakia, loan agreements have been signed to provide $\$ 900$ million for the completion of two nuclear units at the Mochovce site. The loan is covered by a consortium of national banks and four international banks [5].

\section{References}

1. "Japanese Reject Nuclear Power Plant," The Baltimore Sun (August 5, 1996), p. A7.

2. L. Howles, "Load Factors: 1995 Annual Review," Nuclear Engineering International, Vol. 41, No. 502 (May 1996), pp. 30-35.

3. Energy Information Administration, Nuclear Power Generation and Fuel Cycle Report 1996, DOE/EIA0436(96) (Washington, DC, October 1996).
4. B.H. Chung, "Nuclear Power Development in South Korea," Nuclear News, Vol. 38, No. 8 (June 1995), pp. 34-37.

5. "International Section," Nuclear News, Vol. 39, No. 8 (July 1996), pp. 36-40.

6. "International Section," Nuclear News, Vol. 39, No. 9 (August 1996), pp. 70-74.

7. "India," Nuclear Engineering International, Vol. 40, No. 487 (February 1995), pp. 32-40.

8. G.S. Bhargava, "Nuclear Power in India: The Costs of Independence," Energy Policy, Vol. 20, No. 8 (August 1992), pp. 735-742.

9. "Kakrapar 2 Goes Commercial," Nuclear Engineering International, Vol. 40, No. 495 (October 1995), p. 12.

10. "Generation by Nation," Nucleonics Week, Vol. 37, No. 6 (February 8, 1996), p. 8.

11. "India: The Long Road to Self-Sufficiency," Nuclear News, Vol. 38, No. 8 (June 1995), p. 43.

12. "Pact Signed To Revive Twin-Unit Plant in India," Nuclear News, Vol. 38, No. 2 (February 1995), p. 59.

13. J. Barham, "Power Plant Plan Shows Confidence in Turkey," Financial Times (August 27, 1996), p. 23.

14. "International Section," Nuclear News, Vol. 39, No. 11 (October 1996), pp. 36-37.

15. A. MacLachlan, "Energy Chiefs Agree To Open EU Electricity Market by 2003," Nucleonics Week, Vol. 37, No. 26 (June 27, 1996).

16. R. Silver, "Hydro To Restructure Next Year as Privatization Ardor Cools," Nucleonics Week, Vol. 37, No. 43 (October 17, 1996), pp. 14-15.

17. E.M. Blake, "U.S. Capacity Factors: Crowding the Ceiling," Nuclear News, Vol. 39, No. 6 (May 1996), pp. 24-30.

18. A. Cooperman, "The Next Chernobyl?" U.S.News and World Report, Vol. 120, No. 17 (April 29, 1996), pp. $46-49$.

19. "IAEA Says 438 Nuke Plants Operating Worldwide," Reuters NewMedia (May 2, 1996). 


\title{
Hydroelectricity and Other Renewable Resources
}

\author{
Moderate growth in the use of renewable energy resources is projected \\ for all regions of the world. Sustained low prices for fossil fuels make it \\ unlikely that renewables will see significant overall gains in market share.
}

\section{Introduction}

Low fossil fuel prices continue to constrain development of the world's renewable energy sources. While the costs of installing and generating electricity with renewable resources continue to decline and technological advances improve generating efficiencies, they historically have not been able to keep pace with the declining costs of energy from fossil fuels, making it difficult for the use of renewables to increase as a share of total energy consumption (Figure 54).

Nevertheless, in Western Europe-for environmental reasons-and in rural areas of developing countries where populations live far from institutional electricity grids, there is sustained interest in increasing the use of renewable resources. Environmental concerns expressed by more than 100 nations in signing the 1992 United Nations Framework Convention on Climate Change foster interest in renewable energy research, development, and demonstration projects.

Figure 54. World Consumption of Hydroelectricity and Other Renewables Relative to All Other Fuels, 1970-2015

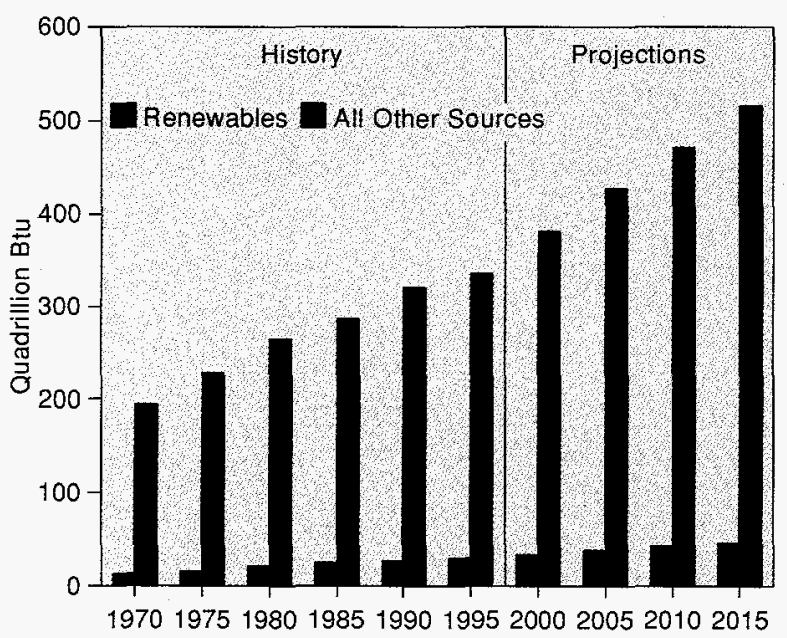

Sources: History: 1970-1975: Energy Information Administration (EIA), Office of Energy Markets and End Use, International Statistics Database. 1980-1995: EIA, International Energy Annual 1995, DOE/ EIA-0219(95) (Washington, DC, December 1996). Projections: EIA, World Energy Projection System (1997).
In recent times, substantial progress has been achieved in wind-based electricity generation. The cost of generating electricity with wind has fallen dramatically since the mid-1970s, when the U.S. Department of Energy estimated that it cost $\$ 1$ per kilowatthour to generate electricity from wind in the United States (Figure 55). By 1996 the cost had dropped to only 5 cents per kilowatthour, and projections suggest that a further reduction to about 2 cents by 2010 might be attainable if favorable project financing is available $[\mathbf{1}, \mathrm{p} .55]$.

Wind is experiencing some of the strongest growth among the renewable energy sources. The American Wind Energy Association forecasts that the five top growth markets for wind energy through 2005 will be the United States, India, China, Germany, and Spain, with capacity additions of between 1,275 and 2,730 megawatts projected in each country [2]. The United States still has the most installed wind capacity (1.8 gigawatts in 1995), but at the present rate of installation, German wind capacity may soon exceed that of

\section{Figure 55. Average Cost of Wind-Powered Electricity Generation in the United States, 1975-2010}

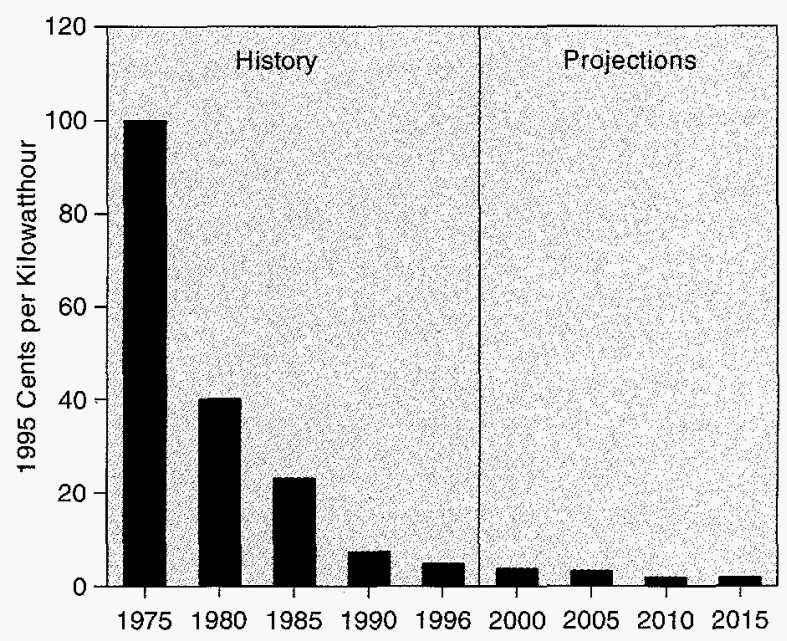

Sources: 1975-1985: U.S. Department of Energy (DOE) (1975 and 1980 estimated from DOE experimental machines). 1990-2015: Energy Information Administration, Annual Energy Outlook 1997, DOE/EIA-0383(97) (Washington, DC, December 1996). 
the United States. In 1995, India and Germany together accounted for two-thirds of the entire world's added wind capacity (Table 22).

Noncommercial fuels from plant and animal sources are important energy sources, especially in the developing countries. Comprehensive data on the use of noncommercial fuels are not available, however, and they are not considered in the IEO97 projections. Similarly, because there are few extensive sources of international data on their use, dispersed renewables (renewable energy consumed on the site of its production, such as solar panels used for water heating) also are not considered in the projections.

By 2015, total world consumption of hydroelectricity and other renewable energy sources is projected to reach 46 quadrillion Btu in the IEO97 reference case, maintaining an 8-percent share of total energy consumption throughout the 1995 to 2015 forecast period (Figure 56). More than one-half of that consumption is attributed to countries in the industrialized world. In general, however, renewable energy sources in the industrialized countries are expected to see only moderate growth over the next two decades, increasing by about 2 percent annually to 26 quadrillion Btu in 2015 . In industrialized countries such as Germany and the United Kingdom, where strong programs or incentives for advancing renewables are in place, alternative energy sources like wind are expected to grow rapidly.

The potential for growth of hydroelectricity and other renewables is higher in parts of the developing world. Renewables are projected to grow by almost 5 percent annually in developing Asia between 1995 and 2015, for the most part because large-scale hydroelectricity projects are still being constructed there. On the other hand, the particularly strong annual growth of renewables in India-almost 7 percent per year-will result from increased use of alternative energy sources, including primarily wind, some photovoltaics, and some hydro- electric power development. As in Western Europe, India's government programs and incentives for installing renewables have resulted in strong growth.

Growth in Eastern Europe and the former Soviet Union (EE/FSU) is expected to be moderate - even lower than the growth of renewables in the industrialized countries-at 1.4 percent annually through 2015. Most of the growth will occur in Eastern Europe, primarily in the form of upgrades and repairs to hydroelectric facilities, although there is some interest in developing geothermal resources and wind power in the region. The continued weak economies of countries in the FSU make it difficult for renewables to penetrate their energy markets, but opportunities exist in harsh climates where conditions are more favorable to wind power.

Figure 56. World Consumption of Hydroelectricity and Other Renewables, 1970-2015

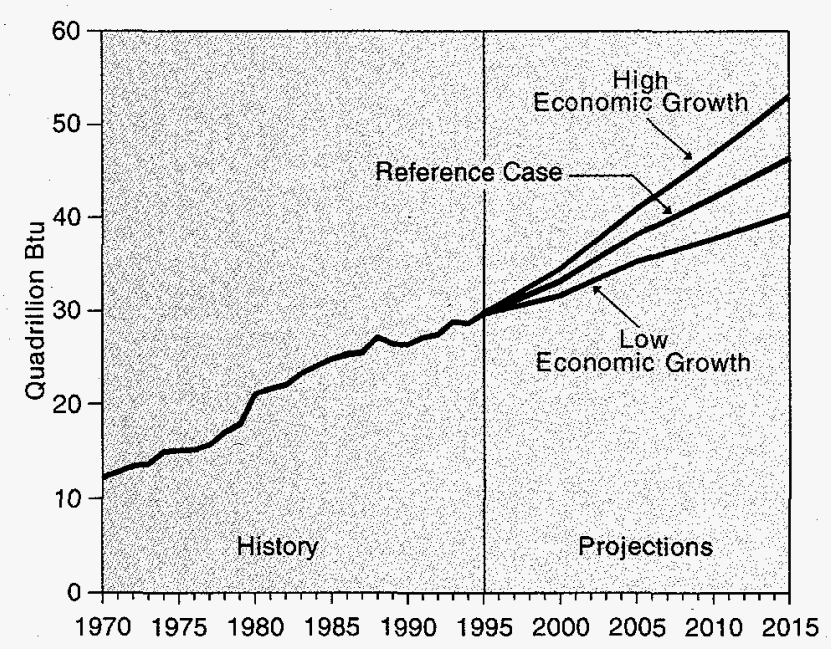

Sources: History: 1970-1979: Energy Information Administration (EIA), Office of Energy Markets and End Use, International Statistics Database. 1980-1995: ElA, International Energy Annual 1995, DOE/ EIA-0219(95) (Washington, DC, December 1996). Projections: EIA, World Energy Projection System (1997).

Table 22. Installed Wind Capacity in Selected Countries, 1994 and 1995 (Megawatts)

\begin{tabular}{|c|c|c|c|}
\hline Country & 1994 & 1995 & Percent Growth, 1994-1995 \\
\hline United States & 1,785 & 1,828 & 2.4 \\
\hline$\ldots \ldots \ldots \ldots \ldots \ldots \ldots$ & 643 & 1,136 & 76.7 \\
\hline Denmark & 540 & 614 & 13.7 \\
\hline India $\ldots .$. & 182 & 565 & 210.0 \\
\hline Netherlands & 153 & 259 & 69.0 \\
\hline United Kingdom & 147 & 193 & 31.0 \\
\hline Spain ........ & 72 & 145 & 100.0 \\
\hline$\ldots \ldots \ldots \ldots \ldots \ldots$ & 30 & 36 & 20.0 \\
\hline
\end{tabular}

Sources: United States: Energy Information Administration, Annual Energy Outlook 1997, DOE/ElA-0383(97) (Washington, DC, December 1996), Table A17. Other Countries: American Wind Energy Association, A Status Report of International Wind Projects (Washington, DC, March 1996). 


\section{Regional Activity}

\section{North America}

The three countries of North America consumed about 10.5 quadrillion Btu of renewable energy in 1995, more than 60 percent of all renewable energy consumed in the industrialized countries. Demand for renewables is expected to grow to about 16 quadrillion Btu in 2015 in this region (Figure 57).

\section{Figure 57. World Consumption of Hydroelectricity and Other Renewables by Region, 1995, 2005, and 2015}

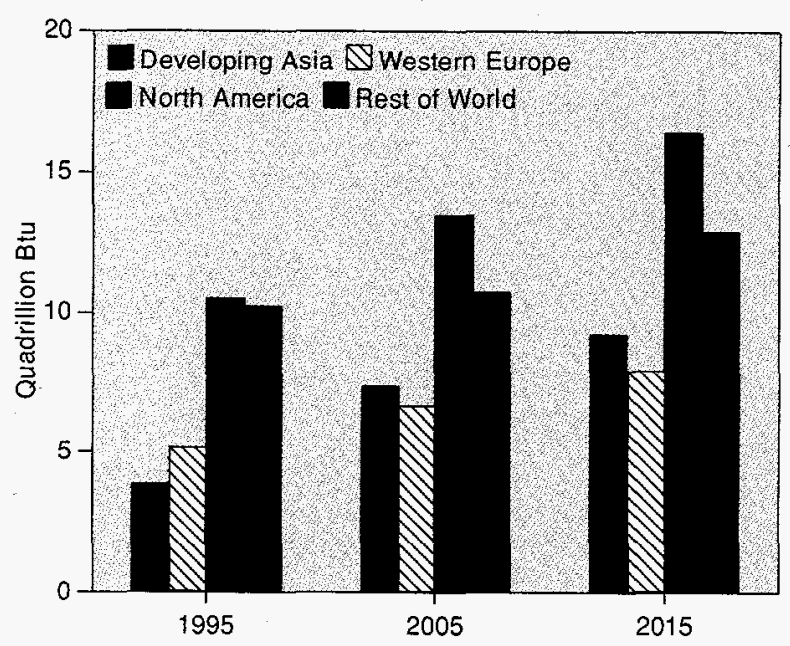

Sources: 1995: Energy Information Administration (EIA), International Energy Annual 1995, DOE/EIA-0219(95) (Washington, DC, December 1996). Projections: EIA, World Energy Projection System (1997).

In the United States, biomass (wood, grasses, and residues) is expected to lead the growth in electricity generation from renewables, which increases from under 47 billion kilowatthours in 1995 to almost 76 billion kilowatthours in 2015 [1, p. 54]; however, most of that amount (70 percent in 2015) is from cogeneration in the wood and paper industries. Most other renewable resources, including hydroelectricity and geothermal energy, are expected to grow more slowly. Conventional hydroelectricity should continue to contribute a substantial share of the country's electricity, but its share of total generation is expected to decrease from about 9 percent in 1995 to less than 7 percent in 2015 because of the substantial increases expected in naturalgas-fired generation in the United States [1, p. 56].

The United States currently has more installed wind capacity than any other nation worldwide. Most U.S. wind capacity is now installed in the western and southern part of the country, and there are plans to expand wind power in the northeast, as well as in
Washington, Wyoming, Iowa, and Minnesota (Figure 58). For continued growth of wind power in the United States, however, it must be cost competitive with other generating technologies. EIA's Annual Energy Outlook 1997 projects that wind capacity will grow to 5.4 gigawatts by 2015 (in the reference case), primarily in the western part of the country, where wind resources are favorable [1, p. 55].

While improvements in both cost and performance of this renewable source have occurred over the past decade, competition from fossil fuel technology, particularly natural gas combustion turbines, has dampened the effectiveness of the improvements. Low fossil fuel prices and the potentially competitive forces created by the emergence of restructured electricity markets, which are expected to favor established technologies, may adversely affect the U.S. wind market.

Hydroelectricity is and will remain the predominant form of renewable energy used in Canada. Still, there was some momentum in the development of wind energy in 1996. In October 1996, a joint venture between Japan's Nichimen Corporation, Denmark's Micon A/S, and Groupe Axor, Inc., was announced, to build the largest wind farm in Canada to date [3]. The 100-megawatt Le Nordais project will be installed in the Caspe Peninsula. In exchange for a 25 -year build-ownoperate agreement with the joint venture representatives, the provincial utility Hydro Quebec will purchase electricity from the project at an initial cost of 5 cents (Canadian) per kilowatthour. Subject to approval by Quebec's Bureau d'Audiences Publiques sur l'Environment, the wind complex should be completed by the end of 1997.

Mexico's consumption of hydroelectricity and other renewable resources more than doubles over the 20 years of the reference case forecast, growing from 0.4 quadrillion Btu to 1.0 quadrillion Btu. There are plans to add 47 megawatts of wind capacity in 1997, as well as 127 megawatts of geothermal capacity over the next several years $[4,5]$. By 2000, Mexico plans to have 960 megawatts of installed geothermal capacity, with plans to develop additional resources at Cerro Prieto and Los Azufres and new resources at La Primavera, where a potential 70 megawatts of geothermal capacity has been estimated [4]. At present, the country has 753 megawatts of installed geothermal capacity: 620 megawatts at Cerro Prieto, 98 megawatts at Los Azufres, and 35 megawatts at Los Humeros.

So far there has been little in the way of wind power development in Mexico, with only one 2-megawatt wind farm, La Venta, which has been in operation since May 1994 [2, p. 6]. The Mexican wind company, Entec 
Figure 58. Grid-Connected Wind Power Plants in the United States as of December 31, 1995

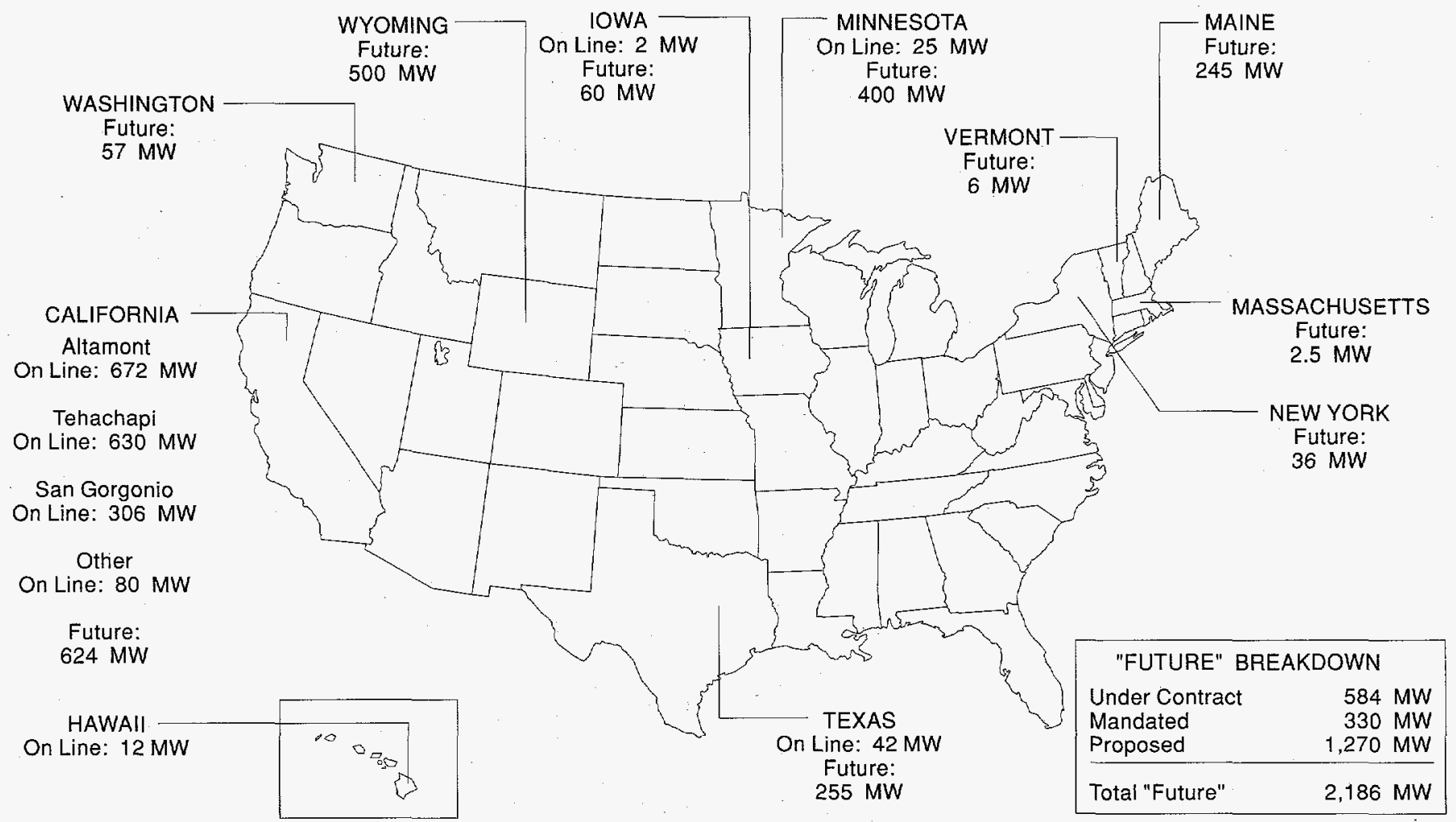

Note: The "mandated" additions noted in the future breakdown consist of wind capacity required by State legislation.

Source: International Energy Agency and National Renewable Energy Laboratory, IEA R\&D Wind Annual Report 1995 (Golden, CO, March 1996), p. 144.

SA, plans to install two wind projects in 1997, a $20-$ megawatt independent power producing facility that will sell electricity to the state utility, CFE, and a 27 megawatt wind farm planned for installation in $\mathrm{La}$ Ventosa in the southern state of Oaxaca [5]. The 20megawatt plant should be completed by mid-1997 and the 27-megawatt plant by the end of the year.

\section{Western Europe}

Consumption of hydroelectricity and other renewable resources is expected to exceed 7 quadrillion Btu in Western Europe by 2015. Most hydroelectric resources have already been exploited in the region, and alternative renewables, in particular wind turbines, account for the projected growth. The fast-paced growth of wind capacity in Germany means that in Fall 1996, 8 percent of the electricity generated in the northern state of Schleswig-Holstein was provided by wind [6]. Denmark has committed to generating 10 percent of its electricity using wind by 2005 [7, p. 31]. Further, in Energy 21, Denmark's energy strategy for the next 35 years, the country has pledged that renewable energy will account for 35 percent of the total Danish energy supply [8].
Almost 45 megawatts of wind capacity was installed in the United Kingdom in 1995, according to the British Wind Energy Association, bringing total installed wind capacity to just over 190 megawatts at the end of 1995 . Most of the projects were funded under the Government's Renewable Energy Obligations (GREOs): the Non-Fossil Fuel Obligation (NFFO) in England and Wales, the Scottish Renewables Obligation (SRO) in Scotland, and the Northern Ireland Renewables Obligation (NIRA) in Northern Ireland. By August 1996, another 9.8 megawatts of wind capacity had been installed, and 62 megawatts was planned or under construction.

The NFFO, enacted as part of the Electricity Act of 1989 , was conceived primarily as a way to subsidize the nuclear power industry after the 1989 privatization of Britain's electricity supply industry [9]. Because the country's nuclear power plants could not attract private investors, they remained government-owned and required public support to continue operating. A small portion of the NFFO tax proceeds was also used to support renewables. The tax, which was originally set at 10 percent of the price of electricity, was reduced to 3.7 percent in November 1996 when the nuclear power 
industry was privatized and is scheduled to be lowered again to 2.2 percent in April 1997. While two-thirds of the money collected through the NFFO still goes to support several older nuclear reactors that could not be privatized, the amount for renewables has grown each year since the tax began, from $£ 13$ million (British) in 1991 to $£ 96$ million in 1995.

A notable success for the NFFO was the November 1996 opening of the wind farm in Carno Wales [10]. The 33.6-megawatt plant comprises 56 wind turbines. It is the largest wind plant in Europe, providing enough electricity to supply some 25,000 Welsh homes. The GREOs are implemented through calls for renewable project proposals. Projects (which include hydroelectricity, landfill gas, and municipal and industrial waste, as well as wind power projects) accepted under the program are guaranteed premium prices for the generated electricity for up to 15 years. The UK announced plans for its fourth NFFO in November 1995, and the projects accepted under NFFO-4 are to be announced in early 1997.

Germany continues fast-paced efforts to install wind capacity. In the first 6 months of 1996 alone, more than 170 megawatts of wind capacity was installed [11, p. 3]. New additions in the past few years have made Germany's installed wind power second only to the United States. The latest addition included 325 turbines. The rate of new wind power installations in Germany is actually lower than in 1995, when 450 machines (200 megawatts of capacity) were installed during the first 6 months of the year [11, p. 4]. The lower rate may be explained by delays in obtaining permits for new installations and by uncertainty over the country's 1990 Electricity Feed Law. The law, which is intended to provide substantial incentive payments for wind-generated electricity, requires utilities to buy wind-generated electricity at 90 percent of its retail price (about 12 cents per kilowatthour in 1996) [11, p. 4; 12]. In August 1996, the German district court, Plön, filed suit at the federal constitutional court in Karlsruhe, claiming that the Electricity Feed Law was unconstitutional because it violated the "free choice of occupation" and the "principle of equality" [13].

Interest in offshore wind farms has begun to appear in Europe, as residential protests about the aesthetics of wind farms have increased. A study commissioned by the European Union has suggested that offshore wind farms in the coastal regions of Germany, Holland, and Denmark could meet all electricity demand in those countries [14]. The British company, PowerGen, announced plans to build a 37-megawatt offshore facility which, if it gains approval from the Department of Trade and Industry, could be operational by the end of
1998 [15]. The farm would be the largest offshore facility to date. The proposal is to build the farm 2 miles from the British coast on Scroby Sands, near Yarmouth, Norfolk. The facility would comprise $251.5-$ megawatt turbines attached to platforms installed in 20foot-deep water. Germany plans to install the $\$ 26.6 \mathrm{mil}-$ lion Sky 2000 wind farm in the Baltic Sea, to be located off the coast of Schleswig-Holstein [14]. It is expected to be the largest German wind farm to date, and should be completed sometime in 1997.

Other Western European countries that have not developed any renewable energy resources in the recent past are beginning to look to the potential of wind as a source of electricity. Luxembourg has begun a wind program, approving construction of a 2-megawatt wind farm at Mompach [16]; the state utility Cegedel has also announced plans to install a 500-kilowatt wind facility at Kaesfurt. Even in France - a country that relies heavily on nuclear power to supply its electricity-the state utility Electricite de France has committed to installing some 500 megawatts of wind capacity in the next decade [13].

\section{Industrialized Asia}

The extent to which available renewable resources are exploited in the industrialized countries of Asia (Australia, Japan, and New Zealand) varies substantially. In New Zealand, for instance, more than 75 percent of the country's electricity needs are met by renewable energy sources-mostly hydroelectricity and geothermal [17]. Twenty-nine of its 39 existing electric utility plants are hydroelectric. Sixty-five percent of the total installed generating capacity is hydroelectric; 3.5 percent is geothermal.

In May 1996 New Zealand's first wind farm began operating [18]. Wairarapa Electricity opened its first wind turbine generator at Haunui, southeast of Martinborough. The seven turbines at the 3.5-megawatt Haunui station are expected to generate up to 500 kilowatthours of electricity each, enough to supply 1,500 homes in Martinborough. It should supply 6 percent of Wairarapa Electricity's power needs. A second wind farm is planned for Tararua Wind Power in Aokautere. This estimated 137-turbine, $\$ 50$ million project (New Zealand dollars) could supply 30,000 domestic customers. The first stage of the project, between 60 and 70 turbines, will have installed capacity of 30 megawatts, 25 percent of the generating requirements of the CentralPower utility.

In contrast to New Zealand, Australia-with its abundant coal reserves-generates 80 percent of its electricity from coal-fired plants and only 11 percent from hydropower [17]. The remaining 9 percent comes from 
gas-fired plants. By some estimates, Australia could meet all its future electricity needs with solar energy, using less than 0.1 percent of its land area. Beginning in 1995-1996, the Australian government initiated a $\$ 4.8$ million (Australian), 4-year grant program to support development of renewable energy technology. A further $\$ 13.5$ million will be provided over 7 years to promote a Cooperative Research Center on renewable energy and related greenhouse gas reduction technologies at Australian universities. These measures are part of the

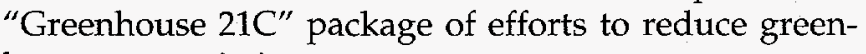
house gas emissions.

The Japanese government has a number of programsdating from the 1970s-which encourage research and development of renewable energy sources, including the Sunshine Program (and its successor the New Sunshine Program) and the Alternative Power Source Plan. There are, however, plans to limit spending on New Sunshine Program projects, and to concentrate on smaller, commercially viable projects [19, p. 269]. Projects will be given 5 years to demonstrate their potential. The Ministry of International Trade and Industry (MITI) reported that up to 40 percent of the New Sunshine Program budget had gone toward construction costs of large research projects without sufficient return. MITI has decided not to participate in the construction of major demonstration facilities, planning instead to transfer the more promising projects to the private sector. More than $\$ 463$ million has been spent by MITI for the New Sunshine Program to promote solar power, coal liquefaction, and other projects.

\section{Developing Asia}

The emerging economies of Asia provide one of the most dynamic markets for renewables worldwide. A wide range of renewables development projects are already in progress, from large-scale hydroelectric facilities, such as the Three Gorges Dam in China, to the fast-paced growth of wind power in India. Rapid economic growth has resulted in large increases in energy demand in Asia, as for example in India, where there is increasing incidence of respiratory disease, and related environmental concerns have resulted in more interest and investment in renewable resources. Consumption of hydroelectricity and other renewable resources is expected to more than double in developing Asia over the next two decades, from 4 quadrillion Btu in 1995 to 9 quadrillion Btu in 2015.

Several hydroelectric projects are currently under construction in China. The most prominent is the 18.2gigawatt, $\$ 30$ billion Three Gorges Dam project. Construction on this large-scale project began in 1994, and it is expected to be completed in 2009. The Chinese government has had problems securing financing for
Three Gorges, in large part because of international concerns about the environmental impact of the dam. The World Bank, the leading source of international financing for large-scale dams, has for some time stated that it will not support the project; and an international bond offering first scheduled for release in April 1994 was delayed because of concerns within the investment community over the financial risk associated with Three Gorges [20].

In 1996, the U.S. Export-Import Bank rejected a request by U.S. companies to provide financial backing for their participation in Three Gorges because of environmental concerns $[21$, p. 6]. As a result of the rejection, Chinese Prime Minister Li Peng stated that China would favor European companies over their U.S. counterparts "as a reward for Europe's 'more lenient' policies toward China." However, several U.S. companies have already sold equipment to the Three Gorges project even without the Bank's support-an indication of how valuable this electricity is to the Chinese [22]. Although export credit agencies in Canada, Japan, Germany, and Switzerland are still considering providing credits for Three Gorges, to date, only the Canadian export credit agency, EDC, has a government-supported financing offer to sales for the project in place [20,22].

There is potential for China to become one of the fastest growing markets for wind power over the next 10 years. Between 1995 and 1996, installed wind capacity grew to 36 megawatts, 23-percent growth. In June 1996, the U.S. Export-Import Bank authorized three tied aid direct loans to support $\$ 12.5$ million in sales of wind energy equipment and services by Zond Systems, Inc., of California [23]. The wind turbines to be sold as part of the agreement will be used in wind farms at various locations by utilities in Inner Mongolia, Liaoning Province, and Nan-Ao Island in Guandong Province.

In the western province of Xinjiang, plans have been made to expand the present 2.1-megawatt Dabancheng wind power plant outside of Urumqi to 10.7 megawatts [24]. In 1996, 34 counties in Xinjiang used some wind power, and Xinjiang's solar power generation was second only to Tibet in China, with 28 counties using solar power for lighting and telecommunications.

India is one of the largest producers of wind energy in the world today. In 1995 India had 565 megawatts of installed wind capacity, and some 1.8 gigawatts of wind capacity was in various stages of planning $[25, \mathrm{p}$. 1.6]. Seventy-seven sites have been identified as feasible for wind development, with a generating capacity of over 4 gigawatts of grid-quality power.

Although the potential for hydroelectric development is high in India, the environmental issues and high 
costs involved in developing the resource make it unlikely that substantial development will occur. It is more likely that very small (mini and micro) hydrotype plants might be commissioned. Currently, however, there are plans to complete 11.3 gigawatts of hydroelectric capacity with individual plant capacities ranging from 25 megawatts to 2,885 megawatts $[25, \mathrm{p}$. 1.21]. On January 12, 1995, the Indian government announced a liberalized tariff norm for hydroelectric projects [26]. To encourage greater participation of the private sector in hydroelectric generation, government incentives are provided for projects commissioned after January 1, 1997.

India's Ministry of Non-Conventional Energy Sources has reported healthy growth in the country's photovoltaic program. Most installations are in the form of dispersed renewable energy, such as solar-powered lanterns and street lights (Table 23). The Indian government offers several financial incentives to Indian photovoltaic producers, including exemptions from excise taxes on many photovoltaic modules; sales tax exemptions in 'most states; an allowance of 100 percent capital depreciation during the first year; and "soft loans" for manufacturing [27, p. 267]. There are plans to electrify villages that do not have access to electric grids with photovoltaics, while at the same time experimenting with grid-connected photovoltaic power plants elsewhere.

In Malaysia, Swiss-Swedish ABB Asea Brown Boveri Ltd. and Brazilian Companhia Brasileira de Projectos e Obras (CBPO) were awarded a $\$ 5.5$ billion contract to design and build the 2.4-gigawatt Bakun Hydroelectric Project located in the Borneo rain forest on the Balui river [28, pp. 6-7]. Construction is scheduled to start at the beginning of 1997, and the project should begin operating in 2002 [29]. The Malaysian government plans to use hydropower for almost 20 percent of the country's total electricity generation by 2005 [30]. As with Three Gorges Dam in China, the Bakun project has been the subject of much controversy. Several environmental groups have protested construction of the largescale hydroelectric dam, citing potential environmental damage from deforestation and population displacement. By some estimates, 9,000 people will be displaced by the dam [31].

Efforts to increase Vietnam's electricity capacity through hydroelectric power continue [32, p. 289]. Electricity of Vietnam (EVN) has begun trying to secure financing for a $\$ 441$ million, 300-megawatt hydroelectric station for the southern state of Binh Thuan. Construction of the Dai Ninh plant is expected to begin in 1998. EVN estimates that electricity generation capacity will have to double by 2000 to meet projected electricity demand requirements.

Laos considers its vast hydroelectric potential to be a major source of income and a way to ensure economic security and stability. In the 1980s, electricity exports from Laos to Thailand accounted for as much 75 percent of the country's hard currency earnings [33]. In 1993, Laos agreed to export 1.5 gigawatthours of electricity per year to Thailand by 2000 , and 3.0 gigawatthours by 2006. The government is currently discussing plans to export 2.0 gigawatthours of electricity to Vietnam. To meet the commitments, Laos has more than 20 hydroelectric projects either under construction or being studied [34].

Thailand clearly expects large increases in electricity demand over the next 20 years. The Thais have proposed to extend a transmission line across Laos into southwestern China so that electricity can be imported from the Chinese Jinghong and Mensong hydroelectric

Table 23. Photovoltaic Technology Installed in India as of July 1996

\begin{tabular}{|c|c|c|}
\hline Technology & Total Number Installed & Average Estimated System Cost \\
\hline$\ldots \ldots \ldots \ldots \ldots \ldots \ldots$ & 73,526 & $\$ 113$ \\
\hline Street Lights . . . . . . . . . . . . . . & 30,917 & $\$ 621$ \\
\hline Photovoltaic Pumps for Agriculture . & 1,318 & NA \\
\hline Village Power Plants. & 166 & $a_{\$ 11,300}$ \\
\hline
\end{tabular}

${ }^{a}$ Average cost to install 1 kilowatt. The aggregate capacity of the 166 installed plants is 909 kilowatts.

$\mathrm{NA}=$ not available.

Source: "Indian PV Program Growing; Incentives Provided But More Needed: MNES," The Solar Letter, Vol. 6, No. 16 (July 19, 1996), p. 267. 
projects, in addition to the substantial amounts of electricity they plan to purchase from Laos. Several additional dams under construction in central and southern Laos, including Nam Theun 1 and 3 and Nam Theun-Himboun, are being developed expressly for the purpose of selling electricity to the Electricity Generating Authority of Thailand.

\section{Eastern Europe and the Former Soviet Union}

The development of renewable energy sources in Eastern Europe and the former Soviet Union (EE/FSU) has been almost exclusively limited to improvements to existing hydroelectric facilities and small pilot projects for other renewables such as geothermal and wind. Because their economies remain weak, the countries in the FSU are unlikely to initiate many renewables programs over much of the forecast period. Reference case projections suggest that hydroelectricity and other renewables will grow by less than 2 percent per year over the next two decades in the region as a whole, from 3.1 to 4.1 quadrillion Btu between 1995 and 2015. The forecast is more optimistic for development in Eastern Europe, where renewables are expected to grow by 5.1 percent annually, mostly after 2005 .

Hydroelectricity represents a substantial source of electricity in only a few East European countries, such as Romania (where it accounts for 23 percent of all electricity generated) and Slovakia (13 percent) [35]. Most of the potential for hydroelectric expansion lies in Albania, Bulgaria, and Romania, as well as in the former Yugoslav republics. The hydroelectric potential for Romania, by one estimate, is 40 terawatthours per year, of which 38 percent has already been developed $[35$, p. 7.9]. However, the countries in this region have found it difficult to secure financing for hydroelectric expansion projects.

The controversy between Hungary and Slovakia over the Gabcikovo hydroelectric project should be resolved by the end of 1997, with a hearing scheduled for the International Court of Justice at The Hague in early 1997 [36]. The dispute dates from the October 1992 opening of the Gabcikovo dam. The Slovaks claim that Hungary broke the 1977 treaty to build the hydroelectric project by abandoning construction on the Hungarian portion of the dam at Nagymaros. The Hungarians claim that Slovakia was not entitled to construct the Slovak portion of the project, given its ecological ramifications. At present the eight turbines at Gabcíkovo produce 2.4 billion kilowatthours of electricity, worth about $\$ 160$ million, per year.

Similarly to Eastern Europe, hydroelectric facilities in the countries of the FSU are being repaired and upgraded in attempts to improve output from existing facilities, with very modest plans for new facilities. For example, in Uzbekistan, an agreement between the German subsidiary of Asea Brown Boveri and the Uzbek Energy and Electrification Ministry was formed to operate the Novo-Angrensk hydroelectric plant [37]. The country is also attempting to secure $\$ 112$ million from the European Bank for Reconstruction and Development for an upgrade of the 3-gigawatt Syrdarya hydroelectric facility that would improve its generating capacity by some 600 megawatts. There is one new hydroelectric plant currently under construction in Uzbekistan, the 800-megawatt Talimardzhan project.

The Malaysian company Tenega PSC Snd Bhd will build a 300-megawatt hydroelectric station at Mainak on the Charyn River and a 49.5-megawatt hydroelectric plant at Kerbulak on the Ili River in Kazakhstan [37]. Under the same contract, Tenega will install two wind generators, one near Almaty, the country's capital, and one in the Talkdykorgan region. In the Ukraine, the World Bank is providing $\$ 114$ million of the $\$ 190$ million needed to rehabilitate eight hydroelectric stations on the Dnieper River [38, p. 272].

The Ukrainian government has passed a resolution to promote development of the country's geothermal resources. Over the next decade, plans are to construct 1,500 geothermal power stations, although the government has not yet secured the financing for all of them [39, p. 26]. With an aggregate capacity of 6 gigawatts, the geothermal stations would be comparable to the Ukraine's largest nuclear power plant at Zaporzhye, which produces around 30 percent of the country's electricity. As of 1996, there were nine geothermal stations operating in Crimea. There are plans to build a 5-megawatt, \$2 million geothermal station there, the costs of which could be recovered within 4 to 6 years.

The development of alternative energy sources such as wind is fairly difficult in the countries of the FSU, not the least because of their weak economies. The prospects for wind development in Russia are potentially strong, however, particularly in northern and far southern areas that are not well electrified [40, p. 4]. Wind systems are particularly attractive in the far northern reaches of Russia because of the high expense and low reliability of fossil fuel alternatives. Diesel and gasoline systems are expensive to maintain when fuels must often be flown into the areas by helicopter or delivered over frozen river beds in the winter months.

The U.S. Agency for International Development (AID) has awarded a $\$ 1.78$ million contract to the U.S. company, Bergey Windpower, for installation of 40 wind turbines and associated equipment in northeastern Russia under the Commodity Import Program 
[40, p. 3]. Phase I of the Russian Northern Rural Electrification Program (NREP) will involve installing small wind energy systems (with capacities ranging from 1.5 to 10 kilowatts) to replace existing diesel and gasoline electric generating equipment, and to install wind turbines to equip weather stations, lighthouses, and settlements in the remote territories of Murmansk and Arkhangelsk. There are about 25 turbines-specially equipped for the harsh conditions of north Russiacurrently operating in Kamchatka Peninsula, Sakhalin Island, and Kurile Islands. Phase II of NREP will attempt to combine AID funding with multilateral assistance in an effort to expand the program to 29 additional regions in Russia, although the program will not necessarily be limited to renewable energy technologies.

\section{Middle East}

There is very little in the way of installed hydroelectric or other renewable capacity in the Middle East. Iran and Syria consume the bulk of the hydroelectricity in the region, 88 percent of the total for 1995. While there is currently little in the way of development of renewables, a joint Israeli-Jordanian 100-megawatt wind farm has been planned for the Wadi Arava region near the Red Sea [41]. The farm would be made up of about 250 wind turbines with a productive capacity of about 200 gigawatthours. Some of the wind turbines would be used to power water desalinization. Funding is currently being sought from both governments, as well as the World Bank.

\section{Central and South America}

Hydroelectric dams remain the dominant source of electricity generation in Central and South America. In 1995 , more than 80 percent of the region's net electricity consumption was attributed to hydropower. More than half of that was consumed by Brazil, 245 billion kilowatthours of the regional total of 467 billion kilowatthours [42, pp. 14, 88].

In Argentina, there are plans to add several small- to medium-scale hydroelectric projects, ranging from 40 to 850 megawatts of capacity [43, p. 35]. The largest project under construction is the 2.7-gigawatt Yacyretá, a joint venture between Argentina and Paraguay, which first began partial operation in September 1994, after 20 years of construction. Yacyretá is projected to be fully operational in 1998, with the potential to deliver 19 terawatthours of electricity. Much of the electricity from Yacyretá will be exported to Brazil. Other major hydroelectric projects are planned for the Alto Uruguay and Parana rivers. They are expected to become operational sometime after 2010.
Brazil and Paraguay own the region's largest operating hydroelectric plant, the 12.6-gigawatt Itaipú project [43, p. 56]. Most of the hydroelectric resources in Brazil that are near to industrial centers have already been developed, making it increasingly prohibitive in terms of costs to install new hydropower that is located far from potential consumers.

There are plans to develop some of the 13-gigawatt generating capacity of the Guri and Macagua hydroelectric plants in Venezuela for export to Brazil [44]. The state-owned utilities Electrificación de Caroni (EDELCA) in Venezuela and Electrobrás in Brazil have entered talks to explore options for exploiting the capacity. EDELCA has proposed laying a $\$ 450$ million, 990-mile transmission line across the border to the Brazilian regions of Boa Vista and Manaus.

Venezuela has extensive plans to develop its hydroelectric potential on the Caroni River [45]. At present, 12.9 megawatts of hydroelectric capacity has been developed on the Lower Caroni River, and EDELCA plans to expand capacity on this part of the river by 4.3 gigawatts before 2010 (Figure 59). The 2.5-gigawatt Managua II Dam should become operational within the next year, and construction on the 2.2-gigawatt Caruachi project has already begun. There are similar plans to expand hydroelectric capacity on the upper Caroni River by 8.5 gigawatts, but projects on that portion of the river are considered to be in the prefeasibility phase.

The Chilean electric utility, Empresa Nacional de Electricidad SA (Endesa), has completed work on the 225-megawatt Pangue hydroelectric dam, the first phase Figure 59. Hydroelectric Capacity on the Lower
Caroni River, Venezuela, 1990-2010

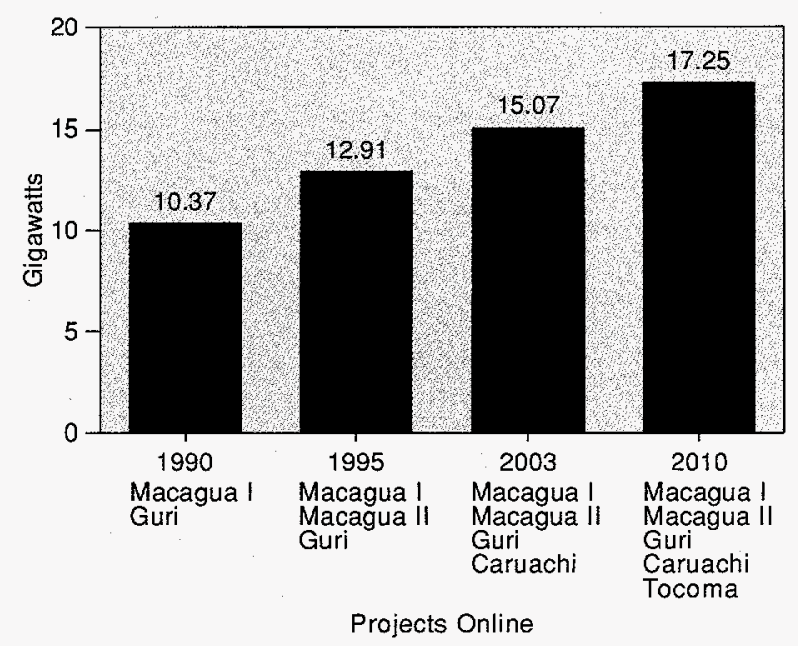

Source: Web site of the Corporacion Venezolana de Guayana. 
of its hydroelectric project on the BioBio River [46]. The project cost $\$ 450$ million to construct. The second dam in the project, the 570-megawatt Ralco, is expected to be completed within the next year.

\section{References}

1. Energy Information Administration, Annual Energy Outlook 1997, DOE/EIA-0383(97) (Washington, DC, December 1996).

2. American Wind Energy Association, A Status Report of International Wind Projects (Washington, DC, March 18, 1996).

3. P. Thisdale, "Nichimen, Micon, Group Axor, 3C Link To Build 100-MWe Windfarm," The Solar Letter, Vol, 6, No. 24 (November 8, 1996), p. 400.

4. International Geothermal Association, IGA Interactive Map Project: Mexico, "Welcome to Our Page with Data for Mexico," web site (June 8, 1996).

5. "Entec Plans Two Wind Power Plants in Southern Mexico," Wind Energy Weekly, Vol. 15, No. 711 (August 26, 1996), p. 4.

6. C. Flavin, "Vital Sign: Windpower: Small, But Growing Fast," World Watch (September/October 1996), pp. 35-37.

7. National Renewable Energy Laboratory, IEA Wind Energy Annual Report 1995 (Golden, CO, March 1996).

8. U.S. Department of Energy, "Denmark Updates Its 1990 Energy Strategy" Unclassified Department of Energy Routine (May 1996).

9. British Wind Energy Association, "The Government's Policy for Renewables," BWEA Factsheet No. 6, web site www.bwea.com (not dated).

10. "Europe's Largest Wind Plant Begins Operation," Wind Energy Weekly, Vol. 15, No. 721 (November 4, 1996).

11. "Germany Installs 170 MW of Wind in First Half of Year," Wind Energy Weekly, Vol. 15, No. 711 (August 26, 1996), pp. 3-4.

12. Paul Gipe \& Associates, 1996 Overview of Wind Generation Worldwide (Tehachapi, CA, March 28, 1996).

13. Wind Energy Research Group, Münster University, “3. Quarter News" (October 1996).

14. L. Gross, "Elsewhere in the News," The Solar Letter, Vol. 6, No. 23 (October 25, 1996), p. 390.
15. "PowerGen Plans 37.5-MW Wind Plant Off Shore of Britain," Wind Energy Weekly, Vol. 15, No. 710 (August 19, 1996), p. 5.

16. "Luxembourg Okays Its First Wind Facility," Wind Energy Weekly, Vol. 15, No. 711 (August 26, 1996), p. 4.

17. U.S. Export Council for Renewable Energy for the Technology Cooperation Expert Group of the APEC \#95-RE-01.3, Compendium of Renewable Energy Programs and Projects in Asia Pacific Economic Cooperation (APEC) Economies, Global Energy Marketplace web site - solstice.crest.org/sustainable/gem/gemdocs/ ecre/asia-pac (November 1995).

18. Energy Efficiency and Conservation Authority of New Zealand, "New Zealand's First Wind Farm Spins into Action," Energy-Wise News (June 1996).

19. D. Lowry, "MITI To Stress Small 'Sunshine' Projects After Determining Big Projects Too Costly," The Solar Letter, Vol. 6, No. 16 (July 19, 1996), p. 269.

20. International Rivers Network, "US Export-Import Bank Says No to World's Most Destructive Dam: Other Export Credit Agencies Urged To Do Same" (press release, May 30, 1996).

21. "China Invites Tenders for Three Gorges Generators," HYDRO.WIRE, Vol. 17, No. 12 (June 17, 1996), p. 6.

22. Export-Import Bank of the United States, "Frequently Asked Questions About the Three Gorges Dam Project" (June 5, 1996).

23. Export-Import Bank of the United States, "Ex-Im Bank Helps California Small Business To Export Wind Energy Technology to China" (press release, June 20, 1996).

24. P.S. Triolo and C. Hegadorn, "China's Wild West," The China Business Review (March/April 1996).

25. WEFA Group, World Power Service: Indian Subcontinent Power Service 1996 (London, UK, June 1996) (advance copy).

26. Ministry of External Affairs, Government of India, web site www.meadev.gov.in (July 10, 1996).

27. "Indian PV Program Growing; Incentives Provided But More Needed: MNES," The Solar Letter, Vol. 6, No. 16 (July 19, 1996), p. 267.

28. "Malaysia Awards Dam Contract to ABB-Brazilian Group," HYDRO.WIRE, Vol. 17, No. 12 (June 17, 1996), pp. 6-7. 
29. J. Kynge, "Malaysia Confident over Borneo Dam," Financial Times (July 4, 1996).

30. Economic Planning Unit, Prime Minister's Department, Malaysia, "Bakun Hydroelectric Project: An Overview," web site maintained by the Malaysian Timber Council (updated May 30, 1996).

31. International River Network, "NGOs Urge ABB To Quit Malaysia Dam: Swedish-Swiss Firm Should Withdraw from Bakun Contract" (press release, July $5,1996)$.

32. R. Bromby, "Elsewhere in the News: Vietnam," The Solar Letter, Vol. 6, No. 17 (August 2, 1996), p. 289.

33. "Laos: One Dam Thing After Another," The Economist, Vol. 338, No. 7959 (March 30, 1996), pp. 39-40.

34. T. Bardacke, "Thais To Buy More Laos Power," World Trade News Digest: Financial Times (June 21, 1996).

35. WEFA Group, World Power Service: Eastern European Report (London, UK, December 1995).

36. H. Wolfson, "The Hague To Rule on Gabcíkovo," The Slovak Spectator, Home Page web site (August 21, 1996).

37. R. Bromby, "Elsewhere in the News," The Solar Letter, Vol. 6, No. 19 (August 30, 1996), p. 325.
38. R. Bromby, "Elsewhere in the News," The Solar Letter, Vol. 6, No. 16 (July 19, 1996), p. 272.

39. "Ukraine Looks to Geothermal," East European Energy Report, Vol. 57 (June 1996), p. 26.

40. "Bergey Wins US-AID Grant: 40 Turbines to North Russia," Wind Energy Weekly, Vol. 15, No. 717 (October 7, 1996), pp. 3-4.

41. J. Bainerman, "Middle East Peace Process Prompts Israeli Offer for Binational Joint Projects," The Solar Letter, Vol. 6, No. 17 (August 2, 1996), p. 286.

42. Energy Information Administration, International Energy Annual 1995, DOE/EIA-0219(95) (Washington, DC, December 1996).

43. DRI/McGraw-Hill, World Energy Service: Latin American Outlook 1996 (Lexington, MA, 1996).

44. R. Colitt, "Brazil and Venezuela Find Togetherness: Long Lost Neighbours Are Developing Strong Links in Trade and Energy," Financial Times (July 17, 1996).

45. "Corporacion Venezolana de Guayana: Energy Sector," web site www.cvg.com.

46. M. Orgill, "Endesa Brings Pangue Dam into Operation," Reuters Business Alert (November 5, 1996). 



\title{
Electricity
}

\author{
From 1995 to 2015, a near doubling of the world's total annual electricity \\ use is expected, with about half the increase coming from the developing world. \\ Dramatic structural changes are occurring in electric power industries around the world.
}

\section{Introduction}

As the world moves into the next century, demand for electricity is expected to increase more rapidly than demand for other forms of energy. Consumption of electricity worldwide is projected to approach 20 trillion kilowatthours in 2015 from a 1995 level of 11.4 trillion kilowatthours.

In the industrialized world, where electrification has been fully achieved throughout all economic sectors (with the exception of remote residential locations), increased demand is fueled by economic growth and growing electrical applications for computers, communications, and other electronics for home and business uses. This demand growth is tempered by increases in energy efficiency brought on by regulation and technological innovation. Nonetheless, the industrialized world is expected to contribute about 3.7 trillion kilowatthours to the total increase of 8.6 trillion by 2015 (Figure 60). Another 0.5 trillion kilowatthours is expected to be added by Eastern Europe and the former Soviet Union (EE/FSU).

Figure 60. World Net Electricity Consumption, 1990-2015

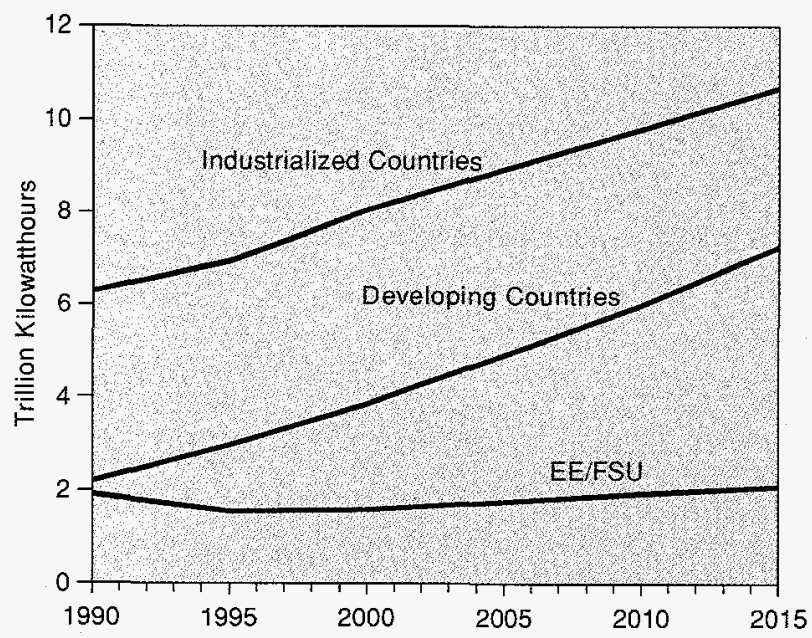

Sources: History: 1970-1979: Energy Information Administration (EIA), Office of Energy Markets and End Use, International Statistics Database. 1980-1995: ElA, International Energy Annual 1995, DOE/ EIA-0219(95) (Washington, DC, December 1996). Projections: EIA, World Energy Projection System (1997).
In the developing world, there are many opportunities for the expansion of electrical applications. The marginal benefit of introducing electricity into a rural village is considerable. High value-added applications such as refrigeration and communication are the reasons that providing electricity to the larger population is high on the priority lists of most of the leaders of the developing world. As countries such as China seek to electrify their rural communities, the demand for new capacity is projected to be large. About 4.3 trillion kilowatthours of the projected total increase of 8.6 trillion kilowatthours in world electricity generation is expected to come from the developing world-where 1995 levels were about 3 trillion kilowatthours.

In many parts of the world, financial capital may be a greater "resource" constraint than primary energy supplies. It has been estimated that over the period 1993 to 2010 investment to sustain the power generation infrastructure will require from 0.1 to 0.2 percent of gross domestic product (GDP) in the industrialized countries, 0.6 to 1.1 percent of GDP in China, and as much as 1.0 to 1.6 percent of GDP in the countries of South Asia [1].

\section{Restructured Markets and Privatized Power Generation}

The market trends described above are developing in the midst of dramatic structural changes in the electric power industry, which have implications for every region of the world. In the industrialized world, restructuring of electricity markets is seen as a way to enhance competition, bringing market forces to bear for the benefit of consumers. In the developing world, privatization is seen as a way to attract foreign capital for investment in the energy infrastructure while preserving public capital for other important projects.

Many changes in the power business worldwide are in the early phases, accompanied by the inevitable trials and tribulations associated with any new regulatory regime or market structure. There appear to be several simultaneous occurrences that have led to the farreaching changes in world markets for electricity:

- The emergence of natural gas as a fuel for electricity generation. Worldwide, natural gas is expected to grow from 16 percent of fuel consumed 
for electricity generation in 1995 to 23 percent in 2015. Although coal is projected to remain the dominant fuel, projections of ample natural gas supplies and relatively low prices have made it the preferred fuel for many independent power producers around the world. The relative modularity of gas turbines as compared with coal plants, in combination with their low initial capital outlay, gives them advantages in a marketplace driven by competition rather than "cost of service" regulation, as competitive markets tend to favor lower risk, less capitalintensive investments.

- Lower transaction costs associated with power trades. As a result of the "information revolution," it is now possible for many power market participants around the world to access information on power prices in their own and other regions. While there is little likelihood of a worldwide grid system, there are ample opportunities for regional electricity trades. Canada, the United States, and Mexico as well as the countries of Europe have been engaged in active electricity markets that offer increased opportunities for electricity trade. Also, the possibility of time-of-use electricity pricing at even the residential retail level exists today as never before. Within countries, wheeling (the transmission of power across common power lines from one independent entity to another) is on the rise. Consequently, electricity prices are likely to become more homogeneous from one adjacent region to the next as consumers seek out least-cost sources of power.

- Rethinking of large-scale projects such as nuclear power in electricity generation markets. Not so many years ago, large-scale nuclear power plants promised electricity that would be "too cheap to meter." When public opinion, regulatory pressures; higher construction costs, and waste storage problems changed the nuclear power scenario, many new opportunities for smaller scale technologies, such as natural gas, arose. Environmental concerns, especially those related to carbon stabilization, could hurt the economic attractiveness of other nonrenewable, large-scale generation technologiesparticularly, coal. Less centralized power technologies, such as natural gas and small-scale renewables, could benefit from tighter environmental controls, especially if new large-scale hydropower projects are found to have undesirable environmental impacts. These developments could be of particular significance in the developing world, where small-scale renewable generation may be the most cost-effective way to bring electricity to remote villages that are not near transmission lines.

\section{Primary Fuel Use}

The structure of primary fuel use for electricity generation differs considerably among the various regions and countries of the world (Table 24). In the industrialized countries, with the notable exceptions of Japan and France, the projected trend is away from nuclear power and toward natural gas. Between 1995 and 2015, oil consumption for electricity generation is projected to remain almost flat in absolute terms, and to drop slightly in relative terms. Coal-powered generation is projected to decrease in fuel share percentage while increasing in absolute terms by almost 6 quadrillion Btu. Renewable power generation, principally in the form of hydropower, is projected to increase in industrialized countries (such as Canada and Japan) that still have unexploited resources.

In other parts of the industrialized world, including the United States, renewable generation is expected to remain flat, with increases in the use of nonhydroelectric renewables offset by decreases in hydropower generation as the result of new environmental priorities [2]. Germany and several other European countries have active programs to promote renewable energy [3]. The net result is that renewables are projected to increase from about 22 percent of the electricity generation market in 1995 to 25 percent in 2015 for the industrialized countries taken as a whole.

In the developing world, with its great demand for new generation capacity, the fuel picture looks quite different. Consumption increases are projected for all the fossil fuels: the use of oil for electricity generation grows from 4.9 quadrillion Btu in 1995 to 9.4 quadrillion Btu in 2015; gas use rises from 4.7 to 12.2 quadrillion Btu; and coal shows the greatest increase, 16.7 to 38.0 quadrillion Btu, with large gains in China and India. Renewable generation is also projected to grow substantially, from 9.6 quadrillion Btu in 1995 to 15.8 quadrillion Btu in 2015.

The increase in coal-fired generation in the developing world is offset to some extent by a decrease in the EE/FSU region, from 6.6 quadrillion Btu in 1995 to 5.4 quadrillion Btu in 2015. The other fossil fuels are projected to rise in share worldwide, and nuclear generation is projected to drop slightly, as less capitalintensive generation (i.e., natural gas) is substituted for nuclear as well as coal. Renewable generation is projected to rise by about 33 percent, from 3.1 to 4.1 quadrillion Btu.

\section{Environmental Implications of Trends in Fuel Shares}

Between 1970 and 1992 world GDP grew by more (85 percent) than world energy consumption (66 percent), 
Table 24. World Energy Consumption for Electricity Generation by Region and Fuel, 1993-2015 (Quadrillion Btu)

\begin{tabular}{|c|c|c|c|c|c|c|c|}
\hline \multirow[b]{2}{*}{ Region/Fuel } & \multicolumn{3}{|c|}{ History } & \multicolumn{4}{|c|}{ Projections } \\
\hline & 1993 & 1994 & 1995 & 2000 & 2005 & 2010 & 2015 \\
\hline Industrialized Countries $\ldots$ & 74.3 & 75.7 & 78.1 & 86.0 & 92.8 & 98.9 & 104.3 \\
\hline Oil $\ldots \ldots \ldots \ldots \ldots \ldots$ & 5.3 & 5.6 & 5.2 & 5.4 & 5.6 & 5.5 & 5.6 \\
\hline Natural Gas $\ldots \ldots \ldots \ldots$ & 6.9 & 7.5 & 8.2 & 11.5 & 14.8 & 17.5 & 21.3 \\
\hline Coal ....... & 27.5 & 27.5 & 28.3 & 29.8 & 30.9 & 32.6 & 34.1 \\
\hline Nuclear .... & 18.1 & 18.7 & 19.4 & 20.0 & 19.7 & 19.2 & 16.9 \\
\hline Renewables & 16.5 & 16.3 & 17.0 & 19.2 & 21.8 & 24.1 & 26.4 \\
\hline EE/FSU Countries $\ldots \ldots \ldots$ & 27.8 & 25.7 & 24.6 & 27.4 & 29.6 & 31.5 & 32.2 \\
\hline Oil $\ldots \ldots \ldots \ldots$ & 3.6 & 2.9 & 2.7 & 3.0 & 3.5 & 4.1 & 4.6 \\
\hline Natural Gas & 11.2 & 10.1 & 9.7 & 12.2 & 13.4 & 14.7 & 15.7 \\
\hline Coal ....... & 7.3 & 7.1 & 6.6 & 6.8 & 6.8 & 6.2 & 5.4 \\
\hline Nuclear & 2.8 & 2.4 & 2.5 & 2.8 & 2.7 & 2.9 & 2.3 \\
\hline Renewables & 3.0 & 3.1 & 3.1 & 2.7 & 3.1 & 3.6 & 4.1 \\
\hline Developing Countries ...... & 33.0 & 35.2 & 37.3 & 46.1 & 56.6 & 67.4 & 79.0 \\
\hline Oil $\ldots \ldots \ldots \ldots \ldots \ldots$ & 4.6 & 4.7 & 4.9 & 5.9 & 7.1 & 8.1 & 9.4 \\
\hline Natural Gas & 3.9 & 4.4 & 4.7 & 6.6 & 8.3 & 10.2 & 12.3 \\
\hline Coal ...... & 14.6 & 15.7 & 16.7 & 20.7 & 25.7 & 31.6 & 38.0 \\
\hline Nuclear $\ldots \ldots \ldots$ & 1.1 & 1.3 & 1.4 & 1.6 & 2.3 & 3.0 & 3.6 \\
\hline Renewables & 8.8 & 9.1 & 9.6 & 11.3 & 13.2 & 14.5 & 15.8 \\
\hline Total World . . . . . . . . & 135.2 & 136.6 & 140.1 & 159.5 & 179.0 & 197.7 & 215.4 \\
\hline Oil $\ldots \ldots \ldots \ldots \ldots \ldots$ & 13.5 & 13.3 & 12.9 & 14.3 & 16.3 & 17.8 & 19.7 \\
\hline Natural Gas $\ldots \ldots \ldots \ldots$ & 22.0 & 22.1 & 22.6 & 30.3 & 36.5 & 42.5 & 49.3 \\
\hline Coal ...... & 49.4 & 50.3 & 51.6 & 57.3 & 63.4 & 70.4 & 77.4 \\
\hline Nuclear & 22.0 & 22.4 & 23.3 & 24.4 & 24.8 & 25.0 & 22.8 \\
\hline Renewables & 28.3 & 28.5 & 29.7 & 33.1 & 38.1 & 42.1 & 46.3 \\
\hline
\end{tabular}

Note: $\mathrm{EE} / \mathrm{FSU}=$ Eastern Europe and the former Soviet Union.

Sources: History: Energy Information Administration (EIA), International Energy Annual 1995, DOE/EIA-0219(95) (Washington, DC, December 1996). Projections: EIA, World Energy Projection System (1997).

which in turn grew by more than carbon emissions (51 percent) [4]. The slower growth of carbon emissions has been attributed largely to the development of nuclear power for electricity generation. Carbon dioxide is a greenhouse gas that is thought to contribute to global climate change. If the projections of a worldwide move away from nuclear power generation and toward natural gas generation hold, while at the same time coal maintains the largest fuel share in a growing market, there are implications for global air pollutants, especially carbon dioxide. For while natural gas is less polluting than coal-producing about half the carbon emissions-it is more polluting than nuclear power in terms of carbon emissions. If the pattern of world fuel consumption for electricity generation changes as shown in Figure 61 for the IEO97 reference case, the result will be an increase of nearly 68 percent in carbon emitted to the atmosphere from electric power plants, or 1,108 million metric tons more than the 1995 level of 1,640 million metric tons of carbon.

\section{Regional Activity}

\section{North America}

Although the growth rate for electricity generation for the United States is a modest 1.5 percent per year, in absolute terms it dominates the region, with about a trillion kilowatthours more electricity generation projected in 2015 than in 1995 (Figure 62). Canada and Mexico combined are projected to consume a trillion kilowatthours total in 2015, and demand in the region as a whole is projected to be 5 trillion kilowatthours, or more than one-quarter of the world total. 
Figure 61. Fuels Consumed for Electricity Generation Worldwide, 1995 and 2015

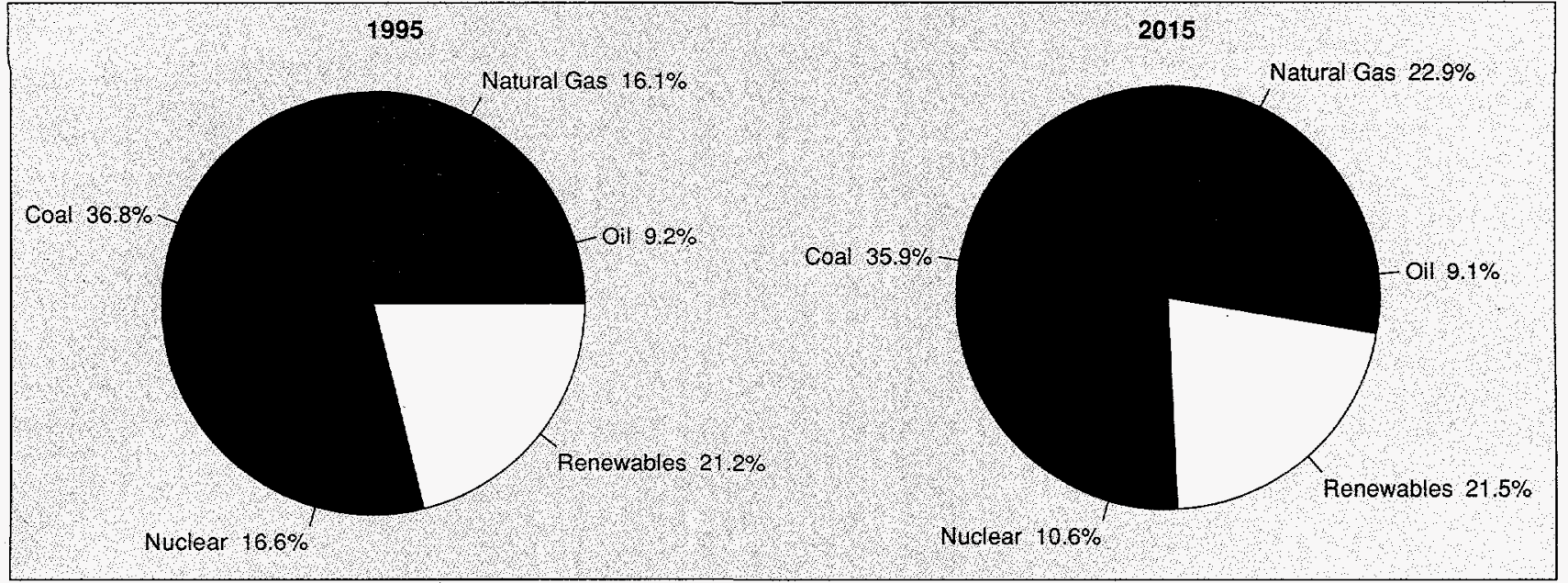

Sources: 1995: Energy Information Administration, International Energy Annual 1995, DOE/EIA-0219(95) (Washington, DC, December 1996). 2015: Energy Information Administration, World Energy Projection System (1997).

The countries of North America differ in their current and projected fuel consumption for electricity generation. Hydropower dominated Canada's generation in 1995, and it is projected to grow in both absolute size and relative importance-exceeding 70 percent of that country's generation in 2015 (Figure 63). In Mexico the dominant fuel consumed for electricity generation has been oil. While oil is still projected to be Mexico's major source of electric power in 2015, it is expected to drop in relative share from 50 percent to about 41 percent. Renewables are projected to rise in relative share (Figure 64).

\section{Figure 62. North America Net Electricity Consumption, 1990-2015}

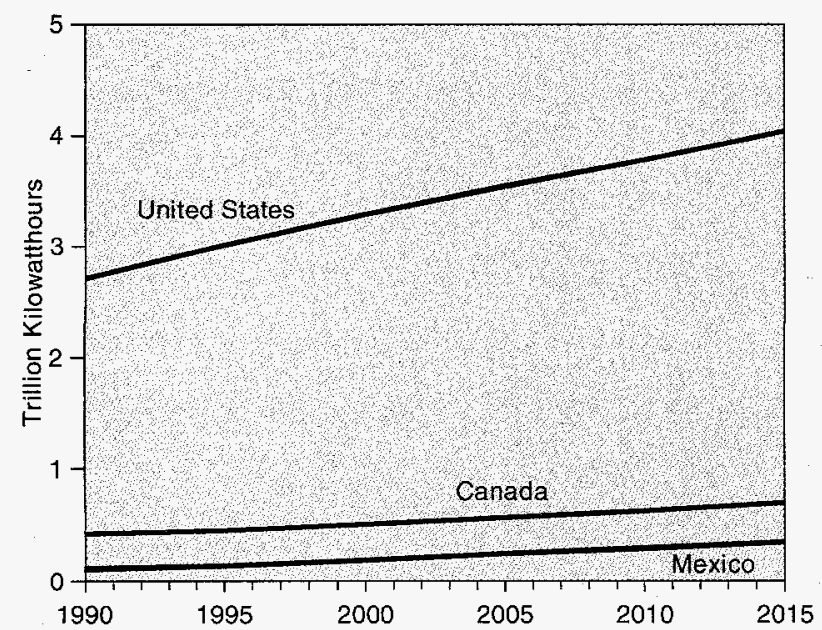

Sources: History: Energy Information Administration (E]A), International Energy Annual 1995, DOE/EIA-0219(95) (Washington, DC, December 1996). Projections: EIA, World Energy Projection System (1997).
In contrast, coal is, and is projected to remain, the dominant fuel for electricity generation in the United States, although its market share is expected to drop slightly. The major change is projected to be an almost one-forone tradeoff between nuclear and gas-fired generation-with nuclear dropping from about 20 percent of generation in 1995 to 11 percent in 2015 and gas generation rising from under 10 to over 20 percent of fuel used for generation (Figure 65). The actual amount of electricity generated from natural gas could grow faster than the rate of fuel consumption, assuming that new gas turbines will be more efficient and therefore

Figure 63. Energy Use for Electricity Generation in Canada by Fuel, 1995 and 2015

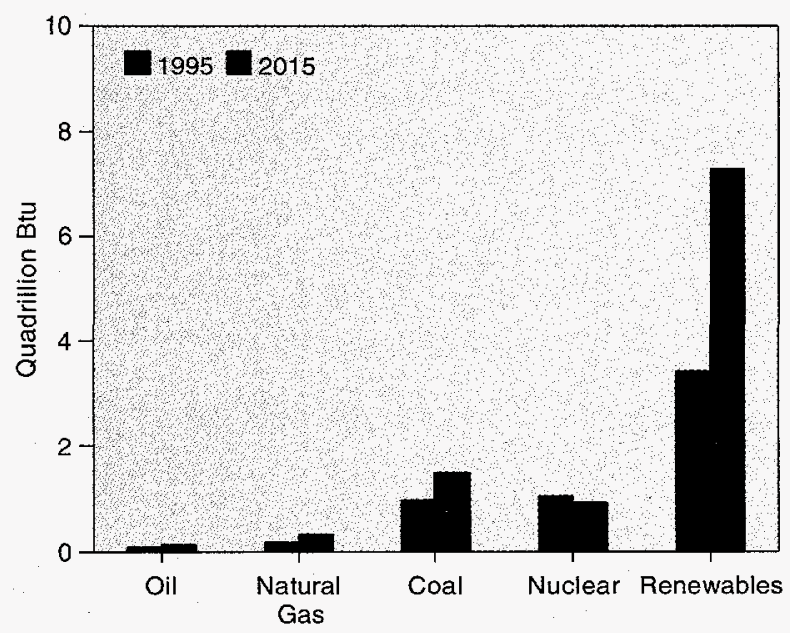

Sources: 1995: Energy Information Administration (EIA), International Energy Annual 1995, DOE/EIA-0219(95) (Washington, DC, December 1996). 2015: ElA, World Energy Projection System (1997). 
Figure 64. Energy Use for Electricity Generation in Mexico by Fuel, 1995 and 2015

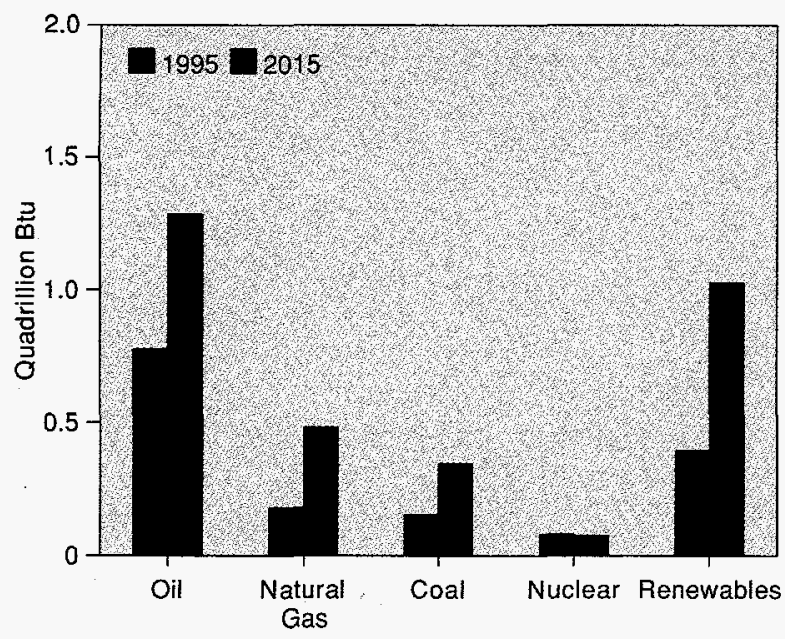

Sources: 1995: Energy Information Administration (EIA), International Energy Annual 1995, DOE/EIA-0219(95) (Washington, DC, December 1996). 2015: EIA, World Energy Projection System (1997).

require less fuel input for every kilowatthour of electricity output.

\section{United States}

In the 1960s, electricity demand in the United States far outpaced GDP growth. For the past several decades electricity growth has more or less moved in tandem with growth in GDP. The relationship of electricity growth to GDP growth is expected to decline slightly, with an annual growth rate of 1.5 percent for electricity sales between 1995 and 2015 [2, p. 108], compared with projected GDP growth of 1.9 percent per year [2, p. 121].

Increased residential electricity demand for equipment such as computers is expected to be largely offset by greater efficiencies in home appliances and heating and cooling equipment. Annual electricity growth in the commercial sector is projected to be 1.3 percent and in the industrial sector 1.5 percent. Electricity sales for transportation are projected to grow by 11.4 percent annually, but their total in 2015 is only 50 billion kilowatthours out of the projected total U.S. electricity consumption of 4 trillion kilowatthours [2, p. 108].

The legislative and regulatory landscape for electricity markets in the United States is changing almost daily. For the most part, U.S. generating capacity is now in the hands of investor-owned utilities, which have for years been operating under State and Federal regulations that provided the utilities with local monopolies in exchange for obligations to serve the public in their areas of control. However, most State governments and
Figure 65. Energy Use for Electricity Generation in the United States by Fuel, 1995 and 2015

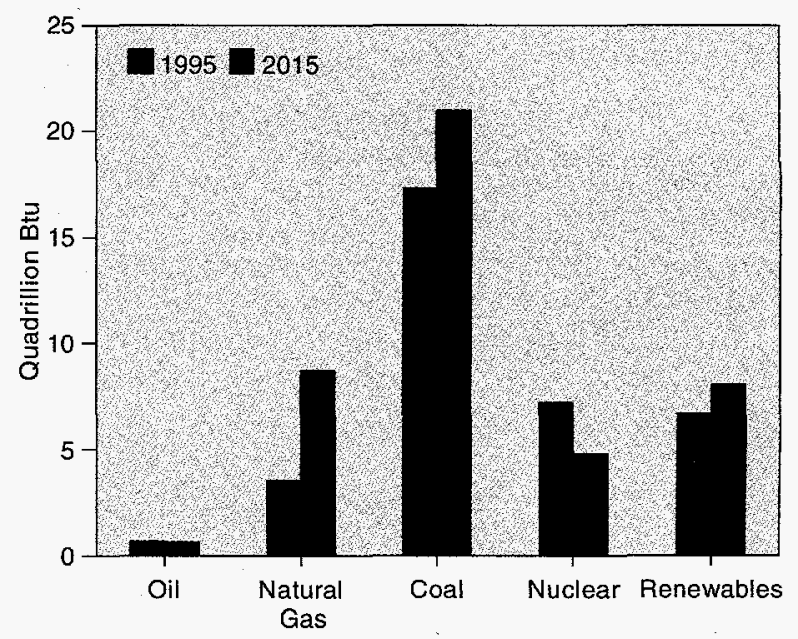

Sources: 1995: Energy Information Administration (EIA), International Energy Annual 1995, DOE/EIA-0219(95) (Washington, DC, December 1996). 2015: ElA, World Energy Projection System (1997).

their public utility commissions have under consideration proposals for restructuring that would change this relationship.

While the details of each State plan differ, there are universal issues that must be addressed. Probably the most controversial is the problem of "stranded assets" or "transition costs." Decisions made under the old "cost of service" regulatory environment may make some utility assets uneconomical in a competitive environment-for example, generation plants that were found to be "prudent" under the former regulatory regime but that operate at higher costs than can be sustained in a competitive market. Also at issues are mandatory power market contracts that utilities were compelled to sign with independent power producers for electricity purchases at "avoided costs" that are much higher than today's projected open market prices.

Another important area in the restructuring debate is transmission access. Although electricity generation offers ample opportunities for competition, transmission and distribution remain natural monopolies. Without a level playing field in the form of open access, some generators-those who control transmission and distribution-will be able to exercise substantial market control. Other issues to be addressed include the small numbers of power producers in some market areas; the treatment of ancillary services such as voltage regulation, reactive power, system integrity, spinning reserves, and maintenance of optimal reserve margins; and the treatment of environmental and other social goals. 


\section{Canada}

Canada's generating capacity will continue to be dominated by hydropower into the foreseeable future. It is assumed that no new nuclear capacity will come on line over the forecast horizon, so that its share of generation will drop. The share of gas-fired generation is projected to rise only slightly, constrained by the availability of hydropower.

Primarily in response to developments in U.S. markets, Canada's electricity producers are preparing for a more competitive environment. For example, Ontario Hydro has created a new unit-Ontario Hydro Interconnected Markets, Inc.-with the goal of expanding export opportunities in the United States, where its rates are more competitive, in order to enhance its value on the open market [5].

The government in Quebec is considering a legislative proposal that would open up Hydro Quebec's transmission grid to electricity trade from other provincial utilities and from independent power producers. Such a move would give access to electricity markets in the United States, in New York, Vermont, New Hampshire, and Maine. Enactment of the bill is projected for March 1997 [6].

Hydro Quebec has established a U.S. subsidiary, Hydro Quebec Energy Services, which is seeking application to sell electricity in the United States. In order to obtain approval from the Federal Energy Regulatory Commission, Hydro Quebec has also proposed to allow wholesale electricity transactions in Quebec by U.S. providers [7].

\section{Mexico}

Electrification of rural villages is a high priority in Mexico. The expected expansion electricity service to all Mexico's citizens, coupled with projections of strong economic growth, gives Mexico the highest projected growth rate for electricity generation in North America. Attracting foreign capital will be one of the keys to achieving that growth. Mexico plans to allow private generators to compete with the state-owned Comision Federal de Eletricidad (CFE) in order to introduce market efficiencies. The government has recently eliminated electricity price subsidies to consumers as a further move toward allowing the market to determine prices. As a result, prices have risen by 35 percent in the past 5 years. Many analysts see this trend reversing over the next 20 years, with electricity prices (relative to other goods and services) dropping in response to lower fossil fuel input costs and relatively low price increases for capital stock for new generation capacity [8, p. 113].

\section{Western Europe}

Total electricity generation in Western Europe is projected to grow from 2.3 trillion kilowatthours in 1995 to 3.8 trillion in 2015 . The relatively slow level of growth in electricity demand in the region is characteristic of developed countries in which energy intensity as a function of GDP has been declining. Most of the new capacity in Western Europe is projected to be fueled by natural gas, especially combined-cycle gas turbines [9, p. ix], and the fuel share for natural gas increases from about 10 percent in 1995 to more than 25 percent in 2015 (Figure 66). The shares for oil, coal, and nuclear drop while the share for renewables increases slightly.

Figure 66. Energy Use for Electricity Generation in Western Europe by Fuel, 1995 and 2015

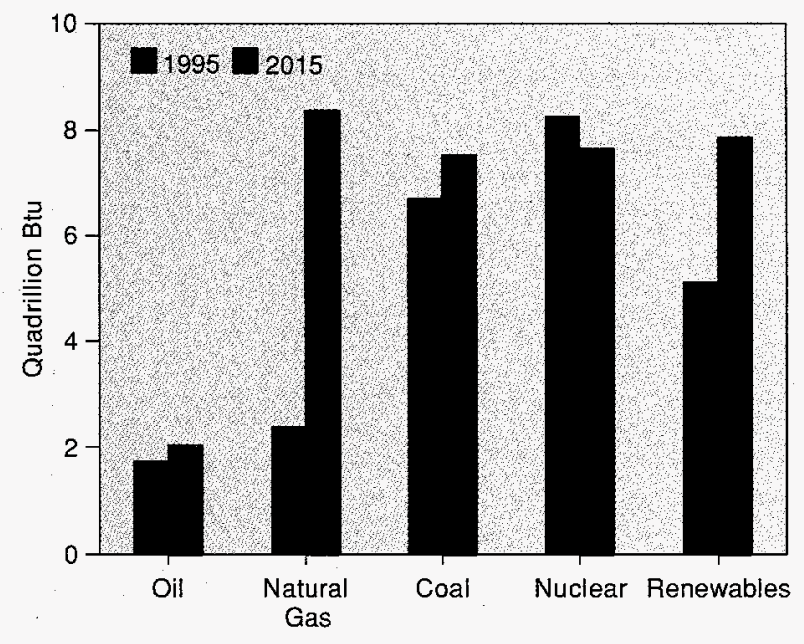

Sources: 1995: Energy Information Administration (EIA), International Energy Annual 1995, DOE/EIA-0219(95) (Washington, DC, December 1996). 2015: EIA, World Energy Projection System (1997).

The structures of electric power industries within Western Europe differ dramatically. In France, for example, the electric power industry is highly integrated both horizontally and vertically; 90 percent of generation and 95 percent of distribution are controlled by Electricite de France (EDF) [9, pp. 7.4-7.5]. In comparison, the United Kingdom and the Netherlands have less concentrated power industries and have been moving recently to even greater decentralization and deregulation.

"Liberalization" is the term used in the European Union for deregulation or restructuring. Although technically in favor of competition and lowering relatively high electricity prices, many European countries are reluctant to push for change too quickly. Some governments are unwilling to give up control over such a vital industry for a variety of reasons, such as fear of economic repercussions and large-scale worker layoffs, 
especially if their own power industries are at an economic disadvantage to those of neighboring countries. Other countries, such as Germany, are split along political lines, with large industrial energy users favoring liberalization and left-of-center political parties and environmental groups opposing it [10].

The existing structure of the electricity industry and its generation profile are important predictors of how a country will respond to liberalization. France, for example, is one of the countries with a go slow policy. In 1993, 79 percent of French electricity generation came from nuclear power plants [9, p. 7.2]. Thus, it would be very difficult both politically and practically to unbundle the French power industry [11]. Until such issues are resolved, it is likely that each country will approach restructuring differently. The countries that have moved forward most aggressively with liberalization-the Netherlands, Norway, Finland, and the United Kingdom-now enjoy lower electricity costs than others in Western Europe (Figure 67). As a result, they would have a competitive edge if international barriers to electricity trade in the region were eliminated.

\section{Industrialized Pacific}

The industrialized Pacific region (Japan, Australia, and New Zealand) is projected to experience more robust growth in electricity demand than are the other industrialized regions of the world. Economic growth is expected to be strong in most countries of the Asia Pacific region, and the industrialized countries there are also likely to benefit from strong regional growth.

\section{Figure 67. Residential Electricity Rates for European Countries as of January 1, 1995}

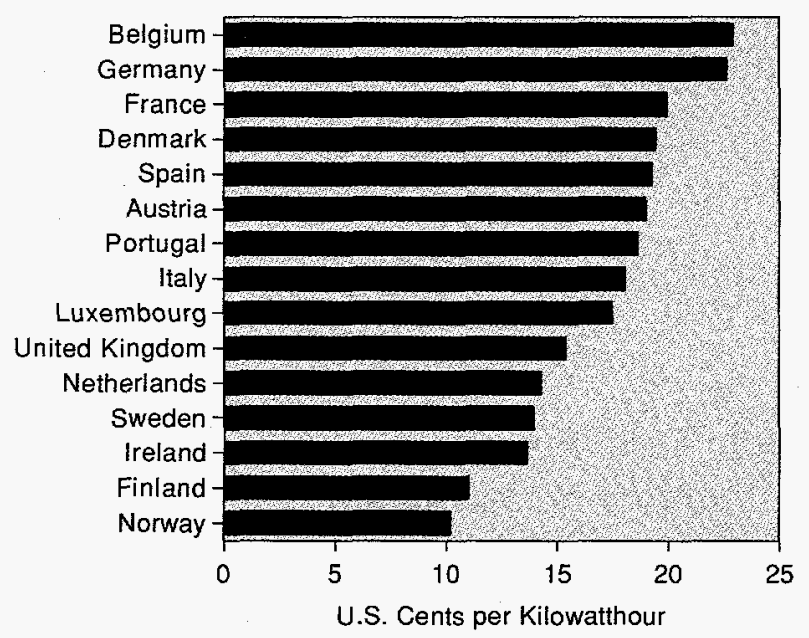

Source: Public Utilities Fortnightly (January 15, 1996), p. 54.
Electricity consumption in the region is projected to grow from 1.1 trillion kilowatthours in 1995 to 1.8 trillion in 2015, with Japan providing much of the expected growth (Figure 68).

\section{Figure 68. Industrialized Pacific Net Electricity Consumption, 1990-2015}

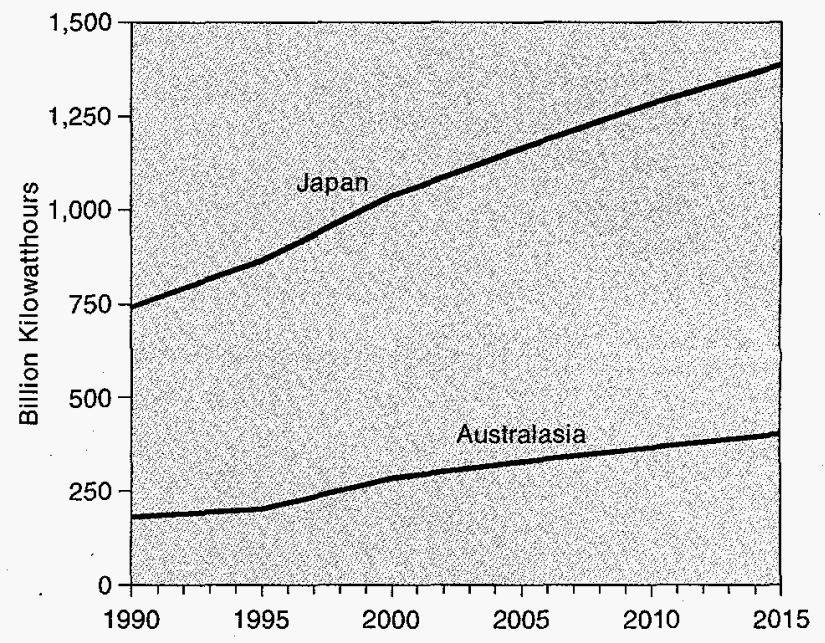

Note: Australasia is defined as Australia, New Zealand, and the U.S. Territories in the Pacific.

Sources: History: Energy Information Administration (EIA), International Energy Annual 1995, DOE/EIA-0219(95) (Washington, DC, December 1996). Projections: EIA, World Energy Projection System (1997).

\section{Japan}

Although its electric power industry is in private hands, Japan is divided into only 10 vertically integrated electricity suppliers with local monopoly power and obligations to serve the public interest. Although Japan has experienced an economic downturn in recent years, its economy is expected to rebound in the forecast period, with moderate growth between 1995 and 2015.

Population growth in Japan-unlike many countries of Asia-is expected to be low. The nation's per capita electricity consumption is projected to increase from its 1995 level of about 7 megawatthours to about 11 megawatthours in 2015 and total electricity consumption from 865 billion kilowatthours in 1995 to 1,385 billion in 2015 .

Despite the fact that natural gas supplies to Japan consist mainly of expensive LNG imports, gas is likely to experience considerable growth as a fuel for electricity generation (Figure 69). Renewables, chiefly hydropower and geothermal energy, are projected to show strong growth for electricity generation early in the forecast, and both coal and nuclear are projected to grow in 
Figure 69. Energy Use for Electricity Generation in
Japan by Fuel, 1995-2015

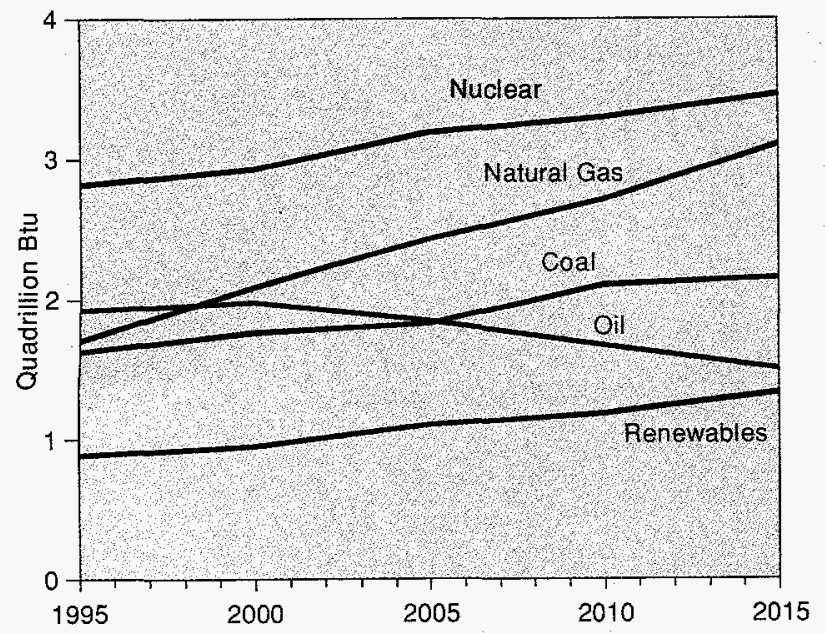

Sources: History: Energy Information Administration (EIA), International Energy Annual 1995, DOE/EIA-0219(95) (Washington, DC, December 1996). Projections: EIA, World Energy Projection System (1997). absolute terms (although the nuclear share drops slightly). An accelerating decline is projected for oil-fired generation.

\section{Australia and New Zealand}

Electricity consumption in Australia and New Zealand is projected to rise from 201 to 402 billion kilowatthours between 1995 and 2015-a somewhat higher growth rate than expected for other developed nations. Inexpensive coal makes it the preferred source for Australia's power generation requirements. New Zealand, on the other hand, depends heavily on hydropower. New Zealand also has coal resources, consisting mainly of high-quality coking coal that is exported to Japan.

\section{Eastern Europe and the Former Soviet Union}

Electricity growth in the EE/FSU region is expected generally to be slow over the 1995 to 2015 time horizon because of projected low levels of economic growth. In the IEO97 forecast, total EE/FSU electricity generation

\section{Electricity Industry Restructuring in New Zealand}

Over the past several years New Zealand has sought to restructure its electricity market, and it has served as one of the laboratories for competition from which other countries have sought examples of the benefits and pitfalls inherent in such an effort. The process began in 1987 when the Electricity Corporation of New Zealand (ECNZ) was formed. The Ministry of Energy formerly held a monopoly ingeneration and transmission, but it was felt that the national economy. had become moribund as the result of excessive reliance on the public sector. Creation of the ECNZ was seen as a step toward reinvigorating the economy.

In 1988 ECNZ's generation was deregulated, and its obligation to supply was removed. The Energy Companies Act of 1992 led to the formation of local distribution companies, all of which were incorporated. Although some remain state-owned, many have been privatized. Also, by April 1994, the nation's retail electricity markets had been deregulated under the Electricity Act of 1992, eliminating exclusive franchises, obligation to serve, and price controls:

The concept of "light-handed" regulation was codified by the Electricity Regulations of 1994 . There are three cornerstenes of "light-handed" regulation. The first is deregulation while at the same time maintaining backup regulatory authority for residential customers (maintained through March 31, 1997). The second is information disclosure, by which line charges (cost of distribution) are separated from energy costs. The third is antitrust oversight, Under the Commerce Act of 1986, the Commerce Commission can impose price controls if evidence of excessive market power is uncovered Thus, with full disclosure of the components of price to the consumer and with the threat of a return to regulation, light-handed" regulation is seen as sufficient to ensure that market players refrain from anticompetitive behavior.

Also in 1994, Trans Power was separated from EONZ. Trans Power became the owner-operator of the national transmission grid and the authority for electricity dispatch. This left ECNZ with responsibility for generation only.

The final steps were carried out in 1996. First was the breakup of ECNZ into fwo generation companies. The new company is known as Contact Energy, Ltd, and the larger company retains the name ECNZ. Both companies remain state-owned. ECNZ is restricted in its ability to add to generation or contract with generators until its share drops from the current level of about 67 percent to 45 percent or less. Finally, on October 1, 1996, an open competitive wholesale mar ket began.

While it is still too early to judge the success of the Nex Zealand market, and the small size and unique circumstances of New Zealand make it figuratively and literally an island unto itself, principles such as "ight-handed" regulation may find wider acceptance in other parts of the world [12]. 
grows from 1.5 trillion kilowatthours in 1995 to 2.1 trillion kilowatthours in 2015. As shown in Figure 70, the projected growth in generation in the FSU between 1995 and 2015 barely brings it back to 1990 levels. In Eastern Europe, where there was a smaller decline between 1990 and 1995, an increase of about 200 billion kilowatthours is projected from 1995 to 2015.

The generation mix differs significantly between the FSU and the countries of Eastern Europe. Historically, Eastern Europe has been much more dependent on coal than has the FSU, which has relied more heavily on natural gas. In both regions, however, the relative share of coal declines and the relative share of natural gas increases over the forecast period. Renewable generation (primarily hydropower) is expected to rise as a percentage of generation in Eastern Europe. Electricity's share of total energy consumption was the same for both regions in 1995 at about 8.9 percent. The share is projected to remain the same for the FSU, but in Eastern Europe it is projected to increase to more than 11 percent in 2015.

Figure 70. EE/FSU Net Electricity Consumption, 1990-2015

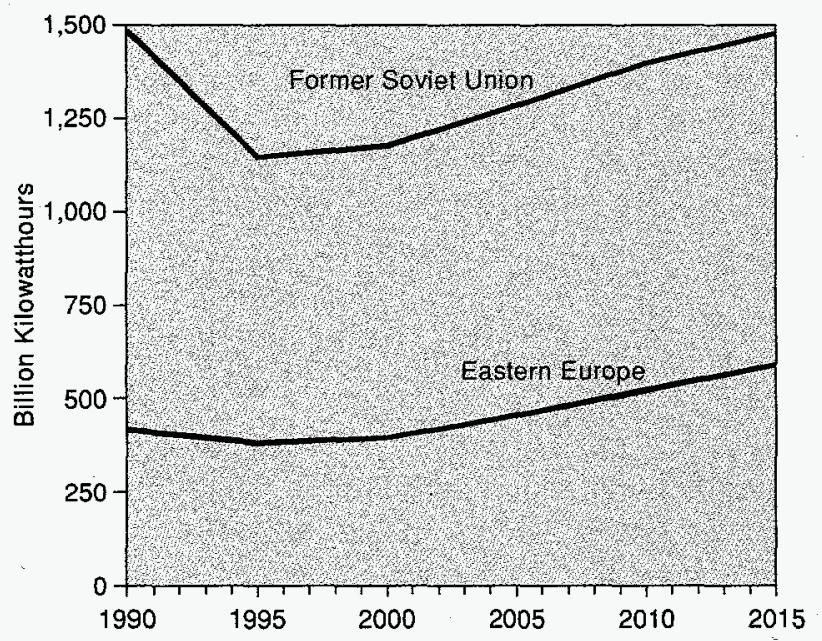

Sources: History: Energy Information Administration (EIA), International Energy Annual 1995, DOE/EIA-0219(95) (Washington, DC, December 1996). Projections: EIA, World Energy Projection System (1997).

\section{Developing Asia}

The developing Asia region, which includes China, India, and Other Asia, is projected to experience stronger growth in electricity consumption than any other region of the world. Total electricity consumption is projected to grow by more than 3 trillion kilowatthours between 1995 and 2015, a growth rate above 5 percent per year, with China alone accounting for more than half the growth (Figure 71).

\section{Figure 71. Developing Asia Net Electricity Consumption, 1990-2015}

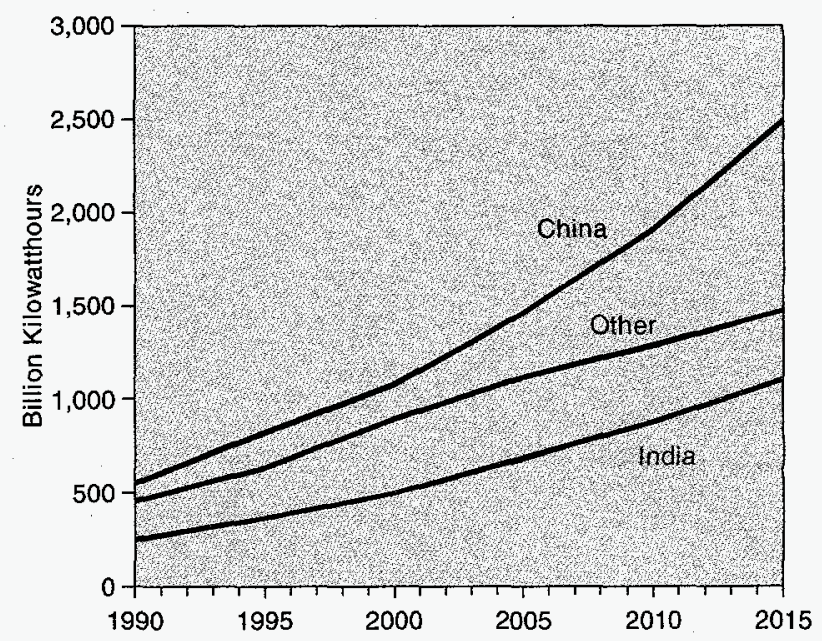

Sources: History: Energy Information Administration (EIA), International Energy Annual 1995, DOE/EIA-0219(95) (Washington, DC, December 1996). Projections: EIA, World Energy Projection System (1997).

The projection of electricity demand growth is driven largely by economic expansion in the region, where GDP is expected to increase by 6 percent annually. Again, China is the leading source of the growth, with an expected annual GDP growth rate of about 7.3 percent. Coal remains the dominant fuel for the region's electricity generation (Figure 72). The relative shares for oil and nuclear power are expected to decline, while natural gas and renewables (principally hydropower) are projected to increase in importance. Both China and India are more heavily dependent on coal for electricity generation than are the other developing Asian nations.

\section{China}

Growth in electricity consumption is projected to outstrip the growth in China's total energy consumption between 1995 and 2015. Expectations of robust electricity demand are driven by rural electrification and projections of high economic growth. Electricity generation in China remains dominated by coal. Natural gas and oil combined provide only 5 percent of generation. Potential hydropower resources in China are large, estimated at 370 gigawatts of generating capacity. Three Gorges Dam, the largest hydroelectric project in history (18.2 gigawatts) is scheduled to be completed around 2010 [13, p. 76]. The Chinese nuclear industry, although projected to grow, will remain a small percentage of total generation capacity. 
Figure 72. Energy Use for Electricity Generation in Developing Asia by Fuel, 1995 and 2015

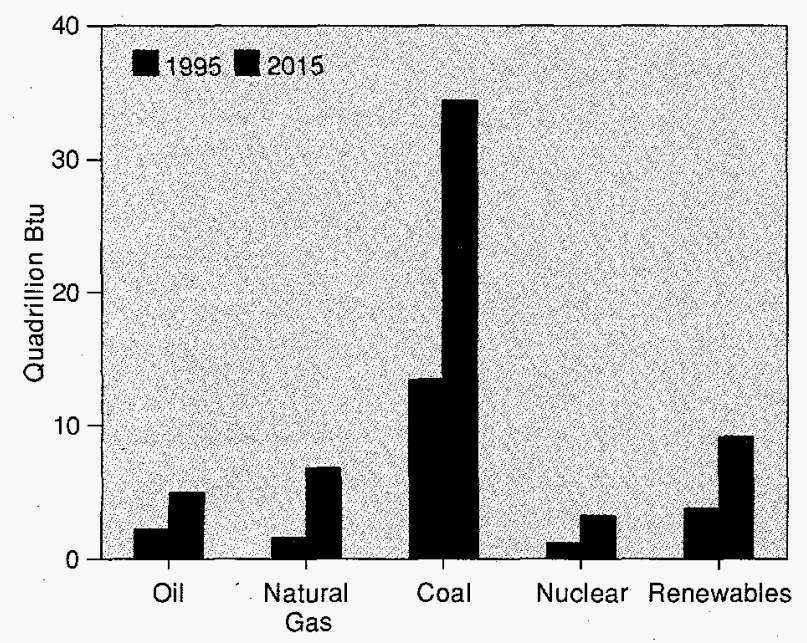

Sources: 1995: Energy Information Administration (EIA), International Energy Annual 1995, DOE/EIA-0219(95) (Washington, DC, December 1996). 2015: EIA, World Energy Projection System (1997).

Historically, China has had difficulty meeting the growing demand for electricity. Continued difficulty could become a hindrance to further strong economic growth. It has been estimated that more than a trillion dollars in capital investment will be required for China's electricity sector to keep up with demand growth between 1995 and 2020 [13, p. 78].

\section{India}

As in China, electricity demand in India is projected to grow dramatically over the next 20 years. Growth in generating capacity over the past 35 years has been substantial, from under 6 gigawatts of capacity in 1960 to almost 83 gigawatts in 1994 [14]. From 1995 to 2000, a capacity expansion rate of over 7 percent a year is projected for India, and a somewhat slower rate of 5 percent a year is projected from 2000 to 2015.

With about 6 percent of total world coal reserves [15], India, like China, relies on coal for much of its energy supply. Although coal's share of India's electricity generation is projected to drop slightly, from 77 percent in 1995 to 64 percent in 2015, the dramatic increase in total generation implies substantial growth in coal-fired capacity. In addition, the contribution of natural gas in electricity generation is projected to rise from only 4 percent in 1995 to 12 percent by 2015.

\section{Other Developing Asia}

Growth in electricity demand is also projected to be robust in other developing Asian countries, including South Korea, Taiwan, Thailand, the Philippines, and
Indonesia, with annual growth of 4.3 percent between 1995 and 2015. Collectively, these countries tend to be less dependent on coal for electricity generation than are China and India, although coal is still the most widely used fuel source for electricity, and its share of the total rises slightly in the forecast, from just under 30 percent in 1995 to 31 percent in 2015. Natural gas also gains share, from 19 percent in 1995 to more than 28 percent in 2015. Oil, second to coal in 1995 at 22 percent, drops to under 20 percent in 2015; nuclear drops from 13 percent to 10 percent; and renewables drop from 17 percent to 11 percent of total electricity generation.

\section{Africa}

Many parts of Africa could see strong growth in electricity demand over the coming 20 years. While many countries in Africa would like to increase electric capacity, political instability has-in many cases-made it difficult to secure financing for much-needed projects. Nevertheless, electricity consumption on the continent is expected to grow by 3.9 percent annually between 1995 and 2015.

South Africa remains the largest electricity consumer in Africa, using almost 50 percent of the total in 1994. More than 90 percent of South Africa's electricity is generated by coal-fired power stations [16]. As a result of the nation's past apartheid policies, many of its rural homes are not electrified. In fact, as recently as 1992, more than half (about 4.2 million) of the homes in South Africa were not electrified [17]. Most rural homes are still heated with fuel wood, and local shortages have resulted in increasing concerns about the environmental impact of deforestation.

In 1990, the South African state-owned electric utility, Eskom, launched its electrification project in an effort to extend the South African electricity grid to rural parts of the country [17]. Eskom plans to increase the percentage of electrified homes to 65 percent before 1999 . By December 1994, 44 percent of South African homes had access to the electricity grid. Eskom borrowed about \$64 million in May 1996 from the European Investment Bank to finance extensions to the South African electric power transmission system.

Electrification is an important element of economic growth in Africa as a whole. Plans for a Southern African electricity grid were developed to link SubSaharan African countries on a single electric power grid [18]. The plans include utilization of the large hydroelectric potential on major African rivers, such as the Zambezi and the Zaire, to provide electricity to participating countries. As of May 1996, 17 African countries had applied for inclusion in the plan. When 
completed, the Southern African electricity grid would encompass numerous projects, some of which already exist, including a portion of a line from Mozambique's Cahora Bassa hydroelectric project to South Africa's Eskom, a line from South Africa to Namibia, and a line from Zimbabwe to Zambia [18].

By the end of 1995, the Botswana Power Corporation, Zimbabwe Electricity Supply Authority, Zambia Electricity Supply Corporation Limited, and South Africa's Eskom had established the Southern African Power Pool, with the hopes that political instability in Zaire-a country with large hydroelectric resources-would moderate so that it could soon join the pool [19]. The Rotek company, a subsidiary of Eskom, is involved in the construction of several electricity projects throughout Africa, including the rehabilitation of the Djoue hydroelectric power station in Brazzaville in the Congo, completed in May 1996 [20].

Political instability in southern Africa makes it difficult to secure private financing for expansion projects. Indeed, it is difficult to envision a completed grid in the foreseeable future. For instance, the Cahora Bassa hydroelectric dam, which first became operational in 1975, was disrupted during the Mozambique civil war. It has been estimated that $\$ 130$ million would be required to repair the dam and power lines [18]. The civil war ended in 1992, and the Mozambique economy has improved enough to be the fastest growing sub-Saharan Africa economy for the past 5 years [21].

Mozambique would like to attract private foreign investment to develop its natural gas and hydroelectric resources. In addition to repairing the Cahora Bassa, the Mozambique government plans to build a hydroelectric project on the Zambezi, downstream from the Cahora Bassa to provide electric power for an aluminum smelter near Maputo. In September 1996, Mozambique announced that it would be able to supply South Africa with electricity from Cahora Bassa by mid-1997, given the progress in repairing electricity grids in the northern Mozambique provinces [22]. So far, 650 of the 2,005 power towers destroyed in the civil war have been restored.

There is already established electricity trade in parts of Africa. In 1993, South Africa exported 120 gigawatthours to Botswana; 510 to Mozambique, 281 to Lesotho, 529 to Swaziland, 999 to Namibia, and 150 to Zimbabwe [18]. Power is also occasionally imported by South Africa from Namibia. In 1996, the Nigerian stateowned generating company, National Electric Power Authority, agreed to supply electricity to its West African neighbors, Togo and Benin [23]. The utility will supply an annual 300 gigawatthours through a 330-kilo- volt transmission line between Ikeja, Nigeria, and Sakete, Benin. Nigeria also exports electricity to Niger.

Infrastructure problems have disrupted the electricity supply within Nigeria, particularly in the industrial sector. It has been estimated that about 60 hours of production per month are lost because of power cuts [24, p. 74]. A $\$ 155$ million project to repair and upgrade the transmission system (funded by international organizations) was completed, and a project to supply 33 rural communities with electricity will be funded by the European Development Fund.

Uganda is another African country that badly needs new supplies of electricity to meet increasing demand. Ugandan officials estimate that electricity demand is increasing by 24 percent per year [25]. But in September 1996, the Uganda Electricity Board terminated an $\$ 84$ million contract for the Chinese firm, Sietco, to expand a hydroelectric power plant at Owen Falls, near the eastern Jinja town, because of shoddy workmanship. The project was supposed to increase capacity at the 160-megawatt station to 180 megawatts by September 1997.

Privatization of Africa's utilities still appears to be far off for most countries. South Africa has considered privatizing Eskom, one of the world's ten largest electric utilities; however, in July 1996, Eskom released a statement that neither the company nor the government was considering privatization at present [19]. The Ivory Coast has been selling off its state monopolies, including electric utilities, since 1991 in an effort to attract large amounts of foreign capital [26].

Morocco's state-owned utility, Office National de $l^{\prime}$ Ectricite (ONE), finalized agreements with the CMS Generation company in April 1996 for the privatization, operation, and expansion of the Jorf Lasfar power plant, southwest of Casablanca [27]. CMS Generation and Asea Brown Boveri Energy Ventures hold 50 percent concession rights to the expanded facility, as well as an agreement to sell electricity to ONE for 30 years. The $\$ 1.3$ billion 1.32-gigawatt coal-fired expansion project makes Jorf Lasfar the largest independent power project in Africa, and it is the first major international private investment in electric power generation allowed by the Moroccan government.

In the Sudan, a recent agreement with the Malaysian company, Multi-Discovery, to build 180 megawatts of electricity generation capacity is supposed to denote a significant step toward privatization in that country [28]. Multi-Discovery will be installing 120 megawatts of capacity in Khartoum and 60 megawatts in Port Sudan on the Red Sea. The two plants are expected to 
increase Sudan's electric power generation by 30 percent, partially alleviating the country's problems in meeting demand, which at present is about 40 percent above the country's generating capabilities. Acute power shortages have resulted in long blackouts in Khartoum and other urban centers. In June 1996, the Sudanese state-owned electric company announced sharp increases in electricity prices.

\section{Middle East}

Electricity demand in the Middle East is expected to grow by 2.1 percent a year over the next 20 years, slowing from the 6.2-percent average annual growth experienced in the 1990s so far. Conflicts in the region over the past decade have damaged the electricity infrastructure in several Middle Eastern countries. Kuwait continues to work on replacing capacity lost in the Gulf War, and Iran continues to repair damage to the electricity infrastructure dating from its war with Iraq.

Saudi Arabia and Iran have the largest electricity markets in the region, accounting for 51 percent of total Middle Eastern consumption in 1994 [29]. Saudi Arabia's electricity consumption can be attributed to its high per capita GDP, whereas Iran's is a function of a large population and diversified economy [24, p. 15]. It is estimated that Iran's per capita electricity consumption in 1995 was 1.11 megawatthours per person, compared with almost 5 megawatthours per person in Saudi Arabia [24, pp. 122, 126].

In Saudi Arabia, electricity supply is provided through regional electric utilities, municipal authorities, desalination utilities, and autoproducers [24, p. 164]. Electric utilities operate among five regional electricity grids and, until recently when the country's capacity became insufficient to meet demand, electricity prices were subsidized by the government. In 1995 electricity prices to the residential sector almost doubled, and prices to industrial consumers were allowed to rise by 30 to 60 percent in an effort to reduce demand.

Saudi Arabia has plans to increase its generating capacity from the present level of 19 gigawatts to 60 gigawatts over the next 25 years [30]. In the next 6 years, the government plans to construct 9 gigawatts of capacity at an estimated cost of about $\$ 10$ billion [24, p. 164]. As part of the plan to increase capacity, Saudi Consolidated Electric Company East signed a $\$ 1.1$ billion. contract with Mitsubishi Heavy Industries in September 1996 to construct a 2.4-gigawatt thermal power plant in Ghazlan. The first of the plant's four units is expected to begin operating in December 1999, and the last should be completed in 2002 [30].
There are several additional projects in the planning stages throughout Saudi Arabia. The National Construction Company won a $\$ 48$ million contract to build a 57.8-megawatt plant in Tabuk (northern Saudi Arabia) for the Tabuk Electric Company. The plant is expected to take 30 months to complete. An announcement inviting bids for a 1.8-gigawatt power plant in Shauiba was made by Saudi Arabia in September 1996, and a 3gigawatt combined-cycle power plant is planned for Rabigh [24, p. 164].

Israel's state-owned public utility, Israel Electric Corporation, owns most of that country's generating capacity [24, p. 134]. However, the government plans to allow 10 percent of the nation's future capacity needs to be filled by the private sector.

\section{Central and South America}

Vigorous growth is projected for the electric power market of Central and South America over the next two decades. Electricity demand is expected to grow by about 3.5 percent annually, exceeding 1.1 trillion kilowatthours by 2015. Renewables (mainly hydroelectric power) are the dominant fuel for electricity generation in the region, providing about 5 quadrillion Btu of energy per year (Figure 73), but future demand growth will be met in large part by natural gas capacity. Increased use of natural gas rather than coal or oil for electric power generation is expected because of

Figure 73. Energy Use for Electricity Generation in Central and South America by Fuel, 1995-2015

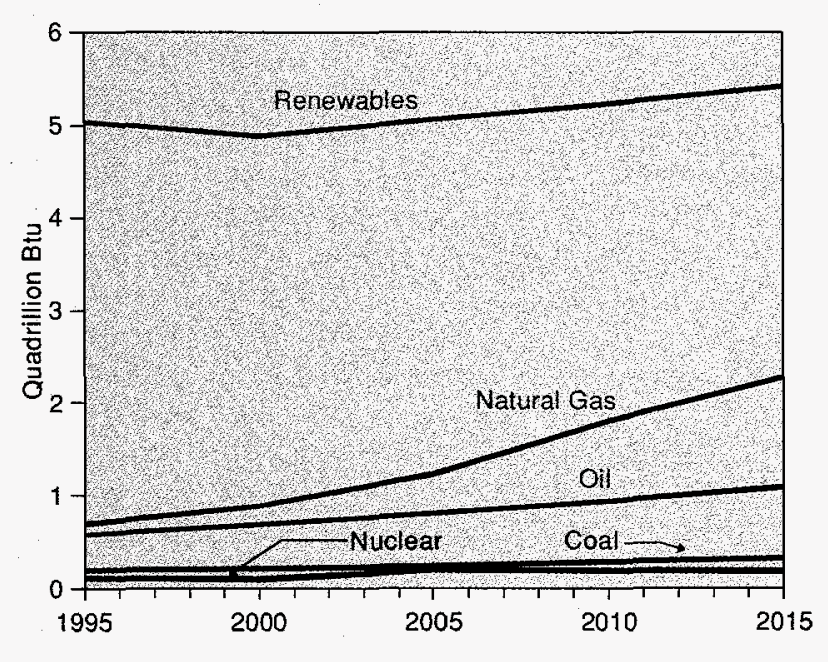

Sources: History: Energy Information Administration (EIA), International Energy Annual 1995, DOE/EIA-0219(95) (Washington, DC, December 1996). Projections: EIA, World Energy Projection System (1997). 
increasing regional concerns about air quality and because natural gas technologies are generally more economical than other power sources [8, p. 14].

The region's strongest electricity growth is expected in Brazil and Argentina. Brazil already consumes 51 percent of the electricity generated in Central and South America-268 billion kilowatthours in 1994 [29]. Argentina accounts for 12 percent of the regional total.

Several major natural-gas-fired projects are currently under construction, and more are planned in anticipation of completion of major gas pipeline agreements signed in 1996 for lines connecting Bolivia and Brazil, Venezuela and Brazil, and Argentina and Chile, as well as projects expanding grids within individual countries, such as Peru. Construction of the 1,900-mile $\$ 1.8$ billion Bolivia-to-Brazil pipeline is scheduled to begin in 1997, and delivery of the first gas to Brazil is scheduled for sometime in 1999 [31]. Talks are underway between Brazil and Venezuela to develop a 2,580-mile $\$ 450$ million transmission line from the Guri and Macagua hydroelectric plants on Venezuela's Caroni river across the Brazilian border to Boa Vista and Manaus [32].

A 400-megawatt $\$ 300$ million natural-gas-fired electricity plant is planned for Mejillones, Chile, to be constructed after the Atacama Pipeline project is completed [33]. The Atacama project will link Argentina's Noroeste Basin to industrial consumers in Mejillones. A final decision to proceed with the project is expected by mid-1997. If the project receives final approval, it should begin commercial operation by early 1999 [34]. The Chilean power company, Empresa Nacional de Electricidad SA, signed a $\$ 350$ million 15year contract with Argentina's YPF to supply Chile's San Isidro electric power plant with natural gas [35]. The San Isidro plant is to be built in central Chile.

Many countries in Central and South America have begun electricity sector privatization programs. Brazil's Electrobras is still 47.5 percent state-owned, but 23 of the 62 companies in Brazil's electricity sector have been privatized, including the utility Escelsa in July 1995 [36]. Strong sales of the power distributor's stock have prompted Brazil's National Development Bank to double the asking price for the remaining 15 percent of the voting stock, which is expected to be offered for sale by the end of 1996 [37].

The Brazilian utility, Light, is currently in the midst of privatization, which began in May 1996 [36]. The 24percent share of the utility still owned by Electrobras is expected to be sold off by mid-1997. The process of privatizing the major assets of Electrobras should be completed by the end of 1997, and prices for the com- pany's 11 small hydroelectric and thermal plants should be set by early 1997 [38].

Several steps have been taken by the Brazilian government to encourage competition in the electricity industry. The Brazilian national grid, National System of Electrical Power Transmission, was established in 1993, and legislation has been enacted to require third-party access to the transmission grid. The Public Service Law and the Concessions Law are expected to provide opportunities for private investment in the electricity sector. All of these developments are expected to increase the pace of privatization.

In January 1992, the Argentine Electricity Act was enacted, unbundling the electricity industry completely $[8, \mathrm{p}$. 34]. The generation sector is organized on a competitive basis, with independent generation companies selling their production on the Wholesale Electricity Market or by private contracts with other market participants [39]. Electricity transmission is regulated, and transmission companies are required to provide third-party access to their transmission systems. Distribution companies operate as geographic monopolies.

Recently the Argentinean government decided to delay privatization of the binational (with Paraguay) hydroelectric project, Yacyreta [40]. The government is concerned about the outcome of the Paraguayan decision on privatizing its share of the project. The 2.7gigawatt Yacyreta project began operating in September 1994 but will not be fully operational until 1998 .

The electricity industry in Chile has also been unbundled, although there are no laws that prohibit vertical integration (that is, one company that participates in two or more aspects of electricity generation, transmission, and distribution) [8, p. 75]. Chile's transmission facilities are predominantly owned by its largest electricity generating company, Endesa. The greater part of the electricity infrastructure is privately owned. Privatization began in 1982. The government controls only the Empresa Electrica Colbun-Manchicura SA utility's 490 megawatts of generating capacity and two other small utilities. Chile does not have a national electricity grid, but its interconnected systems cover most of the population. Twenty separate companies participate in electricity distribution.

In Colombia, the electricity sector is undergoing privatization [8, p. 97]. The country has unbundled generation, transmission, and distribution functions of the primary state-owned utility, Interconexion Electrica Sociedad Anonima Generation SA (ISAGen). Seventy-five percent of ISAGen is still government-owned. Twelve other 
power generating companies serve various regional and municipal areas. The largest include Empresa Energia de Bogota (with 2.2 gigawatts of capacity), Corporacion Electrica de la Costa Atlantica (1.1 gigawatts), Empresa Publicas de Medellin (1.7 gigawatts), and Corporacion Autonoma Regional del Valle del Cauca (0.9 gigawatts). While privatization of ISAGen is proceeding steadily, plans to privatize Empresa Energia de Bogota-the municipal utility serving Bogota-have been delayed because of that utility's debt burden [8, p. 98].

Since 1992, Colombia has encouraged private investment in power generation by allowing companies to build, own. and operate generating capacity [8, p. 98]. At present, over 1 gigawatt of capacity is being built privately, and an additional 1 gigawatt of privately owned capacity is in the planning stages. In September 1996, Amoco announced plans to build, own, and operate a 200-megawatt natural-gas-fired power plant at the Opon natural gas field in the center of the country [41]. The Termo Santander project is expected to begin operating in November 1997. While Amoco currently owns 100 percent of the project, Colombian law requires the company to sell its share down to 50 percent prior to operation [41]. Colombia's 1994 Electricity Law allows any economic entity to construct generation plants, but it outlaws vertical integration [8, p. 98].

Peru enacted the 1992 Electric Utilities Concessions Law declaring that private investment in electricity generation, transmission, and distribution was in the public interest. The law permits private ownership and operation of electricity supply by individuals or corporations (including foreign ones) and also forbids the state to develop new facilities [8, p. 139]. About 42 percent of Peru's power generation is now in the private sector. The unbundling of Lima's largest electricity generatordistributor, Empresa de Generacion Electrica de Lima SA, created one generation company (Generacion Electrica de Lima SA) and two distribution companies (Empresa de Distribucion Electrica de Lima Nort and Empresa de Distribucion Electrica de Lima Sur), all of which are now, at least in part, privately owned [42].

Peru's electricity supply system is currently under the control of state-owned Empresa Publica Electricidad del Peru SA (ElectroPeru), which has 10 regional subsidiaries, including ElectroLima [8, p. 139]. Instead of unbundling the generation and transmission activities into separate companies, the generating assets of ElectroPeru are being offered to private entities piecemeal. For instance, 60 percent of the Cahua hydroelectric plant was sold to Sindicato Pesquero, a fishprocessing company. Of the remaining shares of Cahua, 30 percent will be publicly offered on the stock exchange, and 10 percent will be reserved for Cahua employees. In September 1996, the Peruvian government fixed a $\$ 40$ million base price for the October privatization of its 80-megawatt electricity generating company, Empresa Electrica de Piura S.A. [43].

Ecuador's congress approved the sale of 49 percent of the country's electric utility company, Instituto Ecuatoriano de Electrificacin (INECEL), in September 1996 [44]. The government will release 39 percent of INECEL for sale to private concerns, and 10 percent of the company shares will be reserved for INECEL employees. Private investors will also be allowed to buy into the electricity generation and transmission segments of INECEL. The distribution portion of the business will be unbundled from the rest of the company. There is still some dispute, however, as to whether political issues will allow the scheme to be implemented [45]. The electricity labor union opposes privatization, and a threatened hunger strike by workers resulted in a government agreement not to sell INECEL's transmission lines and to retain electricity price subsidies for poor consumers.

\section{References}

1. International Energy Agency, World Energy Outlook 1996 Edition (Paris, France, 1996), p. 71, Table 2.8.

2. Energy Information Administration, Annual Energy Outlook 1997, DOE/EIA-0383(97) (Washington, DC, December 1996).

3. DRI/McGraw-Hill, The Future of the Electric Power Industry. Volume I: Western Europe (Lexington, MA, November 1995), p. 186.

4. Energy Information Administration, Energy Use and Carbon Emissions: Some International Comparisons, DOE/EIA-0579(94) (Washington, DC, March 1994), p. 8.

5. LCG Consulting, "Ontario Hydro Creates U.S. Unit To Pursue Open Market Power Sales," web site www.energyonline.com (August 22, 1996).

6. LCG Consulting, "Quebec May Open Electric Transmission Grid," web site www.energyonline.com (October 30, 1996).

7. LCG Consulting, "Hydro-Quebec Modifies FERC Applications To Sell in U.S.," web site www. energyonline.com (March 18, 1997).

8. DRI/McGraw-Hill, World Energy Service: Latin American Outlook 1996 (Lexington, MA, 1996).

9. WEFA Group, World Power Service: Western European Report (London, UK, November 1995). 
10. LCG Consulting, "German Minister Wants To Open Up Energy Markets," web site www.energyonline. com (October 30, 1996).

11. LCG Consulting, "French Clout Quashes International Energy Agency Report," web site www. energyonline.com (May 23, 1996).

12. C. Pleatsikas and B. Turner, "Electric Competition in New Zealand: Putting Last Things First," Public Utilities Fortnightly (June 15, 1996), p. 26.

13. DRI/McGraw-Hill, The Future of the Electric Power Industry Around the World. Volume III: Asia/Pacific (Lexington, MA, November 1995).

14. WEFA Group, World Power Service: China and India Subcontinent Reports (London, UK, December 1996), p. 2.15.

15. M. Ishiguro and T. Akiyama, Energy Demand in Five Major Asian Developing Countries: Structure and Prospects, World Bank Discussion Paper (Washington, DC, April 1995), p. 15.

16. South African Communication Service (SACS), "Energy," web site www.sacs.org.za (March 18, 1996).

17. Eskom, "The Electrification Project," web site www.eskom.co.za (August 16, 1995).

18. Eskom, "The Southern African Grid," web site www.escom.co.za (September 10, 1995).

19. South African Embassy to the United States, "Government: Power and Water," web site www.southafrica.net (1995).

20. Mbendi Information for Africa-African Industry and Economy, "Rotek Industries (Pty) Ltd.," web site mbendi.co.za (May 18, 1996).

21. M. Rudolph (Reuters News Service), "Mozambique Economy Stirs from Sick Bed" (September 11, 1996).

22. Xinhua (Comtex copyright), "Mozambique To Resupply S. Africa with Power in 1997," NewsPage web site (September 28, 1996).

23. Reuters America, Inc., "Nigeria To Sell Electric Power to Benin, Togo," NewsPage web site (September 23, 1996).

24. DRI/McGraw-Hill, World Energy Service: Africal Middle East Outlook (Lexington, MA, April 1996).

25. Reuters America, Inc., "Uganda Ends Chinese Dam Power Deal," NewsPage web site (September 12, 1996).

26. H.W. French, "Ivory Coast Sells Itself as West African Powerhouse," New York Times (July 19, 1996).
27. CMS Energy Corporation, "RABAT, Morocco, News Release," web site www.cmsenergy.com (April 26, 1996).

28. Panafrican News Agency, "Malaysian Firm To Build Electricity Plants in Sudan," web site cgi.nando. net:80 (September 26, 1996).

29. Energy Information Administration, "World Energy Database," web site www.eia.doe.gov (1996).

30. Reuters America, Inc., "Saudi To Build New $\$ 48$ Million Power Plant in Tabuk," NewsPage web site (September 12, 1996).

31. "Brazil, Bolivia Sign Final Natural Gas Pipeline Accord, Call Pipe Tender," Latin American Energy Alert, Vol. 3, No. 19 (September 20, 1996), pp. 1-2.

32. R. Colitt, "Brazil and Venezuela Find Togetherness: Long Lost Neighbours Are Developing Strong Links in Trade and Energy" Financial Times, London Edition (July 17, 1996).

33. "Nova Joins Project To Develop Gas Pipeline to Northern Chile," Latin American Energy Alert, Vol. 3, No. 19 (September 20, 1996), p. 3.

34. PR Newswire, "CMS Energy Adds NOVA Corp. as Partner in Atacama Pipeline Connecting Argentina and Chile," NewsPage web site (September 3, 1996).

35. M. Orgill (Reuters America, Inc.), "YPF To Supply Chile's Endesa Plant," NewsPage web site (October 2, 1996).

36. Reuters America, Inc., "Brazil Electrobras Stake in Light To Be Sold," NewsPage web site (September 9, 1996).

37. Reuters America, Inc., "Brazil To Raise Price for Remaining Escelsa Shares," NewsPage web site (September 24, 1996).

38. Reuters America, Inc., "Brazil Electrobras Sell-off To Begin in '97," NewsPage web site (September 13, 1996).

39. Catholic University of Chile, "Briefing on Argentinean Electricity Law," web site www.ing.puc.cl/ power (August 17, 1996).

40. South American Business News, "Yacyreta Privatization Slows Down," NewsPage web site (September 12, 1996).

41. "What's New Around the World," World Gas Intelligence, Vol. 7, No. 17 (September 13, 1996), pp. 11-12.

42. U.S. Department of Commerce, National Trade Data Bank, "Peru: Power Company Privatization," web site www.tradeport.org (August 1996). 
43. A. Cawthorne (Reuters America, Inc.), "Peru Sets \$40 Million Base Price for Electric Sale," NewsPage web site (September 9, 1996).

44. Reuters America, Inc., "Ecuador's Congress Approves Electricity Selloff," NewsPage web site (September 19, 1996).
45. Reuters America, Inc., "Ecuador Says Won't Sell Power Transmission Lines," NewsPage web site (September 24, 1996). 
Appendix A

\section{World Energy Consumption, Oil Production, and Carbon Emissions Tables}



Table A1. World Total Energy Consumption by Region, Reference Case, 1990-2015 (Quadrillion Btu)

\begin{tabular}{|c|c|c|c|c|c|c|c|c|}
\hline \multirow[b]{2}{*}{ Region/Country } & \multicolumn{3}{|c|}{ History } & \multicolumn{4}{|c|}{ Projections } & \multirow{2}{*}{$\begin{array}{c}\text { Average Annual } \\
\text { Percent Change, } \\
\text { 1995-2015 }\end{array}$} \\
\hline & 1990 & 1994 & 1995 & 2000 & 2005 & 2010 & 2015 & \\
\hline \multicolumn{9}{|l|}{ Industrialized Countries } \\
\hline North America $\ldots \ldots \ldots \ldots$ & 99.9 & 106.3 & 108.3 & 119.0 & 127.8 & 134.7 & 140.2 & 1.3 \\
\hline United States $^{a}$ & 84.0 & 88.8 & 90.6 & 97.8 & 103.4 & 107.9 & 110.9 & 1.0 \\
\hline Canada .... & 11.0 & 12.1 & 12.1 & 13.8 & 15.7 & 17.0 & 18.4 & 2.1 \\
\hline Mexico & 4.9 & 5.4 & 5.6 & 7.3 & 8.8 & 9.8 & 10.9 & 3.4 \\
\hline Western Europe $\ldots \ldots \ldots$ & 61.8 & 62.8 & 64.6 & 70.2 & 74.9 & 79.3 & 83.8 & 1.3 \\
\hline Industrialized Asia . . . . . . & 23.1 & 25.9 & 27.3 & 29.7 & 32.3 & 34.7 & 36.8 & 1.5 \\
\hline Japan $\ldots \ldots \ldots \ldots$ & 18.0 & 20.8 & 21.4 & 23.7 & 25.8 & 27.8 & 29.5 & 1.6 \\
\hline Australasia & 5.1 & 5.1 & 5.8 & 6.0 & 6.5 & 6.9 & 7.3 & 1.1 \\
\hline Total Industrialized . . . . . & 184.8 & 195.0 & 200.2 & 218.8 & 235.0 & 248.7 & 260.8 & 1.3 \\
\hline \multicolumn{9}{|l|}{ EE/FSU } \\
\hline Former Soviet Union . . . . . . . & 58.5 & 42.8 & 40.0 & 45.3 & 49.4 & 53.8 & 56.8 & 1.8 \\
\hline Eastern Europe $\ldots \ldots \ldots$ & 15.2 & 11.9 & 12.1 & 14.1 & 15.4 & 16.7 & 18.1 & 2.0 \\
\hline Total EE/FSU $\ldots \ldots \ldots$ & 73.6 & 54.7 & 52.1 & 59.4 & 64.8 & 70.5 & 75.0 & 1.8 \\
\hline \multicolumn{9}{|l|}{ Developing Countries } \\
\hline Developing Asia ... & 51.4 & 66.0 & 69.6 & 90.5 & 112.9 & 134.7 & 159.1 & 4.2 \\
\hline China $\ldots \ldots \ldots \ldots \ldots$ & 27.0 & 34.1 & 35.7 & 45.9 & 57.1 & 69.1 & 82.9 & 4.3 \\
\hline India $\ldots \ldots \ldots \ldots \ldots$ & 7.7 & 9.7 & 10.5 & 13.7 & 17.7 & 21.6 & 26.0 & 4.6 \\
\hline Other Asia $\ldots \ldots \ldots \ldots$ & 16.7 & 22.2 & 23.4 & 30.9 & 38.1 & 44.0 & 50.3 & 3.9 \\
\hline Middle East $\ldots \ldots \ldots \ldots$ & 11.2 & 13.4 & 14.1 & 14.8 & 16.2 & 17.5 & 19.1 & 1.5 \\
\hline Africa $\ldots \ldots \ldots \ldots \ldots$ & 10.2 & 11.7 & 12.1 & 13.0 & 14.5 & 16.1 & 17.8 & 1.9 \\
\hline Central and South America . & 13.8 & 16.1 & 16.8 & 18.9 & 22.4 & 26.0 & 30.2 & 3.0 \\
\hline Total Developing $\ldots \ldots$ & 86.5 & 107.1 & 112.6 & 137.3 & 166.0 & 194.4 & 226.2 & 3.5 \\
\hline Total World $\ldots \ldots \ldots \ldots \ldots$ & 344.9 & 356.8 & 364.9 & 415.6 & 465.7 & 513.6 & 561.9 & 2.2 \\
\hline
\end{tabular}

ancludes the 50 States and the District of Columbia. U.S. Territories are included in Australasia.

Notes: EE/FSU = Eastern Europe/Former Soviet Union. Energy totals include net imports of coal coke and electricity generated from biomass in the United States. Totals may not equal sum of components due to independent rounding. The electricity portion of the national fuel consumption values consists of generation for domestic use plus an adjustment for electricity trade based on a fuel's share of total generation in the exporting country.

Sources: History: Energy Information Administration (EIA), International Energy Annual 1995, DOE/EIA-0219(95) (Washington, DC, December 1996). Projections: EIA, Annual Energy Outlook 1997, DOE/EIA-0383(97) (Washington, DC, December 1996), Table A1; and World Energy Projection System (1997). 
Table A2. World Total Energy Consumption by Region and Fuel, Reference Case, 1990-2015 (Quadrillion Btu)

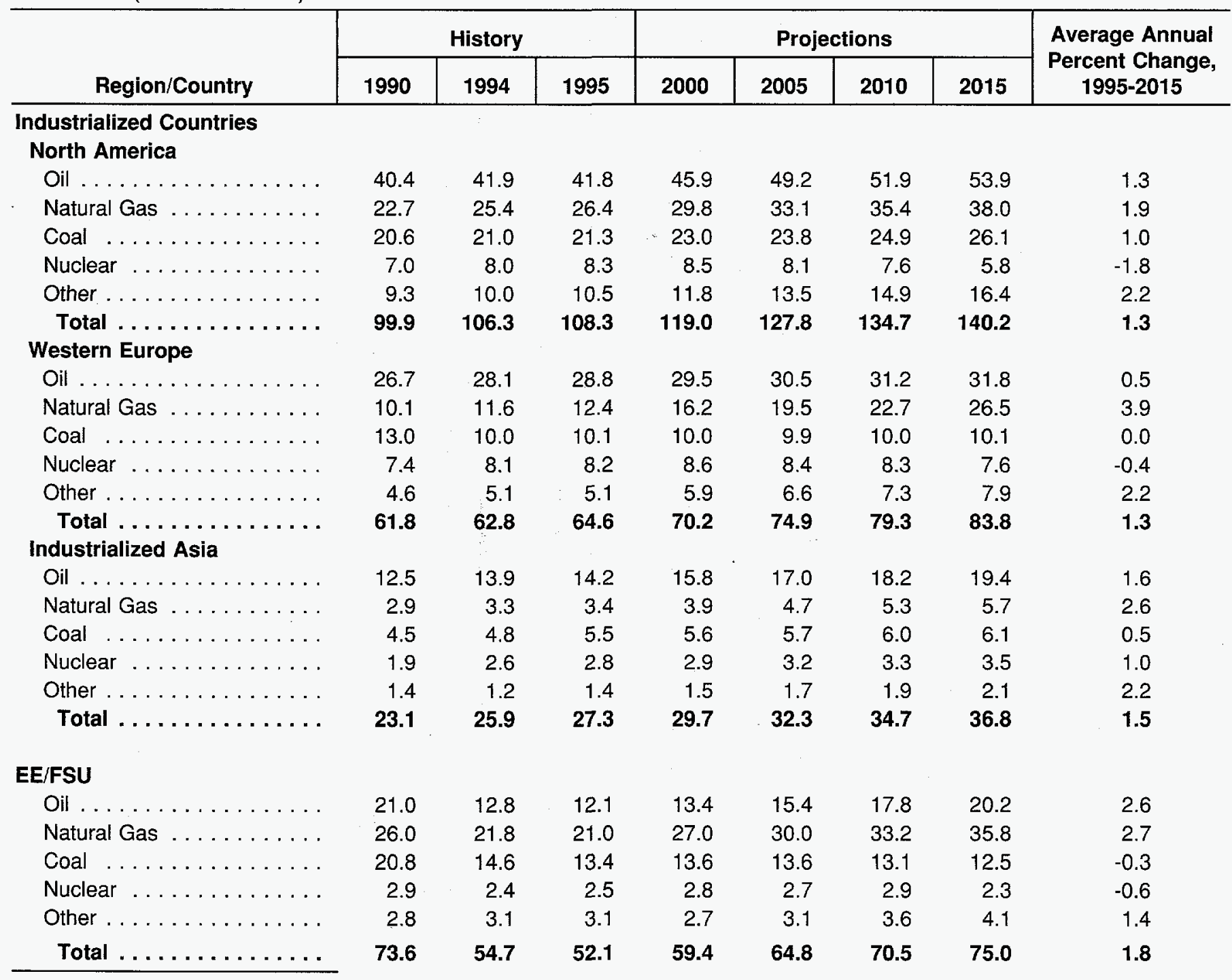

See notes at end of table. 
Table A2. World Total Energy Consumption by Region and Fuel, Reference Case, 1990-2015 (Continued) (Quadrillion Btu)

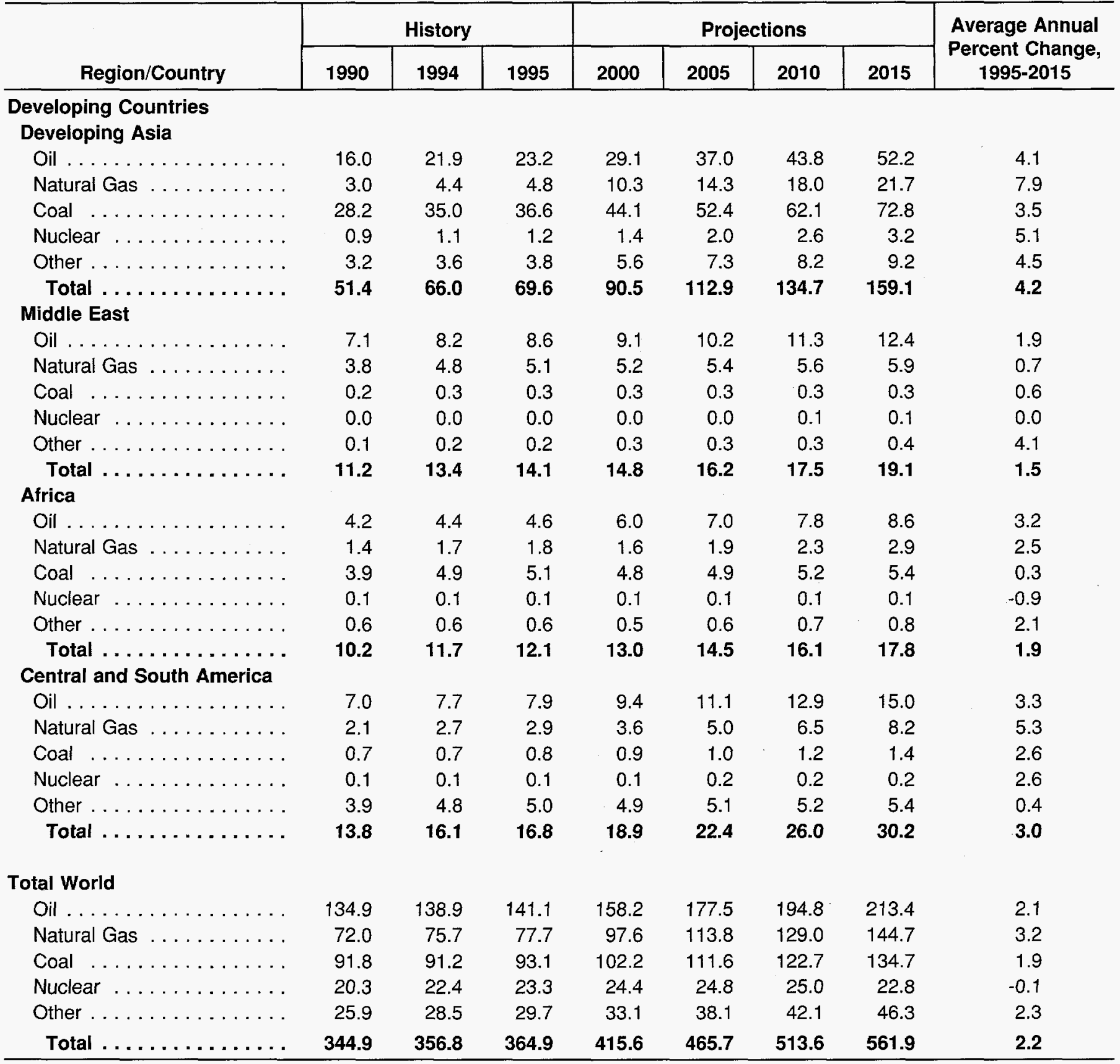

Includes the 50 States and the District of Columbia. U.S. Territories are included in Australasia.

Notes: EE/FSU = Eastern Europe/Former Soviet Union. Energy totals include net imports of coal coke and electricity generated from biomass in the United States. Totals may not equal sum of components due to independent rounding. The electricity portion of the national fuel consumption values consists of generation for domestic use plus an adjustment for electricity trade based on a fuel's share of total generation in the exporting country.

Sources: History: Energy Information Administration (EIA), International Energy Annual 1995, DOE/EIA-0219(95) (Washington, DC, December 1996). Projections: EIA, Annual Energy Outlook 1997, DOE/EIA-0383(97) (Washington, DC, December 1996), Table A1; and World Energy Projection System (1997). 
Table A3. World Total Oil Consumption by Region, Reference Case, 1990-2015 (Million Barrels per Day)

\begin{tabular}{|c|c|c|c|c|c|c|c|c|}
\hline \multirow[b]{2}{*}{ Region/Country } & \multicolumn{3}{|c|}{ History } & \multicolumn{4}{|c|}{ Projections } & \multirow{2}{*}{$\begin{array}{c}\text { Average Annual } \\
\text { Percent Change, } \\
\text { 1995-2015 }\end{array}$} \\
\hline & 1990 & 1994 & 1995 & 2000 & 2005 & 2010 & 2015 & \\
\hline North America . . . . . . . . . . & 20.4 & 21.3 & 21.3 & 23.4 & 25.1 & 26.4 & 27.4 & 1.3 \\
\hline United States $^{\mathrm{a}} \ldots \ldots$ & 17.0 & 17.7 & 17.7 & 19.4 & 20.7 & 21.6 & 22.1 & 1.1 \\
\hline Canada . . . . . . . . . & 1.7 & 1.7 & 1.7 & 1.9 & 2.0 & 2.1 & 2.3 & 1.4 \\
\hline Western Europe $\ldots . . .$. & 12.9 & 13.6 & 13.9 & 14.3 & 14.8 & 15.1 & 15.4 & 0.5 \\
\hline Industrialized Asia $\ldots \ldots$. & 6.2 & 6.8 & 7.0 & 7.7 & 8.3 & 8.9 & 9.4 & 1.5 \\
\hline Japan $\ldots \ldots \ldots \ldots \ldots$ & 5.1 & 5.7 & 5.7 & 6.4 & 6.9 & 7.3 & 7.8 & 1.5 \\
\hline Australasia . . . . . . . . & 1.0 & 1.2 & 1.3 & 1.3 & 1.4 & 1.6 & 1.7 & 1.4 \\
\hline Total Industrialized . . . . . & 39.5 & 41.7 & 42.2 & 45.4 & 48.2 & 50.4 & 52.3 & 1.1 \\
\hline \multicolumn{9}{|l|}{ EE/FSU $\ldots \ldots \ldots \ldots \ldots$} \\
\hline Total EE/FSU $\ldots \ldots \ldots$ & 10.0 & 6.1 & 5.8 & 6.4 & 7.3 & 8.5 & 9.6 & 2.6 \\
\hline \multicolumn{9}{|l|}{ Developing Countries } \\
\hline Developing Asia ... . . . . & 7.6 & 10.5 & 11.1 & 13.9 & 17.6 & 20.9 & 24.9 & 4.1 \\
\hline China . . . . . . . . . . . . & 2.3 & 3.1 & 3.3 & 4.4 & 5.5 & 6.9 & 8.6 & 4.9 \\
\hline India $\ldots \ldots \ldots$ & 1.2 & 1.4 & 1.6 & 1.9 & 2.4 & 2.8 & 3.3 & 3.8 \\
\hline Other Asia . . . . . . . . . . . & 4.2 & 5.9 & 6.2 & 7.6 & 9.7 & 11.2 & 13.0 & 3.7 \\
\hline Middle East . . . . . . . . . . . & 3.4 & 3.9 & 4.1 & 4.4 & 4.9 & 5.4 & 6.0 & 1.9 \\
\hline Africa $\ldots \ldots \ldots \ldots$ & 2.1 & 2.3 & 2.3 & 3.1 & 3.6 & 4.0 & 4.4 & 3.2 \\
\hline Central and South America . & 3.4 & 3.8 & 3.9 & 4.7 & 5.6 & 6.5 & 7.5 & 3.3 \\
\hline
\end{tabular}

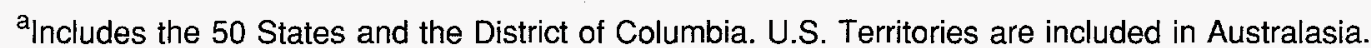

Notes: EE/FSU = Eastern Europe/Former Soviet Union. Totals may not equal sum of components due to independent rounding. The electricity portion of the national fuel consumption values consists of generation for domestic use plus an adjustment for electricity trade based on a fuel's share of total generation in the exporting country.

Sources: History: Energy Information Administration (EIA), International Energy Annual 1995, DOE/EIA-0219(95) (Washington, DC, December 1996). Projections: EIA, Annual Energy Outlook 1997, DOE/EIA-0383(97) (Washington, DC, December 1996), Table A21; and World Energy Projection System (1997). 
Table A4. World Total Natural Gas Consumption by Region, Reference Case, 1990-2015 (Trillion Cubic Feet)

\begin{tabular}{|c|c|c|c|c|c|c|c|c|}
\hline \multirow[b]{2}{*}{ Region/Country } & \multicolumn{3}{|c|}{ History } & \multicolumn{4}{|c|}{ Projections } & \multirow{2}{*}{$\begin{array}{c}\text { Average Annual } \\
\text { Percent Change, } \\
\text { 1995-2015 }\end{array}$} \\
\hline & 1990 & 1994 & 1995 & 2000 & 2005 & 2010 & 2015 & \\
\hline North America . . . . . . . . . . & 22.0 & 24.5 & 25.4 & 28.7 & 31.8 & 34.0 & 36.6 & 1.8 \\
\hline United States $^{\mathrm{a}} \ldots \ldots \ldots$ & 18.7 & 20.8 & 21.6 & 23.9 & 26.2 & 28.0 & 30.2 & 1.7 \\
\hline Canada ......... & 2.4 & 2.8 & 2.8 & 3.1 & 3.3 & 3.5 & 3.8 & 1.5 \\
\hline Industrialized Asia ... . . . & 2.6 & 3.0 & 3.1 & 3.6 & 4.3 & 4.8 & 5.2 & 2.6 \\
\hline Japan ............ & 1.9 & 2.2 & 2.2 & 2.6 & 3.2 & 3.7 & 4.1 & 3.1 \\
\hline Australasia . . . . . . . . & 0.8 & 0.8 & 0.9 & 1.0 & 1.1 & 1.1 & 1.2 & 1.4 \\
\hline Total Industrialized . . . . . & 35.0 & 39.3 & 41.1 & 48.6 & 55.8 & 61.6 & 68.2 & 2.6 \\
\hline Total EE/FSU $\ldots \ldots \ldots$ & 28.1 & 24.1 & 23.2 & 29.7 & 33.0 & 36.5 & 39.4 & 2.7 \\
\hline \multicolumn{9}{|l|}{ Developing Countries } \\
\hline Developing Asia . . . . . . . . & 3.0 & 4.4 & 4.8 & 10.1 & 13.9 & 17.6 & 21.2 & 7.7 \\
\hline China . . . . . . . . . . . & 0.5 & 0.6 & 0.6 & 1.7 & 2.7 & 3.3 & 3.6 & 9.3 \\
\hline India $\ldots \ldots \ldots \ldots \ldots$ & 0.4 & 0.6 & 0.7 & 1.4 & 2.5 & 3.8 & 5.4 & 11.1 \\
\hline Other Asia ....... & 2.1 & 3.2 & 3.6 & 7.0 & 8.7 & 10.4 & 12.2 & 6.3 \\
\hline Middle East . . . . . . . . . . . . & 3.6 & 4.5 & 4.9 & 5.0 & 5.2 & 5.3 & 5.6 & 0.7 \\
\hline Africa $\ldots \ldots \ldots \ldots$ & 1.4 & 1.6 & 1.7 & 1.5 & 1.7 & 2.2 & 2.7 & 2.5 \\
\hline Central and South America . & 2.0 & 2.4 & 2.6 & 3.3 & 4.5 & 5.9 & 7.4 & 5.3 \\
\hline
\end{tabular}

ancludes the 50 States and the District of Columbia. U.S. Territories are included in Australasia.

Notes: $\mathrm{EE} / \mathrm{FSU}=$ Eastern Europe/Former Soviet Union. Totals may not equal sum of components due to independent rounding. The electricity portion of the national fuel consumption values consists of generation for domestic use plus an adjustment for electricity trade based on a fuel's share of total generation in the exporting country. To convert cubic feet to cubic meters, divide each number in the table by 35.315 .

Sources: History: Energy Information Administration (EIA), International Energy Annual 1995, DOE/EIA-0219(95) (Washington, DC, December 1996). Projections: EIA, Annual Energy Outlook 1997, DOE/EIA-0383(97) (Washington, DC, December 1996), Table A13; and World Energy Projection System (1997). 
Table A5. World Total Coal Consumption by Region, Reference Case, 1990-2015 (Million Short Tons)

\begin{tabular}{|c|c|c|c|c|c|c|c|c|}
\hline \multirow[b]{2}{*}{ Region/Country } & \multicolumn{3}{|c|}{ History } & \multicolumn{4}{|c|}{ Projections } & \multirow{2}{*}{$\begin{array}{c}\text { Average Annual } \\
\text { Percent Change, } \\
\text { 1995-2015 }\end{array}$} \\
\hline & 1990 & 1994 & 1995 & 2000 & 2005 & 2010 & 2015 & \\
\hline \multicolumn{9}{|l|}{ Industrialized } \\
\hline North America $\ldots \ldots \ldots \ldots$ & 962 & 996 & 1,019 & 1,103 & 1,151 & 1,202 & 1,264 & 1.1 \\
\hline United States ${ }^{a} \ldots \ldots \ldots$ & 896 & 932 & 949 & 1,017 & 1,054 & 1,099 & 1,156 & 1.0 \\
\hline Canada ............. & 59 & 54 & 58 & 74 & 79 & 82 & 84 & 1.8 \\
\hline Mexico . . . . . . . . . . & 7 & 11 & 12 & 13 & 18 & 21 & 23 & 3.4 \\
\hline Western Europe $\ldots \ldots \ldots$ & 951 & 683 & 678 & 685 & 678 & 687 & 699 & 0.2 \\
\hline Industrialized Asia $\ldots \ldots$ & 243 & 234 & 266 & 266 & 271 & 284 & 288 & 0.4 \\
\hline Japan $\ldots \ldots \ldots \ldots$ & 123 & 134 & 140 & 151 & 154 & 165 & 168 & 0.9 \\
\hline Australasia . & 120 & 101 & 125 & 115 & 117 & 118 & 120 & -0.2 \\
\hline Total Industrialized . . . . . & 2,156 & 1,913 & 1,962 & 2,054 & 2,100 & 2,173 & 2,251 & 0.7 \\
\hline \multicolumn{9}{|l|}{ EE/FSU } \\
\hline Former Soviet Union . & 848 & 553 & 492 & 481 & 479 & 474 & 465 & -0.3 \\
\hline Eastern Europe $\ldots \ldots \ldots$ & 525 & 421 & 412 & 436 & 439 & 410 & 380 & -0.4 \\
\hline Total EE/FSU $\ldots \ldots \ldots$ & 1,374 & 974 & 904 & 917 & 917 & 884 & 845 & -0.3 \\
\hline \multicolumn{9}{|l|}{ Developing Countries } \\
\hline Developing Asia $\ldots \ldots \ldots$ & 1,560 & 1,922 & 2,012 & 2,429 & 2,892 & 3,428 & 4,024 & 3.5 \\
\hline China $\ldots \ldots \ldots \ldots \ldots$ & 1,124 & 1,397 & 1,464 & 1,783 & 2,137 & 2,568 & 3,089 & 3.8 \\
\hline India $\ldots$. & 242 & 309 & 327 & 399 & 479 & 554 & 605 & 3.1 \\
\hline Other Asia & 194 & 217 & 222 & 248 & 277 & 307 & 330 & 2.0 \\
\hline Middle East $\ldots \ldots \ldots \ldots$ & 6 & 9 & 10 & 9 & 9 & 10 & 11 & 0.6 \\
\hline Africa $\ldots \ldots \ldots \ldots \ldots$ & 152 & 175 & 180 & 170 & 174 & 183 & 191 & 0.3 \\
\hline Central and South America . & 30 & 31 & 35 & 39 & 43 & 51 & 58 & 2.6 \\
\hline Total Developing $\ldots \ldots$ & 1,748 & 2,137 & 2,238 & 2,648 & 3,118 & 3,672 & 4,285 & 3.3 \\
\hline Total World & 5,278 & 5,024 & 5,104 & 5,619 & 6,136 & 6,729 & $\mathbf{7 , 3 8 1}$ & 1.9 \\
\hline
\end{tabular}

ancludes the 50 States and the District of Columbia. U.S. Territories are included in Australasia.

Notes: EE/FSU = Eastern Europe/Former Soviet Union. Range values for Western Europe and the four regional totals are not equal to the sum of the component countries or country groups but consist of the base value adjusted by the quantity: the square root of the sum of the squared deviations of the respective component countries or country groups from their base value. Other totals may not equal sum of components due to independent rounding. The electricity portion of the national fuel consumption values consists of generation for domestic use plus an adjustment for electricity trade based on a fuel's share of total generation in the exporting country. To convert short tons to metric tons, divide each number in the table by 1.102.

Sources: History: Energy Information Administration (EIA), International Energy Annual 1995, DOE/EIA-0219(95) (Washington, DC, December 1996). Projections: EIA, Annual Energy Outlook 1997, DOE/EIA-0383(97) (Washington, DC, December 1996), Table A16; and World Energy Projection System (1997). 
Table A6. World Net Nuclear Energy Consumption by Region, Reference Case, 1990-2015 (Billion Kilowatthours)

\begin{tabular}{|c|c|c|c|c|c|c|c|c|}
\hline \multirow[b]{2}{*}{ Region/Country } & \multicolumn{3}{|c|}{ History } & \multicolumn{4}{|c|}{ Projections } & \multirow{2}{*}{$\begin{array}{c}\text { Average Annual } \\
\text { Percent Change, } \\
\text { 1995-2015 }\end{array}$} \\
\hline & 1990 & 1994 & 1995 & 2000 & 2005 & 2010 & 2015 & \\
\hline \multicolumn{9}{|l|}{ Industrialized } \\
\hline North America . & 648 & 746 & 774 & 789 & 756 & 704 & 538 & -1.8 \\
\hline United States $^{a} \ldots \ldots \ldots$ & 577 & 640 & 673 & 687 & 654 & 614 & 448 & -2.0 \\
\hline Canada $\ldots \ldots \ldots \ldots$ & 69 & 102 & 92 & 94 & 94 & 83 & 83 & -0.6 \\
\hline Mexico . . . . . . . . . & 2 & 4 & 8 & 8 & 8 & 8 & 8 & -0.3 \\
\hline Western Europe $\ldots \ldots \ldots$ & 703 & 768 & 786 & 823 & 802 & 795 & 733 & -0.3 \\
\hline Industrialized Asia $\ldots \ldots$ & 182 & 256 & 275 & 286 & 312 & 322 & 339 & 1.0 \\
\hline Japan $\ldots \ldots \ldots \ldots \ldots$ & 182 & 256 & 275 & 286 & 312 & 322 & 339 & 1.0 \\
\hline Australasia $\ldots \ldots \ldots \ldots$ & 0 & 0 & 0 & 0 & 0 & 0 & 0 & - \\
\hline Total Industrialized . . . . . & 1,533 & 1,770 & 1,835 & 1,899 & 1,870 & 1,821 & 1,610 & -0.7 \\
\hline \multicolumn{9}{|l|}{ EE/FSU } \\
\hline Former Soviet Union & 201 & 166 & 172 & 199 & 192 & 206 & 152 & -0.6 \\
\hline Eastern Europe ... & 54 & 56 & 57 & 52 & 57 & 56 & 53 & -0.4 \\
\hline Total EE/FSU $\ldots \ldots \ldots$ & 256 & 222 & 229 & 251 & 249 & 262 & 205 & -0.6 \\
\hline \multicolumn{9}{|l|}{ Developing Countries } \\
\hline Developing Asia ... & 88 & 106 & 118 & 143 & 195 & 256 & 321 & 5.1 \\
\hline China .......... & 0 & 14 & 12 & 13 & 35 & 62 & 112 & 11.6 \\
\hline India . & 6 & 5 & 7 & 10 & 14 & 17 & 26 & 6.7 \\
\hline Other Asia & 82 & 88 & 98 & 119 & 146 & 177 & 182 & 3.2 \\
\hline Middle East . . . . . . . . . & 0 & $\mathbf{0}$ & 0 & 0 & 4 & 9 & 9 & - \\
\hline Africa $\ldots \ldots \ldots \ldots \ldots$ & 8 & 10 & 11 & 10 & 10 & 10 & 10 & -0.9 \\
\hline Central and South America . & 9 & 8 & 9 & 8 & 16 & 16 & 15 & 2.5 \\
\hline Total Developing $\ldots \ldots$ & 105 & 124 & 138 & 160 & 225 & 291 & 355 & 4.8 \\
\hline Total World $\ldots \ldots \ldots \ldots$ & 1,894 & 2,115 & 2,202 & 2,310 & 2,344 & 2,374 & 2,170 & -0.1 \\
\hline
\end{tabular}

ancludes the 50 States and the District of Columbia. U.S. Territories are included in Australasia.

Notes: $E E / F S U=$ Eastern Europe/Former Soviet Union. Totals may not equal sum of components due to independent rounding. The electricity portion of the national fuel consumption values consists of generation for domestic use plus an adjustment for electricity trade based on a fuel's share of total generation in the exporting country.

Sources: History: Energy Information Administration (EIA), International Energy Annual 1995, DOE/EIA-0219(95) (Washington, DC, December 1996). Projections: EIA, Annual Energy Outlook 1997, DOE/EIA-0383(97) (Washington, DC, December 1996), Table A8; and World Energy Projection System (1997). 
Table A7. World Consumption of Hydroelectricity and Other Renewable Energy by Region, Reference Case, 1990-2015

(Quadrillion Btu)

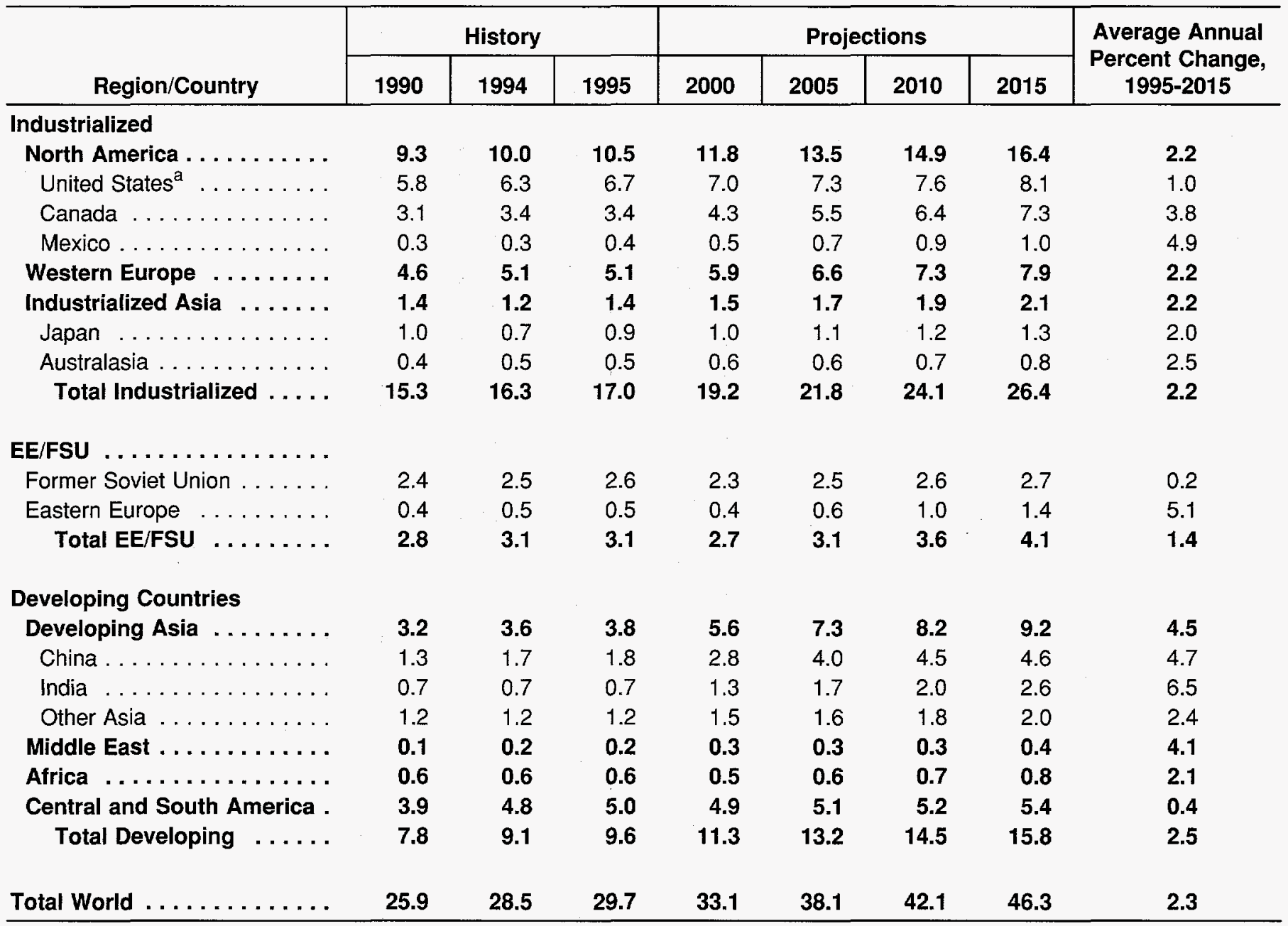

${ }^{a}$ Includes the 50 States and the District of Columbia. U.S. Territories are included in Australasia.

Notes: $\mathrm{EE} / \mathrm{FSU}=$ Eastern Europe/Former Soviet Union. Totals may not equal sum of components due to independent rounding. The electricity portion of the national fuel consumption values consists of generation for domestic use plus an adjustment for electricity trade based on a fuel's share of total generation in the exporting country.

Sources: History: Energy Information Administration (EIA), International Energy Annual 1995, DOE/EIA-0219(95) (Washington, DC, December 1996). Projections: EIA, Annual Energy Outlook 1997, DOE/EIA-0383(97) (Washington, DC, December 1996), Table A1; and World Energy Projection System (1997). 
Table A8. World Total Net Electricity Consumption by Region, Reference Case, 1990-2015 (Billion Kilowatthours)

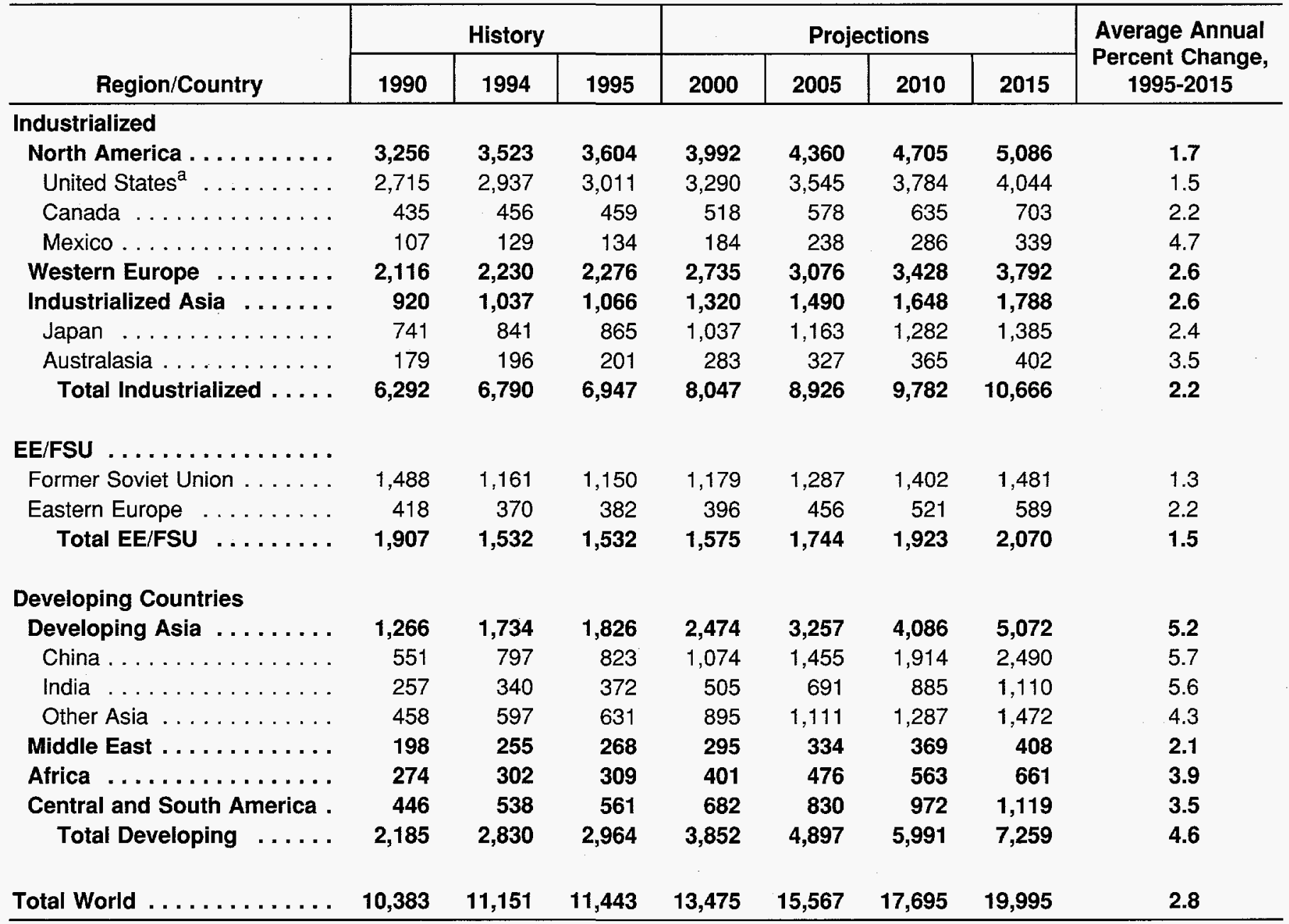

ancludes the 50 States and the District of Columbia. U.S. Territories are included in Australasia.

Notes: $E$ E/FSU $=$ Eastern Europe/Former Soviet Union. Electricity consumption equals generation plus imports minus exports minus distribution losses.

Sources: History: Energy Information Administration (EIA), International Energy Annual 1995, DOE/EIA-0219(95) (Washington, DC, December 1996), Table 6.2. Projections: EIA, Annual Energy Outlook 1997, DOE/EIA-0383(97) (Washington, DC, December 1996), Table A8; and World Energy Projection System (1997). 
Table A9. World Total Carbon Emissions by Region, Reference Case, 1990-2015 (Million Metric Tons)

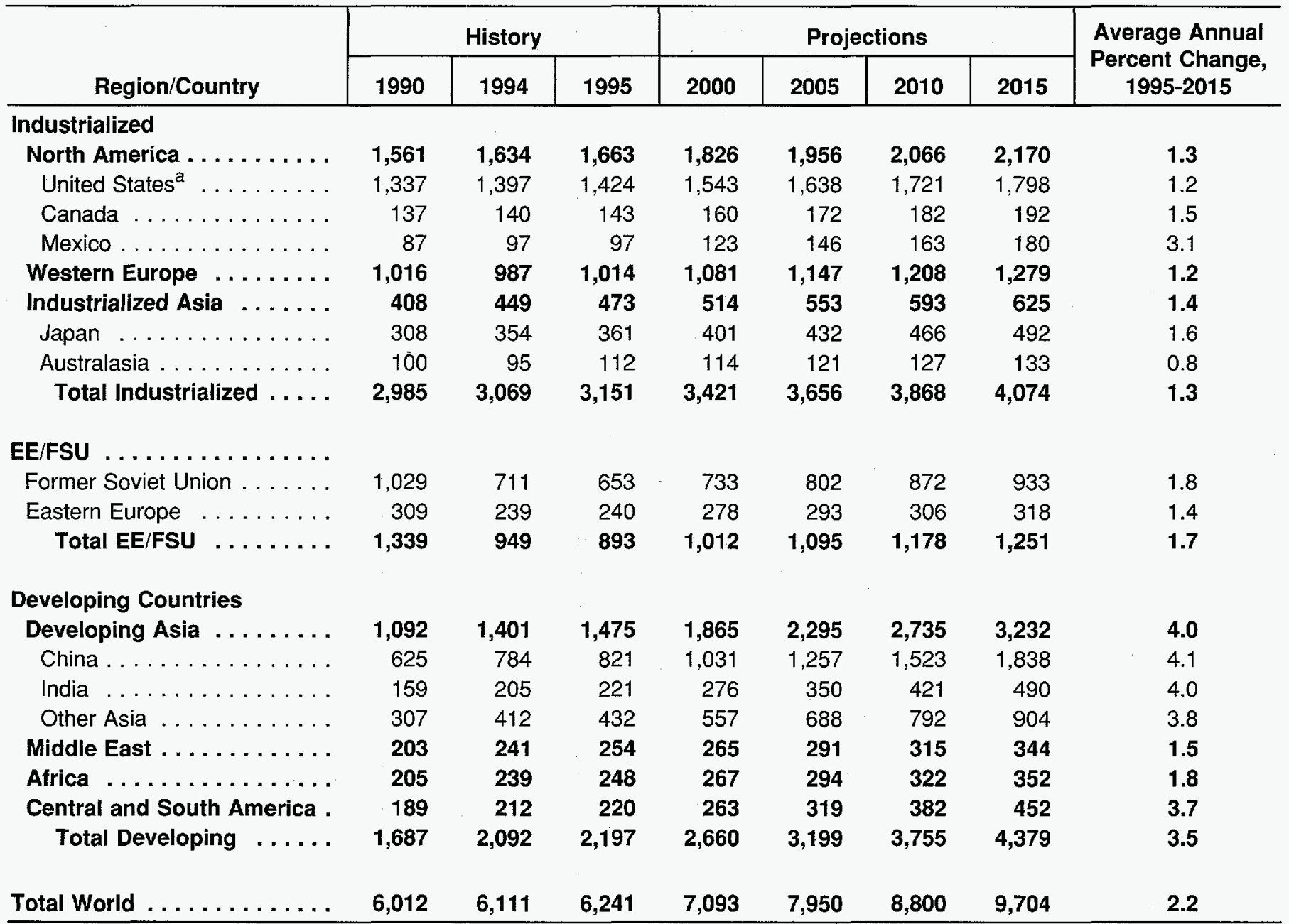

${ }^{a}$ Includes the 50 States and the District of Columbia. U.S. Territories are included in Australasia.

Notes: EE/FSU = Eastern Europe/Former Soviet Union. The U.S. numbers include carbon emissions attributable to renewable energy sources.

Sources: History: Derived from Energy Information Administration. (EIA), International Energy Annual 1995, DOE/EIA0219(95) (Washington, DC, December 1996). Projections: EIA, Annual Energy Outlook 1997, DOE/EIA-0383(97) (Washington, DC, December 1996), Table A19; and World Energy Projection System (1997). 
Table A10. World Carbon Emissions from Oil Use by Region, Reference Case, 1990-2015 (Million Metric Tons)

\begin{tabular}{|c|c|c|c|c|c|c|c|c|}
\hline \multirow[b]{2}{*}{ Region/Country } & \multicolumn{3}{|c|}{ History } & \multicolumn{4}{|c|}{ Projections } & \multirow{2}{*}{$\begin{array}{c}\text { Average Annual } \\
\text { Percent Change, } \\
\text { 1995-2015 }\end{array}$} \\
\hline & 1990 & 1994 & 1995 & 2000 & 2005 & 2010 & 2015 & \\
\hline \multicolumn{9}{|l|}{ Industrialized } \\
\hline North America $\ldots \ldots \ldots \ldots$ & 720 & 737 & 739 & 809 & 871 & 921 & 957 & 1.3 \\
\hline United States $^{\mathrm{a}} \ldots \ldots \ldots$ & 583 & 596 & 599 & 651 & 697 & 730 & 747 & 1.1 \\
\hline Canada $\ldots \ldots \ldots \ldots \ldots$ & 67 & 67 & 67 & 72 & 78 & 83 & 89 & 1.4 \\
\hline Mexico . . . . . . . . . . . & 69 & 74 & 73 & 85 & 96 & 108 & 121 & 2.6 \\
\hline Western Europe $\ldots \ldots \ldots$ & 537 & 562 & 576 & 589 & 610 & 623 & 636 & 0.5 \\
\hline Industrialized Asia $\ldots \ldots \ldots$ & 252 & 278 & 283 & 315 & 339 & 363 & 386 & 1.6 \\
\hline Japan $\ldots \ldots \ldots \ldots \ldots$ & 210 & 230 & 232 & 259 & 278 & 297 & 316 & 1.6 \\
\hline Australasia $\ldots \ldots \ldots \ldots$ & 41 & 47 & 51 & 56 & 61 & 66 & 70 & 1.6 \\
\hline Total Industrialized . . . . & 1,509 & 1,577 & 1,598 & 1,713 & 1,821 & 1,907 & 1,979 & 1.1 \\
\hline \multicolumn{9}{|l|}{ EE/FSU $\ldots \ldots \ldots \ldots \ldots$} \\
\hline Former Soviet Union . . . . . . . & 355 & 206 & 189 & 208 & 247 & 287 & 326 & 2.8 \\
\hline Eastern Europe . . . & 71 & 53 & 56 & 64 & 65 & 74 & 84 & 2.0 \\
\hline Total EE/FSU $\ldots \ldots \ldots$ & 427 & 259 & 245 & 272 & 312 & 361 & 410 & 2.6 \\
\hline \multicolumn{9}{|l|}{ Developing Countries } \\
\hline Developing Asia ... & 325 & 441 & 468 & 586 & 745 & 884 & 1,052 & 4.1 \\
\hline China . . . . . . . . . & 98 & 132 & 139 & 186 & 233 & 291 & 363 & 4.9 \\
\hline India . & 49 & 59 & 66 & 77 & 98 & 117 & 139 & 3.8 \\
\hline Other Asia & 178 & 251 & 263 & 323 & 413 & 476 & 550 & 3.8 \\
\hline Middle East $\ldots \ldots \ldots \ldots$ & 144 & 165 & 172 & 183 & 205 & 227 & 250 & 1.9 \\
\hline Africa $\ldots \ldots \ldots \ldots \ldots$ & 84 & 88 & 92 & 121 & 141 & 156 & 172 & 3.2 \\
\hline Central and South America . & 140 & 154 & 156 & 187 & 221 & 256 & 297 & 3.3 \\
\hline Total Developing $\ldots \ldots$ & 692 & 847 & 889 & 1,077 & 1,313 & 1,523 & 1,771 & 3.5 \\
\hline Total World $\ldots \ldots \ldots \ldots \ldots$ & 2,628 & 2,684 & 2,732 & 3,062 & 3,445 & 3,790 & 4,159 & 2.1 \\
\hline
\end{tabular}

ancludes the 50 States and the District of Columbia. U.S. Territories are included in Australasia.

Notes: EE/FSU = Eastern Europe/Former Soviet Union.

Sources: History: Derived from Energy Information Administration (EIA), International Energy Annual 1995, DOE/EIA0219(95) (Washington, DC, December 1996). Projections: EIA, Annual Energy Outlook 1997, DOE/EIA-0383(97) (Washington, DC, December 1996), Table A19; and World Energy Projection System (1997). 
Table A11. World Carbon Emissions from Natural Gas Use by Region, Reference Case, 1990-2015 (Million Metric Tons)

\begin{tabular}{|c|c|c|c|c|c|c|c|c|}
\hline \multirow[b]{2}{*}{ Region/Country } & \multicolumn{3}{|c|}{ History } & \multicolumn{4}{|c|}{ Projections } & \multirow{2}{*}{$\begin{array}{c}\text { Average Annual } \\
\text { Percent Change, } \\
\text { 1995-2015 }\end{array}$} \\
\hline & 1990 & 1994 & 1995 & 2000 & 2005 & 2010 & 2015 & \\
\hline North America . . . . . . . . . . & 323 & 365 & 377 & 428 & 476 & 509 & 547 & 1.9 \\
\hline United States ${ }^{\mathrm{a}} \ldots \ldots \ldots$ & 274 & 305 & 318 & 351 & 386 & 412 & 444 & 1.7 \\
\hline Canada ............. & 35 & 42 & 42 & 45 & 49 & 52 & 56 & 1.4 \\
\hline Western Europe . . . . . . . & 146 & 169 & 180 & 236 & 284 & 329 & 385 & 3.9 \\
\hline Industrialized Asia . . . . . & 42 & 48 & 49 & 57 & 68 & 77 & 83 & 2.6 \\
\hline Japan ............. & 30 & 35 & 35 & 42 & 51 & 59 & 65 & 3.1 \\
\hline Australasia . . . . . . . . . & 12 & 13 & 14 & 15 & 17 & 17 & 18 & 1.3 \\
\hline Total Industrialized . . . . . & 511 & 581 & 606 & 720 & 828 & 915 & 1,015 & 2.6 \\
\hline \multicolumn{9}{|l|}{ EE/FSU . . . . . . . . } \\
\hline Total EE/FSU $\ldots \ldots \ldots$ & 379 & 317 & 305 & 392 & 436 & 482 & 521 & 2.7 \\
\hline \multicolumn{9}{|l|}{ Developing Countries } \\
\hline Developing Asia . . . . . . . & 44 & 64 & 69 & 150 & 208 & 262 & 316 & 7.9 \\
\hline China . . . . . . . . . . . & 8 & 10 & 8 & 26 & 41 & 51 & 55 & 10.0 \\
\hline India $\ldots \ldots \ldots \ldots \ldots$ & 6 & 9 & 10 & 21 & 38 & 58 & 81 & 11.1 \\
\hline Other Asia $\ldots \ldots \ldots \ldots$. . . . & 30 & 46 & 51 & 103 & .128 & 153 & 180 & 6.5 \\
\hline Middle East . . . . . . . . . . . & 55 & 69 & 74 & 76 & 79 & 81 & 85 & 0.7 \\
\hline Africa $\ldots \ldots \ldots \ldots$ & 21 & 25 & 26 & 23 & 27 & 34 & 42 & 2.5 \\
\hline Central and South America . & 31 & 39 & 42 & 53 & 72 & 95 & 119 & 5.3 \\
\hline
\end{tabular}

${ }^{a}$ Includes the 50 States and the District of Columbia. U.S. Territories are included in Australasia.

Notes: EE/FSU = Eastern Europe/Former Soviet Union.

Sources: History: Derived from Energy Information Administration (EIA), International Energy Annual 1995, DOE/EIA0219(95) (Washington, DC, December 1996). Projections: ElA, Annual Energy Outlook 1997, DOE/EIA-0383(97) (Washington, DC, December 1996), Table A19; and World Energy Projection System (1997). 
Table A12. World Carbon Emissions from Coal Use by Region, Reference Case, 1990-2015 (Million Metric Tons)

\begin{tabular}{|c|c|c|c|c|c|c|c|c|}
\hline \multirow[b]{2}{*}{ Region/Country } & \multicolumn{3}{|c|}{ History } & \multicolumn{4}{|c|}{ Projections } & \multirow{2}{*}{$\begin{array}{c}\text { Average Annual } \\
\text { Percent Change } \\
\text { 1995-2015 }\end{array}$} \\
\hline & 1990 & 1994 & 1995 & 2000 & 2005 & 2010 & 2015 & \\
\hline \multicolumn{9}{|l|}{ Industrialized } \\
\hline North America . . . . . . . . & 518 & 532 & 547 & 589 & 609 & 637 & 666 & 1.0 \\
\hline United States $^{\mathrm{a}} \ldots \ldots \ldots$ & 480 & 496 & 507 & 540 & 555 & 579 & 607 & 0.9 \\
\hline Canada ..... & 35 & 30 & 33 & 42 & 45 & 47 & 48 & 1.8 \\
\hline Mexico . & 4 & 5 & 6 & 7 & 9 & 11 & 12 & 3.4 \\
\hline Western Europe & 333 & 256 & 258 & 256 & 253 & 255 & 258 & 0.0 \\
\hline Industrialized Asia $\ldots \ldots$ & 115 & 124 & 141 & 143 & 146 & 154 & 156 & 0.5 \\
\hline Japan..$\ldots \ldots \ldots \ldots$ & 68 & 89 & 93 & 100 & 102 & 110 & 111 & 0.9 \\
\hline Australasia $\ldots \ldots \ldots \ldots$ & 46 & 35 & 48 & 43 & 44 & 44 & 45 & -0.3 \\
\hline Total Industrialized . . . . . & 966 & 911 & 946 & 988 & 1,008 & 1,046 & 1,081 & 0.7 \\
\hline \multicolumn{9}{|l|}{ EE/FSU } \\
\hline Former Soviet Union & 339 & 218 & 192 & 187 & 186 & 185 & 181 & -0.3 \\
\hline Eastern Europe $\ldots$ & 194 & 155 & 150 & 160 & 161 & 151 & 140 & -0.4 \\
\hline Total EE/FSU $\ldots \ldots \ldots$ & 533 & 373 & 343 & 348 & 348 & 335 & 321 & -0.3 \\
\hline \multicolumn{9}{|l|}{ Developing Countries } \\
\hline Developing Asia $\ldots \ldots \ldots$ & 723 & 895 & 938 & 1,129 & 1,342 & 1,590 & 1,865 & 3.5 \\
\hline China $\ldots \ldots \ldots \ldots \ldots$ & 519 & 642 & 673 & 820 & 983 & 1,181 & 1,421 & 3.8 \\
\hline India $\ldots \ldots \ldots$ & 104 & 137 & 146 & 177 & 213 & 246 & 269 & 3.1 \\
\hline Other Asia $\ldots \ldots \ldots \ldots$ & 99 & 116 & 118 & 132 & 147 & 163 & 175 & 2.0 \\
\hline Middle East $\ldots \ldots \ldots \ldots$ & 4 & 7 & 7 & 7 & 7 & 7 & 8 & 0.6 \\
\hline Africa $\ldots \ldots \ldots \ldots \ldots$ & 100 & 126 & 130 & 123 & 126 & 132 & 138 & 0.3 \\
\hline Central and South America . & 17 & 19 & 21 & 24 & 26 & 31 & 35 & 2.6 \\
\hline Total Developing $\ldots \ldots$ & 844 & 1,047 & 1,097 & 1,282 & 1,501 & 1,760 & 2,047 & 3.2 \\
\hline$\ldots \ldots \ldots \ldots$ & 2,343 & 2,331 & 2,386 & 2,617 & 2,856 & 3,141 & 3,448 & 1.9 \\
\hline
\end{tabular}

${ }^{a}$ Includes the 50 States and the District of Columbia. U.S. Territories are included in Australasia.

Notes: EE/FSU = Eastern Europe/Former Soviet Union.

Sources: History: Derived from Energy Information Administration (EIA), International Energy Annual 1995, DOE/EIA0219(95) (Washington, DC, December 1996). Projections: EIA, Annual Energy Outlook 1997, DOE/EIA-0383(97) (Washington, DC, December 1996), Table A19; and World Energy Projection System (1997). 
Table A13. World Total Energy Consumption in Oil-Equivalent Units by Region, Reference Case, 1990-2015 (Million Tons Oil Equivalent)

\begin{tabular}{|c|c|c|c|c|c|c|c|c|}
\hline \multirow[b]{2}{*}{ Region/Country } & \multicolumn{3}{|c|}{ History } & \multicolumn{4}{|c|}{ Projections } & \multirow{2}{*}{$\begin{array}{c}\text { Average Annual } \\
\text { Percent Change, } \\
1995-2015\end{array}$} \\
\hline & 1990 & 1994 & 1995 & 2000 & 2005 & 2010 & 2015 & \\
\hline North America . . . . . . . . . . & 2,349 & 2,499 & 2,546 & 2,797 & 3,004 & 3,167 & 3,296 & 1.3 \\
\hline United States $^{a} \ldots \ldots \ldots$ & 1,975 & 2,088 & 2,130 & 2,300 & 2,430 & 2,537 & 2,607 & 1.0 \\
\hline Canada ..... & 259 & 283 & 285 & 325 & 368 & 399 & 434 & 2.1 \\
\hline Western Europe . . . . . . . & 1,453 & 1,477 & 1,519 & 1,650 & 1,761 & 1,866 & 1,970 & 1.3 \\
\hline Industrialized Asia . . . . . . & 544 & 608 & 641 & 698 & 759 & 815 & 864 & 1.5 \\
\hline Japan . . . . . . . . . & 423 & 488 & 504 & 556 & 605 & 652 & 692 & 1.6 \\
\hline Australasia . . . . . . . . . & 121 & 120 & 137 & 142 & 153 & 162 & 172 & 1.1 \\
\hline Total Industrialized . . . . . & 4,345 & 4,584 & 4,707 & 5,145 & 5,524 & 5,847 & 6,131 & 1.3 \\
\hline \multicolumn{9}{|l|}{ EE/FSU . . . . . . . . . } \\
\hline Total EE/FSU $\ldots \ldots \ldots$ & 1,732 & 1,286 & 1,225 & 1,397 & 1,524 & 1,658 & 1,762 & 1.8 \\
\hline \multicolumn{9}{|l|}{ Developing Countries } \\
\hline Developing Asia . . . . . . . . & 1,208 & 1,551 & 1,636 & 2,129 & 2,656 & 3,168 & 3,742 & 4.2 \\
\hline China . . . . . . . . . . & 634 & 801 & 839 & 1,080 & 1,343 & 1,625 & 1,948 & 4.3 \\
\hline India $\ldots \ldots \ldots \ldots \ldots$ & 182 & 228 & 247 & 323 & 417 & 508 & 611 & 4.6 \\
\hline Other Asia . . . . . . . . . . . & 392 & 522 & 550 & 726 & 896 & 1,034 & 1,182 & 3.9 \\
\hline Middle East . . . . . . . . . . . & 262 & 315 & 332 & 349 & 382 & 412 & 448 & 1.5 \\
\hline Africa $\ldots \ldots \ldots \ldots \ldots$ & 239 & 274 & 285 & 306 & 340 & 378 & 418 & 1.9 \\
\hline Central and South America . & 324 & 378 & 394 & 445 & 526 & 612 & 710 & 3.0 \\
\hline
\end{tabular}

${ }^{a}$ Includes the 50 States and the District of Columbia. U.S. Territories are included in Australasia.

Notes: EE/FSU = Eastern Europe/Former Soviet Union.

Sources: History: Derived from Energy Information Administration (EIA), International Energy Annual 1995, DOE/EIA0219(95) (Washington, DC, December 1996). Projections: ElA, Annual Energy Outlook 1997, DOE/EIA-0383(97) (Washington, DC, December 1996), Table A19; and World Energy Projection System (1997). 
Table A14. World Total Energy Consumption by Region, High Economic Growth Case, 1990-2015 (Quadrillion Btu)

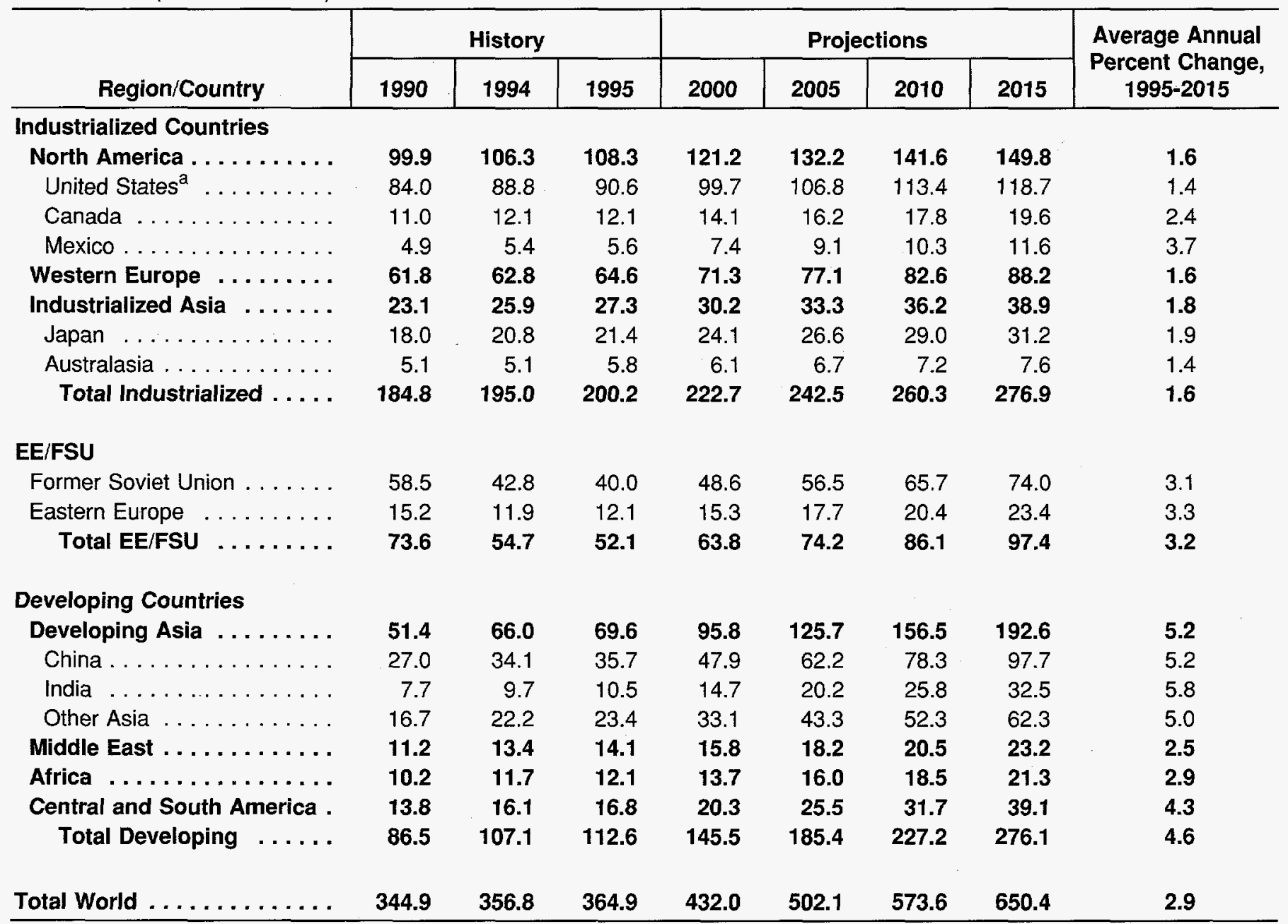

Includes the 50 States and the District of Columbia. U.S. Territories are included in Australasia.

Notes: $\mathrm{EE} / \mathrm{FSU}=$ Eastern Europe/Former Soviet Union. Energy totals include net imports of coal coke and electricity generated from biomass in the United States. Totals may not equal sum of components due to independent rounding. The electricity portion of the national fuel consumption values consists of generation for domestic use plus an adjustment for electricity trade based on a fuel's share of total generation in the exporting country.

Sources: History: Energy Information Administration (EIA), International Energy Annual 1995, DOE/EIA-0219(95) (Washington, DC, December 1996). Projections: EIA, Annual Energy Outlook 1997, DOE/EIA-0383(97) (Washington, DC, December 1996), Table A1; and World Energy Projection System (1997). 
Table A15. World Total Energy Consumption by Region and Fuel, High Economic Growth Case, 1990-2015 (Quadrillion Btu)

\begin{tabular}{|c|c|c|c|c|c|c|c|c|}
\hline \multirow[b]{2}{*}{ Region/Country } & \multicolumn{3}{|c|}{ History } & \multicolumn{4}{|c|}{ Projections } & \multirow{2}{*}{$\begin{array}{c}\text { Average Annual } \\
\text { Percent Change, } \\
1995-2015\end{array}$} \\
\hline & 1990 & 1994 & 1995 & 2000 & 2005 & 2010 & 2015 & \\
\hline \multicolumn{9}{|l|}{ North America } \\
\hline Oil $\ldots \ldots \ldots \ldots \ldots \ldots$ & 40.4 & 41.9 & 41.8 & 46.8 & 50.9 & 54.5 & 57.6 & 1.6 \\
\hline Natural Gas . . . . . . . . . & 22.7 & 25.4 & 26.4 & 30.3 & 34.3 & 37.2 & 40.7 & 2.2 \\
\hline Nuclear . . . . . . . . & 7.0 & 8.0 & 8.3 & 8.6 & 8.4 & 8.0 & 6.2 & -1.5 \\
\hline Other $\ldots \ldots \ldots \ldots \ldots$ & 9.3 & 10.0 & 10.5 & 12.0 & 13.9 & 15.7 & 17.5 & 2.6 \\
\hline $\begin{array}{l}\text { Total } \ldots \ldots \ldots \ldots \ldots \\
\text { Western Europe }\end{array}$ & 99.9 & 106.3 & 108.3 & 121.2 & 132.2 & 141.6 & 149.8 & 1.6 \\
\hline Oil $\ldots \ldots \ldots \ldots \ldots$ & 26.7 & 28.1 & 28.8 & 29.9 & 31.4 & 32.4 & 33.4 & 0.7 \\
\hline $\begin{array}{l}\text { Total } \ldots \ldots \ldots \ldots \ldots \\
\text { Industrialized Asia }\end{array}$ & 61.8 & 62.8 & 64.6 & 71.3 & 77.1 & 82.6 & 88.2 & 1.6 \\
\hline Oil $\ldots \ldots \ldots \ldots \ldots$ & 12.5 & 13.9 & 14.2 & 16.0 & 17.6 & 19.0 & 20.5 & 1.9 \\
\hline Natural Gas . . . . . . . . . & 2.9 & 3.3 & 3.4 & 4.0 & 4.8 & 5.5 & 6.0 & 2.9 \\
\hline Coal $\ldots \ldots \ldots \ldots \ldots$ & 4.5 & 4.8 & 5.5 & 5.7 & 5.9 & 6.3 & 6.4 & 0.8 \\
\hline Nuclear . . . . . . . . . . & 1.9 & 2.6 & 2.8 & 3.0 & 3.3 & 3.4 & 3.7 & 1.3 \\
\hline Other $\ldots \ldots \ldots \ldots \ldots$ & 1.4 & 1.2 & 1.4 & 1.5 & 1.8 & 2.0 & 2.3 & 2.5 \\
\hline Total . . . . . . . . . . . & 23.1 & 25.9 & 27.3 & 30.2 & 33.3 & 36.2 & 38.9 & 1.8 \\
\hline \multicolumn{9}{|l|}{ EE/FSU } \\
\hline
\end{tabular}


Table A15. World Total Energy Consumption by Region and Fuel, High Economic Growth Case, 1990-2015 (Continued)

(Quadrillion Btu)

\begin{tabular}{|c|c|c|c|c|c|c|c|c|}
\hline \multirow[b]{2}{*}{ Region/Country } & \multicolumn{3}{|c|}{ History } & \multicolumn{4}{|c|}{ Projections } & \multirow{2}{*}{$\begin{array}{c}\text { Average Annual } \\
\text { Percent Change, } \\
1995-2015\end{array}$} \\
\hline & 1990 & 1994 & 1995 & 2000 & 2005 & 2010 & 2015 & \\
\hline \multicolumn{9}{|l|}{$\begin{array}{l}\text { Developing Countries } \\
\text { Developing Asia }\end{array}$} \\
\hline Oil $\ldots \ldots \ldots \ldots \ldots$ & 16.0 & 21.9 & 23.2 & 30.9 & 41.5 & 51.4 & 63.7 & 5.2 \\
\hline Natural Gas . . . . . . . . . . & 3.0 & 4.4 & 4.8 & 11.0 & 16.1 & 21.2 & 26.7 & 9.0 \\
\hline Coal $\ldots \ldots \ldots \ldots \ldots$ & 28.2 & 35.0 & 36.6 & 46.4 & 57.8 & 71.3 & 87.0 & 4.4 \\
\hline Nuclear & 0.9 & 1.1 & 1.2 & 1.5 & 2.2 & 3.0 & 4.0 & 6.2 \\
\hline Other . . & 3.2 & 3.6 & 3.8 & 6.0 & 8.1 & 9.5 & 11.1 & 5.5 \\
\hline Total $\ldots \ldots \ldots \ldots \ldots$ & 51.4 & 66.0 & 69.6 & 95.8 & 125.7 & 156.5 & 192.6 & 5.2 \\
\hline \multicolumn{9}{|l|}{ Middle East } \\
\hline Oil $\ldots \ldots \ldots$ & 7.1 & 8.2 & 8.6 & 9.7 & 11.4 & 13.2 & 15.1 & 2.9 \\
\hline Natural Gas ... & 3.8 & 4.8 & 5.1 & 5.6 & 6.1 & 6.5 & 7.1 & 1.7 \\
\hline Coal $\ldots .$. & 0.2 & 0.3 & 0.3 & 0.3 & 0.3 & 0.3 & 0.4 & 1.6 \\
\hline Nuclear & 0.0 & 0.0 & 0.0 & 0.0 & 0.0 & 0.1 & 0.1 & 0.0 \\
\hline Other . . & 0.1 & 0.2 & 0.2 & 0.3 & 0.3 & 0.4 & 0.4 & 5.1 \\
\hline Total $\ldots \ldots \ldots \ldots \ldots$ & 11.2 & 13.4 & 14.1 & 15.8 & 18.2 & 20.5 & 23.2 & 2.5 \\
\hline \multicolumn{9}{|l|}{ Africa } \\
\hline Oil $\ldots \ldots \ldots \ldots$ & 4.2 & 4.4 & 4.6 & 6.4 & 7.8 & 9.0 & 10.3 & 4.1 \\
\hline Natural Gas $\ldots \ldots \ldots \ldots$ & 1.4 & 1.7 & 1.8 & 1.7 & 2.0 & 2.7 & 3.5 & 3.4 \\
\hline Coal $\ldots \ldots \ldots$ & 3.9 & 4.9 & 5.1 & 5.0 & 5.4 & 5.9 & 6.5 & 1.2 \\
\hline Nuclear & 0.1 & 0.1 & 0.1 & 0.1 & 0.1 & 0.1 & 0.1 & 0.1 \\
\hline Other $\ldots \ldots \ldots \ldots \ldots$ & 0.6 & 0.6 & 0.6 & 0.5 & 0.6 & 0.8 & 1.0 & 3.0 \\
\hline Total $\ldots \ldots \ldots \ldots \ldots$ & 10.2 & 11.7 & 12.1 & 13.7 & 16.0 & 18.5 & 21.3 & 2.9 \\
\hline \multicolumn{9}{|l|}{ Central and South America } \\
\hline Oil $\ldots \ldots \ldots \ldots \ldots$ & 7.0 & 7.7 & 7.9 & 10.1 & 12.7 & 15.7 & 19.4 & 4.6 \\
\hline Natural Gas $\ldots \ldots \ldots \ldots$ & 2.1 & 2.7 & 2.9 & 3.9 & 5.7 & 7.9 & 10.6 & 6.7 \\
\hline Coal $\ldots$. & 0.7 & 0.7 & 0.8 & 1.0 & 1.2 & 1.5 & 1.8 & 3.9 \\
\hline$\ldots \ldots \ldots \ldots \ldots$ & 0.1 & 0.1 & 0.1 & 0.1 & 0.2 & 0.2 & 0.2 & 4.0 \\
\hline Other $\ldots \ldots \ldots \ldots \ldots$ & 3.9 & 4.8 & 5.0 & 5.2 & 5.8 & 6.4 & 7.1 & 1.7 \\
\hline Total $\ldots \ldots \ldots \ldots \ldots$ & 13.8 & 16.1 & 16.8 & 20.3 & 25.5 & 31.7 & 39.1 & 4.3 \\
\hline \multicolumn{9}{|l|}{ Total World } \\
\hline Oil $\ldots \ldots \ldots \ldots \ldots$ & 134.9 & 138.9 & 141.1 & 164.2 & 190.9 & 216.9 & 246.2 & 2.8 \\
\hline Natural Gas $\ldots \ldots \ldots \ldots$ & 72.0 & 75.7 & 77.7 & 101.9 & 123.3 & 145.1 & 169.0 & 4.0 \\
\hline Coal $\ldots \ldots \ldots \ldots \ldots$ & 91.8 & 91.2 & 93.1 & 106.5 & 120.9 & 137.9 & 156.9 & 2.6 \\
\hline Nuclear $\ldots \ldots \ldots \ldots$ & 20.3 & 22.4 & 23.3 & 25.1 & 26.1 & 27.1 & 25.3 & 0.4 \\
\hline Other. . & 25.9 & 28.5 & 29.7 & 34.3 & 40.9 & 46.6 & 53.0 & 2.9 \\
\hline Total $\ldots \ldots \ldots \ldots \ldots$ & 344.9 & 356.8 & 364.9 & 432.0 & 502.1 & 573.6 & 650.4 & 2.9 \\
\hline
\end{tabular}

Includes the 50 States and the District of Columbia. U.S. Territories are included in Australasia.

Notes: $\mathrm{EE} / \mathrm{FSU}=$ Eastern Europe/Former Soviet Union. Energy totals include net imports of coal coke and electricity generated from biomass in the United States. Totals may not equal sum of components due to independent rounding. The electricity portion of the national fuel consumption values consists of generation for domestic use plus an adjustment for electricity trade based on a fuel's share of total generation in the exporting country.

Sources: History: Energy Information Administration (EIA), International Energy Annual 1995, DOE/EIA-0219(95) (Washington, DC, December 1996). Projections: EIA, Annual Energy Outlook 1997, DOE/EIA-0383(97) (Washington, DC, December 1996), Table A1; and World Energy Projection System (1997). 
Table A16. World Total Oil Consumption by Region, High Economic Growth Case, 1990-2015 (Million Barrels per Day)

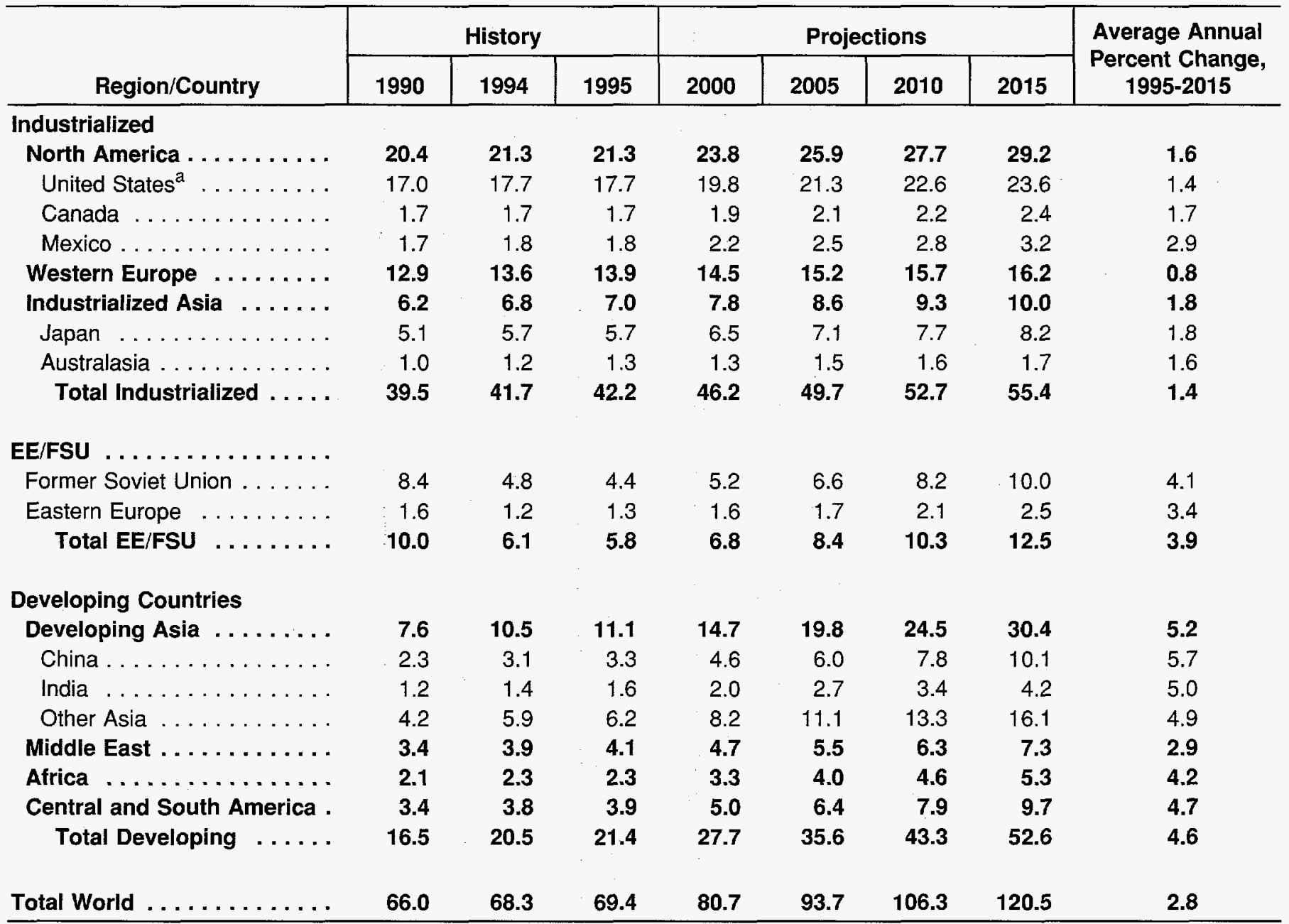

Includes the 50 States and the District of Columbia. U.S. Territories are included in Australasia.

Notes: $E E / F S U=$ Eastern Europe/Former Soviet Union. Totals may not equal sum of components due to independent rounding. The electricity portion of the national fuel consumption values consists of generation for domestic use plus an adjustment for electricity trade based on a fuel's share of total generation in the exporting country.

Sources: History: Energy Information Administration (EIA), International Energy Annual 1995, DOE/EIA-0219(95) (Washington, DC, December 1996). Projections: ElA, Annual Energy Outlook 1997, DOE/EIA-0383(97) (Washington, DC, December 1996), Table A21; and World Energy Projection System (1997). 
Table A17. World Total Natural Gas Consumption by Region, High Economic Growth Case, 1990-2015 (Trillion Cubic Feet)

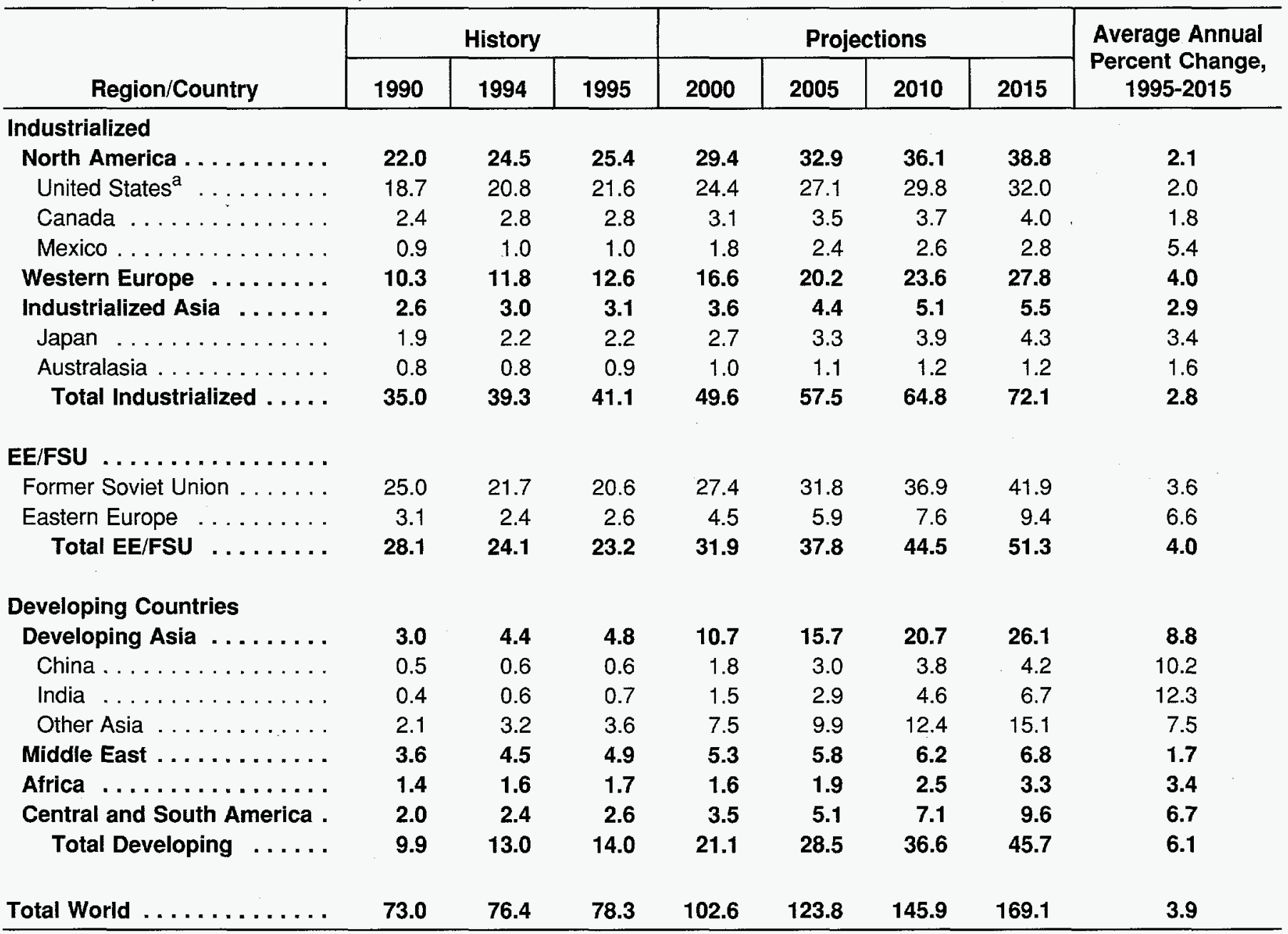

${ }^{a}$ Includes the 50 States and the District of Columbia. U.S. Territories are included in Australasia.

Notes: $\mathrm{EE} / \mathrm{FSU}=$ Eastern Europe/Former Soviet Union. Totals may not equal sum of components due to independent rounding. The electricity portion of the national fuel consumption values consists of generation for domestic use plus an adjustment for electricity trade based on a fuel's share of total generation in the exporting country. To convert cubic feet to cubic meters, divide each number in the table by 35.315 .

Sources: History: Energy Information Administration (EIA), International Energy Annual 1995, DOE/EIA-0219(95) (Washington, DC, December 1996). Projections: EIA, Annual Energy Outlook 1997, DOE/EIA-0383(97) (Washington, DC, December 1996), Table A13; and World Energy Projection System (1997). 
Table A18. World Total Coal Consumption by Region, High Economic Growth Case, 1990-2015 (Million Short Tons)

\begin{tabular}{|c|c|c|c|c|c|c|c|c|}
\hline \multirow[b]{2}{*}{ Region/Country } & \multicolumn{3}{|c|}{ History } & \multicolumn{4}{|c|}{ Projections } & \multirow{2}{*}{$\begin{array}{c}\text { Average Annual } \\
\text { Percent Change, } \\
\text { 1995-2015 }\end{array}$} \\
\hline & 1990 & 1994 & 1995 & 2000 & 2005 & 2010 & 2015 & \\
\hline \multicolumn{9}{|l|}{ Industrialized } \\
\hline North America. & 962 & 996 & 1,019 & 1,127 & 1,209 & 1,280 & 1,402 & 1.6 \\
\hline United States ${ }^{a}$ & 896 & 932 & 949 & 1,039 & 1,109 & 1,172 & 1,288 & 1.5 \\
\hline Canada ..... & 59 & 54 & 58 & 75 & 82 & 86 & 89 & 2.1 \\
\hline Mexico . & 7 & 11 & 12 & 14 & 19 & 22 & 25 & 3.7 \\
\hline Western Europe $\ldots \ldots \ldots$ & 951 & 683 & 678 & 696 & 698 & 715 & 736 & 0.4 \\
\hline Industrialized Asia $\ldots \ldots$ & 243 & 234 & 266 & 270 & 279 & 296 & 304 & 0.7 \\
\hline Japan $\ldots \ldots \ldots \ldots \ldots$ & 123 & 134 & 140 & 153 & 159 & 173 & 178 & 1.2 \\
\hline Australasia . . . . . . . . & 120 & 101 & 125 & 117 & 120 & 123 & 126 & 0.0 \\
\hline Total Industrialized . . . . . & 2,156 & 1,913 & 1,962 & 2,093 & 2,186 & 2,292 & 2,441 & 1.1 \\
\hline \multicolumn{9}{|l|}{ EE/FSU $\ldots \ldots \ldots \ldots \ldots$} \\
\hline Former Soviet Union . . . . . . . & 848 & 553 & 492 & 516 & 548 & 579 & 605 & 1.0 \\
\hline Eastern Europe $\ldots \ldots \ldots$ & 525 & 421 & 412 & 471 & 505 & 500 & 490 & 0.9 \\
\hline Total EE/FSU $\ldots \ldots \ldots$ & 1,374 & 974 & 904 & 987 & 1,053 & 1,079 & 1,095 & 1.0 \\
\hline \multicolumn{9}{|l|}{ Developing Countries } \\
\hline Developing Asia $\ldots \ldots \ldots$ & 1,560 & 1,922 & 2,012 & 2,554 & 3,186 & 3,936 & 4,808 & 4.5 \\
\hline China . . . . . . . . . & 1,124 & 1,397 & 1,464 & 1,861 & 2,326 & 2,910 & 3,643 & 4.7 \\
\hline India $\ldots \ldots \ldots$ & 242 & 309 & 327 & 428 & 545 & 662 & 756 & 4.3 \\
\hline Other Asia . . . . . . & 194 & 217 & 222 & 266 & 314 & 364 & 409 & 3.1 \\
\hline Middle East . . . . . . . . . & 6 & 9 & 10 & 10 & 10 & 12 & 14 & 1.6 \\
\hline Africa $\ldots \ldots \ldots \ldots \ldots$ & 152 & 175 & 180 & 179 & 192 & 211 & 230 & 1.2 \\
\hline Central and South America . & 30 & 31 & 35 & 42 & 49 & 62 & 75 & 3.9 \\
\hline Total Developing $\ldots \ldots$ & 1,748 & 2,137 & 2,238 & 2,784 & 3,438 & 4,221 & 5,127 & 4.2 \\
\hline Total World $\ldots \ldots \ldots \ldots \ldots$ & 5,278 & 5,024 & 5,104 & 5,865 & 6,677 & 7,592 & 8,663 & 2.7 \\
\hline
\end{tabular}

ancludes the 50 States and the District of Columbia. U.S. Territories are included in Australasia.

Notes: EE/FSU = Eastern Europe/Former Soviet Union. Range values for Western Europe and the four regional totals are not equal to the sum of the component countries or country groups but consist of the base value adjusted by the quantity: the square root of the sum of the squared deviations of the respective component countries or country groups from their base value. Other totals may not equal sum of components due to independent rounding. The electricity portion of the national fuel consumption values consists of generation for domestic use plus an adjustment for electricity trade based on a fuel's share of total generation in the exporting country. To convert short tons to metric tons, divide each number in the table by 1.102 .

Sources: History: Energy Information Administration (EIA), International Energy Annual 1995, DOE/EIA-0219(95) (Washington, DC, December 1996). Projections: EIA, Annual Energy Outlook 1997, DOE/EIA-0383(97) (Washington, DC, December 1996), Table A16; and World Energy Projection System (1997). 
Table A19. World Net Nuclear Energy Consumption by Region, High Economic Growth Case, 1990-2015 (Billion Kilowatthours)

\begin{tabular}{|c|c|c|c|c|c|c|c|c|}
\hline \multirow[b]{2}{*}{ Region/Country } & \multicolumn{3}{|c|}{ History } & \multicolumn{4}{|c|}{ Projections } & \multirow{2}{*}{$\begin{array}{c}\text { Average Annual } \\
\text { Percent Change, } \\
1995-2015\end{array}$} \\
\hline & 1990 & 1994 & 1995 & 2000 & 2005 & 2010 & 2015 & \\
\hline \multicolumn{9}{|l|}{ Industrialized } \\
\hline North America . . . . . . . . & 648 & 746 & 774 & 791 & 760 & 709 & 544 & -1.7 \\
\hline United States $^{\mathrm{a}} \ldots \ldots \ldots$ & 577 & 640 & 673 & 687 & 654 & 614 & 448 & -2.0 \\
\hline Canada ..... & 69 & 102 & 92 & 96 & 98 & 87 & 88 & -0.3 \\
\hline Mexico . & 2 & 4 & 8 & 8 & 8 & 8 & 8 & 0.0 \\
\hline Western Europe $\ldots \ldots \ldots$ & 703 & 768 & 786 & 836 & 825 & 828 & 773 & -0.1 \\
\hline Industrialized Asia $\ldots \ldots \ldots$ & 182 & 256 & 275 & 291 & 322 & 337 & 359 & 1.3 \\
\hline Japan $\ldots \ldots \ldots \ldots \ldots$ & 182 & 256 & 275 & 291 & 322 & 337 & 359 & 1.3 \\
\hline Australasia $\ldots \ldots \ldots \ldots$ & 0 & 0 & 0 & 0 & 0 & 0 & 0 & - \\
\hline Total Industrialized . . . . . & 1,533 & 1,770 & 1,835 & 1,918 & 1,907 & 1,874 & 1,676 & -0.5 \\
\hline \multicolumn{9}{|l|}{ EE/FSU $\ldots \ldots \ldots \ldots \ldots$} \\
\hline Former Soviet Union . . . . . . . & 201 & 166 & 172 & 213 & 220 & 252 & 198 & 0.7 \\
\hline Eastern Europe $\ldots \ldots \ldots$ & 54 & 56 & 57 & 57 & 65 & 69 & 68 & 0.9 \\
\hline Total EE/FSU $\ldots \ldots \ldots$ & 256 & 222 & 229 & 270 & 285 & 320 & 266 & 0.7 \\
\hline \multicolumn{9}{|l|}{ Developing Countries } \\
\hline Developing Asia $\ldots \ldots \ldots$ & 88 & 106 & 118 & 152 & 219 & 299 & 387 & 6.1 \\
\hline China $\ldots \ldots \ldots \ldots \ldots$ & 0 & 14 & 12 & 13 & 36 & 69 & 128 & 12.4 \\
\hline India $\ldots \ldots \ldots \ldots$ & 6 & 5 & 7 & 11 & 16 & 20 & 33 & 7.9 \\
\hline Other Asia & 82 & 88 & 98 & 128 & 166 & 210 & 226 & 4.3 \\
\hline Middle East $\ldots \ldots \ldots \ldots$ & $\mathbf{0}$ & 0 & 0 & 0 & 5 & 10 & 11 & - \\
\hline Africa $\ldots \ldots \ldots \ldots \ldots$ & 8 & 10 & 11 & 10 & 11 & 11 & 11 & 0.1 \\
\hline Central and South America . & 9 & 8 & 9 & 9 & 19 & 19 & 20 & 3.8 \\
\hline Total Developing $\ldots .$. & 105 & 124 & 138 & 170 & 253 & 340 & 430 & 5.8 \\
\hline Total World $\ldots \ldots \ldots \ldots \ldots$ & 1,894 & 2,115 & 2,202 & 2,359 & 2,445 & 2,534 & 2,372 & 0.4 \\
\hline
\end{tabular}

Includes the 50 States and the District of Columbia. U.S. Territories are included in Australasia.

Notes: $E E / F S U=$ Eastern Europe/Former Soviet Union. Totals may not equal sum of components due to independent rounding. The electricity portion of the national fuel consumption values consists of generation for domestic use plus an adjustment for electricity trade based on a fuel's share of total generation in the exporting country.

Sources: History: Energy Information Administration (EIA), International Energy Annual 1995, DOE/ElA-0219(95) (Washington, DC, December 1996). Projections: EIA, Annual Energy Outlook 1997, DOE/EIA-0383(97) (Washington, DC, December 1996), Table A8; and World Energy Projection System (1997). 
Table A20. World Consumption of Hydroelectricity and Other Renewable Energy by Region, High Economic Growth Case, 1990-2015 (Quadrillion Btu)

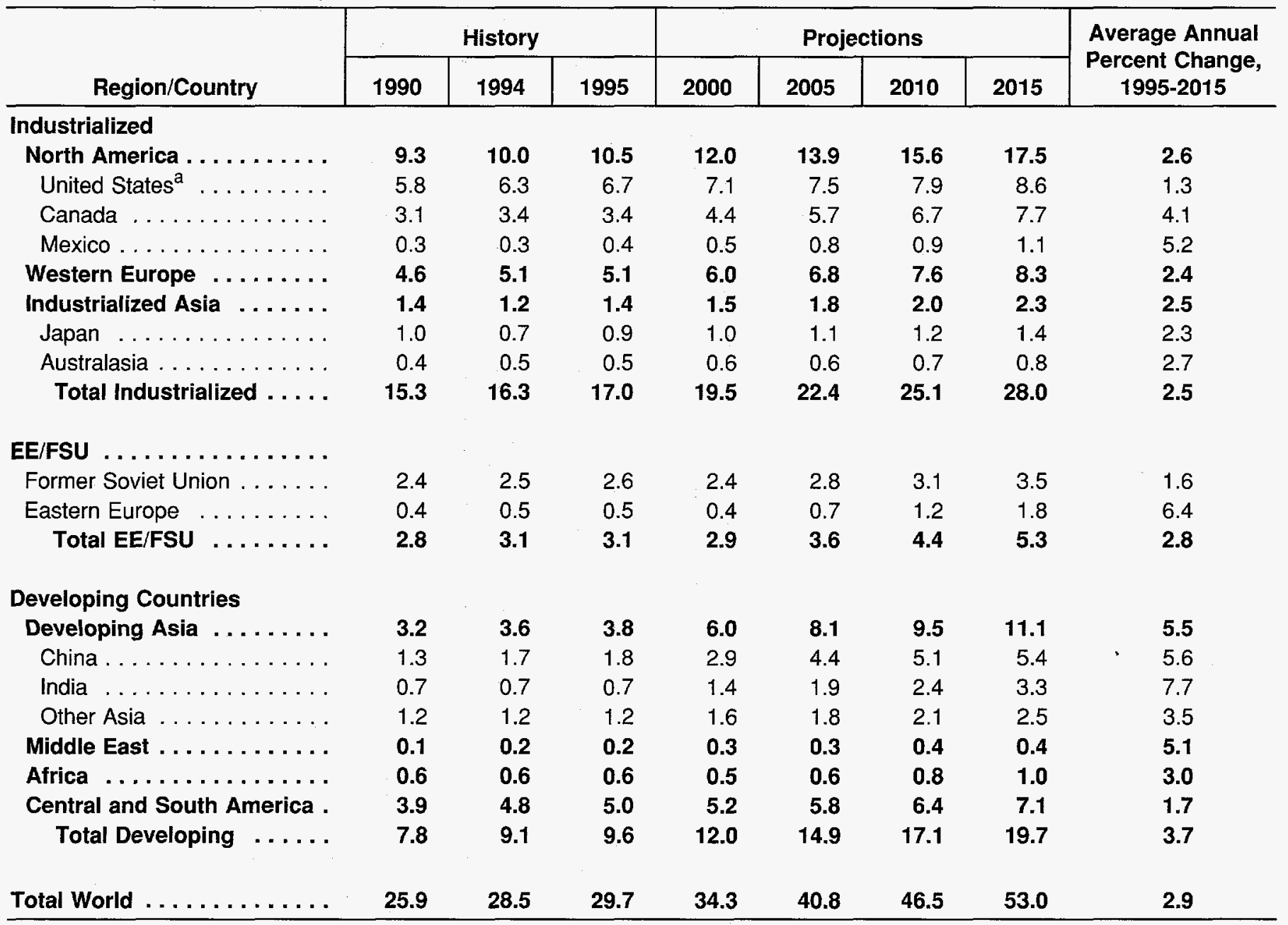

ancludes the 50 States and the District of Columbia. U.S. Territories are included in Australasia.

Notes: EE/FSU = Eastern Europe/Former Soviet Union. Totals may not equal sum of components due to independent rounding. The electricity portion of the national fuel consumption values consists of generation for domestic use plus an adjustment for electricity trade based on a fuel's share of total generation in the exporting country.

Sources: History: Energy Information Administration (EIA), International Energy Annual 1995, DOE/EIA-0219(95) (Washington, DC, December 1996). Projections: EIA, Annual Energy Outlook 1997, DOE/EIA-0383(97) (Washington, DC, December 1996), Table A1; and World Energy Projection System (1997). 
Table A21. World Total Net Electricity Consumption by Region, High Economic Growth Case, 1990-2015 (Billion Kilowatthours)

\begin{tabular}{|c|c|c|c|c|c|c|c|c|}
\hline \multirow[b]{2}{*}{ Region/Country } & \multicolumn{3}{|c|}{ History } & \multicolumn{4}{|c|}{ Projections } & \multirow{2}{*}{$\begin{array}{c}\text { Average Annual } \\
\text { Percent Change } \\
1995-2015\end{array}$} \\
\hline & 1990 & 1994 & 1995 & 2000 & 2005 & 2010 & 2015 & \\
\hline North America . . . . . . . . . . & 3,256 & 3,523 & 3,604 & 4,007 & 4,538 & 4,976 & 5,477 & 2.1 \\
\hline United States $^{a} \ldots \ldots \ldots$ & 2,715 & 2,937 & 3,011 & 3,291 & 3,693 & 4,009 & 4,370 & 1.9 \\
\hline Canada . . . . . . . . . & 435 & 456 & 459 & 528 & 598 & 666 & 747 & 2.5 \\
\hline Western Europe ........ & 2,116 & 2,230 & 2,276 & 2,778 & 3,165 & 3,569 & 3,992 & 2.8 \\
\hline Industrialized Asia . . . . . . & 920 & 1,037 & 1,066 & 1,342 & 1,537 & 1,721 & 1,890 & 2.9 \\
\hline Japan .............. & 741 & 841 & 865 & 1,055 & 1,201 & 1,342 & 1,469 & 2.7 \\
\hline Australasia . . . . . . . . . & 179 & 196 & 201 & 288 & 336 & 379 & 422 & 3.8 \\
\hline Total Industrialized . . . . . & 6,292 & 6,790 & 6,947 & 8,127 & 9,240 & 10,266 & 11,359 & 2.5 \\
\hline \multicolumn{9}{|l|}{ EE/FSU $\ldots \ldots \ldots \ldots \ldots \ldots$} \\
\hline Total EE/FSU $\ldots \ldots \ldots$ & 1,907 & 1,532 & 1,532 & 1,693 & 1,998 & 2,346 & 2,688 & 2.9 \\
\hline \multicolumn{9}{|l|}{ Developing Countries } \\
\hline Developing Asia . . . . . . . . & 1,266 & 1,734 & 1,826 & 2,622 & 3,635 & 4,757 & 6,148 & 6.3 \\
\hline China ............... & 551 & 797 & 823 & 1,120 & 1,584 & 2,170 & 2,936 & 6.6 \\
\hline India $\ldots \ldots \ldots \ldots \ldots$ & 257 & 340 & 372 & 542 & 787 & 1,058 & 1,387 & 6.8 \\
\hline Other Asia . . . . . . . . . & 458 & 597 & 631 & 959 & 1,264 & 1,530 & 1,826 & 5.5 \\
\hline Middle East . . . . . . . . . . & 198 & 255 & 268 & 314 & 374 & 431 & 495 & 3.1 \\
\hline Africa $\ldots \ldots \ldots \ldots$ & 274 & 302 & 309 & 422 & 525 & 650 & 793 & 4.8 \\
\hline Central and South America. & 446 & 538 & 561 & 704 & 893 & 1,112 & 1,373 & 4.6 \\
\hline
\end{tabular}

${ }^{a}$ Includes the 50 States and the District of Columbia. U.S. Territories are included in Australasia.

Notes: $\mathrm{EE} / \mathrm{FSU}=$ Eastern Europe/Former Soviet Union. Electricity consumption equals generation plus imports minus exports minus distribution losses.

Sources: History: Energy Information Administration (EIA), International Energy Annual 1995, DOE/EIA-0219(95) (Washington, DC, December 1996), Table 6.2. Projections: EIA, Annual Energy Outlook 1997, DOE/EIA-0383(97) (Washington, DC, December 1996), Table A8; and World Energy Projection System (1997). 
Table A22. World Total Carbon Emissions by Region, High Economic Growth Case, 1990-2015 (Million Metric Tons)

\begin{tabular}{|c|c|c|c|c|c|c|c|c|}
\hline \multirow[b]{2}{*}{ Region/Country } & \multicolumn{3}{|c|}{ History } & \multicolumn{4}{|c|}{ Projections } & \multirow{2}{*}{$\begin{array}{c}\text { Average Annual } \\
\text { Percent Change, } \\
\text { 1995-2015 }\end{array}$} \\
\hline & 1990 & 1994 & 1995 & 2000 & 2005 & 2010 & 2015 & \\
\hline \multicolumn{9}{|l|}{ Industrialized } \\
\hline North America . & 1,561 & 1,634 & 1,663 & 1,864 & 2,031 & 2,179 & 2,335 & 1.7 \\
\hline United States ${ }^{a}$ & 1,337 & 1,397 & 1,424 & 1,575 & 1,702 & 1,817 & 1,939 & 1.6 \\
\hline Canada ..... & 137 & 140 & 143 & 163 & 178 & 191 & 204 & 1.8 \\
\hline Mexico . . . . . . & 87 & 97 & 97 & 126 & 151 & 171 & 192 & 3.5 \\
\hline Western Europe $\ldots \ldots \ldots$ & 1,016 & 987 & 1,014 & 1,098 & 1,180 & 1,257 & 1,346 & 1.4 \\
\hline Industrialized Asia $\ldots \ldots$ & 408 & 449 & 473 & 523 & 570 & 620 & 661 & 1.7 \\
\hline Japan $\ldots \ldots \ldots \ldots \ldots$ & 308 & 354 & 361 & 408 & 446 & 488 & 522 & 1.9 \\
\hline Australasia $\ldots \ldots \ldots \ldots$ & 100 & 95 & 112 & 115 & 125 & 132 & 139 & 1.1 \\
\hline Total Industrialized . . . . & 2,985 & 3,069 & 3,151 & 3,485 & 3,781 & 4,056 & 4,341 & 1.6 \\
\hline \multicolumn{9}{|l|}{ EE/FSU $\ldots \ldots \ldots$} \\
\hline Former Soviet Union & 1,029 & 711 & 653 & 787 & 917 & 1,065 & 1,214 & 3.2 \\
\hline Eastern Europe . . . & 309 & 239 & 240 & 301 & 338 & 373 & 411 & 2.7 \\
\hline Total EE/FSU $\ldots \ldots \ldots$ & 1,339 & 949 & 893 & 1,087 & 1,255 & 1,438 & 1,625 & 3.0 \\
\hline \multicolumn{9}{|l|}{ Developing Countries } \\
\hline Developing Asia ... & 1,092 & 1,401 & 1,475 & 1,970 & 2,549 & $\mathbf{3 , 1 7 0}$ & 3,901 & 5.0 \\
\hline China ......... & 625 & 784 & 821 & 1,076 & 1,368 & 1,726 & 2,167 & 5.0 \\
\hline India $\ldots .$. & 159 & 205 & 221 & 296 & 398 & 503 & 612 & 5.2 \\
\hline Other Asia . . . . & 307 & 412 & 432 & 597 & 783 & 941 & 1,122 & 4.9 \\
\hline Middle East $\ldots \ldots \ldots \ldots$ & 203 & 241 & 254 & 282 & 326 & 368 & 418 & 2.5 \\
\hline Africa $\ldots \ldots \ldots \ldots \ldots$ & 205 & 239 & 248 & 281 & 324 & 372 & 422 & 2.7 \\
\hline Central and South America . & 189 & 212 & 220 & 282 & 364 & 465 & 585 & 5.0 \\
\hline Total Developing $\ldots .$. & 1,687 & 2,092 & 2,197 & 2,815 & 3,564 & 4,374 & 5,325 & 4.5 \\
\hline Total World $\ldots \ldots \ldots \ldots$ & 6,012 & 6,111 & 6,241 & 7,387 & 8,600 & 9,868 & 11,292 & 3.0 \\
\hline
\end{tabular}

${ }^{a}$ Includes the 50 States and the District of Columbia. U.S. Territories are included in Australasia.

Notes: $\mathrm{EE} / \mathrm{FSU}=$ Eastern Europe/Former Soviet Union. The U.S. numbers include carbon emissions attributable to renewable energy sources.

Sources: History: Derived from Energy Information Administration (EIA), International Energy Annual 1995, DOE/EIA0219(95) (Washington, DC, December 1996). Projections: EIA, Annual Energy Outlook 1997, DOE/EIA-0383(97) (Washington, DC, December 1996), Table A19; and World Energy Projection System (1997). 
Table A23. World Carbon Emissions from Oil Use by Region, High Economic Growth Case, 1990-2015 (Million Metric Tons)

\begin{tabular}{|c|c|c|c|c|c|c|c|c|}
\hline \multirow[b]{2}{*}{ Region/Country } & \multicolumn{3}{|c|}{ History } & \multicolumn{4}{|c|}{ Projections } & \multirow{2}{*}{$\begin{array}{c}\text { Average Annual } \\
\text { Percent Change, } \\
1995-2015\end{array}$} \\
\hline & 1990 & 1994 & 1995 & 2000 & 2005 & 2010 & 2015 & \\
\hline \multicolumn{9}{|l|}{ Industrialized } \\
\hline North America . . . . . . . . & 720 & 737 & 739 & 824 & 899 & 964 & 1,018 & 1.6 \\
\hline United States $^{a} \ldots \ldots \ldots$ & 583 & 596 & 599 & 663 & 719 & 763 & 795 & 1.4 \\
\hline Canada $\ldots \ldots \ldots \ldots$ & 67 & 67 & 67 & 74 & 81 & 87 & 94 & 1.7 \\
\hline Mexico & 69 & 74 & 73 & 87 & 99 & 113 & 129 & 2.9 \\
\hline Western Europe $\ldots \ldots \ldots$ & 537 & 562 & 576 & 599 & 628 & 649 & 669 & 0.7 \\
\hline Industrialized Asia $\ldots \ldots$ & 252 & 278 & 283 & 320 & 350 & 379 & 408 & 1.9 \\
\hline Japan $\ldots \ldots \ldots \ldots \ldots$ & 210 & 230 & 232 & 263 & 287 & 311 & 335 & 1.9 \\
\hline Australasia . . . . . . . . & 41 & 47 & 51 & 57 & 63 & 68 & 74 & 1.9 \\
\hline Total Industrialized . . . . . & 1,509 & 1,577 & 1,598 & 1,743 & 1,878 & 1,991 & 2,095 & 1.4 \\
\hline \multicolumn{9}{|l|}{ EE/FSU } \\
\hline Former Soviet Union . . . . . . . & 355 & 206 & 189 & 223 & 282 & 350 & 424 & 4.1 \\
\hline Eastern Europe $\ldots \ldots \ldots$ & 71 & 53 & 56 & 69 & 75 & 90 & 108 & 3.4 \\
\hline Total EE/FSU $\ldots \ldots \ldots$ & 427 & 259 & 245 & 292 & 357 & 440 & 533 & 4.0 \\
\hline \multicolumn{9}{|l|}{ Developing Countries } \\
\hline Developing Asia $\ldots \ldots \ldots$ & 325 & 441 & 468 & 623 & 836 & 1,035 & 1,283 & 5.2 \\
\hline China $\ldots \ldots \ldots \ldots \ldots$ & 98 & 132 & 139 & 194 & 254 & 330 & 428 & 5.8 \\
\hline India $\ldots \ldots \ldots \ldots \ldots$ & 49 & 59 & 66 & 83 & 112 & 140 & 174 & 5.0 \\
\hline Other Asia . . . . . . . . . & 178 & 251 & 263 & 346 & 470 & 565 & 682 & 4.9 \\
\hline Middle East $\ldots \ldots \ldots \ldots$ & 144 & 165 & 172 & 194 & 230 & 265 & 304 & 2.9 \\
\hline Africa $\ldots \ldots \ldots \ldots \ldots$ & 84 & 88 & 92 & 127 & 156 & 180 & 206 & 4.1 \\
\hline Central and South America . & 140 & 154 & 156 & 200 & 252 & 312 & 385 & 4.6 \\
\hline Total Developing $\ldots \ldots$ & 692 & 847 & 889 & 1,145 & 1,475 & 1,791 & 2,178 & 4.6 \\
\hline Total World $\ldots \ldots \ldots \ldots$ & 2,628 & 2,684 & 2,732 & 3,180 & 3,709 & 4,223 & 4,806 & 2.9 \\
\hline
\end{tabular}

${ }^{\mathrm{a}}$ Includes the 50 States and the District of Columbia. U.S. Territories are included in Australasia.

Notes: EE/FSU $=$ Eastern Europe/Former Soviet Union.

Sources: History: Derived from Energy Information Administration (EIA), International Energy Annual 1995, DOE/EIA0219(95) (Washington, DC, December 1996). Projections: EIA, Annual Energy Outlook 1997, DOE/EIA-0383(97) (Washington, DC, December 1996), Table A19; and World Energy Projection System (1997). 
Table A24. World Carbon Emissions from Nat: 1990-2015

Gas Use by Region, High Economic Growth Case, (Million Metric Tons)

\begin{tabular}{|c|c|c|c|c|c|c|c|c|}
\hline \multirow[b]{2}{*}{ Region/Country } & \multicolumn{3}{|c|}{ History } & \multicolumn{4}{|c|}{ Projections } & \multirow{2}{*}{$\begin{array}{c}\text { Average Annual } \\
\text { Percent Change, } \\
\text { 1995-2015 }\end{array}$} \\
\hline & 1990 & 1994 & 1995 & 2000 & 2005 & 2010 & 2015 & \\
\hline North America . . . . . . . . . . & 323 & 365 & 377 & 438 & 492 & 540 & 580 & 2.2 \\
\hline United States $^{\mathrm{a}} \ldots \ldots \ldots$ & 274 & 305 & 318 & 360 & 399 & 438 & 471 & 2.0 \\
\hline Canada $\ldots \ldots \ldots \ldots \ldots$ & 35 & 42 & 42 & 46 & 51 & 55 & 59 & 1.7 \\
\hline Western Europe . . . . . . . & 146 & 169 & 180 & 240 & 292 & 343 & 405 & 4.1 \\
\hline Industrialized Asia $\ldots \ldots \ldots$ & 42 & 48 & 49 & 58 & 70 & 80 & 88 & 2.9 \\
\hline Japan $\ldots \ldots \ldots \ldots \ldots$ & 30 & 35 & 35 & 43 & 53 & 62 & 69 & 3.4 \\
\hline Australasia . . . . . . . . . & 12 & 13 & 14 & 15 & 17 & 18 & 19 & 1.6 \\
\hline Total Industrialized . . . . . & 511 & 581 & 606 & 735 & 854 & 963 & 1,072 & 2.9 \\
\hline Total EE/FSU $\ldots \ldots \ldots$ & 379 & 317 & 305 & 421 & 499 & 588 & 677 & 4.1 \\
\hline \multicolumn{9}{|l|}{ Developing Countries } \\
\hline Developing Asia . . . . . . . & 44 & 64 & 69 & 160 & 234 & 309 & 389 & 9.0 \\
\hline China $\ldots . \ldots \ldots \ldots \ldots$ & 8 & 10 & 8 & 27 & 45 & 58 & 64 & 10.9 \\
\hline India $\ldots \ldots \ldots \ldots$ & 6 & 9 & 10 & 23 & 43 & 69 & 102 & 12.3 \\
\hline Other Asia . . . . . . . . . . . & 30 & 46 & 51 & 110 & 146 & 182 & 223 & 7.6 \\
\hline Middle East . . . . . . . . . . . & 55 & 69 & 74 & 81 & 88 & 95 & 104 & 1.7 \\
\hline Africa $\ldots \ldots \ldots \ldots$ & 21 & 25 & 26 & 25 & 30 & 39 & 50 & 3.4 \\
\hline Central and South America . & 31 & 39 & 42 & 56 & 82 & 115 & 154 & 6.7 \\
\hline
\end{tabular}

ancludes the 50 States and the District of Columbia. U.S. Territories are included in Australasia.

Notes: EE/FSU = Eastern Europe/Former Soviet Union.

Sources: History: Derived from Energy Information Administration (EIA), International Energy Annual 1995, DOE/EIA0219(95) (Washington, DC, December 1996). Projections: ElA, Annual Energy Outlook 1997, DOE/EIA-0383(97) (Washington, DC, December 1996), Table A19; and World Energy Projection System (1997). 
Table A25. World Carbon Emissions from Coal Use by Region, High Economic Growth Case, 1990-2015 (Million Metric Tons)

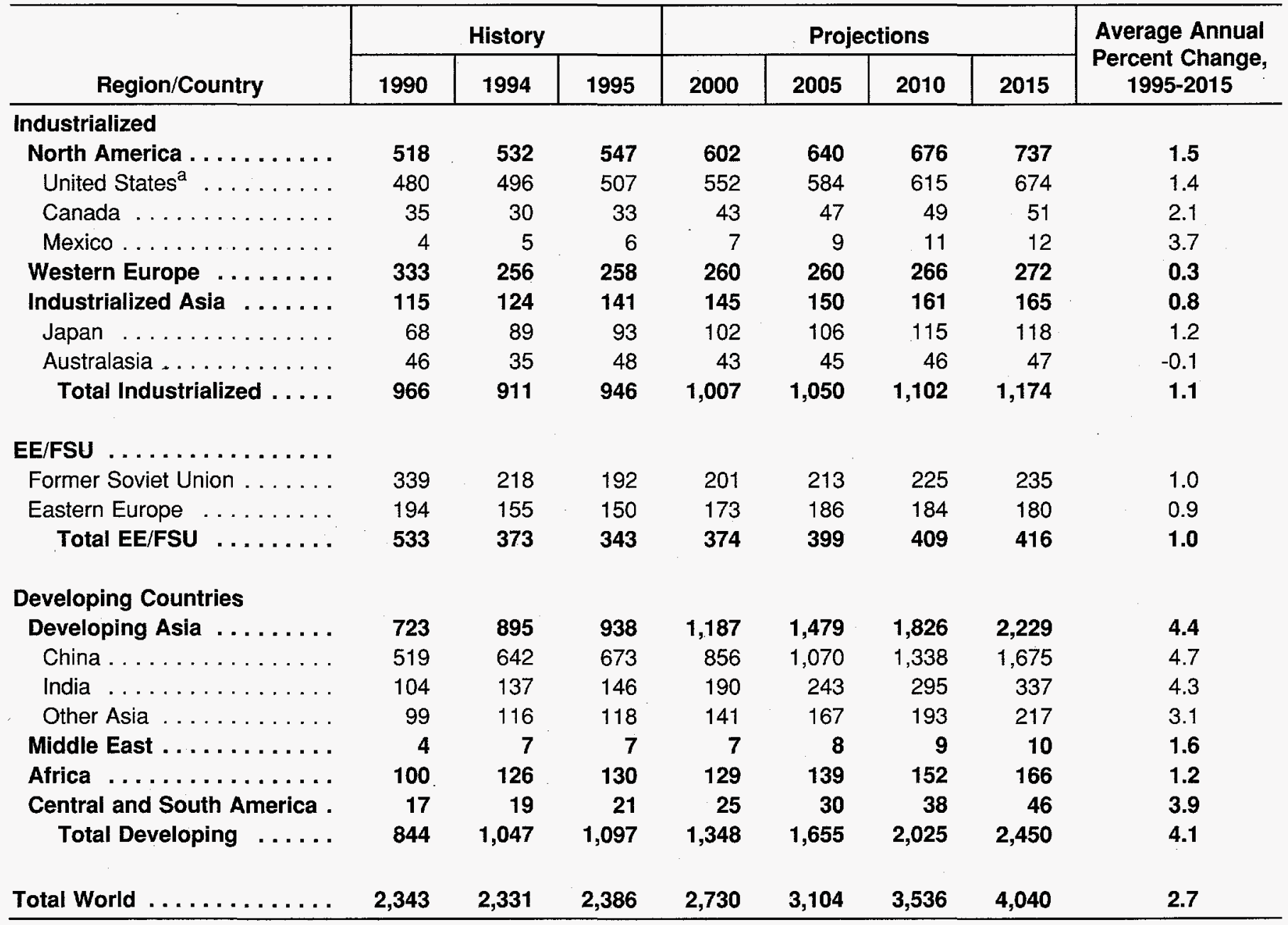

${ }^{a}$ Includes the 50 States and the District of Columbia. U.S. Territories are included in Australasia.

Notes: EE/FSU $=$ Eastern Europe/Former Soviet Union.

Sources: History: Derived from Energy Information Administration (EIA), International Energy Annual 1995, DOE/EIA0219(95) (Washington, DC, December 1996). Projections: EIA, Annual Energy Outlook 1997, DOE/EIA-0383(97) (Washington, DC, December 1996), Table A19; and World Energy Projection System (1997). 
Table A26. World Total Energy Consumption in Oil-Equivalent Units by Region, High Economic Growth Case, 1990-2015

(Million Tons Oil Equivalent)

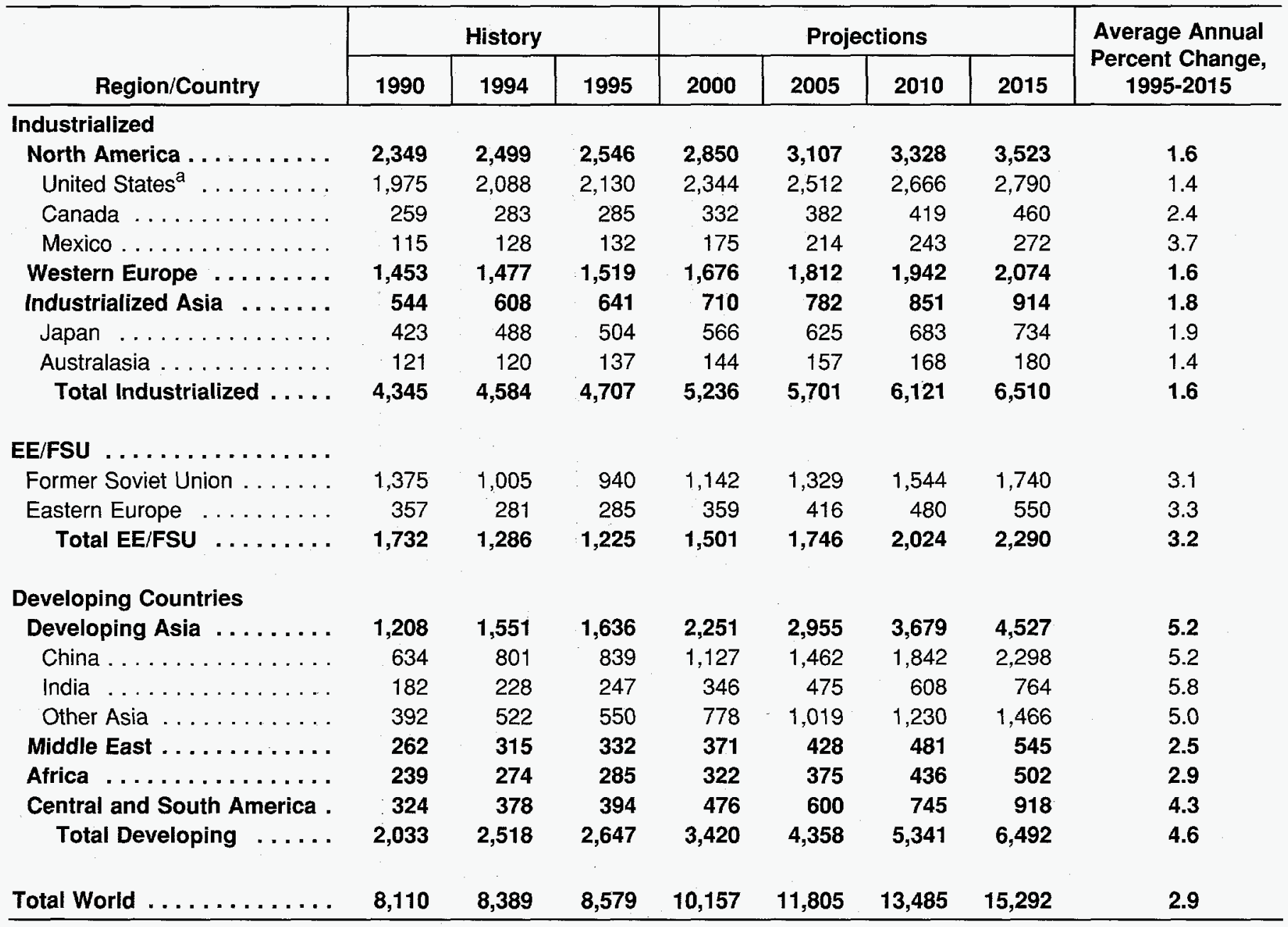

$\mathrm{a}_{\text {Includes the }} 50$ States and the District of Columbia. U.S. Territories are included in Australasia.

Notes: EE/FSU = Eastern Europe/Former Soviet Union.

Sources: History: Derived from Energy Information Administration (EIA), International Energy Annual 1995, DOE/EIA0219(95) (Washington, DC, December 1996). Projections: EIA, Annual Energy Outlook 1997, DOE/EIA-0383(97) (Washington, DC, December 1996), Table A19; and World Energy Projection System (1997). 
Table A27. World Total Energy Consumption by Region, Low Economic Growth Case, 1990-2015 (Quadrillion Btu)

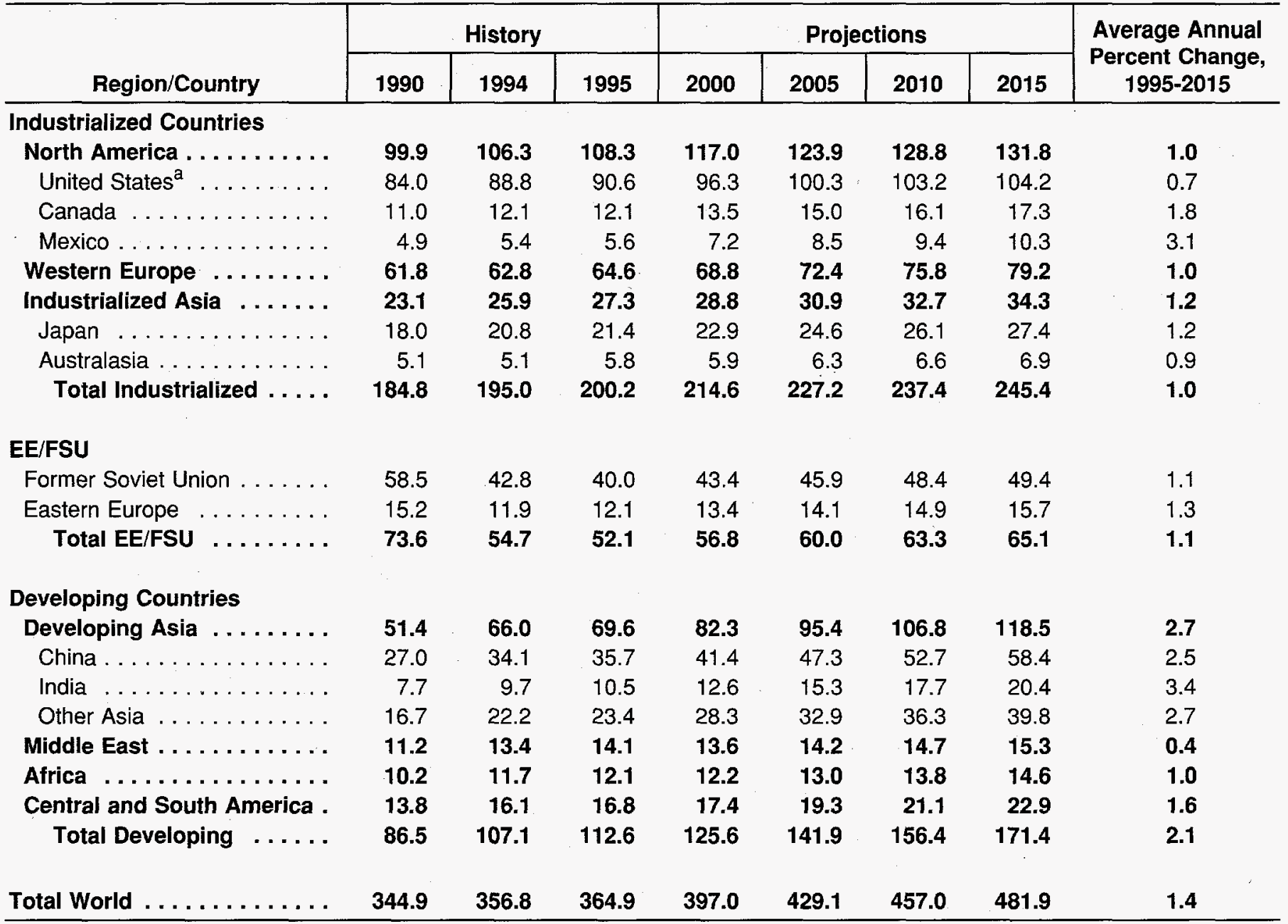

${ }^{a}$ Includes the 50 States and the District of Columbia. U.S. Territories are included in Australasia.

Notes: $E E / F S U=$ Eastern Europe/Former Soviet Union. Energy totals include net imports of coal coke and electricity generated from biomass in the United States. Totals may not equal sum of components due to independent rounding. The electricity portion of the national fuel consumption values consists of generation for domestic use plus an adjustment for electricity trade based on a fuel's share of total generation in the exporting country.

Sources: History: Energy Information Administration (EIA), International Energy Annual 1995, DOE/EIA-0219(95) (Washington, DC, December 1996). Projections: EIA, Annual Energy Outlook 1997, DOE/EIA-0383(97) (Washington, DC, December 1996), Table A1; and World Energy Projection System (1997). 
Table A28. World Total Energy Consumption by Region and Fuel, Low Economic Growth Case, 1990-2015 (Quadrillion Btu)

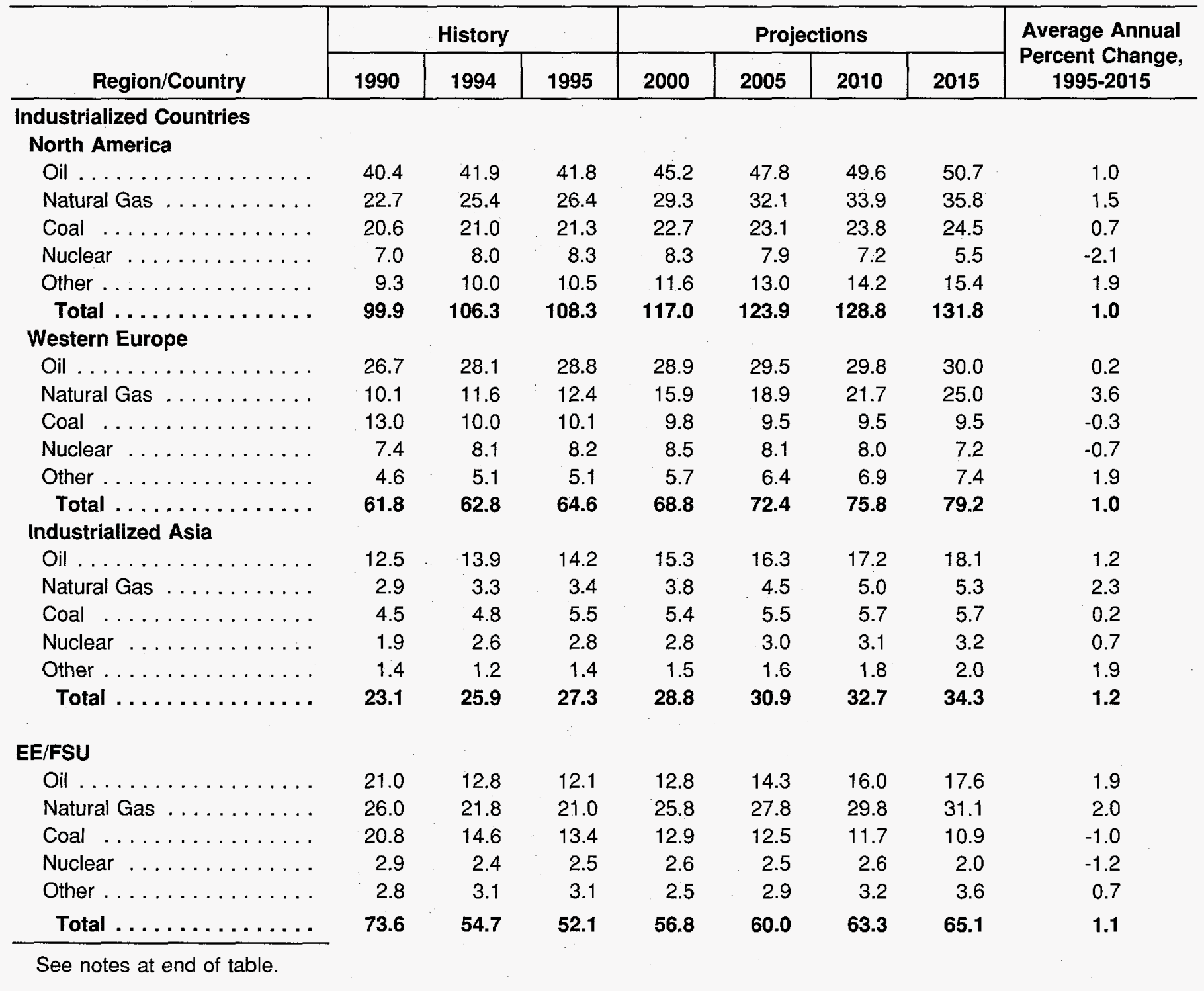


Table A28. World Total Energy Consumption by Region and Fuel, Low Economic Growth Case, 1990-2015 (Continued)

(Quadrillion Btu)

\begin{tabular}{|c|c|c|c|c|c|c|c|c|}
\hline \multirow[b]{2}{*}{ Region/Country } & \multicolumn{3}{|c|}{ History } & \multicolumn{4}{|c|}{ Projections } & \multirow{2}{*}{$\begin{array}{c}\text { Average Annual } \\
\text { Percent Change, } \\
\text { 1995-2015 }\end{array}$} \\
\hline & 1990 & 1994 & 1995 & 2000 & 2005 & 2010 & 2015 & \\
\hline \multicolumn{9}{|l|}{$\begin{array}{l}\text { Developing Countries } \\
\text { Developing Asia }\end{array}$} \\
\hline Oil $\ldots \ldots \ldots \ldots \ldots$ & 16.0 & 21.9 & 23.2 & 26.5 & 31.5 & 35.3 & 39.7 & 2.7 \\
\hline Natural Gas . . . . . . . . & 3.0 & 4.4 & 4.8 & 9.4 & 12.2 & 14.6 & 16.8 & 6.5 \\
\hline Coal $\ldots \ldots \ldots \ldots \ldots$ & 28.2 & 35.0 & 36.6 & 39.9 & 43.9 & 48.3 & 52.7 & 1.8 \\
\hline Nuclear $\ldots \ldots \ldots \ldots \ldots$ & 0.9 & 1.1 & 1.2 & 1.3 & 1.7 & 2.1 & 2.5 & 3.7 \\
\hline Other $\ldots \ldots \ldots \ldots \ldots \ldots$ & 3.2 & 3.6 & 3.8 & 5.1 & 6.2 & 6.5 & 6.9 & 3.0 \\
\hline Total $\ldots \ldots \ldots \ldots \ldots$ & 51.4 & 66.0 & 69.6 & 82.3 & 95.4 & 106.8 & 118.5 & 2.7 \\
\hline \multicolumn{9}{|l|}{ Middle East } \\
\hline Oil .............. & 7.1 & 8.2 & 8.6 & 8.3 & 8.9 & 9.4 & 10.0 & 0.8 \\
\hline Natural Gas . . . . . . . . . & 3.8 & 4.8 & 5.1 & 4.8 & 4.7 & 4.7 & 4.7 & -0.4 \\
\hline Coal $\ldots \ldots \ldots \ldots \ldots$ & 0.2 & 0.3 & 0.3 & 0.2 & 0.2 & 0.2 & 0.3 & -0.4 \\
\hline Nuclear $\ldots \ldots \ldots \ldots \ldots$ & 0.0 & 0.0 & 0.0 & 0.0 & 0.0 & 0.1 & 0.1 & 0.0 \\
\hline Other $\ldots \ldots \ldots \ldots \ldots$ & 0.1 & 0.2 & 0.2 & 0.2 & 0.3 & 0.3 & 0.3 & 3.0 \\
\hline Total $\ldots \ldots \ldots \ldots \ldots$ & 11.2 & 13.4 & 14.1 & 13.6 & 14.2 & 14.7 & 15.3 & 0.4 \\
\hline \multicolumn{9}{|l|}{ Africa } \\
\hline$\ldots \ldots \ldots$ & 4.2 & 4.4 & 4.6 & 5.7 & 6.3 & 6.7 & 7.1 & 2.2 \\
\hline Natural Gas . . . . . . . . & 1.4 & 1.7 & 1.8 & 1.5 & 1.7 & 2.0 & 2.4 & 1.5 \\
\hline Coal $\ldots \ldots \ldots \ldots \ldots$ & 3.9 & 4.9 & 5.1 & 4.5 & 4.4 & 4.4 & 4.4 & -0.7 \\
\hline Nuclear $\ldots \ldots \ldots \ldots$ & 0.1 & 0.1 & 0.1 & 0.1 & 0.1 & 0.1 & 0.1 & -1.8 \\
\hline Other $\ldots \ldots \ldots \ldots \ldots$ & 0.6 & 0.6 & 0.6 & 0.4 & 0.5 & 0.6 & 0.7 & 1.1 \\
\hline Total $\ldots \ldots \ldots \ldots \ldots$ & 10.2 & 11.7 & 12.1 & 12.2 & 13.0 & 13.8 & 14.6 & 1.0 \\
\hline \multicolumn{9}{|l|}{ Central and South America } \\
\hline Oil $\ldots \ldots \ldots \ldots \ldots \ldots$ & 7.0 & 7.7 & 7.9 & 8.7 & 9.6 & 10.4 & 11.4 & 1.8 \\
\hline Natural Gas . . . . . . . . & 2.1 & 2.7 & 2.9 & 3.3 & 4.3 & 5.3 & 6.2 & 3.9 \\
\hline Coal $\ldots \ldots \ldots \ldots \ldots$ & 0.7 & 0.7 & 0.8 & 0.8 & 0.9 & 1.0 & 1.0 & 1.2 \\
\hline Nuclear $\ldots \ldots \ldots \ldots \ldots$ & 0.1 & 0.1 & 0.1 & 0.1 & 0.2 & 0.2 & 0.1 & 1.2 \\
\hline Other $\ldots \ldots \ldots \ldots \ldots$ & 3.9 & 4.8 & 5.0 & 4.5 & 4.4 & 4.2 & 4.1 & -1.0 \\
\hline Total $\ldots \ldots \ldots \ldots$ & 13.8 & 16.1 & 16.8 & 17.4 & 19.3 & 21.1 & 22.9 & 1.6 \\
\hline \multicolumn{9}{|l|}{ Total World } \\
\hline Oil ....... & 134.9 & 138.9 & 141.1 & 151.4 & 164.1 & 174.4 & 184.5 & 1.3 \\
\hline Natural Gas & 72.0 & 75.7 & 77.7 & 93.9 & 106.1 & 116.8 & 127.4 & 2.5 \\
\hline Coal $\ldots .$. & 91.8 & 91.2 & 93.1 & 96.3 & 100.0 & 104.7 & 109.1 & 0.8 \\
\hline Nuclear $\ldots \ldots \ldots \ldots \ldots$ & 20.3 & 22.4 & 23.3 & 23.8 & 23.6 & 23.3 & 20.6 & -0.6 \\
\hline Other $\ldots \ldots \ldots \ldots \ldots$ & 25.9 & 28.5 & 29.7 & 31.6 & 35.2 & 37.7 & 40.4 & 1.6 \\
\hline Total $\ldots \ldots \ldots \ldots \ldots$ & 344.9 & 356.8 & 364.9 & 397.0 & 429.1 & 457.0 & 481.9 & 1.4 \\
\hline
\end{tabular}

${ }^{a}$ Includes the 50 States and the District of Columbia. U.S. Territories are included in Australasia.

Notes: $\mathrm{EE} / \mathrm{FSU}=$ Eastern Europe/Former Soviet Union. Energy totals include net imports of coal coke and electricity generated from biomass in the United States. Totals may not equal sum of components due to independent rounding. The electricity portion of the national fuel consumption values consists of generation for domestic use plus an adjustment for electricity trade based on a fuel's share of total generation in the exporting country.

Sources: History: Energy Information Administration (EIA), International Energy Annual 1995, DOE/EIA-0219(95) (Washington, DC, December 1996). Projections: EIA, Annual Energy Outlook 1997, DOE/EIA-0383(97) (Washington, DC, December 1996), Table A1; and World Energy Projection System (1997). 
Table A29. World Total Oil Consumption by Region, Low Economic Growth Case, 1990-2015 (Million Barrels per Day)

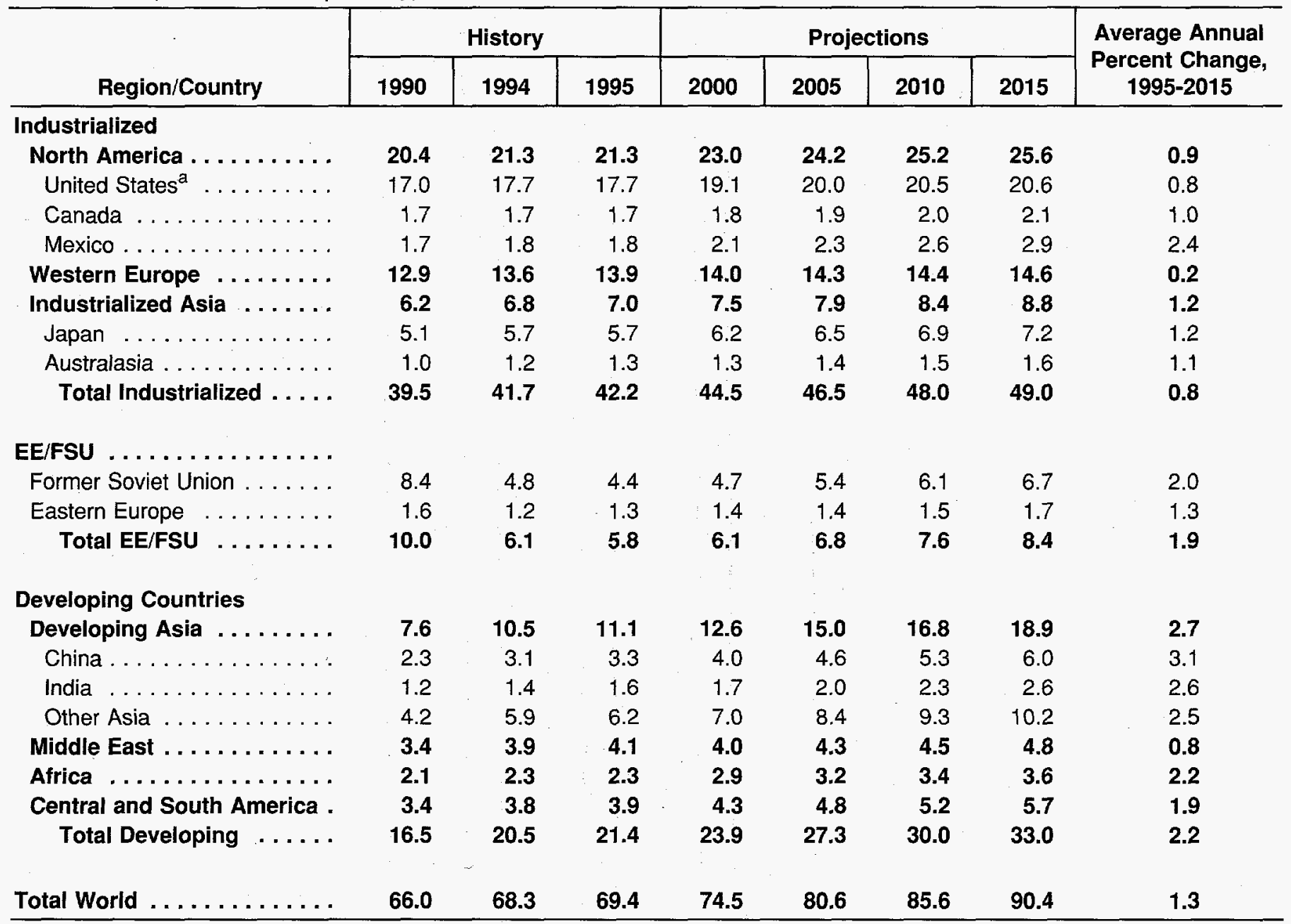

Includes the 50 States and the District of Columbia. U.S. Territories are included in Australasia.

Notes: EE/FSU = Eastern Europe/Former Soviet Union. Totals may not equal sum of components due to independent rounding. The electricity portion of the national fuel consumption values consists of generation for domestic use plus an adjustment for electricity trade based on a fuel's share of total generation in the exporting country.

Sources: History: Energy Information Administration (EIA), International Energy Annual 1995, DOE/EIA-0219(95) (Washington, DC, December 1996). Projections: ElA, Annual Energy Outlook 1997, DOE/EIA-0383(97) (Washington, DC, December 1996), Table A21; and World Energy Projection System (1997). 
Table A30. World Total Natural Gas Consumption by Region, Low Economic Growth Case, 1990-2015 (Trillion Cubic Feet)

\begin{tabular}{|c|c|c|c|c|c|c|c|c|}
\hline \multirow[b]{2}{*}{ Region/Country } & \multicolumn{3}{|c|}{ History } & \multicolumn{4}{|c|}{ Projections } & \multirow{2}{*}{$\begin{array}{c}\text { Average Annual } \\
\text { Percent Change, } \\
\text { 1995-2015 }\end{array}$} \\
\hline & 1990 & 1994 & 1995 & 2000 & 2005 & 2010 & 2015 & \\
\hline \multicolumn{9}{|l|}{ Industrialized } \\
\hline North America $\ldots \ldots \ldots \ldots$ & 22.0 & 24.5 & 25.4 & 28.0 & 30.8 & 32.3 & 34.4 & 1.5 \\
\hline United States $^{\mathrm{a}} \ldots \ldots \ldots$ & 18.7 & 20.8 & 21.6 & 23.3 & 25.4 & 26.5 & 28.4 & 1.4 \\
\hline Canada $\ldots \ldots \ldots \ldots \ldots$ & 2.4 & 2.8 & 2.8 & 3.0 & 3.2 & 3.4 & 3.5 & 1.2 \\
\hline Mexico $\ldots \ldots \ldots \ldots \ldots$ & 0.9 & 1.0 & 1.0 & 1.7 & 2.2 & 2.4 & 2.5 & 4.8 \\
\hline Western Europe $\ldots \ldots \ldots$ & 10.3 & 11.8 & 12.6 & 16.0 & 19.0 & 21.7 & 25.0 & 3.5 \\
\hline Industrialized Asia $\ldots \ldots \ldots$ & 2.6 & 3.0 & 3.1 & 3.5 & 4.1 & 4.6 & 4.9 & 2.3 \\
\hline Japan $\ldots \ldots \ldots \ldots \ldots$ & 1.9 & 2.2 & 2.2 & 2.5 & 3.0 & 3.5 & 3.8 & 2.7 \\
\hline Australasia $\ldots \ldots \ldots \ldots$ & 0.8 & 0.8 & 0.9 & 0.9 & 1.1 & 1.1 & 1.1 & 1.1 \\
\hline Total Industrialized . . . . . & 35.0 & 39.3 & 41.1 & 47.5 & 53.9 & 58.6 & 64.3 & 2.3 \\
\hline \multicolumn{9}{|l|}{ EE/FSU $\ldots \ldots \ldots$} \\
\hline Former Soviet Union & 25.0 & 21.7 & 20.6 & 24.5 & 25.8 & 27.2 & 28.0 & 1.5 \\
\hline Eastern Europe $\ldots$ & 3.1 & 2.4 & 2.6 & 3.9 & 4.7 & 5.5 & 6.3 & 4.5 \\
\hline Total EE/FSU $\ldots \ldots \ldots$ & 28.1 & 24.1 & 23.2 & 28.4 & 30.6 & 32.8 & 34.3 & 2.0 \\
\hline \multicolumn{9}{|l|}{ Developing Countries } \\
\hline Developing Asia $\ldots \ldots \ldots$ & 3.0 & 4.4 & 4.8 & 9.2 & 11.9 & 14.3 & 16.4 & 6.3 \\
\hline China $\ldots \ldots \ldots \ldots \ldots$ & 0.5 & 0.6 & 0.6 & 1.5 & 2.2 & 2.6 & 2.5 & 7.4 \\
\hline India $\ldots \ldots \ldots \ldots \ldots$ & 0.4 & 0.6 & 0.7 & 1.3 & 2.2 & 3.1 & 4.2 & 9.8 \\
\hline Other Asia $\ldots \ldots \ldots \ldots$ & 2.1 & 3.2 & 3.6 & 6.4 & 7.5 & 8.6 & 9.6 & 5.1 \\
\hline Middle East $\ldots \ldots \ldots \ldots$ & 3.6 & 4.5 & 4.9 & 4.6 & 4.5 & 4.5 & 4.5 & -0.4 \\
\hline Africa $\ldots \ldots \ldots \ldots \ldots$ & 1.4 & 1.6 & 1.7 & 1.4 & 1.6 & 1.9 & 2.2 & 1.5 \\
\hline Central and South America . & 2.0 & 2.4 & 2.6 & 3.0 & 3.9 & 4.7 & 5.6 & 3.9 \\
\hline Total Developing $\ldots \ldots$ & 9.9 & 13.0 & 14.0 & 18.2 & 21.9 & 25.4 & 28.8 & 3.7 \\
\hline Total World $\ldots \ldots \ldots \ldots$ & 73.0 & 76.4 & 78.3 & 94.1 & 106.4 & 116.7 & 127.3 & 2.5 \\
\hline
\end{tabular}

ancludes the 50 States and the District of Columbia. U.S. Territories are included in Australasia.

Notes: $\mathrm{EE} / \mathrm{FSU}=$ Eastern Europe/Former Soviet Union. Totals may not equal sum of components due to independent rounding. The electricity portion of the national fuel consumption values consists of generation for domestic use plus an adjustment for electricity trade based on a fuel's share of total generation in the exporting country. To convert cubic feet to cubic meters, divide each number in the table by 35.315 .

Sources: History: Energy Information Administration (EIA), International Energy Annual 1995, DOE/EIA-0219(95) (Washington, DC, December 1996). Projections: EIA, Annual Energy Outlook 1997, DOE/EIA-0383(97) (Washington, DC, December 1996), Table A13; and World Energy Projection System (1997). 
Table A31. World Total Coal Consumption by Region, Low Economic Growth Case, 1990-2015 (Million Short Tons)

\begin{tabular}{|c|c|c|c|c|c|c|c|c|}
\hline \multirow[b]{2}{*}{ Region/Country } & \multicolumn{3}{|c|}{ History } & \multicolumn{4}{|c|}{ Projections } & \multirow{2}{*}{$\begin{array}{c}\text { Average Annual } \\
\text { Percent Change } \\
\text { 1995-2015 }\end{array}$} \\
\hline & 1990 & 1994 & 1995 & 2000 & 2005 & 2010 & 2015 & \\
\hline \multicolumn{9}{|l|}{ Industrialized } \\
\hline North America . . . . . . . . . . & 962 & 996 & 1,019 & 1,087 & 1,116 & 1,158 & 1,192 & 0.8 \\
\hline United States $^{\mathrm{a}} \ldots \ldots \ldots$ & 896 & 932 & 949 & 1,002 & 1,022 & 1,060 & 1,091 & 0.7 \\
\hline Canada ..... & 59 & 54 & 58 & 72 & 76 & 78 & 79 & 1.5 \\
\hline Mexico . . . . . . . . . . & 7 & 11 & 12 & 13 & 18 & 20 & 22 & 3.1 \\
\hline Western Europe $\ldots \ldots \ldots$ & 951 & 683 & 678 & 671 & 656 & 657 & 662 & -0.1 \\
\hline Industrialized Asia $\ldots \ldots$ & 243 & 234 & 266 & 259 & 260 & 269 & 270 & 0.1 \\
\hline Japan $\ldots \ldots \ldots \ldots$ & 123 & 134 & 140 & 146 & 147 & 156 & 156 & 0.5 \\
\hline Australasia $\ldots \ldots \ldots \ldots$ & 120 & 101 & 125 & 113 & 114 & 114 & 114 & -0.5 \\
\hline Total Industrialized . . . . . & 2,156 & 1,913 & 1,962 & 2,017 & 2,032 & 2,084 & 2,123 & 0.4 \\
\hline \multicolumn{9}{|l|}{ EE/FSU } \\
\hline Former Soviet Union . . . . . . & 848 & 553 & 492 & 462 & 445 & 426 & 404 & -1.0 \\
\hline Eastern Europe $\ldots \ldots \ldots$ & 525 & 421 & 412 & 413 & 403 & 365 & 329 & -1.1 \\
\hline Total EE/FSU $\ldots \ldots \ldots$ & 1,374 & 974 & 904 & 875 & 847 & 792 & 733 & -1.0 \\
\hline \multicolumn{9}{|l|}{ Developing Countries } \\
\hline Developing Asia $\ldots \ldots \ldots$ & 1,560 & 1,922 & 2,012 & 2,199 & 2,419 & 2,666 & 2,911 & 1.9 \\
\hline China $\ldots \ldots \ldots \ldots \ldots$ & 1,124 & 1,397 & 1,464 & 1,607 & 1,768 & 1,959 & 2,175 & 2.0 \\
\hline India $\ldots \ldots \ldots \ldots$ & 242 & 309 & 327 & 365 & 412 & 454 & 475 & 1.9 \\
\hline Other Asia $\ldots \ldots \ldots \ldots$ & 194 & 217. & 222 & 227 & 239 & 253 & 261 & 0.8 \\
\hline Middle East $\ldots \ldots \ldots \ldots$ & 6 & 9 & 10 & 8 & 8 & 8 & 9 & -0.5 \\
\hline Africa $\ldots \ldots \ldots \ldots \ldots$ & 152 & 175 & 180 & 160 & 156 & 157 & 158 & -0.7 \\
\hline Central and South America . & 30 & 31 & 35 & 36 & 37 & 41 & 44 & 1.2 \\
\hline Total Developing $\ldots \ldots$ & 1,748 & 2,137 & 2,238 & 2,404 & 2,621 & 2,873 & 3,122 & 1.7 \\
\hline Total World & 5,278 & 5,024 & 5,104 & 5,295 & 5,500 & 5,749 & 5,979 & 0.8 \\
\hline
\end{tabular}

${ }^{a}$ Includes the 50 States and the District of Columbia. U.S. Territories are included in Australasia.

Notes: EE/FSU $=$ Eastern Europe/Former Soviet Union. Range values for Western Europe and the four regional totals are not equal to the sum of the component countries or country groups but consist of the base value adjusted by the quantity: the square root of the sum of the squared deviations of the respective component countries or country groups from their base value. Other totals may not equal sum of components due to independent rounding. The electricity portion of the national fuel consumption values consists of generation for domestic use plus an adjustment for electricity trade based on a fuel's share of total generation in the exporting country.To convert short tons to metric tons, divide each number in the table by 1.102 .

Sources: History: Energy Information Administration (EIA), International Energy Annual 1995, DOE/EIA-0219(95) (Washington, DC, December 1996). Projections: EIA, Annual Energy Outlook 1997, DOE/EIA-0383(97) (Washington, DC, December 1996), Table A16; and World Energy Projection System (1997). 
Table A32. World Net Nuclear Energy Consumption by Region, Low Economic Growth Case, 1990-2015 (Billion Kilowatthours)

\begin{tabular}{|c|c|c|c|c|c|c|c|c|}
\hline \multirow[b]{2}{*}{ Region/Country } & \multicolumn{3}{|c|}{ History } & \multicolumn{4}{|c|}{ Projections } & \multirow{2}{*}{$\begin{array}{c}\text { Average Annual } \\
\text { Percent Change, } \\
\text { 1995-2015 }\end{array}$} \\
\hline & 1990 & 1994 & 1995 & 2000 & 2005 & 2010 & 2015 & \\
\hline \multicolumn{9}{|l|}{ Industrialized } \\
\hline North America . & 648 & 746 & 774 & 786 & 752 & 699 & 533 & -1.8 \\
\hline United States $^{\mathrm{a}} \ldots \ldots \ldots$ & 577 & 640 & 673 & 687 & 654 & 614 & 448 & -2.0 \\
\hline Canada $\ldots \ldots \ldots \ldots$ & 69 & 102 & 92 & 92 & 91 & 78 & 77 & -0.9 \\
\hline Mexico ............. & 2 & 4 & 8 & 7 & 7 & 7 & 7 & -0.6 \\
\hline Western Europe & 703 & 768 & 786 & 806 & 775 & 758 & 690 & -0.6 \\
\hline Industrialized Asia . . . . . & 182 & 256 & 275 & 277 & 297 & 303 & 315 & 0.7 \\
\hline Japan $\ldots \ldots \ldots$ & 182 & 256 & 275 & 277 & 297 & 303 & 315 & 0.7 \\
\hline Australasia . . . . . . . . . & 0 & 0 & 0 & 0 & 0 & 0 & 0 & - \\
\hline Total Industrialized . . . . . & 1,533 & 1,770 & 1,835 & 1,869 & 1,824 & 1,761 & 1,538 & -0.9 \\
\hline \multicolumn{9}{|l|}{ EE/FSU } \\
\hline Former Soviet Union & 201 & 166 & 172 & 191 & 179 & 185 & 132 & -1.3 \\
\hline Eastern Europe $\ldots$ & 54 & 56 & 57 & 50 & 52 & 50 & 46 & -1.1 \\
\hline Total EE/FSU $\ldots \ldots \ldots$ & 256 & 222 & 229 & 240 & 231 & 235 & 178 & -1.3 \\
\hline \multicolumn{9}{|l|}{ Developing Countries } \\
\hline Developing Asia $\ldots \ldots \ldots$ & 88 & 106 & 118 & 130 & 166 & 206 & 241 & 3.7 \\
\hline China $\ldots \ldots \ldots \ldots \ldots$ & 0 & 14 & 12 & 11 & 28 & 46 & 76 & 9.5 \\
\hline India $\ldots \ldots \ldots \ldots$ & 6 & 5 & 7 & 9 & 12 & 14 & 21 & 5.4 \\
\hline Other Asia $\ldots \ldots \ldots \ldots$ & 82 & 88 & 98 & 109 & 126 & 146 & 144 & 1.9 \\
\hline Middle East $\ldots \ldots \ldots \ldots$ & 0 & 0 & 0 & 0 & 4 & 7 & 8 & - \\
\hline Africa $\ldots \ldots \ldots \ldots \ldots$ & 8 & 10 & 11 & 9 & 9 & 8 & 8 & -1.8 \\
\hline Central and South America . & 9 & 8 & 9 & 7 & 14 & 13 & 12 & 1.1 \\
\hline Total Developing $\ldots \ldots$ & 105 & 124 & 138 & 146 & 192 & 235 & 269 & 3.4 \\
\hline Total World $\ldots \ldots \ldots \ldots \ldots$ & 1,894 & 2,115 & 2,202 & 2,256 & 2,247 & 2,231 & 1,984 & -0.5 \\
\hline
\end{tabular}

${ }^{a}$ Includes the 50 States and the District of Columbia. U.S. Territories are included in Australasia.

Notes: EE/FSU = Eastern Europe/Former Soviet Union. Totals may not equal sum of components due to independent rounding. The electricity portion of the national fuel consumption values consists of generation for domestic use plus an adjustment for electricity trade based on a fuel's share of total generation in the exporting country.

Sources: History: Energy Information Administration (EIA), International Energy Annual 1995, DOE/EIA-0219(95) (Washington, DC, December 1996). Projections: EIA, Annual Energy Outlook 1997, DOE/EIA-0383(97) (Washington, DC, December 1996), Table A8; and World Energy Projection System (1997). 
Table A33. World Consumption of Hydroelectricity and Other Renewable Energy by Region, Low Economic Growth Case, 1990-2015 (Quadrillion Btu)

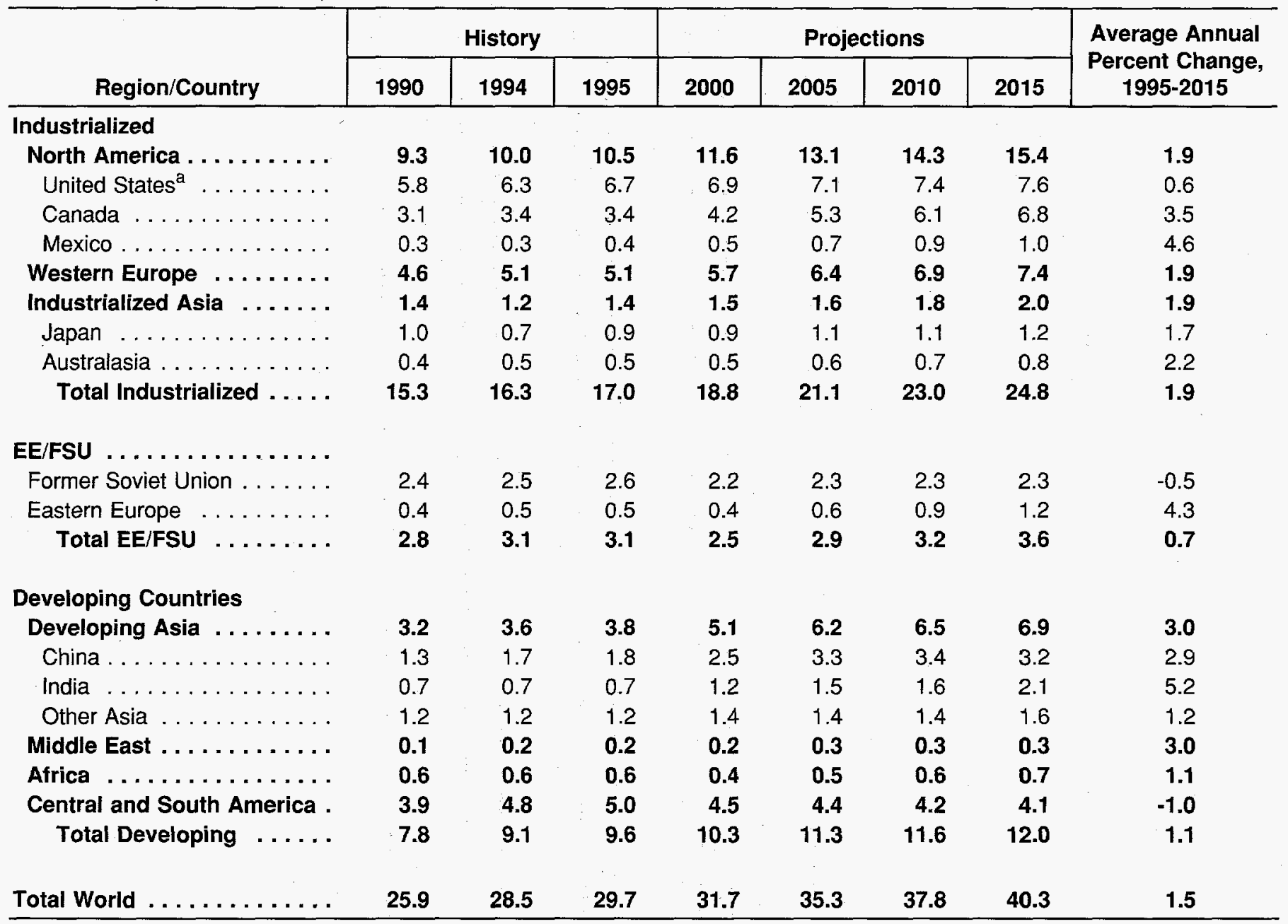

ancludes the 50 States and the District of Columbia. U.S. Territories are included in Australasia.

Notes: $\mathrm{EE} / \mathrm{FSU}=$ Eastern Europe/Former Soviet Union. Totals may not equal sum of components due to independent rounding. The electricity portion of the national fuel consumption values consists of generation for domestic use plus an adjustment for electricity trade based on a fuel's share of total generation in the exporting country.

Sources: History: Energy Information Administration (EIA), International Energy Annual 1995, DOE/ElA-0219(95) (Washington, DC, December 1996). Projections: EIA, Annual Energy Outlook 1997, DOE/EIA-0383(97) (Washington, DC, December 1996), Table A1; and World Energy Projection System (1997). 
Table A34. World Total Net Electricity Consumption by Region, Low Economic Growth Case, 1990-2015 (Billion Kilowatthours)

\begin{tabular}{|c|c|c|c|c|c|c|c|c|}
\hline \multirow[b]{2}{*}{ Region/Country } & \multicolumn{3}{|c|}{ History } & \multicolumn{4}{|c|}{ Projections } & \multirow{2}{*}{$\begin{array}{c}\text { Average Annual } \\
\text { Percent Change, } \\
\text { 1995-2015 }\end{array}$} \\
\hline & 1990 & 1994 & 1995 & 2000 & 2005 & 2010 & 2015 & \\
\hline \multicolumn{9}{|l|}{ Industrialized } \\
\hline North America...$\ldots \ldots$ & 3,256 & 3,523 & 3,604 & 3,744 & 4,007 & 4,265 & 4,574 & 1.2 \\
\hline United States $^{a} \ldots \ldots \ldots$ & 2,715 & 2,937 & 3,011 & 3,057 & 3,221 & 3,388 & 3,593 & 0.9 \\
\hline Canada $\ldots \ldots \ldots \ldots$ & 435 & 456 & 459 & 505 & 555 & 603 & 659 & 1.8 \\
\hline Mexico . . . . . . . . . & 107 & 129 & 134 & 182 & 231 & 275 & 321 & 4.5 \\
\hline Western Europe...$\ldots$. & 2,116 & 2,230 & 2,276 & 2,679 & 2,974 & 3,276 & 3,583 & 2.3 \\
\hline Industrialized Asia . . . . . & 920 & 1,037 & 1,066 & 1,282 & 1,426 & 1,557 & 1,669 & 2.3 \\
\hline Japan $\ldots \ldots \ldots \ldots \ldots$ & 741 & 841 & 865 & 1,004 & 1,110 & 1,207 & 1,287 & 2.0 \\
\hline Australasia $\ldots \ldots \ldots \ldots$ & 179 & 196 & 201 & 278 & 317 & 350 & 382 & 3.3 \\
\hline Total Industrialized . . . . & 6,292 & 6,790 & 6,947 & 7,705 & 8,408 & 9,099 & 9,826 & 1.7 \\
\hline \multicolumn{9}{|l|}{ EE/FSU } \\
\hline Former Soviet Union & 1,488 & 1,161 & 1,150 & 1,131 & 1,195 & 1,260 & 1,288 & 0.6 \\
\hline Eastern Europe ... & 418 & 370 & 382 & 376 & 419 & 464 & 511 & 1.5 \\
\hline Total EE/FSU $\ldots \ldots \ldots$ & 1,907 & 1,532 & 1,532 & 1,507 & 1,614 & 1,724 & 1,799 & 0.8 \\
\hline \multicolumn{9}{|l|}{ Developing Countries } \\
\hline Developing Asia $\ldots \ldots \ldots$ & 1,266 & 1,734 & 1,826 & 2,251 & 2,759 & 3,249 & 3,788 & 3.7 \\
\hline China..$\ldots \ldots \ldots \ldots$ & 551 & 797 & 823 & 968 & 1,204 & 1,460 & 1,753 & 3.9 \\
\hline India $\ldots \ldots \ldots \ldots \ldots$ & 257 & 340 & 372 & 462 & 594 & 726 & 871 & 4.3 \\
\hline Other Asia $\ldots \ldots \ldots \ldots$ & 458 & 597 & 631 & 821 & 960 & 1,063 & 1,164 & 3.1 \\
\hline Middle East $\ldots \ldots \ldots \ldots$ & 198 & 255 & 268 & 271 & 292 & 309 & 328 & 1.0 \\
\hline Africa $\ldots \ldots \ldots \ldots \ldots$ & 274 & 302 & 309 & 377 & 427 & 483 & 545 & 2.9 \\
\hline Central and South America . & 446 & 538 & 561 & 606 & 675 & 739 & 805 & 1.8 \\
\hline Total Developing $\ldots \ldots$ & 2,185 & 2,830 & 2,964 & 3,505 & 4,152 & 4,781 & 5,466 & 3.1 \\
\hline Total World $\ldots \ldots \ldots \ldots \ldots$ & 10,383 & 11,151 & 11,443 & 12,717 & 14,174 & 15,604 & 17,091 & 2.0 \\
\hline
\end{tabular}

ancludes the 50 States and the District of Columbia. U.S. Territories are included in Australasia.

Notes: $\mathrm{EE} / \mathrm{FSU}=$ Eastern Europe/Former Soviet Union. Electricity consumption equals generation plus imports minus exports minus distribution losses.

Sources: History: Energy Information Administration (EIA), International Energy Annual 1995, DOE/EIA-0219(95) (Washington, DC, December 1996), Table 6.2. Projections: EIA, Annual Energy Outlook 1997, DOE/EIA-0383(97) (Washington, DC, December 1996), Table A8; and World Energy Projection System (1997). 
Table A35. World Total Carbon Emissions by Region, Low Economic Growth Case, 1990-2015 (Million Metric Tons)

\begin{tabular}{|c|c|c|c|c|c|c|c|c|}
\hline \multirow[b]{2}{*}{ Region/Country } & \multicolumn{3}{|c|}{ History } & \multicolumn{4}{|c|}{ Projections } & \multirow{2}{*}{$\begin{array}{c}\text { Average Annual } \\
\text { Percent Change } \\
1995-2015\end{array}$} \\
\hline & 1990 & 1994 & 1995 & 2000 & 2005 & 2010 & 2015 & \\
\hline \multicolumn{9}{|l|}{ Industrialized } \\
\hline North America . & 1,561 & 1,634 & 1,663 & 1,793 & 1,894 & 1,973 & 2,039 & 1.0 \\
\hline United States $^{a}$ & 1,337 & 1,397 & 1,424 & 1,515 & 1,587 & 1,644 & 1688 & 0.9 \\
\hline Canada $\ldots \ldots \ldots \ldots \ldots$ & 137 & 140 & 143 & 156 & 165 & 173 & 180 & 1.2 \\
\hline Mexico . . . . . . . & 87 & 97 & 97 & 122 & 142 & 156 & 171 & 2.9 \\
\hline Western Europe $\ldots \ldots \ldots$ & 1,016 & 987 & 1,014 & 1,059 & 1,109 & 1,155 & 1,209 & 0.9 \\
\hline Industrialized Asia $\ldots \ldots \ldots$ & 408 & 449 & 473 & 499 & 529 & 561 & 584 & 1.1 \\
\hline Japan $\ldots \ldots \ldots$ & 308 & 354 & 361 & 388 & 412 & 439 & 457 & 1.2 \\
\hline Australasia ........ & 100 & 95 & 112 & 111 & 118 & 122 & 126 & 0.6 \\
\hline Total Industrialized & 2,985 & 3,069 & 3,151 & 3,352 & 3,533 & 3,689 & 3,831 & 1.0 \\
\hline \multicolumn{9}{|l|}{ EE/FSU $\ldots \ldots \ldots \ldots$} \\
\hline Former Soviet Union . & 1,029 & 711 & 653 & 703 & 744 & 784 & 811 & 1.1 \\
\hline Eastern Europe $\ldots$. & 309 & 239 & 240 & 264 & 269 & 272 & 276 & 0.7 \\
\hline Total EE/FSU & 1,339 & 949 & 893 & 967 & 1,014 & 1,057 & 1,087 & 1.0 \\
\hline \multicolumn{9}{|l|}{ Developing Countries } \\
\hline Developing Asia ... & 1,092 & 1,401 & 1,475 & 1,693 & 1,936 & 2,161 & 2,394 & 2.5 \\
\hline China ......... & 625 & 784 & 821 & 930 & 1,040 & 1,162 & 1,294 & 2.3 \\
\hline India .... & 159 & 205 & 221 & 252 & 301 & 345 & 384 & 2.8 \\
\hline Other Asia & 307 & 412 & 432 & 511 & 594 & 654 & 716 & 2.5 \\
\hline Middle East $\ldots \ldots \ldots \ldots$ & 203 & 241 & 254 & 244 & 254 & 264 & 276 & 0.4 \\
\hline Africa $\ldots \ldots \ldots \ldots \ldots$ & 205 & 239 & 248 & 251 & 264 & 277 & 290 & 0.8 \\
\hline Central and South America . & 189 & 212 & 220 & 243 & 275 & 309 & 343 & 2.2 \\
\hline Total Developing $\ldots .$. & 1,687 & 2,092 & 2,197 & 2,431 & 2,729 & 3,010 & 3,303 & 2.1 \\
\hline Total World $\ldots \ldots \ldots \ldots$ & 6,012 & 6,111 & 6,241 & 6,750 & 7,275 & 7,755 & 8,222 & 1.4 \\
\hline
\end{tabular}

ancludes the 50 States and the District of Columbia. U.S. Territories are included in Australasia.

Notes: EE/FSU = Eastern Europe/Former Soviet Union. The U.S. numbers include carbon emissions attributable to renewable energy sources.

Sources: History: Derived from Energy Information Administration (EIA), International Energy Annual 1995, DOE/EIA0219(95) (Washington, DC, December 1996). Projections: EIA, Annual Energy Outlook 1997, DOE/EIA-0383(97) (Washington, DC, December 1996), Table A19; and World Energy Projection System (1997). 
Table A36. World Carbon Emissions from Oil Use by Region, Low Economic Growth Case, 1990-2015 (Million Metric Tons)

\begin{tabular}{|c|c|c|c|c|c|c|c|c|}
\hline \multirow{2}{*}{ Region/Country } & \multicolumn{3}{|c|}{ History } & \multicolumn{4}{|c|}{ Projections } & \multirow{2}{*}{$\begin{array}{c}\text { Average Annual } \\
\text { Percent Change } \\
\text { 1995-2015 }\end{array}$} \\
\hline & 1990 & 1994 & 1995 & 2000 & 2005 & 2010 & 2015 & \\
\hline North America . . . . . . . . . . . & 720 & 737 & 739 & 797 & 842 & 877 & 895 & 1.0 \\
\hline United States $^{a} \ldots \ldots \ldots$ & 583 & 596 & 599 & 642 & 674 & 695 & 697 & 0.8 \\
\hline Canada . . . . . . . . . & 67 & 67 & 67 & 71 & 75 & 79 & 83 & 1.1 \\
\hline Western Europe ........ & 537 & 562 & 576 & 577 & 590 & 596 & 601 & 0.2 \\
\hline Industrialized Asia $\ldots \ldots$. & 252 & 278 & 283 & 306 & 325 & 343 & 360 & 1.2 \\
\hline Japan ............. & 210 & 230 & 232 & 251 & 266 & 280 & 293 & 1.2 \\
\hline Australasia . . . . . . . . . & 41 & 47 & 51 & 55 & 59 & 63 & 67 & 1.4 \\
\hline Total Industrialized . . . . . & 1,509 & 1,577 & 1,598 & 1,680 & 1,757 & 1,815 & 1,856 & 0.8 \\
\hline \multicolumn{9}{|l|}{ EE/FSU $\ldots \ldots \ldots \ldots \ldots \ldots$} \\
\hline Total EE/FSU $\ldots \ldots \ldots$ & 427 & 259 & 245 & 260 & 289 & 324 & 356 & 1.9 \\
\hline \multicolumn{9}{|l|}{ Developing Countries } \\
\hline Developing Asia . . . . . . . . & 325 & 441 & 468 & 535 & 635 & 711 & 799 & 2.7 \\
\hline China . . . . . . . . . . & 98 & 132 & 139 & 168 & 193 & 222 & 255 & 3.1 \\
\hline India $\ldots \ldots \ldots \ldots$ & 49 & 59 & 66 & 71 & 85 & 96 & 109 & 2.6 \\
\hline Other Asia . . . . . . . . . & 178 & 251 & 263 & 296 & 357 & 393 & 435 & 2.5 \\
\hline Middle East $\ldots \ldots \ldots \ldots$. . . . & 144 & 165 & 172 & 168 & 179 & 190 & 201 & 0.8 \\
\hline Africa $\ldots \ldots \ldots \ldots \ldots$ & 84 & 88 & 92 & 114 & 127 & 134 & 142 & 2.2 \\
\hline Central and South America. & 140 & 154 & 156 & 172 & 191 & 207 & 226 & 1.8 \\
\hline
\end{tabular}

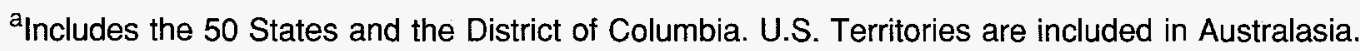

Notes: $\mathrm{EE} / \mathrm{FSU}=$ Eastern Europe/Former Soviet Union.

Sources: History: Derived from Energy Information Administration (EIA), International Energy Annual 1995, DOE/EIA0219(95) (Washington, DC, December 1996). Projections: EIA, Annual Energy Outlook 1997, DOE/ElA-0383(97) (Washington, DC, December 1996), Table A19; and World Energy Projection System (1997). 
Table A37. World Carbon Emissions from Natural Gas Use by Region, Low Economic Growth Case, 1990-2015

(Million Metric Tons)

\begin{tabular}{|c|c|c|c|c|c|c|c|c|}
\hline \multirow[b]{2}{*}{ Region/Country } & \multicolumn{3}{|c|}{ History } & \multicolumn{4}{|c|}{ Projections } & \multirow{2}{*}{$\begin{array}{c}\text { Average Annual } \\
\text { Percent Change, } \\
1995-2015\end{array}$} \\
\hline & 1990 & 1994 & 1995 & 2000 & 2005 & 2010 & 2015 & \\
\hline \multicolumn{9}{|l|}{ Industrialized } \\
\hline North America $\ldots \ldots \ldots \ldots$ & 323 & 365 & 377 & 417 & 461 & 483 & 514 & 1.6 \\
\hline United States $^{\mathrm{a}}$ & 274 & 305 & 318 & 342 & 374 & 391 & 417 & 1.4 \\
\hline Canada ...... & 35 & 42 & 42 & 44 & 47 & 50 & 52 & 1.1 \\
\hline Mexico ........ & 14 & 17 & 18 & 31 & 40 & 42 & 45 & 4.8 \\
\hline Western Europe $\ldots \ldots \ldots$ & 146 & 169 & 180 & 231 & 274 & 315 & 364 & 3.6 \\
\hline Industrialized Asia $\ldots \ldots$ & 42 & 48 & 49 & 55 & 65 & 73 & 77 & 2.3 \\
\hline Japan $\ldots \ldots \ldots \ldots \ldots$ & 30 & 35 & 35 & 41 & 49 & 56 & 60 & 2.7 \\
\hline Australasia ........ & 12 & 13 & 14 & 15 & 16 & 17 & 17 & 1.1 \\
\hline Total Industrialized . . . . . & 511 & 581 & 606 & 704 & 800 & 870 & 955 & 2.3 \\
\hline \multicolumn{9}{|l|}{ EE/FSU $\ldots \ldots \ldots$} \\
\hline Former Soviet Union & 335 & 286 & 271 & 325 & 342 & 360 & 371 & 1.6 \\
\hline Eastern Europe . . . & 44 & 31 & 34 & 51 & 62 & 72 & 82 & 4.5 \\
\hline Total EE/FSU $\ldots \ldots \ldots$ & 379 & 317 & 305 & 376 & 404 & 433 & 453 & 2.0 \\
\hline \multicolumn{9}{|l|}{ Developing Countries } \\
\hline Developing Asia $\ldots \ldots \ldots$ & 44 & 64 & 69 & 137 & 178 & 213 & 244 & 6.5 \\
\hline China $\ldots \ldots \ldots \ldots \ldots$ & 8 & 10 & 8 & 23 & 34 & 39 & 38 & 8.1 \\
\hline India $\ldots$ & 6 & 9 & 10 & 19 & 33 & 47 & 64 & 9.8 \\
\hline Other Asia & 30 & 46 & 51 & 94 & 111 & 127 & 142 & 5.2 \\
\hline Middle East $\ldots \ldots \ldots \ldots$ & 55 & 69 & 74 & 70 & 69 & 68 & 69 & -0.4 \\
\hline Africa $\ldots \ldots \ldots \ldots \ldots$ & 21 & 25 & 26 & 22 & 24 & 29 & 34 & 1.5 \\
\hline Central and South America . & 31 & 39 & 42 & 48 & 62 & 77 & 90 & 3.9 \\
\hline Total Developing $\ldots \ldots$ & 151 & 198 & 211 & 277 & 333 & 387 & 438 & 3.7 \\
\hline Total World .... & 1,040 & 1,096 & 1,123 & 1,356 & 1,537 & 1,689 & 1,846 & 2.5 \\
\hline
\end{tabular}

${ }^{a}$ Includes the 50 States and the District of Columbia. U.S. Territories are included in Australasia.

Notes: EE/FSU = Eastern Europe/Former Soviet Union.

Sources: History: Derived from Energy Information Administration (EIA), International Energy Annual 1995, DOE/EIA0219(95) (Washington, DC, December 1996). Projections: EIA, Annual Energy Outlook 1997, DOE/EIA-0383(97) (Washington, DC, December 1996), Table A19; and World Energy Projection System (1997). 
Table A38. World Carbon Emissions from Coal Use by Region, Low Economic Growth Case, 1990-2015 (Million Metric Tons)

\begin{tabular}{|c|c|c|c|c|c|c|c|c|}
\hline \multirow[b]{2}{*}{ Region/Country } & \multicolumn{3}{|c|}{ History } & \multicolumn{4}{|c|}{ Projections } & \multirow{2}{*}{$\begin{array}{c}\text { Average Annual } \\
\text { Percent Change } \\
\text { 1995-2015 }\end{array}$} \\
\hline & 1990 & 1994 & 1995 & 2000 & 2005 & 2010 & 2015 & \\
\hline \multicolumn{9}{|l|}{ Industrialized } \\
\hline North America $\ldots \ldots \ldots$. . & 518 & 532 & 547 & 579 & 591 & 613 & 630 & 0.7 \\
\hline United States $^{a} \ldots \ldots \ldots$ & 480 & 496 & 507 & 531 & 539 & 559 & 573 & 0.6 \\
\hline Canada ..... & 35 & 30 & 33 & 41 & 43 & 44 & 45 & 1.5 \\
\hline Mexico ........ & 4 & 5 & 6 & 7 & 9 & 10 & 11 & 3.1 \\
\hline Western Europe $\ldots \ldots \ldots$ & 333 & 256 & 258 & 250 & 244 & 244 & 244 & -0.3 \\
\hline Industrialized Asia $\ldots \ldots \ldots$ & 115 & 124 & 141 & 139 & 140 & 146 & 146 & 0.2 \\
\hline Japan $\ldots \ldots \ldots \ldots$ & 68 & 89 & 93 & 97 & 98 & 104 & 104 & 0.5 \\
\hline Australasia $\ldots \ldots \ldots \ldots$ & 46 & 35 & 48 & 42 & 42 & 42 & 42 & -0.6 \\
\hline Total Industrialized . . . . . & 966 & 911 & 946 & 968 & 975 & 1,003 & 1,020 & 0.4 \\
\hline \multicolumn{9}{|l|}{ EE/FSU $\ldots \ldots \ldots \ldots \ldots$} \\
\hline Former Soviet Union . . . . . . & 339 & 218 & 192 & 180 & 173 & 166 & 157 & -1.0 \\
\hline Eastern Europe $\ldots \ldots \ldots$ & 194 & 155 & 150 & 152 & 148 & 134 & 121 & -1.1 \\
\hline Total EE/FSU $\ldots \ldots \ldots$ & 533 & 373 & 343 & 332 & 321 & 300 & 278 & -1.0 \\
\hline \multicolumn{9}{|l|}{ Developing Countries } \\
\hline Developing Asia $\ldots \ldots \ldots$ & 723 & 895 & 938 & 1,022 & 1,123 & 1,237 & 1,350 & 1.8 \\
\hline China $\ldots \ldots \ldots \ldots \ldots$ & 519 & 642 & 673 & 739 & 813 & 901 & 1,000 & 2.0 \\
\hline India $\ldots \ldots \ldots \ldots$ & 104 & 137 & 146 & 162 & 183 & 202 & 211 & 1.9 \\
\hline Other Asia $\ldots \ldots \ldots \ldots$ & 99 & 116 & 118 & 121 & 127 & 134 & 138 & 0.8 \\
\hline Middle East $\ldots \ldots \ldots \ldots$ & 4 & 7 & 7 & 6 & 6 & 6 & 7 & -0.4 \\
\hline Africa $\ldots \ldots \ldots \ldots \ldots$ & 100 & 126 & 130 & 115 & 113 & 113 & 114 & -0.7 \\
\hline Central and South America . & 17 & 19 & 21 & 22 & 22 & 25 & 27 & 1.2 \\
\hline Total Developing $\ldots .$. & 844 & 1,047 & 1,097 & 1,165 & 1,265 & 1,382 & 1,497 & 1.6 \\
\hline Total World & 2,343 & 2,331 & 2,386 & 2,465 & 2,561 & 2,685 & 2,795 & 0.8 \\
\hline
\end{tabular}

Includes the 50 States and the District of Columbia. U.S. Territories are included in Australasia.

Notes: EE/FSU = Eastern Europe/Former Soviet Union.

Sources: History: Derived from Energy Information Administration (EIA), International Energy Annual 1995, DOE/EIA0219(95) (Washington, DC, December 1996). Projections: EIA, Annual Energy Outlook 1997, DOE/EIA-0383(97) (Washington, DC, December 1996), Table A19; and World Energy Projection System (1997). 
Table A39. World Total Energy Consumption in Oil-Equivalent Units by Region, Low Economic Growth Case, 1990-2015

(Million Tons Oil Equivalent)

\begin{tabular}{|c|c|c|c|c|c|c|c|c|}
\hline \multirow[b]{2}{*}{ Region/Country } & \multicolumn{3}{|c|}{ History } & \multicolumn{4}{|c|}{ Projections } & \multirow{2}{*}{$\begin{array}{c}\text { Average Annual } \\
\text { Percent Change, } \\
\text { 1995-2015 }\end{array}$} \\
\hline & 1990 & 1994 & 1995 & 2000 & 2005 & 2010 & 2015 & \\
\hline \multicolumn{9}{|l|}{ Industrialized } \\
\hline North America . . . . . . . . . & 2,349 & 2,499 & 2,546 & 2,751 & 2,913 & 3,028 & 3,100 & 1.0 \\
\hline United States $^{\mathrm{a}} \ldots \ldots \ldots$ & 1,975 & 2,088 & 2,130 & 2,264 & 2,359 & 2,426 & 2,451 & 0.7 \\
\hline Canada $\ldots \ldots \ldots \ldots$ & 259 & 283 & 285 & 318 & 354 & 379 & 406 & 1.8 \\
\hline Mexico . . . . . . . . . & 115 & 128 & 132 & 169 & 200 & 222 & 243 & 3.1 \\
\hline Western Europe $\ldots \ldots \ldots$ & 1,453 & 1,477 & 1,519 & 1,616 & 1,703 & 1,783 & 1,863 & 1.0 \\
\hline Industrialized Asia $\ldots \ldots$ & 544 & 608 & 641 & 678 & 726 & 770 & 806 & 1.2 \\
\hline Japan $\ldots \ldots \ldots \ldots \ldots$ & 423 & 488 & 504 & 539 & 578 & 614 & 643 & 1.2 \\
\hline Australasia . . . . . . . . & 121 & 120 & 137 & 139 & 148 & 155 & 163 & 0.9 \\
\hline Total Industrialized . . . . . & 4,345 & 4,584 & 4,707 & 5,045 & 5,342 & 5,580 & 5,769 & 1.0 \\
\hline \multicolumn{9}{|l|}{ EE/FSU } \\
\hline Former Soviet Union & 1,375 & 1,005 & 940 & 1,021 & 1,079 & 1,137 & 1,162 & 1.1 \\
\hline Eastern Europe $\ldots$ & 357 & 281 & 285 & 315 & 332 & 350 & 369 & 1.3 \\
\hline Total EE/FSU & 1,732 & 1,286 & 1,225 & 1,336 & 1,411 & 1,488 & 1,532 & 1.1 \\
\hline \multicolumn{9}{|l|}{ Developing Countries } \\
\hline Developing Asia $\ldots \ldots \ldots$ & 1,208 & 1,551 & 1,636 & 1,935 & 2,244 & 2,511 & 2,786 & 2.7 \\
\hline China . . . . . . . & 634 & 801 & 839 & 974 & 1,112 & 1,240 & 1,372 & 2.5 \\
\hline India . & 182 & 228 & 247 & 295 & 359 & 417 & 480 & 3.4 \\
\hline Other Asia & 392 & 522 & 550 & 666 & 774 & 854 & 935 & 2.7 \\
\hline Middle East $\ldots \ldots \ldots \ldots$ & 262 & 315 & 332 & 320 & 333 & 346 & 361 & 0.4 \\
\hline Africa $\ldots \ldots \ldots \ldots \ldots$ & 239 & 274 & 285 & 288 & 305 & 324 & 344 & 1.0 \\
\hline Central and South America . & 324 & 378 & 394 & 410 & 453 & 495 & 539 & 1.6 \\
\hline Total Developing $\ldots .$. & 2,033 & 2,518 & 2,647 & 2,953 & 3,335 & 3,676 & 4,030 & 2.1 \\
\hline Total World & 8,110 & 8,389 & 8,579 & 9,334 & 10,088 & 10,744 & 11,331 & 1.4 \\
\hline
\end{tabular}

ancludes the 50 States and the District of Columbia. U.S. Territories are included in Australasia.

Notes: $\mathrm{EE} / \mathrm{FSU}=$ Eastern Europe/Former Soviet Union.

Sources: History: Derived from Energy Information Administration (EIA), International Energy Annual 1995, DOE/EIA0219(95) (Washington, DC, December 1996). Projections: EIA, Annual Energy Outlook 1997, DOE/EIA-0383(97) (Washington, DC, December 1996), Table A19; and World Energy Projection System (1997). 
Table A40. World Oil Production Capacity by Region and Country, Reference Case, 1990-2015 (Million Barrels per Day)

\begin{tabular}{|c|c|c|c|c|c|c|}
\hline \multirow[b]{2}{*}{ Region/Country } & \multicolumn{2}{|c|}{ History (Estimates) } & \multicolumn{4}{|c|}{ Projections } \\
\hline & 1990 & 1995 & 2000 & 2005 & 2010 & 2015 \\
\hline \multicolumn{7}{|l|}{ OPEC } \\
\hline \multicolumn{7}{|l|}{ Persian Gulf } \\
\hline $\operatorname{Iran} \ldots \ldots \ldots \ldots$ & 3.2 & 3.9 & 4.0 & 5.1 & 5.5 & 5.9 \\
\hline$\ldots \ldots \ldots \ldots \ldots$ & 2.2 & 0.6 & 4.3 & 5.8 & 7.0 & 7.4 \\
\hline Kuwait $\ldots \ldots \ldots \ldots \ldots$ & 1.7 & 2.6 & 2.8 & 3.7 & 4.4 & 4.6 \\
\hline Qatar $\ldots \ldots \ldots \ldots$ & 0.5 & 0.6 & 0.5 & 0.6 & 0.6 & 0.5 \\
\hline Saudi Arabia $\ldots \ldots \ldots$. . . & 8.5 & 10.6 & 11.4 & 13.3 & 15.8 & 22.3 \\
\hline United Arab Emirates . . . . & 2.5 & 2.6 & 2.9 & 3.6 & 4.5 & 4.7 \\
\hline Total Persian Gulf . . . . . . & 18.6 & 20.9 & 25.9 & 32.1 & 37.8 & 45.4 \\
\hline \multicolumn{7}{|l|}{ Other OPEC } \\
\hline Algeria $\ldots \ldots \ldots \ldots$ & 1.4 & 1.4 & 1.4 & 1.3 & 1.1 & 0.9 \\
\hline$\ldots \ldots \ldots \ldots$ & 0.3 & 0.4 & 0.3 & 0.3 & 0.3 & 0.2 \\
\hline Indonesia $\ldots \ldots \ldots \ldots$ & 1.5 & 1.7 & 1.3 & 1.1 & 1.0 & 0.9 \\
\hline Libya . . . . . . . . . . . & 1.6 & 1.5 & 1.8 & 2.2 & 2.4 & 2.5 \\
\hline Nigeria $\ldots \ldots \ldots \ldots \ldots$ & 1.8 & 2.2 & 2.2 & 2.5 & 2.6 & 2.6 \\
\hline Venezuela . . . . . . . . & 2.6 & 2.9 & 3.3 & 4.2 & 4.8 & 5.1 \\
\hline Total Other OPEC...$\ldots$ & 9.2 & 10.1 & 10.3 & 11.6 & 12.2 & 12.2 \\
\hline Total OPEC $\ldots \ldots \ldots \ldots$ & 27.8 & 31.0 & 36.2 & 43.7 & 50.0 & 57.6 \\
\hline \multicolumn{7}{|l|}{$\begin{array}{l}\text { Non-OPEC } \\
\text { Industrialized }\end{array}$} \\
\hline United States . . . . . . . . . & 9.7 & 9.4 & 8.8 & 8.7 & 8.8 & 8.8 \\
\hline Canada $\ldots \ldots \ldots \ldots$ & 2.0 & 2.4 & 2.6 & 2.5 & 2.6 & 2.5 \\
\hline Mexico $\ldots \ldots \ldots \ldots$ & 3.0 & 3.1 & 3.2 & 3.2 & 3.3 & 3.4 \\
\hline Australia $\ldots \ldots \ldots \ldots$ & 0.7 & 0.8 & 0.7 & 0.7 & 0.7 & 0.6 \\
\hline North Sea $\ldots \ldots \ldots \ldots$ & 3.8 & 5.6 & 6.4 & 5.9 & 5.2 & 4.5 \\
\hline Other $\ldots \ldots \ldots \ldots \ldots$ & 0.8 & 1.2 & 0.8 & 0.7 & 0.8 & 0.7 \\
\hline Total Industrialized . . . . . & 20.0 & 22.5 & 22.5 & 21.7 & 21.4 & 20.5 \\
\hline \multicolumn{7}{|l|}{ Eurasia } \\
\hline China $\ldots \ldots \ldots \ldots \ldots$ & 2.8 & 3.0 & 3.1 & 3.2 & 3.3 & 3.5 \\
\hline Former Soviet Union . & 11.4 & 7.0 & 7.7 & 9.1 & 9.8 & 10.6 \\
\hline Eastern Europe $\ldots \ldots \ldots$ & 0.3 & 0.3 & 0.3 & 0.3 & 0.2 & 0.2 \\
\hline Total Eurasia $\ldots \ldots \ldots$ & 14.5 & 10.3 & 11.1 & 12.6 & 13.3 & 14.3 \\
\hline \multicolumn{7}{|l|}{ Other Non-OPEC } \\
\hline Central and South America & 2.4 & 3.1 & 4.3 & 4.7 & 5.2 & 6.0 \\
\hline Middle East $\ldots \ldots \ldots \ldots$ & 1.3 & 1.9 & 2.3 & 2.5 & 2.6 & 2.8 \\
\hline Africa $\ldots \ldots \ldots \ldots \ldots$ & 1.9 & 2.1 & 2.3 & 2.3 & 2.4 & 2.5 \\
\hline Asia $\ldots \ldots \ldots \ldots \ldots$ & 1.7 & 2.1 & 2.7 & 3.0 & 3.2 & 3.2 \\
\hline Total Other Non-OPEC .. & 7.4 & 9.2 & 11.6 & 12.5 & 13.4 & 14.5 \\
\hline Total Non-OPEC $\ldots \ldots \ldots$ & 41.9 & 42.0 & 45.2 & 46.8 & 48.1 & 49.3 \\
\hline Total World . & 69.7 & 73.0 & 81.4 & 90.5 & 98.1 & 106.9 \\
\hline
\end{tabular}

Note: OPEC $=$ Organization of Petroleum Exporting Countries.

Sources: History: Energy Information Administration (EIA), Energy Markets and Contingency Information Division. Projections: EIA, Office of Integrated Analysis and Forecasting, World Energy Projection System and "DESTINY" International Energy Forecast Software (Dallas, TX: Petroconsultants, 1997). 
Table A41. World Oil Production Capacity by Region and Country, High Oil Price Case, 1990-2015 (Million Barrels per Day)

\begin{tabular}{|c|c|c|c|c|c|c|}
\hline \multirow[b]{2}{*}{ Region/Country } & \multicolumn{2}{|c|}{ History (Estimates) } & \multicolumn{4}{|c|}{ Projections } \\
\hline & 1990 & 1995 & 2000 & 2005 & 2010 & 2015 \\
\hline \multicolumn{7}{|l|}{ OPEC } \\
\hline \multicolumn{7}{|l|}{ Persian Gulf } \\
\hline $\operatorname{Iran} \ldots \ldots \ldots \ldots \ldots$ & 3.2 & 3.9 & 3.6 & 4.5 & 4.7 & 4.8 \\
\hline $\operatorname{Iraq} \ldots \ldots \ldots \ldots \ldots$ & 2.2 & 0.6 & 4.1 & 5.3 & 6.3 & 6.3 \\
\hline Kuwait $\ldots \ldots \ldots \ldots \ldots$ & 1.7 & 2.6 & 2.6 & 3.4 & 3.9 & 3.9 \\
\hline Qatar $\ldots \ldots \ldots \ldots \ldots$ & 0.5 & 0.6 & 0.4 & 0.5 & 0.5 & 0.4 \\
\hline Saudi Arabia $\ldots \ldots \ldots$. & 8.5 & 10.6 & 11.0 & 12.4 & 14.4 & 19.5 \\
\hline United Arab Emirates . . . . & 2.5 & 2.6 & 2.6 & 3.1 & 3.8 & 3.8 \\
\hline Total Persian Gulf . . . . . . & 18.6 & 20.9 & 24.3 & 29.2 & 33.6 & 38.7 \\
\hline \multicolumn{7}{|l|}{ Other OPEC } \\
\hline Algeria $\ldots \ldots \ldots \ldots$ & 1.4 & 1.4 & 1.3 & 1.1 & 0.9 & 0.7 \\
\hline Gabon $\ldots \ldots \ldots \ldots \ldots$ & 0.3 & 0.4 & 0.3 & 0.3 & 0.2 & 0.2 \\
\hline Indonesia . . . . . . . . & 1.5 & 1.7 & 1.2 & 1.0 & 0.9 & 0.7 \\
\hline Libya .............. & 1.6 & 1.5 & 1.7 & 2.0 & 2.1 & 2.1 \\
\hline Nigeria $\ldots \ldots \ldots \ldots \ldots$ & 1.8 & 2.2 & 1.9 & 2.1 & 2.2 & 2.1 \\
\hline Venezuela $\ldots \ldots \ldots \ldots$ & 2.6 & 2.9 & 3.2 & 3.9 & 4.4 & 4.5 \\
\hline Total Other OPEC . . . . . & 9.2 & 10.1 & 9.6 & 10.4 & 10.7 & 10.3 \\
\hline Total OPEC $\ldots \ldots \ldots \ldots$ & 27.8 & 31.0 & 33.9 & 39.6 & 44.3 & 49.0 \\
\hline \multirow{2}{*}{\multicolumn{7}{|c|}{$\begin{array}{l}\text { Non-OPEC } \\
\text { Industrialized }\end{array}$}} \\
\hline & & & & & & \\
\hline United States & 9.7 & 9.4 & 9.4 & 9.7 & 10.0 & 10.6 \\
\hline Canada .... & 2.0 & 2.4 & 2.5 & 2.4 & 2.5 & 2.4 \\
\hline Mexico . . & 3.0 & 3.1 & 3.1 & 3.1 & 3.2 & 3.2 \\
\hline Australia & 0.7 & 0.8 & 0.7 & 0.7 & 0.7 & 0.6 \\
\hline North Sea & 3.8 & 5.6 & 6.4 & 6.0 & 5.3 & 4.4 \\
\hline Other $\ldots \ldots \ldots \ldots \ldots$ & 0.8 & 1.2 & 0.8 & 0.7 & 0.8 & 0.7 \\
\hline Total Industrialized . . . . & 20.0 & 22.5 & 22.9 & 22.6 & 22.5 & 21.9 \\
\hline \multicolumn{7}{|l|}{ Eurasia } \\
\hline China $\ldots \ldots \ldots \ldots \ldots$ & 2.8 & 3.0 & 3.1 & 3.2 & 3.3 & 3.5 \\
\hline Former Soviet Union . . . . . & 11.4 & 7.0 & 7.9 & $9.3^{\circ}$ & 9.2 & 9.2 \\
\hline Eastern Europe $\ldots \ldots \ldots$ & 0.3 & 0.3 & 0.3 & 0.4 & 0.2 & 0.2 \\
\hline Total Eurasia $\ldots \ldots \ldots$ & 14.5 & 10.3 & 11.3 & 12.9 & 12.7 & 12.9 \\
\hline \multicolumn{7}{|l|}{ Other Non-OPEC } \\
\hline Central and South America & 2.4 & 3.1 & 4.5 & 5.0 & 6.1 & 7.9 \\
\hline Middle East $\ldots \ldots \ldots \ldots$ & 1.3 & 1.9 & 2.3 & 2.6 & 2.9 & 3.3 \\
\hline Africa $\ldots \ldots \ldots \ldots \ldots$ & 1.9 & 2.1 & 2.2 & 2.0 & 2.3 & 2.4 \\
\hline Asia $\ldots \ldots \ldots \ldots \ldots$ & 1.7 & 2.1 & 2.8 & 3.2 & 3.6 & 3.8 \\
\hline Total Other Non-OPEC .. & 7.4 & 9.2 & 11.8 & 12.8 & 14.9 & 17.4 \\
\hline Total Non-OPEC $\ldots \ldots \ldots$ & 41.9 & 42.0 & 46.0 & 48.3 & 50.1 & 52.2 \\
\hline Total World $\ldots \ldots \ldots \ldots$ & 69.7 & 73.0 & 79.9 & 87.9 & 94.4 & 101.2 \\
\hline
\end{tabular}

Note: OPEC $=$ Organization of Petroleum Exporting Countries.

Sources: History: Energy Information Administration (EIA), Energy Markets and Contingency Information Division. Projections: EIA, Office of Integrated Analysis and Forecasting, World Energy Projection System and "DESTINY" International Energy Forecast Software (Dallas, TX: Petroconsultants, 1997). 
Table A42. World Oil Production Capacity by Region and Country, Low Oil Price Case, 1990-2015 (Million Barrels per Day)

\begin{tabular}{|c|c|c|c|c|c|c|}
\hline \multirow[b]{2}{*}{ Region/Country } & \multicolumn{2}{|c|}{ History (Estimates) } & \multicolumn{4}{|c|}{ Projections } \\
\hline & 1990 & 1995 & 2000 & 2005 & 2010 & 2015 \\
\hline \multicolumn{7}{|l|}{ OPEC } \\
\hline \multicolumn{7}{|l|}{ Persian Gulf } \\
\hline Iran $\ldots . .$. & 3.2 & 3.9 & 4.2 & 5.7 & 6.3 & 6.8 \\
\hline Iraq $\ldots \ldots \ldots \ldots \ldots$ & 2.2 & 0.6 & 4.7 & 6.8 & 8.4 & 8.9 \\
\hline Kuwait $\ldots \ldots \ldots \ldots \ldots$ & 1.7 & 2.6 & 3.0 & 4.3 & 5.3 & 5.5 \\
\hline Qatar . . . . . . . . . . & 0.5 & 0.6 & 0.5 & 0.7 & 0.7 & 0.6 \\
\hline Saudi Arabia $\ldots \ldots \ldots \ldots$ & 8.5 & 10.6 & 12.6 & 15.9 & 19.4 & 27.3 \\
\hline United Arab Emirates . . . . & 2.5 & 2.6 & 3.0 & 4.0 & 5.2 & 5.4 \\
\hline Total Persian Gulf . . . . . & 18.6 & 20.9 & 28.0 & 37.4 & 45.3 & 54.5 \\
\hline \multicolumn{7}{|l|}{ Other OPEC } \\
\hline Algeria $\ldots \ldots \ldots \ldots$ & 1.4 & 1.4 & 1.5 & 1.5 & 1.3 & 1.0 \\
\hline Gabon $\ldots \ldots \ldots \ldots \ldots$ & 0.3 & 0.4 & 0.3 & 0.3 & 0.3 & 0.2 \\
\hline Indonesia . . . . . . . . & 1.5 & 1.7 & 1.4 & 1.2 & 1.2 & 1.0 \\
\hline Libya . . . . . . . . . . . & 1.6 & 1.5 & 2.0 & 2.6 & 2.9 & 3.0 \\
\hline Nigeria $\ldots \ldots \ldots \ldots \ldots$ & 1.8 & 2.2 & 2.2 & 2.7 & 2.9 & 2.9 \\
\hline Venezuela . . . . . . . . . . & 2.6 & 2.9 & 3.7 & 5.0 & 5.9 & 6.3 \\
\hline Total Other OPEC $\ldots .$. & 9.2 & 10.1 & 11.1 & 13.3 & 14.5 & 14.4 \\
\hline Total OPEC $\ldots \ldots \ldots \ldots$ & 27.8 & 31.0 & 39.1 & 50.7 & 59.8 & 68.9 \\
\hline \multicolumn{7}{|l|}{$\begin{array}{l}\text { Non-OPEC } \\
\text { Industrialized }\end{array}$} \\
\hline United States . . . . . . . . & 9.7 & 9.4 & 8.4 & 7.5 & 7.4 & 7.5 \\
\hline Canada $\ldots \ldots \ldots \ldots$ & 2.0 & 2.4 & 2.4 & 2.3 & 2.4 & 2.3 \\
\hline Mexico ............. & 3.0 & 3.1 & 3.1 & 3.0 & 3.0 & 3.0 \\
\hline Australia $\ldots \ldots \ldots \ldots$ & 0.7 & 0.8 & 0.7 & 0.7 & 0.7 & 0.6 \\
\hline North Sea $\ldots \ldots \ldots \ldots$ & 3.8 & 5.6 & 6.4 & 5.8 & 5.0 & 4.2 \\
\hline Other $\ldots \ldots \ldots \ldots \ldots$ & 0.8 & 1.2 & 0.8 & 0.7 & 0.8 & 0.6 \\
\hline Total Industrialized . . . . . & 20.0 & 22.5 & 21.8 & 20.0 & 19.3 & 18.2 \\
\hline \multicolumn{7}{|l|}{ Eurasia } \\
\hline China ............... & 2.8 & 3.0 & 3.0 & 3.0 & 3.1 & 3.2 \\
\hline Former Soviet Union . . . . . . & 11.4 & 7.0 & 7.8 & 9.0 & 8.8 & 8.6 \\
\hline Eastern Europe $\ldots \ldots \ldots$ & 0.3 & 0.3 & 0.3 & 0.4 & 0.2 & 0.2 \\
\hline Total Eurasia $\ldots \ldots \ldots$ & 14.5 & 10.3 & 11.1 & 12.4 & 12.1 & 12.0 \\
\hline \multicolumn{7}{|l|}{ Other Non-OPEC } \\
\hline Central and South America & 2.4 & 3.1 & 4.4 & 4.8 & 5.8 & 7.4 \\
\hline Middle East $\ldots \ldots \ldots \ldots$ & 1.3 & 1.9 & 2.2 & 2.5 & 2.8 & 3.1 \\
\hline Africa $\ldots \ldots \ldots \ldots \ldots$ & 1.9 & 2.1 & 2.2 & 2.0 & 2.1 & 2.3 \\
\hline Asia $\ldots \ldots \ldots \ldots \ldots$ & 1.7 & 2.1 & $2.7^{\prime}$ & 3.1 & 3.4 & 3.5 \\
\hline Total Other Non-OPEC .. & 7.4 & 9.2 & 11.5 & 12.4 & 14.1 & 16.3 \\
\hline Total Non-OPEC $\ldots \ldots \ldots$ & 41.9 & 42.0 & 44.4 & 44.8 & 45.5 & 46.5 \\
\hline Total World & 69.7 & 73.0 & 83.5 & 95.5 & 105.3 & 115.4 \\
\hline
\end{tabular}

Note: OPEC = Organization of Petroleum Exporting Countries.

Sources: History: Energy Information Administration (EIA), Energy Markets and Contingency Information Division. Projections: EIA, Office of Integrated Analysis and Forecasting, World Energy Projection System and "DESTINY" International Energy Forecast Software (Dallas, TX: Petroconsultants, 1997). 
Table A43. World Oil Production Capacity by Region and Country, High Non-OPEC Supply Case, 1990-2015 (Million Barrels per Day)

\begin{tabular}{|c|c|c|c|c|c|c|}
\hline \multirow[b]{2}{*}{ Region/Country } & \multicolumn{2}{|c|}{ History (Estimates) } & \multicolumn{4}{|c|}{ Projections } \\
\hline & 1990 & 1995 & 2000 & 2005 & 2010 & 2015 \\
\hline \multicolumn{7}{|l|}{ OPEC } \\
\hline \multicolumn{7}{|l|}{ Persian Gulf } \\
\hline $\operatorname{Iran} \ldots \ldots \ldots \ldots \ldots$ & 3.2 & 3.9 & 3.7 & 4.5 & 4.7 & 4.8 \\
\hline $\operatorname{Iraq} \ldots \ldots \ldots \ldots \ldots$ & 2.2 & 0.6 & 4.1 & 5.3 & 6.2 & 6.4 \\
\hline Kuwait $\ldots \ldots \ldots \ldots \ldots$ & 1.7 & 2.6 & 2.7 & 3.4 & 3.9 & 4.0 \\
\hline Qatar $\ldots \ldots \ldots \ldots \ldots$ & 0.5 & 0.6 & 0.4 & 0.5 & 0.5 & 0.4 \\
\hline Saudi Arabia $\ldots \ldots \ldots \ldots$ & 8.5 & 10.6 & 11.1 & 12.4 & 14.3 & 19.5 \\
\hline United Arab Emirates $\ldots \ldots$ & 2.5 & 2.6 & 2.7 & 3.1 & 3.8 & 3.9 \\
\hline Total Persian Gulf . . . . . & 18.6 & 20.9 & 24.7 & 29.2 & 33.4 & 39.0 \\
\hline \multicolumn{7}{|l|}{ Other OPEC } \\
\hline Algeria $\ldots \ldots \ldots \ldots \ldots$ & 1.4 & 1.4 & 1.3 & 1.1 & 0.9 & 0.7 \\
\hline Gabon $\ldots \ldots \ldots \ldots \ldots$ & 0.3 & 0.4 & 0.3 & 0.3 & 0.2 & 0.2 \\
\hline Indonesia . . . . . . . . . & 1.5 & 1.7 & 1.2 & 1.0 & 0.9 & 0.7 \\
\hline Libya . . . . . . . . . . & 1.6 & 1.5 & 1.7 & 2.0 & 2.1 & 2.1 \\
\hline Nigeria . . . . . . . . . . & 1.8 & 2.2 & 2.0 & 2.1 & 2.1 & 2.1 \\
\hline Venezuela . . . . . . . . & 2.6 & 2.9 & 3.2 & 3.9 & 4.4 & 4.5 \\
\hline Total Other OPEC $\ldots \ldots$ & 9.2 & 10.1 & 9.7 & 10.4 & 10.6 & 10.3 \\
\hline Total OPEC $\ldots \ldots \ldots \ldots \ldots$ & 27.8 & 31.0 & 34.4 & 39.6 & 44.0 & 49.3 \\
\hline \multicolumn{7}{|l|}{$\begin{array}{l}\text { Non-OPEC } \\
\text { Industrialized }\end{array}$} \\
\hline United States & 9.7 & 9.4 & 8.8 & 8.7 & 8.8 & 8.8 \\
\hline Canada $\ldots \ldots \ldots \ldots \ldots$ & 2.0 & 2.4 & 2.6 & 2.6 & 2.7 & 2.7 \\
\hline Mexico $\ldots \ldots \ldots \ldots \ldots$ & 3.0 & 3.1 & 3.3 & 3.4 & 3.6 & 3.7 \\
\hline Australia ..... & 0.7 & 0.8 & 0.7 & 0.8 & 0.8 & 0.7 \\
\hline North Sea & 3.8 & 5.6 & 6.7 & 6.8 & 6.1 & 5.4 \\
\hline Other $\ldots \ldots \ldots \ldots \ldots$ & 0.8 & 1.2 & 0.8 & 0.8 & 0.9 & 0.8 \\
\hline Total Industrialized . . . . & 20.0 & 22.5 & 22.9 & 23.1 & 22.9 & 22.1 \\
\hline \multicolumn{7}{|l|}{ Eurasia } \\
\hline China...... & 2.8 & 3.0 & 3.2 & 3.2 & 3.4 & 3.5 \\
\hline Former Soviet Union . . . . . & 11.4 & 7.0 & 8.2 & 9.8 & 10.5 & 12.3 \\
\hline Eastern Europe $\ldots \ldots \ldots$ & 0.3 & 0.3 & 0.3 & 0.4 & 0.4 & 0.4 \\
\hline Total Eurasia $\ldots \ldots \ldots$ & 14.5 & 10.3 & 11.7 & 13.4 & 14.3 & 16.2 \\
\hline \multicolumn{7}{|l|}{ Other Non-OPEC } \\
\hline Central and South America . & 2.4 & 3.1 & 4.6 & 5.4 & 7.0 & 7.7 \\
\hline Middle East $\ldots \ldots \ldots \ldots$ & 1.3 & 1.9 & 2.4 & 2.8 & 3.3 & 3.9 \\
\hline Africa $\ldots \ldots \ldots \ldots \ldots$ & 1.9 & 2.1 & 2.3 & 2.4 & 2.6 & 2.8 \\
\hline Asia $\ldots \ldots \ldots \ldots$ & 1.7 & 2.1 & 2.9 & 3.7 & 4.1 & 4.6 \\
\hline Total Other Non-OPEC & 7.4 & 9.2 & 12.2 & 14.3 & 17.0 & 19.0 \\
\hline Total Non-OPEC $\ldots \ldots \ldots$ & 41.9 & 42.0 & 46.8 & 50.8 & 54.2 & 57.3 \\
\hline Total World ............ & 69.7 & 73.0 & 81.2 & 90.4 & 98.2 & 106.6 \\
\hline
\end{tabular}

Note: OPEC = Organization of Petroleum Exporting Countries.

Sources: History: Energy Information Administration (EIA), Energy Markets and Contingency Information Division. Projections: EIA, Office of Integrated Analysis and Forecasting, World Energy Projection System and "DESTINY" International Energy Forecast Software (Dallas, TX: Petroconsultants, 1997). 
Table A44. World Oil Production by Region and Country, Reference Case, 1990-2015 (Million Barrels per Day)

\begin{tabular}{|c|c|c|c|c|c|c|}
\hline \multirow[b]{2}{*}{ Region/Country } & \multicolumn{2}{|c|}{ History (Estimates) } & \multicolumn{4}{|c|}{ Projections } \\
\hline & 1990 & 1995 & 2000 & 2005 & 2010 & 2015 \\
\hline \multicolumn{7}{|l|}{ OPEC } \\
\hline Persian Gulf & 15.9 & 18.4 & 22.6 & 29.1 & 35.6 & 43.4 \\
\hline Other OPEC $\ldots \ldots \ldots$ & 8.6 & 9.6 & 10.0 & 11.3 & 11.9 & 11.9 \\
\hline Total OPEC $\ldots \ldots \ldots \ldots$ & 24.5 & 28.0 & 32.6 & 40.4 & 47.5 & 55.3 \\
\hline \multicolumn{7}{|l|}{$\begin{array}{l}\text { Non-OPEC } \\
\text { Industrialized }\end{array}$} \\
\hline United States . . . . . . & 9.7 & 9.4 & 8.8 & 8.7 & 8.8 & 8.8 \\
\hline Canada $\ldots \ldots \ldots \ldots$ & 2.0 & 2.4 & 2.6 & 2.5 & 2.6 & 2.5 \\
\hline Mexico $\ldots \ldots \ldots \ldots$ & 3.0 & 3.2 & 3.2 & 3.2 & 3.3 & 3.4 \\
\hline Western Europe .... & 4.6 & 6.6 & 7.1 & 6.6 & 5.7 & 5.1 \\
\hline Other $\ldots \ldots \ldots \ldots \ldots$ & 0.8 & 0.8 & 0.8 & 0.7 & 1.0 & 0.7 \\
\hline Total Industrialized . . . . . & 20.0 & 22.4 & 22.5 & 21.7 & 21.4 & 20.5 \\
\hline \multicolumn{7}{|l|}{ Eurasia } \\
\hline China...$\ldots \ldots \ldots$ & 2.8 & 2.9 & 3.1 & 3.2 & 3.3 & 3.5 \\
\hline Former Soviet Union & 11.4 & 7.0 & 7.7 & 9.1 & 9.8 & 10.6 \\
\hline Eastern Europe ... & 0.3 & 0.3 & 0.3 & 0.3 & 0.2 & 0.2 \\
\hline Total Eurasia $\ldots \ldots \ldots$ & 14.5 & 10.3 & 11.1 & 12.6 & 13.3 & 14.3 \\
\hline \multicolumn{7}{|l|}{ Other Non-OPEC } \\
\hline Central and South America & 2.4 & 3.1 & 4.3 & 4.7 & 5.2 & 6.0 \\
\hline Pacific Rim . . . . . . . . . & 1.7 & 2.0 & 2.7 & 3.0 & 3.2 & 3.2 \\
\hline Other $\ldots \ldots \ldots \ldots \ldots$ & 3.3 & 4.0 & 4.6 & 4.8 & 5.0 & 5.3 \\
\hline Total Other Non-OPEC . . & 7.4 & 9.1 & 11.6 & 12.5 & 13.4 & 14.5 \\
\hline Total World $\ldots . . \ldots \ldots \ldots$ & 66.5 & 69.8 & 77.8 & 87.2 & 95.6 & 104.6 \\
\hline $\begin{array}{l}\text { Persian Gulf Production } \\
\text { as a Percentage of } \\
\text { World Consumption } \ldots \ldots \ldots\end{array}$ & 23.9 & 26.4 & 29.0 & 33.4 & 37.2 & 41.5 \\
\hline
\end{tabular}

Notes: OPEC = Organization of Petroleum Exporting Countries. Production includes crude oil (including lease condensates), natural gas liquids, other hydrogen and hydrocarbons for refinery feedstocks, refinery gains, alcohol, and liquids produced from coal and other sources. Totals may not equal sum of components due to independent rounding.

Sources: History: Energy Information Administration (EIA), Energy Markets and Contingency Information Division. Projections: EIA, Office of Integrated Analysis and Forecasting, World Energy Projection System and "DESTINY" International Energy Forecast Software (Dallas, TX: Petroconsultants, 1997). 
Table A45. World Oil Production by Region and Country, High Oil Price Case, 1990-2015 (Million Barrels per Day)

\begin{tabular}{|c|c|c|c|c|c|c|}
\hline \multirow[b]{2}{*}{ Region/Country } & \multicolumn{2}{|c|}{ History (Estimates) } & \multicolumn{4}{|c|}{ Projections } \\
\hline & 1990 & 1995 & 2000 & 2005 & 2010 & 2015 \\
\hline \multicolumn{7}{|l|}{ OPEC } \\
\hline Persian Gulf & 15.9 & 18.4 & 21.2 & 26.3 & 31.2 & 37.0 \\
\hline Other OPEC . & 8.6 & 9.6 & 9.4 & 10.1 & 10.4 & 10.0 \\
\hline Total OPEC $\ldots \ldots \ldots \ldots$ & 24.5 & 28.0 & 30.5 & 36.4 & 41.6 & 47.0 \\
\hline \multicolumn{7}{|l|}{$\begin{array}{l}\text { Non-OPEC } \\
\text { Industrialized }\end{array}$} \\
\hline United States & 9.7 & 9.4 & 9.4 & 9.7 & 10.0 & 10.6 \\
\hline Canada $\ldots \ldots \ldots \ldots$ & 2.0 & 2.4 & 2.5 & 2.4 & 2.5 & 2.4 \\
\hline Mexico $\ldots \ldots \ldots \ldots \ldots$ & 3.0 & 3.2 & 3.1 & 3.1 & 3.2 & 3.2 \\
\hline Western Europe & 4.6 & 6.6 & 7.1 & 6.7 & 6.0 & 5.0 \\
\hline Other $\ldots \ldots \ldots \ldots \ldots$ & 0.8 & 0.8 & 0.8 & 0.7 & 0.8 & 0.7 \\
\hline Total Industrialized . . . . . & 20.0 & 22.4 & 22.9 & 22.6 & 22.5 & 21.9 \\
\hline \multicolumn{7}{|l|}{ Eurasia } \\
\hline China $\ldots \ldots \ldots \ldots \ldots$ & 2.8 & 2.9 & 3.1 & 3.2 & 3.3 & 3.5 \\
\hline Former Soviet Union . . . . . . & 11.4 & 7.0 & 7.9 & 9.3 & 9.2 & 9.2 \\
\hline Eastern Europe .... & 0.3 & 0.3 & 0.3 & 0.4 & 0.2 & 0.2 \\
\hline Total Eurasia $\ldots \ldots \ldots$ & 14.5 & 10.3 & 11.3 & 12.9 & 12.7 & 12.9 \\
\hline \multicolumn{7}{|l|}{ Other Non-OPEC } \\
\hline Central and South America . & 2.4 & 3.1 & 4.5 & 5.0 & 6.1 & 7.9 \\
\hline Pacific Rim $\ldots \ldots \ldots \ldots$ & 1.7 & 2.0 & 2.8 & 3.2 & 3.6 & 3.8 \\
\hline Other $\ldots \ldots \ldots \ldots \ldots$ & 3.3 & 4.0 & 4.5 & 4.6 & 5.2 & 5.7 \\
\hline Total Other Non-OPEC . . & 7.4 & 9.1 & 11.8 & 12.8 & 14.9 & 17.4 \\
\hline Total World $\ldots \ldots \ldots \ldots$ & 66.5 & 69.8 & 76.5 & 84.7 & 91.7 & 99.2 \\
\hline $\begin{array}{l}\text { Persian Gulf Production } \\
\text { as a Percentage of } \\
\text { World Consumption } \ldots \ldots \ldots\end{array}$ & 23.9 & 26.4 & 27.6 & 31.0 & 34.0 & 37.3 \\
\hline
\end{tabular}

Notes: OPEC $=$ Organization of Petroleum Exporting Countries. Production includes crude oil (including lease condensates), natural gas liquids, other hydrogen and hydrocarbons for refinery feedstocks, refinery gains, alcohol, and liquids produced from coal and other sources. Totals may not equal sum of components due to independent rounding.

Sources: History: Energy Information Administration (EIA), Energy Markets and Contingency Information Division. Projections: EIA, Office of Integrated Analysis and Forecasting, World Energy Projection System and "DESTINY" International Energy Forecast Software (Dallas, TX: Petroconsultants, 1997). 
Table A46. World Oil Production by Region and Country, Low Oil Price Case, 1990-2015 (Million Barrels per Day)

\begin{tabular}{|c|c|c|c|c|c|c|}
\hline \multirow[b]{2}{*}{ Region/Country } & \multicolumn{2}{|c|}{ History (Estimates) } & \multicolumn{4}{|c|}{ Projections } \\
\hline & 1990 & 1995 & 2000 & 2005 & 2010 & 2015 \\
\hline \multicolumn{7}{|l|}{ OPEC } \\
\hline Persian Gulf & 15.9 & 18.4 & 24.4 & 33.7 & 42.1 & 52.1 \\
\hline Other OPEC . . & 8.6 & 9.6 & 10.8 & 13.0 & 14.1 & 14.0 \\
\hline Total OPEC $\ldots \ldots \ldots \ldots$ & 24.5 & 28.0 & 35.2 & 46.6 & 56.2 & 66.1 \\
\hline \multicolumn{7}{|l|}{$\begin{array}{l}\text { Non-OPEC } \\
\text { Industrialized }\end{array}$} \\
\hline United States & 9.7 & 9.4 & 8.4 & 7.5 & 7.4 & 7.5 \\
\hline Canada $\ldots \ldots \ldots \ldots \ldots$ & 2.0 & 2.4 & 2.4 & 2.3 & 2.4 & 2.3 \\
\hline Mexico $\ldots \ldots \ldots \ldots \ldots$ & 3.0 & 3.2 & 3.1 & 3.0 & 3.0 & 3.0 \\
\hline Western Europe $\ldots \ldots \ldots$ & 4.6 & 6.6 & 7.2 & 6.5 & 5.8 & 4.8 \\
\hline Other $\ldots \ldots \ldots \ldots \ldots$ & 0.8 & 0.8 & 0.7 & 0.7 & 0.7 & 0.6 \\
\hline $\begin{array}{l}\text { Total Industrialized . . . . . } \\
\text { Eurasia }\end{array}$ & 20.0 & 22.4 & 21.8 & 20.0 & 19.3 & 18.2 \\
\hline China $\ldots \ldots \ldots \ldots \ldots$ & 2.8 & 2.9 & 3.0 & 3.0 & 3.1 & 3.2 \\
\hline Former Soviet Union & 11.4 & 7.0 & 7.8 & 9.0 & 8.8 & 8.6 \\
\hline Eastern Europe $\ldots \ldots \ldots$ & 0.3 & 0.3 & 0.3 & 0.4 & 0.2 & 0.2 \\
\hline Total Eurasia $\ldots \ldots \ldots$ & 14.5 & 10.3 & 11.1 & 12.4 & 12.1 & 12.0 \\
\hline Other Non-OPEC & & & & & & \\
\hline Central and South America . & 2.4 & 3.1 & 4.4 & 4.8 & 5.8 & 7.4 \\
\hline Pacific Rim . . . . . . . . & 1.7 & 2.0 & 2.7 & 3.1 & 3.4 & 3.5 \\
\hline Other $\ldots \ldots \ldots \ldots \ldots$ & 3.3 & 4.0 & 4.4 & 4.5 & 4.9 & 5.4 \\
\hline Total Other Non-OPEC .. & 7.4 & 9.1 & 11.5 & 12.4 & 14.1 & 16.3 \\
\hline Total World $\ldots \ldots \ldots \ldots$ & 66.5 & 69.8 & 79.6 & 91.4 & 101.7 & 112.6 \\
\hline $\begin{array}{l}\text { Persian Gulf Production } \\
\text { as a Percentage of } \\
\text { World Consumption } \ldots \ldots \ldots\end{array}$ & 23.9 & 26.4 & 30.6 & 36.8 & 41.4 & 46.3 \\
\hline
\end{tabular}

Notes: OPEC = Organization of Petroleum Exporting Countries. Production includes crude oil (including lease condensates), natural gas liquids, other hydrogen and hydrocarbons for refinery feedstocks, refinery gains, alcohol, and liquids produced from coal and other sources. Totals may not equal sum of components due to independent rounding.

Sources: History: Energy Information Administration (EIA), Energy Markets and Contingency Information Division. Projections: EIA, Office of Integrated Analysis and Forecasting, World Energy Projection System and "DESTINY" International Energy Forecast Software (Dallas, TX: Petroconsultants, 1997). 
Table A47. World Oil Production by Region and Country, High Non-OPEC Supply Case, 1990-2015 (Million Barrels per Day)

\begin{tabular}{|c|c|c|c|c|c|c|}
\hline \multirow[b]{2}{*}{ Region/Country } & \multicolumn{2}{|c|}{ History (Estimates) } & \multicolumn{4}{|c|}{ Projections } \\
\hline & 1990 & 1995 & 2000 & 2005 & 2010 & 2015 \\
\hline \multicolumn{7}{|l|}{ OPEC } \\
\hline Persian Gulf & 15.9 & 18.4 & 21.5 & 26.3 & 31.0 & 37.3 \\
\hline Other OPEC . & 8.6 & 9.6 & 9.5 & 10.1 & 10.3 & 10.0 \\
\hline Total OPEC $\ldots \ldots \ldots \ldots$ & 24.5 & 28.0 & 31.0 & 36.4 & 41.4 & 47.3 \\
\hline \multicolumn{7}{|l|}{$\begin{array}{l}\text { Non-OPEC } \\
\text { Industrialized }\end{array}$} \\
\hline United States & 9.7 & 9.4 & 8.8 & 8.7 & 8.8 & 8.8 \\
\hline Canada .... & 2.0 & 2.4 & 2.6 & 2.6 & 2.7 & 2.7 \\
\hline Mexico $\ldots \ldots \ldots \ldots \ldots$ & 3.0 & 3.2 & 3.3 & 3.4 & 3.6 & 3.7 \\
\hline Western Europe $\ldots \ldots \ldots$ & 4.6 & 6.6 & 7.4 & 7.6 & 6.9 & 6.1 \\
\hline Other $\ldots \ldots \ldots \ldots \ldots \ldots$ & 0.8 & 0.8 & 0.8 & $0.8^{\circ}$ & 0.9 & 0.8 \\
\hline $\begin{array}{l}\text { Total Industrialized . . . . } \\
\text { Eurasia }\end{array}$ & 20.0 & 22.4 & 22.9 & 23.1 & 22.9 & 22.1 \\
\hline China $\ldots \ldots \ldots \ldots \ldots$ & 2.8 & 2.9 & 3.2 & 3.2 & 3.4 & 3.5 \\
\hline Former Soviet Union $\ldots \ldots$ & 11.4 & 7.0 & 8.2 & 9.8 & 10.5 & 12.3 \\
\hline Eastern Europe $\ldots \ldots \ldots$ & 0.3 & 0.3 & 0.3 & 0.4 & 0.4 & 0.4 \\
\hline Total Eurasia & 14.5 & 10.3 & 11.7 & 13.4 & 14.3 & 16.2 \\
\hline Other Non-OPEC & & & & & & \\
\hline Central and South America & 2.4 & 3.1 & 4.6 & 5.4 & 7.0 & 7.7 \\
\hline Pacific $\operatorname{Rim} \ldots \ldots \ldots \ldots$ & 1.7 & 2.0 & 2.9 & 3.7 & 4.1 & 4.6 \\
\hline Other $\ldots \ldots \ldots \ldots \ldots$ & 3.3 & 4.0 & 4.7 & 5.2 & 5.9 & 6.7 \\
\hline Total Other Non-OPEC .. & 7.4 & 9.1 & 12.2 & 14.3 & 17.0 & 19.0 \\
\hline Total World $\ldots \ldots \ldots \ldots \ldots$ & 66.5 & 69.8 & 77.8 & 87.2 & 95.6 & 104.6 \\
\hline $\begin{array}{l}\text { Persian Gulf Production } \\
\text { as a Percentage of } \\
\text { World Consumption } \ldots \ldots \ldots\end{array}$ & 23.9 & 26.4 & 27.7 & 30.1 & 32.5 & 35.6 \\
\hline
\end{tabular}

Notes: OPEC $=$ Organization of Petroleum Exporting Countries. Production includes crude oil (including lease condensates), natural gas liquids, other hydrogen and hydrocarbons for refinery feedstocks, refinery gains, alcohol, and liquids produced from coal and other sources. Totals may not equal sum of components due to independent rounding.

Sources: History: Energy Information Administration (EIA), Energy Markets and Contingency Information Division. Projections: EIA, Office of Integrated Analysis and Forecasting, World Energy Projection System and "DESTINY" International Energy Forecast Software (Dallas, TX: Petroconsultants, 1997). 
Appendix B World Energy
Projection System 



\section{Appendix B World Energy Projection System}

The projections of world energy consumption published annually by the Energy Information Administration (EIA) in the International Energy Outlook (IEO) are derived from the World Energy Projection System (WEPS). WEPS is an integrated set of personalcomputer-based spreadsheets containing data compilations, assumption specifications, descriptive analysis procedures, and projection models. The WEPS accounting framework incorporates projections from independently documented models and assumptions about the future energy intensity of economic activity (ratios of total energy consumption divided by gross domestic product [GDP]) and about the rate of incremental energy requirements met by natural gas, coal, and renewable energy sources (hydroelectricity, geothermal, solar, wind, biomass, and other renewable sources).

WEPS provides projections of total world primary energy consumption, as well as projections of energy consumption by primary energy type (oil, natural gas, coal, nuclear, and hydroelectric and other renewable resources), and projections of net electricity consumption. Carbon emissions resulting from fossil fuel use are derived from the energy consumption projections. All projections are computed in 5-year intervals through the year 2015. For both historical series and projection series, WEPS provides analytical computations of energy intensity and energy elasticity (the percentage change in energy consumption per percentage change in GDP).

WEPS projections are provided for regions and selected countries. Projections are made for six individual countries, four of which-United States, Canada, Mexico, and Japan - are part of the designation "industrialized countries." Individual country projections are also made for China and India, both of which are considered "developing countries." Beyond these individual countries, the rest of the world is divided into regions. Industrialized regions include North America (Canada, Mexico, and the United States), Western Europe, and Pacific (Japan and Australasia [Australia, New Zealand, and the U.S. Territories]). Developing regions include developing Asia (China, India, and Other Asia), Middle East, Africa, and Central and South
America. The transitional economies consisting of the countries in Eastern Europe (EE) and the former Soviet Union (FSU) are considered as a separate country grouping, neither industrialized nor developing.

The process of creating the projections begins with the calculation of a reference case total energy consumption projection for each country or region for each 5-year interval in the forecast period. The total energy consumption projection for each forecast year is the product of an assumed GDP growth rate, an assumed energy elasticity, and the total energy consumption for the prior forecast year. For the first year of the forecast, the prior year consumption is based on historical data. Subsequent calculations are based on the energy consumption projections for the preceding years.

Projections of world oil supply are provided to WEPS from EIA's International Energy Module, which is a submodule of the National Energy Modeling System (NEMS). Projections of world nuclear energy consumption are derived from nuclear power electricity generation projections from EIA's International Nuclear Model (INM), PC Version (PC-INM). All U.S. projections are taken from EIA's Annual Energy Outlook (AEO).

A full description of the WEPS is provided in a model documentation report: Energy Information Administration, World Energy Projection System Model Documentation, DOE/EIA-M050(92) (Washington, DC, June 1992). The report presents a thorough description of each of the spreadsheets associated with the WEPS, along with descriptions of the methodologies and assumptions used to produce the projections. It is available from the National Energy Information Center (202/586-8800).

The WEPS model will be made available for downloading through the internet on EIA's home page (http:// www.eia.doe.gov) by May 1997. The package will allow users to replicate the projections that appear in IEO97. It is coded in Lotus 1-2-3 for Windows, Release 5.0, and can be executed on any IBM-compatible personal computer in a Windows 3.1 environment. The package requires about 5 megabytes of hard disk space and about 640 kilobytes of random access memory (RAM). 

Appendix C Forecast Comparisons 



\section{Appendix C Forecast Comparisons}

To measure the uncertainty associated with any set of projections, it is useful to compare them with other forecasts. The tables in this appendix represent an expansion of the tables presented in the "World Energy Consumption" chapter of this report (page 5). Comparable forecast values are available from three organizations. The International Energy Agency (IEA) provides two energy demand scenarios as part of its World Energy Outlook 1996: the Capacity Constraints Case (IEA $\mathrm{CC}$ ) and the Energy Savings Case (IEA ES). Petroleum Economics, Ltd. (PEL) and Petroleum Industry Research Associates (PIRA) also publish energy forecasts.

Comparisons are limited by variation in forecast details. Only the IEA provides forecasts with the same regional and energy source detail as the International Energy Outlook 1997 (IEO97). That is, comparisons between IEO97 and the IEA CC and IEA ES cases can be made by fuel and region. PIRA provides energy demand forecasts by fuel source as well as the aggregated regional breakout shown in Table 11 of this report (page 26) but does not further disaggregate regionally to the extent shown elsewhere in IEO97. In contrast, the PEL forecast does not include a breakout by fuel, except for the oil consumption and production forecasts discussed in the chapter of this report on "The World Oil Market" (page 43). Therefore, Table $\mathrm{Cl}$ compares the available forecasts by fuel; Table $\mathrm{C} 2$ compares total energy consumption forecasts by region; and Tables $\mathrm{C} 3$ through $\mathrm{C} 8$ compare energy demand forecasts by region and fuel.
For total energy consumption over the period 1990 to 2010, all the forecasts fall within the range defined by the IEO97 high and low economic growth cases (Table $\mathrm{C} 1)$. There is general agreement among the forecasts that oil use will grow by about 2 percent annually: the projected annual growth rates range from 1.8 percent (IEA ES) to 2.1 percent (PIRA and IEA CC). The forecasts show stronger growth rates for natural gas (with the exception of IEA ES) and renewable resources, and lower growth rates for nuclear energy.

In the forecasts for energy sources, the largest differences involve coal consumption. IEO97 and the IEA ES case show rather slow annual growth for coal worldwide over the next two decades, 1.2 percent and 1.6 percent, respectively. In contrast, PIRA expects coal demand to increase by 2.5 percent per year over the forecast. PIRA contends that coal will compete successfully with natural gas for existing electric power plants, although natural gas will fuel most of the new plants. Thus, PIRA projects that over the next 10 years coal will fuel about one-half of the growth in electricity generation [1, p. 20], compared with less than one-third in the IEO97 projections for the same period.

Regionally, most forecasts agree that, within the industrialized countries, the strongest growth expectations between 1990 and 2010 are for the industrialized Asia countries (Table $\mathrm{C} 2$ ). The highest growth rates in all the forecasts are for the developing countries, especially

Table C1. Comparison of World Energy Consumption Growth Rates, 1990-2010, by Fuel (Average Annual Percent Growth)

\begin{tabular}{|c|c|c|c|c|c|c|c|}
\hline \multirow[b]{2}{*}{ Fuel } & \multicolumn{3}{|c|}{ IEO97 } & \multirow[b]{2}{*}{ IEO96 } & \multirow[b]{2}{*}{ IEA CC ${ }^{a}$} & \multirow[b]{2}{*}{ IEA ES ${ }^{\mathbf{a}}$} & \multirow[b]{2}{*}{ PIRA $^{b}$} \\
\hline & $\begin{array}{l}\text { Low } \\
\text { Growth }\end{array}$ & Reference & $\begin{array}{l}\text { High } \\
\text { Growth }\end{array}$ & & & & \\
\hline Oil & 1.3 & 1.9 & 2.4 & 1.6 & 2.1 & 1.8 & 2.1 \\
\hline Natural Gas & 2.4 & 2.9 & 3.5 & 2.5 & 2.9 & 1.7 & 2.8 \\
\hline Coal $\ldots \ldots$ & 0.4 & 1.2 & 1.8 & 1.3 & 2.0 & 1.6 & 2.5 \\
\hline Nuclear ... & 0.8 & 1.1 & 1.4 & 0.9 & 1.0 & 1.0 & 1.6 \\
\hline Other . . & 1.4 & 2.4 & 2.9 & 2.5 & 3.3 & 3.5 & 2.8 \\
\hline Total $\ldots \ldots \ldots \ldots \ldots$ & 1.4 & 2.0 & 2.6 & 1.8 & 2.2 & 1.8 & 2.4 \\
\hline
\end{tabular}

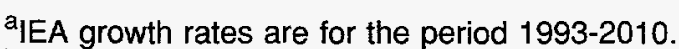

bPIRA growth rates are for the period 1990-2005.

Sources: IEO97: Energy Information Administration (EIA), World Energy Projection System (1997). IEO96: EIA, International Energy Outlook 1996, DOE/EIA-0484(96) (Washington, DC, May 1996), Table A1, p. 91. IEA CC: International Energy Agency, World Energy Outlook 1996 (Paris, France, 1996), Capacity Constraints Case, pp. 237-249. IEA ES: International Energy Agency, World Energy Outlook 1996 (Paris, France, 1996), Energy Savings Case, pp. 257-269. PIRA: Petroleum Industry Research Associates, Inc., Annual Retainer Client Seminar-World Energy (New York, NY, October 1996 ), Table II-4. 
developing Asia. Little growth or declines are expected for energy consumption in Eastern Europe and the former Soviet Union (EE/FSU). PEL is the most pessimistic about demand in the EE/FSU, expecting energy consumption to decline by 2.1 percent annually in the FSU over the 20-year period. All the forecasts expect Eastern Europe to fare better than the FSU.

Tables C 3 through C8 compare the IEO97 forecasts with the two cases from the IEA's World Energy Outlook 1996 by energy source and region for the period 1993 to 2010. IEO97 and the IEA CC case show similar expectations for the industrialized subregions and the EE/FSU. However, the IEA CC case is somewhat more optimistic than IEO97 for the developing regions. The largest differences between the two forecasts are for the Middle East and Africa. For the Middle East, the IEA $\mathrm{CC}$ case relates economic growth rates to projected increases in world oil prices [2, p. 167-169]; as a result, the region's gross domestic product (GDP) is projected to grow by 3.6 percent annually between 1993 and 2010 , commensurate with oil prices that rise to more than $\$ 26$ per barrel (1995 U.S. dollars) in 2010. The IEA ES case expects an average GDP growth rate of 3.1 percent per year for the Middle East, as compared with the IEO97 assumptions of 2.5-percent annual growth in GDP for the Middle East and a 2010 world oil price of $\$ 20$ per barrel.

The IEA CC and IEA ES cases also assume higher economic growth rates for Africa over the 1993 to 2010 forecast period than does the IEO97. Both IEA cases assume a 4.1-percent annual increase in GDP for Africa, whereas IEO97 projects an average annual economic growth rate of 3.3 percent. The differences among the forecasts for Africa and the Middle East are most pronounced for natural gas and coal (Tables C5 and C6), with IEO97 projecting demand growth rates that are less than half those in the IEA cases.

\section{References}

1. Petroleum Industry Research Associates, Inc., Annual Retainer Client Seminar (Part 2): Presentations (New York, NY, October 1996).

2. International Energy Agency, World Energy Outlook 1996, (Paris, France, 1996).

Table C2. Comparison of Energy Consumption Growth Rates, 1990-2010, by Region (Average Annual Percent Growth)

\begin{tabular}{|c|c|c|c|c|c|c|c|}
\hline \multirow[b]{2}{*}{ Region } & \multicolumn{3}{|c|}{ IEO97 } & \multirow[b]{2}{*}{ IEO96 } & \multirow[b]{2}{*}{ IEA CC ${ }^{a}$} & \multirow[b]{2}{*}{ IEA ES ${ }^{a}$} & \multirow[b]{2}{*}{ PEL } \\
\hline & $\begin{array}{l}\text { Low } \\
\text { Growth }\end{array}$ & Reference & $\begin{array}{l}\text { High } \\
\text { Growth }\end{array}$ & & & & \\
\hline Industrialized & 1.3 & 1.5 & 1.7 & 1.3 & 1.4 & 0.8 & 1.2 \\
\hline North America $\ldots \ldots \ldots$ & 1.2 & 1.5 & 1.7 & 1.3 & 1.3 & 0.8 & 1.3 \\
\hline Western Europe $\ldots \ldots \ldots$ & 1.0 & 1.3 & 1.5 & 1.1 & 1.1 & 0.5 & 0.9 \\
\hline Pacific $\ldots \ldots$. & 1.8 & 2.1 & 2.4 & 1.8 & 2.1 & 1.6 & 1.5 \\
\hline EE/FSU $\ldots \ldots \ldots \ldots \ldots$ & -0.7 & -0.2 & 0.8 & -0.1 & 0.8 & 0.0 & -1.2 \\
\hline Former Soviet Union . . . . . . & -0.9 & -0.4 & 0.6 & -0.3 & 0.5 & -0.3 & -2.1 \\
\hline Eastern Europe . . . & 0.0 & 0.6 & 1.6 & 0.6 & 1.7 & 1.0 & 0.8 \\
\hline Developing Countries $\ldots \ldots$ & 3.0 & 4.1 & 4.9 & 3.7 & 4.3 & 4.0 & 4.4 \\
\hline Developing Asia .... & 3.7 & 4.9 & 5.7 & 4.6 & 4.6 & 4.4 & 4.9 \\
\hline China $\ldots . . .$. & 3.4 & 4.8 & 5.5 & 4.6 & 4.2 & 4.1 & 3.9 \\
\hline Other Asia & 4.0 & 5.0 & 6.0 & 4.5 & 5.1 & 4.7 & 5.7 \\
\hline Middle East & 1.3 & 2.2 & 3.0 & 2.4 & 4.2 & 3.4 & 4.1 \\
\hline Africa ..... & 1.5 & 2.3 & 3.0 & 1.6 & 4.0 & 3.5 & 3.0 \\
\hline Central and South America & 2.1 & 3.2 & 4.2 & 2.3 & 3.1 & 2.4 & 3.8 \\
\hline Total World $\ldots \ldots \ldots \ldots \ldots$ & 1.4 & 2.0 & 2.6 & 1.8 & 2.2 & 1.8 & 1.9 \\
\hline
\end{tabular}

a IEA growth rates are for the period 1993-2010.

Notes: IEO97, IEO96: India is included in Developing Other Asia. Mexico is included in North America. PEL: North America includes only the United States. Industrialized Pacific includes only Japan. Mexico is included in Central and South America.

Sources: IEO97: Energy Information Administration (EIA), World Energy Projection System (1997). IEO96: EIA, International Energy Outlook 1996, DOE/EIA-0484(96) (Washington, DC, May 1996). IEA CC: International Energy Agency, World Energy Outlook 1996 (Paris, France, 1996), Capacity Constraints Case, pp. 237-249. IEA ES: International Energy Agency, World Energy Outlook 1996 (Paris, France, 1996), Energy Savings Case, pp. 257-269. PEL: Petroleum Economics, Ltd., Oil and Energy Outlook to 2010 (London, United Kingdom, December 1996). 
Table C3. Comparison of Energy Consumption Growth Rates, 1993-2010, by Region (Average Annual Percent Growth)

\begin{tabular}{|c|c|c|c|c|c|c|}
\hline \multirow[b]{2}{*}{ Region } & \multicolumn{3}{|c|}{ IEO97 } & \multirow[b]{2}{*}{ IEO96 } & \multirow[b]{2}{*}{ IEA CC } & \multirow[b]{2}{*}{ IEA ES } \\
\hline & $\begin{array}{l}\text { Low } \\
\text { Growth }\end{array}$ & Reference & $\begin{array}{l}\text { High } \\
\text { Growth }\end{array}$ & & & \\
\hline Industrialized $\ldots \ldots \ldots \ldots \ldots \ldots \ldots$ & 1.3 & 1.5 & 1.8 & 1.4 & 1.4 & 0.8 \\
\hline North America $\ldots \ldots \ldots \ldots \ldots \ldots$ & 1.2 & 1.5 & 1.8 & 1.3 & 1.3 & 0.8 \\
\hline Western Europe ... & 1.1 & 1.4 & 1.6 & 1.3 & 1.1 & 0.5 \\
\hline Pacific ......... & 1.6 & 2.0 & 2.2 & 1.8 & 2.1 & 1.6 \\
\hline EE/FSU $\ldots \ldots \ldots \ldots \ldots \ldots \ldots \ldots$ & 0.3 & 0.9 & 2.1 & 1.2 & 0.8 & 0.0 \\
\hline Former Soviet Union $\ldots \ldots \ldots \ldots \ldots \ldots$ & 0.0 & 0.6 & 1.8 & 0.9 & 0.5 & -0.3 \\
\hline Eastern Europe ... & 1.2 & 1.9 & 3.1 & 1.8 & 1.7 & 1.0 \\
\hline Developing Countries $\ldots \ldots \ldots \ldots \ldots$ & 2.6 & 3.9 & 4.9 & 3.7 & 4.3 & 4.0 \\
\hline Developing Asia $\ldots \ldots \ldots \ldots \ldots \ldots$ & 3.3 & 4.7 & 5.6 & 4.5 & 4.6 & 4.4 \\
\hline China . ...... & 3.0 & 4.7 & 5.4 & 4.5 & 4.2 & 4.1 \\
\hline Other Asia & 3.5 & 4.7 & 5.8 & 4.4 & 5.1 & 4.7 \\
\hline Middle East & 0.8 & 1.9 & 2.8 & 2.4 & 4.2 & 3.4 \\
\hline Africa $\ldots \ldots \ldots \ldots \ldots \ldots \ldots \ldots$ & 1.3 & 2.2 & 3.1 & 2.0 & 4.0 & 3.5 \\
\hline Central and South America .......... & 1.9 & 3.1 & 4.3 & 2.4 & 3.1 & 2.4 \\
\hline Total World $\ldots \ldots \ldots \ldots \ldots \ldots \ldots \ldots$ & 1.6 & 2.2 & 2.9 & 2.1 & 2.2 & 1.8 \\
\hline
\end{tabular}

Note: IEO97, IEO96: India is included in Developing Other Asia.

Sources: IEO97: Energy Information Administration (EIA), World Energy Projection System (1997). IEO96: EIA, International Energy Outlook 1996, DOE/EIA-0484(96) (Washington, DC, May 1996). IEA CC: International Energy Agency, World Energy Outlook 1996 (Paris, France, 1996), Capacity Constraints Case, pp. 237-249. IEA ES: International Energy Agency, World Energy Outlook 1996 (Paris, France, 1996), Energy Savings Case, pp. 257-269. 
Table C4. Comparison of Oil Consumption Growth Rates, 1993-2010, by Region (Average Annual Percent Growth)

\begin{tabular}{|c|c|c|c|c|c|c|}
\hline \multirow[b]{2}{*}{ Region } & \multicolumn{3}{|c|}{ IEO97 } & \multirow[b]{2}{*}{ IEO96 } & \multirow[b]{2}{*}{ IEA CC } & \multirow[b]{2}{*}{ IEA ES } \\
\hline & $\begin{array}{l}\text { Low } \\
\text { Growth }\end{array}$ & Reference & $\begin{array}{l}\text { High } \\
\text { Growth }\end{array}$ & & & \\
\hline Industrialized & 1.0 & 1.2 & 1.5 & 1.0 & 1.2 & 0.9 \\
\hline North America $\ldots \ldots \ldots \ldots \ldots \ldots$ & 1.2 & 1.4 & 1.7 & 1.2 & 1.3 & 1.0 \\
\hline Western Europe $\ldots \ldots \ldots \ldots \ldots \ldots$ & 0.4 & 0.6 & 0.9 & 0.5 & 0.9 & 0.7 \\
\hline Pacific $\ldots \ldots \ldots \ldots \ldots \ldots \ldots$ & 1.6 & 1.9 & 2.2 & 1.5 & 1.4 & 1.2 \\
\hline EE/FSU $\ldots \ldots \ldots \ldots \ldots \ldots \ldots \ldots$ & 0.6 & 1.2 & 2.4 & 1.0 & 1.0 & 0.4 \\
\hline Former Soviet Union . . . . . . . . . & 0.4 & 1.1 & 2.2 & 0.8 & 0.5 & 0.0 \\
\hline Eastern Europe $\ldots \ldots \ldots \ldots$ & 1.3 & 1.9 & 3.1 & 2.0 & 3.1 & 2.3 \\
\hline Developing Countries $\ldots \ldots \ldots \ldots \ldots$ & 2.6 & 3.8 & 4.8 & 3.7 & 4.0 & 3.6 \\
\hline Developing Asia $\ldots \ldots \ldots \ldots \ldots \ldots$ & 3.3 & 4.6 & 5.6 & 4.8 & 4.7 & 4.5 \\
\hline China $\ldots \ldots \ldots \ldots \ldots \ldots \ldots \ldots$ & 3.4 & 5.1 & 5.9 & 4.6 & 5.0 & 5.0 \\
\hline Other Asia ... & 3.2 & 4.4 & 5.5 & 4.9 & 4.6 & 4.2 \\
\hline Middle East . . & 1.1 & 2.1 & 3.1 & 2.4 & 2.7. & 2.0 \\
\hline Africa $\ldots \ldots \ldots \ldots \ldots \ldots$ & 2.6 & 3.6 & 4.4 & 2.4 & 4.3 & 3.9 \\
\hline Central and South America . . . . . . . & 2.0 & 3.3 & 4.5 & 2.1 & 2.8 & 2.2 \\
\hline Total World $\ldots \ldots \ldots \ldots \ldots \ldots \ldots$ & 1.5 & 2.1 & 2.8 & 1.9 & 2.1 & 1.8 \\
\hline
\end{tabular}

Note: IEO97, IEO96: India is included in Developing Other Asia.

Sources: IEO97: Energy Information Administration (EIA), World Energy Projection System (1997). IEO96: EIA, International Energy Outlook 1996, DOE/EIA-0484(96) (Washington, DC, May 1996). IEA CC: International Energy Agency, World Energy Outlook 1996 (Paris, France, 1996), Capacity Constraints Case, pp. 237-249. IEA ES: International Energy Agency, World Energy Outlook 1996 (Paris, France, 1996), Energy Savings Case, pp. 257-269. 
Table C5. Comparison of Natural Gas Consumption Growth Rates, 1993-2010, by Region (Average Annual Percent Growth)

\begin{tabular}{|c|c|c|c|c|c|c|}
\hline \multirow[b]{2}{*}{ Region } & \multicolumn{3}{|c|}{ IEO97 } & \multirow[b]{2}{*}{ IEO96 } & \multirow[b]{2}{*}{ IEA CC } & \multirow[b]{2}{*}{ IEA ES } \\
\hline & $\begin{array}{c}\text { Low } \\
\text { Growth }\end{array}$ & Reference & $\begin{array}{c}\text { High } \\
\text { Growth }\end{array}$ & & & \\
\hline$\ldots \ldots \ldots \ldots \ldots \ldots \ldots$ & 2.6 & 2.9 & 3.1 & 2.4 & 2.5 & 1.0 \\
\hline North America $\ldots \ldots \ldots \ldots \ldots \ldots \ldots$ & 1.9 & 2.1 & 2.4 & 1.6 & 2.2 & 0.9 \\
\hline Western Europe $\ldots \ldots \ldots \ldots \ldots \ldots$ & 3.8 & 4.1 & 4.3 & 3.7 & 2.8 & 0.9 \\
\hline Pacific $\ldots \ldots \ldots \ldots \ldots \ldots \ldots \ldots$ & 3.0 & 3.4 & 3.7 & 2.8 & 3.7 & 2.0 \\
\hline EE/FSU $\ldots \ldots \ldots \ldots \ldots \ldots \ldots \ldots$ & 1.3 & 2.0 & 3.2 & 2.1 & 0.9 & -0.1 \\
\hline Former Soviet Union . . . . . . . . . . & 0.8 & 1.4 & 2.6 & 1.6 & 0.5 & -0.2 \\
\hline Eastern Europe ... & 4.8 & 5.5 & 6.8 & 5.1 & 2.8 & 0.8 \\
\hline Developing Countries $\ldots \ldots \ldots \ldots \ldots$ & 4.4 & 5.7 & 6.7 & 4.5 & 6.1 & 5.3 \\
\hline Developing Asia & 7.9 & 9.2 & 10.3 & 7.2 & 7.6 & 7.1 \\
\hline China . . . . . . & 9.0 & 10.7 & 11.5 & 9.2 & 8.1 & 5.0 \\
\hline Other Asia & 7.7 & 8.9 & 10.0 & 6.7 & 7.4 & 6.9 \\
\hline Middle East & 0.2 & 1.3 & 2.2 & 2.0 & 6.0 & 5.1 \\
\hline Africa $\ldots \ldots \ldots \ldots \ldots \ldots \ldots \ldots$ & 1.2 & 2.1 & 3.0 & 2.7 & 5.4 & 4.4 \\
\hline Central and South America $\ldots \ldots \ldots \ldots$ & 4.4 & 5.7 & 6.9 & 4.4 & 3.6 & 2.5 \\
\hline Total World $\ldots \ldots \ldots \ldots \ldots \ldots \ldots \ldots$ & 2.6 & 3.2 & 3.9 & 2.7 & 2.9 & 1.7 \\
\hline
\end{tabular}

Note: IEO97, IEO96: India is included in Developing Other Asia.

Sources: IEO97: Energy Information Administration (EIA), World Energy Projection System (1997). IEO96: EIA, International Energy Outlook 1996, DOE/EIA-0484(96) (Washington, DC, May 1996). IEA CC: International Energy Agency, World Energy Outlook 1996 (Paris, France, 1996), Capacity Constraints Case, pp. 237-249. IEA ES: International Energy Agency, World Energy Outlook 1996 (Paris, France, 1996), Energy Savings Case, pp. 257-269. 
Table C6. Comparison of Coal Consumption Growth Rates, 1993-2010, by Region (Average Annual Percent Growth)

\begin{tabular}{|c|c|c|c|c|c|c|}
\hline \multirow[b]{2}{*}{ Region } & \multicolumn{3}{|c|}{ IEO97 } & \multirow[b]{2}{*}{ IEO96 } & \multirow[b]{2}{*}{ IEA CC } & \multirow[b]{2}{*}{ IEA ES } \\
\hline & $\begin{array}{l}\text { Low } \\
\text { Growth }\end{array}$ & Reference & $\begin{array}{l}\text { High } \\
\text { Growth }\end{array}$ & & & \\
\hline$\ldots \ldots \ldots \ldots \ldots \ldots \ldots$ & 0.5 & 0.8 & 1.1 & 1.0 & 0.8 & 0.2 \\
\hline North America $\ldots \ldots \ldots \ldots \ldots \ldots$ & 0.8 & 1.0 & 1.3 & 1.1 & 0.8 & 0.4 \\
\hline Western Europe $\ldots \ldots \ldots \ldots \ldots \ldots$ & -0.4 & -0.2 & 0.1 & 0.7 & 0.2 & -0.6 \\
\hline Pacific $\ldots \ldots \ldots \ldots \ldots \ldots \ldots \ldots$ & 1.1 & 1.4 & 1.6 & 1.0 & 2.4 & 1.4 \\
\hline EE/FSU & -1.9 & -1.3 & -0.1 & -0.3 & -0.2 & -0.8 \\
\hline Former Soviet Union $\ldots \ldots \ldots \ldots \ldots$ & -2.6 & -2.0 & -0.8 & -0.3 & -0.6 & -1.4 \\
\hline Eastern Europe $\ldots \ldots \ldots \ldots \ldots \ldots$ & -1.0 & -0.3 & 0.9 & -0.3 & 0.4 & 0.3 \\
\hline Developing Countries $\ldots \ldots \ldots \ldots \ldots$ & 2.0 & 3.5 & 4.3 & 3.5 & 3.8 & 3.6 \\
\hline Developing Asia $\ldots \ldots \ldots \ldots \ldots \ldots$ & 2.3 & 3.8 & 4.6 & 3.7 & 3.9 & 3.7 \\
\hline China..... & 2.4 & 4.1 & 4.8 & 4.0 & 3.6 & 3.5 \\
\hline Other Asia & 1.9 & 3.0 & 4.1 & 2.9 & 4.6 & 4.3 \\
\hline Middle East & 0.1 & 1.1 & 2.0 & 2.4 & 6.6 & 6.5 \\
\hline Africa $\ldots \ldots \ldots \ldots \ldots$ & -0.1 & 0.8 & 1.6 & 0.9 & 2.9 & 2.7 \\
\hline Central and South America & 1.4 & 2.7 & 3.9 & 5.5 & 3.0 & 2.5 \\
\hline 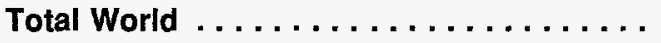 & 0.8 & 1.8 & 2.5 & 2.0 & 2.0 & 1.6 \\
\hline
\end{tabular}

Note: IEO97, IEO96: India is included in Developing Other Asia.

Sources: IEO97: Energy Information Administration (EIA), World Energy Projection System (1997). IEO96: ElA, International Energy Outlook 1996, DOE/EIA-0484(96) (Washington, DC, May 1996). IEA CC: International Energy Agency, World Energy Outlook 1996 (Paris, France, 1996), Capacity Constraints Case, pp. 237-249. IEA ES: International Energy Agency, World Energy Outlook 1996 (Paris, France, 1996), Energy Savings Case, pp. 257-269. 
Table C7. Comparison of Nuclear Power Consumption Growth Rates, 1993-2010, by Region (Average Annual Percent Growth)

\begin{tabular}{|c|c|c|c|c|c|c|}
\hline \multirow[b]{2}{*}{ Region } & \multicolumn{3}{|c|}{ IEO97 } & \multirow[b]{2}{*}{ IEO96 } & \multirow[b]{2}{*}{ IEA CC } & \multirow[b]{2}{*}{ IEA ES } \\
\hline & $\begin{array}{l}\text { Low } \\
\text { Growth }\end{array}$ & Reference & $\begin{array}{l}\text { High } \\
\text { Growth }\end{array}$ & & & \\
\hline Industrialized $\ldots \ldots \ldots \ldots \ldots \ldots$ & 0.1 & 0.3 & 0.6 & 0.2 & 0.5 & 0.5 \\
\hline North America $\ldots \ldots \ldots \ldots \ldots \ldots$ & -0.3 & 0.0 & 0.3 & -0.1 & 0.1 & 0.1 \\
\hline Western Europe & -0.1 & 0.2 & 0.4 & -0.1 & 0.1 & 0.1 \\
\hline Pacific ...... & 1.5 & 1.8 & 2.1 & 2.0 & 2.7 & 2.7 \\
\hline EE/FSU $\ldots \ldots \ldots \ldots$ & -0.4 & 0.3 & 1.4 & 0.2 & 1.1 & 1.1 \\
\hline Former Soviet Union . . . & -0.4 & 0.3 & 1.4 & 0.0 & 1.1 & 1.1 \\
\hline Eastern Europe $\ldots$. & -0.4 & 0.3 & 1.4 & 0.6 & 0.8 & 0.8 \\
\hline Developing Countries $\ldots \ldots \ldots \ldots \ldots$ & 4.5 & 5.8 & 6.8 & 4.7 & 6.1 & 6.1 \\
\hline Developing Asia . . . . & 4.7 & 6.0 & 7.0 & 4.8 & 6.3 & 6.3 \\
\hline China ....... & 18.8 & 20.7 & 21.6 & 15.8 & 24.7 & 24.7 \\
\hline Other Asia . . & 3.3 & 4.4 & 5.5 & 4.1 & 4.5 & 4.5 \\
\hline Middle East & -- & -- & -- & -- & -- & -- \\
\hline Africa $\ldots \ldots \ldots \ldots$ & 0.7 & 1.6 & 2.5 & 1.1 & 2.0 & 2.0 \\
\hline Central and South America & 3.1 & 4.4 & 5.6 & 5.2 & 6.4 & 6.4 \\
\hline Total World $\ldots \ldots \ldots \ldots \ldots \ldots \ldots \ldots$ & 0.3 & 0.8 & 1.2 & 0.6 & 1.0 & 1.0 \\
\hline
\end{tabular}

Note: IEO97, IEO96: India is included in Developing Other Asia.

Sources: IEO97: Energy Information Administration (EIA), World Energy Projection System (1997). IEO96: EIA, International Energy Outlook 1996, DOE/EIA-0484(96) (Washington, DC, May 1996). IEA CC: International Energy Agency, World Energy Outlook 1996 (Paris, France, 1996), Capacity Constraints Case, pp. 237-249. IEA ES: International Energy Agency, World Energy Outlook 1996 (Paris, France, 1996), Energy Savings Case, pp. 257-269. 
Table C8. Comparison of Other Energy Consumption Growth Rates, 1993-2010, by Region (Average Annual Percent Growth)

\begin{tabular}{|c|c|c|c|c|c|c|}
\hline \multirow[b]{2}{*}{ Region } & \multicolumn{3}{|c|}{ IEO97 } & \multirow[b]{2}{*}{ IEO96 } & \multirow[b]{2}{*}{ IEA CC } & \multirow[b]{2}{*}{ IEA ES } \\
\hline & $\begin{array}{l}\text { Low } \\
\text { Growth }\end{array}$ & Reference & $\begin{array}{l}\text { High } \\
\text { Growth }\end{array}$ & & & \\
\hline Industrialized $\ldots \ldots \ldots \ldots \ldots \ldots$ & 1.8 & 2.2 & 2.3 & 2.3 & 2.3 & 2.6 \\
\hline North America $\ldots \ldots \ldots \ldots \ldots \ldots$ & 1.9 & 2.4 & 2.4 & 2.3 & 2.5 & 3.0 \\
\hline Western Europe & 1.9 & 2.1 & 2.4 & 1.8 & 1.7 & 1.8 \\
\hline Pacific ...... & 1.1 & 1.4 & 1.7 & 4.0 & 3.3 & 3.5 \\
\hline EE/FSU $\ldots \ldots \ldots \ldots \ldots \ldots \ldots \ldots$ & 0.4 & 1.0 & 2.2 & 1.8 & 2.0 & 2.0 \\
\hline Former Soviet Union $\ldots \ldots \ldots \ldots \ldots$ & -0.5 & 0.1 & 1.3 & 1.1 & 1.5 & 1.5 \\
\hline Eastern Europe $\ldots \ldots \ldots \ldots \ldots \ldots$ & 3.6 & 4.3 & 5.5 & 4.9 & 4.2 & 4.2 \\
\hline Developing Countries $\ldots \ldots \ldots \ldots \ldots$ & 1.6 & 3.0 & 4.0 & 3.4 & 5.0 & 5.1 \\
\hline Developing Asia $\ldots \ldots \ldots \ldots \ldots \ldots$ & 3.7 & 5.2 & 6.1 & 5.6 & 6.3 & 6.7 \\
\hline China ....... & 4.7 & 6.4 & 7.2 & 7.7 & 7.1 & 7.1 \\
\hline Other Asia ... & 2.8 & 4.0 & 5.1 & 3.2 & 5.8 & 6.5 \\
\hline Middle East ... & 2.2 & 3.3 & 4.3 & 6.4 & 7.3 & 7.3 \\
\hline Africa $\ldots \ldots \ldots \ldots \ldots \ldots \ldots$ & 0.5 & 1.4 & 2.3 & 2.9 & 2.8 & 2.8 \\
\hline Central and South America $\ldots \ldots \ldots \ldots$ & -0.5 & 0.8 & 2.0 & 0.8 & 3.3 & 2.9 \\
\hline Total World $\ldots \ldots \ldots \ldots \ldots \ldots \ldots$ & 2.3 & 2.4 & 3.5 & 2.6 & 3.3 & 3.5 \\
\hline
\end{tabular}

Note: IEO97, IEO96: India is included in Developing Other Asia.

Sources: IEO97: Energy Information Administration (EIA), World Energy Projection System (1997). IEO96: EIA, International Energy Outlook 1996, DOE/EIA-0484(96) (Washington, DC, May 1996). IEA CC: International Energy Agency, World Energy Outlook 1996 (Paris, France, 1996), Capacity Constraints Case, pp. 237-249. IEA ES: International Energy Agency, World Energy Outlook 1996 (Paris, France, 1996), Energy Savings Case, pp. 257-269. 


\section{A}

Africa. See also specific countries

coal consumption in, 68

electric power industry in, 106-108

listing of countries in, $x$

natural gas industry in, 56-57

oil production in, 29, 39

Air pollution. See also Carbon emissions

from coal consumption, 64-65

government policies regarding, 9

Algeria, 57

Alliance of Small Island States (AOSIS), 24

American Wind Energy Association, 85

Annex I countries

Framework Convention on Climate Change and, 24

listing of, $x \mathrm{i}$

Annual Energy Outlook 1997 (AEO97), ix

Argentina

hydroelectricity in, 93

natural gas industry in, 54

Asia, x. See also Developing Asia; specific countries

Australia

electric power industry in, 104

renewable energy in, 89-90

Automobile ownership, 8-9

\section{B}

Berlin Mandate, 24

Biomass, 87

Brazil

electric power industry in, 109

natural gas industry in, 54

\section{C}

Canada. See also North America

electric power industry in, 99, 100, 102

natural gas industry in, 50

nuclear power industry in, 83

oil production in, 29

renewable energy in, 87

Capacity Constraints Case (IEA CC), 25, 26, 171, 172

Carbon emissions

in Eastern Europe and former Soviet Union, 15-16

electricity generation and, 99

high economic growth case and, 138-141

low economic growth case and, 152-155

projections for, $4,23,25$

reference case and, 124-127

stabilization of, 10
Caspian Sea, 29

Central and South America

countries included in, $x \mathbf{i}$

electric power industry in, 108-110

natural gas consumption in, 3,54

natural gas industry in, 48, 54-55

oil demand in, 32

oil production in, 29,39

renewable energy in, $48,93-94$

Chile

electric power industry in, 109

hydroelectricity in, 93-94

natural gas industry in, 54

China

air pollution in, 9

coal consumption in, 9, 11, 63, 67

economic growth in, 17

electric power industry in, 105-106

energy consumption in, 12-13

energy intensity in, 12, 18-19

hydropower in, 4, 20, 90

natural gas projects in, 48,55

oil consumption in, 32

transportation sector in, 32

wind power in, 90

Climate Change Convention of 1992, 7, 24, 65

Coal

liquid fuels from, 37

overview of, 63

production of, 71

recoverable reserves of, $65-66$

trade in, 68-70, 72

Coal consumption

carbon emissions from, 25

for electricity generation, 98

environmental issues related to, 64-65

growth rate comparisons for, 171,176

high economic growth case and, 134

low economic growth case and, 148

projections for, 3,20

reference case and, 120

regional variations in, $66-68$

trends in, 63-64

Coal Export Submodule (CES) (NEMS), ix

Colombia

electric power industry in, 109-110

natural gas industry in, 54-55

Country groupings. See also specific country groupings

description of new, 6

listing of, $x-x i$

Czech Republic, 6 
D

Department of Energy Organization Act of 1977, ix Developing Asia coal consumption in, 3, 9, 11, 20, 66-67

coal trade in, 70

countries included in, $x$

economic growth in, 10

electric power industry in, 105-106

electricity consumption in, 12,20

energy consumption in, 1, 10-12

hydroelectric projects in, 4, 20, 90-92

natural gas consumption in, 3, 47-48, 55

natural gas industry in, 55-56

nuclear power in, 76,78

oil demand in, 31-32

renewable energy in, 4, 20, 90-92

Developing countries. See also specific countries;

specific country groupings

carbon emissions in, 25

energy consumption in, 10-11

energy intensity in, 18-19

explanation of, 6

nuclear power in, 78

oil demand in, 30-32

DRI/McGraw-Hill (DRI), 42, 43, 54

\section{E}

Earth Summit of 1992 (Brazil), 7, 24, 65

Eastern Europe and Former Soviet Union (EE/FSU)

coal consumption in, 64, 67-68

countries included in, $x$

economic growth in, 10,13,15,17, 18

electric power industry in, 104-105

energy consumption in, 1-2, 10, 13-15

forecast differences for, 25,27

fuel mix in, 15-16

natural gas reserves/industry in, 15, 52-53

nuclear power in, 83-84

OECD membership and, 6

oil demand in, 32-33

renewable energy in, $86,92-93$

Economic growth

energy demand and, 8-9

forecast differences for, 25-27

Ecuador, 110

Electricity

access to, 8

income and demand for, 9

overview of, 97

world markets for, $97-98$

Electricity consumption

generated by nuclear power, 76

high economic growth case and, 137

low economic growth case and, 151 projections for, $4,19-20,97$

reference case and, 123

Electricity Corporation of New Zealand (ECNZ), 104

Electricity generation

in Africa, 106-108

carbon emissions and, 99

in Central and South America, 108-110

consumption of fuels for, 20-21

in developing Asia, 12, 105-106

in Eastern Europe and former Soviet Union, 104-105

in industrialized Pacific, 103-104

in Middle East, 108

in North America, 99-102

primary fuel use for, 98,99

in Western Europe, 102-103

Energy consumption. See also specific countries;

specific country groupings

economic growth and, 8-9

forecast uncertainties for, 9

growth rate comparisons and, 25, 26, 171-178

high economic growth case and, 129-131, 142

low economic growth case and, 143-145, 156

overview of, 5-8, 10-11

projections for, 1-4

reference case and, 115-116, 128

Energy Information Administration (EIA), 167

Energy intensity. See also Gross domestic product (GDP)

in China, 12, 18-19

in EE/FSU region, 14-15

influence of, 18

reference case projections for, 18-19

Energy Savings Case (IEA ES), 25, 26, 171, 172

Environmental issues. See also Air pollution;

Carbon emissions

related to coal consumption, 64-65

related to electricity generation, $98-99$

$\mathbf{F}$

Former Soviet Union (FSU). See also Eastern Europe and Former Soviet Union (EE/FSU)

countries included in, $x$

energy consumption in, 1-2

hydroelectric facilities in, 92

natural gas reserves in, $15,52-53$

nuclear power in, 21

OECD membership and, 6

oil demand in, 33

oil production in, 38,39

Framework Convention on Climate Change, 24, 25

France, nuclear power industry in, 78, 82-83

G

G-7 countries, $x i$

Gabcíkovo hydroelectric project, 92 
Gas Research Institute (GRI), 42

Gazprom, 53

Germany

coal production in, $67,70,71$

renewable energy programs in, 89

Government policies

on electricity regulation, 102-103

to encourage private investment, 33-34

forecast uncertainties due to, 9

Greenhouse gas emissions, 24, 25, 65. See also

Air pollution; Carbon emissions

Gross domestic product (GDP). See also Energy intensity energy demand and, 8

for OECD member nations, 6

Gulf of Mexico, 29

\section{H}

Heavy-water technology, 80

High economic growth case assumptions for, 16-17

carbon emissions in, 138-141

coal consumption in, 134

electricity consumption in, 137

energy consumption in, 129-131, 142

hydroelectricity in, 136

natural gas consumption in, 133

nuclear energy consumption in, 135

oil consumption in, 30, 132

renewable energy in, 136

High non-OPEC supply case

oil production capacity in, 160

oil production in, 39-40, 164

High oil price case

oil production capacity in, 158

oil production in, 162

Hydroelectricity

in Central and South America, 48, 93-94

in developing Asia, 90-92

in Eastern Europe and former Soviet Union, 92

in industrialized Asia, 89

in Middle East, 93

in North America, 87

in Western Europe, 88

Hydroelectricity consumption

high economic growth case and, 136

low economic growth case and, 150

projections for, $4,20,85,86$

in reference case, 122

\section{1}

India

coal consumption in, 67

electric power industry in, 106

hydropower in, 90-91 natural gas project in, 55

nuclear power in, 79-82

oil consumption in, 32

photovoltaic technology in, 91

wind energy in, 90

Industrial sector, energy intensity in, 12-13, 15

Industrialized countries. See also specific regions

or countries

electricity consumption in, 19, 97

growth projections for, 4,9

listing of, $x, 6$

natural gas markets in, 48, 50-52

nuclear power in, $78,82-83$

oil demand in, 31

petroleum trade and, 41-42

Intergovernmental Panel on Climate Change (IPCC), 65

International Energy Agency (IEA), 25, 26, 42, 171

International Energy Module (NEMS), ix, 167

International Energy Outlook 1996 (IEO96)

oil price projections in, 29, 33

oil production projections in, 38

International Energy Outlook 1997 (IEO97), ix

assumptions in, 16

comparisons with other forecasts, $25-27$

oil price projections in, 29, 33, 42, 43

oil production projections in, 38,43

outlook in, 1

regional definitions used in, 6

International Nuclear Model, PC Version

(PC-INM), ix, 167

Iran

electric power industry in, 108

hydroelectricity in, 93

natural gas exports from, 57

Israel, 57

J

Japan

electric power industry in, 103-104

nuclear power in, 78

renewable energy in, 90

$\mathbf{L}$

Libya, 56-57

Lignite, 66

Liquefied natural gas (LNG)

projects to expand trade in, 48

regional activity in, 57-58

Low economic growth case

assumptions for, $16-18$

carbon emissions in, 152-155

coal consumption in, 148

electricity consumption in, 151

energy consumption in, 143, 144-145, 156 
hydroelectricity in, 150

natural gas consumption in, 147

nuclear energy consumption in, 149

oil consumption in, 30, 146

renewable energy in, 150

Low oil price case

oil production capacity in, 159

oil production in, 163

\section{M}

Maghreb-Europe pipeline, 52

Mexico. See also North America

electric power industry in, 99, 100, 102

natural gas industry in, 50-51

nuclear power industry in, 83

renewable energy in, $87-88$

Middle East

electric power industry in, 108

listing of countries in, $x$

natural gas industry in, 57

renewable energy in, 93

Myanmar, natural gas project in, 55

\section{$\mathbf{N}$}

National Energy Modeling System (NEMS), ix, 167

Natural gas consumption

for electricity generation, 97-98

growth rate comparisons for, 175

high economic growth case and, 133

low economic growth case and, 147

projections for, $3,21,47-48$

reference case and, 119

Natural gas industry

in Africa, 56-57

in Asia, 55-56

in Central and South America, 48, 54-55

in Eastern Europe and former Soviet Union, 48, 52-53

in Middle East, 57

in North America, 50-51

in Western Europe, 48, 51-52

Natural gas reserves

in Africa, 56-57

in Eastern Europe and former Soviet Union, 15, 52-53

in North America, 50

regions containing, 49-50

Natural Resources Canada (NRCan), 42

NatWest Securities, Ltd. (NatWest), 42, 43

New Zealand

electric power industry in, 104

wind energy in, 89

Nigeria, natural gas industry in, 56, 58

Noncommercial fuels, 86

Non-Fossil Fuel Obligation (NFFO), 88, 89
Nonindustrialized countries

explanation of, 6

petroleum trade and, 41-42

North America. See also Canada; Mexico; United States

electric power industry in, 99-102

natural gas industry in, 50-51

natural gas reserves in, 50

nuclear power in, 83

renewable energy in, 87-88

wind energy in, 87

North American Free Trade Agreement (NAFTA), 72

Nuclear power

capacity for, 3-4, 75-77

in developing Asia, 78-82

in Eastern Europe and former Soviet Union, 83-84

for electricity generation, 98

in industrialized Asia, 78

in North America, 83

in other developing countries, 78

in Western Europe, 78, 82-83

Nuclear power consumption

growth rate comparisons for, 177

high economic growth case and, 135

low economic growth case and, 149

projections for, 21

reference case and, 121

Nuclear Power Corporation of India (NPC), 80, 82

0

OECD, xi

Oil consumption

growth rate comparisons for, 174

high economic growth case and, 132

low economic growth case and, 146

projections for, 2-3, 21-23, 30-31

reference case and, 118

regional variations in, 31-33

Oil prices

in $1996,29,34$

projection comparisons for, 33-34, 42, 43

projections for, 2, 22-23

Oil production

high non-OPEC supply case and, 39-40, 164

high oil price case and, 162

low oil price case and, 163

1996 developments in, 29

projection comparisons for, $42-44$

reference case and, 161

Oil production capacity

expansion of OPEC, 35-38

high non-OPEC supply case and, 160

high oil price case and, 158

low oil price case and, 159

reference case and, 35, 157 
Oil reserves, in former Soviet Union, 38

Oil resources, nonconventional, 37

Oil supply

expansion of OPEC, 35-38

1996 developments in, 29

non-OPEC, 34, 36, 38-40

OPEC, 34,35

Oman, 38,58

Organization for Economic Cooperation and

Development (OECD), membership profile for, 6

Organization of Petroleum Exporting Countries (OPEC), $x i$

\section{$\mathbf{P}$}

Pacific Rim Developing Countries, xi

Persian Gulf, xi

Peru, electric power industry in, 110

Petroleum Economics, Ltd. (PEL), energy forecasts of, $25,26,42,43,171$

Petroleum Industry Research Associates (PIRA), energy forecasts of, 25, 26, 42, 43, 171

Petroleum trade, in reference case, 41-42

Philippines, natural gas industry in, 56

Phoenix Natural Gas, 51

Photovoltaic technology, 91

Pollution. See Air pollution

\section{$\mathbf{R}$}

Reference case

assumptions for, 16,17

carbon emissions in, 124-127

coal consumption in, 120

coal trade in, 69

electricity consumption in, 123

energy consumption in, 115, 116, 128

energy intensity in, 18-19

hydroelectricity consumption in, 122

natural gas consumption in, 119

nuclear energy consumption in, 75, 121

oil consumption in, 34, 118

oil prices in, 2

oil production capacity in, 157

oil production in, 161

petroleum trade in, $41-42$

preparation of, ix

renewable energy in, 122

Regional groupings. See Country groupings;

specific country groupings

Renewable energy

in Central and South America, 48, 93-94

in developed Asia, 90-92

in Eastern Europe and former Soviet Union, 92-93

for electric power generation, 20

in industrialized Asia, 89-90 in Middle East, 93

in North America, 87-88

in Western Europe, 88-89

Renewable energy consumption

growth in, 85-86

high economic growth case and, 136

low economic growth case and, 150

projections for, 4

reference case and, 122

Russia, 92-93

\section{$\mathbf{S}$}

Saudi Arabia, 108

Shale oil reserves, 37

Slovakia, 6

South Africa

coal production and consumption in, 68

electric power industry in, 106, 107

South America. See Central and South America

South Korea, 56, 58

Southern Africa electricity grid, 106-107

Southern Africa Power Pool, 107

Soviet Union, former. See Former Soviet Union (FSU)

Synthetic crude oil, 37

Syria, 93

\section{T}

Tar sands, 37

Tarapur Atomic Power Station (TAPS) (India), 79, 80

Thailand

electricity demand in, 91-92

natural gas industry in, 55-56

Three Gorges Dam project (China), 4, 90

Transportation sector

in China, 32

energy consumption in, 13

$\mathbf{U}$

Ukraine

geothermal resources in, 92

nuclear power industry in, 83-84

United Kingdom

coal production in, $67,70,71$

nuclear power issues in, 76

renewable energy in, 88-89

United Nations Framework Convention on

Climate Change, 4, 24, 25, 65, 85

United States

coal consumption in, 68

electric power industry in, 99, 101

natural gas industry in, 50

nuclear power industry in, 83

renewable energy in, 87 
Uruguay, 54

U.S. Geological Survey (USGS), 34

\section{W}

Western Europe. See also specific countries electric power industry in, 102-103 natural gas industry in, 48, 51-52 nuclear power in, $78,82-83$ renewable energy in, 88-89

Wind energy in former Soviet Union, $92-93$ growth in, 4, 85-86 in North America, 87 in Western Europe, 88, 89
World Energy Outlook 1996, 25, 171, 172

World Energy Projection System Model Documentation (Department of Energy), 167

World Energy Projection System (WEPS), ix, 167

World Integrated Nuclear Evaluation System

(WINES), ix

World Petroleum Congress, 34

\section{Y}

Yacheng 13-1 (China), 48

Yemen, 38 